PNL-6728

UC. 11, 41

58

\title{
Geohydrologic \\ Characterization of the \\ Area Surrounding the 183-H \\ Solar Evaporation Basins
}

T. L. Liikala, Project Manager

December 1988

Prepared for

the U.S. Department of Energy

under Contract DE-AC06-76RLO 1B30

Pacific Northwest Laboratory

Operated for the U.S. Department of Energy

by Battelle Memorial Instifute 


\title{
DISCLAIMER
}

This report was prepared as an account of work sponsoted by an agency of the Lnited States Government. Nathet the Inited States Covernturent nof any agency thereof, nor bartelle Memorial institute, nor any or their employees, makes any warranty, fapressed or implied, or asstimes any legal liability or respounsibility for the accuracy, completeness, or usefulness af arty information, apparatus, product, or process disclosed, or repents that is lise would not intringe privatedy owned ights. Reference herein to any specitic commercial product, process, or service by trade name, trademark, funtutacturer, or otherwise does not necessarify constiute of imply its endorsement, ecommendation, or favoting by the United States

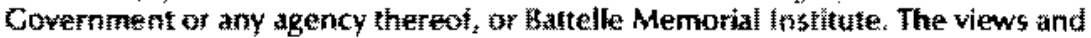
opinions of atuhors expressed herein to nol mecessarify state of reflect those of the United Stateverniment or any agency thereof.

\author{
PACIFIC NORTHWEST LABORATORY \\ operated by \\ BATTEILE MEMORIAL INSTITUTE \\ lar the \\ UNITEO STATES DEPARTMENT OF ENERGY \\ under Contract DE-ACOS-76RLO 1830
}

\begin{tabular}{|c|c|}
\hline \multicolumn{2}{|c|}{ Prinţed in the lunted States of America } \\
\hline \multicolumn{2}{|c|}{ 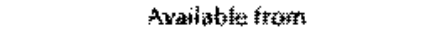 } \\
\hline \multicolumn{2}{|c|}{ 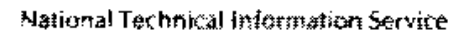 } \\
\hline \multicolumn{2}{|c|}{ Unt ted States Deparirfant of Commerte } \\
\hline \multicolumn{2}{|c|}{ 5.25\% grt Royal Road } \\
\hline \multicolumn{2}{|c|}{ 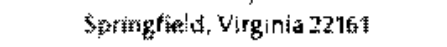 } \\
\hline \multirow{2}{*}{\multicolumn{2}{|c|}{ 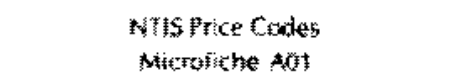 }} \\
\hline & \\
\hline \multicolumn{2}{|c|}{ Pfirtatei Catay } \\
\hline & fitioe \\
\hline 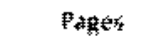 & Coxtes \\
\hline $59+42 \%$ & $A 02$ \\
\hline IOG & $A 03$ \\
\hline $05 a^{2} 075$ & Axt4 \\
\hline 076.10$)$ & Alos \\
\hline 101.125 & $A x$ \\
\hline $126-150$ & Afsy \\
\hline 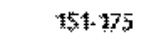 & 做 \\
\hline $37-24 i$ & Acoz \\
\hline 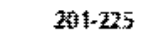 & A 10 \\
\hline $325-750$ & A11 \\
\hline $25 \div 225$ & At2 \\
\hline $276-30$ & 443 \\
\hline
\end{tabular}


PNL-6728

UC $-11,41$

GEOHYDROLOGIC CHARACTERIZATION OF THE AREA SURROUNDING THE 183-H SOLAR EVAPORATION BASINS
T. L. Lijkala
P. L. obertander
R. L. Aaberg
K. B. Olsen
N. J. Aino
K. R. Oster
D. J. Bates
L. $R$. Roone
T. J. Gilmore
J. C. Simpson
E. J. Jensen
S. S. Teel
G. V. Last
E. J. Westergard

December 1988

Prepared for

the U.S. Department of Energy

under Contract DE-ACOG-76RLO 1930

Pacific Northwest Laboratory

Richland, washington 99352 


\section{SUMMARY}

Since June 1985, the Pacific Northwest Laboratory has been conducting a geohydrologic investigation of the area surrounding the $183-\mathrm{H}$ Solar Evaporation Basins (183-H Basins), located on the Hanford Site in southeastern Washington state. The purpose of this investigation is to achieve regulatory compliance with the applicable ground-water monitoring requirements of the Resource Conservation and Recovery Act (RCRA) and the Washington Administrative Code (WAC).

An assessment-level compltance monitoring project was established for the 183-H Basins because hazardous waste constituents were known to have entered the ground water beneath the factlity. Three phases were defined for this project with work being concentrated in five areas: geology, hydrology, ground-water monitoring, geochemistry, and ground-water modeling.

These characterization activities have resulted in the definition of principal lithologic and hydrostratigraphic units. Ground-water monitoring results indicated contamination peak, which occurred between April and August 1986. Further monitoring has shown that nitrate, sodium, gross alpha, and gross beta are the clearest indicators of ground-water contamination attributable to the 183-H Basins. In addition, the concentrations of these contaminants are affected by variations in Columbia River stage. Future studies will focus on continued ground-water monitoring throughout the c10sure and post-closure periods for the 183-H Basins, sampling of the Columbia River and nearby ground-water springs, and soil sampling adjacent to the facility. 
, 


\section{CONTENTS}

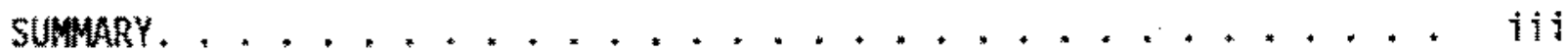

1.0 INTRODUCTION $\ldots \ldots \ldots \ldots$ I $\ldots \ldots \ldots \ldots \ldots$

1.1 PRE-1985 MONITORING PROGRAM ............. 1

1.2 INTERIM STATUS MONITORING PROGRAM $\ldots \ldots \ldots$

2.0 BACKGROUND $\ldots \ldots \ldots \ldots$

2.1 REGIONAL PHYSIOGRAPHY AND GEOHYROLOGY ...........

2.1.1 Climate of the Hanford Site .......... 9

2.1.2 Geology of the Hanford Site .......... 11

2.1 .3 Hydrology of the Hanford Site . . . . . . . 16

2.2 DESCRIPTION OF THE $183-H$ BASINS $\ldots \ldots \ldots$

2.3 OPERATIONAL HISTORY OF THE $183-H$ BASINS $\ldots \ldots \ldots 21$

2.4 WASTE CHARACTERIZATION .............. 22

2.4 .1 Basin \#1 Sampling . . . . . . . . , . . . 24

2.4 .2 Basin 2 Sampling .................. 30

3.0 GEOLOGY OF THE $100-H$ AREA $\ldots \ldots 33$

3.1 SADDLE MOUNTAINS BASALT FORMATION ........... 33

3.2 RINGOLD FORMATION ................. 45

3.2 .1 Silty Clayey Sand to Sandy Silty Clay Unit . . . . 48

3.2 .2 silty Sand Unit ............... 48

3.2 .3 Gravelly Silty Sand Unit . . . . . . . . 49

3.3 HANFORO FORMATION ................. 49

4.0 HYOROLOGY OF THE 100-H AREA ............ 53

4.1 LOWER CONFINED AQUIFER .............. 53

4.2 UPPER CONFINED AQUIFER ................. 53 
4.3 SILTY SAND AND GRAVELLY SILTY SAND UNITS . . . . . . 56

4.4 SATURATED SEDIMENTS OF THE HANFORO FORMATION . ...... 58

4.5 UNSATURATEO SEDIMENTS OF THE HANFORD FORMATION . . . . 67

5.0 DESCRIPTION OF THE WELL INSTALLATION AND GEOHYDROLOGIC

CHARACTERIZATION EFFORT $\ldots \ldots \ldots 73$

5.1 DETAILS OF WELL DESIGN AND CONSTRUCTION $\ldots \ldots . \ldots 73$

5.1 .1 Wells Installed Before 1985 ......... 73

5.1 .2 Phase II Wells ............ 75

5.1 .3 Phase III Wells.............. 77

5.2 FIELD METHODS $\ldots \ldots \ldots \ldots \ldots$

5.3 WELL LOCATIONS ................... 78

6.0 SAMPLING AND ANALYSIS PLAN $\ldots \ldots \ldots 81$

6.1 SAMPLING SCHEDULE ................. 81

6.2 SAMPLE ANALYSES $\ldots \ldots \ldots . \ldots . \ldots$

6.3 QUALITY CONTROL ..................... 84

6.4 SAMPLING PUMPS . ...................... 87

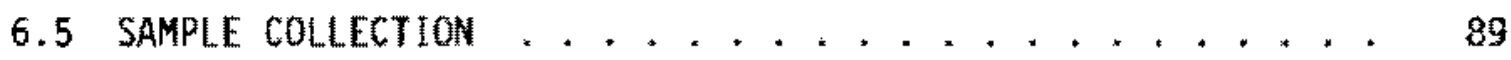

6.6 SAMPLE PRESERVATION AND SHIPMENT ............. 91

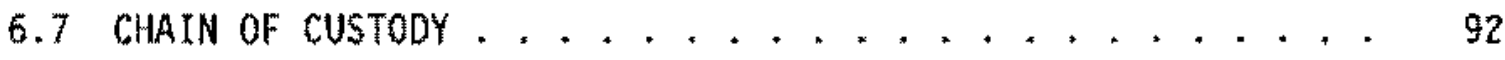

7.0 ANALYTICAL RESULTS $\ldots \ldots \ldots . \ldots \ldots$

7.1 SUMMARY OF RESULTS TO DATE .................... 95

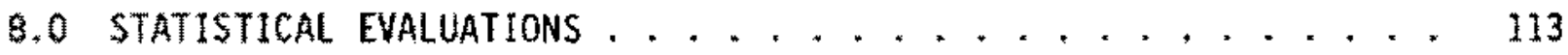

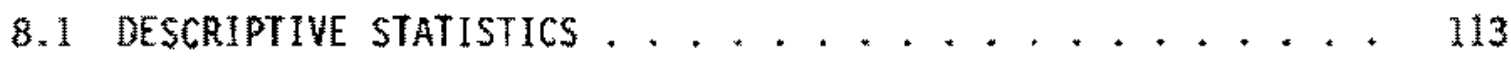

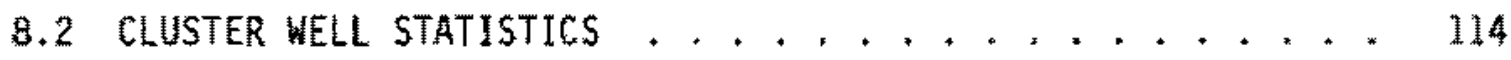

8.3 LINEAR REgRESSION ANALYSES . . . . . . . . . 115

9.0 CONTAMINANT PLUME DESCRIPTION ............ 123 
9.1 BACKGROUND CONCENTRATIONS .............. 123

9.2 HORIZONTAL EXTENT OF CONTAMINATION .......... 125

9.3 VERTICAL EXTENT OF CONTAMINATION $\ldots \ldots \ldots$

9.4 GEOCHEMICAL INTERACTION OF SELECTED CONSTITUENTS $\ldots \ldots 152$

9.5 PATHLINE ANALYSIS $\ldots \ldots \ldots . \ldots \ldots$

10.0 CONCLUSIONS $\ldots \ldots \ldots \ldots \ldots \ldots . \ldots \ldots$

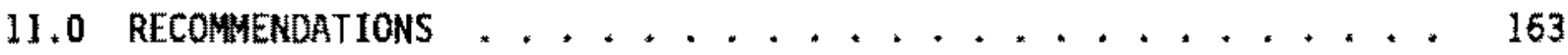

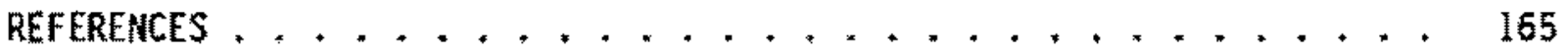

APPENDIX A - CONSTRUCTION DIAGRAMS, LITHOLOGIC DIAGRAMS, AND GEOPHYSICAL LOGS FOR THE 100-H AREA WELLS. ...... A.1

APPENDIX B - BASIC DESCRIPTIVE STATISTICS FOR THE 68 CONSTITUENTS

THAT HAD AT LEAST ONE VALUE ABOVE THE DETECTION LIMIT . . B.I

vi ิ 
* 


\section{FIGURES}

1 Location of the Hanford site ............... 1

2 Locations of the original Monitoring Wells . . . . . . . 2

3 Annual Average Concentrations of Nitrate in Well 199-H4-3 . . . 4

4 Annual Average Concentrations of Chromium in Wel1 199-H4-3 ...4 4

5 Locations of the Phase II Wells .............5 5

6 Locations of the Phase III Wells ............. 7

7 Structural Geology of the Pasco Basin ............. 10

8 Generalized Geologic Cross Section of the Hanford Site . . . . 12

9 Stratigraphic Units Present in the Pasco Basin ....... 13

10 Distribution of the Ringold Formation Section Types....... 15

Il Water Table Elevations for June $1987 \ldots \ldots$. . . . . . . 17

$12100-H$ Area Map ...................... 19

13 Schematic Cross Section of the 183-H Basins ..........20

14 Plan View of the $183-H$ Basins . . . . . . . . . 21

15 Sample Locations for Basin \#1 ............. 25

16 Concentrations of Copper, Sulfur, and Zirconium in the Slurry

17 Concentrations of Chromium, Iron, Manganese, and Tin in the
Siurry Liquid and slurry Solid from Basin 11.29

Concentrations of Molybdenum, Nickel, and Uranium in the
Slurry Liquid and Slurry Solid from Basin $\# 1 \ldots \ldots 29$

19 Concentrations of chloride, Chromium, Copper, and Potassium in the Basin \#l Slurry Liquid and Basin \#2 Solution ........32

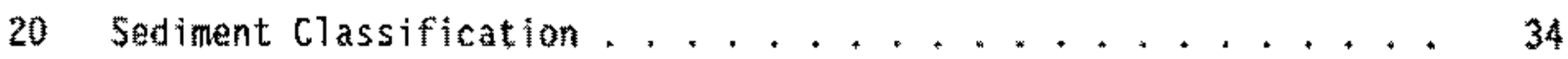

21 Generalized Geologic Column for the 100-H Area . . . . . . 35

22 Three-Dimensional Distribution and Stratigraphic Correlations of the Geologic Formations Beneath the 100-H Area ....... 
23 Locations of the 100-H Area Cross Sections . . . . . . . . 38

24 Cross Sections $A-A^{\prime}$ and $B-B^{\prime}$ of the Stratigraphic Formations Beneath the 100-H Area .............. 39

25 Cross Sections $C-C^{\prime}$ and $D-D^{\prime}$ of the Stratigraphic Formations

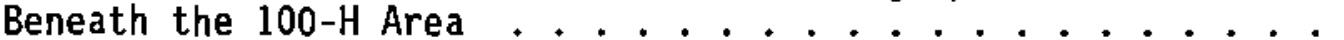

26 Cross Sections $E-E^{\prime}$ and $F-F^{\prime}$ of the Stratigraphic Formations Beneath the 100-H Area ............... 43

27 Top-of-Basalt Map . . . . . . . . . . . 47

28 Surface of the Ringold Formation Beneath the 100-H Area . . . . 50

29 Aerial Photograph of the $100-H$ Area . . . . . . . . . . . 52

30 Generalized Hydrostratigraphic Column for the 100-H Area . . . 54

31 Hydrographs for Wells 199-H4-15A, 199-H4-15B, and 199-H4-15C . . 55

32 Hydrographs for Wells 199-H3-2A, 199-H3-2B, and 199-H3-2C ... 59

33 Hydrographs for Wells 199-H4-12A, 199-H4-12B, and 199-H4-12C. . 59

34 Hydraulic Conductivity (K) Values for the Silty Sand and Gravelly Silty Sand Units Within the Ringold Formation . . . . . 60

35 Hydraulic Conductivity (K) Values for the Unconfined Aquifer . . 60

36 Transmissivity ( $T$ ) Values for the Silty Sand and Gravelly Silty Sand Units Within the Ringold Formation ......... . 61

37 Transmissivity (T) Values for the Unconfined Aquifer . . . . . 61

38 Relative Water Leve1s in the Columbia River and 100-H Area Monitoring Wells .............. 63

39 100-H Area Water Table Map Corresponding to Low CoTumbia River Stage ...................

40 100-H Area Water Table Map Corresponding to Mean Columbia River Stage ................ 65

41 100-H Area Water Table Map Corresponding to High Columbia River Stage................. 66

42 Closure Schedule for the $183-H$ Basins . . . . . . . . . 83

43 Field Record Form . . . . . . . . . . . . . . . 90 
44 Chain-of-Custody Form ................ . . 93

45 Sample Analysis Request Form . . . . . . . . . . . . 94

46 Specific Conductance in the Original Monitoring Wells ..... 98

47 Gross Alpha Concentrations in the Original Monitoring Wells . . 99

48 Gross Beta Concentrations in the Original Monitoring Welis . . 100

49 Nitrate Concentrations in the Original Monitoring Wells . . . . 101

50 Barium Concentrations in the Original Monitoring Wells . . . . 102

51 Sulfate Concentrations in the Original Monitoring Welis . . . . 103

52 Sodium Concentrations in the Original Monitoring Wells .... 104

53 Strontium Concentrations in the Original Monitoring Wells . . . 105

54 Calcium Concentrations in the Original Monitoring Wells . . . . 106

55 Nickel Concentrations in the Original Monitoring Wells . . . . 107

56 Copper Concentrations in the Original Monitoring Wells ..... 108

57 Potassium Concentrations in the Original Monitoring Wells ... 109

58 Chromium Concentrations in the Original Monitoring Wells . . . 110

59 Nitrate Concentration Trends in Well 199-H4-3 . . . . . . 118

60 Sodium Concentration Trends in Well 199-H4-3 . . . . . . . 119

61 Nitrate Concentration Trends in Well 199-H4-4 . . . . . . . 120

62 Sodium Concentration Trends in We11 199-H4-4 . . . . . . 121

63 Nitrate Concentrations, September $1987 \ldots \ldots 126$

64 Nitrate Concentrations, Oecember 1986 . . . . . . . . 127

65 Nitrate Concentrations, May 1987 . . . . . . . . 128

66 Filtered Sodium Concentrations, September 1987 . . . . . . 129

67 Filtered Sodium Concentrations, December 1986 . . . . . . . 130

68 Filtered Sodium Concentrations, May 1987. . . . . . . 131

69 Gross Alpha Concentrations, September $1987 \ldots 132$ 
70 Gross Alpha Concentrations, December 1986 . . . . . . . 133

71 Gross Alpha Concentrations, May 1987 . . . . . . . . . 134

72 Gross Beta Concentrations, September 1987 . . . . . . . 135

73 Gross Beta Concentrations, December 1986 . . . . . . . 136

74 Gross Beta Concentrations, May 1987 . . . . . . . . 137

75 HorizontaT Distribution of Nitrate Concentrations . . . . . 138

76 Horizontal Distribution of Filtered Sodium Concentrations . . . 139

77 Horizontal Distribution of Gross Alpha Concentrations . . . . 140

78 Horizontal Distribution of Gross Beta Concentrations ...... 141

79 Filtered Chromium Concentrations, September 1987 . . . . . 142

80 Filtered Chromium Concentrations, December 1986 . . . . . . 143

81 Filtered Chromium Concentrations, May 1987 . . . . . . . . . . . 144

82 Horizontal Distribution of Filtered Chromium Concentrations . . 145

83 Nitrate Concentrations with Depth in Wells 199-H4-12A,

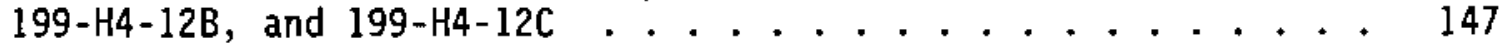

84 Filtered Sodium Concentrations with Depth in Wells 199-H4-12A,

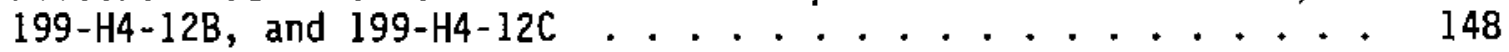

85 Gross Alpha Concentrations with Depth in Wells 199-H4-12A, 199-H4-12B, and 199-H4-12C ................ 149

86 Gross Beta Concentrations with Depth in We1ls 199-H4-12A, 199-H4-12B, and 199-H4-12C ............... 150

87 Filtered Chromium Concentrations with Depth in Wells 199-H4-12A,

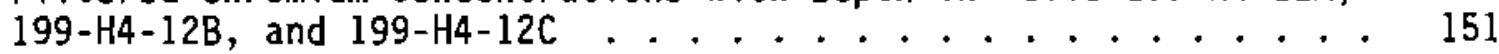

88 Breakthrough Curves for Nitrate and Chromium . . . . . . . . 153

89 Finite-Element Grid Used for Simulations . . . . . . . . 156

90 Simulated Pathlines ................. 157 


\section{TABLES}

1 Quantities of Selected Materials Discharged to the $183 \mathrm{H}$

Basins in $1985 \ldots \ldots . \ldots 23$

2 Characterization Results for the solid Waste Fraction of

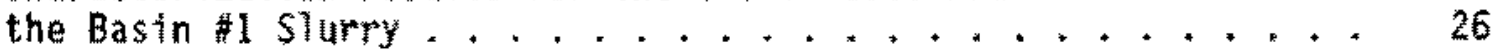

3 Characterization Results for the Liquid Waste Fraction of

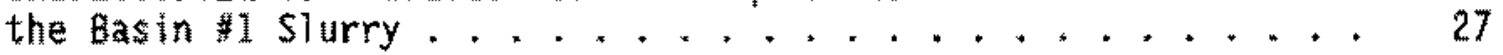

4 Analytical Results for the Basin $\$ 2$ Solution ......... 31

5 General Characteristics of the Geologic Formations Beneath the 100-H Area .................... 36

$6 \quad x$-Ray Fluorescence Analysis of Basalt Chips from Two

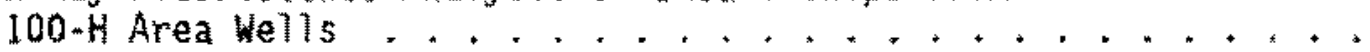

7 Vertical Hydraulic Conductivity Values for Split-Spoon Sanples..................... 56

8 Surmary of Aquifer Testing Results ........... 57

9 Field Moisture Contents and Water Retention Characteristics for the Phase II and III Wells ............... 68

10 Completion Data for the 100-H Area Wells ......... 74

11 FY 1988 Sampling Schedule for the 100-H Area Wells . . . . . . 82

12 Standard List of Analyses for the 100-H Area Ground-Water Sanples....................... 85

13 Proposed Schedule and Sample Analyses for Future 100-H Area

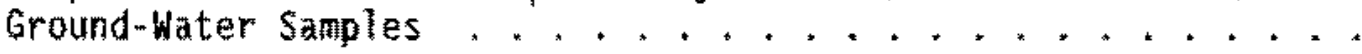

14 Chemical Constituents Used for Linear Regression Trend

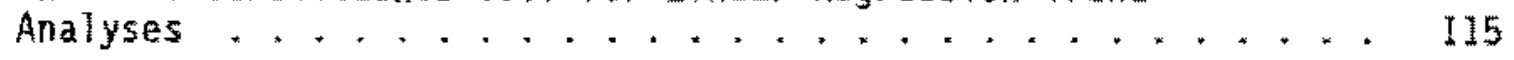

15 Weils Used for Linear Regression Trend Anatyses . . . . . 116

16 Background Concentrations ................. 123

17 Comparison of Background Values from Selected Upgradient Wells Near the 183-H Bas ins with Background Values on the Hanford Site 
18 Sodium Dichromate Inventories for Four Inactive Waste

Disposal Facilities at the $100-\mathrm{H}$ Area . . . . . . . . . 146

19 Trave1 Time and Distances .................. 158 


\subsection{INTRODUCTION}

The RCRA Compliance Ground-Water Monitoring Project for the 183-H Solar Evaporation Basins (183-H Basins; see Figures 1 and 2) was implemented in June 1985. This project was designed as an assessment-level program for interim status facilities. The applicable monitoring requirements are described in 40 Code of Federal Regulations (CFR) 264 and 265 (EPA 1984) and the WAC 173-303-645(8) (WDOE 1986a). A brief historical description of the project is provided below. The complete project plan is described in the Revised Ground-Water Monitoring Compliance Plan for the 183-H Solar Evaporation Basins (PNL 1986).

\subsection{PRE-1985 MONITORING PRDGRAM}

Before June 1985, ground water in the $100-\mathrm{H}$ Area had been monitored for several years on a routine basis as a part of the Hanford Ground-Water

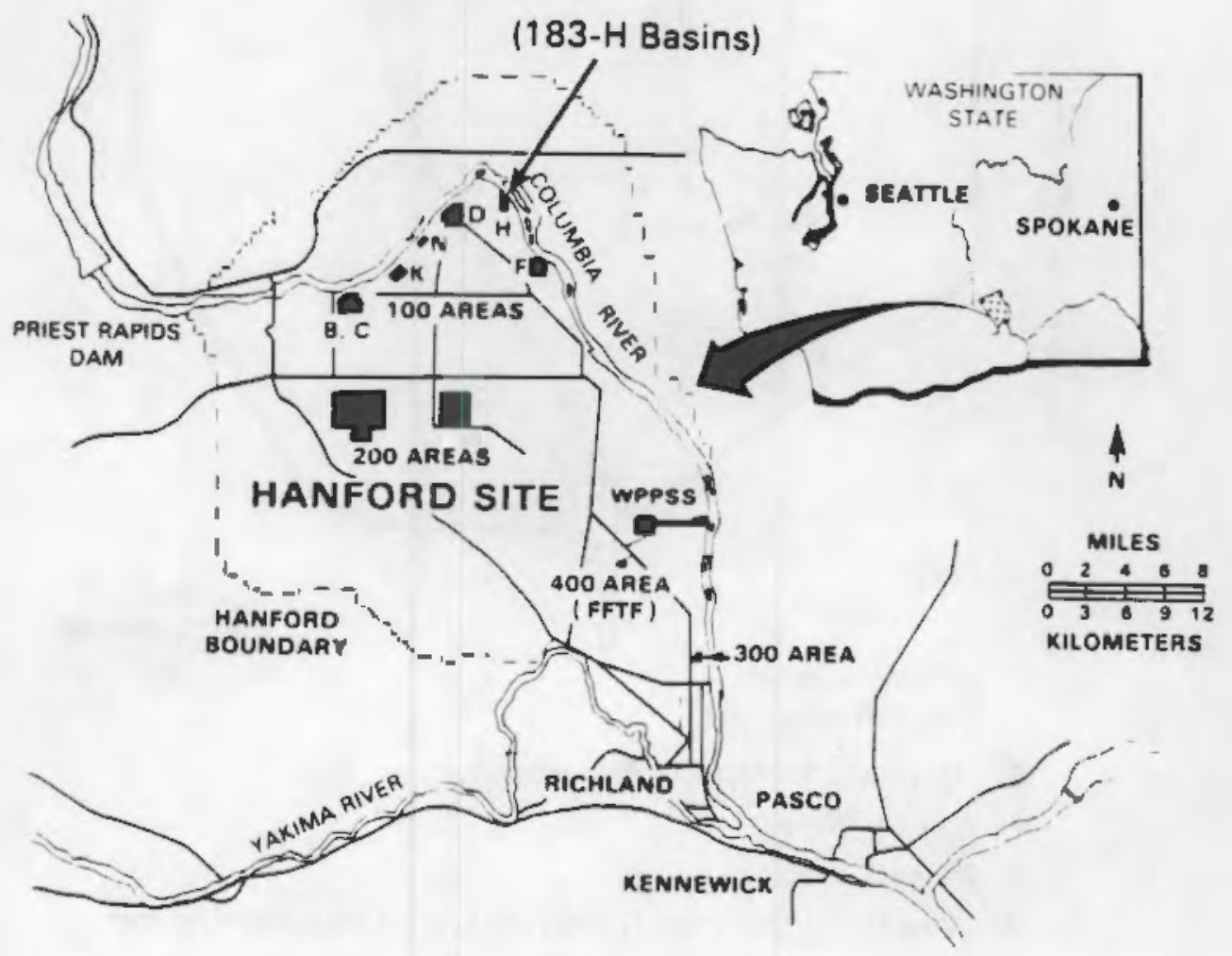

FIGURE 1. Location of the Hanford Site 


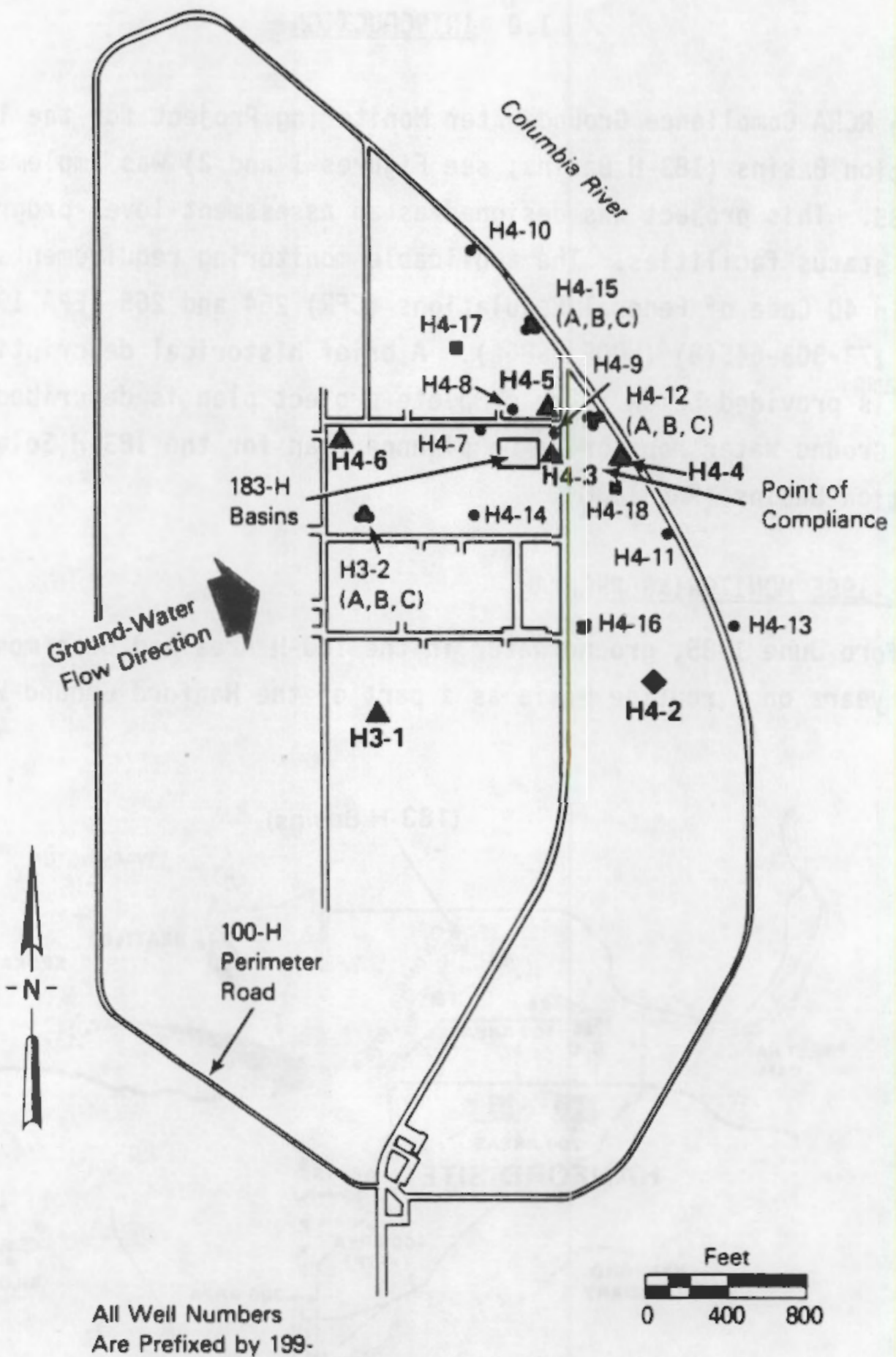

$\Delta$ Original Monitoring Network

- Phase II Wells

- Phase III Weils

- Well Used Only for Geohydrologic Characterization

FIGURE 2. Locations of the Original Monitoring Wells 
Monitoring Project. A network of five wells (199-H3-1, 199-H4-3, 199-H4-4, 199-H4-5, and 199-H4-6) was used by that project to monitor the unconfined aquifer. Another well, 199-H4-2, was drilled into basalt in 1952. Data from this well were used only for geohydrologic characterization activities. The locations of these six wells relative to the $183-\mathrm{H}$ Basins and the general direction of ground-water flow are shown in Figure 2.

Shortly after completion in 1974, sampling of Well 199-H4-3 began. Continued sampling and review of the analytical data accumulated through 1978 revealed that nitrate and chromium levels in this well were increasing. Evaluation of the data indicated that Basin \#1, which was the only basin in use at the time, was the apparent source of the ground-water contamination. As shown in Figures 3 and 4 , the concentrations of nitrate and chromium in this well peaked in 1978.

\subsection{INTERIM STATUS MONITORING PROGRAM}

In February 1985, detailed plans for an interim status ground-water monitoring project for the $183-\mathrm{H}$ Basins were developed. This facilityspecific effort was designed 1) to collect additional site-specific geohydrologic data needed to more fully characterize the 100-H Area and support decisions concerning the monitoring network for the 183-H Basins, and 2) to conduct an expanded sampling and analysis effort to determine both the extent of contamination originating from the basins and the rate of contaminant movement.

Three phases were defined for this project, with work concentrated in five areas: geology, hydrology, geochemistry, ground-water modeling, and ground-water monitoring. Phase I of the project was initiated in June 1985, with 1) the development of a sampling program for the existing wells, 2) the development of a ground-water flow model, and 3) the compilation of all available data into the Revised Ground-Water Monitoring Compliance Plan for the 1B3-H Solar Evaporation Basins (PNL 1986). In Phase II of the project, the sampling program was expanded with the installation of 16 wells (Figure 5), and the Interim Characterization Report for the Area Surrounding the 183-H Basins (PNL 1987) was completed. Three additional wells were installed 


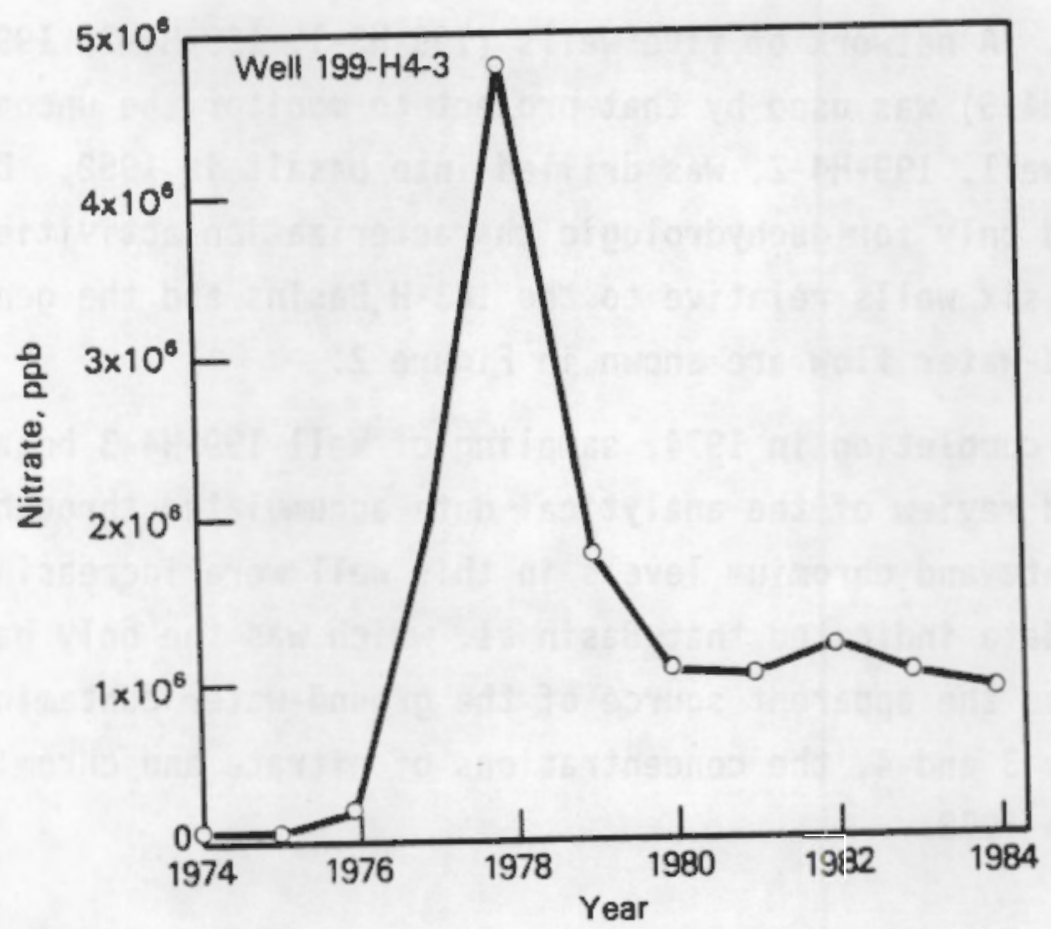

FIGURE 3. Annual Average Concentrations of Nitrate in Well 199-H4-3

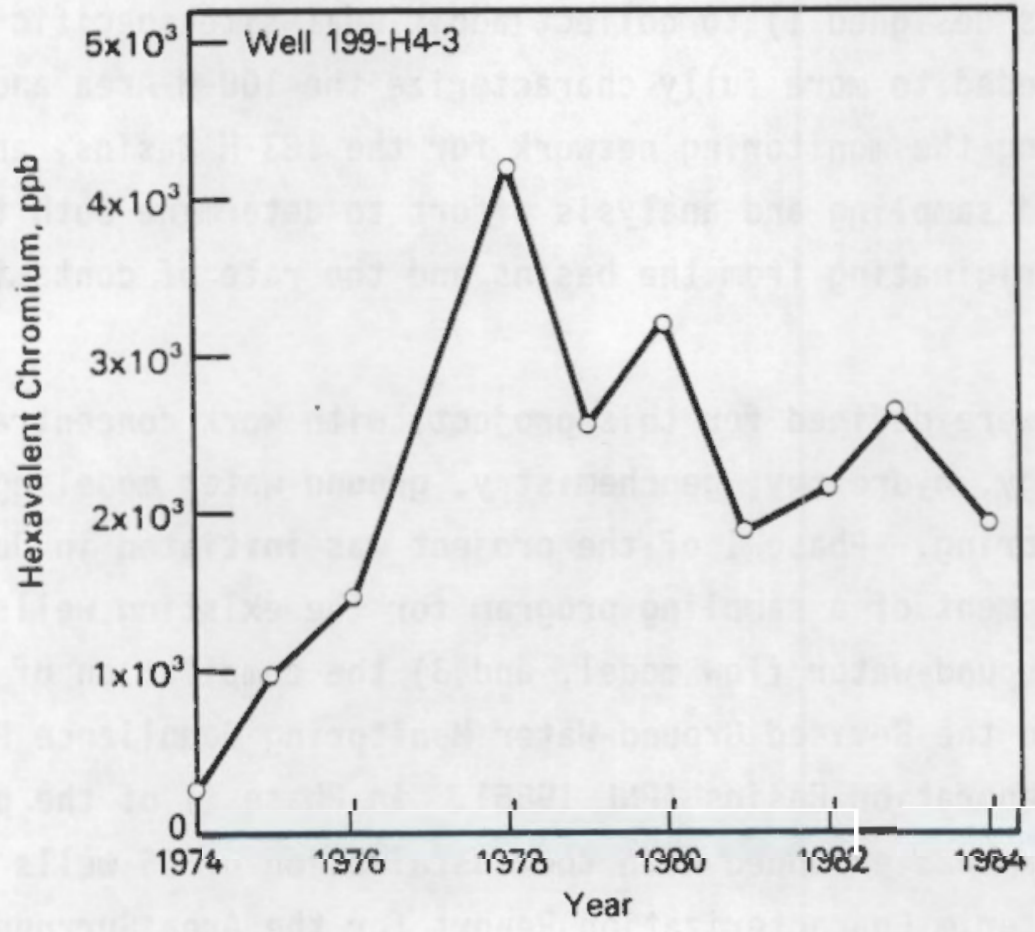

FIGURE 4. Annual Average Concentrations of Chromium in Well 199-H4-3 


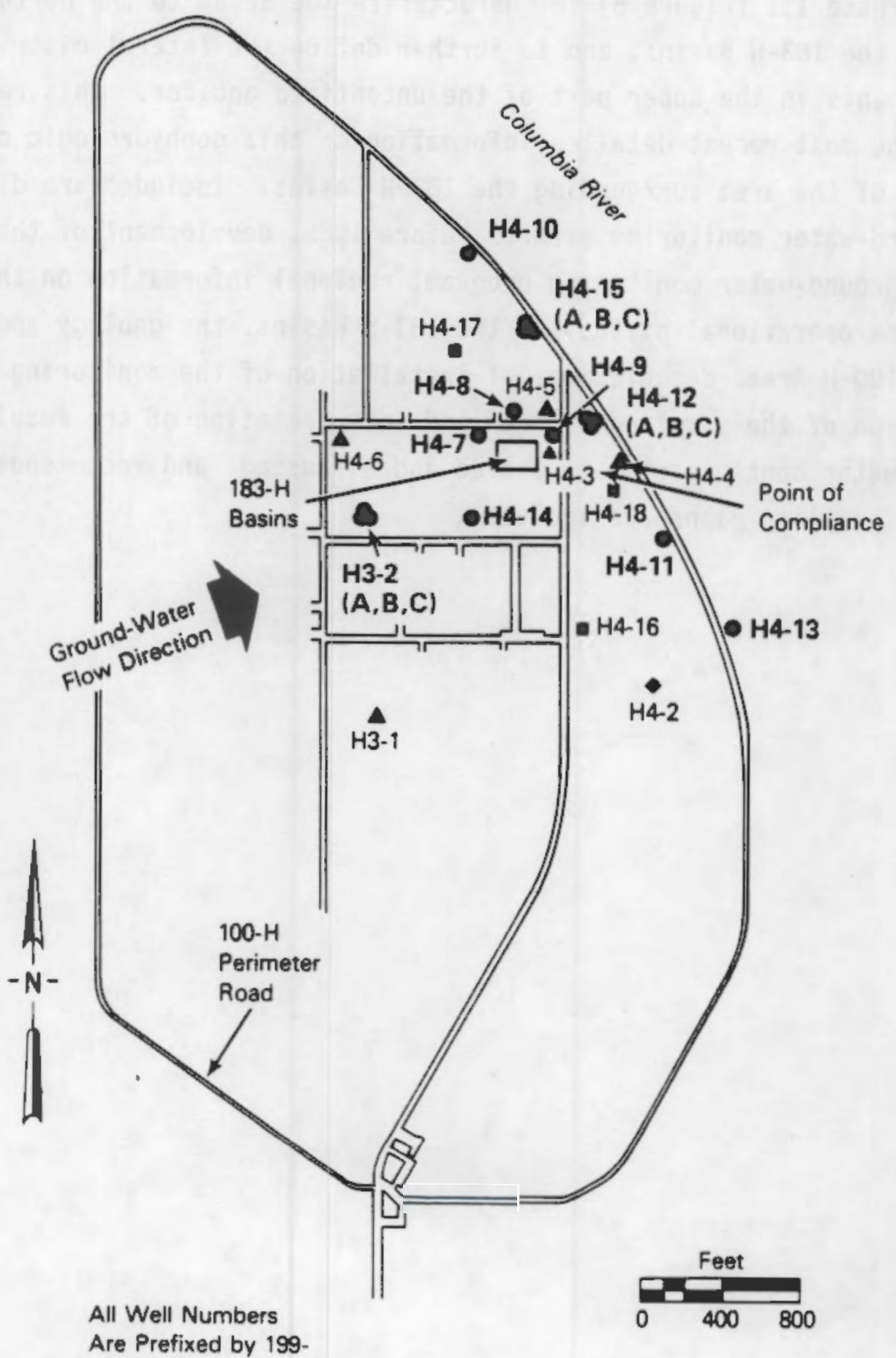

- Original Monitoring Nerwork

- Phase II Welis

- Phase III Wells

- Well Used only for Geohydrologic Characterization

FIGURE 5. Locations of the Phase II Wells 
during Phase III (Figure 6) to characterize the areas to the north and southeast of the 183-H Basins, and to further define the lateral distribution of contaminants in the upper part of the unconfined aquifer. This report contains the most recent detailed information on this geohydrologic characterization of the area surrounding the 183-H Basins. Included are discussions of ground-water monitoring efforts before 1985, development of the interim status ground-water monitoring program, regional information on the Hanford Site, the operational history of the 183-H Basins, the geology and hydrology of the 100-H Area, descriptions of installation of the monitoring wells, and the design of the sampling program and interpretation of the results. Ground-water contaminants are tabled and discussed, and recommendations for further sampling $\mathrm{plans}$ are included. 


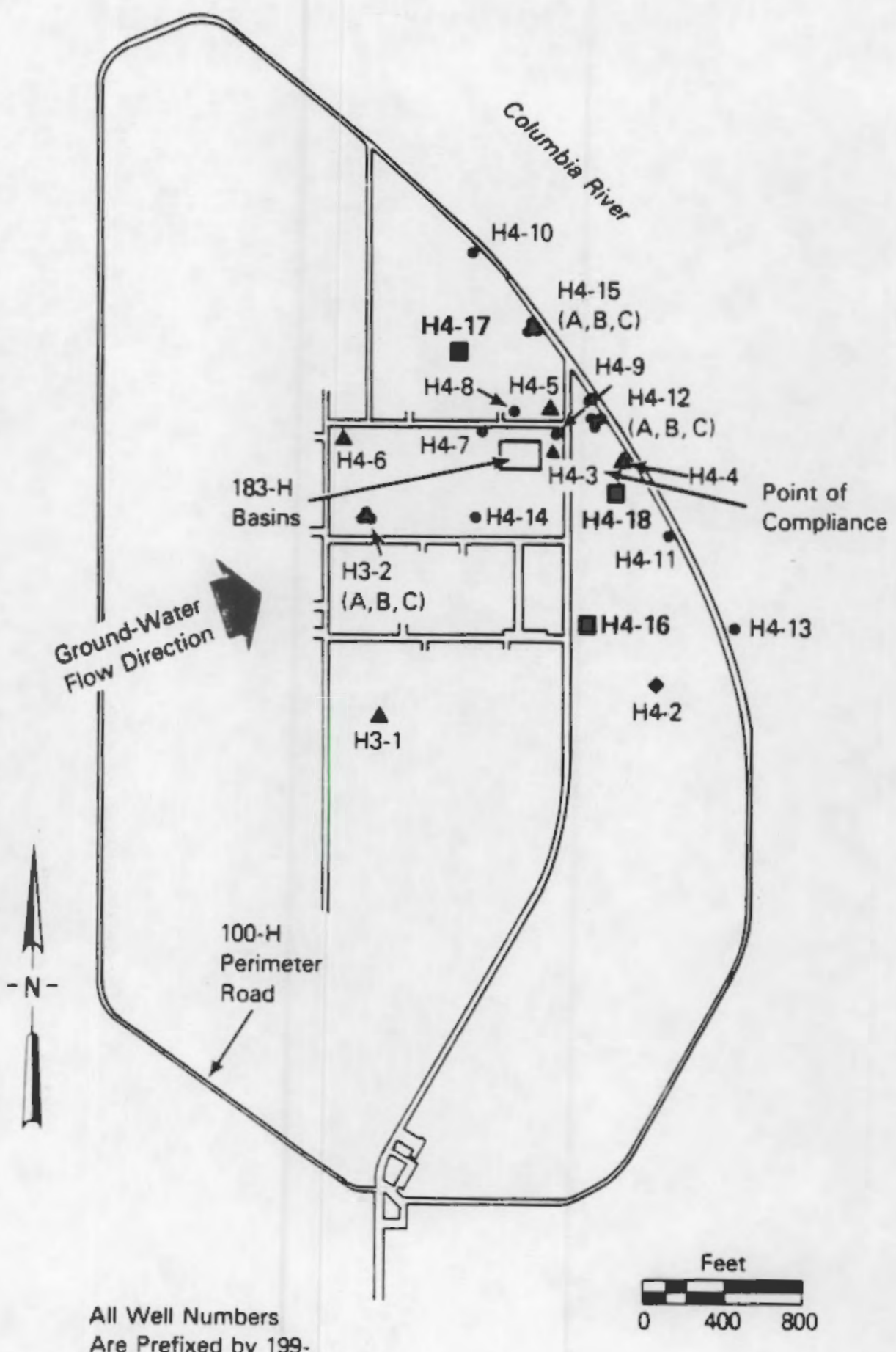

- Original Monitoring Network

- Phase II Weils

- Phase III Wells

- Well Used only for Geohydrologic Characterization

FIGURE 6 . Locations of the Phase III Wells 

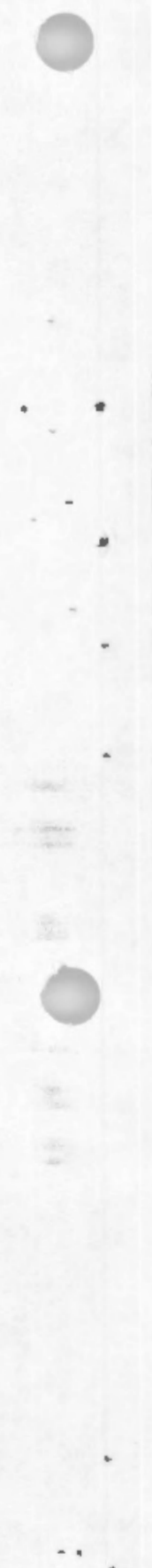

$-1$

$\bullet$ 


\subsection{BACKGROUND}

This section of the report provides background information on the regional physiography and geohydrology of the Hanford Site. Descriptions of the 183-H Basins, waste management activities, and waste characterization are a) so included.

\subsection{REGIONAL PHYSIOGRAPHY AND GEOHYDROLOGY}

The Hanford Site is located in a semiarid region of south-central Washington State within the Pasco Basin (Figure 1). The site occupies an area of approximately $560 \mathrm{mi}^{2}$ and is used for reactor and fuel processing operations, waste storage, and waste disposal. The adjacent lands to the west, north, and east are primarily range and agricultural lands. The Tri-Cities (Richland, Kennewick, and Pasco) comprise the nearest population center and are located approximately $5 \mathrm{mi}$ southeast of the Site.

The Hanford Site overlies the structural low point of the Pasco Basin and is bounded to the southwest, west, and north by large anticlinal ridges (Figure 7). These basaltic ridges trend to the east and southeast from the Cascade Mountains. The Site is bounded to the north and east by the Columbia River and Ringold bluffs and to the south by the Yakima River.

The elevations of the Hanford Site vary from $3583 \mathrm{ft}$ above mean sea level (msl) on Rattlesnake Mountain at the southwestern border of the Site to $345 \mathrm{ft}$ above ms 1 in the southeast corner of the Site near the 300 Area.

\subsubsection{Climate of the Hanford Site}

The climate of the Hanford Site is greatly affected by the Cascade Mountains to the west (Stone et a1. 1983). The site is located in the rain shadow formed by the mountains. The average annual precipitation on the Hanford Site ranges from less than 7 in. at the Hanford Meteorological Station near the 200 Areas to slightly more than 15 in. atop Rattlesnake Mountain at the southwest border of the site (Gephart et al. 1979). More than $30 \%$ of this precipitation occurs in November, December, and January, 


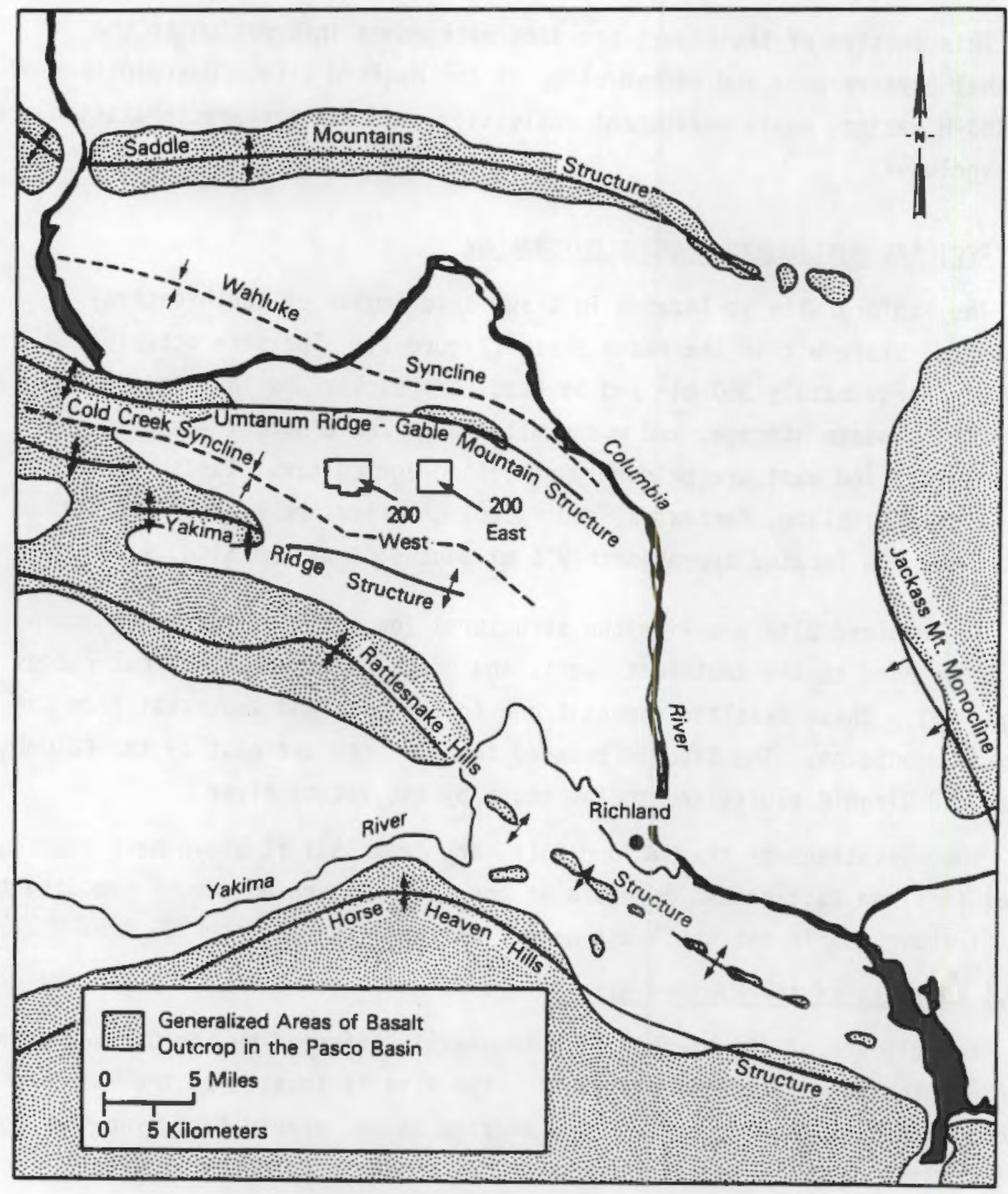

FIGURE 7. Structural Geology of the Pasco Basin (modified from DOE 1984) 
with $38 \%$ of the precipitation from December to February occurring in the form of snow (Stone et al. 1983).

The wind at the Hanford Site is controlled in a large part by the Cascade Range, which serves as a source of cold air drainage. With the added effects of topographic channeling, average hourly wind speeds in June can vary from 5 to $13 \mathrm{mi} / \mathrm{h}$ during the day. The hourly average wind speeds for days in January are about $6 \mathrm{mi} / \mathrm{h}$. Temperatures at the Hanford Site can vary greatly, with winter minima ranging from $-27^{\circ}$ to $+22^{\circ} \mathrm{F}$ and summer maxima ranging from $100^{\circ}$ to $115^{\circ} \mathrm{F}$ (Stone et al. 1983). Winters are generally mild, and summers are hot.

\subsubsection{Geology of the Hanford Site}

The principal geologic units beneath the Hanford Site are, in ascending order: the Columbia River Basalt Group with interbeds of the Ellensburg Formation, the Ringold Formation, the Plio-Pleistocene Unit (early "Palouse" soi1), and the Hanford formation. Local1y, Pleistocene/Holocene alluvium, colluvium, and eolian deposits veneer the surface. A generalized geologic cross section of the Site is shown in Figure 8 . A summary of the major stratigraphic units present in the Pasco Basin is shown in Figure 9.

Columbia River Basalt Group -- The tholeiitic flood basalts of the Columbia River Basalt Group form the bedrock of the Pasco Basin. This thick sequence of basalt was formed between 6 and 17 million years before present (mybp) when large volumes of lava erupted from fissures in the southeastern portion of the Columbia Plateau. The Columbia River Basalt Group is subdivided into five formations (Ledgerwood et al. 1978; Swanson et al. 1979) and consists of more than $48,000 \mathrm{mi}^{3}$ of basalt covering more than $59,900 \mathrm{mi}^{2}$. Beneath the Pasco Basin, this basalt sequence may be as much as $14,000 \mathrm{ft}$ thick. Flows of the Columbia River Basalt Group are interbedded with and overlain by Miocene-Pliocene epiclastic and volcaniclastic sediments of the Ellensburg Formation (Myers and Price et al. 1979).

Ringold Formation -- Following cessation of the Columbia River Basalt volcanism, sediments of the Ringold Formation accumulated in the Pasco Basin. 


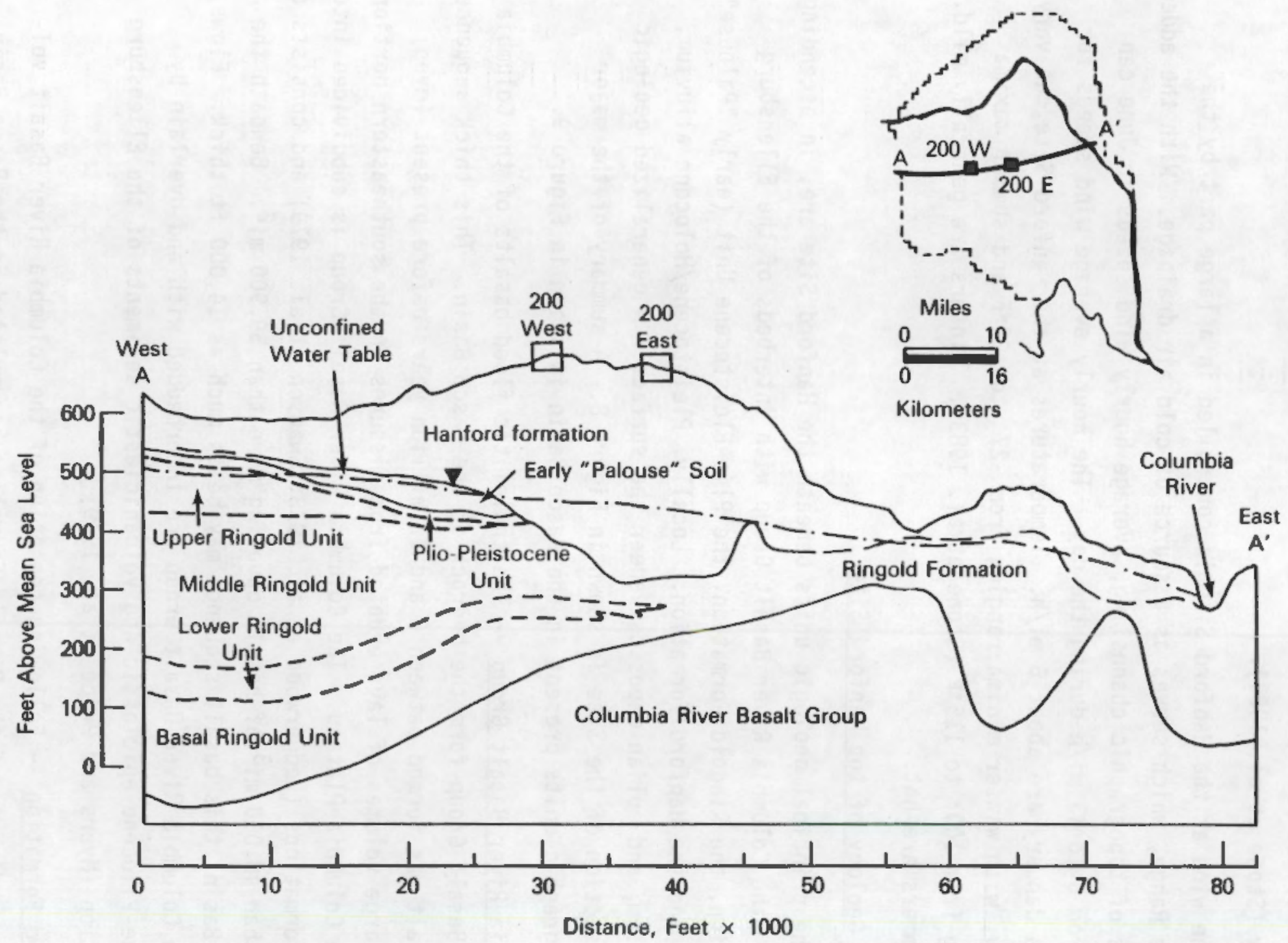

FIGURE 8. Generalized Geologic Cross Section of the Hanford Site (Tallman et al. 1979) 


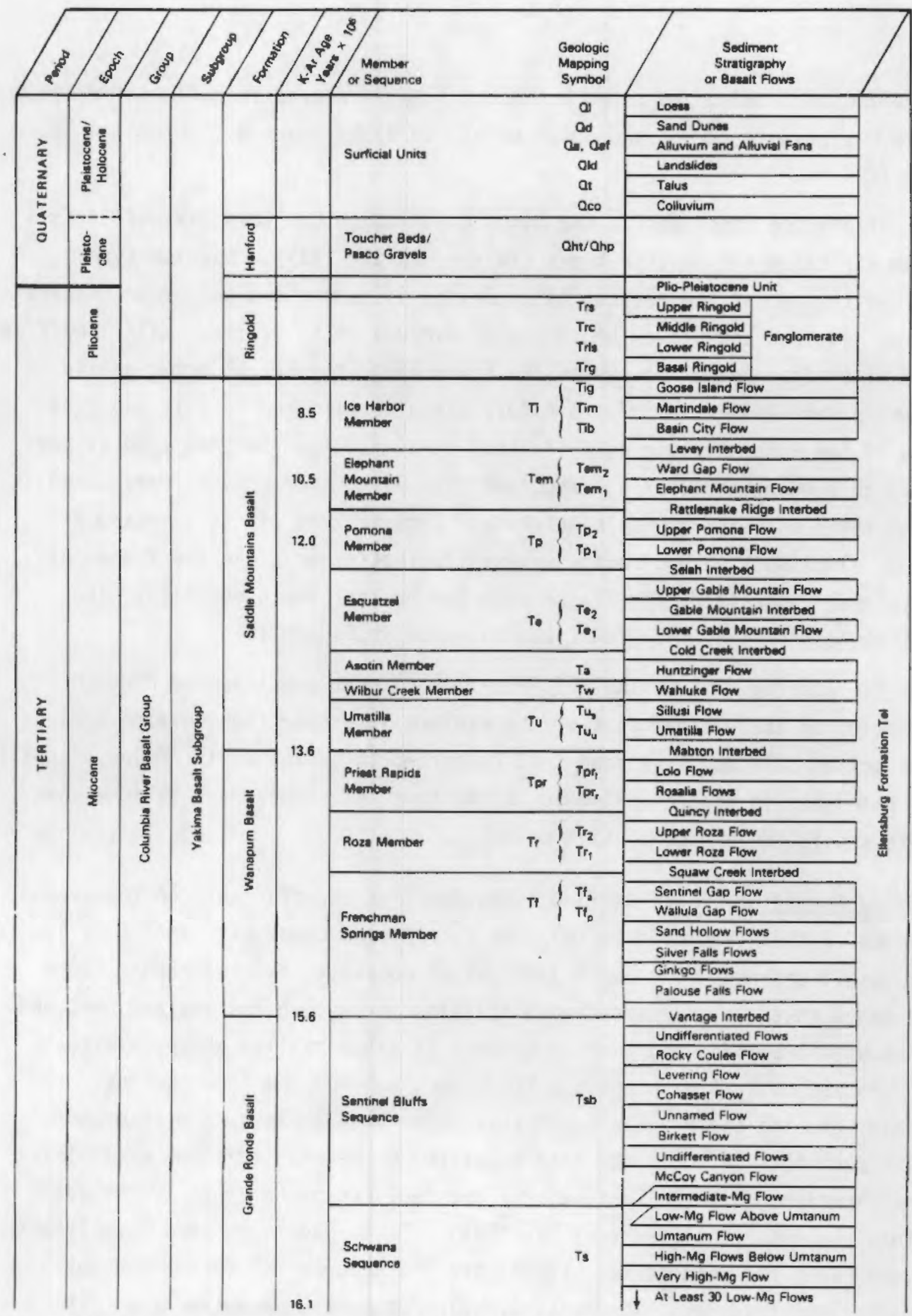

FIGURE 9. Stratigraphic Units Present in the Pasco Basin (after Reidel and Fecht 1981) 
These sediments were deposited between 8.5 and 3.7 mybp in a fluvial/flood plain environment (Myers and Price et al. 1979) to reach a thickness of more than $1200 \mathrm{ft}$.

Within the Pasco Basin, the Ringold Formation has been classified into three stratigraphic section types (Tallman et al. 1981). Section type I, located throughout the central Pasco Basin, is subdivided into four textural units: 1) sand and gravel of the basal Ringold unit; 2) clay, silt, and fine sand with minor gravel lenses of the lower Ringold unit; 3) occasionally cemented sand and gravel of the middle Ringold unit; and 4) silt and fine sand of the upper Ringold unit (Tallman et al. 1981). Section type II consists of predominantly silt, sand, and clay with minor gravel lenses, and is found north and east of Gable Mountain. Section type III is composed of talus, slope wash, and sidestream deposits that occur along the flanks of anticlinal ridges and interfinger with the central basin deposits. The distribution of these section types is shown in Figure 10.

Plio-Pleistocene Unit -- The Plio-Pleistocene unit overlies the Ringold Formation in the western part of the Hanford Site near the 200-West Area. This eolian silt and fine sand unit (referred to as the early "Palouse" soil) was deposited as reworked Ringold sediments. Relatively high caliche contents are found in much of this unit.

Hanford Formation -- The Hanford formation lies unconformably on the eroded surface of the Ringold Formation, the Plio-Pleistocene unit, and, locally, the basait bedrock. The Hanford formation consists of catastrophic flood sediments that were deposited when ice dams in western Montana and northern Idaho were breached, and massive volumes of water spilled abruptly across eastern and central Washington. The floods scoured the land surface, locally eroding the Ringold Formation, upper basalt flows, and interbeds. Thick sequences of sediments were deposited by several episodes of Pleistocene flooding, with the last major flood sequence dated about 12,000 years before present (ybp) (Fecht et al. 1985). These sediments have locally been divided into two main facies, termed the "Pasco Gravels" facies and the "Touchet Beds" facies. The Pasco Gravels facies are composed of poorly sorted gravels and coarse sand indicative of a high-energy depositional 


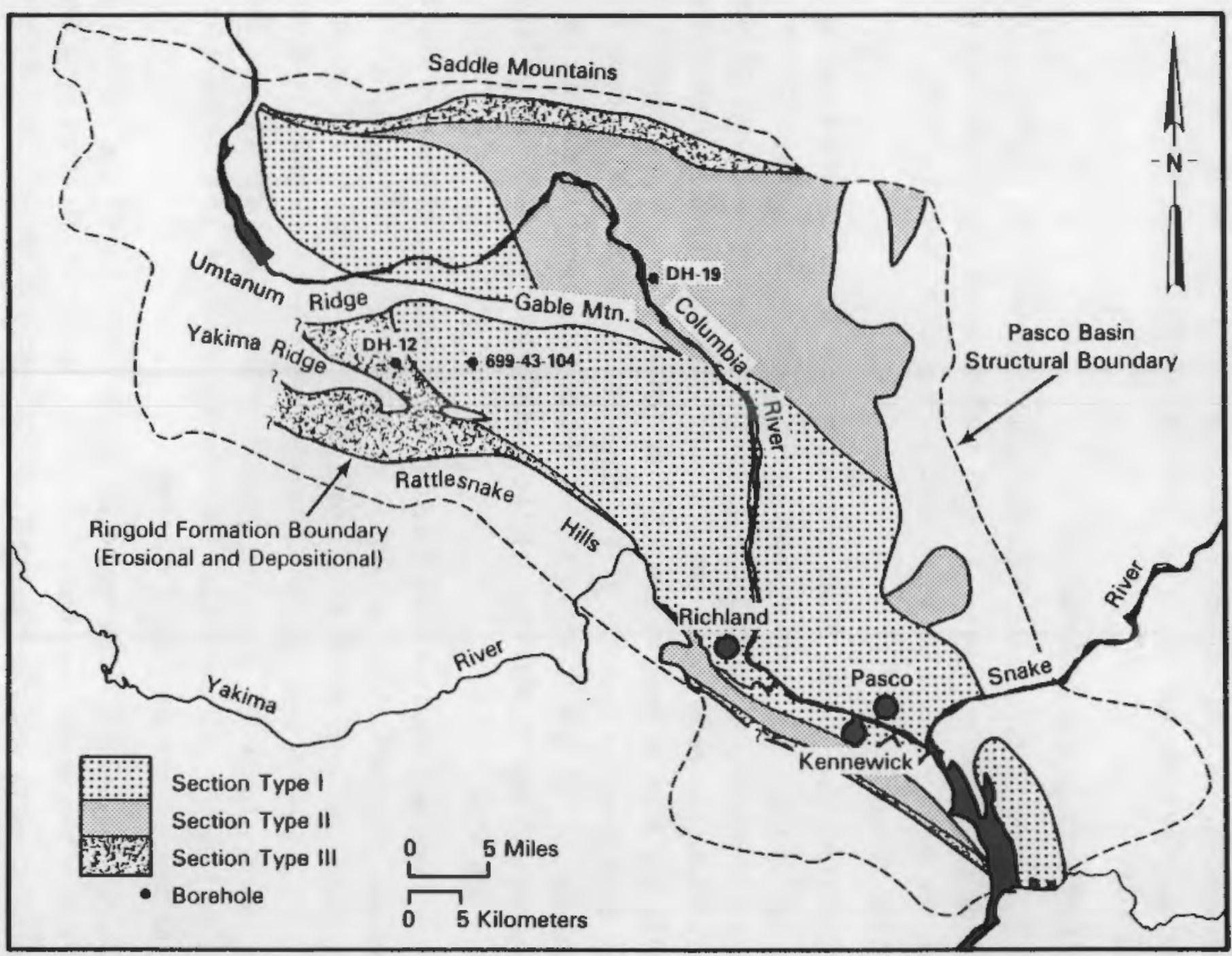

FIGURE 10. Distribution of the Ringold Formation Section Types (after Tallman et al. 1981) 
environment. The Touchet Beds facies consist of rhythmically bedded sequences of graded silt, sand, and minor gravel units (Myers and Price et al. 1979). These sediments are limited to areas where slack-water conditions existed. Eolian sediments, consisting of loess, active and inactive sand dunes, alluvium, and colluvium, locally veneer the surface of the Hanford Site.

\subsubsection{Hydrology of the Hanford Site}

The primary surface-water features associated with the Hanford Site are the Columbia and Yakima rivers. Several surface ponds and ditches are present onsite and are generally associated with reactor fuel and waste processing activities.

Flow along the Hanford Reach of the Columbia River is controlled by Priest Rapids Dam. The average annual river flow in this area, based on 65 years of records, is about $110,000 \mathrm{ft}^{3} / \mathrm{s}$. Large-scale flooding of the Columbia River has occurred in the past, but the likelihood of such flooding recurring has been reduced by the construction of several flood control/water storage dams upstream from the Site. Normal Columbia River elevations within the Site range from $394 \mathrm{ft}$ above ms 1 at the northwestern boundary of the Site near Vernita to $341 \mathrm{ft}$ above $\mathrm{ms} 1$ at the southeastern boundary of the Site near the 300 Area.

Ground water beneath the Site occurs under both unconfined and confined conditions. The unconfined aquifer is contained predominantly within the silts, sands, and gravels of the Ringold Formation in the central Pasco Basin. To the north and east of Gable Mountain, the water table is found within the glaciofluvial sands and gravels of the Hanford formation. The basalt surface or, in some areas, the clay zones of the lower Ringold unit form the base of the unconfined aquifer.

Sources of natural recharge to the unconfined aquifer are rainfall and run-off from the higher bordering elevations, water infiltrating from small ephemeral streams, and river water aiong influent reaches of the Yakima and Columbia rivers. From the recharge areas to the west, the unconfined ground water flows primarily eastward to the discharge areas along the Columbia River (Figure 11). The general eastward flow is affected locally by the 


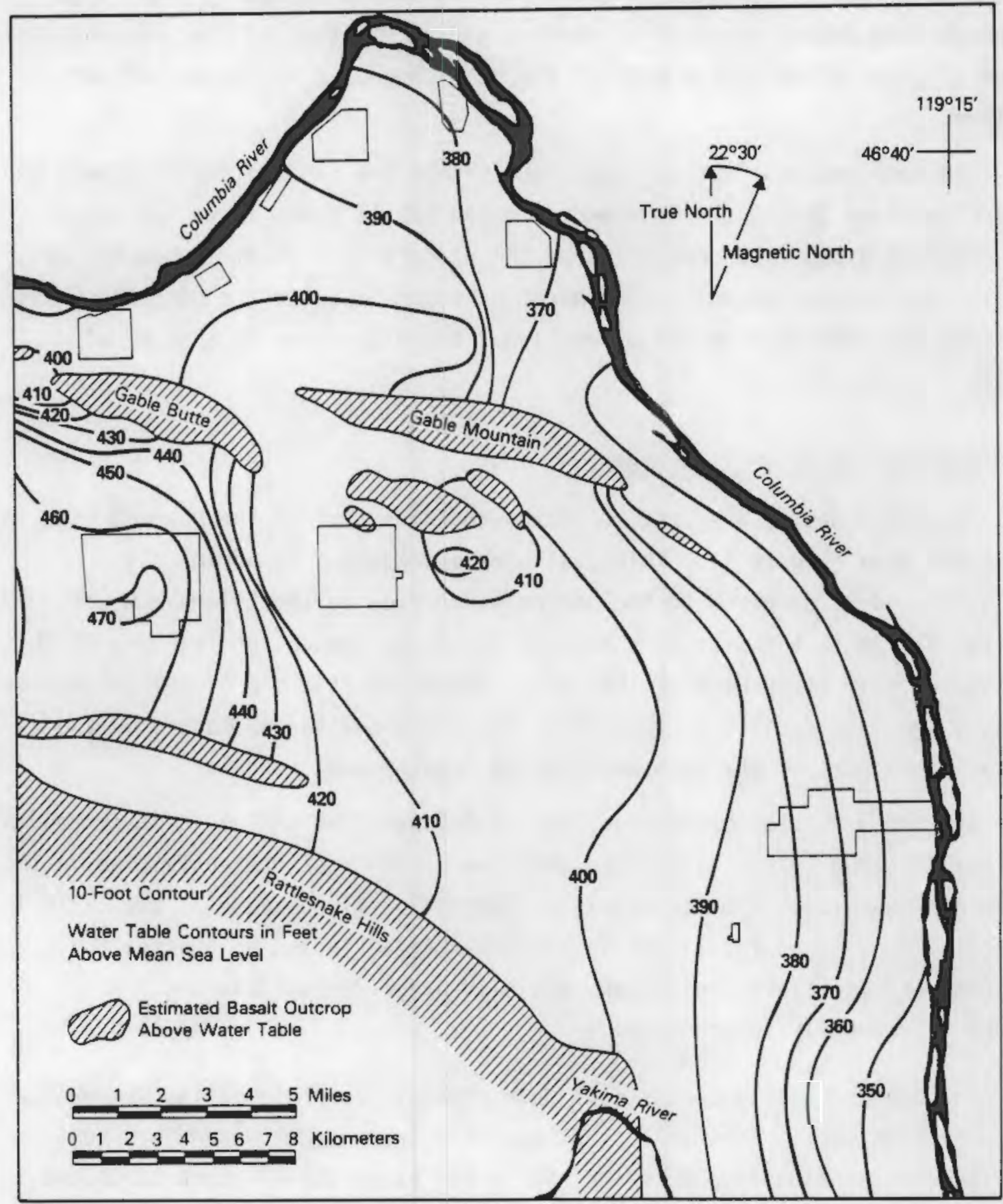

FIGURE 11. Water Table Elevations for June 1987 (from Schatz et al. 1987) 
ground-water mounds beneath the 200 Areas, which are caused by artificial recharge from onsite disposal of cooling water. This artificial recharge to disposal sites accounts for most of the total recharge to the unconfined aquifer.

The confined aquifers are contained within the sedimentary interbeds and interflow zones that occur between the dense basalt flows in the Columbia River Basalt Group. In some areas of the Hanford Site (i.e., Gable Mountain Pond), significant hydraulic communication occurs between the unconfined and confined aquifers as a result of erosional unconformities (Graham et al. 1984).

\subsection{DESCRIPTION OF THE $183-H$ BASINS}

The 183-H Basins are located in the northern part of the Hanford Site in the 100-H Area (Figure 1). This oval area encompasses approximately 320 acres and is bordered on the northeastern side by the Columbia River. The 100-H Area is the site of a retired plutonium-production reactor, which is located near the center of the area. Figure 12 is a map of the $100-\mathrm{H}$ Area showing the main facilities, including the 183-H Basins, which are in the northeastern part of the area between the reactor and the river.

The 100-H Reactor began operating in October 1949 and was deactivated in April 1965 (ERDA 1975). Since the shutdown of the reactor, activities in the 100-H Area have been limited mainly to storage of mixed waste at the $183-\mathrm{H}$ Basins. The retired facilities in the $100-\mathrm{H}$ Area, including the reactor building and ancillary facilities, are slated for decommissioning. This effort is currently in progress.

The 183-H facility consists of four separate concrete basins surrounded by an earthen berm. Figure 13 is a schematic cross section showing the facility's dimensions and relationship to the water table. Each basin consists of a flocculator basin (shallow section) and a subsidence basin (deep section), as shown in the plan view of the facility in Figure 14. The concrete floor is $6 \mathrm{in}$. thick in the subsidence basin and $10 \mathrm{in.}$ thick in the 


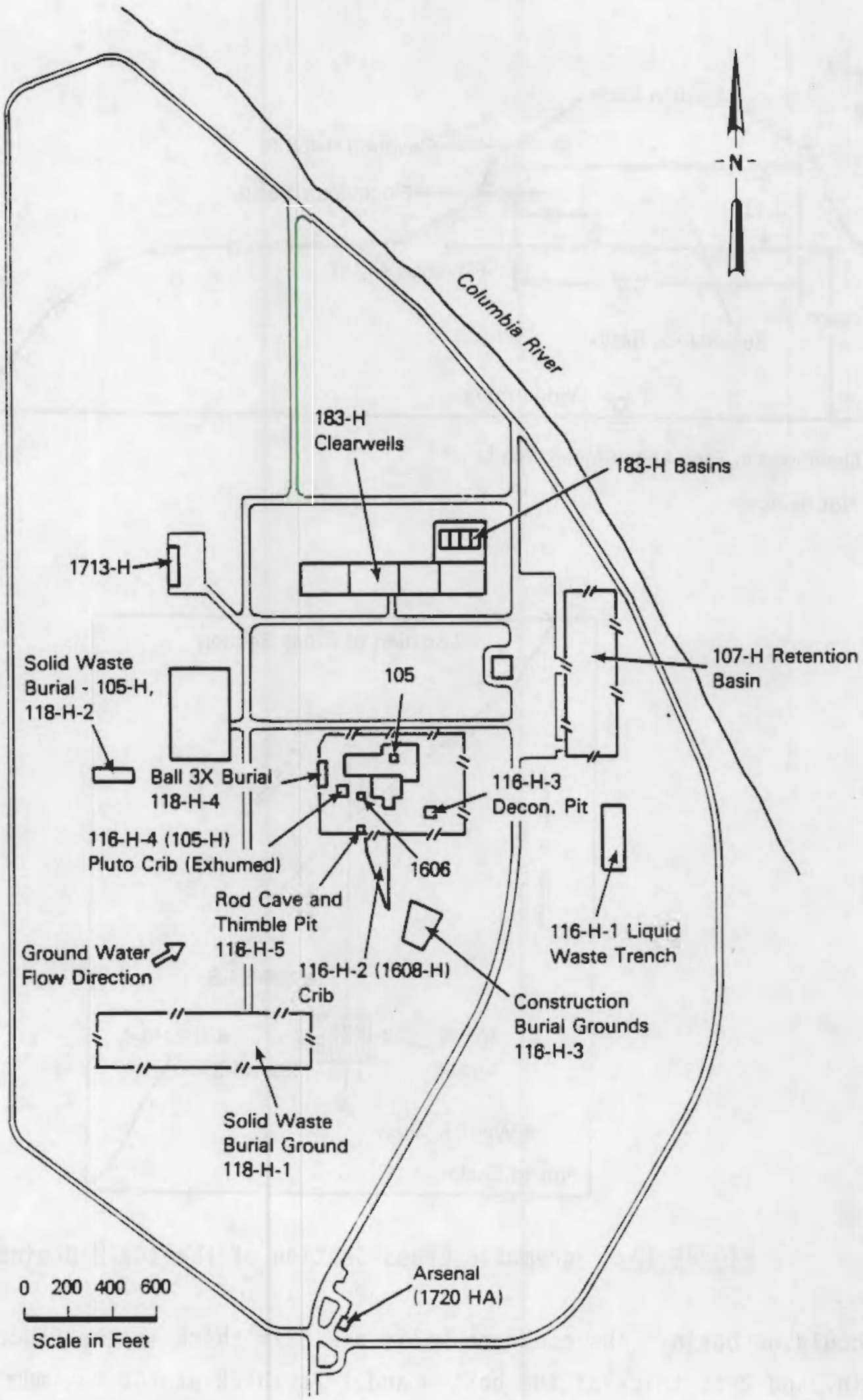

FIGURE 12. 100-H Area Map 


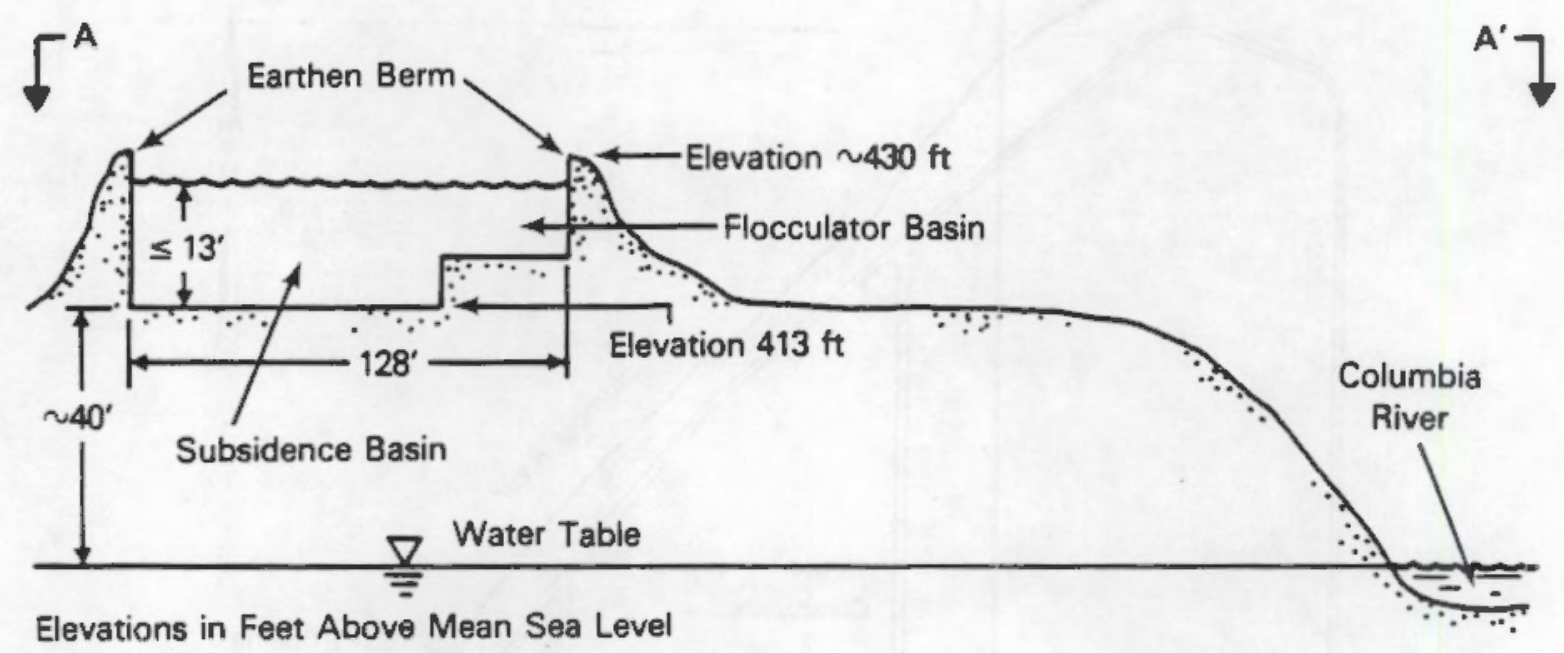

Not to Scale

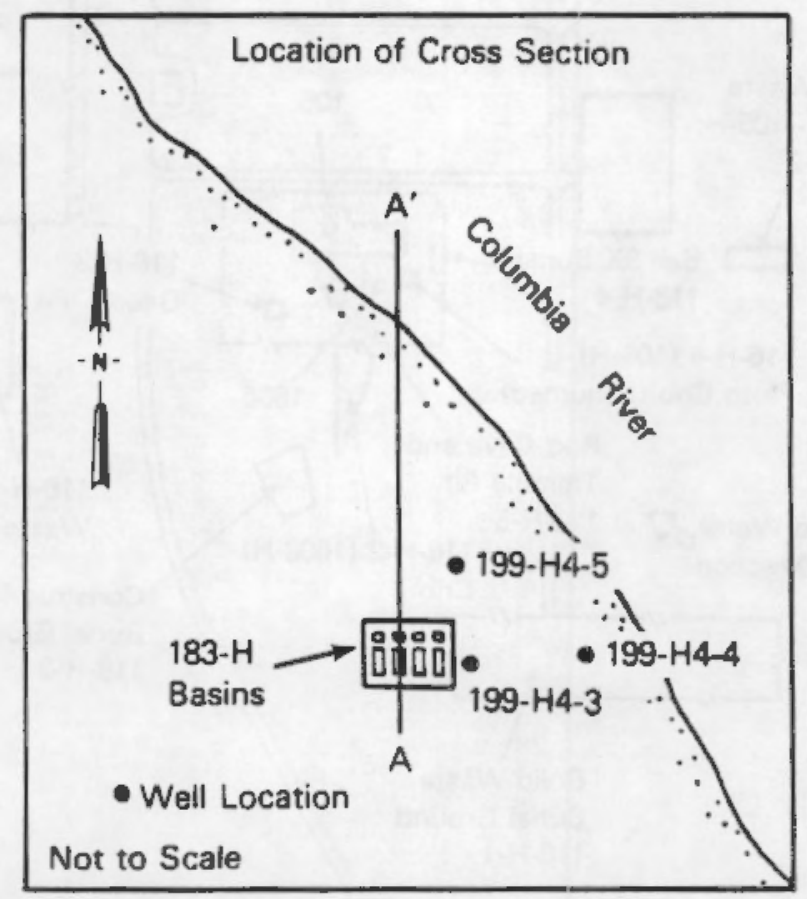

FIGURE 13. Schematic Cross Section of the 183-H Basins

flocculator basin. The concrete walls are $1 \mathrm{ft}$ thick in the flocculator basin, and $2 \mathrm{ft}$ thick at the bottom and $1 \mathrm{ft}$ thick at the maximum $\mathrm{fill}$ level in the subsidence basin. 


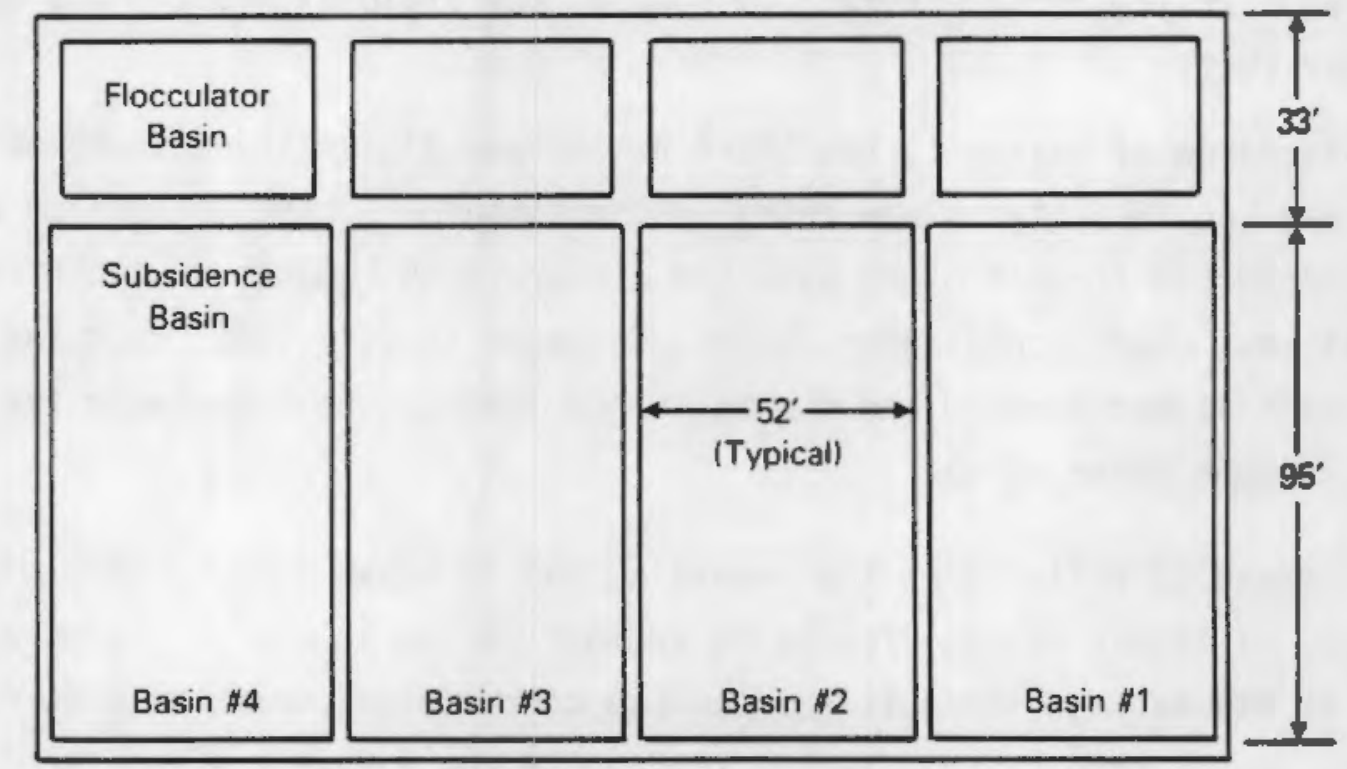

FIGURE 14. Plan View of the 183-H Basins (from Greager 1982)

\subsection{OPERATIONAL HISTORY OF THE 183-H BASINS}

From 1943 to 1964 , the $183-\mathrm{H}$ Basins were used as flocculator/subsidence basins for the $100-\mathrm{H}$ water treatment plant. The basins were inactive unti] 1973, when they were designated for use as evaporation basins for storage and treatment of waste solutions from the 300 Area fuel fabrication facility. At that time, the basins were modified by permanently plugging the drains with concrete and installing a pipeline for filling the basins (Greager 1982).

Mixed wastes from the 300 Area fuel fabrication facilities were first discharged to basin \#1 in June 1973. After 2 months of service, use of the basin was postponed for more than a year because of operational problems in the 300 Area. Use of basin \#1 was resumed in January 1975, but was discontinued again in August 1978, after nitrate contamination, was discovered in the ground water in well 199-H4-3, and was attributed to seepage of wastes from this unlined basin (Figure 3 ). Basins $\# 2$ and \#3 were prepared for use by coating the walls and floors with urethane. Basin \#1 was permanently removed from service, and the liquid wastes were pumped to basins \#2 and \#3, leaving a sludge. Filling of these two basins to capacity led to use of 
basin \#4 starting in late 1982 . This basin was lined with butyl and hypalon (Greager 1982).

Discharge of wastes to the 183-H Basins was discontinued in November 1985, and the facility is now being decommissioned. These activities are being conducted in accordance with the closure requirements of the RCRA regulations. The decommissioning process began in July 1985, when the sludge from basin \#1 was removed and the walls and floors were decontaminated with a high-pressure water spray.

Removal of wastes from the remaining basins began in July 1986 with the transfer of liquid wastes from basin \#2 into basins \#3 and \#4. Sludge from basin \#2 was packaged into 55-gal painted carbon steel drums with 90-mil liners, and shipped to retrievable storage in the 200-West Area. Depth of wastes in each of these three basins before removal was 7 to $8 \mathrm{ft}$, for an estimated total of 620,000 gal of liquid and $36,000 \mathrm{ft}^{3}$ of solid material. This work was completed in September 1986. The walls and floors of basin \#2 were cleaned with an air-water lance. A cement-mortar mixture was used to grout existing piping and patch the walls and floors.

In October 1986, a 36-mil hypalon liner was installed in basin \#2, and the liquid wastes from basins \#3 and \#4, approximately 498,800 gal, were then pumped into basin \#2. Sludge from basin \#3 was packaged into 55-gal galvanized steel drums with 90-mil liners, and shipped to retrievable storage in the 200-West Area. A 36-mil hypalon liner was then installed in basin \#3. This work was completed in October 1987.

$\mathrm{Pl}$ ans for the remainder of the waste-removal process include removing the sludge from basin \#4. The liquid wastes will then be distributed equally into basins \#2 and \#3 to evaporate or be disposed of offsite.

\subsection{WASTE CHARACTERIZATION}

The primary wastes discharged to the $183-\mathrm{H}$ Basins were acid solutions $\left(\mathrm{HNO}_{3}, \mathrm{H}_{2} \mathrm{SO}_{4}, \mathrm{HF}\right.$, and $\mathrm{H}_{2} \mathrm{CrO}_{4}$ ) neutralized with sodium hydroxide $(\mathrm{NaOH})$. These wastes were generated from routine operations in the 300 Area fuel fabrication facilities. Table 1 gives the quantities of selected materials 
TABLE 1. Quantities of Selected Materials Discharged to the 183-H Basins in 1985 (Rokkan 1986)

\begin{tabular}{|c|c|}
\hline Material & Pounds \\
\hline Ammonium ion & 520 \\
\hline Fluoride ion & 27,000 \\
\hline Nitrate ion & 550,000 \\
\hline Chromium & 90 \\
\hline Copper & 49,000 \\
\hline Manganese & 200 \\
\hline Sulfate & 97,000 \\
\hline Uranium & 440 \\
\hline
\end{tabular}

discharged to the basins for the period January 1 through November 8, 1985 . These materials are also representative of waste solutions discharged before January 1,1985 . The annual discharge rate rose steadily to a maximum of 369,000 gal in 1985 (Rokkan 1986). The total volume of routine waste discharged to the $183-\mathrm{H}$ Basins since 1973 was 2,542,000 gal. In November 1985, all shipments of waste to the $183-\mathrm{H}$ Basins were halted.

The neutralized chemical waste contained high concentrations of nitrate and copper resulting from the use of nitric acid in the copper stripping procedures used in the fuel fabrication process. Chromium wastes, including hexavalent chromium $\left(\mathrm{Cr}^{6+}\right)$, were also discharged to the basin. Most of the hexavalent chromium was derived from the use of chromic acid in the fuel fabrication process. After 1983, hexavalent chromium was reduced to $\mathrm{Cr}^{3+}$ before disposal to the basins. Two other minor sources of chromium were derived from the etching of stainless steel by a hydrofluoric/nitric acid bath (mostly $\mathrm{Cr}^{3+}$ ) and from the disposal of approximately $300 \mathrm{gal} /$ year of various industrial solutions (Greager 1982).

Small quantities of other chemical wastes were also discharged to the 183-H Basins on a nonroutine basis. These wastes were required to be nonflammable, nonexplosive, and compatible with the fuel fabrication wastes before disposal was allowed. Constituents in these wastes included:

- cadmium and cadmium compounds

- copper and copper compounds

- oxalic acid 
- cyanide compounds

- mercury compounds

- barium perchlorate

- hydrazine

- chromium and chromium compounds

- vanadium pentoxide

- lead compounds

- nickel and nickel compounds.

Slurry samples from basin \#1 and solution samples from basin \#2 were collected and chemically characterized in October 1984 and November 1986, respectively. Characterization of these samples provided a detailed description of the wastes and identified potential ground-water contaminants associated with the 183-H Basins.

\subsubsection{Basin \#1 Sampling}

Seven randomly selected samples, five inner and two outer (Figure 15), were collected for analysis from basin \#1 using core tubes driven into the waste. The waste material within the core tube was then frozen with liquid nitrogen before removal. This procedure allowed observation of the stratification of each core. In general, the inner cores consisted of a hard crystalline surface layer, which softened into a high liquid content slurry; this was followed by another crystalline layer, then a thick black slurry to the bottom of the basin. The thickness of the inner cores ranged from approximately 14 to 28 in., depending on the sampling location. The slurry samples were separated into liquid and solid phases by centrifuging. Each phase was then submitted for chemical analysis (Vedder 1985).

The outer cores contained no liquid phase and consisted mostly of sodium sulfate with some bird droppings from swallows nesting in the basin. Similar analyses were performed on both the outer and inner samples. 


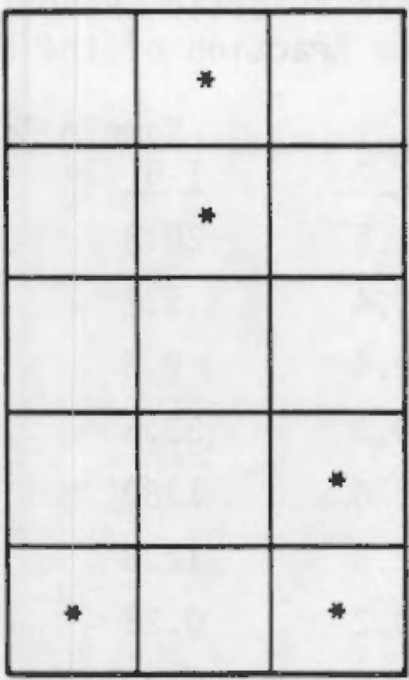

* Inner Samples Randomly Selected for Analysis

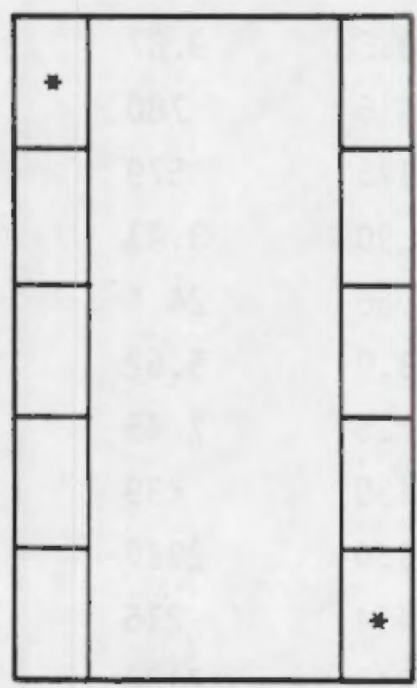

* Outer Samples Randomly Selected for Analysis

FIGURE 15. Sample Locations for Basin \#1

The results of radiological and chemical analyses performed on the solid and liquid phases of the homogenized waste core material from basin \#1, shown in Tabies 2 and 3 , respectively, indicate a wide variability in chemical composition among sampling locations. This variability is probably related to the operational history of the facility. As acidic solutions with various chemical constituents were neutralized with $\mathrm{NaOH}$ and discharged into the 
TABLE 2. Characterization Results for the Solid Waste Fraction of the Basin \#1 Slurry

\begin{tabular}{|c|c|c|c|c|c|c|}
\hline & & & Samn & dent if & inon & \\
\hline Component & Units & $I-2$ & $I-5$ & $\frac{1-12}{1-1}$ & $\frac{1-13}{1-13}$ & $\underline{I-15}$ \\
\hline $\mathrm{Na}$ & $\%$ & 23.5 & 20.3 & 18.8 & 19.5 & 17.7 \\
\hline $\mathrm{F}^{-}$ & $\%$ & 5.4 & 6.2 & 6.1 & 6.4 & 6.1 \\
\hline $\mathrm{NO}_{3}{ }^{-}$ & $\%$ & 10.4 & 9.6 & 7.4 & 6.9 & 6.1 \\
\hline $\mathrm{SO}_{4}{ }^{2-}$ & $\%$ & 19.8 & 23.5 & 20.3 & 19.7 & 17.7 \\
\hline $\mathrm{Cr}$ & $\mathrm{ppm}$ & 930 & 1380 & 1450 & 1280 & 1380 \\
\hline $\mathrm{Cu}$ & $\%$ & 12.6 & 12.8 & 12.7 & 11.2 & 10.0 \\
\hline $\mathrm{Fe}$ & $\%$ & 0.2 & 0.23 & 0.28 & 0.29 & 0.3 \\
\hline Mn & ppm & 1540 & 2130 & 2360 & 2190 & 2380 \\
\hline Mo & $\mathrm{ppm}$ & 189 & 338 & 364 & 396 & 419 \\
\hline $\mathrm{Ni}$ & $\mathrm{ppm}$ & 64 & 169 & 183 & 163 & 169 \\
\hline$S$ & $\%$ & 10.38 & 9.67 & 7.86 & 8.42 & 7.46 \\
\hline Sn & ppm & 516 & 780 & 902 & 925 & 943 \\
\hline$U$ & ppm & 375 & 579 & 678 & 685 & 647 \\
\hline $\mathrm{Zr}$ & $\%$ & 1.90 & 3.43 & 3.55 & 3.32 & 3.85 \\
\hline${ }^{60} \mathrm{Co}$ & $\mathrm{pCi} / \mathrm{g}$ & 1.56 & 24.5 & 28.2 & 12.1 & 22.1 \\
\hline${ }^{137} \mathrm{Cs}$ & $\mathrm{pCi} / \mathrm{g}$ & $<3.0$ & 5.62 & $<3.3$ & $<2.3$ & $<2.8$ \\
\hline $54 \mathrm{Mn}$ & $\mathrm{pCi} / \mathrm{g}$ & $<2.5$ & 7.45 & $<2.7$ & $<1.7$ & $<2.5$ \\
\hline${ }^{99} \mathrm{Tc}$ & $p C i / g$ & $<439$ & $<39$ & $<116$ & $<90$ & $<93$ \\
\hline $234 U$ & $\mathrm{pCi} / \mathrm{g}$ & 6960 & 2920 & 9030 & 5470 & 5900 \\
\hline $235 \mathrm{U}$ & $\mathrm{pCi} / \mathrm{g}$ & 454 & 216 & 602 & 409 & 401 \\
\hline $238 U$ & $\mathrm{pCi} / \mathrm{g}$ & 4940 & 2130 & 6390 & 3980 & 4170 \\
\hline
\end{tabular}

basin, several different chemical reactions occurred, resulting in the formation of precipitates both before and after disposal. The precipitates eventually settled to the bottom of the basin, forming several solid and slurry-like layers. In addition, the slurry samples from basin \#1 were collected after a 7 -year period of inactivity. During this time, substantial amounts of precipitates formed as solubility products were exceeded as a result of evaporation. 
IABLE 3. Characterization Results for the Liquid Waste Fraction of the Basin \#1 Slurry

Sample Identification

\begin{tabular}{|c|c|c|c|c|c|c|}
\hline Compo & $\underline{\text { Units }}$ & $I-2$ & $\mathrm{I}-5$ & $I-12$ & $\mathrm{I}-13$ & $I-15$ \\
\hline pH & -- & 9.53 & 9.32 & 9.54 & 9.66 & 9.71 \\
\hline $\mathrm{Na}$ & ppm & 130,000 & 134,000 & 92,000 & 92,000 & 86,000 \\
\hline $\mathrm{Br}$ & $\mathrm{ppm}$ & 87.9 & 78 & 68.9 & 69.8 & 67 \\
\hline $\mathrm{Cr}$ & $\mathrm{ppm}$ & 53 & 85 & 60 & 63 & 60 \\
\hline $\operatorname{Cr}(V I)$ & $\mathrm{ppm}$ & 50 & 81 & 57 & 60 & 54 \\
\hline $\mathrm{Cu}$ & $\mathrm{ppm}$ & 520 & 560 & 360 & 170 & 180 \\
\hline $\mathrm{Fe}$ & $\mathrm{ppm}$ & $<4.4$ & 13 & 8 & $<4.4$ & $<4.5$ \\
\hline $\mathrm{K}$ & $\mathrm{ppm}$ & 430 & 2,370 & 347 & 309 & 299 \\
\hline Mn & $\mathrm{ppm}$ & $<7.6$ & $<9.5$ & $<8.4$ & $<7.2$ & $<7.9$ \\
\hline Mo & $\mathrm{ppm}$ & 11.9 & 11 & 9.4 & $<7.9$ & $<7.6$ \\
\hline $\mathrm{Ni}$ & $\mathrm{ppm}$ & 17 & 19 & 15 & 17 & 16 \\
\hline$S$ & $\mathrm{ppm}$ & 3,600 & 9,290 & 8,280 & 9,270 & 10,170 \\
\hline Sn & $\mathrm{ppm}$ & $<5.6$ & $<5.3$ & $<6.1$ & $<5.9$ & $<6.1$ \\
\hline U & ppm & 662 & 628 & 619 & 684 & 673 \\
\hline $\mathrm{Zr}$ & $\mathrm{ppm}$ & 520 & 560 & 360 & 280 & 170 \\
\hline$F^{-}$ & $\mathrm{ppm}$ & 2,700 & 2,700 & 4,100 & 5,100 & 5,100 \\
\hline $\mathrm{Cl}^{-}$ & $\mathrm{ppm}$ & 900 & 800 & 600 & 600 & 500 \\
\hline $\mathrm{NO}_{3}^{-}$ & $\mathrm{ppm}$ & 280,000 & 290,000 & 180,000 & 190,000 & 160,000 \\
\hline $\mathrm{SO}_{4}{ }^{2-}$ & $\mathrm{ppm}$ & 13,000 & 20,000 & 24,000 & 28,000 & 31,000 \\
\hline${ }^{60} \mathrm{Co}$ & $\mathrm{pCi} / \mathrm{L}$ & 473 & $<270$ & $<180$ & $<270$ & $<180$ \\
\hline${ }^{137}$ Cs & $\mathrm{pCi} / \mathrm{L}$ & $<90$ & $<180$ & $<135$ & $<180$ & $<135$ \\
\hline $54 \mathrm{Mn}$ & $\mathrm{pCi} / \mathrm{L}$ & $<90$ & $<180$ & $<135$ & $<180$ & $<135$ \\
\hline${ }^{99} \mathrm{Tc}$ & $\mathrm{pCi} / \mathrm{L}$ & $8.90 E+05$ & $7.00 E+05$ & $7.88 E+05$ & $8.68 \mathrm{E}+05$ & $4.94 \mathrm{E}+05$ \\
\hline $234 U$ & $\mathrm{pCi} / \mathrm{L}$ & $2.68 \mathrm{E}+05$ & $3.65 E+05$ & $2.38 \mathrm{E}+05$ & $2.60 E+05$ & $2.36 \mathrm{E}+05$ \\
\hline $235 u$ & $\mathrm{pCi} / \mathrm{L}$ & $1.89 E+04$ & $2.36 E+04$ & $1.66 \mathrm{E}+04$ & $1.62 E+04$ & $1.67 \mathrm{E}+04$ \\
\hline $238 U$ & $\mathrm{pCi} / \mathrm{L}$ & $1.90 E+05$ & $2.64 E+05$ & $1.66 \mathrm{E}+05$ & $1.90 \mathrm{E}+05$ & $1.69 \mathrm{E}+05$ \\
\hline
\end{tabular}


Comparisons of the slurry solid and slurry liquid concentrations for copper, sulfur, and zirconium; chromium, iron, manganese, and tin; and molybdenum, nickel, and uranium are shown in Figures 16, 17, and 18, respectively. As shown in these figures, all elements listed, with the exception of uranium, had higher concentrations in the solid phase of the slurry than the liquid. These differences indicate that the solubility product of compounds containing these elements had been exceeded and precipitates were formed. This also means the solids were in equilibrium with the liquid before the waste was removed.

The notably different behavior for uranium may be related to the complex chemistry involved with this element. Uranium, in the neutralized process waste, initially existed as a highly insoluble diuranate complex. Upon

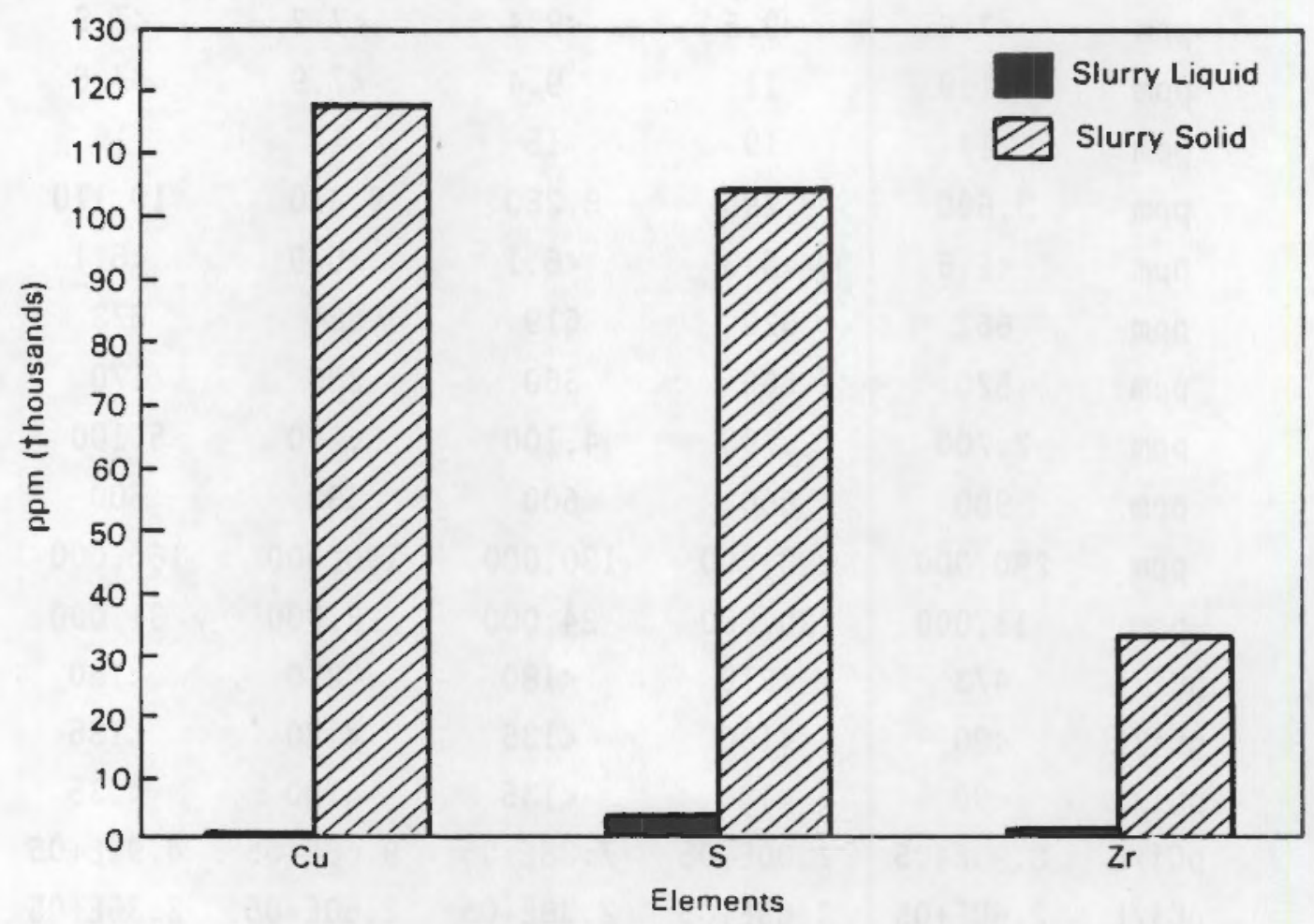

FIGURE 16. Concentrations of Copper, Sulfur, and Zirconium in the Slurry Liquid and Slurry Solid from Basin \#1 


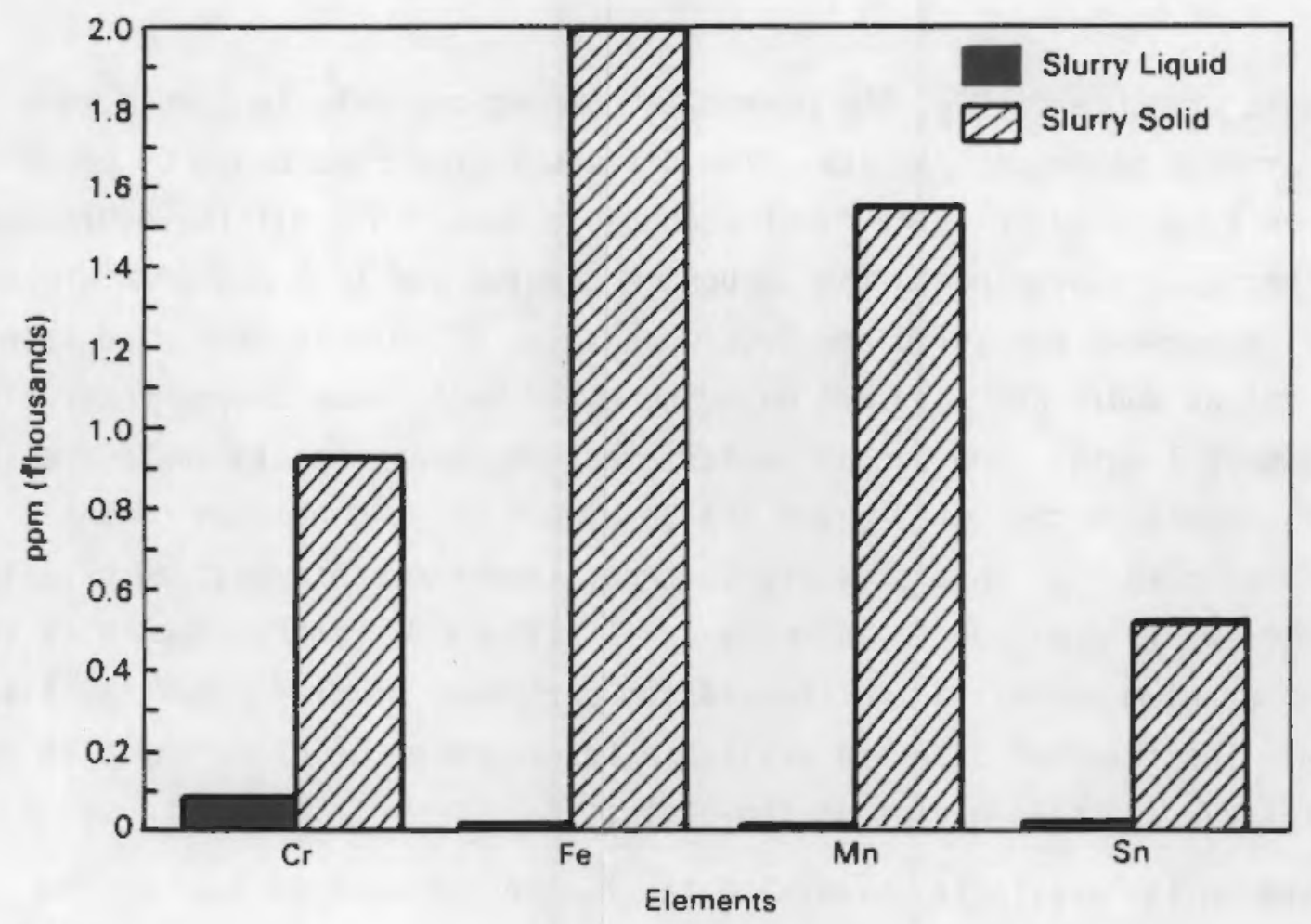

FIGURE 17. Concentrations of Chromium, Iron, Manganese, and Tin in the Slurry Liquid and Slurry Solid from Basin \#1

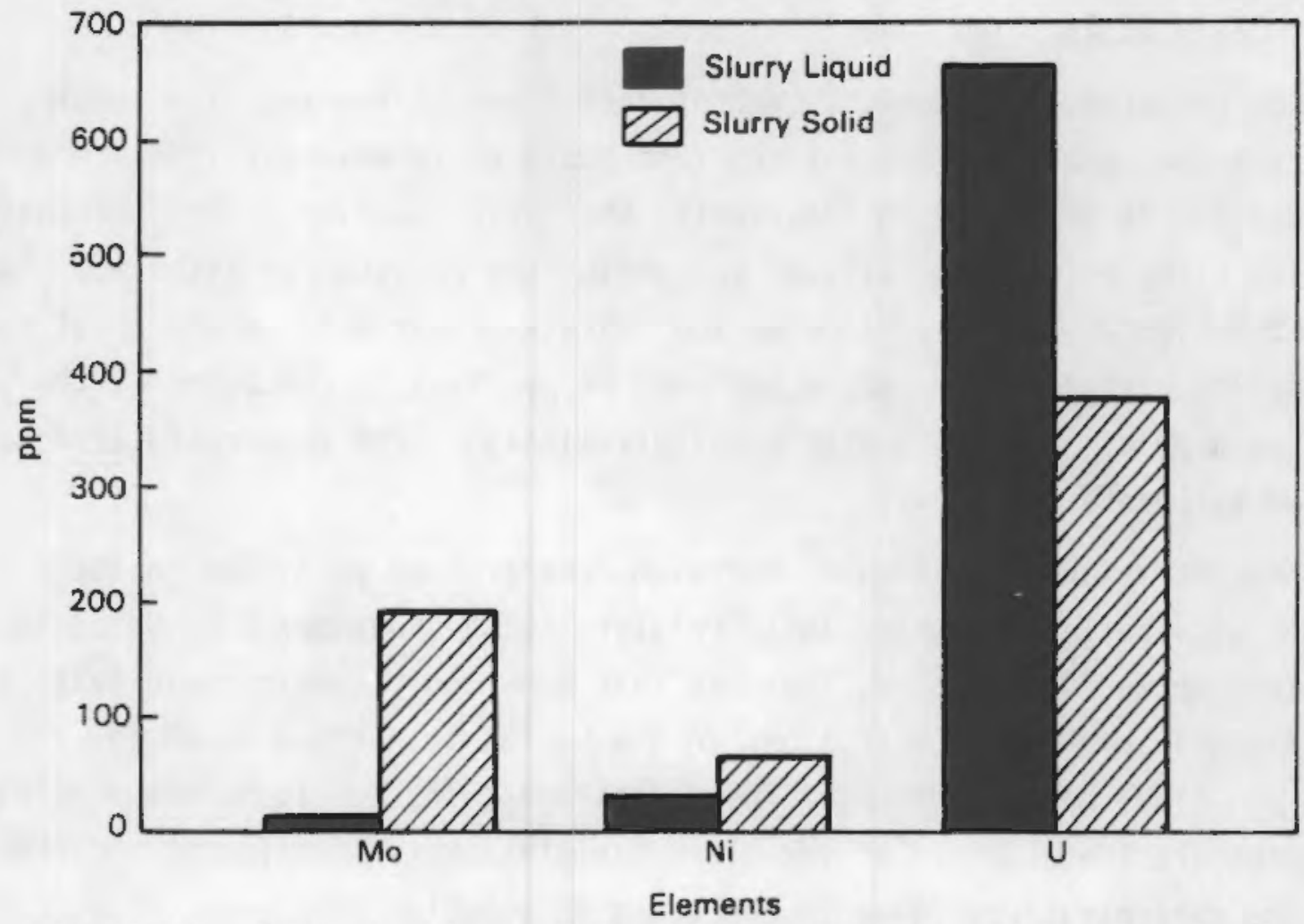

FIGURE 18. Concentrations of Molybdenum, Nickel, and Uranium in the Slurry Liquid and Slurry Solid from Basin \#1 
exposure to atmospheric $\mathrm{CO}_{2}$, the diuranate complex converts to a much more soluble uranium carbonate complex. Two different scenarios could be postulated from this behavior. The first scenario assumes that all the diuranate complex has been converted to the carbonate complex and that the uranium is in equilibrium between the solid and liquid phases. If this is true, the uranium concentrations would probably not have increased much above the concentration in the slurry liquid. The second scenario assumes that the diuranate complex is still present in the solid phase and is slowly being converted to the carbonate complex. If this scenario is true, then the concentration of uranium in solution would continue to increase until all the diuranate complex is converted to uranium carbonate and the uranium carbonate complex saturates the solution. Insufficient data are available to determine which scenario is more representative of the behavior in the basins.

Based on the available chemical data, the constituent content of the solution that leaked from basin \#1 would probably approach the concentration of constituents in the liquid phase of the slurry shown in Table 3.

\subsubsection{Basin \#2 Sampling}

Concentrations of chemical constituents found in the solution samples collected one foot below the surface from basin \#2 in November 1986 are shown in Table 4. As indicated in this table, the basin solution is predominantly a sodium nitrate solution ( $113,000 \mathrm{ppm}$ sodium and $260,000 \mathrm{ppm}$ nitrate). Two other solution components, fluoride and sulfate, contribute to the total anion composition with $2,200 \mathrm{ppm}$ and $8,900 \mathrm{ppm}$, respectively. Furthermore, the solution had a pH of 10.5 and a high total alkalinity, 2,700 ppm, calculated as calcium carbonate (Table 4).

Concentrations of chloride, chromium, copper, and potassium in the October 1984 basin \#1 slurry liquid relative to the November 1986 basin \#2 solution, shown in Figure 19, indicate that some constituents could exist at significantly higher concentrations in the basins than those found in basin \#2. The concentrations of the constituents in the liquid phase of basin $\# 1$, which are the averages of the slurry samples, were significantly higher than the concentrations found in the basin \#2 solution. 
IABLE 4. Analytical Results for the Basin \#2 Solution (November 1986)

\begin{tabular}{|c|c|c|}
\hline Parameter & Units & Concentration \\
\hline $\mathrm{pH}$ & - & 10.5 \\
\hline Eh & $\mathrm{mV}$ & 290 \\
\hline Al & $\mathrm{ppm}$ & 2 \\
\hline As & $\mathrm{ppm}$ & $<0.8$ \\
\hline B & $\mathrm{ppm}$ & 2 \\
\hline $\mathrm{Ba}$ & $\mathrm{ppm}$ & 0.1 \\
\hline $\mathrm{Ca}$ & $\mathrm{ppm}$ & 0.6 \\
\hline Cd & $\mathrm{ppm}$ & $<0.4$ \\
\hline Co & $\mathrm{ppm}$ & $<0.1$ \\
\hline $\mathrm{Cr}$ & $\mathrm{ppm}$ & 8.3 \\
\hline $\mathrm{Cu}$ & ppm & 4.1 \\
\hline $\mathrm{Fe}$ & $\mathrm{ppm}$ & $<0.5$ \\
\hline K & $\mathrm{ppm}$ & 160 \\
\hline $\mathrm{Li}$ & $\mathrm{ppm}$ & 1.0 \\
\hline $\mathrm{Mg}$ & $\mathrm{ppm}$ & 3.5 \\
\hline $\mathrm{Mn}$ & $\mathrm{ppm}$ & $<0.2$ \\
\hline Mo & $\mathrm{ppm}$ & 0.5 \\
\hline $\mathrm{Na}$ & $\mathrm{ppm}$ & 113,000 \\
\hline $\mathrm{Ni}$ & $\mathrm{ppm}$ & 3.4 \\
\hline P & $\mathrm{ppm}$ & $<1.0$ \\
\hline $\mathrm{Pb}$ & $\mathrm{ppm}$ & $<0.6$ \\
\hline Si & $\mathrm{ppm}$ & 10 \\
\hline $\mathrm{Sr}$ & $\mathrm{ppm}$ & $<2$ \\
\hline Zn & $\mathrm{ppm}$ & $<2$ \\
\hline $\mathrm{F}^{-}$ & $\mathrm{ppm}$ & 2,200 \\
\hline $\mathrm{Cl}^{-}$ & $\mathrm{ppm}$ & 200 \\
\hline $\mathrm{NO}_{2}^{-}$ & $\mathrm{ppm}$ & 600 \\
\hline $\mathrm{NO}_{3}^{-}$ & $\mathrm{ppm}$ & 260,000 \\
\hline $\mathrm{SO}_{4}^{-}$ & $\mathrm{ppm}$ & 8,900 \\
\hline $\begin{array}{l}\text { Alkalinity } \\
\text { as } \mathrm{CaCO}_{3}\end{array}$ & $\mathrm{ppm}$ & 2,722 \\
\hline
\end{tabular}




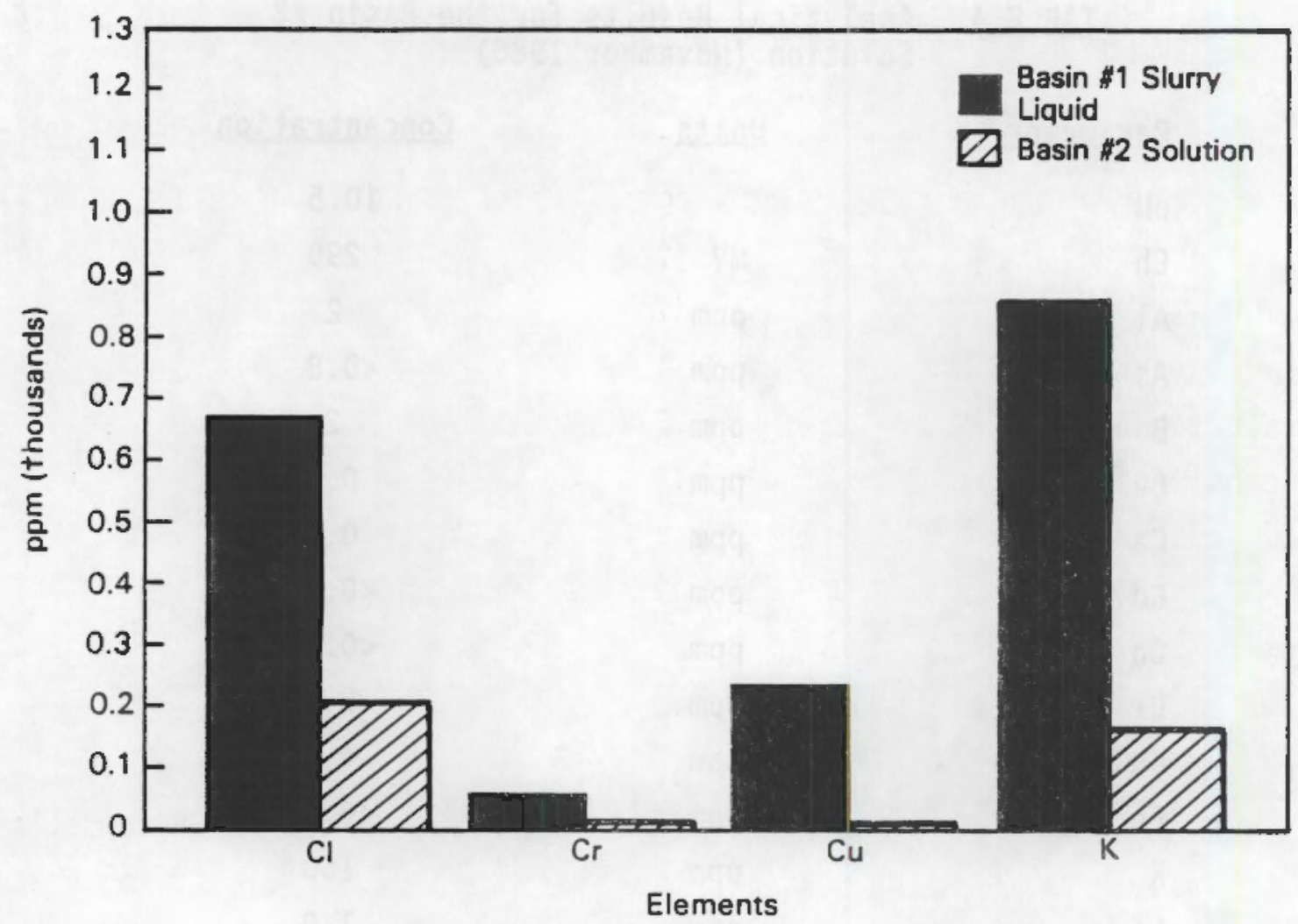

FIGURE 19. Concentrations of Chloride, Chromium, Copper, and Potassium in the Basin \#1 Slurry Liquid and Basin \#2 Solution

Given the analytical results from the wastes contained in basins \#1 and $\# 2$, the following constituents were present in sufficient quantities to be identified as potential ground-water contaminants associated with the 183-H Basins: chromium, technetium, sodium, uranium, fluoride, nitrate, and sulfate. In addition, copper and nickel were identified; however, the usefuiness of these two constituents was thought to depend on geochemical interaction (absorption) in the soil column and dilution factors in the ground water. These results were used in developing the sampling program to monitor for site-specific constituents. 


\subsection{GEOLOGY OF THE 100-H AREA}

The following discussion focuses on the principal lithologic units, distribution, and thicknesses of the geologic formations beneath the 100-H Area. Specific interpretation of the lithologic units is based on geologic sample descriptions, geophysical logs, and sediment analyses from the 100-H Area wells, the generalized stratigraphy of the Pasco Basin (Figure 9) and a topof-basalt map (Myers and Price et al. 1979). Textural divisions, derived from ternary diagrams (Figure 20), were chosen from the sieve data and correlated with sample descriptions and geophysical logs. Well construction diagrams, lithologic diagrams, and geophysical logs for the 100-H Area wells are contained in Appendix A.

Three major stratigraphic formations were encountered during drilling operations at the 100-H Area. They are, in ascending order: the Saddle Mountains Basalt Formation, the Ringold Formation, and the Hanford formation. Figure 21 is a generalized geologic column for the $100-\mathrm{H}$ Area, showing the order, principal lithologic units, average elevation, and relative degree of consolidation of these formations. Table 5 lists the general lithologic characteristics for each formation. Figure 22 is a fence diagram illustrating the three-dimensional distribution and stratigraphic correlations between the formations of the $100-\mathrm{H}$ Area. Figure 23 shows the locations of six cross sections. The detailed cross sections, both parallel and perpendicular to ground-water flow, are included in Figures 24 through 26. A discussion of each stratigraphic formation follows. Further references to depth in this discussion are given in feet below land surface, with elevation in feet above msl in parentheses.

\subsection{SADDLE MOUNTAINS BASALT FORMATION}

The Saddle Mountains Basalt Formation is the uppermost formation of the Columbia River Basalt Group underlying the 100-H Area. The Saddle Mountains Basalt Formation was encountered in Well 199-H4-15C at a depth of $314 \mathrm{ft}$ (91 ft above ms 1). Geologic samples were characterized as dark-grey and black to very dark-brown basalt mixed with increasing amounts of yellowishbrown and rust-colored clay with depth. Basalt density appeared to decrease 


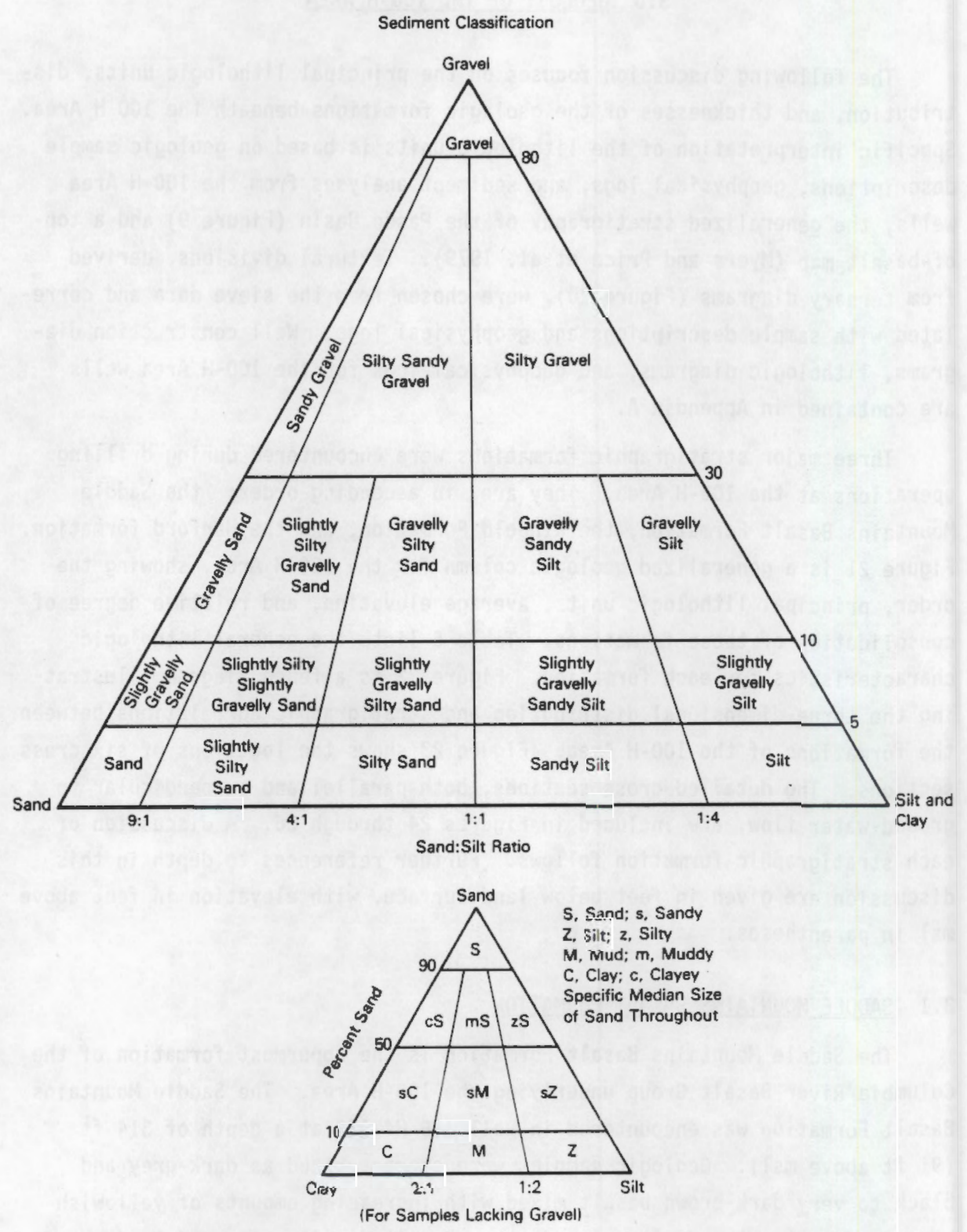

FIGURE 20. Sediment Classification (modified from Folk 1968) 


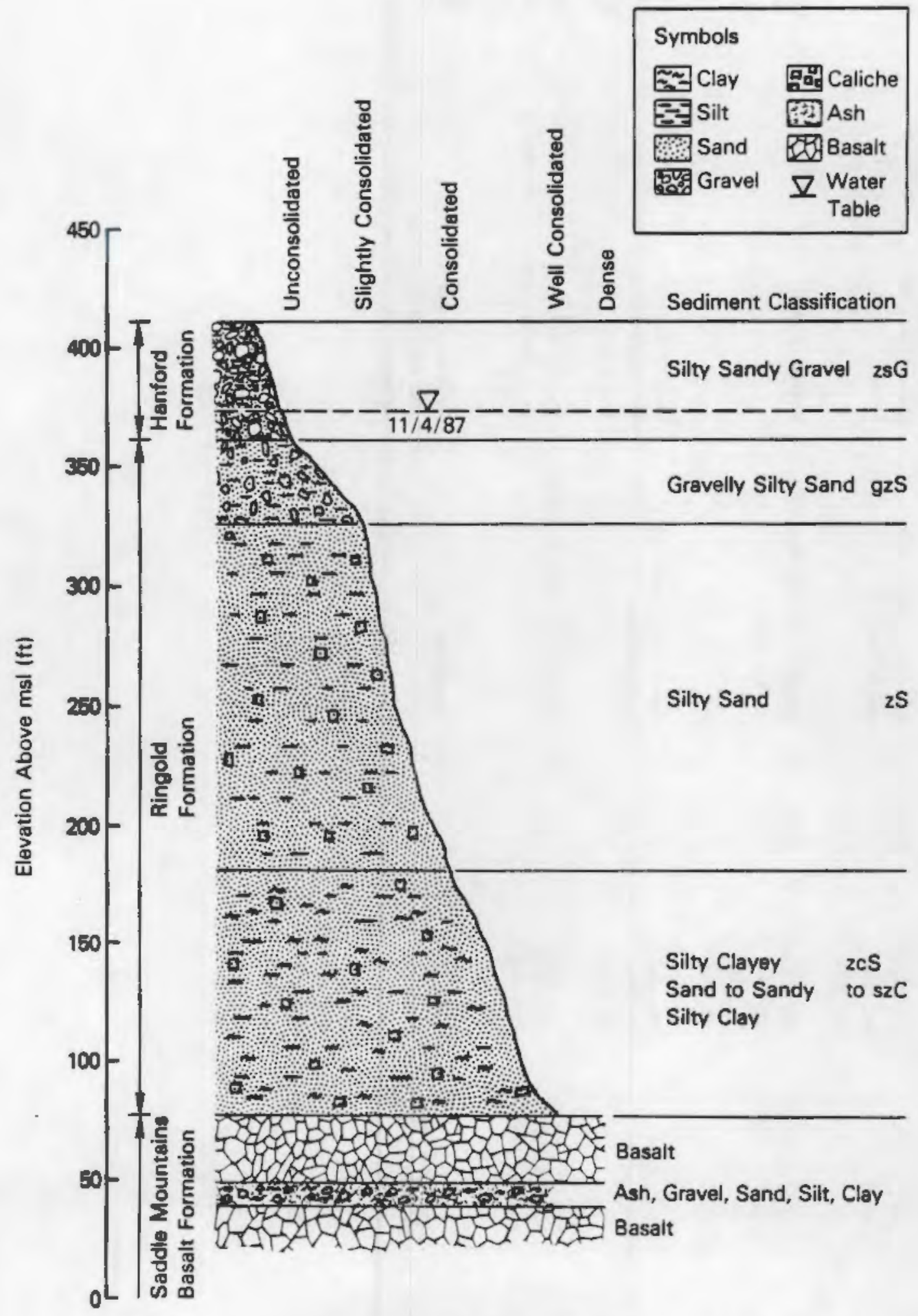

FIGURE 21. Generalized Geologic Column for the 100-H Area 
TABLE 5. General Characteristics of the Geologic Formations Beneath the 100-H Area

\begin{tabular}{|c|c|c|c|c|c|c|c|}
\hline Formation & Unit/Member & Texture & Sorting & Mineralogy & Color & HCL Reaction & Consolidation \\
\hline $\begin{array}{l}\text { Hanford } \\
\text { formation }\end{array}$ & $\begin{array}{l}\text { silty Sandy } \\
\text { Gravel }\end{array}$ & $\begin{array}{l}50 \% \text { Gravel } \\
40 \% \text { Sand } \\
10 \% \text { silt }\end{array}$ & Poor & $\begin{array}{l}\text { Basaltic, Quartz-Rich, } \\
\text { ard Metanorphic }\end{array}$ & $\begin{array}{l}\text { Gray, Black, and } \\
\text { Brown }\end{array}$ & $\begin{array}{l}\text { None to } \\
\text { Strong }\end{array}$ & Unconsol idated \\
\hline \multirow[t]{3}{*}{$\begin{array}{l}\text { Ringold } \\
\text { Formation }\end{array}$} & $\begin{array}{l}\text { Gravelly silty } \\
\text { Sand }\end{array}$ & $\begin{array}{l}\text { 5\% Gravel } \\
70 x \text { Sand } \\
20 \% \text { Silt } \\
5 \% \text { Clay }\end{array}$ & Poor & $\begin{array}{l}\text { Quartz-Rich and Basaltic } \\
\text { with Caliche }\end{array}$ & Reddish Brown & strong & $\begin{array}{l}\text { Unconsol idated } \\
\text { to stightly } \\
\text { Consolidated }\end{array}$ \\
\hline & silty Sand & $\begin{array}{l}75 \% \text { Sand } \\
15 \% \text { silt } \\
10 \% \text { Clay }\end{array}$ & Well & $\begin{array}{l}\text { Quartz-Rich and Basaltic } \\
\text { with Caliche }\end{array}$ & $\begin{array}{l}\text { Reddish Brown, } \\
\text { Yellowish Brown, } \\
\text { and Brown }\end{array}$ & $\begin{array}{l}\text { Slight to } \\
\text { strong }\end{array}$ & $\begin{array}{l}\text { slightly } \\
\text { Consol idated to } \\
\text { Consol idated }\end{array}$ \\
\hline & $\begin{array}{l}\text { Silty Clayey } \\
\text { Sand to Sandy } \\
\text { silty Clay }\end{array}$ & $\begin{array}{l}50 \% \text { Sand } \\
25 \% \text { silt } \\
25 \% \text { Clay }\end{array}$ & Well & Quartz-Rich with Caliche & $\begin{array}{l}\text { Yellow, Green, } \\
\text { Blue, Grown, and } \\
\text { Black }\end{array}$ & $\begin{array}{l}\text { slight to } \\
\text { strong }\end{array}$ & $\begin{array}{l}\text { Consol idated } \\
\text { to Hell } \\
\text { Consol idated }\end{array}$ \\
\hline $\begin{array}{l}\text { Saddle } \\
\text { Mountains } \\
\text { Basalt }\end{array}$ & $\begin{array}{l}\text { Elephant } \\
\text { Mountain }\end{array}$ & $\begin{array}{l}80 \% \text { Basalt } \\
20 \% \text { Clay }\end{array}$ & & Basaltic & $\begin{array}{l}\text { Dark Grey, Black, } \\
\text { and Very Dark } \\
\text { Brown }\end{array}$ & & Dense \\
\hline & $\begin{array}{l}\text { Interflow } \\
\text { Zone }\end{array}$ & $\begin{array}{l}\text { Ash, Gravel, } \\
\text { Sand, silt } \\
\text { and Cley }\end{array}$ & & & & & \\
\hline & $\begin{array}{l}\text { Elephant } \\
\text { Mountain }\end{array}$ & Basalt & & & & & \\
\hline
\end{tabular}




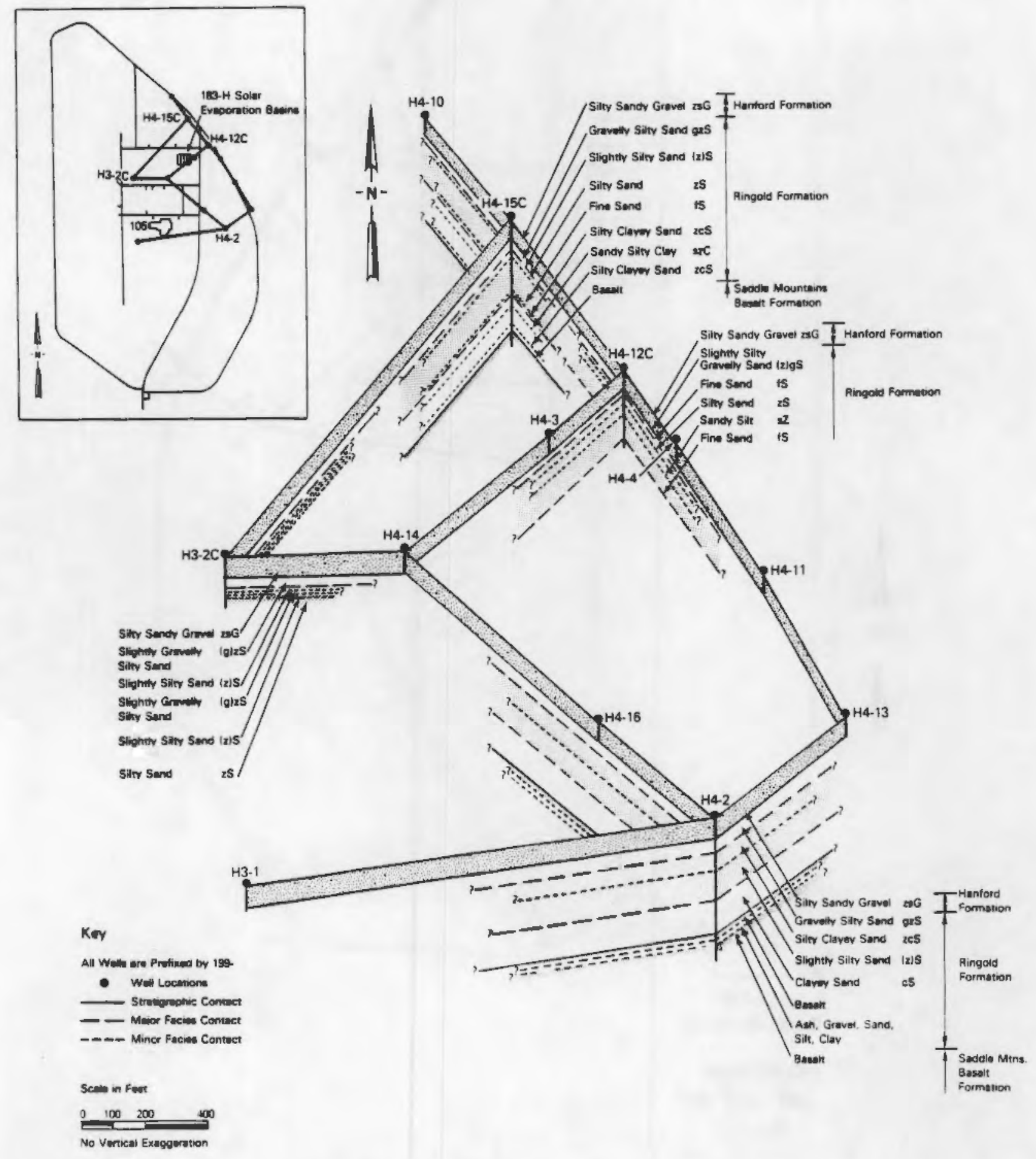

FIGURE 22. Three-Dimensional Distribution and Stratigraphic Correlations of the Geologic Formations Beneath the 100-H Area 


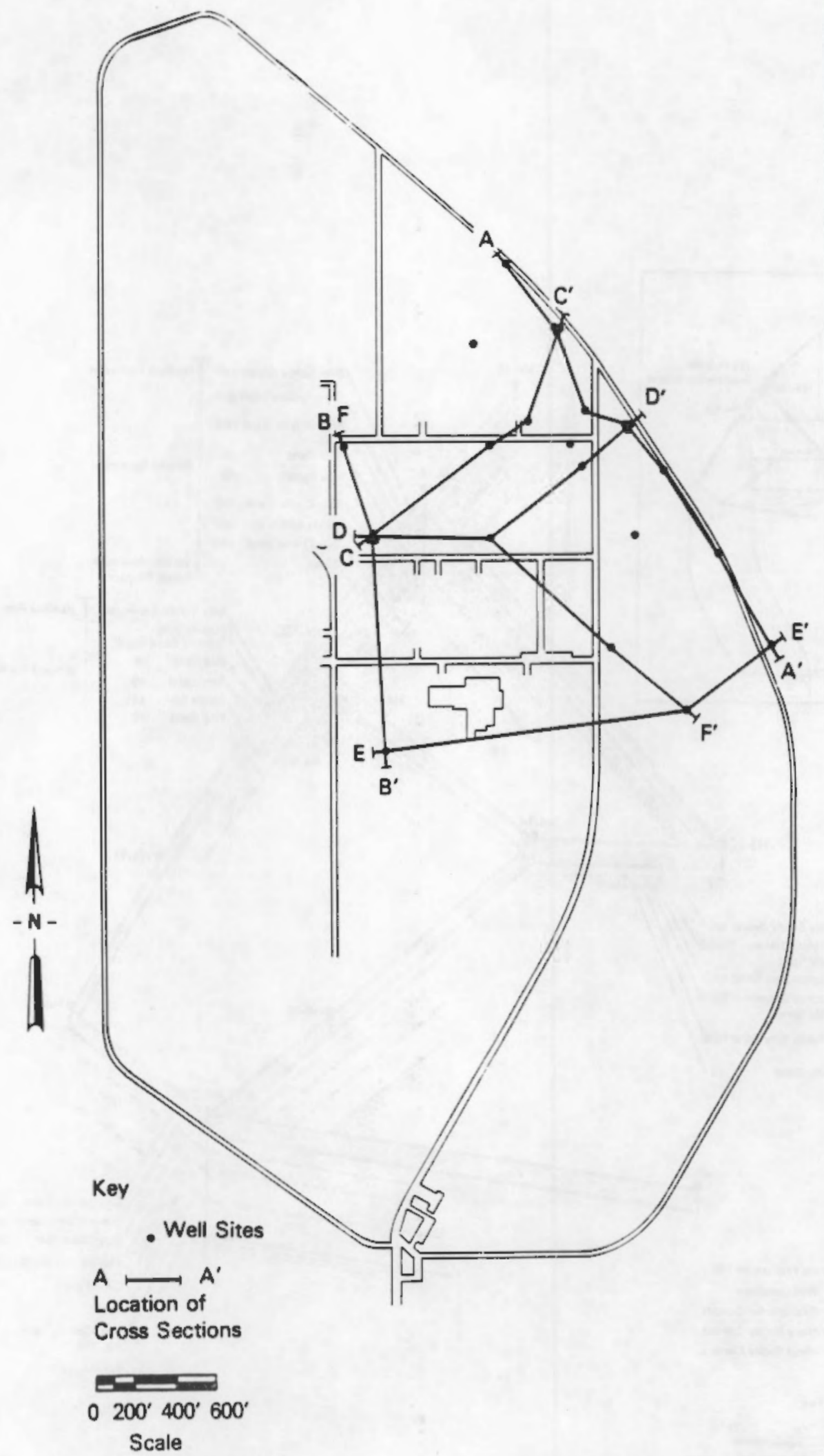

FIGURE 23. Locations of the 100-H Area Cross Sections (shown in Figures 24 through 26) 


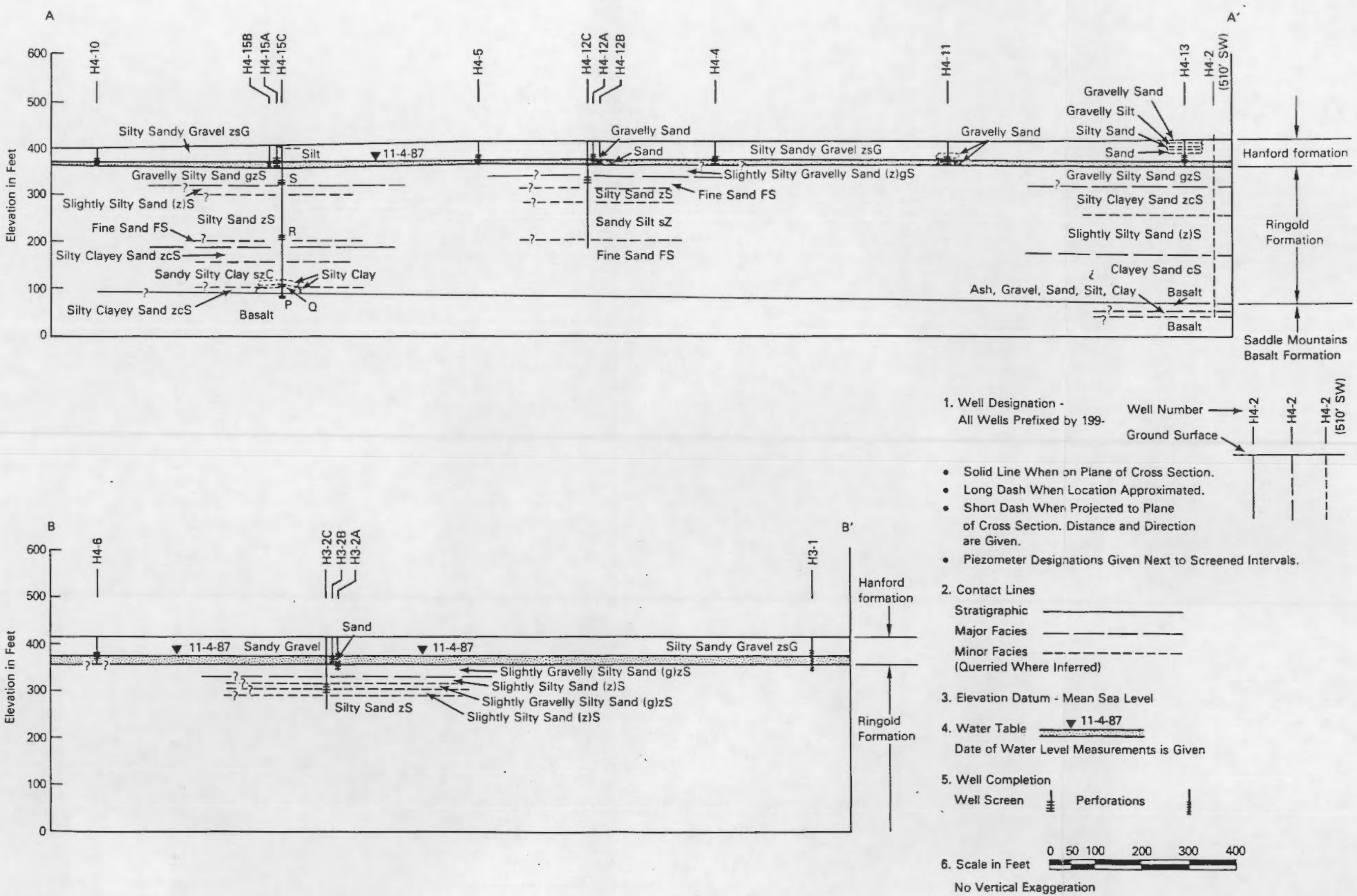

FIGURE 24. Cross Sections $A-A^{\prime}$ and $B-B^{\prime}$ of the Stratigraphic Formations Beneath the $100-H$ Area 



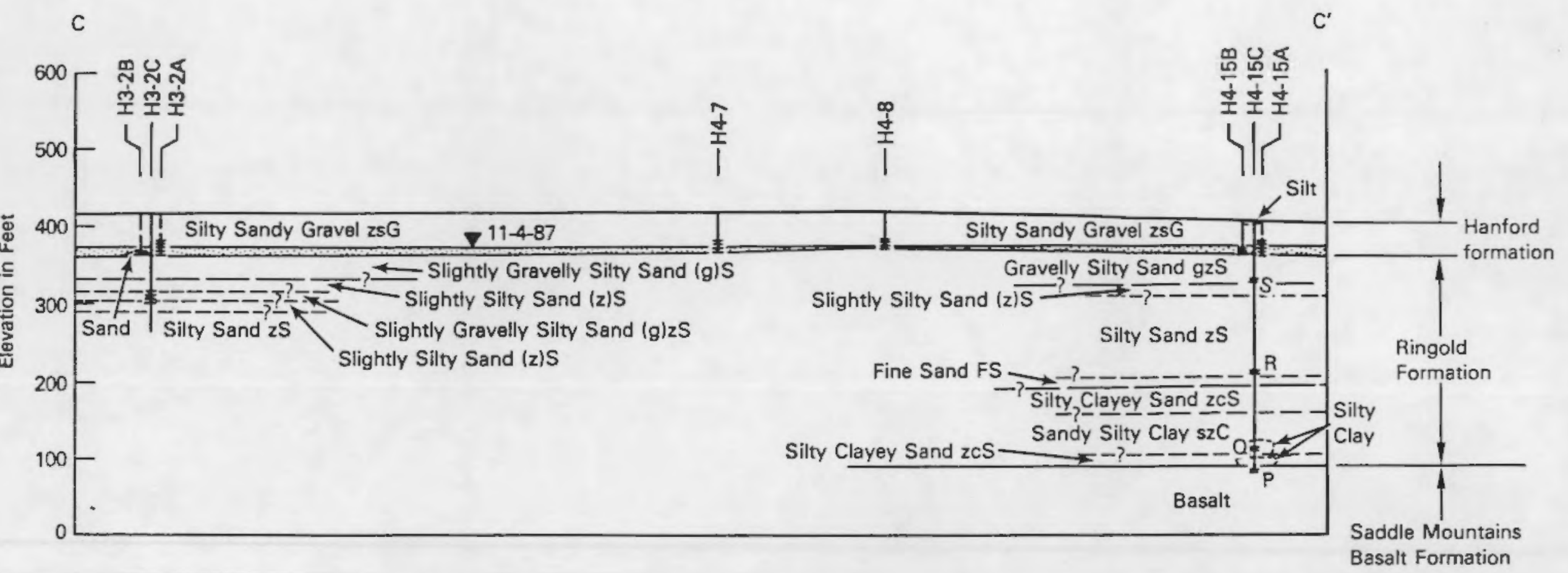

1. Well Designation

All Wells Prefixed by 199

- Solid Line When on Plane of Cross Section.

- Long Dash When Location Approximated.

- Short Dasi When Projected to Plane

of Cross Section. Distance and Direction

are Given.

- Piezometer Designations Given Next to Screened Intervals.

2. Contact Lines

Stratigraphic

Major Facies

Minor Facies

(Querried Where inferred)

3. Elevation Datum - Mean Sea Level

4. Water Table

Date of Water Level Measurements is Given

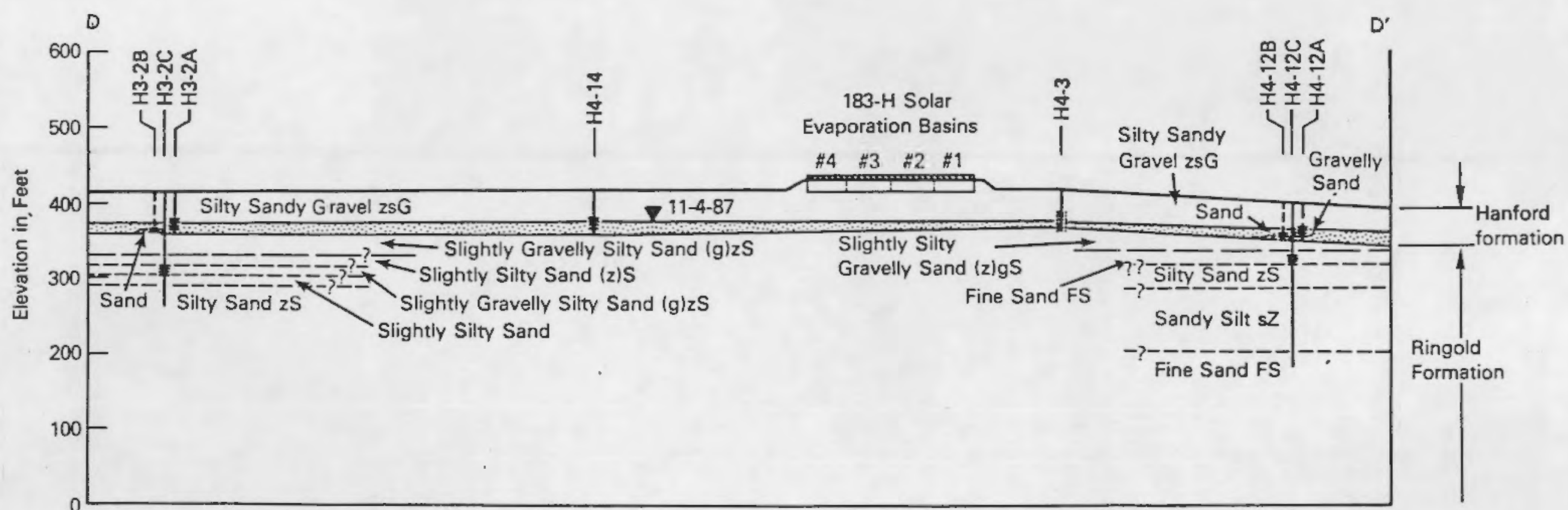

5. Well Compietion

Well Screen $\$$ Perforations

. Scale in Feer

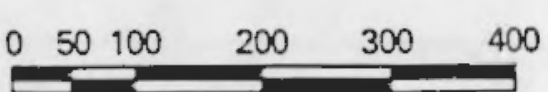

No Vertical Exaggeration

FIGURE 25. Cross Sections $C-C^{\prime}$ and $D-D^{\prime}$ of the Stratigraphic Formations Beneath the $100-H$ Area 



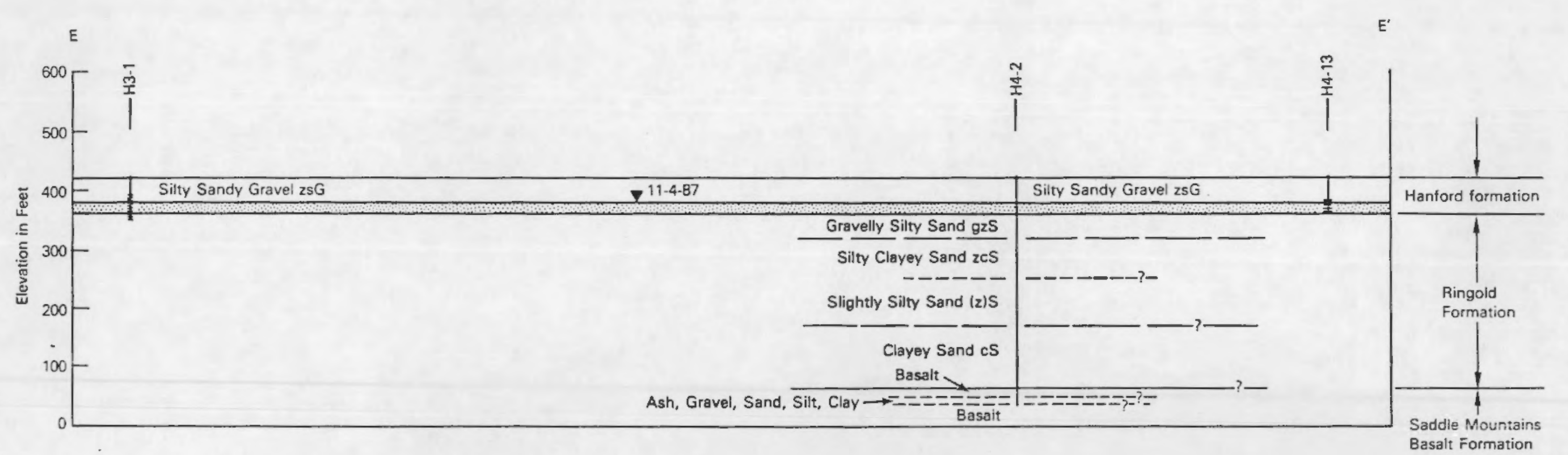

1. Well Designation .

All Wells Prefixed by 199

Well Number $\longrightarrow$ round Surface

- Solid Line When on Plane of Cross Section.

- Long Dash When Location Approximated.

- Short Dash When Projected to Plane

of Cross Section. Distance and Direction
are Given.

- Piezometer Designations Given Next to Screened Intervals.

2. Contact Lines

Stratigraphic

- -

Minor Facies -

3. Elevation Datum - Mean Sea Leve|

4. Water Table $>11-4-87$

Date of Water Level Measurements is Given

5. Well Completion

Well Screen $\frac{1}{ \pm}$ Perforations

Saddle Mountain

6. Scale in Feet $\begin{aligned} & 0 \quad 50100 \quad 200 \quad 300 \quad 400 \\ & =\end{aligned}$

No Vertical Exaggeration

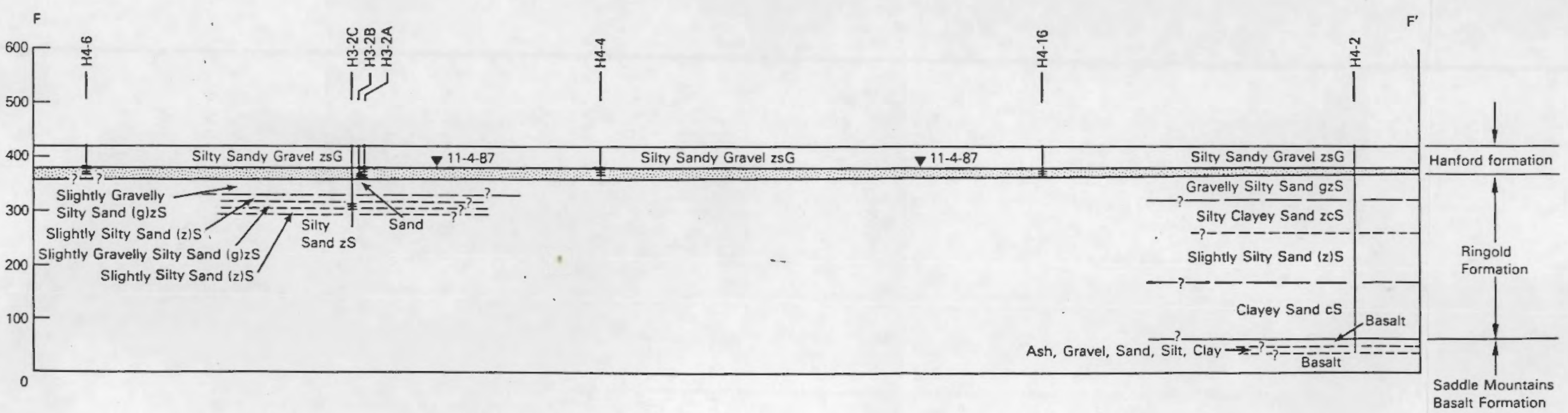

FIGURE 26. Cross Sections E-E' and F-F' of the Stratigraphic Formations Beneath the $100-H$ Area 

with depth, as indicated by a faster drill rate, increased clay content, and finer drill cuttings. No structural features such as fractures, folds, or faults were noted during drilling operations.

Well 199-H4-2 was drilled into basalt in April 1952. Basalt was noted from a depth of $355 \mathrm{ft}$ ( $64 \mathrm{ft}$ above msl) to $370 \mathrm{ft}$ ( $49 \mathrm{ft}$ above msl) and again at $381 \mathrm{ft}$ ( $38 \mathrm{ft}$ above $\mathrm{ms} 1$ ), but no further descriptive comments were found in the drilling log. An interflow zone containing ash, gravel, sand, silt, and clay-sized material was described from a depth of $370 \mathrm{ft}(49 \mathrm{ft}$ above ms l) to $381 \mathrm{ft}$ ( $38 \mathrm{ft}$ above ms 1 ).

Myers and Price et al. (1979) indicate that the topmost (youngest) basalt flow in the 100-H Area is the Elephant Mountain Member of the Saddle Mountains Basalt Formation. X-ray fluorescence analysis of basalt chips (Table 6) from $355 \mathrm{ft}$ and $385 \mathrm{ft}$ in Well 199-H4-2 and 324 to $325 \mathrm{ft}$ in Well 199-H4-15C confirm the chemical type as Elephant Mountain. This basalt member was extruded from feeder dikes in southeast Washington approximately 10.5 mybp, near the end of the Columbia River Basalt volcanism. Myers and Price et a1. (1979) also indicate that this member consists of two flows and that both the upper and lower flows are present beneath the 100-H Area. It is further suggested that the lower flow may be as much as $100 \mathrm{ft}$ thick. Drilling logs from Well 199-H4-2 indicate that the upper flow may be at least $20 \mathrm{ft}$ thick. Figure 27, the top-of-basalt map, shows that the Elephant Mountain Member dips to the south and southwest directly beneath the $100-\mathrm{H}$ Area. This dip reflects the gently sloping attitude of the northern limb of the Wahluke syncline.

\subsection{RINGOLD FORMATION}

The Saddle Mountains Basalt Formation is overlain by the Ringold Formation. The Ringold Formation consists predominantly of sands, silts, and clays, with minor amounts of grave1. Tallman et al. (1981) describe these sediments as being section type II of the Ringold Formation. The upper portion of the Ringold Formation outcrops along the prominent White Bluffs that form the eastern bank of the Columbia River, across from the 100-H Area. Myers and Price (1981) suggest that the Ringold sediments were deposited in a 
TABLE 6. X-Ray Fluorescence Analysis of Basalt Chips from Two 100-H Area Wells

Well No.:

Depth:

Analysis Date:

Chemical Type:
199-H4-2
$355 \mathrm{ft}$ Below
Land Surface

February 21, 1987

Elephant Mountain
199-H4-15C 324 - $325 \mathrm{ft}$ Below Land Surface

February 21, 1987

Elephant Mountain
199- H4-2 $385 \mathrm{ft}$ Below Land Surface January 15, 1988 Elephant Mountain

\begin{tabular}{|c|c|c|c|}
\hline $\begin{array}{l}\text { Element } \\
\text { Compound } \\
\end{array}$ & $\begin{array}{c}\text { Chemical } \\
\text { Composition } \\
\text { (wt\%) }\end{array}$ & $\begin{array}{c}\text { Chemical } \\
\text { Composition } \\
\text { (wt\%) }\end{array}$ & $\begin{array}{l}\text { Chemical } \\
\text { Composition } \\
\text { (wt\%) }\end{array}$ \\
\hline $\mathrm{SiO}_{2}$ & 50.58 & 49.83 & 52.00 \\
\hline $\mathrm{Al}_{2} \mathrm{O}_{3}$ & 13.25 & 13.27 & 13.39 \\
\hline $\mathrm{TiO}_{2}$ & 3.825 & 3.855 & 3.426 \\
\hline $\mathrm{Fe}_{2} \mathrm{O}_{3}$ & 15.78 & 16.44 & 13.08 \\
\hline Mno & 0.190 & 0.177 & 0.209 \\
\hline $\mathrm{CaO}$ & 9.22 & 9.06 & 9.34 \\
\hline MgO & 3.52 & 3.96 & 4.20 \\
\hline $\mathrm{K}_{2} \mathrm{O}$ & 0.73 & 0.63 & 1.16 \\
\hline $\mathrm{Na}_{2} \mathrm{O}$ & 2.12 & 2.03 & 2.66 \\
\hline $\mathrm{P}_{2} \mathrm{O}_{5}$ & 0.566 & 0.571 & 0.540 \\
\hline $\mathrm{Ni}$ & 0.0018 & 0.0016 & 0.0007 \\
\hline $\mathrm{Cr}$ & 0.0044 & 0.0022 & 0.0036 \\
\hline Sc & 0.0037 & 0.0030 & 0.0036 \\
\hline V & 0.0471 & 0.0476 & 0.0414 \\
\hline $\mathrm{Ba}$ & 0.0627 & 0.0443 & 0.0501 \\
\hline $\mathrm{Rb}$ & 0.0021 & 0.0022 & 0.0027 \\
\hline $\mathrm{Sr}$ & 0.0279 & 0.0276 & 0.0257 \\
\hline $\mathrm{Zr}$ & 0.0262 & 0.0267 & 0.0237 \\
\hline Y & 0.0054 & 0.0051 & 0.0046 \\
\hline $\mathrm{Nb}$ & 0.0024 & 0.0025 & 0.0027 \\
\hline Ga & 0.0023 & 0.0023 & 0.0025 \\
\hline $\mathrm{Cu}$ & 0.0044 & 0.0009 & 0.0028 \\
\hline $\mathrm{Zn}$ & 0.0168 & 0.0152 & 0.0146 \\
\hline
\end{tabular}




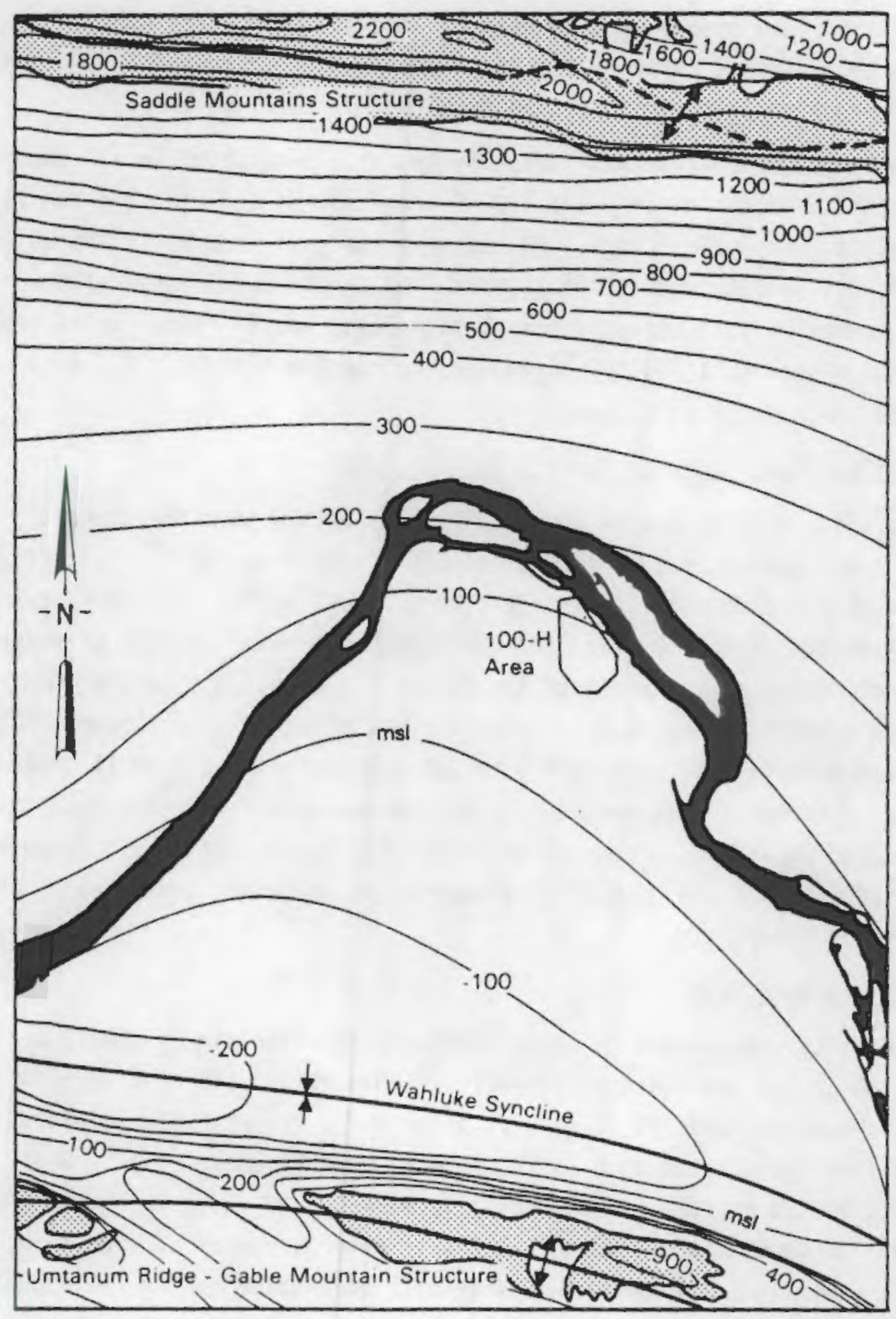

FIGURE 27. Top-of-Basalt Map (contours in feet above ms ?; modified from Myers and Price et a1. 1979) 
fluvial/floodplain environment between 8.5 and 3.7 mybp. The Ringold sediments in this portion of the Pasco Basin are further described as a floodplain-overbank stratigraphic section type (Myers and Price 1981).

The Ringold Formation was partially or fully penetrated in all the $100-\mathrm{H}$ wells with the exception of Wells 199-H4-4 and 199-H4-6. Geologic sample descriptions, geophysical logs, and sediment analyses from Wells 199-H3-2C, 199-H4-2, 199-H4-12C, and 199-H4-15C resulted in the subdivision of the Ringold Formation into three principal lithologic units. These units are, in ascending order: 1) silty clayey sand to sandy silty clay, 2) silty sand, and 3) gravelly silty sand.

\subsubsection{Silty $\mathrm{Clayey}$ Sand to Sandy Silty Clay Unit}

The silty clayey sand to sandy silty clay unit within the Ringold Formation was encountered in two wells, 199-H4-15C at a depth of $212 \mathrm{ft}$ (193 $\mathrm{ft}$ above ms 1 ) and $199-\mathrm{H} 4-2$ at $249 \mathrm{ft}$ (170 ft above $\mathrm{ms} 1)$. This unit typically consists of $50 \%$ sand, $25 \%$ silt, and $25 \%$ clay, with minor amounts of grave 1 and caliche noted near the top of the basalt. The unit was further characterized as well sorted, quartz rich, and consolidated to well consolidated. The fine materials reacted slightly in $10 \%$ hydrochloric acid ( $\mathrm{HCl}$ ), whereas the caliche strongly effervesced. Color changes were frequent within this unit, including yellow, green, blue, brown, and black. This unit is approximately $100 \mathrm{ft}$ thick and appears to slope to the south and southwest at the same rate as the basalt.

\subsubsection{Silty Sand Unit}

The silty clayey sand to sandy silty clay is overlain by a well-sorted silty sand unit. The contacts in Wells 199-H4-15C and 199- $\mathrm{H} 4-2$ were $84 \mathrm{ft}$ (321 ft above $\mathrm{ms} 1$ ) and $100 \mathrm{ft}(319 \mathrm{ft}$ above $\mathrm{ms} 1)$, respectively. This unit was partially penetrated at a depth of $84 \mathrm{ft}(332 \mathrm{ft}$ above $\mathrm{ms} 1$ ) in We11 199-H3-2C and $72 \mathrm{ft}$ (338 ft above msl) in Well 199-H4-12C. This unit consists of $75 \%$ sand, $15 \%$ silt, and $10 \%$ clay. Several lenses of fine sand, slightly gravelly silty sand, and sandy silt were noted in the individual wells. The sediments were both quartz rich and basaltic, with some caliche present. The colors are reddish-brown, yellowish-brown, and brown. The fine 
materials reacted slightly in $10 \% \mathrm{HCl}$, whereas the caliche strongly effervesced. This unit is approximately $145 \mathrm{ft}$ thick.

\subsubsection{Gravelly Silty Sand Unit}

The gravelly silty sand forms the top of the Ringold Formation and was partially or fully penetrated in all but two of the 100-H Area wells. This unit was poorly sorted, consisting of $5 \%$ grave1, $70 \%$ sand, $20 \%$ silt, and $5 \%$ clay. The sediments were both quartz-rich and basaltic, with increased amounts of caliche present. The unit was further characterized as reddishbrown and unconsolidated to slightly consolidated. The gravelly silty sand is approximately $35 \mathrm{ft}$ thick. The top of this unit is an erosional unconformity, with peak elevations located to the east and northeast of the $183-\mathrm{H}$ Basins (Figure 28).

\subsection{HANFORD FORMATION}

The Ringold Formation is overlain by a composite of unconsolidated and poorly sorted sediments, which comprise the Hanford formation. These surficial sediments were characterized as a silty sandy gravel, al though texture and mineralogy varied significantly between wells. The sediments contained a mixture of boulders, cobbles, pebbles, sand, and silt. Backfill materials, silt and sand pipe linings, and coal fly ash were noted on the surface and at depths to $30 \mathrm{ft}$. The backfill materials were often indistinguishable from the in situ gravels and sands. As a result, the Hanford formation is treated as a single silty sandy gravel unit.

The silty sandy gravel consists of $50 \%$ gravel, $40 \%$ sand, and $10 \%$ silt. The gravels are composed of mainly subrounded to rounded basaltic clasts with some quartz-rich and metamorphic clasts present. The silts and sands were described as grey, black, and brown quartz-rich and basaltic grains. The grains were angular to subangular and ranged from very coarse to very fine sand. Calcium carbonate deposits were noted on several clasts and effervesced strongly in $10 \% \mathrm{HCl}$. The reaction of the sands varied from none to slight. Lenses of gravelly sand and medium sand were noted in Wells 199-H4-11 and 199-H4-13; however, no cross-borehole correlations were evident. The Hanford formation is approximately $65 \mathrm{ft}$ thick at the 100-H Area. 


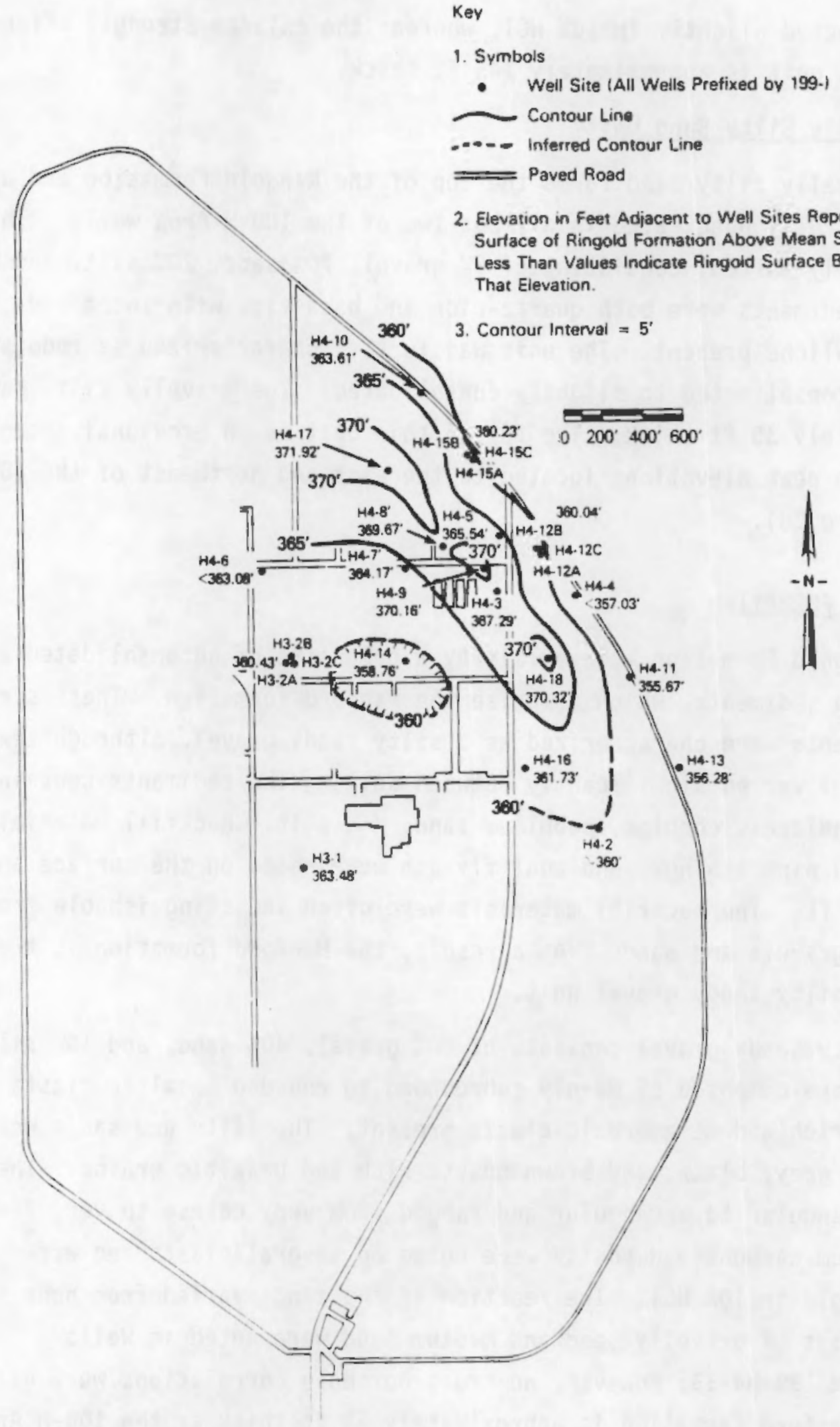

FIGURE 28. Surface of the Ringold Formation Beneath the 100-H Area 
The topography of the 100-H Area has been severely modified by past operational and waste management activities and no geomorphic features other than the present Columbia River channel can be identified (Figure 29). 


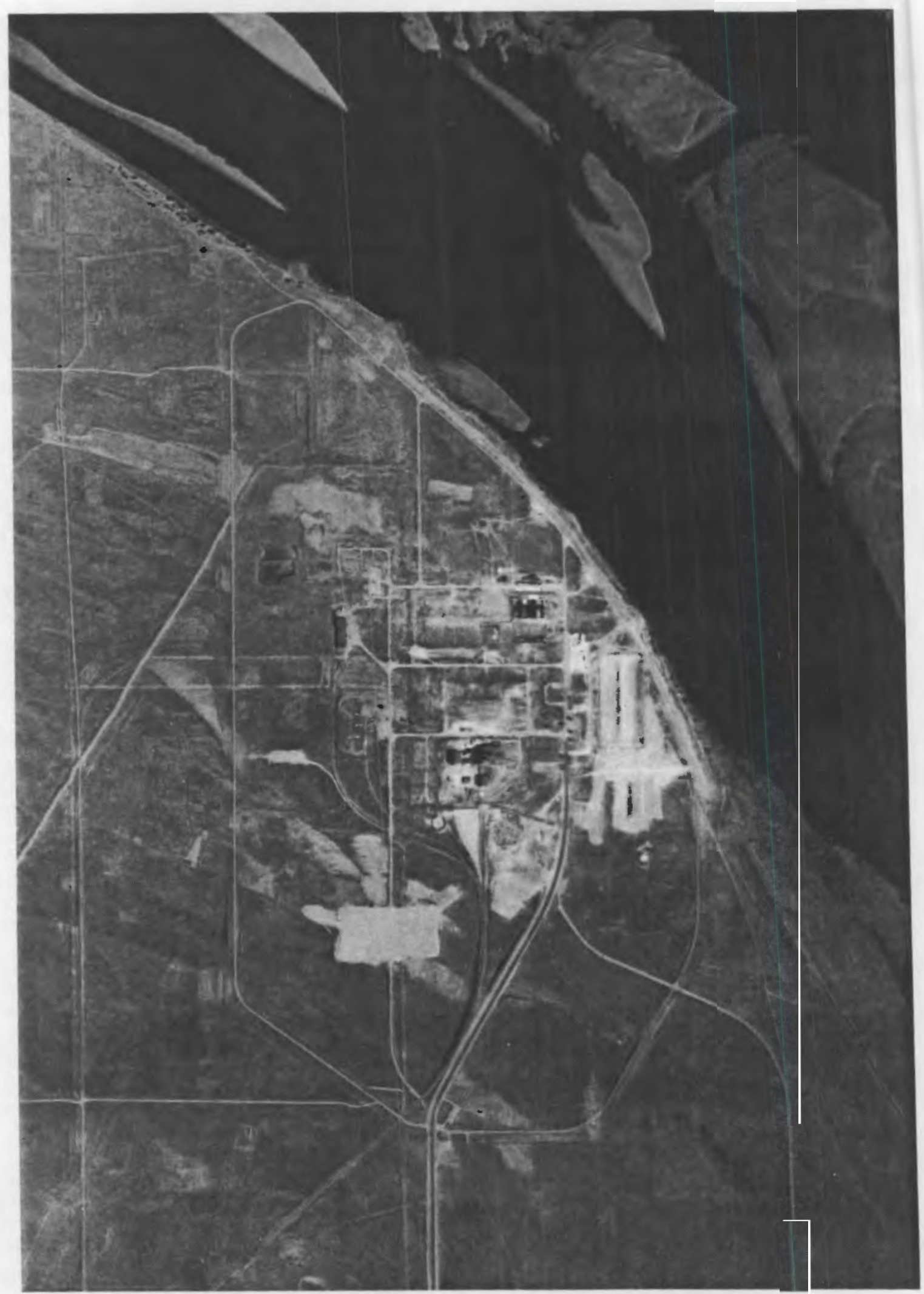

FIGURE 29. Aerial Photograph of the 100-H Area 


\subsection{HYDROLOGY OF THE 100-H AREA}

The following discussion focuses on the principal hydrostratigraphic units beneath the 100-H Area. Specific interpretation of the hydrostratigraphic units is based on geologic sample descriptions, geophysical logs, sediment analyses, water level measurements, and aquifer testing results.

Five principal hydrostratigraphic units were encountered beneath the 100-H Area. They are, in ascending order: 1) a lower confined aquifer (within the Saddle Mountains Basalt Formation), 2) an upper confined aquifer (within the silty clayey sand to sandy silty clay unit of the Ringold Formation), 3) the silty sand and gravelly silty sand units of the Ringold Formation, 4) the saturated sediments of the Hanford formation, and 5) the unsaturated sediments of the Hanford formation. Figure 30 is a generalized hydrostratigraphic column for the 100-H Area.

\subsection{LOWER CONFINED AOUIFER}

The lower confined aquifer occurs within the uppermost basalt flow of the Saddle Mountains Basalt Formation and was penetrated in two wells, 199-H4-2 and 199-H4-15C. Piezometer (P) in Well 199-H4-15C was completed from 325 to $327 \mathrm{ft}$ in a water-bearing zone ( 318 to $330 \mathrm{ft}$ ) within the basalt. This piezometer has a water level higher than land surface and is capped to prevent it from flowing. The upper portion of the basalt ( 314 to $318 \mathrm{ft}$ ) contains no water and appears to be the confining layer for this aquifer. Well 199-H4-2 also penetrates this aquifer and has a water level above land surface.

\subsection{UPPER CONFINED AQUIFER}

The upper confined aquifer occurs within the silty clayey sand to sandy silty clay unit of the Ringold Formation. The water level in this aquifer is monitored in Well 199-H4-15C (Q) at a depth of 295 to $297 \mathrm{ft}$. Before May 1987, this water level indicated a difference in hydraulic head of approximately $30 \mathrm{ft}$ greater than the water tabie, as shown in the hydrographs for cluster Wells 199-H4-15A, 199-H4-15B, and 199-H4-15C (Figure 31). However, 


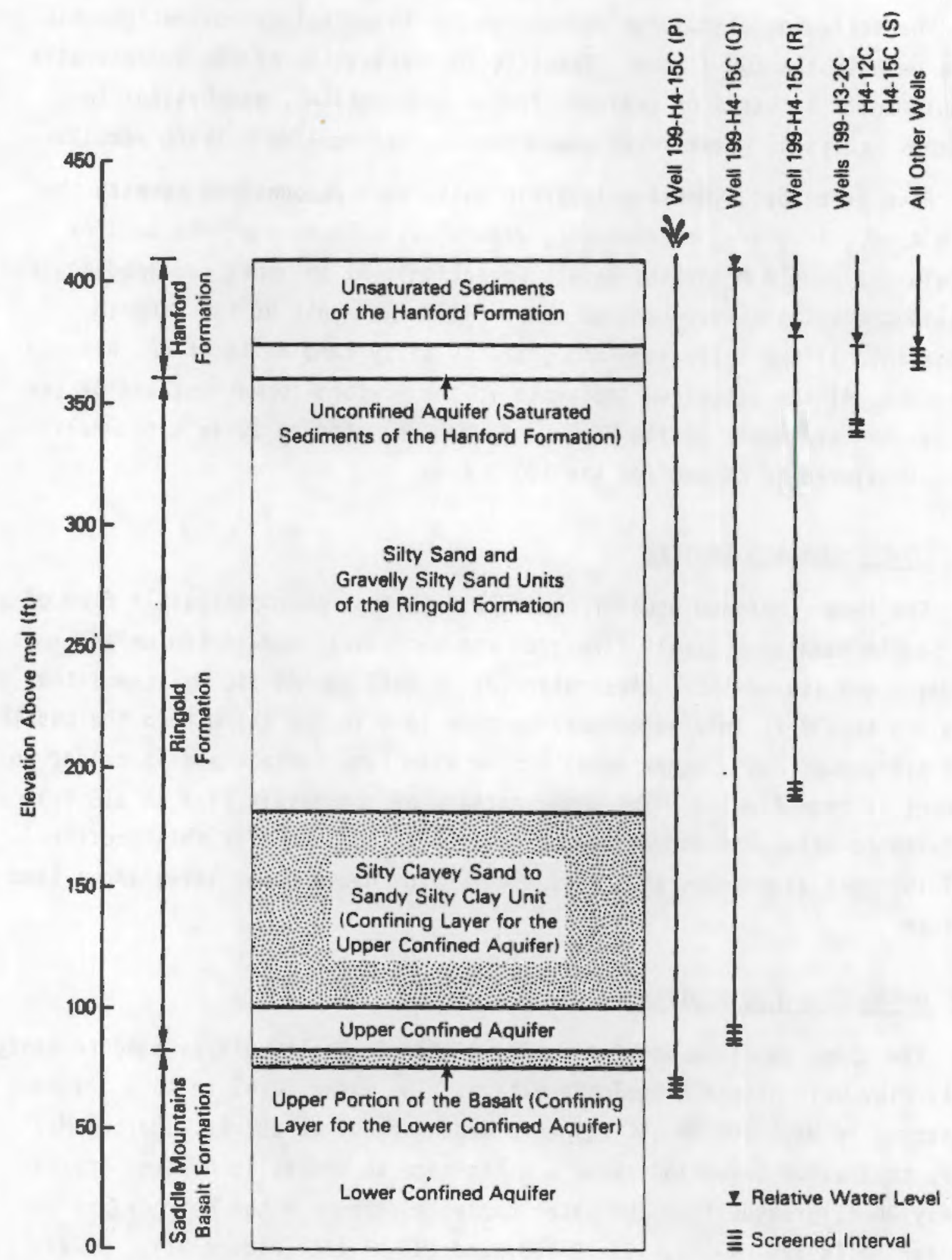

FIGURE 30. Generalized Hydrostratigraphic Column for the 100-H Area 


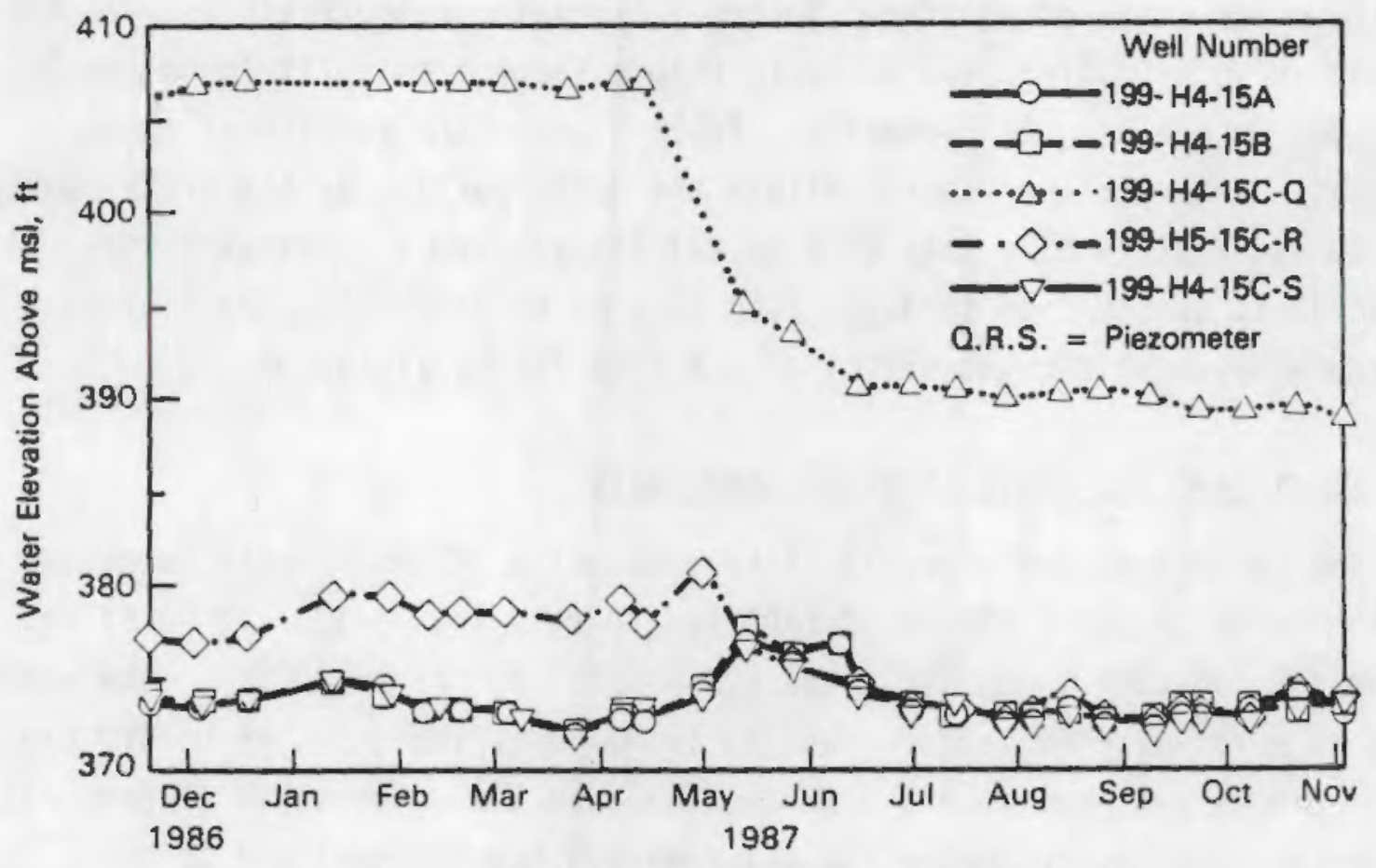

Starting Date: $11 / 20 / 86$ Ending Date: $11 / 04 / 87$

FIGURE 31. Hydrographs for Wells 199-H4-15A, 199-H4-15B, and 199-H4-15C

testing of piezometers $(Q)$ and $(R)$ in May 1987 may have altered the integrity of the bentonite seals adjacent to their screened intervals. Cloudy water noted at the surface following testing was assumed to be a result of well development. The hydrographs in Figure 31 indicate that piezometer $(Q)$ has lost approximately $15 \mathrm{ft}$ of hydraulic head and piezometer $(R)$ has lost approximately $3 \mathrm{ft}$ of hydraulic head. Piezometer (R) has reached equilibrium with wells 199-H4-15A, 199-H4-15B, and 199-H4-15C (S).

The large vertical separation and seals between these screened intervals were thought to have provided sufficient protection from hydraulic interconnection prior to testing. The annulus around the piezometers may reseal with time as the silty clayey sand to sandy silty clay and silty sand units settle through lithostatic pressure. Observation of the piezometers for several years may be necessary to determine if this process is occurring.

The upper portion of the silty clayey sand to sandy silty clay unit of the Ringold Formation (approximately $80 \mathrm{ft}$ ) is considered the confining layer 
for the upper confined aquifer. Vertical hydraulic conductivities were calculated using a falling head analysis (Klute 1986) from split-spoon samples collected in the Ringold Formation. Table 7 shows the results of these analyses. The sample collected within the upper portion of the silty clayey sand to sandy silty clay unit (275 to $277 \mathrm{ft}$ ) yielded a vertical horizontal conductivity of $1.0 \mathrm{E}-04 \mathrm{ft} /$ day. Slug testing of piezometer (Q) yielded a horizontal hydraulic conductivity of $1.4 \mathrm{E}-01 \mathrm{ft} /$ day (Table 8 ).

\subsection{SILTY SAND AND GRAVELLY SILTY SAND UNITS}

The silty sand and gravelly silty sand units of the Ringold Formation are monitored in Wells 199-H3-2C (100 to $110 \mathrm{ft}$ ), 199-H4-12C (72 to $82 \mathrm{ft}$ ), 199-H4-15C (R) (195 to $197 \mathrm{ft}$ ), and 199-H4-15C (S) (78 to $80 \mathrm{ft}$ ). The water level in piezometer ( $R$ ) before testing in May 1987 indicated an upward hydraulic gradient approximately $3 \mathrm{ft}$ greater than the water table (Figure 31 ). The water level in piezometer $(S)$ has remained nearly identical to Wells 199-H4-15A and 199-H4-15B (Figure 31).

The hydrographs for cluster We11s 199-H3-2A, 199-H3-28, and 199-H3-2C are shown in Figure 32. Wells 199-H3-2A and 199-H3-2B are completed in the Hanford formation. The water levels for these wells are nearly identical.

The hydrographs for cluster We11s 199-H4-12A, 199-H4-12B, and 199-H4-12C are shown in Figure 33. Wells 199-H4-12A and 199-H4-12B are completed in the Hanford formation. The water levels for these wells are nearly identical.

Two split-spoon samples were collected from within the silty sand and gravelly silty sand units. Vertical hydraulic conductivity values of

IABLE 7. Vertical Hydraulic Conductivity Values for Split-Spoon Samples

\begin{tabular}{|c|c|c|}
\hline Well & Depth $(\mathrm{ft})$ & $\begin{array}{l}\text { Hydraulic } \\
\text { Conductivity } \\
\text { (ft/day) } \\
\end{array}$ \\
\hline $199-\mathrm{H} 4-12 \mathrm{C}$ & $125-127$ & $1.5 \mathrm{E}-02$ \\
\hline $199-\mathrm{H} 4-15 \mathrm{C}$ & $120-122$ & $2.9 E-03$ \\
\hline $199-\mathrm{H} 4-15 \mathrm{C}$ & $275-277$ & $1.0 \mathrm{E}-04$ \\
\hline
\end{tabular}




\section{IABLE 8. Summary of Aquifer Testing Results}

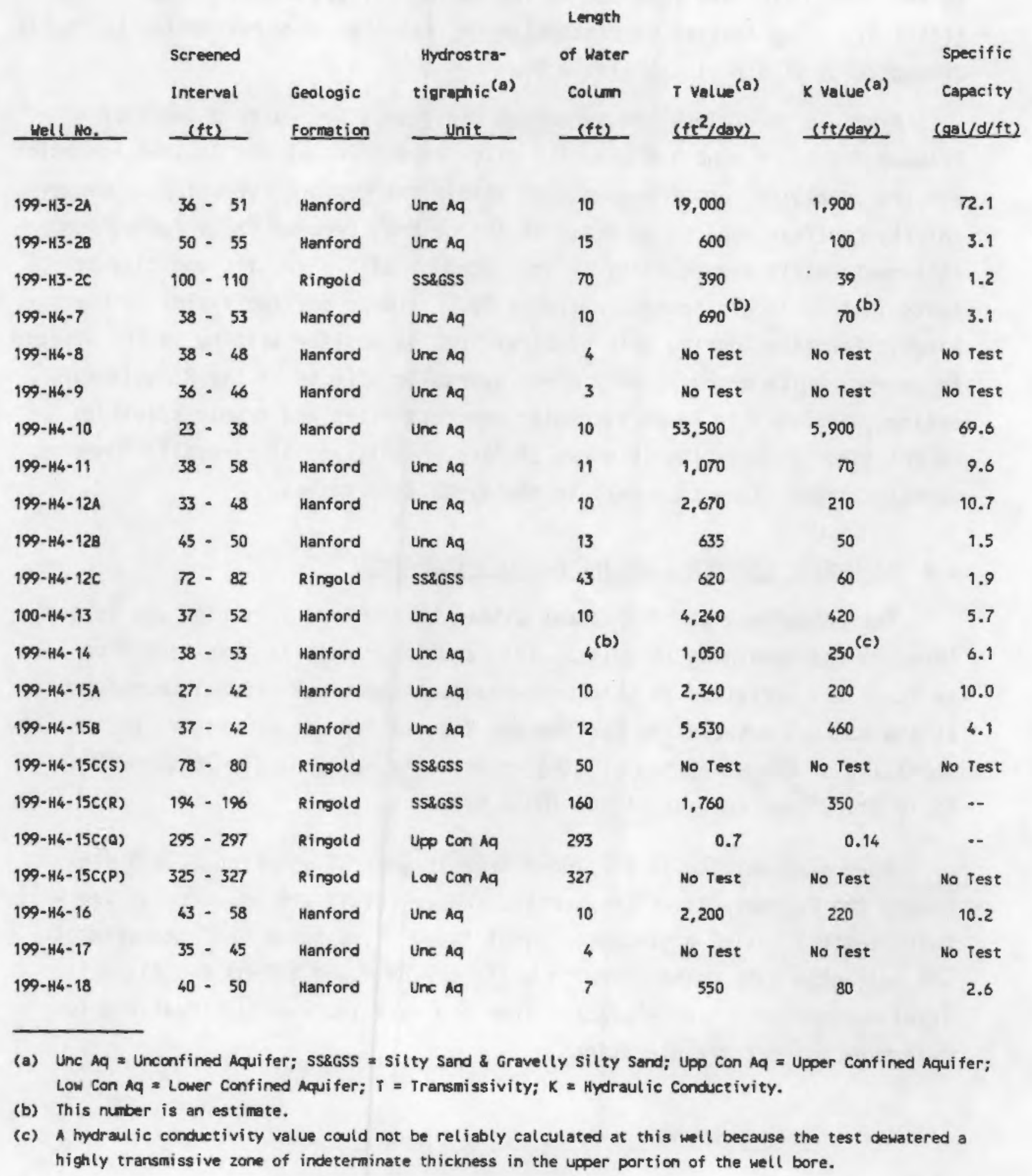


1.5 E-2 ft/day and $2.9 \mathrm{E}-3 \mathrm{ft} /$ day were measured for the $125-$ to $127-\mathrm{ft}$ sample in Well 199-H4-12C and from 120 to $122 \mathrm{ft}$ in Well 199-H4-15C, respectively (Table 7). Slug testing of piezometer $(R)$ resulted in a horizontal hydraulic conductivity of $350 \mathrm{ft} /$ day (Table 8 ).

Although water level measurements indicate a hydraulic connection between the silty sand and gravelly silty sand units of the Ringold Formation and the overlying unconfined aquifer within the Hanford formation, a permeability contrast appears to exist at the contact between these formations. This contrast in permeability is indicated by 1) higher silt and clay contents in the Ringold Formation (Table 5), 2) lower bailing yields in the Ringold Formation during well construction, 3) aquifer testing in the Hanford formation, which produced only minor hydraulic effects in the Ringold Formation, 4) generally lower hydraulic conductivities and transmissivities in the Ringold Formation (Figures 34 through 37), and 5) generally lower concentrations of contaminants in the Ringold Formation.

\subsection{SATURATED SEDIMENTS OF THE HANFORD FORMATION}

The unconfined aquifer occurs within the Hanford formation and is monitored in the remaining 16 wells. This aquifer ranges in thickness from 3 to $15 \mathrm{ft}$. This variation in thickness results from the erosional unconformity at the contact between the Hanford and Ringold Formations (Figure 28) and the variation of the water table. The water table is typically located 30 to $50 \mathrm{ft}$ below land surface at the $100-\mathrm{H}$ Area.

Ground-water flow in the 100-H Area is generally northeast and east toward the Columbia River (Figure 1). Water levels are measured in the wells twice monthly, using a graduated steel tape. Continuous head measurements are collected with transducers in Wells 199-H4-4 and 199-H4-5. All water level measurements are subtracted from the surveyed casing elevations to determine water table elevations. 


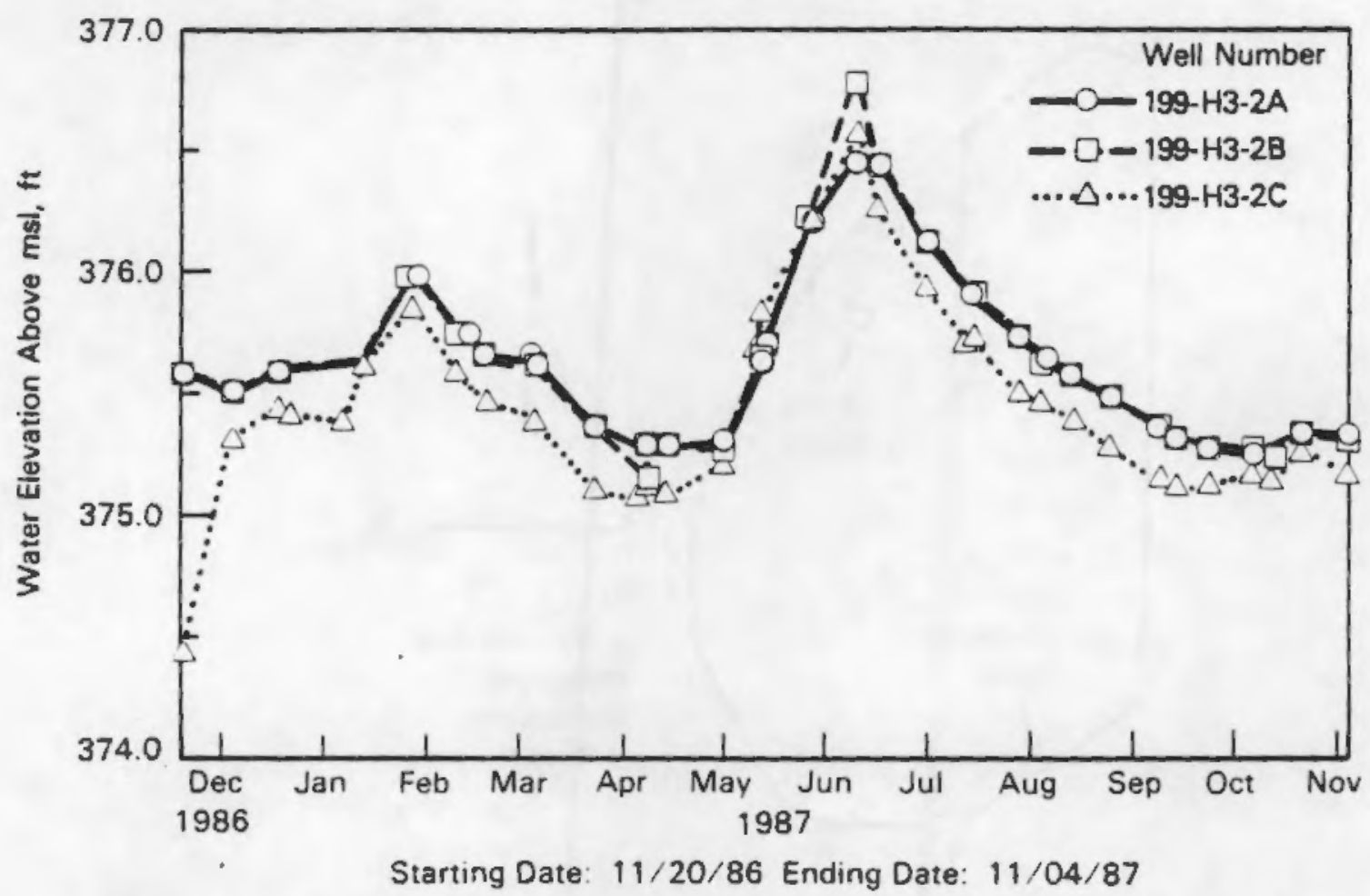

FIGURE 32. Hydrographs for Wells 199-H3-2A, 199-H3-2B, and 199-H3-2C

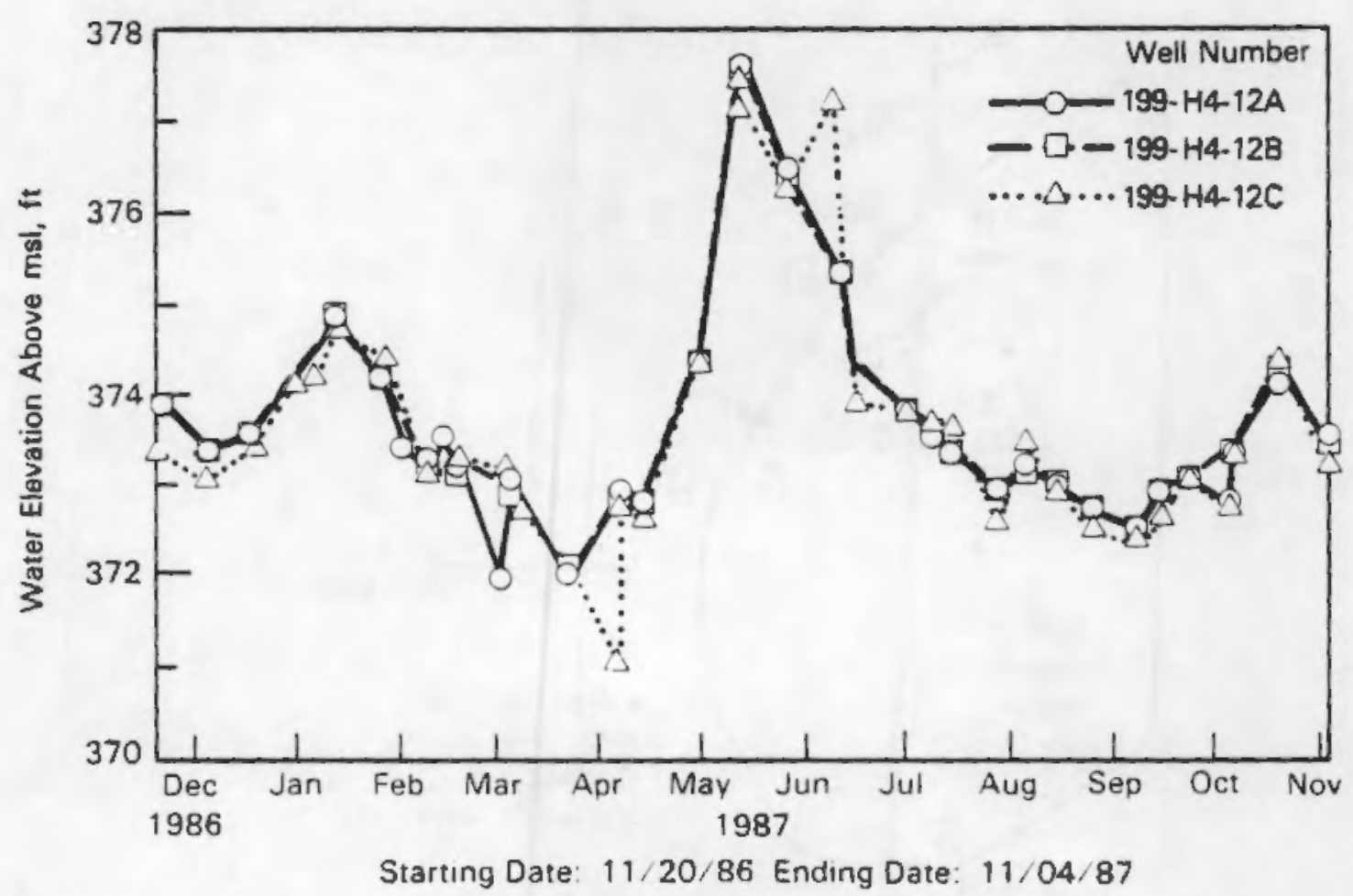

FIGURE 33. Hydrographs for Wells 199-H4-12A, 199-H4-128, and 199-H4-12C 


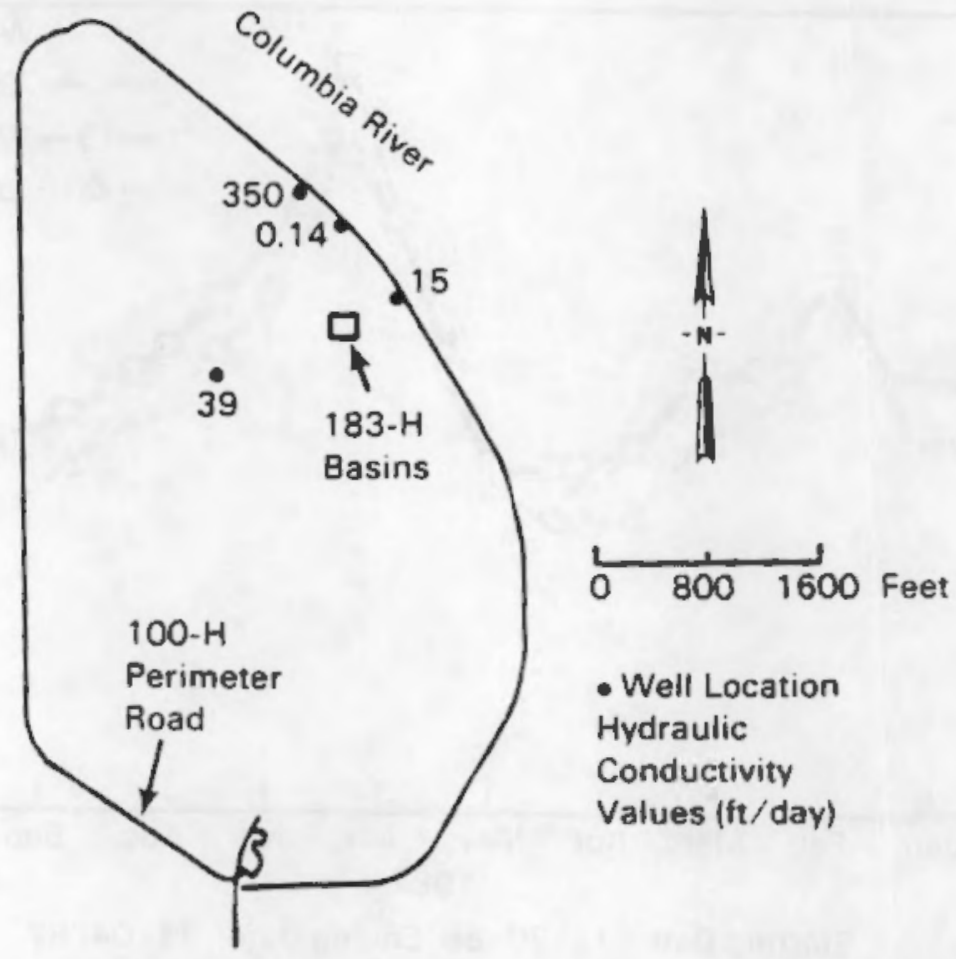

FIGURE 34. Hydraulic Conductivity (K) Values for the Silty Sand and Gravelly Silty Sand Units Within the Ringold Formation

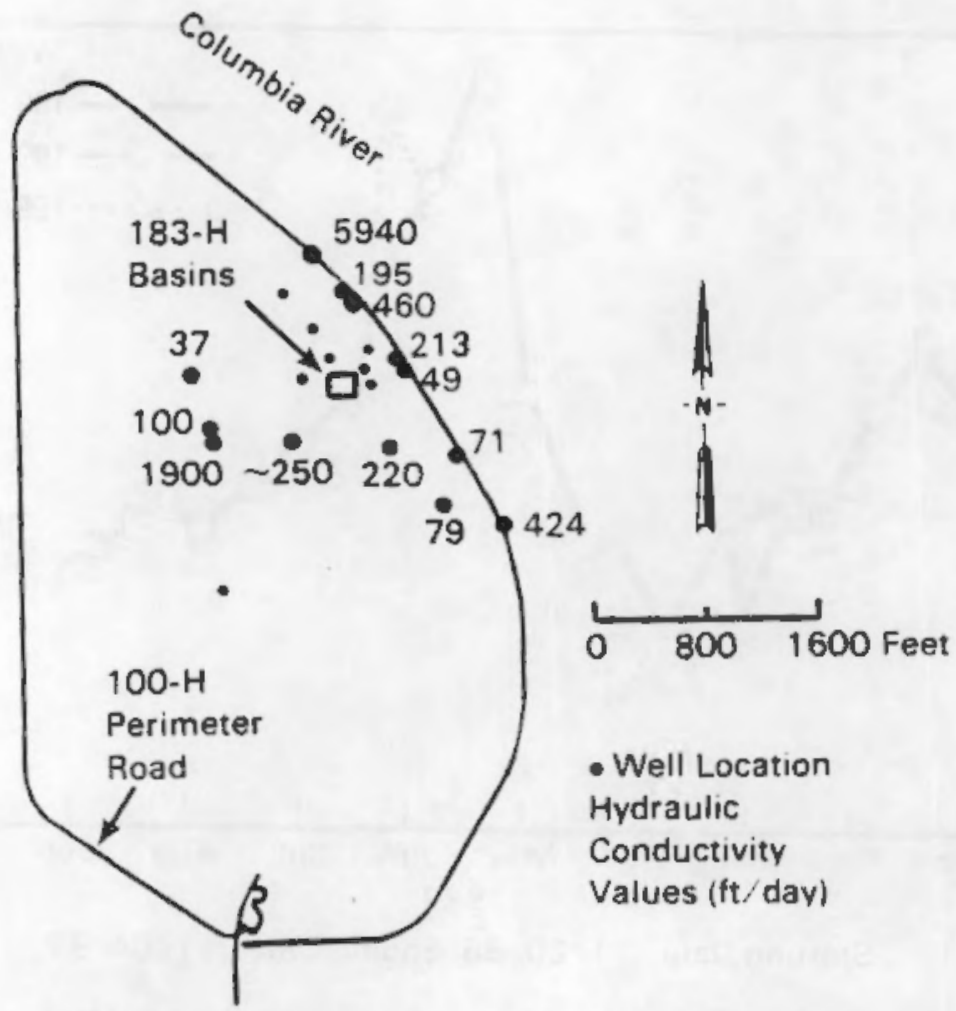

FIGURE 35. Hydraulic Conductivity (K) Values for the Unconfined Aquifer 


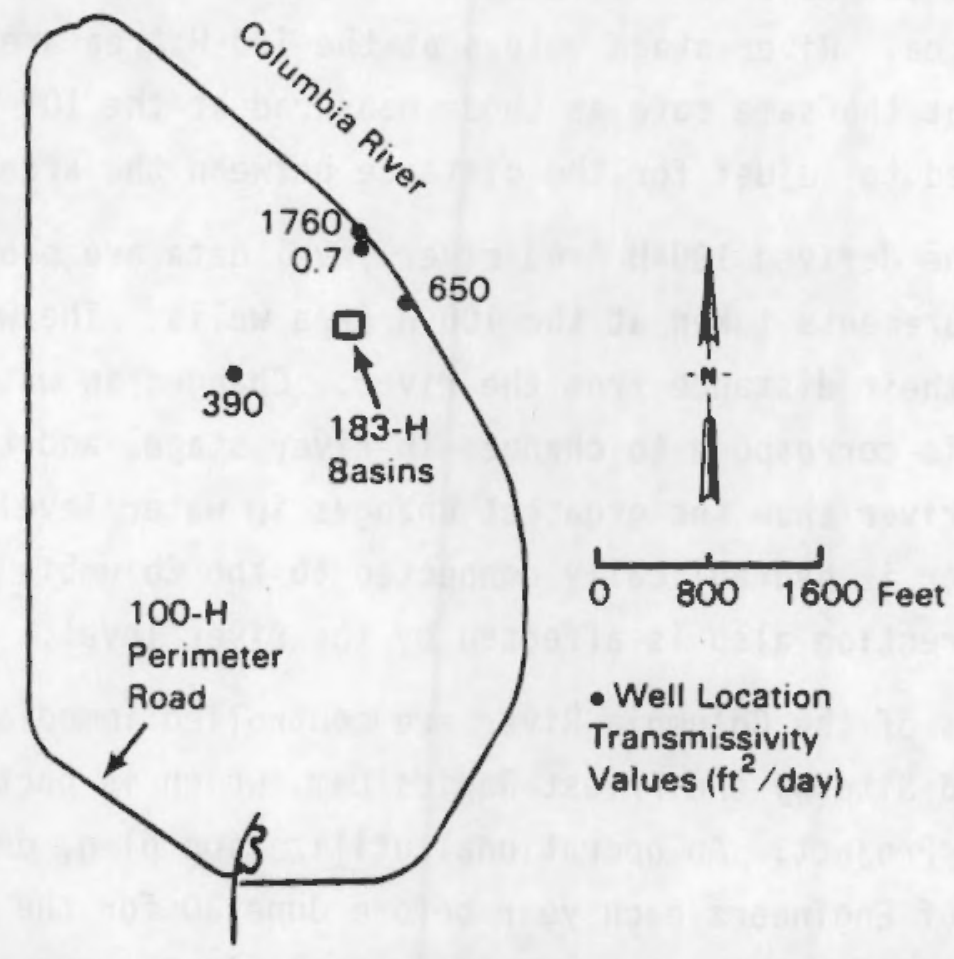

FIGURE 36. Transmissivity (T) Values for the Silty Sand and Gravelly Silty Sand Units Within the Ringold Formation

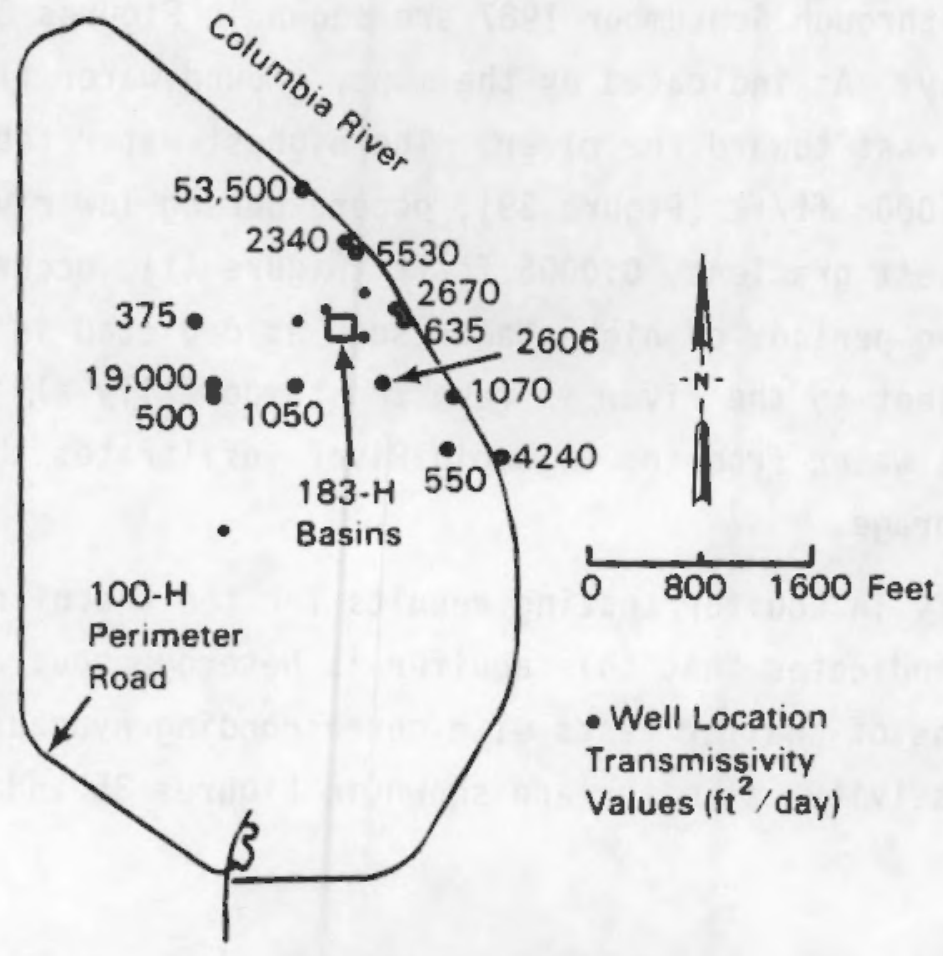

FIGURE 37. Transmissivity (T) Values for the Unconfined Aquifer 
Columbia River level data are collected from the Hanford Generating Plant at the 100-N Area. River-stage values at the 100- $\mathrm{H}$ Area are then assumed to increase at the same rate as those measured at the 100-N Area. A set time lag is used to adjust for the distance between the areas.

In Figure 38, the derived $100-\mathrm{H}$ Area river level data are plotted with the water level measurements taken at the $100-\mathrm{H}$ Area wells. The wells are plotted relative to their distance from the river. Changes in water table elevation in all wells correspond to changes in river stage, and those wells located nearest the river show the greatest changes in water level. Because the unconfined aquifer is hydraulically connected to the Columbia River, ground-water flow direction also is affected by the river level.

The fluctuations of the Columbia River are controlled immediately upstream of the Hanford Site by the Priest Rapids Dam, which is part of the Columbia Basin Water Project. An operational utilization plan, developed by the U.S. Army Corps of Engineers each year before June 30 for the forthcoming year, administers the water releases and river levels in the system.

Water table maps for the unconfined aquifer corresponding to low (September 1987), mean (December 1986), and high (May 1987) Columbia River stages for September 1986 through September 1987 are shown in Figures 39, 40, and 41 , respectively. As indicated by the maps, ground-water flow is generally northeast and east toward the river. The highest water table gradient across the site, $0.0008 \mathrm{ft} / \mathrm{ft}$ (Figure 39 ), occurs during low river stage, and conversely, the lowest gradient, $0.0005 \mathrm{ft} / \mathrm{ft}$ (Figure 41), occurs at the high river stage. During periods of high stage, such as depicted in Figure 41, the hydraulic gradient to the river is reversed temporarily all the way to the 183-H Basins as water from the Columbia River infiltrates the unconfined aquifer as bank storage.

The variability in aquifer testing results for the unconfined aquifer, given in Table 8, indicates that this aquifer is heterogeneous at the $100-\mathrm{H}$ Area. The locations of aquifer tests with corresponding hydrautic conductivity and transmissivity estimates are shown in Figures 35 and 37 , respectively. 


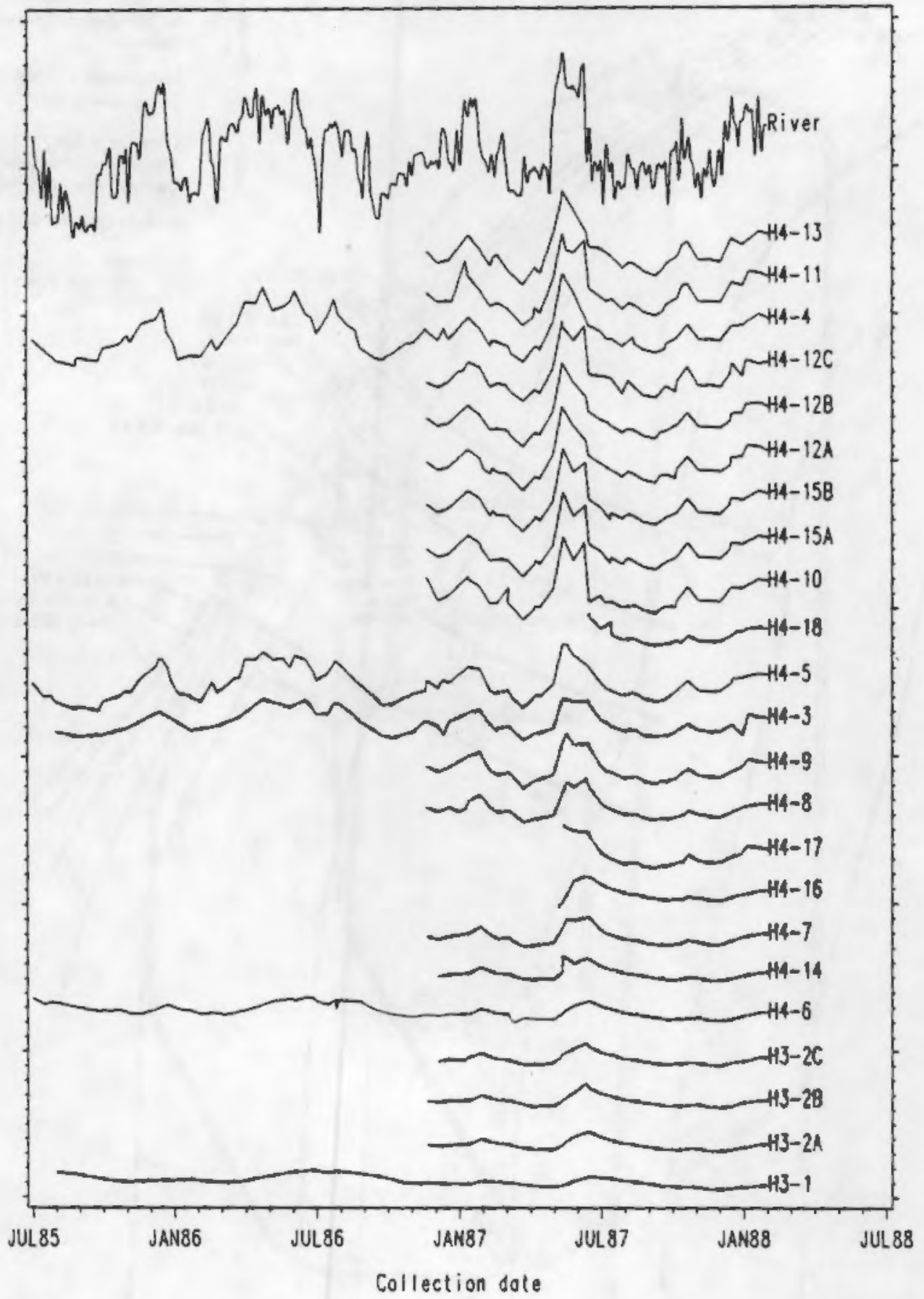

FIGURE 38. Relative Water Levels in the Columbia River and 100-H Area Monitoring Wells. (Wells are plotted relative to distance from the river. Vertical axis is marked in l-ft intervals for estimating fluctuations in individual wells, but not for comparing water levels between wells.) 


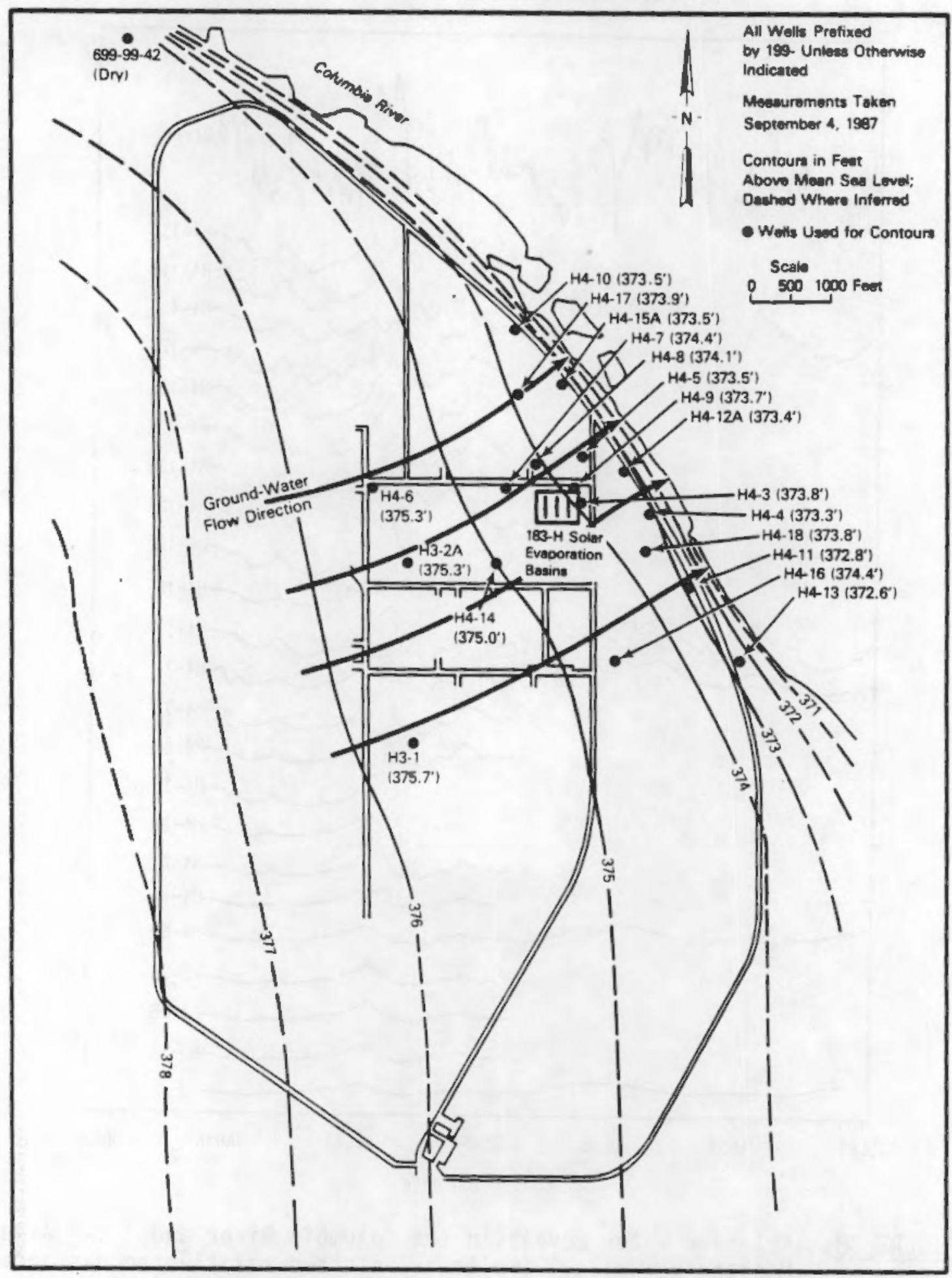

FIGURE 39. 100-H Area Water Table Map Corresponding to Low Columbia River Stage (September 1987) 


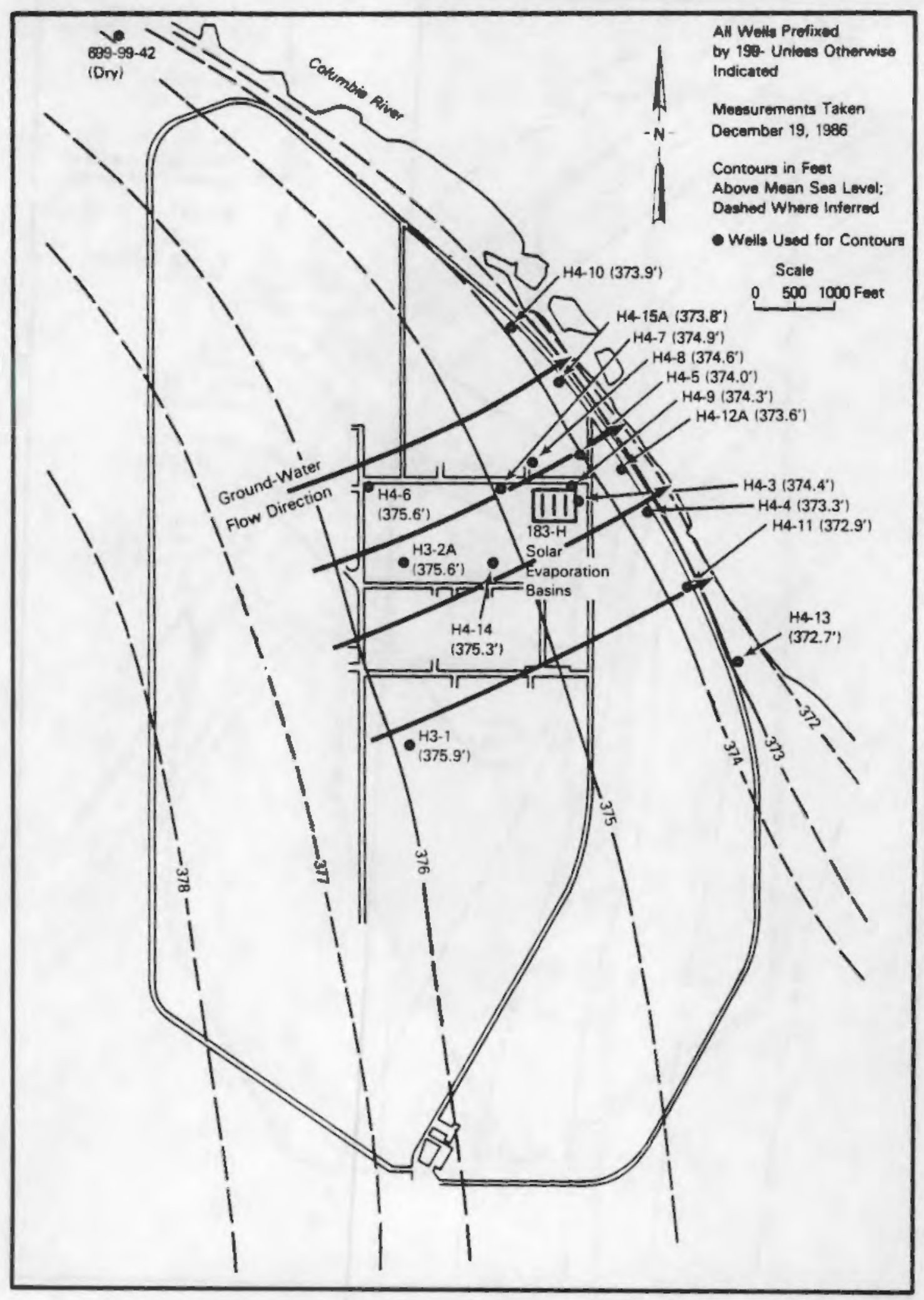

FIGURE 40. 100-H Area Water Table Map Corresponding to Mean Columbia River Stage (December 1986) 


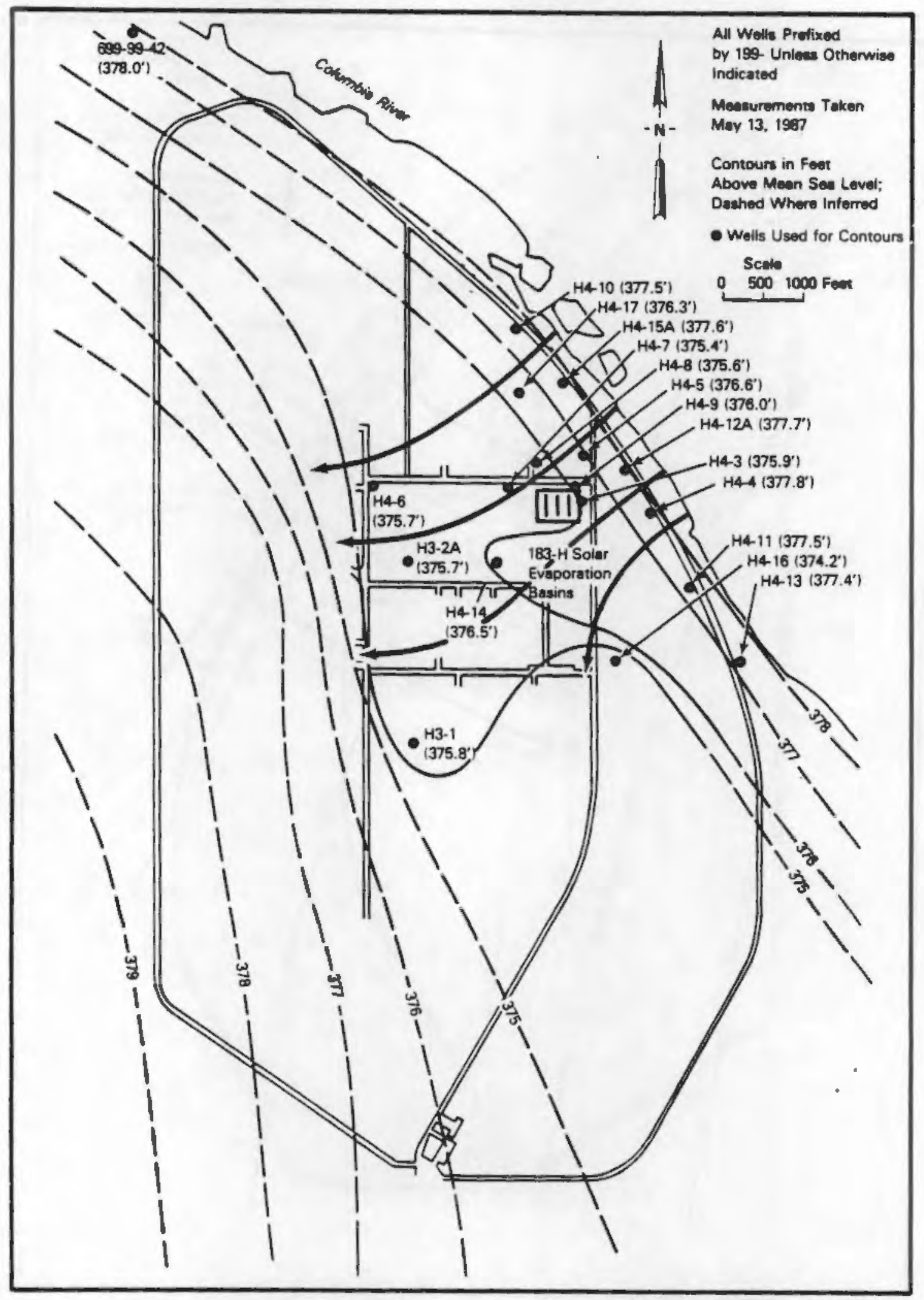

FIGURE 41. 100-H Area Water Table Map Corresponding to High Columbia River Stage (May 1987) 


\subsection{UNSATURATED SEDIMENTS OF THE HANFORD FORMATION}

The unsaturated sediments of the Hanford farmation extend frow the land surface to approximately 30 to $50 \mathrm{ft}$ below Iand surface. These sediments are a composfte of unconsolidated and poorly sorted boulders, cobbles, pebbles, sand, and silt. Table 9 lists the field moisture contents and mojsture contents at selected pressures, respectively, for the Phase II and III wells. These samples were collected with a drive barrel above the water tabie. 
IABLE 9. Field Motsture Contents and Water Retention Characteristics for the Phase II and III hells

\begin{tabular}{|c|c|c|c|c|c|}
\hline \multirow[b]{2}{*}{$\mathrm{Ne}] 1 \mathrm{Ho}$} & \multirow[b]{2}{*}{ Depth $(\mathrm{ft})$} & \multirow{2}{*}{$\begin{array}{l}\text { Field Water } \\
\text { content (wtw) }\end{array}$} & \multicolumn{3}{|c|}{ Water Retention (wt\%) } \\
\hline & & & 0.1 bar & $0.3 \mathrm{bar}$ & $1.0 \mathrm{bar}$ \\
\hline $\begin{array}{l}199-H 3-2 A \\
199-H 3-2 A \\
199-H 3-2 A \\
199-H B-2 A \\
199-H B-2 A \\
199-H 3-2 A \\
199-H 3-2 A\end{array}$ & $\begin{array}{r}4=5 \\
9=10 \\
14=15 \\
19-20 \\
24-25 \\
29-30 \\
39=40\end{array}$ & $\begin{array}{l}1.15 \\
1.24 \\
1.41 \\
1.18 \\
1.80 \\
1.56 \\
1.71\end{array}$ & $\begin{array}{r}6.44 \\
9.75 \\
11.33 \\
10.78 \\
5.11 \\
9.29 \\
11.08\end{array}$ & $\begin{array}{l}3.44 \\
6.20 \\
8.18 \\
7.82 \\
3.12 \\
5.91 \\
6.73\end{array}$ & $\begin{array}{l}2.34 \\
3.40 \\
4.72 \\
4.54 \\
1.94 \\
3.98 \\
4.64\end{array}$ \\
\hline $\begin{array}{l}199-13-2 B \\
199-H 3-28 \\
199-H 3-2 B \\
199-H 3-2 B \\
199-H 3-2 B \\
199-13-2 B \\
199-13-2 B \\
199-H 3-2 B\end{array}$ & $\begin{array}{r}4=5 \\
9=10 \\
14=15 \\
19=20 \\
24=25 \\
29=30 \\
34-35 \\
39=40\end{array}$ & $\begin{array}{l}2.20 \\
1.19 \\
1.56 \\
1.44 \\
\ldots \\
\cdots \\
\cdots \\
\cdots\end{array}$ & $\begin{array}{r}12.99 \\
8.73 \\
12.10 \\
11.59 \\
13.48 \\
13.63 \\
18.00 \\
26.96\end{array}$ & $\begin{array}{r}5.63 \\
5.07 \\
8.89 \\
7.05 \\
6.47 \\
4.80 \\
8.29 \\
21.31\end{array}$ & $\begin{array}{l}3.82 \\
2.71 \\
5.71 \\
3.81 \\
5.26 \\
4.94 \\
5.96 \\
3.94\end{array}$ \\
\hline $\begin{array}{l}199-1 \mathrm{H}-2 \mathrm{C} \\
199-\mathrm{H3}-2 \mathrm{C} \\
199-113-2 \mathrm{C} \\
199-\mathrm{H3}-2 \mathrm{C} \\
199-\mathrm{H3}-2 \mathrm{C} \\
199-\mathrm{H}^{3}-2 \mathrm{C} \\
199-\mathrm{H3}-2 \mathrm{C} \\
199-43-2 \mathrm{C}\end{array}$ & $\begin{array}{r}3-5 \\
9-10 \\
14-15 \\
19-20 \\
24-25 \\
29-30 \\
34-35 \\
39-40\end{array}$ & $\begin{array}{l}1.39 \\
0.83 \\
1.32 \\
1.31 \\
1.73 \\
1.56 \\
1.56 \\
4.23\end{array}$ & $\begin{array}{r}11.19 \\
10.16 \\
11.57 \\
11.86 \\
12.98 \\
9.85 \\
11.57 \\
13.07\end{array}$ & $\begin{array}{r}7.87 \\
6.92 \\
8.70 \\
8.49 \\
9.63 \\
5.97 \\
8.78 \\
10.38\end{array}$ & $\begin{array}{l}5.13 \\
4.29 \\
5.28 \\
4.69 \\
4.80 \\
3.17 \\
4.10 \\
6.36\end{array}$ \\
\hline $\begin{array}{l}199-H 4-7 \\
199-H 4-7 \\
199-H 4-7 \\
199-14-7 \\
199-144-7 \\
199-44-7 \\
199-144-7 \\
199-44-7\end{array}$ & $\begin{array}{r}4-5 \\
8-10 \\
14-15 \\
19=20 \\
24-25 \\
29-30 \\
34-35 \\
39-40\end{array}$ & $\begin{array}{l}2.67 \\
2.92 \\
3.81 \\
4.44 \\
1.76 \\
1.99 \\
1.64 \\
3.31\end{array}$ & $\begin{array}{r}7.33 \\
7.82 \\
6.32 \\
10.93 \\
9.13 \\
12.16 \\
13.21 \\
13.57\end{array}$ & $\begin{array}{l}4.49 \\
3.83 \\
5.59 \\
9.87 \\
3.20 \\
6.71 \\
8.18 \\
9.79\end{array}$ & $\begin{array}{l}4.15 \\
3.57 \\
5.59 \\
6.89 \\
4.22 \\
5.94 \\
7.35 \\
6.88\end{array}$ \\
\hline $\begin{array}{l}199-14-8 \\
199-.-14-8 \\
199-144-8\end{array}$ & $\begin{array}{r}5-5 \\
9-10 \\
14-15\end{array}$ & $\begin{array}{l}4.98 \\
1.60 \\
1.57\end{array}$ & $\begin{array}{r}10.12 \\
6.71 \\
7.83\end{array}$ & $\begin{array}{l}6.30 \\
5.25 \\
6.53\end{array}$ & $\begin{array}{l}6.14 \\
2.28 \\
3.41\end{array}$ \\
\hline
\end{tabular}


IABLE 9. (contd)

\begin{tabular}{|c|c|c|c|c|c|}
\hline Well No. & Depth $(\mathrm{ft})$ & $\begin{array}{l}\text { Field Water } \\
\text { Content (wt\%) }\end{array}$ & $\frac{\text { Wate }}{0.1 \text { bar }}$ & $\frac{\text { Retentiol }}{0.3 \text { bar }}$ & $\frac{w t \%)}{1.0 \text { bar }}$ \\
\hline $\begin{array}{l}199-H 4-8 \\
199-H 4-8 \\
199-H 4-8 \\
199-144-8 \\
199-14-8 \\
199-44-8\end{array}$ & $\begin{array}{l}19-20 \\
24=25 \\
29=30 \\
34=35 \\
39=40 \\
44=45\end{array}$ & $\begin{array}{l}1.66 \\
1.65 \\
1.76 \\
1.94 \\
1.69 \\
4.54\end{array}$ & $\begin{array}{r}9.26 \\
7.91 \\
9.27 \\
12.33 \\
9.69 \\
8.81\end{array}$ & $\begin{array}{r}6.27 \\
6.08 \\
7.36 \\
11.88 \\
7.69 \\
7.18\end{array}$ & $\begin{array}{l}3.73 \\
2.70 \\
3.71 \\
3.90 \\
3.79 \\
4.04\end{array}$ \\
\hline $\begin{array}{l}199-144-9 \\
199-H 4-9 \\
199-44-9 \\
199-H 4-9 \\
199-H 4-9 \\
199-144-9 \\
199-H 4-9 \\
199-H 4-9\end{array}$ & $\begin{array}{c}4-5 \\
10 \\
14-15 \\
19=20 \\
24=25 \\
29-30 \\
35-36 \\
40\end{array}$ & $\begin{array}{l}8.77 \\
3.44 \\
6.84 \\
6.54 \\
3.83 \\
1.58 \\
1.57 \\
2.15\end{array}$ & $\begin{array}{l}17.06 \\
12.94 \\
10.05 \\
11.68 \\
10.79 \\
11.36 \\
14.91 \\
7.49\end{array}$ & $\begin{array}{r}7.98 \\
6.17 \\
6.36 \\
7.12 \\
6.16 \\
9.66 \\
12.36 \\
6.61\end{array}$ & $\begin{array}{l}6.36 \\
5.24 \\
6.06 \\
6.55 \\
5.18 \\
6.01 \\
7.71 \\
3.68\end{array}$ \\
\hline $\begin{array}{l}199-\mathrm{H} 4-10 \\
199-\mathrm{H}-10 \\
199-\mathrm{H}-10 \\
199-\mathrm{H}-10 \\
199-\mathrm{H}-10 \\
199-\mathrm{H}-10\end{array}$ & $\begin{array}{r}5-6 \\
9-10 \\
15-16 \\
19-20 \\
24-25 \\
29-30\end{array}$ & $\begin{array}{l}8.35 \\
2.37 \\
2.37 \\
1.37 \\
2.47 \\
3.03\end{array}$ & $\begin{array}{r}11.87 \\
7.36 \\
9.57 \\
9.11 \\
9.35 \\
10.17\end{array}$ & $\begin{array}{l}5.29 \\
3.17 \\
6.42 \\
5.69 \\
5.49 \\
7.02\end{array}$ & $\begin{array}{l}5.37 \\
2.83 \\
4.84 \\
4.21 \\
4.45 \\
5.91\end{array}$ \\
\hline $\begin{array}{l}199-H 4-11 \\
199-H 4-11 \\
199-H 4-11 \\
199-H 4-11 \\
199-H 4-11 \\
199-H 4-11 \\
199-H 4-11 \\
199-H 4-11 \\
199-H 4-11\end{array}$ & $\begin{array}{r}4-5 \\
9-10 \\
14-15 \\
19=20 \\
24-25 \\
29-30 \\
34=35 \\
39=40 \\
44=45\end{array}$ & $\begin{array}{l}7.35 \\
2.97 \\
1.69 \\
2.24 \\
1.99 \\
2.78 \\
3.08 \\
2.76 \\
3.60\end{array}$ & $\begin{array}{r}9.41 \\
9.65 \\
5.21 \\
4.61 \\
14.22 \\
15.30 \\
8.91 \\
11.74 \\
10.56\end{array}$ & $\begin{array}{l}6.45 \\
6.21 \\
3.96 \\
6.25 \\
7.74 \\
7.76 \\
6.04 \\
9.13 \\
5.22\end{array}$ & $\begin{array}{l}4.01 \\
3.51 \\
2.54 \\
2.39 \\
3.03 \\
2.88 \\
4.04 \\
6.02 \\
4.31\end{array}$ \\
\hline $\begin{array}{l}199-H 4-12 A \\
199-H 4-12 A \\
199-H 4-12 A \\
199-H 4-12 A \\
199-H 4-12 A \\
199-H 4-12 A \\
199-H 4-12 A\end{array}$ & $\begin{array}{r}4-5 \\
9=10 \\
14=15 \\
19-20 \\
24-25 \\
29=30 \\
34-35\end{array}$ & $\begin{array}{l}3.56 \\
1.76 \\
2.67 \\
2.07 \\
1.73 \\
2.04 \\
3.00\end{array}$ & $\begin{array}{r}11.27 \\
7.27 \\
9.14 \\
8.44 \\
9.67 \\
9.62 \\
11.91\end{array}$ & $\begin{array}{l}5.68 \\
4.59 \\
5.04 \\
9.87 \\
5.20 \\
6.69 \\
7.52\end{array}$ & $\begin{array}{l}3.98 \\
1.92 \\
4.19 \\
2.82 \\
3.04 \\
3.34 \\
4.72\end{array}$ \\
\hline
\end{tabular}


TABLE 9. (contd)

Field Water Well No. Depth (ft) Content (wt)

$199-\mathrm{H} 4-128$

$199-\mathrm{H} 4-12 B$

$199-\mathrm{H} 4-12 \mathrm{~B}$

$199-\mathrm{H4}-12 \mathrm{~B}$

$199-\mathrm{H} 4-12 \mathrm{~B}$

$199-H 4-128$

$199-44-12 B$

$199-144-12 \mathrm{C}$

$199-\mathrm{H} 4-12 \mathrm{C}$

$199-44-12 C$

$199+\mathrm{H4}-12 \mathrm{C}$

$199-44-12 C$

$199-\mathrm{H}^{4}-12 \mathrm{C}$

199- $\mathrm{H} 4-12 \mathrm{C}$

$199+144-13$

$199-\mathrm{H} 4-13$

$199-144-13$

$199-\mathrm{H} 4-13$

199- $44-13$

$199-H 4-13$

199-44-13

$199-144-13$

199-144-14

199- H4- 14

$199-\mathrm{H} 4-14$

$199-134-14$

$199-144-14$

199-H4-14

199-H4-14

199- H4 - 14

199- H4-15A

199-H4-15A

199-44-15A

199- H - 4 - 15A

$199 *-14-15 A$

199-H4-15A
$4-5$

9- 10

$14-15$

$19-20$

$24-25$

$29-30$

$34-35$

5
10
$14-15$
$19-20$
$24=25$
$29-30$
$34=35$

$4-5$

$9-10$

$14-15$

$19-20$

$24-25$

29 - 30

$34-35$

$39-40$

$4-5$

$9-10$

$14-15$

$19-20$

$24-25$

$29-30$

$34-35$

$39-40$

$$
\begin{array}{r}
4-5 \\
9-10 \\
14-15 \\
19=20 \\
24-25 \\
29-30
\end{array}
$$

3.26

10.70

5.89

6.19

2.27

2.91

2.83

\begin{tabular}{|c|c|c|}
\hline Q. I bar & $0.3 \mathrm{bar}$ & $1.0 \mathrm{bar}$ \\
\hline $\begin{array}{r}14.63 \\
9.61 \\
12.00 \\
11.24 \\
12.87 \\
10.84 \\
16.84\end{array}$ & $\begin{array}{l}8.55 \\
5.98 \\
6.96 \\
6.32 \\
6.86 \\
6.61 \\
9.54\end{array}$ & $\begin{array}{l}3.38 \\
2.95 \\
4.34 \\
4.04 \\
3.63 \\
4.49 \\
5.09\end{array}$ \\
\hline
\end{tabular}

2.54

2.20

-.

-

-
Water Retention (wt; )

16.86

18.06

21.03

21.22

9.46

9.26

10.54

7.78

7.18

3.80

9.02

11.47

5.48

5.71

7.64

3.11

3.11

3.24

3.42

3.98

5.32

8.49
11.99
10.74
9.96
8.48
5.45
8.05
8.34

5.80

8.52

7.32

7.04

3.59

3.12

3.08

2,20

4.49

6.00

6.02

6.05

2.40

2.47

3.64

3.67

$\begin{array}{ll}-\infty & 15.31\end{array}$

12.23

11.87

24.23

13.19

8.12

9.91

5.44

19.37

10.84

11.83

9.15

10.48

5.14

6.51

5.82

6.34

6.64

7.39

12.41

14.22

6.49

6.50

7.92

5.91

6.75

11.57

10.69

9.75

14.53

16.03

10.74

3.77

11.49

13.49

3.77

4.30

6.94

7.84

9.83 
TABLE 9. (contd)

\begin{tabular}{|c|c|c|c|c|c|}
\hline \multirow[b]{2}{*}{ Kell No. } & \multirow[b]{2}{*}{ Depth (ft) } & \multirow{2}{*}{$\begin{array}{l}\text { Field Water } \\
\text { Content (wtin) }\end{array}$} & \multicolumn{3}{|c|}{ Vater Retention (wto) } \\
\hline & & & 0.1 bar & 0.3 bar & 1.0 bar \\
\hline $\begin{array}{l}199-H 4-15 B \\
199-H 4-15 B \\
199-H 4-15 B \\
199-H 4-15 B \\
199-H 4-15 B \\
199-H 4-15 B\end{array}$ & $\begin{array}{r}4-5 \\
9-10 \\
14-15 \\
19-20 \\
24-25 \\
29-30\end{array}$ & $\begin{array}{l}3.99 \\
=- \\
\cdots \\
\cdots \\
\cdots\end{array}$ & $\begin{array}{l}10.04 \\
11.49 \\
16.79 \\
17.19 \\
18.85 \\
21.53\end{array}$ & $\begin{array}{r}5.86 \\
7.65 \\
11.56 \\
12.39 \\
13.90 \\
15.28\end{array}$ & $\begin{array}{l}4.49 \\
5.61 \\
8.98 \\
8.56 \\
9.98 \\
9.86\end{array}$ \\
\hline $\begin{array}{l}199-H 4-15 C \\
199-H 4-15 C \\
199-H 4-15 C \\
199-H 4-15 C \\
199-H 4-15 C \\
199-H 4-15 C\end{array}$ & $\begin{array}{r}3-5 \\
9-10 \\
14-15 \\
19-20 \\
24-25 \\
29-30\end{array}$ & $\begin{array}{l}7.05 \\
2.17 \\
1.96 \\
3.61 \\
3.39 \\
2.36\end{array}$ & $\begin{array}{l}16.18 \\
11.62 \\
10.28 \\
10.11 \\
11.75 \\
9.55\end{array}$ & $\begin{array}{r}11.34 \\
7.48 \\
6.80 \\
6.62 \\
8.98 \\
6.78\end{array}$ & $\begin{array}{l}7.49 \\
5.02 \\
4.06 \\
3.91 \\
5.57 \\
3.95\end{array}$ \\
\hline $\begin{array}{l}199-H 4-16 \\
199-H 4-16 \\
199-H 4-16 \\
199-H 4-16 \\
199-H 4-16 \\
199-H 4-16 \\
199-H 4-16 \\
199-H 4-16 \\
199-H 4-16\end{array}$ & $\begin{array}{r}4-5 \\
9-10 \\
14=15 \\
19-20 \\
24-25 \\
29-30 \\
34-35 \\
39-40 \\
44-45\end{array}$ & $\begin{array}{l}3.06 \\
1.14 \\
1.37 \\
1.25 \\
1.30 \\
1.32 \\
1.29 \\
1.41 \\
1.44\end{array}$ & $\begin{array}{r}15.27 \\
6.16 \\
13.30 \\
8.46 \\
10.11 \\
8.45 \\
12.27 \\
10.41 \\
11.89\end{array}$ & $\begin{array}{l}8.45 \\
3.71 \\
7.26 \\
4.84 \\
6.76 \\
4.96 \\
7.92 \\
6.13 \\
7.30\end{array}$ & $\begin{array}{l}6.06 \\
2.13 \\
5.02 \\
3.28 \\
5.17 \\
4.17 \\
5.32 \\
3.69 \\
4.39\end{array}$ \\
\hline $\begin{array}{l}199-\mathrm{H} 4-17 \\
199-\mathrm{H} 4-17 \\
199-\mathrm{H} 4-17\end{array}$ & $\begin{array}{r}4-5 \\
9-0 \\
14-15\end{array}$ & $\begin{array}{l}3.68 \\
3.20 \\
1.87\end{array}$ & $\begin{array}{l}17.98 \\
12.96 \\
12.02\end{array}$ & $\begin{array}{l}7.33 \\
6.38 \\
5.83\end{array}$ & $\begin{array}{l}5.59 \\
5.04 \\
4.19\end{array}$ \\
\hline $\begin{array}{l}199-H 4-18 \\
199-H 4-18\end{array}$ & $\begin{array}{l}4-5 \\
9-10\end{array}$ & $\begin{array}{l}2.49 \\
1.46\end{array}$ & $\begin{array}{l}14.34 \\
13.18\end{array}$ & $\begin{array}{r}10.29 \\
7.93\end{array}$ & $\begin{array}{l}6.48 \\
4.91\end{array}$ \\
\hline
\end{tabular}





\subsection{DESCRIPTION OF THE WELL INSTALLATION AND GEOHYOROLOGIC CHARACTERIZATION EFFORT}

This section of the report provides information on the details of well design and construction, field methods employed during construction, and well locations.

\subsection{DETAILS OF HELL DESIGN AND CONSTRUCTION}

The monitoring wells at the 100-H Area can be divided into three groups based of construction design: 1) wells constructed with perforated carbon steel casing, 2) wells constructed with carbon steel casing and stanless steel screen, and 3) wells constructed with stainless steel casing and screen. All the wells were installed using the cable-tool drilling method. Completion data for these wells are given in Table 10. Construction diagrams, Tthologic diagrams, and geophysical logs for each well are contained in Appendix A.

\section{1 .1 Hells Installed Before 1985}

Wells 199-43-1 and 199-H4-3 were constructed with 8-in. and 6-in, perforated carbon steel casing, respectively. Well 199-H3-1 was installed upgradient of the 183-H Basins in 1960 as part of a sitewide network to monitor tritium and nitrate in the ground water at the Hanford Site. The well is perforated from 29 to $74 \mathrm{ft}$. Well $199 \mathrm{H} 4-3$ was installed directly downgradient from the 183-H Basins in 1974 and is perforated froti 34 to $55 \mathrm{ft}$. Both these wells are designed to monitor the top of the unconfined aquifer. Inital depths to water were $45 \mathrm{ft}$ in Well $199-\mathrm{H} 3-1$ and $39 \mathrm{ft}$ in Well 199-H4-3. In 1987, concrete pads and protective steel posts were installed around both these wells to prevert pooling of water and to protect the surface casing.

Wells 199-H4-4, 199-H4-5, and 199-44-6 were installed in 1983 for the speciflc purpose of monitoring the 163-H Basins. These wells were con structed with carbon steel casing and telescoping stainless steel screen. The wells are screened in the upper portion of the unconfined aquifer, from 33 to $43 \mathrm{ft}, 32$ to $42 \mathrm{ft}$, and 39 to $49 \mathrm{ft}$, respectively. Initial depths to 
IABLE 10. Completion Data for the 100-H Area We11s

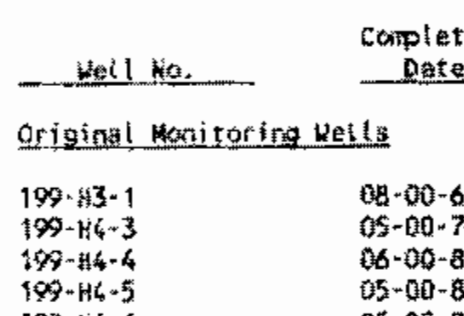

$05+00-83$

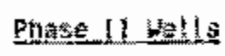

\section{$198-13-2$ 南}

$198-+13^{2}+28$

$196-\mathrm{h} 3-\mathrm{z}$.

$199 \cdot 44^{4}-7$

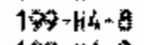

$198-19+9$

$19+4-40$

$198-13+11$

$194-H 4-12 A$

$=199 \times 12+12$

$199 \cdot-14.120$

$199 \cdot \mathrm{H} 4-16$

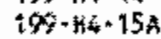

$190.144-55$

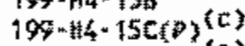

$109-H_{4}^{*} \cdot 15 \mathrm{C}(2)$ (e)

$190-44-150(2)\{c t$
$109 \cdot 44-150(5)$

$05-00+83$

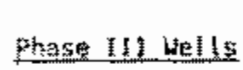

\section{9-H每数}

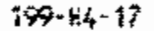

$190-14.18$

$$
\begin{aligned}
& 11+04-86 \\
& 11+14+86 \\
& 10-15+86 \\
& 09-22-86 \\
& 09-11+86 \\
& 09-24-86 \\
& 09-22-86 \\
& 11-10+86 \\
& 11+04-86 \\
& 11+11-86 \\
& 11-03-86 \\
& 11-20-86 \\
& 12+65-86 \\
& 11+19 \cdot 86 \\
& 11-19-86 \\
& 10-29-86 \\
& 10-28-86 \\
& 10-26-86 \\
& 10-29-86
\end{aligned}
$$

\begin{tabular}{|c|c|c|}
\hline & $p p t h\langle f t\}^{(a)}$ & \\
\hline $\begin{array}{c}70 \\
\text { astong }\end{array}$ & $\begin{array}{c}\text { co } \\
\text { Water }\end{array}$ & $\begin{array}{l}\text { of seretned } \\
\text { Interval }\end{array}$ \\
\hline
\end{tabular}

$04-30+87$

05-ch-8?

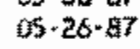

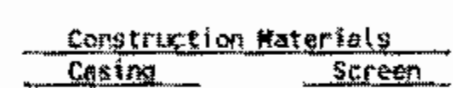

sereen carbon steel

Carbon steel

tarbon steel

Catwon steet

carbon steet
Perfaratsod Partforated stainless Sthinl cess

stairti ess
45
39
36
36
41

75
55
50
60
54

stainfese

Statinless

steinless

St任解妿

stainless

stậntes

statinless

stojatles

stainles:

Statinless

stainless

Statituless

Staintiss

stainless

Stainless

Staini ess

staintess

Stacintess

Stantess

staintess
statinless

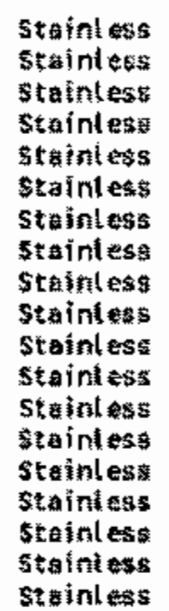

Stainless

Stginless
Staintess

45
39
36
36
41

41
40.5
41
43
44
43
29
43
38
37
36
4.4
43
52
30
560 wing
0.25
27.5
30.5

$3 x+31$

$30-55$
$100-110$

$38+53$

$38-45$

36,46

23- 38

$38-53$

$33 * 48$

$45-50$

$72-32$

$37-52$

xa-53

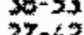

$27-42$

$37 \div 42$

$325-327$
$465-247$

$695-297$
$194-1 \%$

$78-80$

57.5
45
51

49.5
41.5
4.5
$42.5-57.5$
$35+45$
4. 150

Hodrostrati

sropitif

Coordinates

Une Aq

Whe Ad

Whe an

the an

whe $\mathrm{kg}$

the Aq

Unte $A q$

Une Aq

Une Aq

thes the

Inin ka

Ine Aa

une Aq

in ta

558655

the Aq

the to

Une tha

une Aa

Unc Aa

Low Con 19

Uipo con

558655

SSRt5S

Whetry Aq

the on 승

uncon Aa
$4099 \times 3$ w 40052.4

186372.3 \& 39070.7

* 9635x.3 W3685.8

\% 96639.7 y 3908.5

1) 96472.9 U 40245.5

96010.8 40117.0

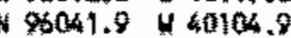

4 90019.4 40003

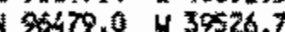

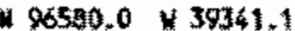

96488.3 उo136.2

$\begin{array}{ll}96488.3 & 39136.2 \\ 67344.6 & 39429.1\end{array}$

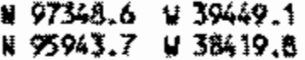

96549.5 \& 38854.0

16568.3 W 38389.6

a 4572.8 y 38543.3

5506.3 1

19024 , $3952 \%, 2$

H Trote. $\mathrm{v}$ 30197.

$\kappa 97032.2$ บ 39212.3

N 70033.5 \% 39185.8

N $97033.5 \cup 37185.6$

I 97033.5 \$ 39185.8

$N$ g7033.5 \& 39185.6

N5486.0 U 38645.6

$1006100 \%$

N \%o3s.8 1 38925.2

(a) All dopths are given in weet retative to lard sufface.

(b) Unc Aq = uncontined Aquifer, SS Low Con Aq I Low contined Aquifer,

(i) Pictorictera. 
water were $36 \mathrm{ft}$ in Well 199-H4-4, $36 \mathrm{ft}$ in Well 199-H4-5, and $41 \mathrm{ft}$ in well 199-H4-6. A cement seal, extending from the ground surface down to a depth of approximately $20 \mathrm{ft}$, was placed around the outside of the carbon steel casing. In 1987, concrete pads and protective steel posts were installed around each of these wells to prevent pooling of water and to protect the surface casing.

\section{1 .2 Phase II Wells}

In 1986, the monitoring network was expanded with the addition of 16 wells, including seven single shallow wells and three clusters consisting of three wells each (shallow, internediate, and deep). The cluster wells are located approximately $25 \mathrm{ft}$ apart in a triangular arrangement. The Phase II wells were constructed and completed in accordance with RCRA and WAC regulations in 40 CFR 265, WAC 173-160, and WAC 173-303-645(8) (CFR 1987; WDOE $1986 \mathrm{a}, \mathrm{b}$ ) and the specifications contained in the Interin Characterjzation Report for the Area Surrounding the 183-H Basins (PNL 1987). Some modifications to the original well designs and locations were made in response to the initial data collected during the drilling of the deep wells. The modifications and general construction information are addressed in the following discussion.

Al1 the Phase II wells, with the exception of 199-H4-15C, were constructed with 6-in, type 304 stainless steel casing and screen. Sand filter packs were placed around each screened interval, and the annulus was sealed with bentonite pellets, bentonite slurry (below the water table), granular bentonite (above the water table), and concrete. A concrete pad and protective steel posts were placed around each well to prevent pooling of water and to protect the surface casing.

The deep wells within each cluster $(199+\mathrm{H} 3-2 \mathrm{C}, 199-\mathrm{H} 4-12 \mathrm{C}$, and 199-H4-15C) were the first to be drilled in Phase 11. This strategy allowed for the definition of significant geohydrologic units and anticipation of geologic conditions at the remaining well locations. The planned compietion zone within the Ringold Formation, a gravel unit noted on the drilling log of Well 199-H4-2, was not encountered upon drilling to $220 \mathrm{ft}$ in wells $199-\mathrm{H4}-12 \mathrm{C}$ and 199-H4-15C, and $155 \mathrm{ft}$ in well 199-H3-2C. Therefore, alternate 
completion strategies based on the drilling logs and geophysical logs were chosen for wells 199-H3-2C, 199-H4-12C, and 199-H4-15C.

Well 199-H4-15C was continued into the top of basalt to fully characterize the suprabasalt geology. The well was completed with four 2 -in. piezometers: (P), set from 325 to $327 \mathrm{ft}$ within the Saddle Mountains Basalt; (O), set from 295 to $297 \mathrm{ft}$ within the silty clayey sand to sandy silty clay unit of the Ringold Formation; (R), set from 194 to $196 \mathrm{ft}$ within the silty sand unit of the Ringold Formation; and (S), set from 78 to $80 \mathrm{ft}$ within the gravelly silty sand unit of the Ringold Formation. The piezometers were constructed with z-in.-diameter stainless steel casing and screen. Sand filter packs were placed around each 20 -5lot screen. The interyal between piezometers (P) and (Q) was sealed with bentonite pellets and neat cement. All other intervals between piezometers were sealed with bentonite slurry and bentonite pellets. A ball valve and pressure gauge were installed on piezometer $(P)$ to prevent it from flowing.

Water-bearing zones within the Ringold Formation were chosen for completion of We17s $199-\mathrm{H} 3-2 \mathrm{C}$ and $199-\mathrm{H4}-12 \mathrm{C}$. Well 199-H4-12C was completed within the gravelly silty sand unit of the Ringold Formation at a depth of 72 to $82 \mathrm{ft}$. The well was backfilled fron 220 to $82 \mathrm{ft}$ with a bentonite slurry seal, bentonite pellet seal, and artificial sand pack. A sand filter pack was placed around the screened interval, and the annulus was sealed with bentonite pellets, bentonite slurry, granular bentonite, and concrete. The well was completed with a 10-slat stainless steel screen.

Well 199-H3-2C was completed within the gravelly silty sand unit of the Ringoid Formation at a depth of 100 to $110 \mathrm{ft}$. The well was backfilled from $155 \mathrm{ft}$ to $110 \mathrm{ft}$ with a bentonite siurry seal, bentonite pellet seal, and artificial sand pack. A sand filter pack was placed around the screened interval, and the annulus was sealed with bentonite pellets, bentanite slurry, granular bentonite, and concrete. The well was completed with a 10-slot stainless steel screen,

The intermediate depth cluster wells (199-H3-2B, 199-H4-12B, and 199-H4-15B) were completed at the top of the Ringold Formation to monitor the lower portion of the unconfined aquifer. The wells were completed at 50 to 
$55 \mathrm{ft}, 45$ to $50 \mathrm{ft}$, and 37 to $42 \mathrm{ft}$, respectively. The actual completion intervals were shallower than the anticipated depths of approxinately 60 ft because of an erosional unconformity between the Ringold and Hanford Formations. The wells were completed with 20-3lot stainless steel screens. Initial depths to water were 40.5 ft for Well 199-H3-2B, 37 ft for well 199-H4-12B, and $30 \mathrm{ft}$ for Well 199-H4-15B.

The single shallow wells (199-H4-7, 199-H4*8, 199-H4-9, 199-H4-10, 199-14-11, 199-H4-13, and 199-44-14) and shallow cluster wells (199-H3-2A, 199-H4-12A, and 199-H4-15A) were completed in the upper portion of the unconfined aquifer. The shallowest of these, We11 199-H4-10, was completed from 23 to $38 \mathrm{ft}$; the deepest of these, Wells 199-H4-11 and 199-H4-14, were completed from 38 to $53 \mathrm{ft}$. All but two of the shallow wells were completed with 15-ft sections of 20-slot screen. Wells 199-H4-8 and 199-H4-9 were completed with 10-ft sections of $20-$ slot screen because of their short water columns. Initial depths to water for the shallow wells ranged from 29 to $4 \mathrm{ft}$.

\subsubsection{Phase III Nells}

Three additional sha110w we11s, 199-H4-16, 199-H4-17, and 199-H4-18, were installed during Phase III to further characterize the area to the north and southeast of the $183-1 \mathrm{~B}$ Basins. These wells were completed at 42.5 to $57.5 \mathrm{ft}, 35$ to $45 \mathrm{ft}$, and 40 to $50 \mathrm{ft}$, respectively. Initial depths to water ranged from 41.5 to $48.5 \mathrm{ft}$. Well specifications and installation protocol for these wells were the same as those used for the single shallow and shallow cluster wells in phase 11.

\subsection{FIELO METHOOS}

Geologic samples were collected at 5 -ft intervals and when changes in formation appeared during dritling operations. Soll moisture samples were collected above the water table when drilling with a drive barrel. Each sample was characterized by the well site geologist and recorded on a drilling 709 .

Salected Tithologic samples were analyzed in the PNL Solls Laboratory for the following parameters: 1) grain-size distribution, 2) soil moisture 
content, 3) soil moisture retention, 4) bulk density, 5) bulk porosity, and 6) hydraulfc conductivity. Samples were selected for these tests as follows:

- Grain-size distribution was performed on all samples.

- Soil moisture content and soil moisture retention were performed on all drive-barrel samples collected above the water table.

- Bulk density was performed on six to eight samples from Wells 199-43-2C, 199-H4-12C, and 199-H4-15C.

- Bulk porosity was calculated for the bulk density samples.

- Hydraulic conductivity was performed on a total of three splitspoon samples from Wells 199-H4-12C and 199-H4-15C.

Results from these analyses have been incorporated into the discussions in "Geology of the 100-H Area," Section 3.0, and "Hydrology of the 100-H Area," Section 4.0.

Welts 199-H3-1, 199-H4-3,199-H4-4,199-H4-5, and 199-H4-6 were geophysically logged in 1986 with natural gamma and neutron probes. These two logs and a density log were run in each of the Phase II and III wells upon completion of drilling. The temperature probe was used in Well 199-H4-15C to heip locate the top of the bentonite slurry seals during completion. The natural gamma, neutron, and denstty logs for each well are shown in Appendix A.

Aquifer tests were performed on selected wells during installation and on most other wells after completion. The methods used and results obtained are sumarized in Table 8 .

\subsection{HELL LOCAIIONS}

Twenty-five wells are currently located in the 100-H Area (Figure 2). Hanford site coordinates for the wells are provided in Table 10. Well 199-H4-2 was used only for geohydrologic characterization and is capped to prevent it from flowing. Well 199-H4-15C has been dedicated to hydraulic head measurements. The remaining 23 ground-water monitoring we 11 s comprise the ground-water sampling network for the 183-H Basins. 
The following ground-water monitoring wells are located hydraulically upgradient of and directly with the flow related to the 183-H Basins:

$$
\begin{array}{lll}
199-\mathrm{H} 3-2 \mathrm{~A} & 199-\mathrm{H} 3-2 \mathrm{C} & 199-\mathrm{H} 4-7 \\
199-\mathrm{H}^{3}-2 \mathrm{~B} & 199-\mathrm{H} 4-6 & 199-\mathrm{H} 4-14
\end{array}
$$

The following ground-water monitoring wells are located hydraulically downgradient of and directly within the flow related to the 183-H Basins:

$\begin{array}{lll}199-\mathrm{H} 4-3 & 199-\mathrm{H} 4-9 & 199-\mathrm{H} 4-12 \mathrm{~B} \\ 199-\mathrm{H} 4-4 & 199-\mathrm{H} 4-\mathrm{Il} & 199-\mathrm{H} 4-12 \mathrm{C} \\ 199-\mathrm{H} 4-5 & 199-\mathrm{H} 4-\mathrm{I} 2 \mathrm{~A} & 199-\mathrm{H} 4-18\end{array}$

The following ground-water nonitoring wells are not located within the flow directly related to the 183-H Basins:

$\begin{array}{lll}199-\mathrm{H} 3-1 & 199-\mathrm{H} 4-13 & 199-\mathrm{H} 4-16 \\ 199-\mathrm{H} 4-8 & 199-\mathrm{H} 4-15 \mathrm{~A} & 199-\mathrm{H} 4-17 \\ 199-\mathrm{H} 4-10 & 199-\mathrm{H} 4-15 \mathrm{~B} & \end{array}$

The point of compliance for the 183-H Basins is Well 199-H4-3 (Figure 2). This well is located approximately $75 \mathrm{ft}$ downgradient of the facility and has shown the highest concentrations of contaminants attributable to the 183-H Basins. 



\subsection{SAMPLING AND ANALYSIS PLAN}

\subsection{SAMPLING SCHEDULE}

Ground-water sampling for hazardous waste constituents was initiated on a monthly basis in June 1985 for the five wells in the original monitoring network (Figure 2). This frequency was chosen to define the seasonal variability expected in the analytical data resulting from the proximity of the 183-H Basins and the wells to the Columbia River. On completion, the Phase II and III wells were added to the monthly sampling schedule. Wells 199-H3-2C, 199-H4-7, 199-H4-8, 199-H4-10, 199-H4-11, and 199-H4-12C were initially sampled in December 1986. Wells 199-H3-2A, 199-H4-9, and 199-H4-15A were intitially sampled in January 1987. The renaining phase II wells (199-H3-2B, 199-H4-12A, 199-H4-128, 199-H4-13, 199-H4-14, and 199-H4-15B) were added to the sampling network in February 1987. We11 199-H4-16 was initially sampled in May 1987, and Wells 199-H4-17 and 199-H4-18 were initially sampled in June 1987.

The sampling schedule for fiscal Year (FY) 1988 is shown in Table 11. Sample collection for Wells $199-\mathrm{H3}-1,199-\mathrm{H} 4-5$, and 199-H4-6 is now conducted on a quarterly basis. Monthly sampling of the Phase II and III wells will continue for at least 1 year after initial sampling. Those wells which are not located hydraulically downgradient of and directly within the flow related to the 183-H Basins $(199-H 3-2 A, 199-H 3-2 B, 199-H 3-2 C, 199-H 4-7$, 199-H4-8, 199-H4-10, 199-H4-13, 199-H4-14, 199-H4-15A, 199-H4-158, 199-H4-16, and 199-H4-17) will then be sampled quarterly through the end of Fy 1988.

The proposed sampling schedule for the period beyond FY 1988 (extending through the closure and post-closure periods) is based on analytical results obtained to date. 8oth the number of wells to be sampled and the sampling frequency are subject to change, pending results of future characterization activities at the facility. Beginning in FY 1989, Wells 199-H3-2A, 199-H4-3, $199-\mathrm{H} 4-4,199-\mathrm{H} 4-5,199-\mathrm{H} 4-6,199-\mathrm{H} 4-9,199-\mathrm{H} 4-12 \mathrm{~A}, 199-\mathrm{H} 4-12 \mathrm{~B}, 199-\mathrm{H} 4-12 \mathrm{C}$, and $199-\mathrm{H} 4-1 \mathrm{~B}$ will be sampled on a quarterly basis until closure activities commence and during the post-closure period. Sampling of these wells will 
TABLE 11. FY 1988 Sampling Schedule for the 100-H Area WeIls

\begin{tabular}{|c|c|c|c|c|c|c|c|c|c|c|c|}
\hline Nell & $0 \quad N(a)$ & D & 3 & $E$ & N & A. & 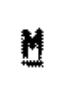 & $\mathfrak{J}$ & $\underline{\mathfrak{J}}$ & A & $\underline{s}$ \\
\hline $199-13-1$ & & $x$ & & & $x$ & & & $x$ & & & $x$ \\
\hline $199-H 3-2 A$ & $x$ & $x$ & & & $x$ & & & $x$ & & & $x$ \\
\hline $199-H 3-2 B$ & $x$ & $x$ & & & $x$ & & & $x$ & & & $x$ \\
\hline $199-\mathrm{H}^{3}-2 \mathrm{C}$ & $x$ & & & & $x$ & & & $x$ & & & $x$ \\
\hline $199-44-3$ & $x$ & X & $x$ & $x$ & $x$ & $x$ & $x$ & $x$ & $x$ & $x$ & $x$ \\
\hline $199-H 4-4$ & $x$ & $x$ & $x$ & $x$ & $x$ & $x$ & $x$ & $x$ & $x$ & $x$ & $x$ \\
\hline $199-\mathrm{H} 4-5$ & & $x$ & & & $x$ & & & $x$ & & & $x$ \\
\hline $199-44-6$ & & $x$ & & & $x$ & & & $x$ & & & $x$ \\
\hline $199-44-7$ & $x$ & & & & $x$ & & & $x$ & & & $x$ \\
\hline $199-144-8$ & $x$ & & & & $x$ & & & $x$ & & & $x$ \\
\hline $199-144-9$ & $x$ & $x$ & $x$ & $x$ & $x$ & $x$ & $x$ & $x$ & $X$ & $x$ & $x$ \\
\hline $199-\mathrm{H} 4-10$ & $x$ & & & & $x$ & & & $x$ & & & $x$ \\
\hline $199-H 4-11$ & $x$ & $x$ & $x$ & $x$ & $x$ & $x$ & $x$ & $x$ & $x$ & $x$ & $x$ \\
\hline $199-H 4-12 A$ & $x$ & $x$ & $x$ & $x$ & $x$ & $x$ & $x$ & $x$ & $x$ & $x$ & $x$ \\
\hline $199-44-12 B$ & $x$ & $x$ & $x$ & $x$ & $x$ & $x$ & $x$ & $x$ & $x$ & $x$ & $x$ \\
\hline $199 \cdot \mathrm{H} 4-12 \mathrm{C}$ & $x$ & $x$ & $x$ & $x$ & $x$ & $x$ & $x$ & $x$ & $x$ & $x$ & $x$ \\
\hline $199-44-13$ & $x$ & $x$ & & & $x$ & & & $x$ & & & $x$ \\
\hline $199-44-14$ & $x$ & $x$ & & & $x$ & & & $x$ & & & $x$ \\
\hline $199-H 4-15 A$ & $x$ & $x$ & & & $x$ & & & $x$ & & & $x$ \\
\hline $199-+44-15 B$ & $x$ & $x$ & & & $x$ & & & $x$ & & & $x$ \\
\hline $199-14-16$ & $x$ & $x$ & $x$ & $x$ & $x$ & $x$ & & & & & $x$ \\
\hline $199-H 4-17$ & $x$ & $x$ & $x$ & $x$ & $x$ & $x$ & $x$ & & & & $x$ \\
\hline $199-H 4-18$ & $x$ & $x$ & $x$ & $x$ & $x$ & $x$ & $x$ & $x$ & $x$ & $x$ & $x$ \\
\hline TOTALS & 20 & 19 & 10 & 10 & 23 & 10 & 9 & 21 & 8 & 8 & $23=161$ \\
\hline
\end{tabular}

(a) Per verbal direction from DOE-RL, sampling of all wells in the $100-\mathrm{H}$ Area was suspended during November 1987.

increase to a monthly frequency during closure activities. Sampling of the remaining 13 wells will be conducted on an annual basis. The schedule for closure of the 183-H Basins is shown in Figure 42 . 


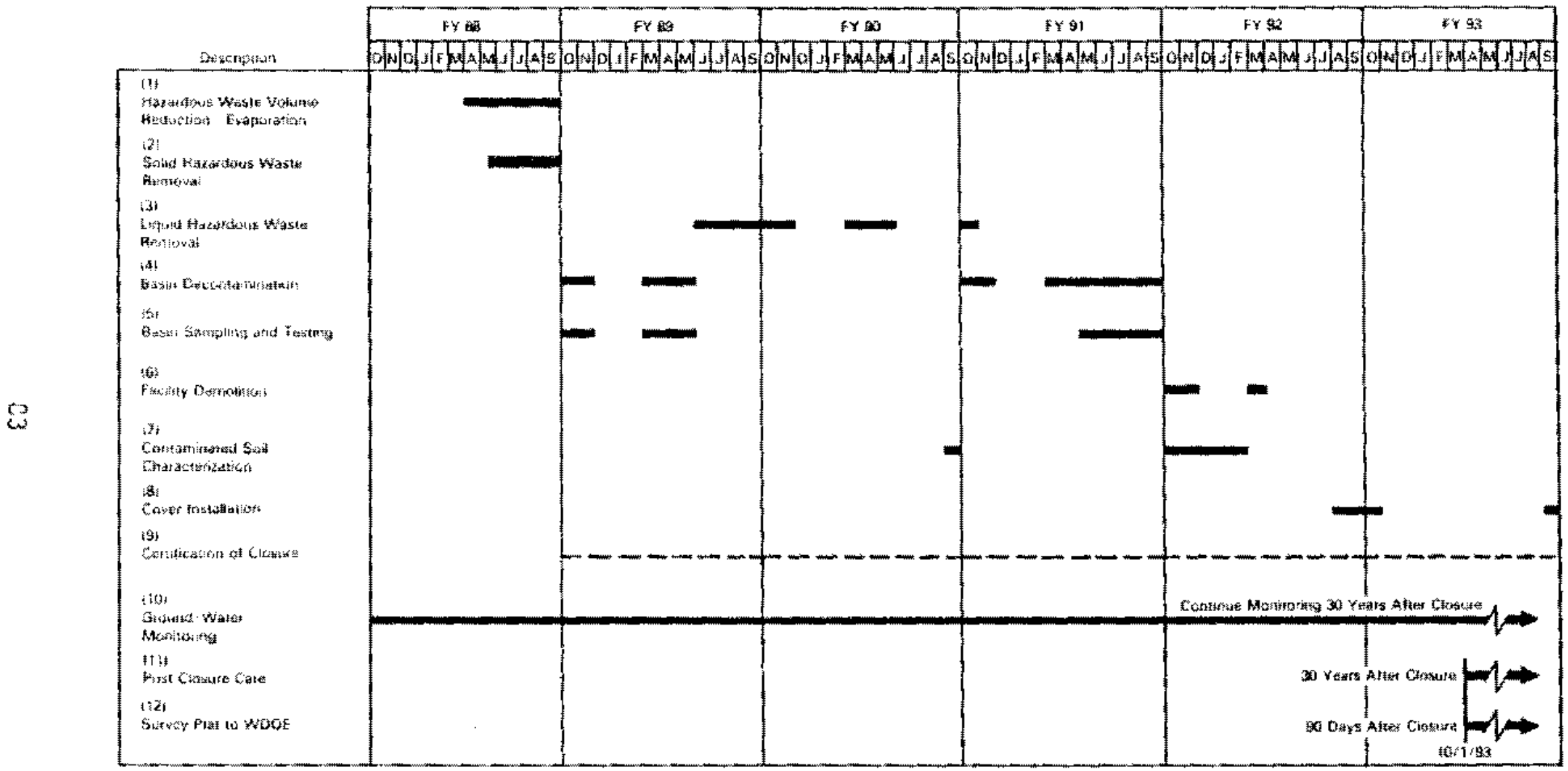

FIGURE 42. Closure Schedule for the 183-H Basins 


\subsection{SAMPLE ANALYSES}

The standard list of analyses currently being conducted on the 100-H Area ground-water samples is given in Table 12. These analyses include the prinary drinking water standards (DWS), water quality parameters, contamination indicators, and specific dangerous waste constituents known to have been discharged to the 183-H Basins. Table 12 aiso contains inforation on the bottle types used for collection, sample preservation techniques, analytical methods, and detection limits for each of the constituents. Additional dangerous waste constituents listed in the WAC 173-303-9905 are analyzed on a quarterly basis at the point of compliance, Well 199-H4-3, and Well 199-H3-1. The WAC 173-303-9905 constituent list may change pending the Washington State Department of Ecology (HDOE) adoption of 40 CFR 264 and 270 Appendix IX. As particular analyses become obsolete for characterization and/or modeling activities, they will be deleted, unjess mandated by regulations.

Proposed sample analyses to be conducted on the 100-H Area ground-water samples for the period beyond Fy 1988 lextending through the closure and post-closure periods) are listed in Table 13. These analyses and frequencies are based on current results and are subject to change in the types of constituents and frequency analyzed, pending future characterization activities at the facility.

\subsection{QUALITY CONTROL}

A Quality Control (QC) Program for the Ground-Water Monitoring Project at the 183-H Basins was estabiished to document the quality of the analytical results being produced by the primary analytical laboratory, United States Testing Company (UST). This program features submission of bind standards, replicates, and blanks, as well as investigation of problems and follow-up with corrective actions. Selected field samples are also anaiyzed by independent Taboratories to verify the analytical results. UST participates in interlaboratory comparisons and U.S. Environmental Protection Agency- (EPA-) sponsored Perfomance Studies. UST performs and reports the results of routine internal oc procedures and corrective actions. 
IABLE 12. Standard List of Analyses for the 100-H Area Ground-Water Samples

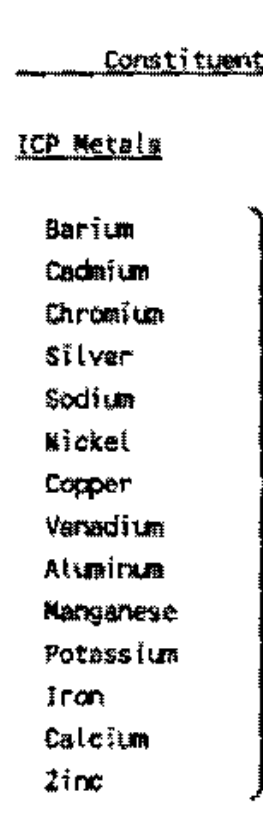

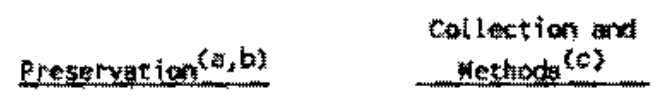

Derection

Wethodg (c)

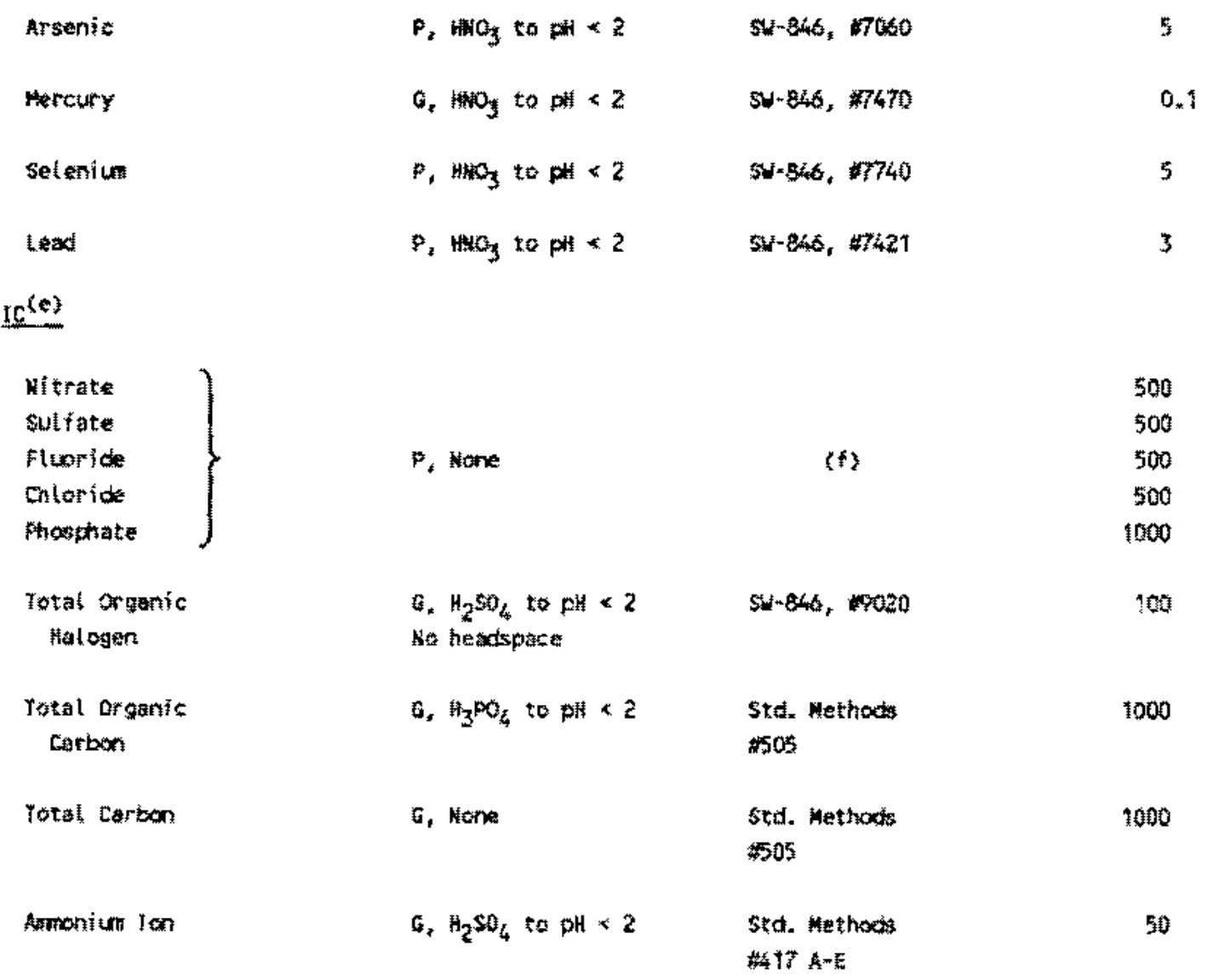




\section{IABLE 12. (contd)}

\begin{tabular}{|c|c|c|c|}
\hline Constitunt & Presefurytion $(a, b)$ & $\begin{array}{c}\text { Collection ard } \\
\text { Hethot }\{c\}\end{array}$ & $\begin{array}{c}\text { Detection } \\
\text { Linit (opos) }\end{array}$ \\
\hline Phenol & A, kone & $54-860,4340$ & 10 \\
\hline
\end{tabular}

\section{Pesticides}

\section{Endrin Nethoxyetilor \\ Toxaptiese \\ Lindare (4 is somers)}

Hafbicteses
6. Ware

$54-846$,
0.1

3

1

0. 1

2

2

Yotatile organics (yoa)

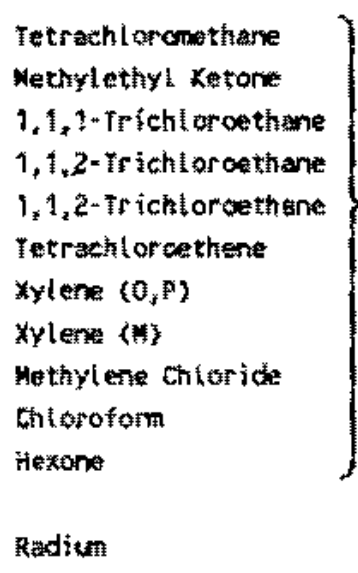

Eross Alphe

Grous Beta
$54+846,480$

S. None

4.8.,

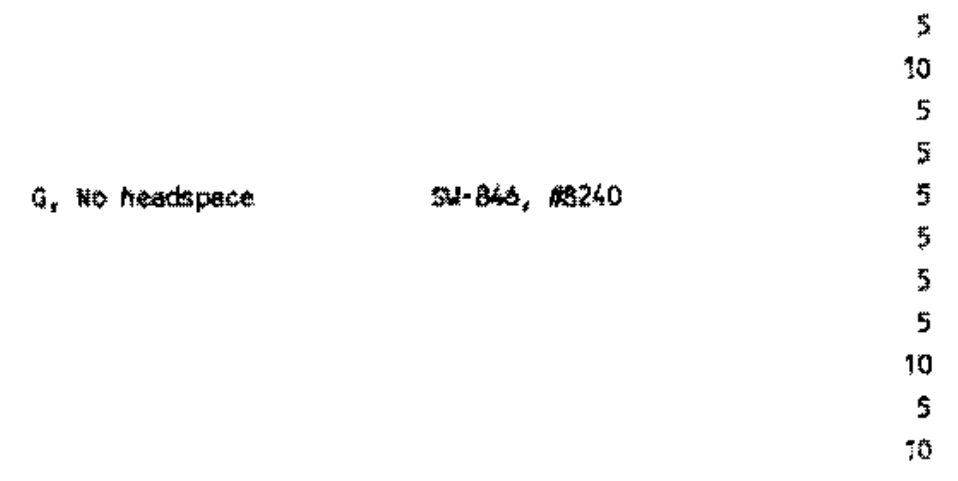

P. $\mathrm{HNO}_{3}$ रa

EPA Hothed

1 ptif

\section{a)}

(xtieger 1980)

EPA Hethut

4 pxith

$p, 107$ to 42

EPA $600 / 4 \cdot 75-701$

(toins 1575)

EPA Metho

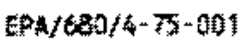

(Jahn 1975)
EFA/600/4-80-032 
TABLE 12. (contd)

\begin{tabular}{|c|c|c|c|}
\hline 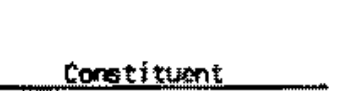 & Preseryation $\{a, b)$ & $\begin{array}{c}\text { coll lection and } \\
\text { Methots (4) }\end{array}$ & $\begin{array}{c}\text { Derection } \\
\text { Limit toxy }\end{array}$ \\
\hline Itantion & P, HOH & $\begin{array}{l}\text { Fluorowetrit } \\
\text { (hexone } \\
\text { extraction) }\end{array}$ & $4 \mathrm{pCi} / \mathrm{l}$ \\
\hline Techetiun- & D. $\mathrm{HNO}_{3}$ to $\mathrm{ph}<2$ & & $15 \mathrm{pCc} A$ \\
\hline Total bitasolved Sollos & P. Hore & $\begin{array}{l}\text { Stes. Methoxts } \\
\$ 209\end{array}$ & $-\infty$ \\
\hline Caltutarm Sacterita & P, 畨ane & $\begin{array}{l}\text { Std. Wethods } \\
\text { eqcen }\end{array}$ & $2.3 \mathrm{mPN}$ \\
\hline pH (lats) & P. Wone & $\begin{array}{l}\text { stul. hethods } \\
\text { St23 }\end{array}$ & $* *$ \\
\hline Temperatuse & Field Measurement & & \\
\hline speciutic Condictance & 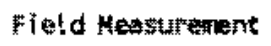 & & \\
\hline H & Fiel d Mogusurentent & & \\
\hline
\end{tabular}

\footnotetext{
(a) $P$ plestit:; $G=$ talns.

(b) Alt sampies will be cooled to $4^{*}$ on collation.

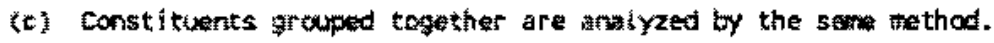

(d) Detextion limit units except where inticated.

(e) itc = ion throwetograchy.

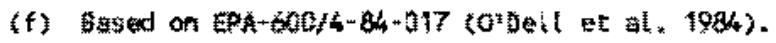

\subsection{SAMPLIHG PUMPS}

Dedicated sampling pumps have been installed in each well. Each of the five wells in the original monitoring network has an electric submersible pump for purging the well and collecting samples that are analyzed for nonvolatile constituents and a bladder pump for collecting samples that are analyzed for volatile, semivolatile, and other organic chemicals.

In September 1985, investigations by the manufacturer(a) confirmed the existence of low levels of chlorinated hydrocarbon contaminants in a shipment

(a) Q.E.O. Environmental Systems, Inc., Ann Arbor, Michigan. 


\section{TABLE 13. Proposed Schedule and Sample Analyses for \\ Future 100-H Area Ground-Water Samples $(a)$}

\begin{tabular}{|c|c|c|c|}
\hline Constituent (b) & $\begin{array}{l}\text { Fy } 1989 \\
\text { Frequency }\end{array}$ & $\begin{array}{c}\text { Closure Period } \\
\text { Frequency }\end{array}$ & $\begin{array}{c}\text { Post-closure } \\
\text { Period Frequency }\end{array}$ \\
\hline Nitrate (IC) & Quarterly & Monthly & Quarterly \\
\hline Chromium (ICP) & Quarterly & Monthly & quarterly \\
\hline Gross Alpha & Quarterly & Monthly & Quarterly \\
\hline Gross Beta & Quarteriy & Monthly & Quarteriy \\
\hline Uranium (uchen) & Quarterly & Monthly & Quarterly \\
\hline Technetium & Quarterily & Monthiy & Quarteriy \\
\hline TOX & Quarterly & Monthly & Quarterly \\
\hline Alkalinity & Quarterly & Monthly & Quarterly \\
\hline $\mathrm{pH}$ & Quarterly & Monthly & Quarterly \\
\hline $9905(c)$ & $\begin{array}{l}\text { Annually } \\
\text { on point of. } \\
\text { compliance } \\
\text { well only }\end{array}$ & $\begin{array}{l}\text { Annually } \\
\text { on point-of- } \\
\text { compliance } \\
\text { well oniy }\end{array}$ & $\begin{array}{l}\text { Annually } \\
\text { on point-of- } \\
\text { comptiance } \\
\text { well only }\end{array}$ \\
\hline
\end{tabular}

(a) Analysis for 9905 constituents will only be conducted for Weli 199-H4-3. Analysis for the remaning constituents will be conducted for Welis $199-\mathrm{H} 3-2 \mathrm{~A}, 199-\mathrm{H} 4-3,199-\mathrm{H} 4-4, \mathrm{I} 99-\mathrm{H} 4-5,199-\mathrm{H} 4-6,199-44-9,199-\mathrm{H} 4-\mathrm{I} 2 \mathrm{~A}$, 199-H4-12B, 199-H4-12C, and 199-H4-18 per this scheduie. All other wells will be sampled annually for non-9905 constituents.

(b) IC = Ion Chromatography; ICP = Inductively Coupled Plasma; UChem = Chemical Analysis for Uranium.

(c) The 9905 constituent list may change pending wDoE's adoption of 40 CFR 264 and 270, Appendix IX.

of biadder pumps used at the Hanford site. Further investigation determined that none of the pumps used in the $100-\mathrm{H}$ Area were from the affected shipment.

Piston-actuated sampling pumps have been installed in all Phase II and III sampling wells. These pumps are used for both purging and sampiing. Table 10 provides information on the pump intake settings and initial depths 
to water for all of the wells, Additional fnformation on the pump types, materials, and intake settings is given in Appendix $A$.

\subsection{SAMPLE COLLECTION}

Ground-water samples are collected on a routine basts in 23 wells surrounding the 183-H Basins. The samples are collected by teans of two trained Sentor Environmental Radiation Protection Technologists (SERPTs). Hazardous materials sampling procedures have been developed and specifically designed to ensure the integrity of these samples. These procedures include punp operation, borehole purging, field measurements (water levels, temperature, specific conductance, and $p H$ ), sample collection, sample preservation and shipnent, and chain of custody. A brief summary of these procedures follows.

Water level measurements are taken each time a well is sampled, before purging. These depth-to-water measurements are taken from the designated measuring point on the top of the well casing using a graduated steel tape. The procedure is then repeated until two steel tape measurements agree win $\pm 0.05 \mathrm{ft}$. The well is purged following the sample collection procedure cor. responding to the type of dedicated pump(s) installed in the well. The purge time is calculated based on the volume of water within the weil and the pump discharge rate.

A minimum of three borehole volumes of water is removed from each well to ensure that the sample collected is representative of the water in the aquifer surrounding the well. Temperature, conductivity, and pH measurements are taken during purging of the well and just before sample collection. Measurenents taken during purging are used to help ensure that the well bore has been sufficientiy evacuated as indicated by stabilization of these three parameters. The temperature is considered stable when two consecutive mea surements agree within $0.2^{\circ} \mathrm{C}$. Conductivity 15 considered stable when two consecutive measurements agree within 10 mhos. The pH is considered stabla when two consecutive masurements agree within $0.2 \mathrm{pH}$ units. The final temperature, conductivity, and ph measurements are recorded as the analytical values for the sample. All field measurements and observations are recorded on field record forms (figure 43 ). 


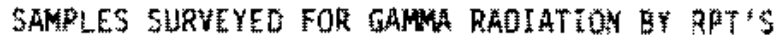

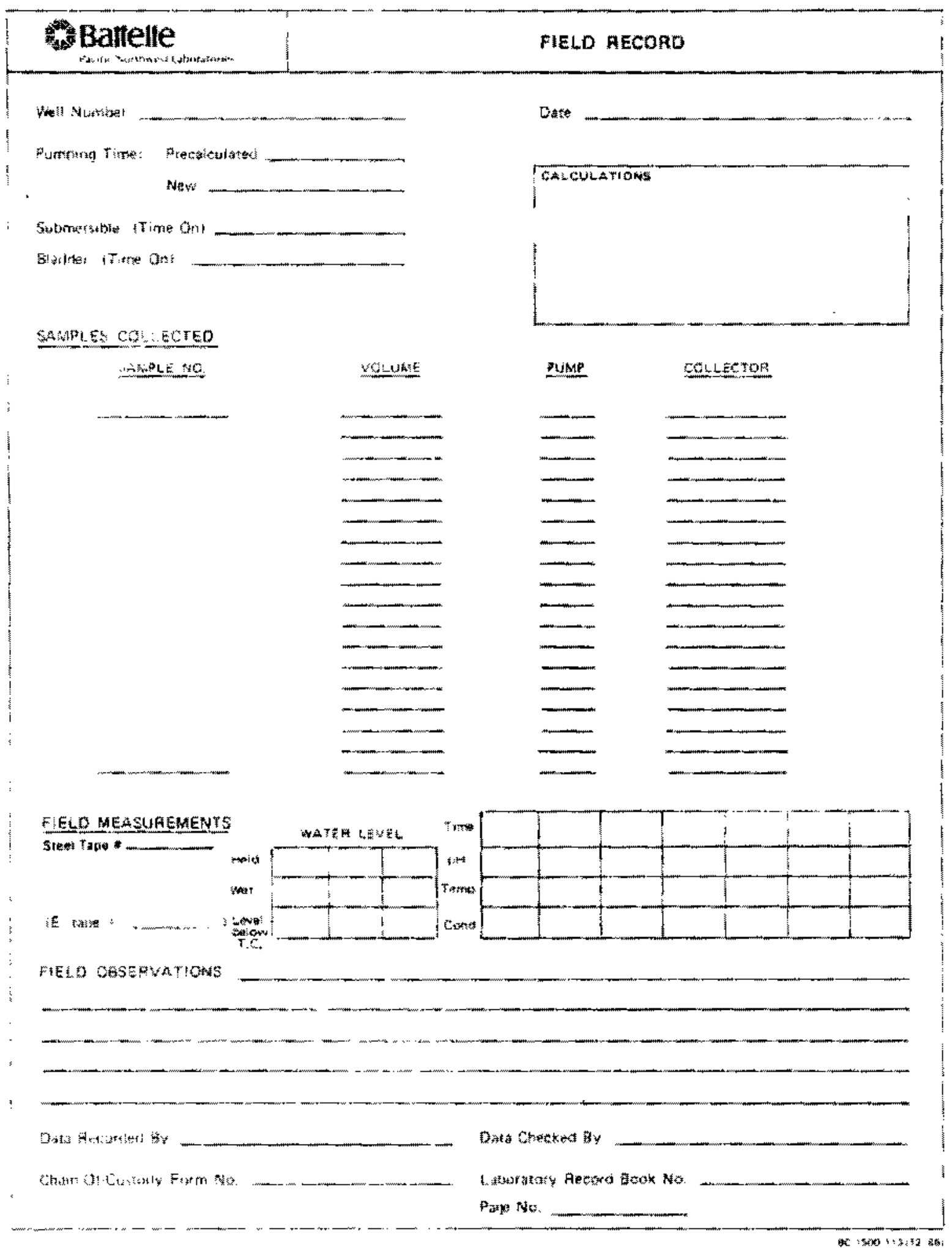

FIGURE 43. Fjeld Record Form 
After the well has been properly purged, ground-water samples are collected through Teflon(a) tubing (submersible and piston pumps) or poiyethylene tubing (bladder pump). Extreme care is taken to avoid potential sources of contamination. As each container is filled, a sample seal is placed around the cap to maintain sample integrity during transport to the laboratory. After collection, the sample containers are surveyed with a Geiger-Maller (G-M) instrument. Counts greater than $200 \mathrm{cpm}$ are recorded on the field record form, and radiation work procedures take precedence. An average of three wells are sampled per day by each SERPT team.

\subsection{SAMPLE PRESERVATION AND SHIPMENT}

Sample preservation is required for those constituents that are not chemically stable. Methods of sample preservation are intended to I) retard biological action, 2) retard hydrolysis, and 3) reduce sorption effects. Specific preservation methods include $\mathrm{pH}$ control, chemical addition, refrigeration, and protection from light. Table 12 ists the constituents analyzed, bottle types used for collection, sample preservation methods, analytical methods, and detection limits for each constituent.

Sample containers are purchased precleaned and are selectively analyzed to confirm EPA protocols. Chemical additions and $\mathrm{pH}$ controls are performed by the analytical subcontractor before the bottles are labeled and sent to the field. Procedure manuals containing the sample preservation and handing techniques for each analytical method are maintained by the analytical subcontractor.

After collection, samples are placed in an ice chest and cooled to $4^{\circ} \mathrm{C}$. Light-sensitive samples are collected in anber glass bottles. Because of the proximity of the analytical laboratory to the site, Washington State Department of Transportation (WSOOT) packaging requirements do not apply. Samples are normally delivered directly to the laboratory on the day of collection. If the SERPTs return from the field after contractual receiving hours at the

(a) ${ }^{\oplus}$ Teflon is a registered trademark of E. I. du Pont de Nemours and Company, Alinington, Delaware. 
laboratory, the samples are stored overnight in a secured refrigerator and delivered at the beginning of the following business day.

\subsection{CHAIN OF CUSTODY}

The chain-of-custody procedure ensures the integrity of the samples from the time of collection through data reporting. The procedure contains instructions for sample labels, sample seals, field record forms, chain-ofcustody forms, sample analysis request forms, and sample delivery. Laboratory acceptance procedures and copies of the sample log-in forms are also included. Copies of the chain-of-custody form and sample analysis request form are shown in Figures 44 and 45 , respectively. 


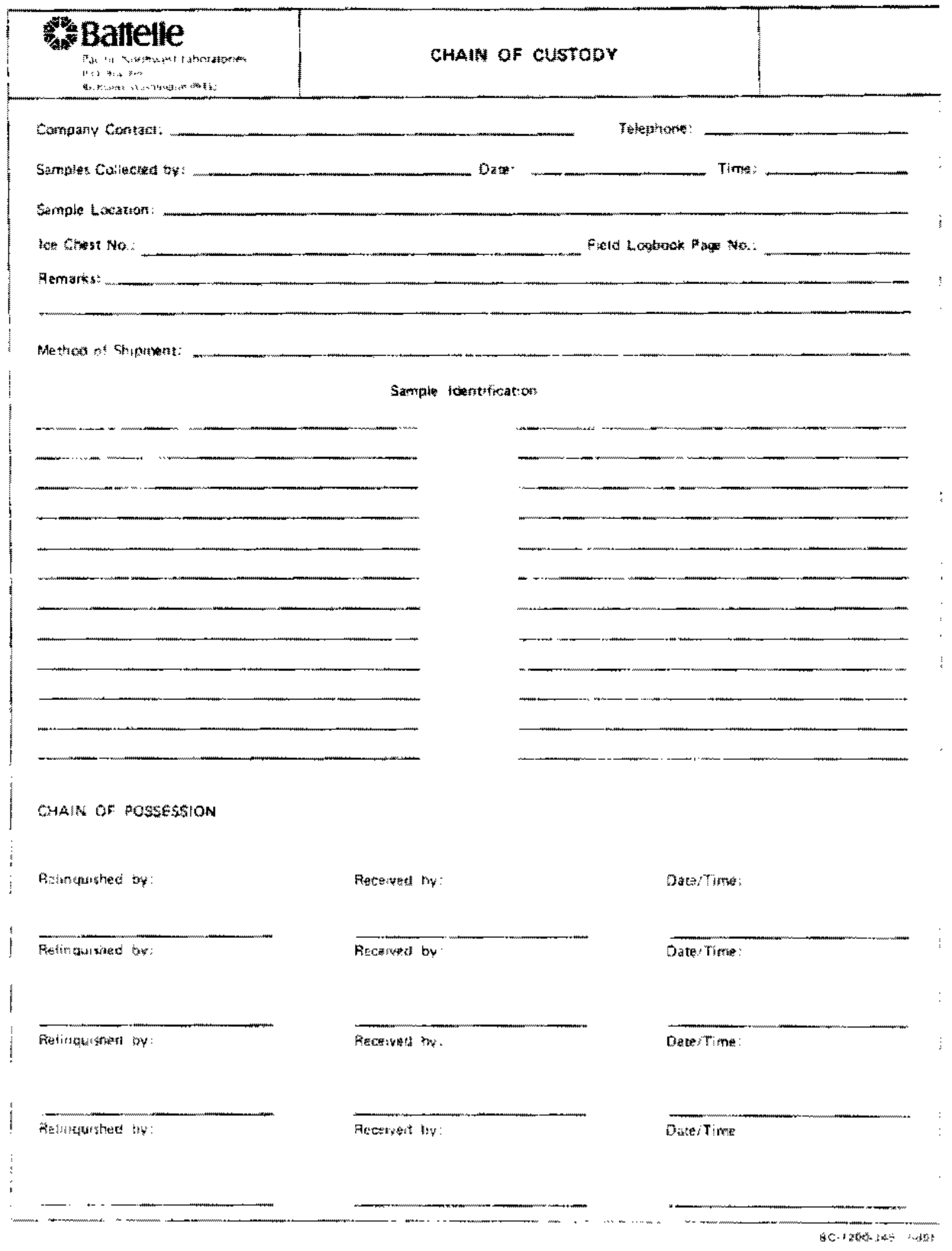

FIGURE 44. Chain-of-Custady Form 


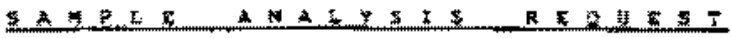

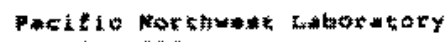
Fo sox $\$$

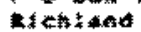
WA 235

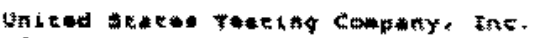

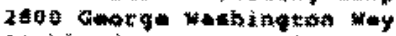

rictiond in 38143

$\cos x \cos$

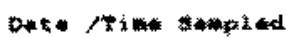

Cotpiny Constet

CHxis of 5ustonx

EAMELE

EST SAMPLE ID

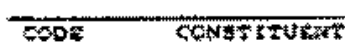

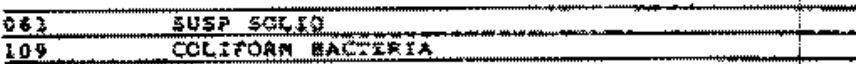

12.

VAs

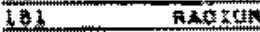

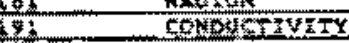

IV

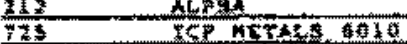

726 KCP METALE SALS EXHANCE

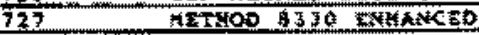

320 OSSICIRE

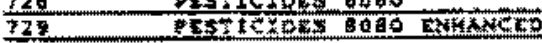

T)

I3

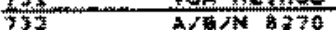

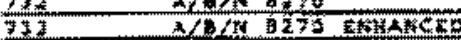

736 m E

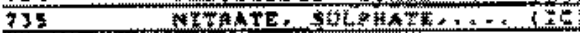

736 J年

737 HOWA

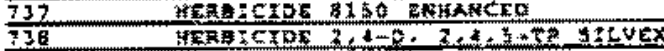

739 PCa

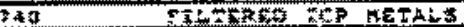

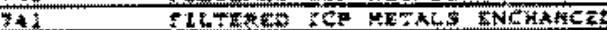

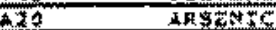

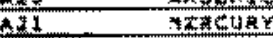

132 .

X23

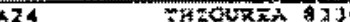

AS

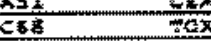

$T C$

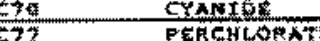

C78

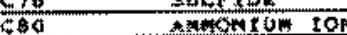

SB

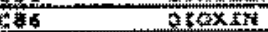

SZ

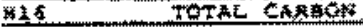

yis ?

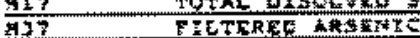

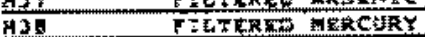

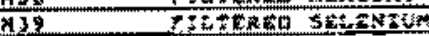

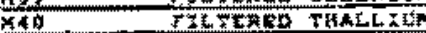

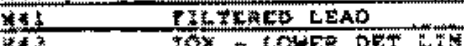

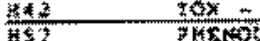

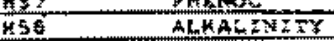

H53 OF

462 MYDRAZTEZ

H\& FCOOSIDE IIE

HAt BZSALTH

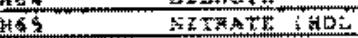

จ粠?

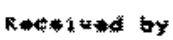

岀 1010

\$1:

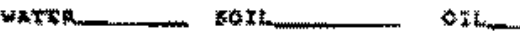

atsise

(1)
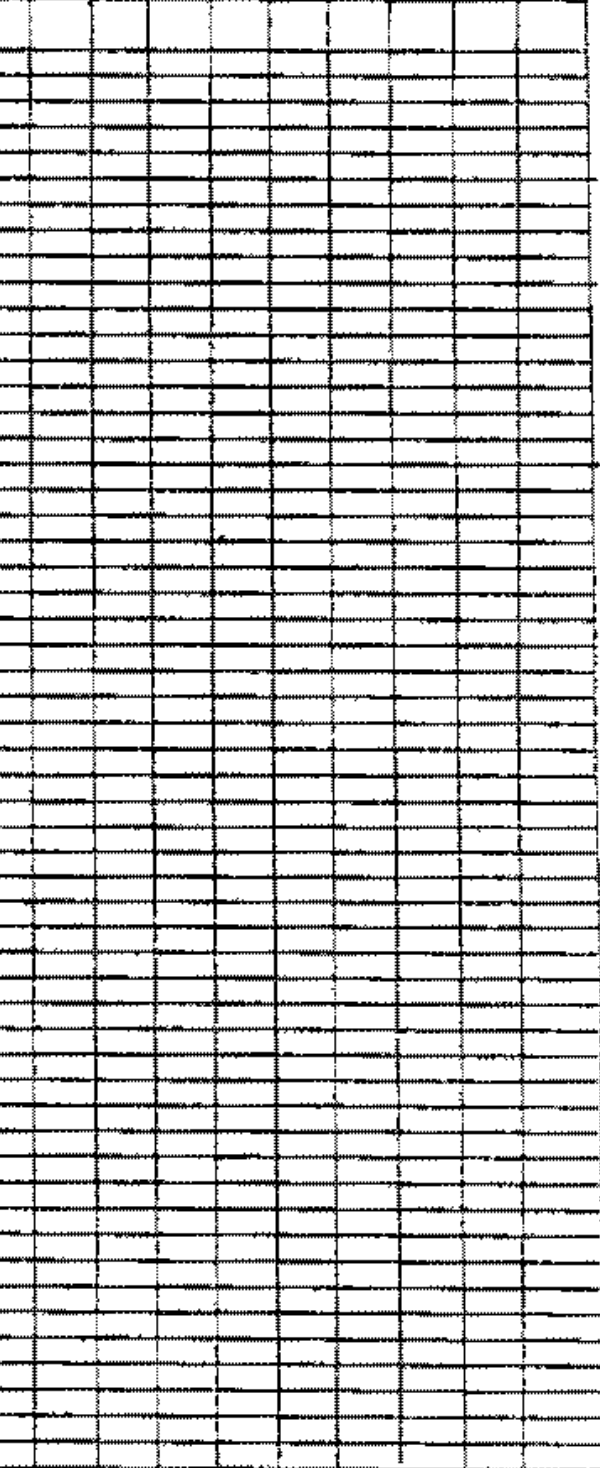

Paw

FIGURE 45. Sample Analys is Request Form 


\subsection{ANALYTICAL RESULTS}

The raw analytical data collected from the ground-water monitoring network at the 100-H Area for June 1985 through December 1987 are included in the quarterly progress reports for the Ground-Water Monitoring Compliance Projects for Hanford Sjte Facitities (DOE 1986; 1987a,b,c,d; 1988).

\subsection{SUMMARY OF RESULTS TO DATE}

The following discussion contains a sumbary of the ground-water sampling results from June 1985 through Dctober 1987.

Pesticides and herbicides from the list of primary DWS, phenol from the ground-water quality parameters, and most of the constituents listed in the WAC 173-303-9905 generally have not been detected in ground-water samples from the 183-H monitoring network. The following general ciasses of constituents have been reported at detectable levels: contamination indicators; most of the metals and radioactive constituents and a few of the volatile organic compounds from the list of primary DWS; most of the ground-water quality paraneters; and most of the site-specific constituents. In addition, Maximum Contaminant Levels (MCLs) have been exceeded by one or more samples for the following constituents: coliform bacteria, screening limits for gross alpha and gross beta, strontium-90, cadmium, chromium, mercury, selenium, and nitrate.

Most of the constituents that have been detected in the monitoring network exhibit a large degree of variability and require detailed analysis. Constituents with a small degree of variability include laboratory pH, coli. form, filtered and unfiltered cadmium, silver, arsenic, mercury, selenium, lead, beryllium, phosphate, 1,1,1-trichloroethane, perchloroethylene, thallium, bis(2-ethylexyl) phthalate, total carbon, total dissolved solids (TDS), laboratory $\mathrm{pH}_{3}$ cobalt-60, strontium-90, and uranium. These constituents are either not considered to be indicative of contamination in the ground water attributable to the 183-H Basins, or information is too linited to make defensible conclusions. A short summary for each of these constituents follows. 
- Cadmium - sporadically reported in several wells usually at or near the detection limit of $2 \mathrm{ppb}$

- Silver - reported once in Well 199-H4-3

- Arsenic - consistently reported in several wells near the 183-H Basins at levels just above the detection limit of $5 \mathrm{ppb}$

- Mercury - reported in several wells in July 1985 but otherwise below the detection limit of $0.1 \mathrm{ppb}$

- Selenium - reported twice in Well 199-H4-5 and once in Well 199-H4-9

- Lead - sporadically reported in several wells, usualiy at or near the detection limit of $5 \mathrm{ppb}$

- Beryllium - reported twice at the detection limit of $5 \mathrm{ppb}$

- Phosphate - reported once above the detection limit of $1000 \mathrm{ppb}$

- 1,1,1-Trichloroethane - sporadically reported in several wells

- Perchloroethylene - sporadically reported in several wells

- Thallium - reported once above the detection limit of $10 \mathrm{ppb}$ in the initial sampling in June 1985

- Bis(2-ethylexyl) phthalate - reported once above the detection 1 imit of $10 \mathrm{ppb}$

- Total carbon - initially reported in October 1987

- TDS - initially reported in October 1987

- Laboratory pH - initially reported in 0ctober 1987

- Cobalt-60 - limited data, mostly less than counting error

- Strontium-90 - limited data, near $1 \mathrm{pCi} / \mathrm{L}$ except one value

- Uranium - limited data, initially analyzed in March 1988.

Sufficient data are avajlable for the following constituents to allow their use in the characterization of the contaminated ground water at the 100-H Area: specific conductance, field pH, total organic haijdes (TOX), and 
total organic carbon (TOC) from the 1 ist of contamination indicators; gross alpha, gross beta, radium, nitrate, fluoride, filtered and unfiltered barium and chromium from the list of drinking water standards; sulfate, chloride, filtered and unfiltered sodium, manganese, and iron from the list of groundwater quality parameters; and chloroform, ammonium, filtered and unfiltered strontium, zinc, calcium, nickel, copper, vanadium, aluminum, potassium, and magnesium from the list of site-specific constituents.

Review of these data revealed that concentrations of approximately 20 constituents showed very marked increases in the point-of-compliance well, 199-H4-3, between April and August 1986. Concentrations of this magnitude have not been repeated since that time.

Plots of concentration versus time for specific conductance, gross alpha, gross beta, nitrate, barium, sulfate, sodium, strontium, calcium, nickel, copper, and potassium clearly indicate when this peak occurred (Figures 46 through 57). Chromium (Figure 58), although it does not exhibit a similar concentration peak as the other indicator constituents, remains above the MCL of $50 \mathrm{ppb}$ for most of the wells in the present network.

Additional constituents to be used as indicators of contamination from the 183-H Basins are TOC, radium, fluoride, chloroform, and magnesium. Alkalinity, $\mathrm{pH}$, and TOX will be used for geochemical modeling. A short summary of the remaining constituents that do not appear to be indicative of ground-water contamination from the $183-\mathrm{H}$ 8asins follows:

- Manganese - concentrations in Well 199-H4-3 are lower than in background We11 199-H4-6

- Iron - concentrations are lower during the April to August 1986 peak

- Chloride - no discernible increase in concentrations over background

- Zinc - concentrations are lower than background

- Vanadium - no discernible increase in concentrations over background 
RCRA Compliance Groundwater Monltoring Project 183-H Solar Evaporation Basing Assessment Program Phase I Wells, June 1985 to October 1987

Plotting symbols are abbreviations of Well name

Horizontal solid line is detection limit

Constituent-181 CONDFLD UKHO BPA Limit-None

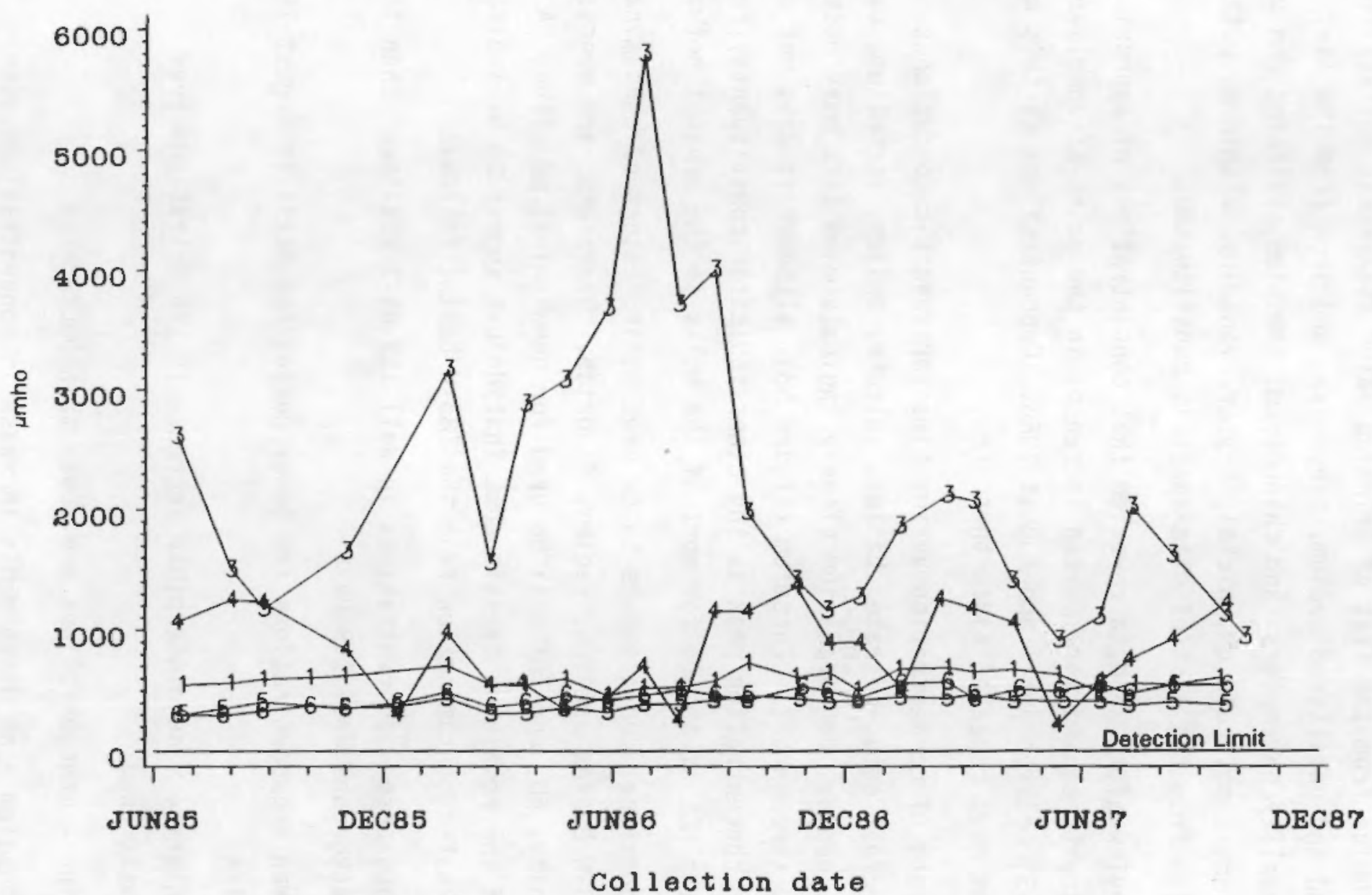

FIGURE 46. Specific Conductance in the Original Monitoring Wells 
RCRA Compliance Groundwater Monltoring Project 183-H Solar Evaporation Basing Assessment Program Phase I Welle, June 1985 to October 1987

Plotting eymbols are abbreviations of Well name

Horizontal solid line 18 detection limit

Constituent=212 ALPHA PCI/L Screening Limit-15

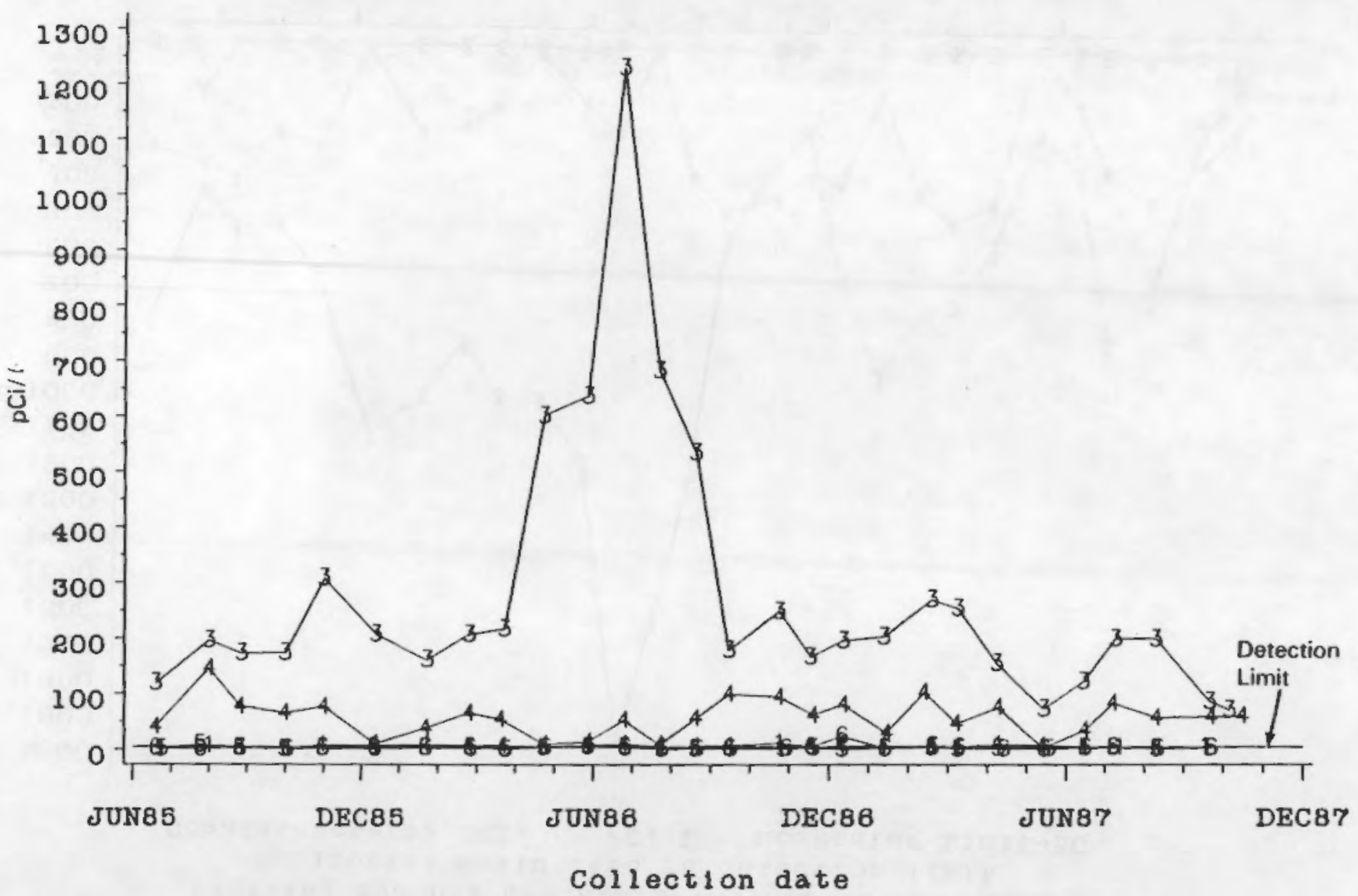

FIGURE 47. Gross Alpha Concentrations in the Original Monitoring Wells 
RCRA Compliance Groundwater Konitoring Project

183-H Solar Evaporation Basins Assessment Program

Phase I Wells, June 1985 to October 1987

Plotting symbole are abbreviations of Well name

Horizontal solid line is detection limit

Constituent-111 BETA PCI/L Screening Limit-50

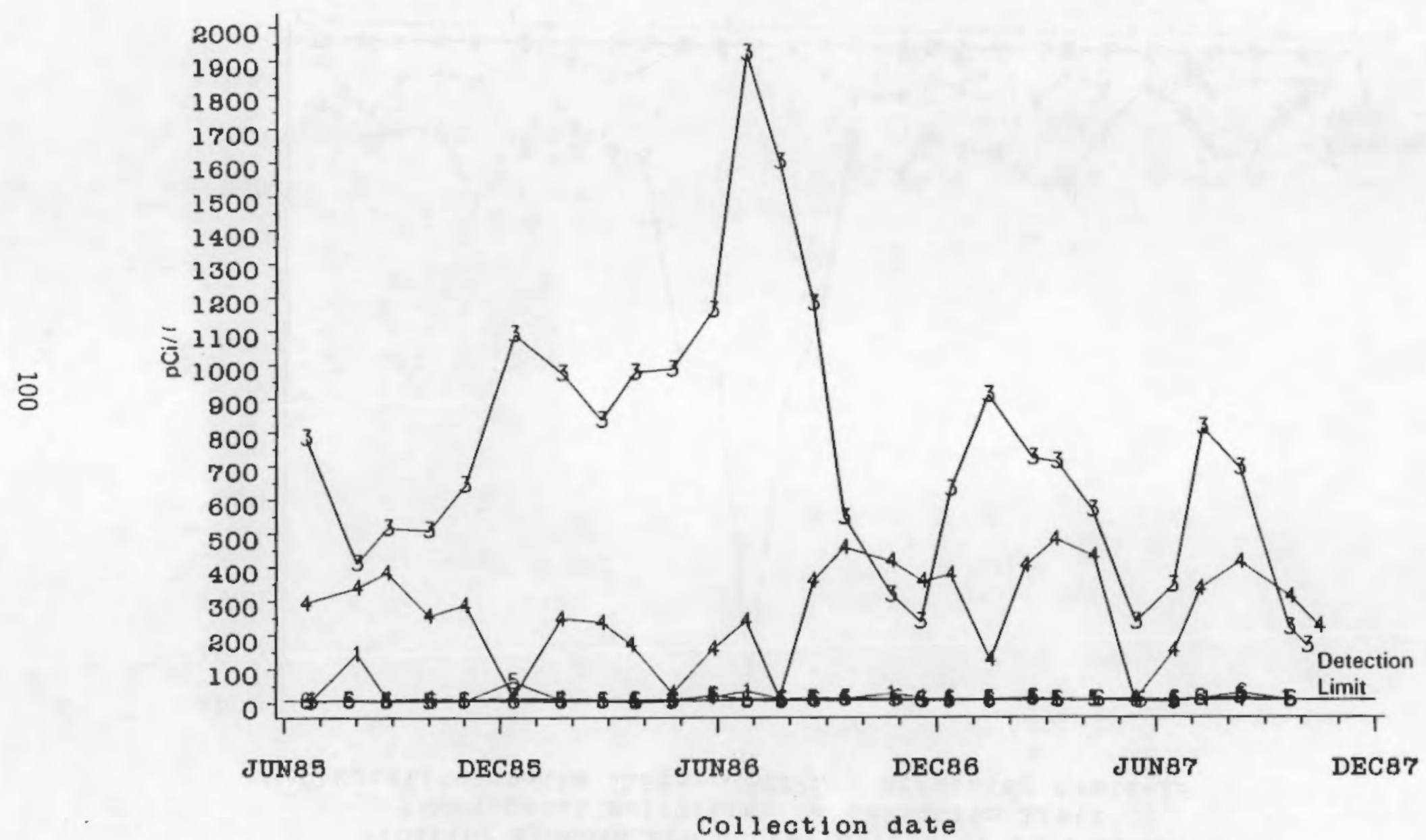

FIGURE 48. Gross Beta Concentrations in the Original Monitoring Wells 
RCRA Compliance Groundwater Monitoring Project 183-H Solar Evaporation Basins Assessment Program Pbase I Wells, June 1985 to October 1987

Plotting symbols are abbreviations of Well name

Horlzontal solid line is detection limit

Constituent=C72 NITRATE PPB EPA Lim1t=45000

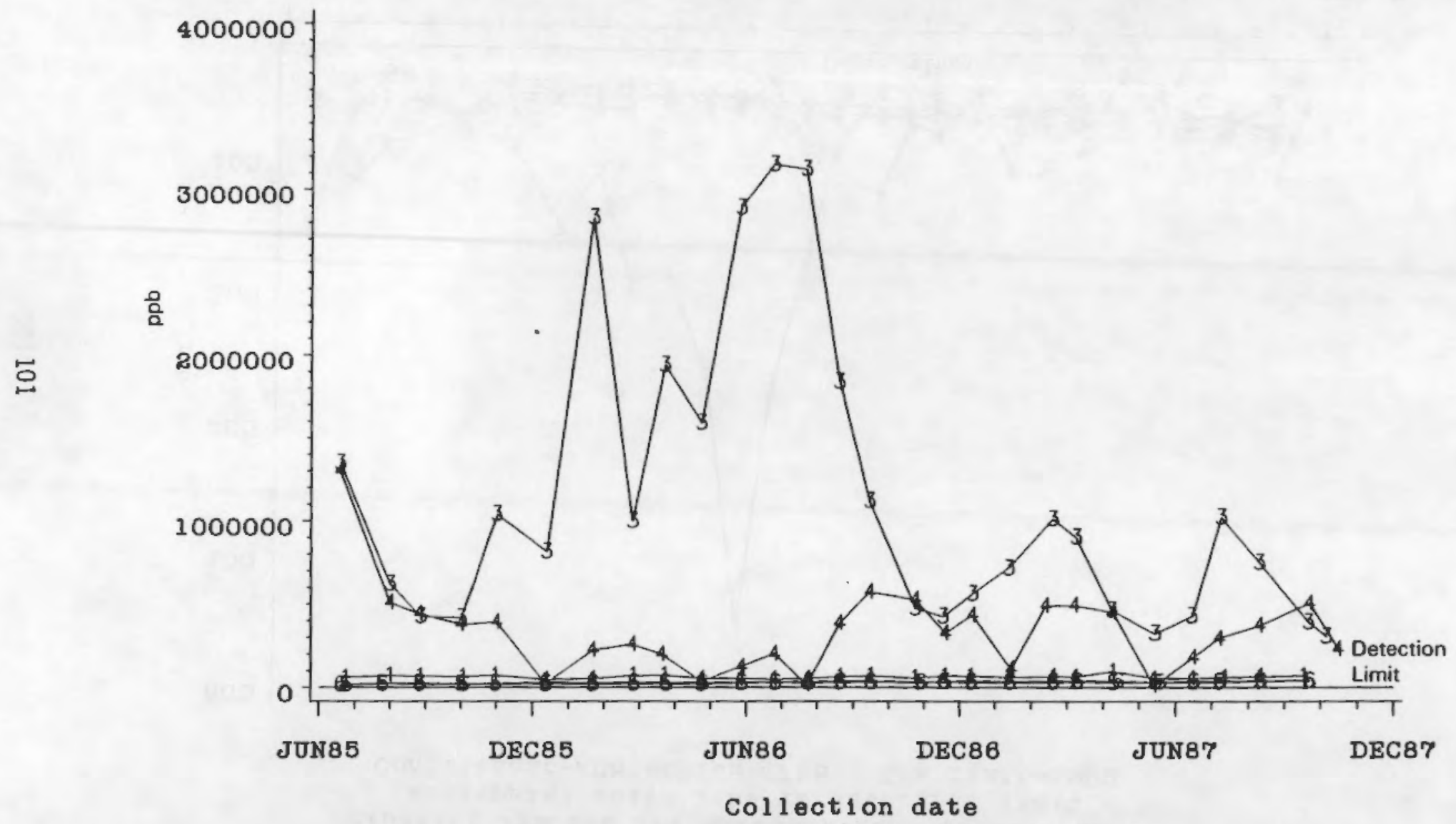

FIGURE 49. Nitrate Concentrations in the Original Monitoring Wells 
RCRA Compliance Groundwater Mon1toring Project 183-H Solar Evaporation Basing Ase日sgment Program Phase I Vells, June 1885 to October 1887

Plotting symbols are abbreviations of Well name Horizontal solid line is detection limit Constituent=A06 BARIUM PPB EPA LIm1t-1000

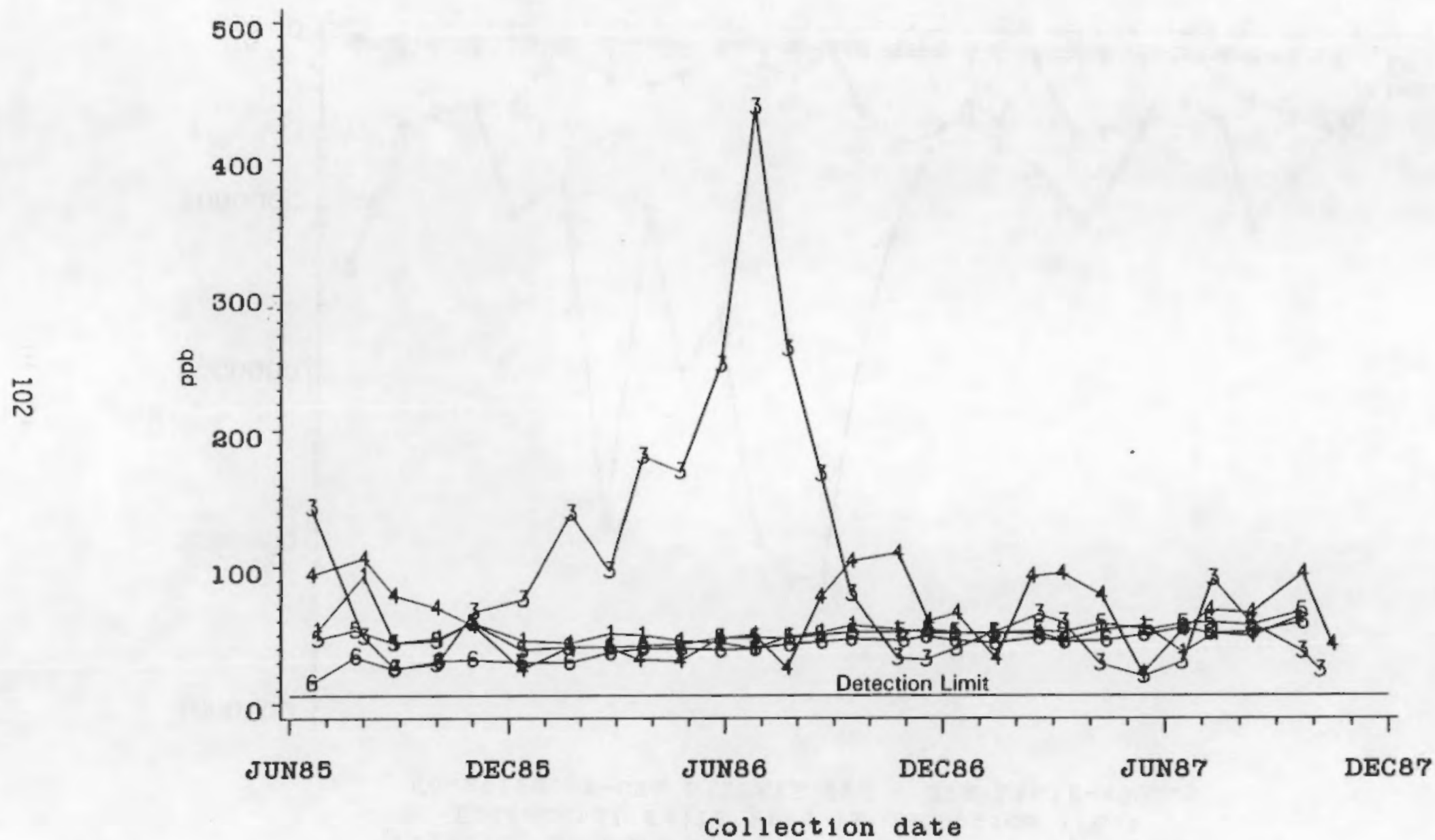

FIGURE 50. Barium Concentrations in the Original Monitoring Wells 
RCRA Compliance Groundwater Yonltoring Project 183-H Solar Bvaporation Basins Assesement Program Phase I Wells, June 1885 to October 1987

Plotting symbols are abbreviations of Well name

Horizontal solid line is detection limit

Constituent-C73 SULFATE PPB EPA L1mit-None

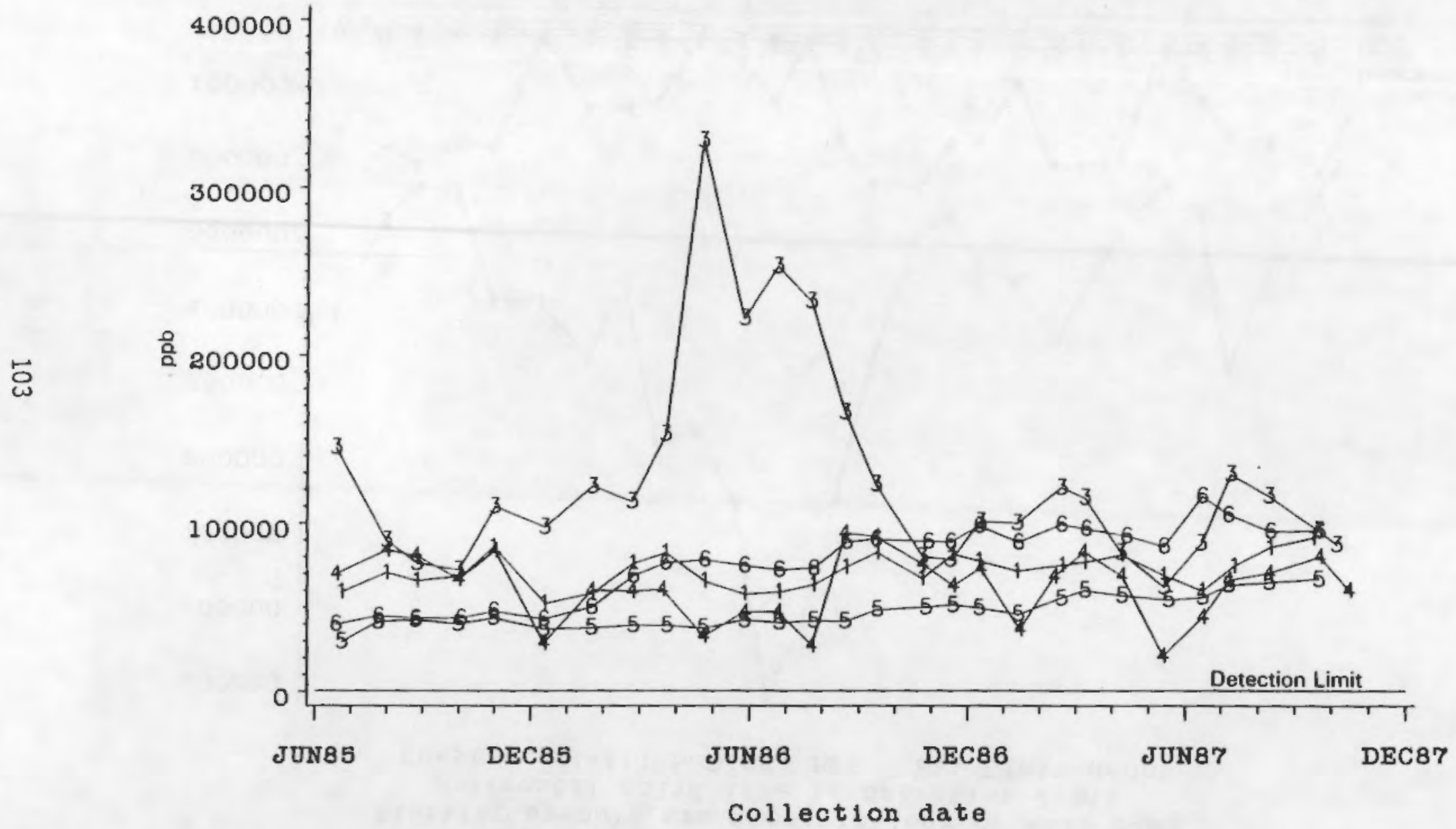

FIGURE 51. Sulfate Concentrations in the Original Monitoring Wells 
RCRA Compliance Groundwater Monitoring Project

183-H Solar Evaporation Basins Assessment Program

Pbase I Wells, June 1985 to October 1987

Plotting symbols are abbreviations of Well name

Horizontal solid line is detection limit

Constituent-A1I SODIUM PPB EPA Limlt-None

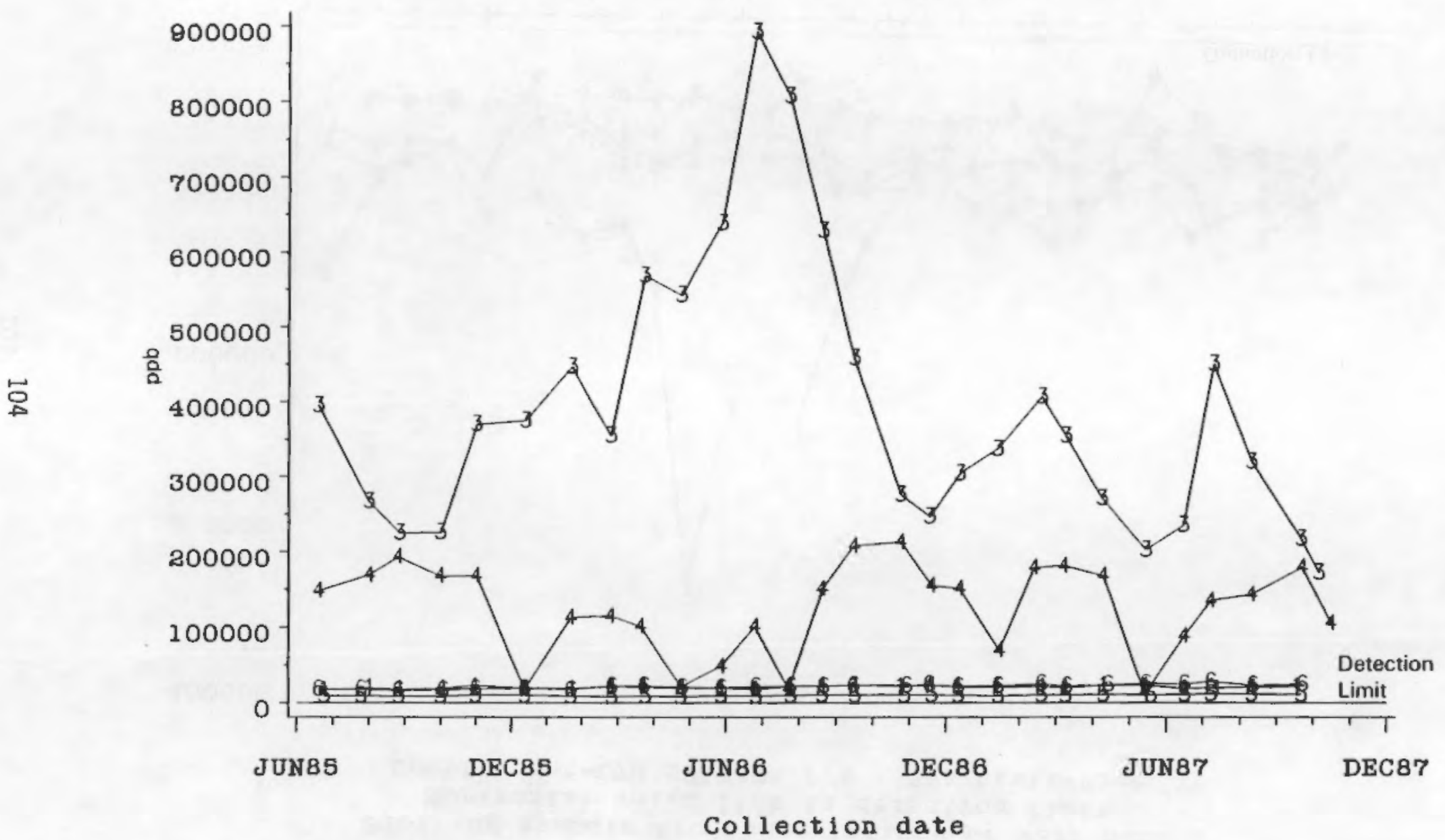

FIGURE 52. Sodium Concentrations in the Original Monitoring Wells 
RCRA Compliance Groundwater Monitoring Project 183-H Solar Evaporation Basins Assessment Program Phase I Welle, June 1985 to October 1887

Plotting symbols are abbreviations of Well name

Horizontal volid line $1 \mathrm{~s}$ detection $11 \mathrm{mit}$

Constituent-AO3 STRONUM PPB EPA Limlt-None

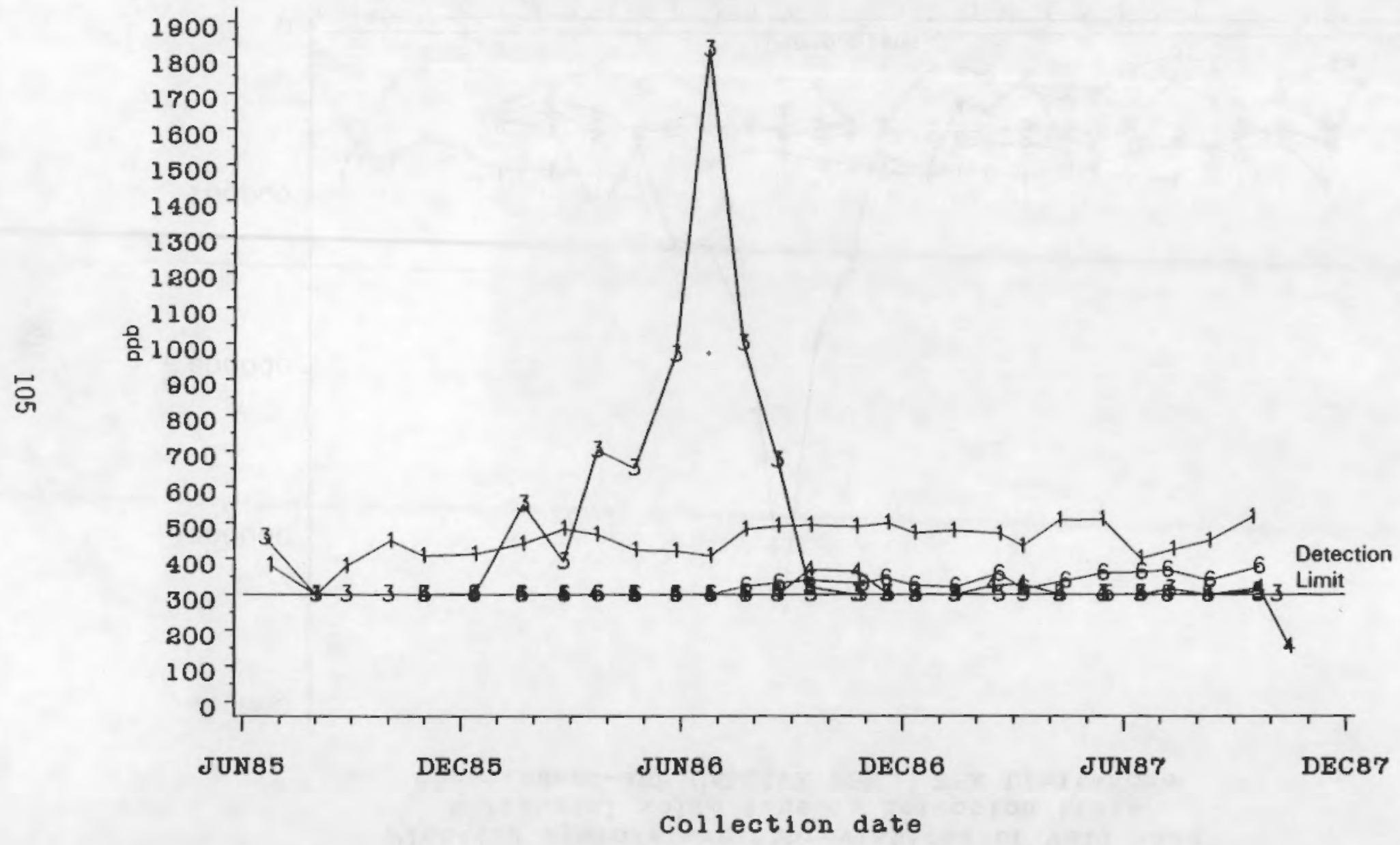

FIGURE 53. Strontium Concentrations in the Original Monitoring Wells 
RCRA Compliance Groundwater Monitoring Project

183-H Solar Evaporation Basins Assessment Program

Phase I Wells, June 1885 to October 1887

Plotting symbols are abbreviations of Well name

Horizontal solid line $1 \mathrm{~g}$ detection $11 \mathrm{~m} 1 \mathrm{t}$

Constituent=AO5 CALCIUM PPB EPA Limit-None

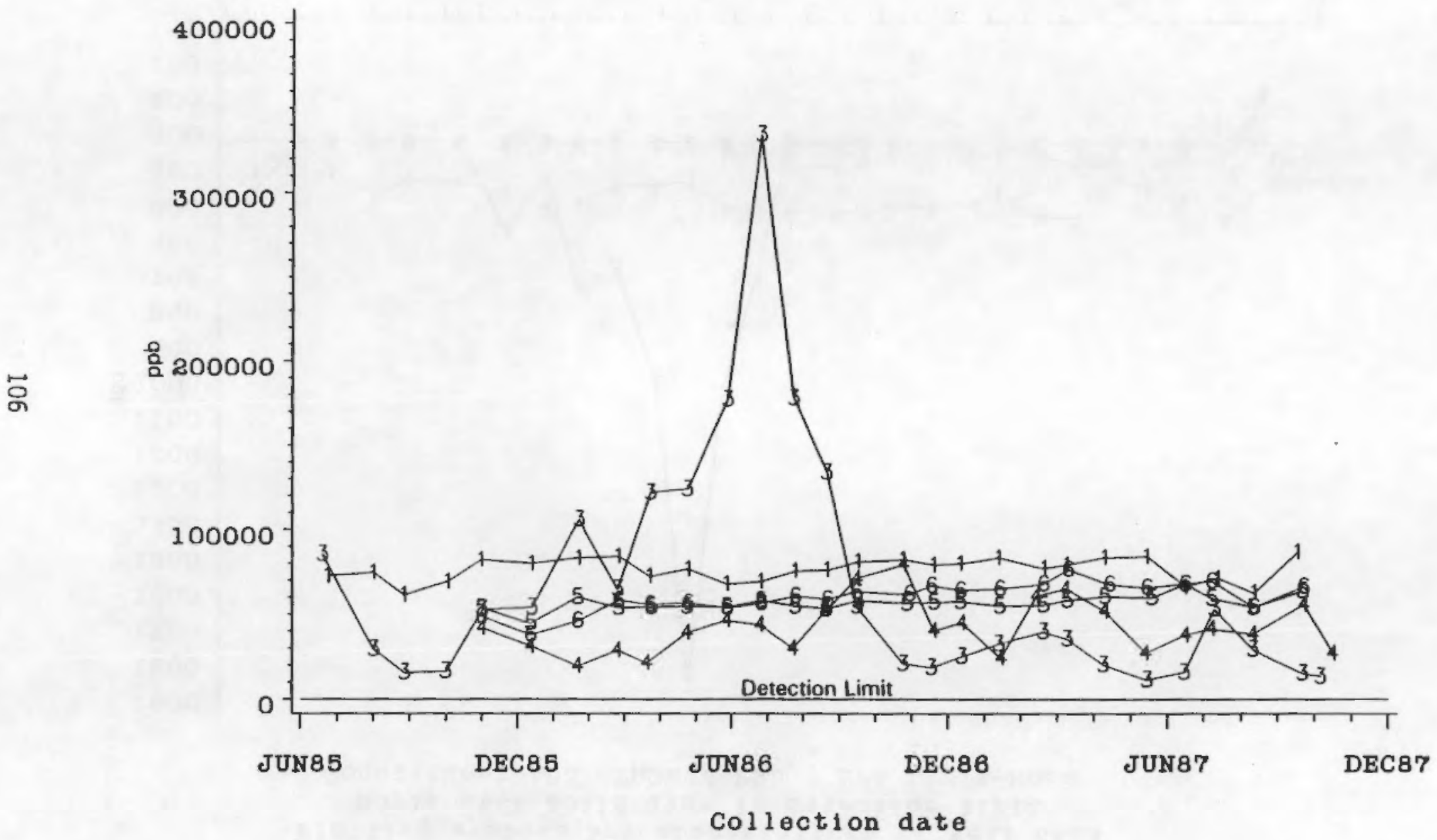

FIGURE 54. Calcium Concentrations in the Original Monitoring Wells 
RCRA Compliance Groundwater Mon1toring Project

183-H Solar Evaporation Basins Assessment Program

Phase I Wells, June 1885 to October 1887

Plotting symbols are abbreviations of Well name

Horizontal oolid line 18 detection limit

Constituent-A12 NICKEL PPB BPA Limit=None

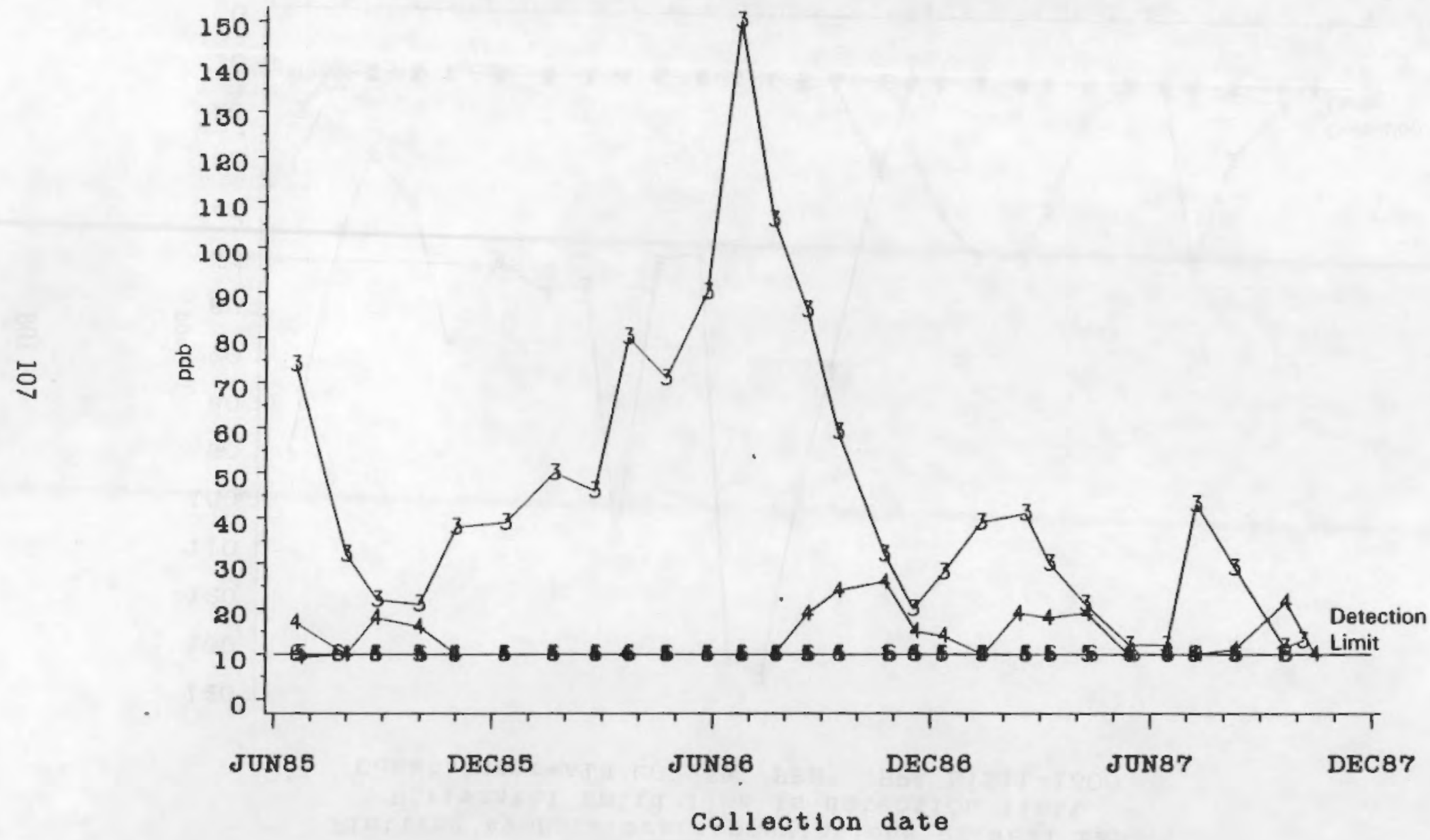

FIGURE 55. Nickel Concentrations in the Original Monitoring Wells 
RCRA Compliance Groundwater Monitoring Project 183-H Solar Bvaporation Basins Assessment Program Phase I Wells, June 1985 to October 1987

Plotting symbols are abbreviations of Well name

Horizontal solid line $1 \mathrm{~s}$ detection $11 \mathrm{mit}$

Constituent-A13 COPPER PPB EPA Lim1t-1300

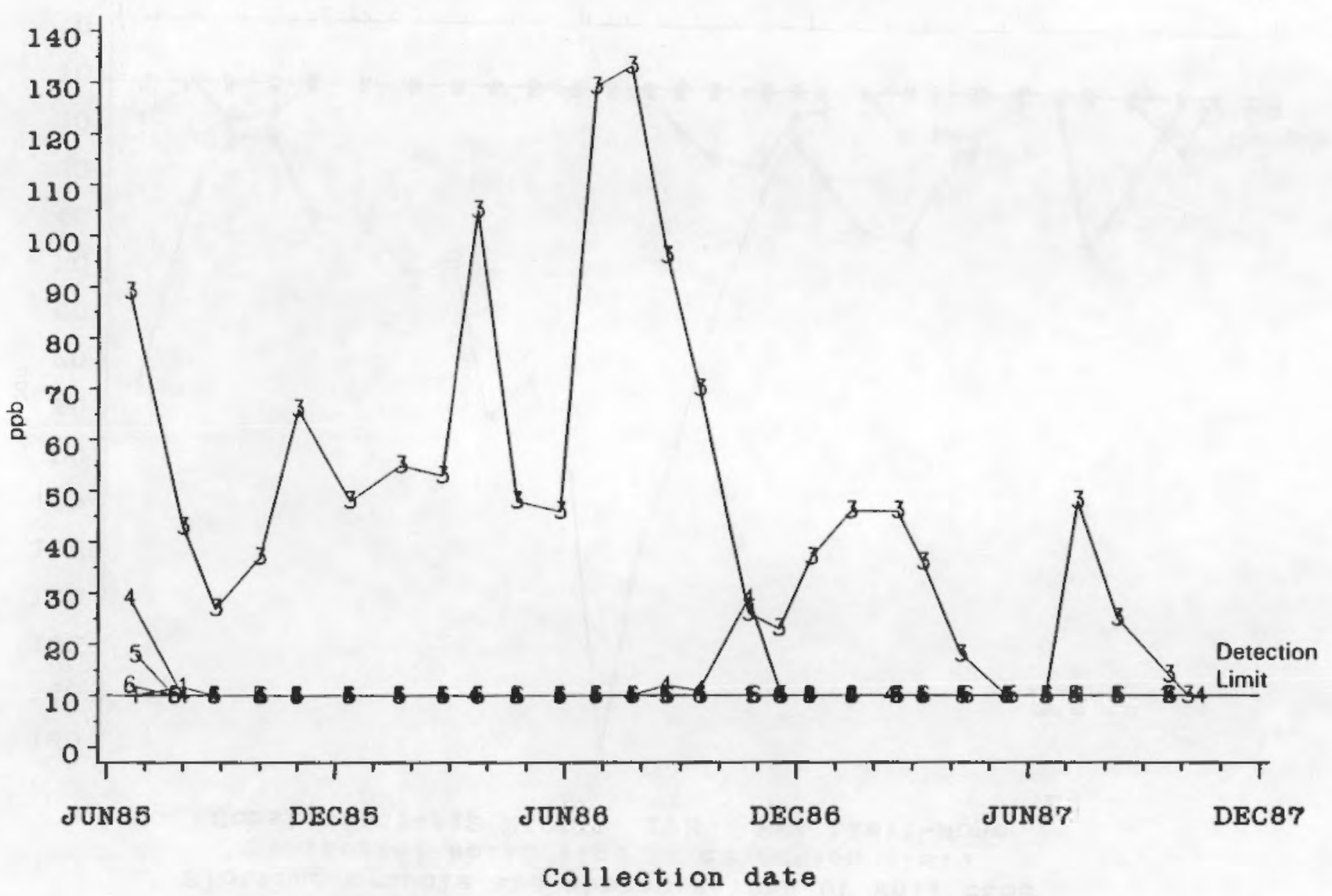

FIGURE 56. Copper Concentrations in the Original Monitoring Wells 
RCRA Compliance Groundwater Mon1toring Project 183-H Solar Evaporation Basing Assessment Program Phase I Wells, June 1985 to October 1987

Plotting eymbole are abbreviationg of Well name

Horizontal solid line 18 detection limit

Congtituent-A18 POTASUS PPB EPA L1mit-None

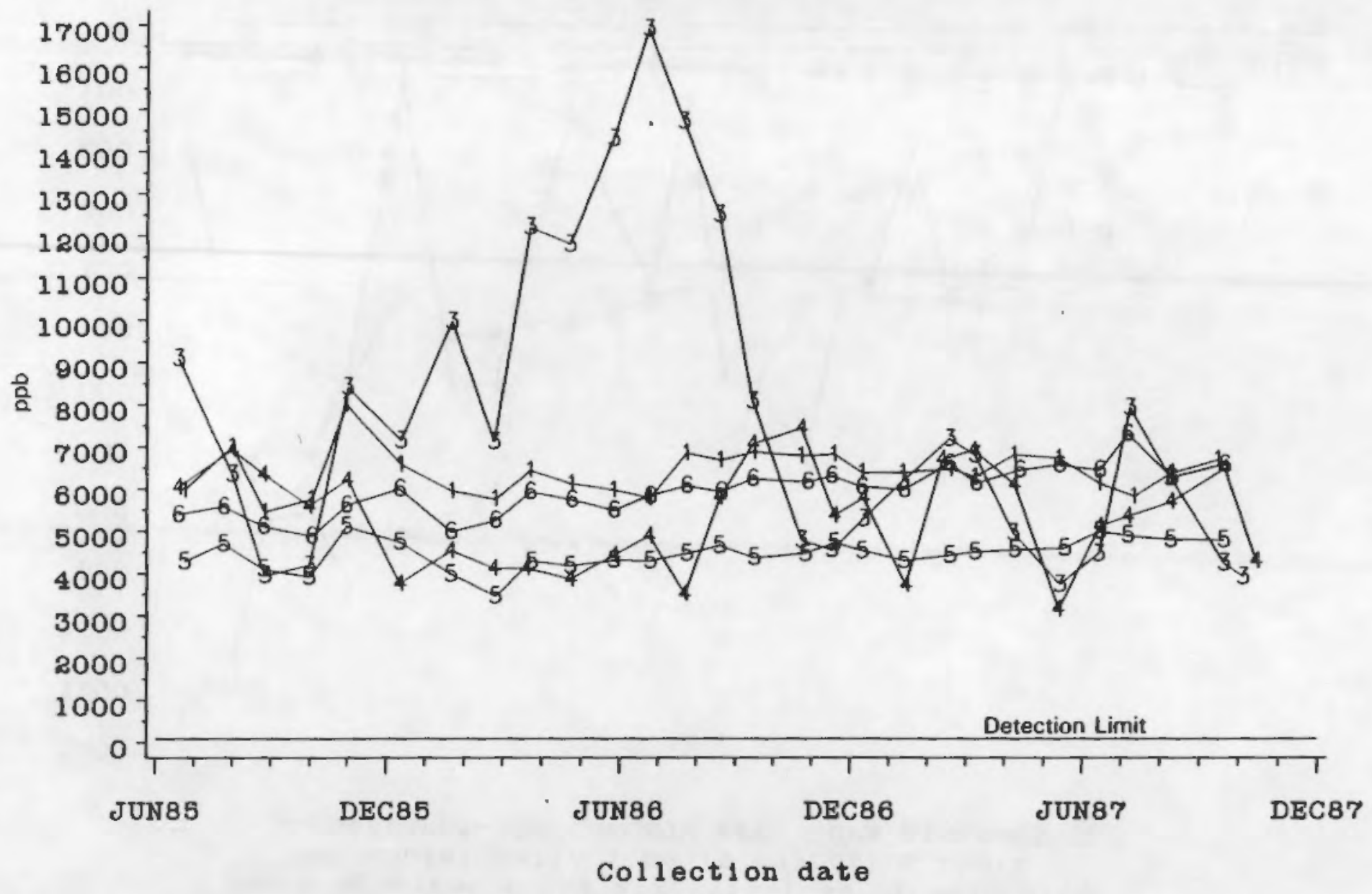

FIGURE 57. Potassium Concentrations in the Original Monitoring Wells 
RCRA Compliance Groundwater Monitoring Project 183-H Solar Evaporation Basins Assessment Program Phase I Wells, June 1985 to October 1987

Plotting symbols are abbreviations of Well name Horizontal solid line is detection limit

Constituent=A08 CHROMUY PPB EPA L1m1t=50

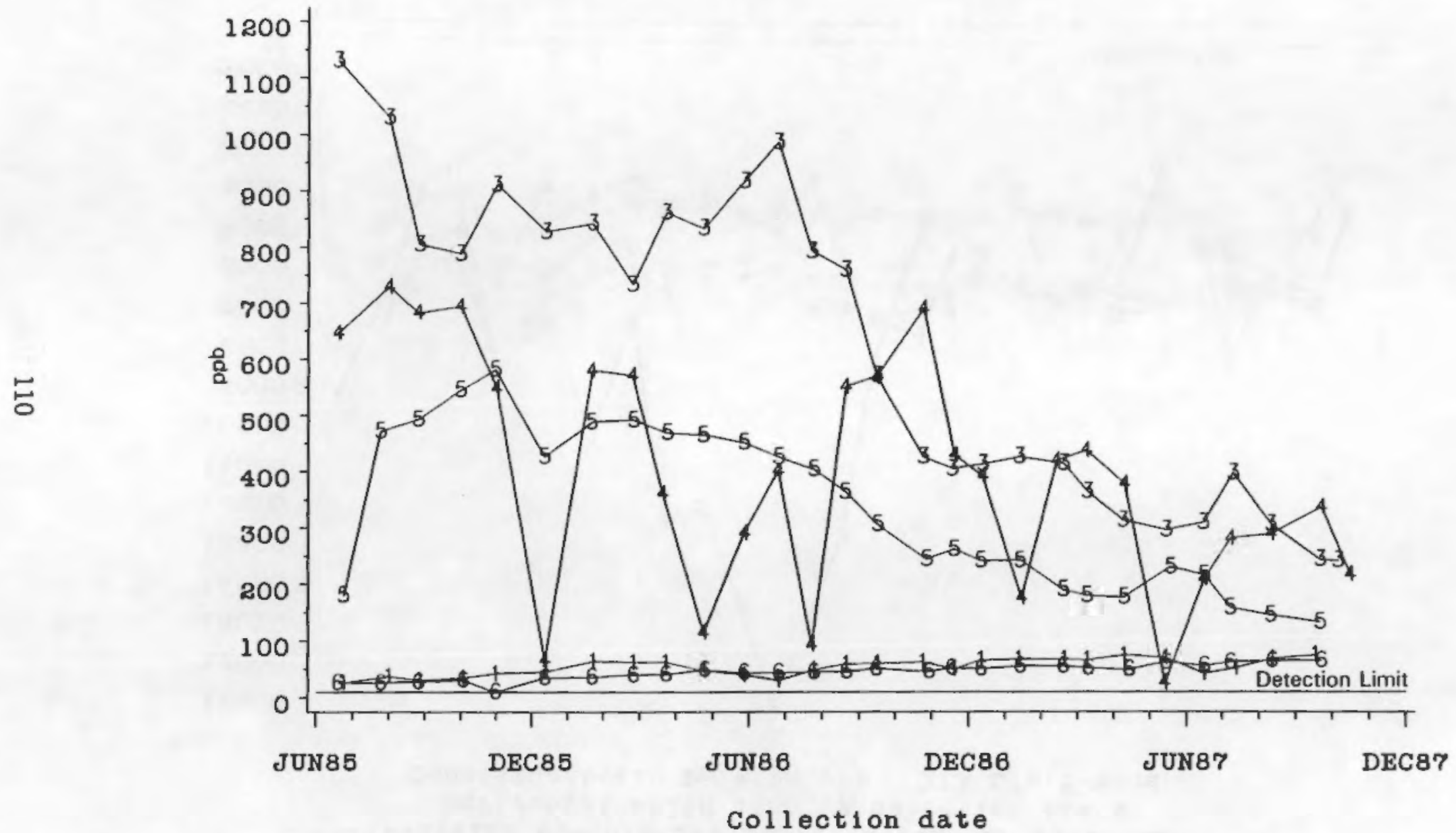

FIGURE 58. Chromium Concentrations in the Original Monitoring Wells 
- Aluminum - concentrations are lower during the April to August 1986 peak

- Ammonium - concentrations are generally less than background.

A discussion of the clearest indicators of contamination attributable to the 183-H Basins appears in Section 9.0 "Contaminant Plume Description." 


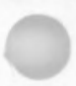

-

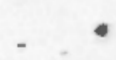

$:$
$:-$

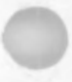

-

:

-

-

.

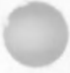




\subsection{STATISTICAL EVALUATIONS}

As discussed in Sections 1.0 "Introduction," and 7.0 "Analytical Results, " a compliance monitoring program was established in June 1985 because hazardous waste constituents were known to have entered the ground water beneath the 183-H Basins. Based on these data and guidance provided in the WAC 173-303-645, the following statistical evaluations were performed.

\subsection{DESCRIPTIVE STATISTICS}

Basic descriptive statistics were calculated for the 68 constituents that had at least one value above the detection limit to determine the variability in the data for the sampling period June 1985 through October 1987 (Appendix B). These statistics include: the maximum (MAX), median, minimum (MIN), range (MAX-MIN), mean, standard deviation (STD), and coefficient of variation ( $C V=S T D / m e a n)$. Appendix $B$ gives the number of samples analyzed, the number of samples that were below the detection limit (or flagged by being reported with a "less than" value), and the number of days that samples were collected. The median values for the days (N) that had at least one value above the detection 1 imit were used to calculate the descriptive statistics. A "." in Appendix B indicates that the statistic could not be calculated because of an insufficient number of values above the detection limit. The following observations were made with regard to these data.

Concentrations in filtered and unfiltered samples for the same constituent often do not appear similar in Wells 199-H3-1, 199-H4-3, 199-H4-4, 199-H4-5, and 199-H4-6. These differences arise primarily because samples collected during different time periods were used for concentration analyses: the unfiltered constituents for these wells have been collected since June 1985, while the filtered constituents have been collected only since September 1986.

The standard deviations and coefficients of variation are relatively large for a number of constituents and wells. Several of these constituents 
are changing significantly with time (either increasing or decreasing). The concentrations are also changing significantly with the water levels in the wells.

\subsection{CLUSTER WELL STATISTICS}

Descriptive statistics for the three cluster well locations were reviewed individually to determine statistical differences in constituent concentrations with depth. The following observations were made from these data:

- Aluminum, ammonium, iron, and vanadium are generally detected only in the deep wells (199-H3-2C and 199-H4-12C).

- Barium concentrations are lowest in the deep wells and highest in the intermediate wells (199-H2-2B, 199-H4-12B, and 199-H4-15B).

- Calcium, chromium, strontium, and sulfate concentrations are lowest in the deep wells and the same in the shallow (199-H3-2A, 199-H4-12A, and 199-H4-15A) and intermediate wells.

- Chloride has the largest mean but lowest median in the deep wells. No differences occur in the shallow and intermediate wells.

- Chloroform is not often detected in the deep wells.

- Gross alpha and gross beta concentrations decrease with depth in Wells 199-H4-12A, 199-H4-12B, and 199-H4-12C. These constituents are below DWS at the other cluster well locations.

- Manganese is generally detected only in the intermediate and deep wells.

- Nitrate concentrations and specific conductance decrease with depth.

- Potassium and zinc concentrations increase with depth.

- Sodium concentrations are highly variable in the deep wells. 


\subsection{LINEAR REGRESSION ANALYSES}

A series of simple and multiple linear regression analyses were performed to determine if the chemical constituents in the wells were changing with time and water table elevation. Analyses were performed for the period June 1985 through October 1987 using 18 chemical constituents (Table 14) in 20 wells (Table 15). These constituents were chosen because their concentrations (except those of chloroform and chromium) were routinely reported above detection limits in all the wells.

Wells 199-H3-1, 199-H4-3, 199-H4-4, 199-H4-5, and 199-H4-6 were divided into two time periods (pre- and post-September 1, 1986) because of the significant change in concentration trends in Well 199-H4-3 at this time. Prior to September 1, 1986, concentrations of al1 chemical constituents in this well were increasing with time and with increases in water table elevation (Figures 59 and 60). However, these concentrations have no statistically significant increases or decreases with time or water table elevation after September 1, 1986 .

Several wells along the Columbia River are affected by changes in water table elevation. Most of the chemical constituents in Wells 199-H4-4 (preand post-) (Figures 61 and 62), 199-H4-10, 199-H4-12A, and 199-H4-12B significantly decreased with increases in water table elevation.

TABLE 14. Chemical Constituents Used for Linear Regression Trend Analyses

Gross Alpha

Gross Beta

Filtered Barium Unfiltered Barium

Filtered Calcium

Chloroform

Chloride

Filtered Chromium Unfiltered Chromium
Specific Conductance

Filtered Magnesium

Unfiltered Magnesium

Nitrate

Filtered Potassium

Unfiltered Potassium

Filtered Sodium

Unfiltered Sodium

Sulfate 
TABLE 15. Wells Used for Linear Regression Trend Analyses

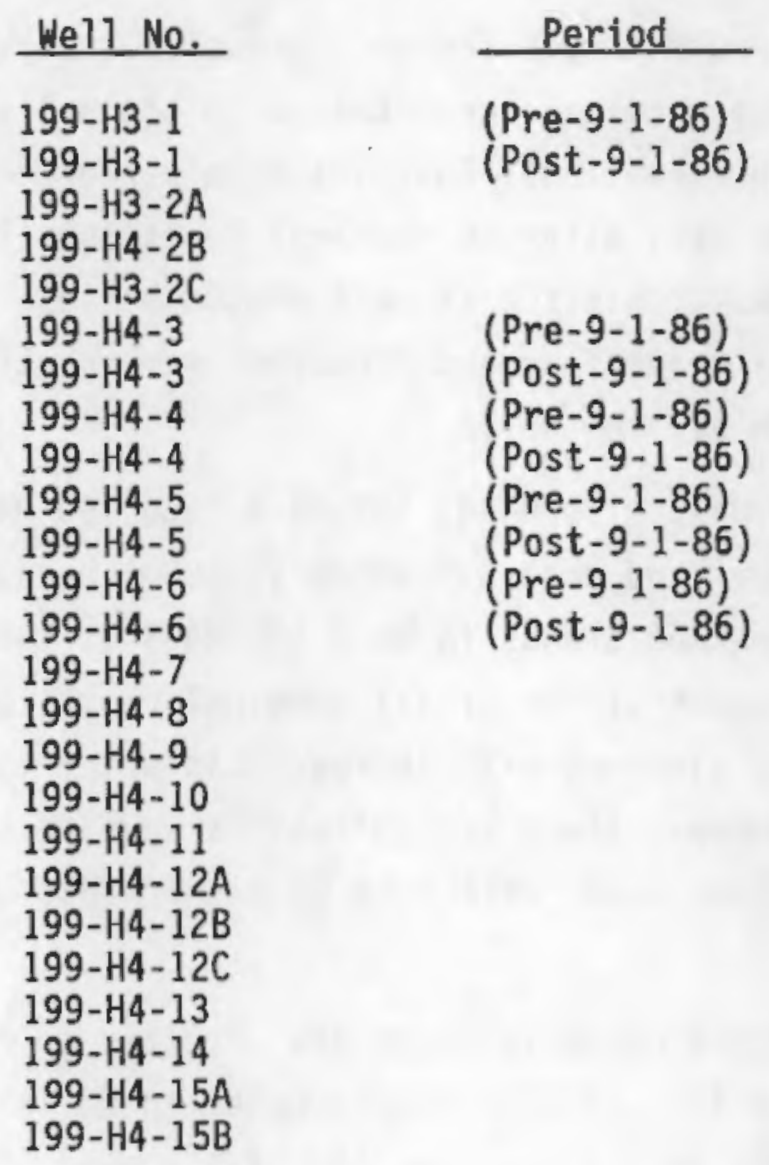

Concentrations of chemical constituents in several upgradient wells were also significantly affected by changes in water table elevation. Concentrations in Well 199-H3-1 decreased significantly with increases in water table elevation. Most of the chemical constituents in Wells 199-H3-2A and 199-H3-2B significantly increased with increases in water table elevation. Well 199-H4-6 showed no consistent effects.

Well 199-H4-7 had significant increases in chemical concentrations when the water table elevation increased. Other wells located adjacent to the 183-H Basins [Wells 199-H4-3 (post-), 199-H4-5 (post-), 199-H4-8, 199-H4-9, and 199-H4-14] had almost no significant effects caused by changes in water table elevation. 
Wells $199-\mathrm{H} 3-2 \mathrm{C}$ and $199-\mathrm{H} 4-12 \mathrm{C}$ had only a few chemical constituents that were affected by the water table elevation. However, most of the constituents in these wells are significantly decreasing over time.

Al1 the chemical constituents in Well 199-H4-6 (pre-) were increasing significantly with time, except chloroform, which was significantly decreasing. Gross beta, chloroform, calcium, specific conductance, gross alpha, and sulfate were no longer significantly increasing after September 1, 1986.

Several of the wells had a number of chemical constituents that were either significantly increasing or significantly decreasing with time. Wells 199-H3-1 (pre-), 199-H3-2A, 199-H3-2B, 199-H4-5 (pre-), 199-H4-6 (pre-), 199-H4-7, 199-H4-8, and 199-H4-11 had increasing trends with time. Decreasing trends with time were noted for We11s 199-H3-1 (post-), 199-H4-12A, 199-H4-12B, and 199-H4-13. Wells 199-H4-3 (post-), 199-H4-4, 199-H4-14, 199-H4-15A, and 199-H4-15B do not show significant changes over time. 
RCRA Compliance Ground-Water Monitoring Project 183-H Solar Evaporation Basins Assessment Program Plots of relationship between Water Level and Concentration Dashed line is water level. Solid line is constituent

Well name $=1-\mathrm{H} 4-3$

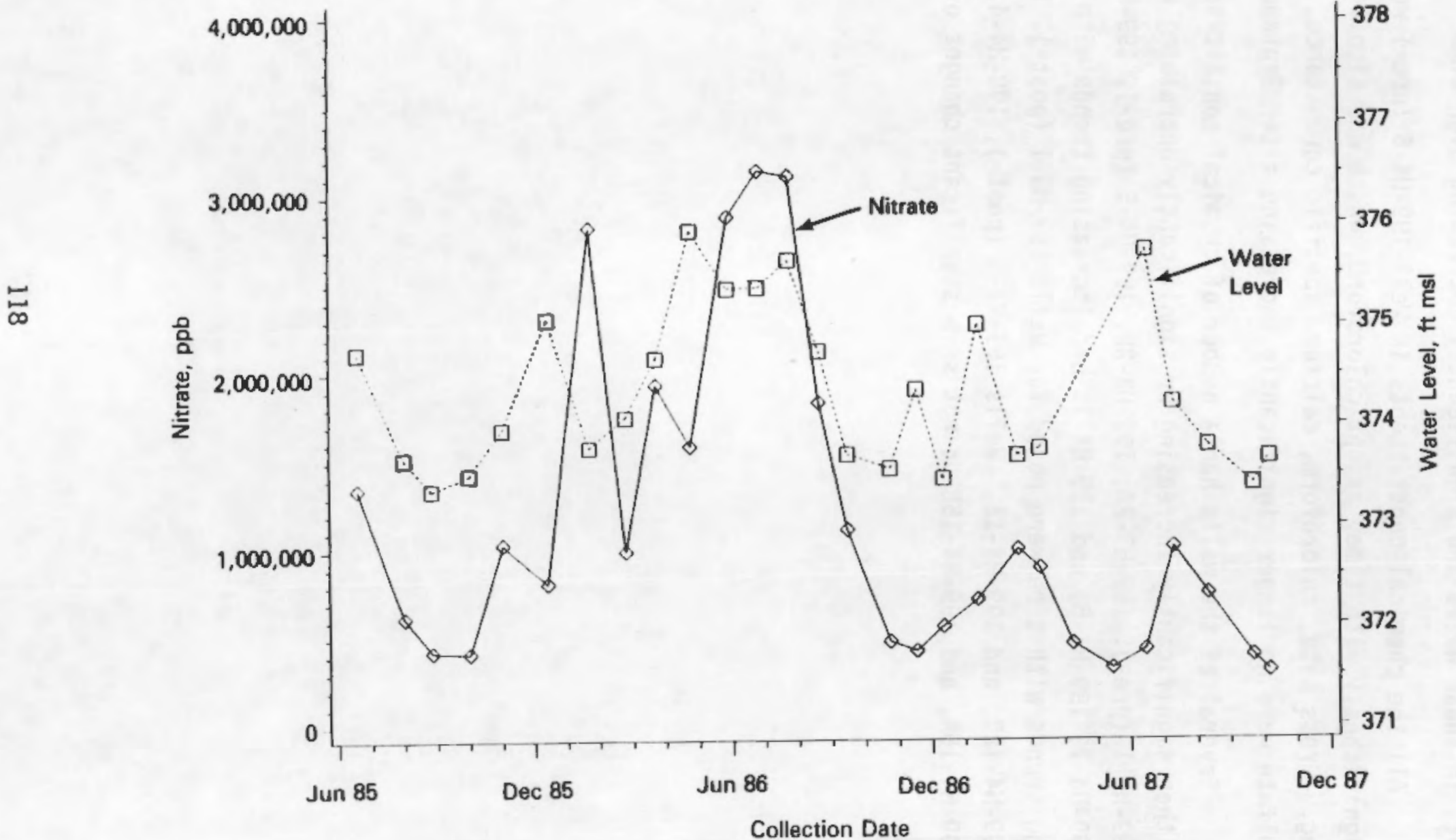

FIGURE 59. Nitrate Concentration Trends in Well 199-H4-3 

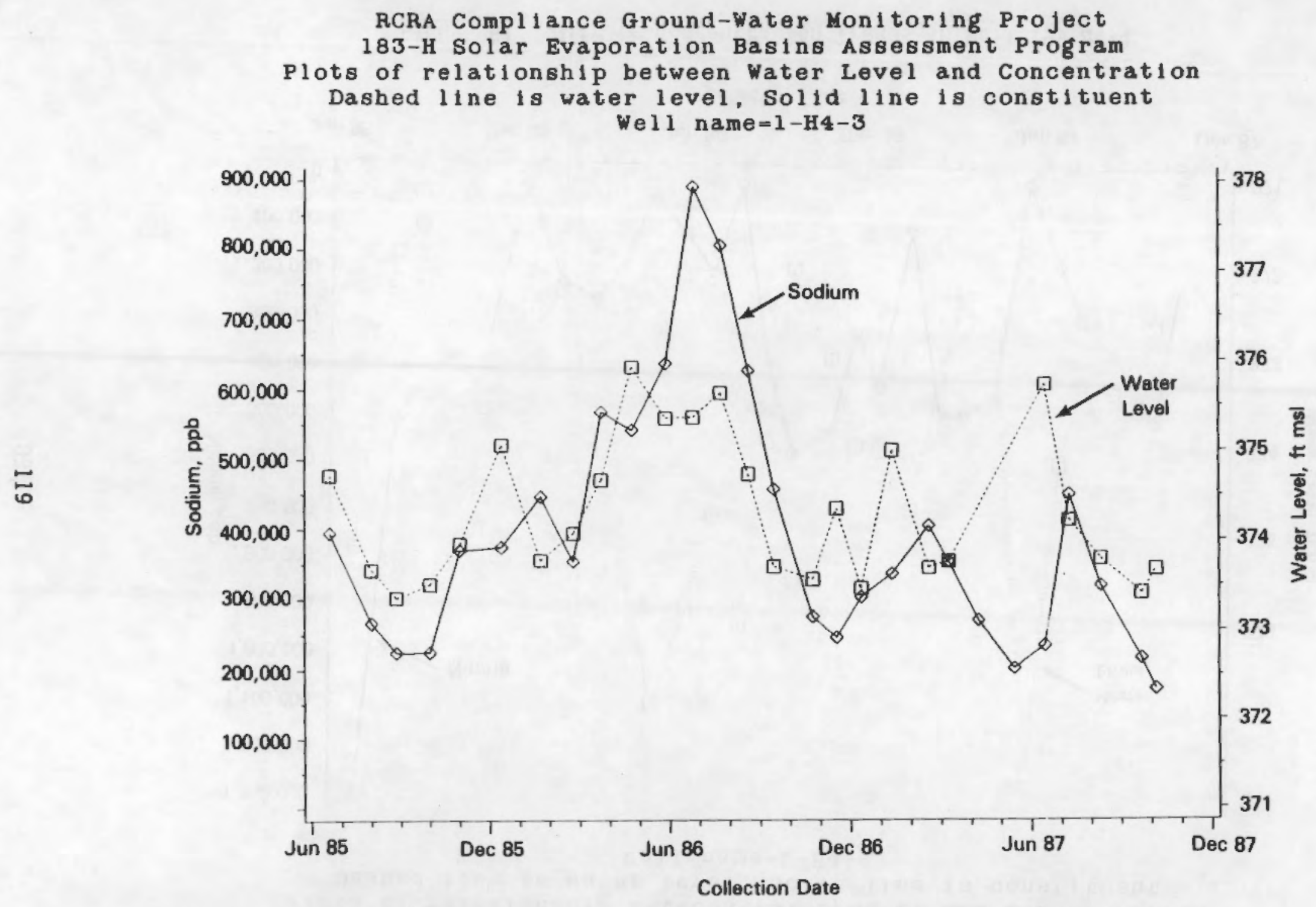

FIGURE 60. Sodium Concentration Trends in Well 199-H4-3 
RCRA Compliance Ground-Water Monitoring Project 183-H Solar Evaporation Basins Assessment Program Plots of relationship between Water Level and Concentration Dashed line is water level. Solid line is constituent Well name $=1-\mathrm{H} 4-4$

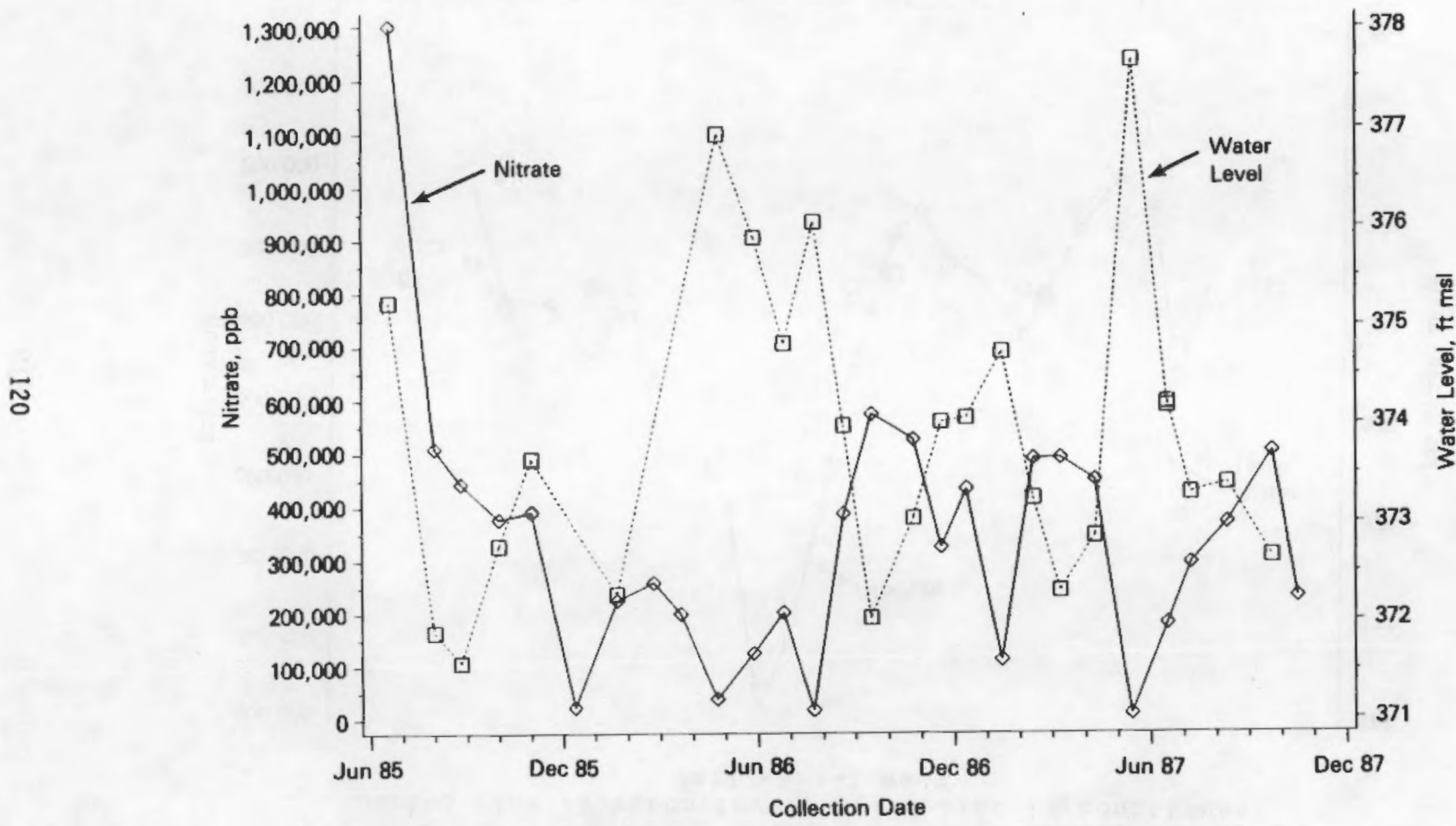

FIGURE 61. Nitrate Concentration Trends in Well 199-H4-4 
RCRA Compliance Ground-Water Monitoring Project

183-H Solar Evaporation Basins Assessment Program

Plots of relationship between Water Level and Concentration

Dashed line is water level, Solid line is constituent

Well name $=1-\mathrm{H} 4-4$

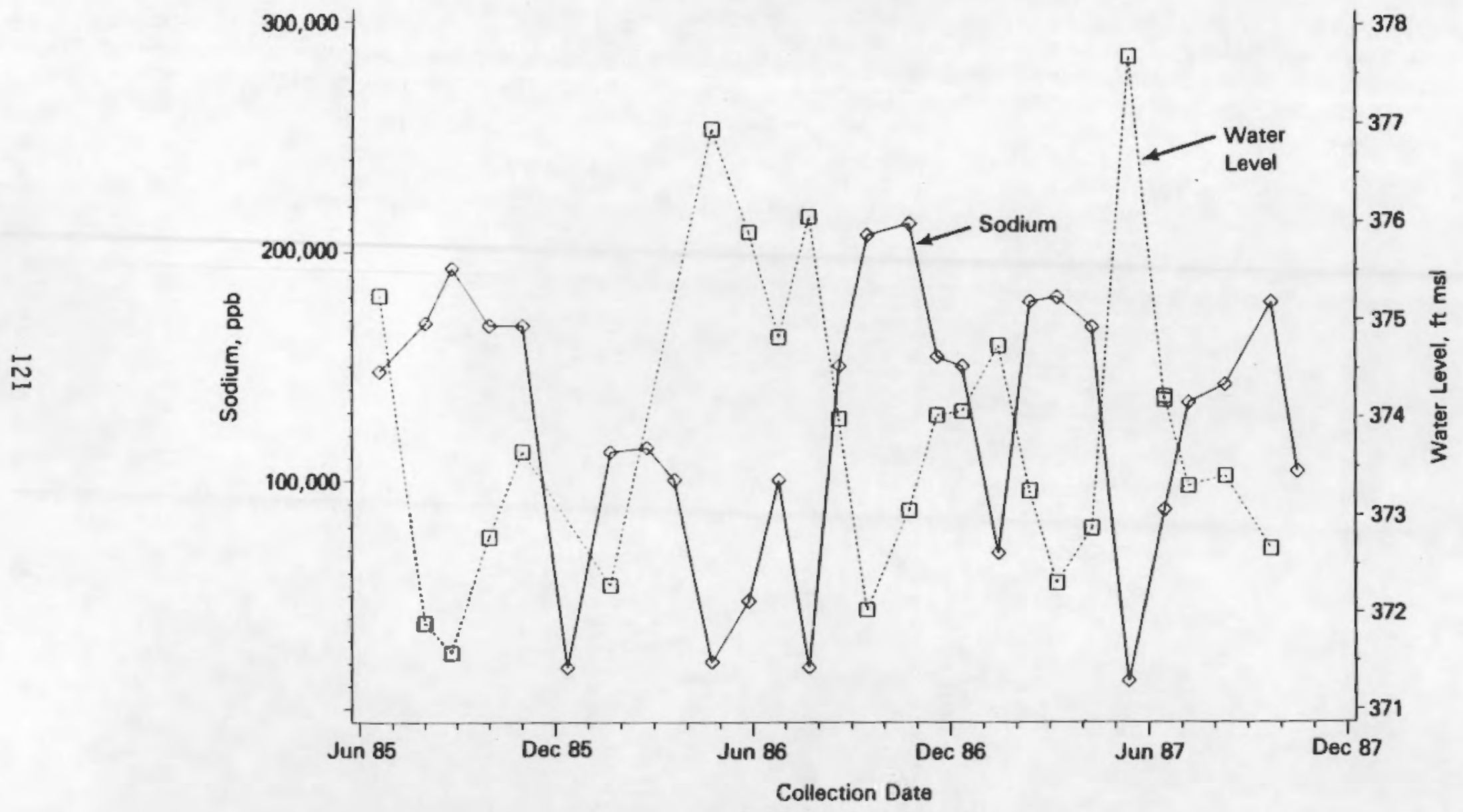

FIGURE 62. Sodium Concentration Trends in Well 199-H4-4 


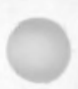

-

-

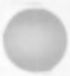

-

,

$\because$

-

-

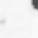




\subsection{CONTAMINANT PLUME DESCRIPTION}

This section focuses on the ground-water contaminant plume attributable to the 183-H Basins. The extent of this plume was determined using data collected after January 1, 1987. Analytical data collected before this date were limited to the five wells in the original monitoring network, because sampling of the Phase II and III wells did not commence until 1987. This section includes information on background concentrations, horizontal and vertical extent of contamination, geochemical interaction of selected constituents, and ground-water modeling results.

\subsection{BACKGROUND CONCENTRATIONS}

Background concentrations in selected upgradient wells were calculated for the clearest indicators of contamination attributable to the 183-H Basins (Table 16). These constituents include nitrate, filtered sodium, gross aipha, and gross beta.

Background values were also calculated for $\mathrm{pH}$ (field) and TOX, which will be used for geochemical modeling. The background value for filtered chromium is shown in Table 16, al though other potential sources of

IABLE 16. Background Concentrations

\begin{tabular}{|c|c|c|c|c|c|}
\hline Constituent & $\underline{\text { Units }}$ & $\begin{array}{l}\text { No. of } \\
\text { Samples }\end{array}$ & Average & $\begin{array}{l}\text { Standard } \\
\text { Deviation }\end{array}$ & $\begin{array}{l}\text { Coefficient } \\
\text { of Variation }\end{array}$ \\
\hline Nitrate & $\mathrm{ppb}$ & 32 & 28,740 & 9,290 & 32.3 \\
\hline $\begin{array}{l}\text { Filtered } \\
\text { Sodium }\end{array}$ & $\mathrm{ppb}$ & 32 & 15,940 & 5,872 & 36.8 \\
\hline Gross Alpha & $\mathrm{pCi} / \mathrm{L}$ & 32 & 2.35 & 1.23 & 52.5 \\
\hline Gross Beta & $\mathrm{pCi} / \mathrm{L}$ & 32 & 8.55 & 4.53 & 53.0 \\
\hline $\begin{array}{l}\text { Filtered } \\
\text { Chromium }\end{array}$ & $\mathrm{ppb}$ & 32 & 71.3 & 44.2 & 62.0 \\
\hline $\mathrm{pH}$ (field) & -- & 31 & 7.542 & 0.4137 & 5.5 \\
\hline TOX & $\mathrm{ppb}$ & 31 & 62.15 & 38.73 & 62.3 \\
\hline
\end{tabular}


chromium have been identified in the $100-\mathrm{H}$ Area. Monthly ground-water monitoring data for 1987 from Wells 199-H3-2A, 199-H4-6, and 199-H4-7 were used to calculate these values.

The statistics were calculated by pooling all available data as if each observation were a random sample. Seasonal variability was expected to be minimal because these wells are generally removed from the influence of the Columbia River, relative to the point of compliance, Well 199-H4-3. However, a high degree of spatial variability was noted in the data.

Constituents for which background values are not calculated are alkalinity, technetium-99, and uranium. Analysis for alkalinity began in May 1988 and will be used for geochemical modeling. Analyses for technetium-99 and uranium were initiated in March 1988. These constituents are thought to be the primary contributors to the gross beta and gross alpha concentrations, respectively. Background values for these constituents will be calculated similar to those shown in Table 16.

Table 17 compares background values for the clearest indicators of contamination attributable to the 183-H Basins and background values for the Hanford Site (Jacquish and Mitchell 1988). Chromium is also included in this table.

The background values for nitrate and filtered chromium in the upgradient wells near the 183-H Basins were higher than the background values for the Hanford Site, indicating other sources of these constituents located

IABLE 17. Comparison of Background Values from Selected Upgradient Wells Near the 183-H Basins with Background Values on the Hanford Site

\begin{tabular}{|c|c|c|c|}
\hline Constituent & $\underline{\text { Units }}$ & 183-H Basins & Hanford Site \\
\hline Nitrate & $\mathrm{ppb}$ & $28,740 \pm 19,000$ & $500-2,000$ \\
\hline Filtered Sodium & $\mathrm{ppb}$ & $15,940 \pm 6,000$ & $20,500 \pm 6,700$ \\
\hline Gross Alpha & $\mathrm{pCi} / \mathrm{L}$ & $2.35 \pm 1.40$ & $2.5 \pm 1.4$ \\
\hline Gross Beta & $\mathrm{pCi} / \mathrm{L}$ & $8.55 \pm 1.70$ & $19 \pm 12$ \\
\hline Filtered Chromium & $\mathrm{ppb}$ & $71.3 \pm 74$ & $<10$ \\
\hline
\end{tabular}


upgradient of the 1B3-H Basins. Background concentrations of filtered sodium, gross alpha, and gross beta were similar to the background concentrations on the Hanford Site.

\subsection{HORIZONTAL EXTENT OF CONTAMINATION}

As shown in the isoconcentration maps (Figures 63 through 74 ) and columnar diagrams (Figures 75 through 78 ), nitrate, sodium, gross alpha, and gross beta are the clearest indicators of contamination attributable to the 183-H Basins. Because of the proximity of the facility to the Columbia River and the demonstrated effect that the river has on many of the wells, isoconcentration maps data were plotted for low (September 1987), mean (December 1986), and high (May 1987) river stages.

In general, Wells 199-H4-3, 199-H4-4, 199-H4-9, and 199-H4-12A show the highest constituent concentrations for all three time periods. The basic shape and location of the plumes and columnar plots for a particular period were similar for most of the constituents found in these wells. As shown in Figures 63 through 74, concentrations of contaminants in the ground water are affected by variations in river stage. General1y, concentrations increase during periods of low river stage and decrease during periods of high river stage.

Gross beta contamination is also evident in Wells $199-\mathrm{H} 4-11$ and 199-H4-13 and, to a lesser extent, in Wells 199-H4-16 and 199-H4-18. These concentrations do not correlate with the distribution of the other major contaminants attributable to the $183-\mathrm{H}$ Basins (Figures 72 through 74 ) and may be a result of past operational practices at the 107-H Retention Basin (Figure 12). Further studies of gross beta distribution are warranted to discriminate the contaminant contributions of each facility.

Chromium concentrations have generally been found above the MCL in all but four wells in the network. These concentrations do not correlate with the distribution of the other major contaminants attributable to the $183-\mathrm{H}$ Basins (Figures 79 through 82). Four other potential sources of chromium from inactive waste disposal facilities at the $100-\mathrm{H}$ Area have been identified (Figure 12). These facilities, 116- H-1, 116- H-2, 116- H-3, and 116- H-4, 


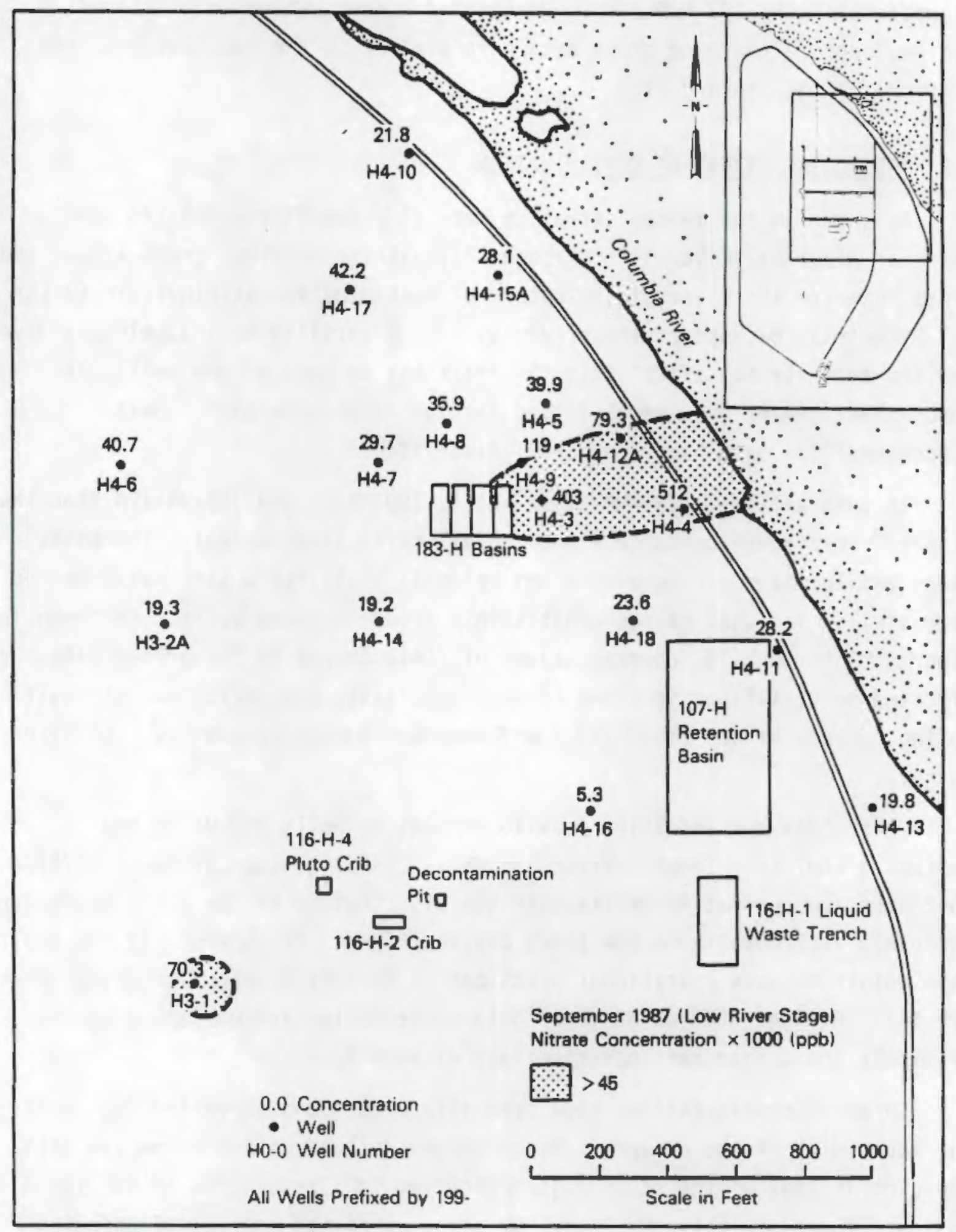

FIGURE 63. Nitrate Concentrations (low river stage), September 1987 


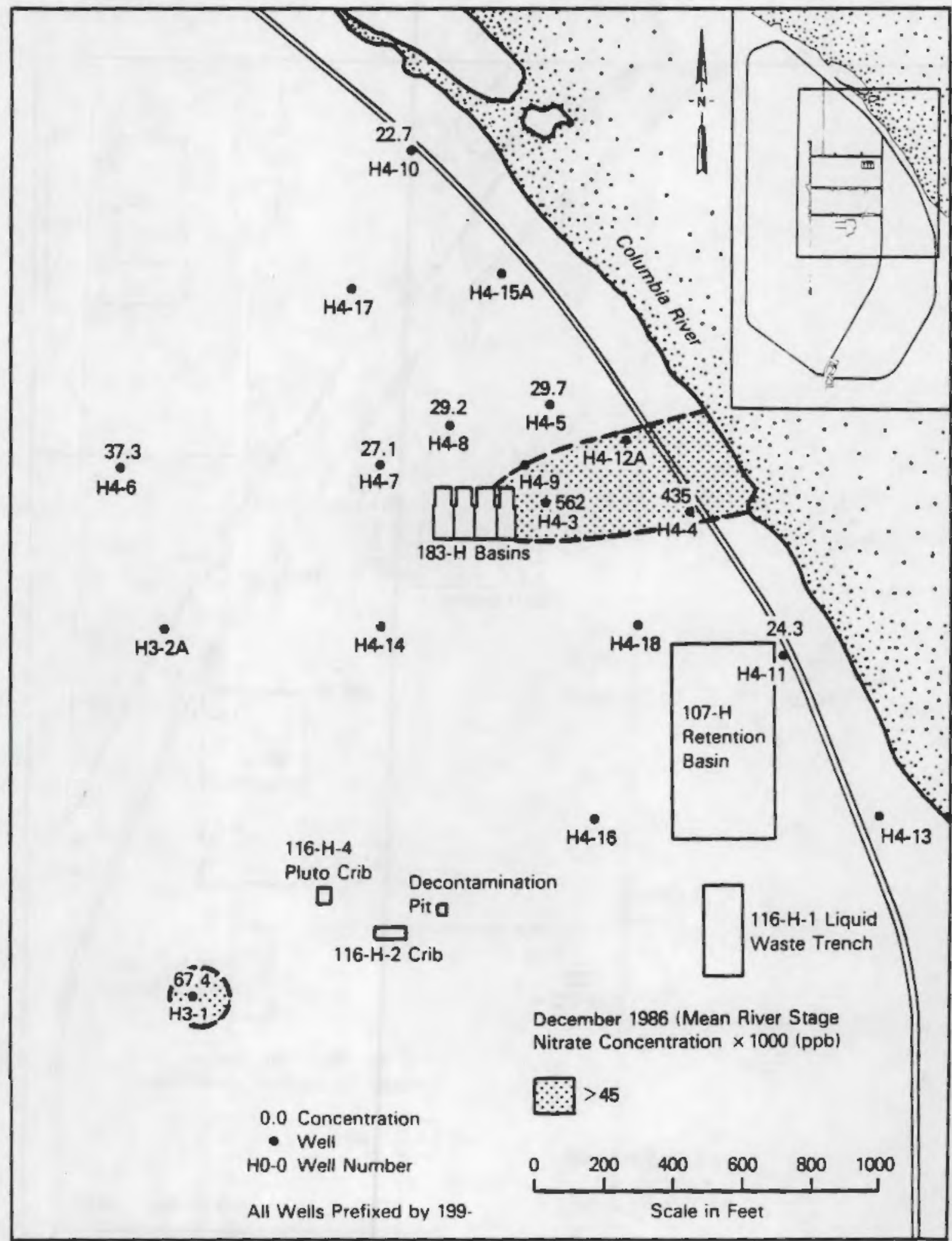

- Concentration data is limited for December because not all of the wells had been completed

FIGURE 64. Nitrate Concentrations (mean river stage), December 1986 


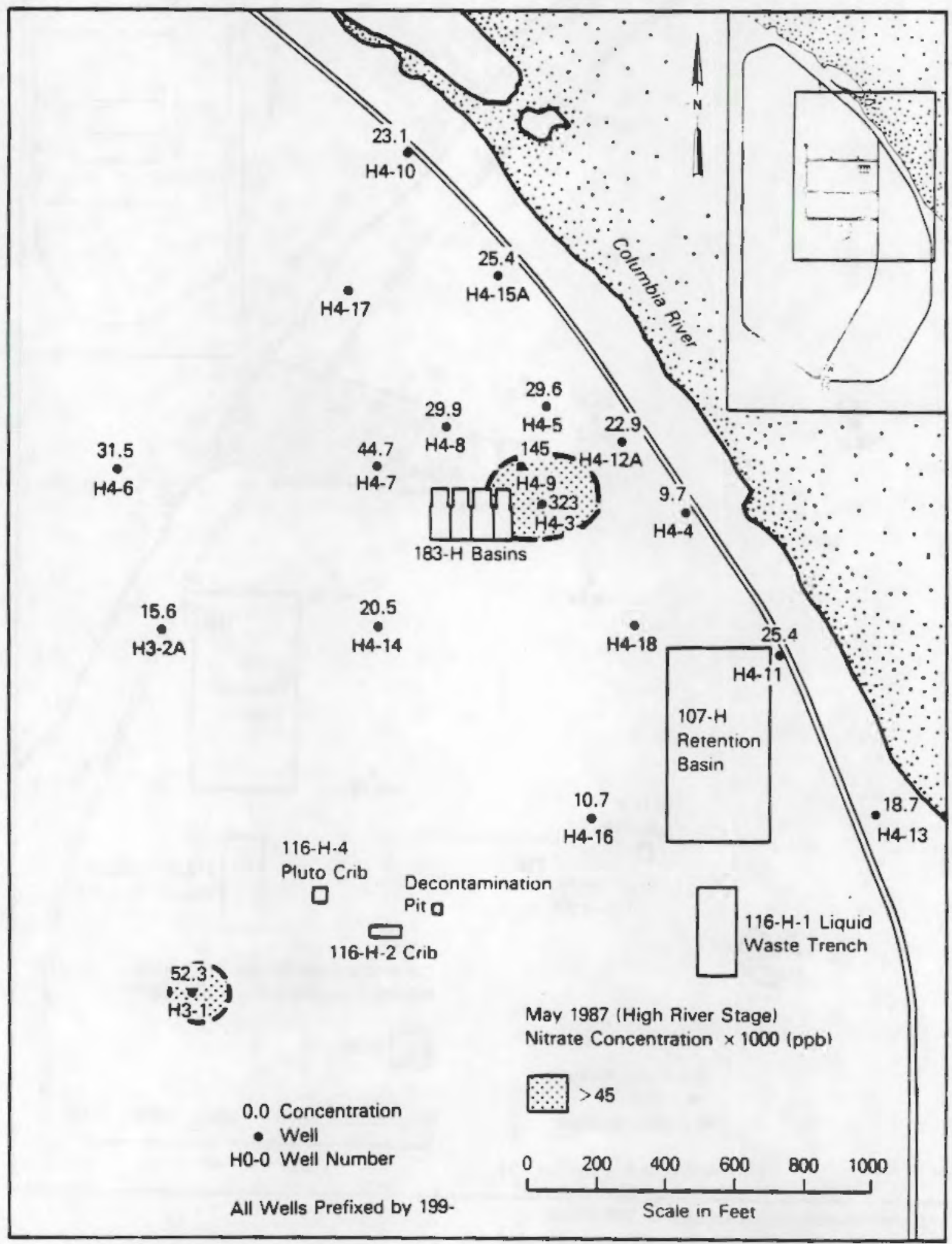

FIGURE 65. Nitrate Concentrations (high river stage), May 1987 


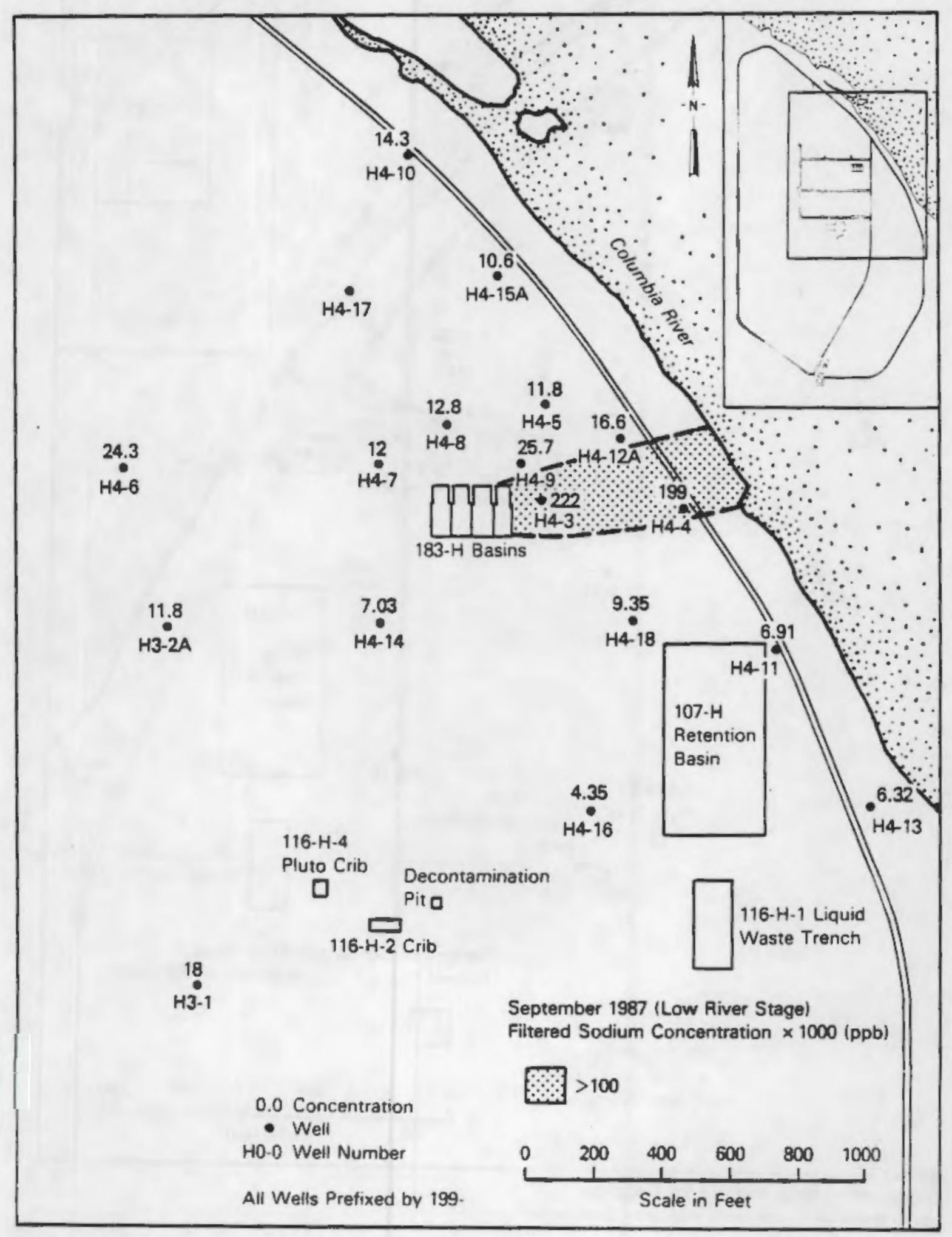

FIGURE 66. Filtered Sodium Concentrations (low river stage), September 1987 


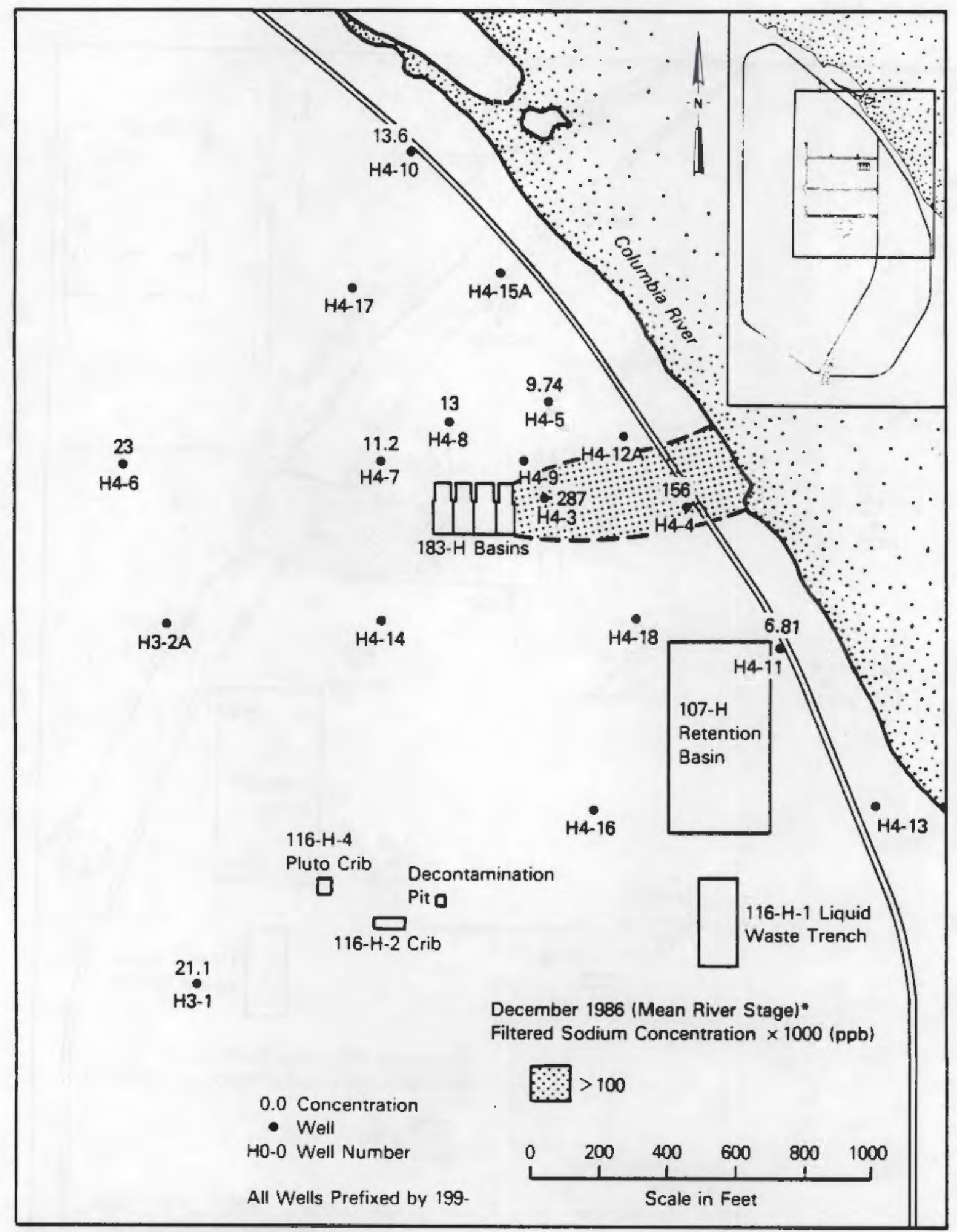

- Concentration data is limited for December because not all of the wells had been completed

FIGURE 67. Filtered Sodium Concentrations (mean river stage), December 1986 


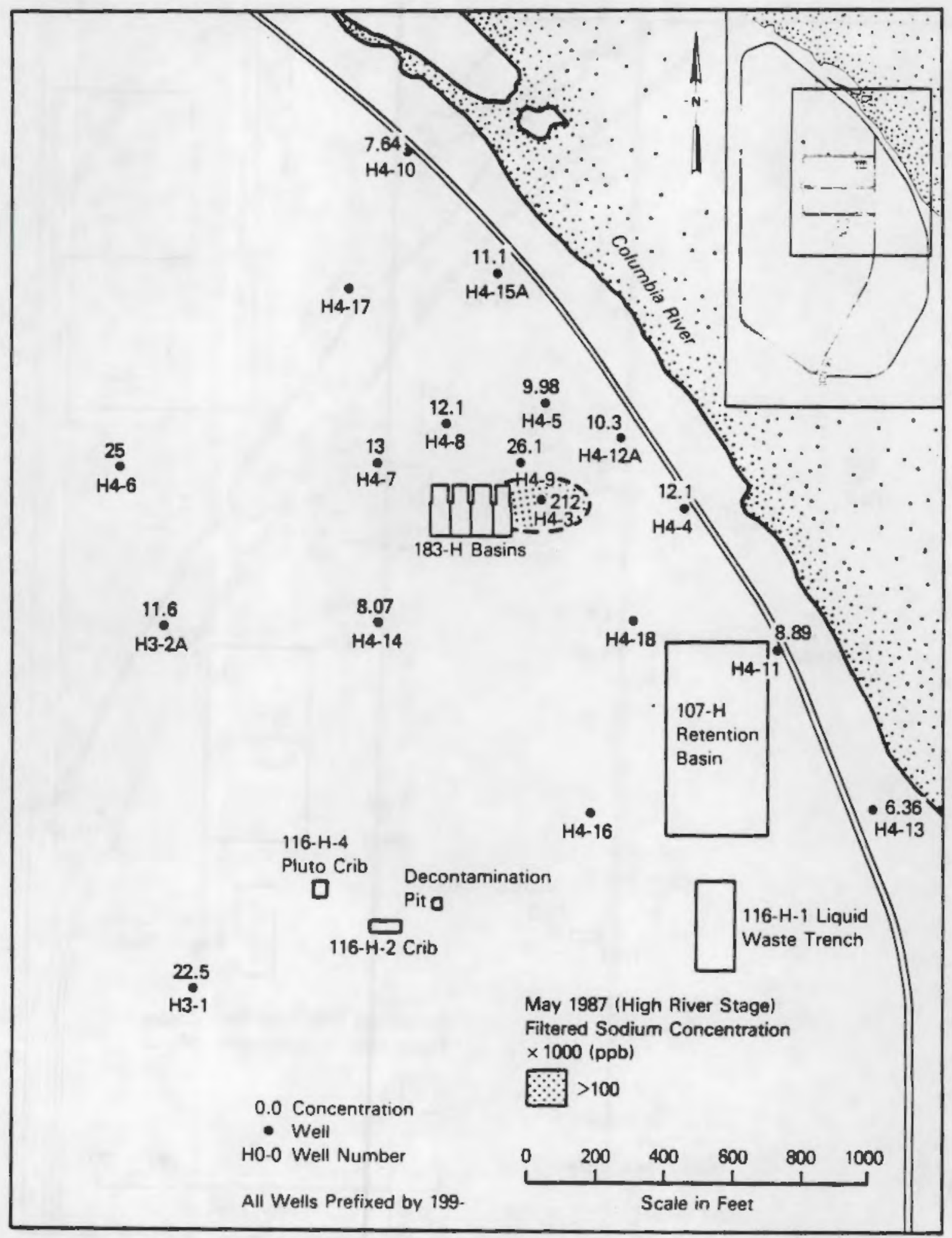

FIGURE 68. Filtered Sodium Concentrations (high river stage), May 1987 


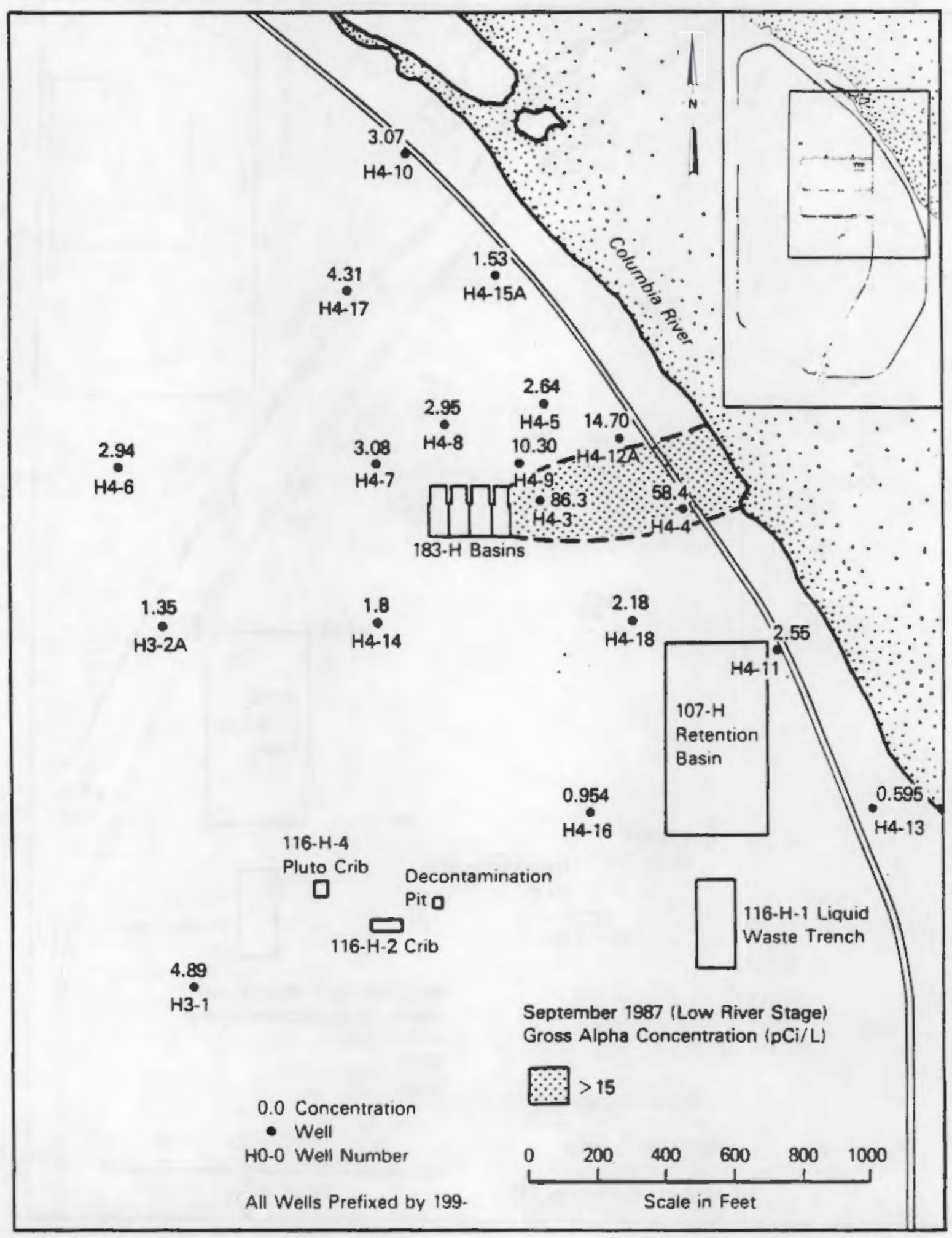

FIGURE 69. Gross ATpha Concentrations (10w river stage), September 1987 


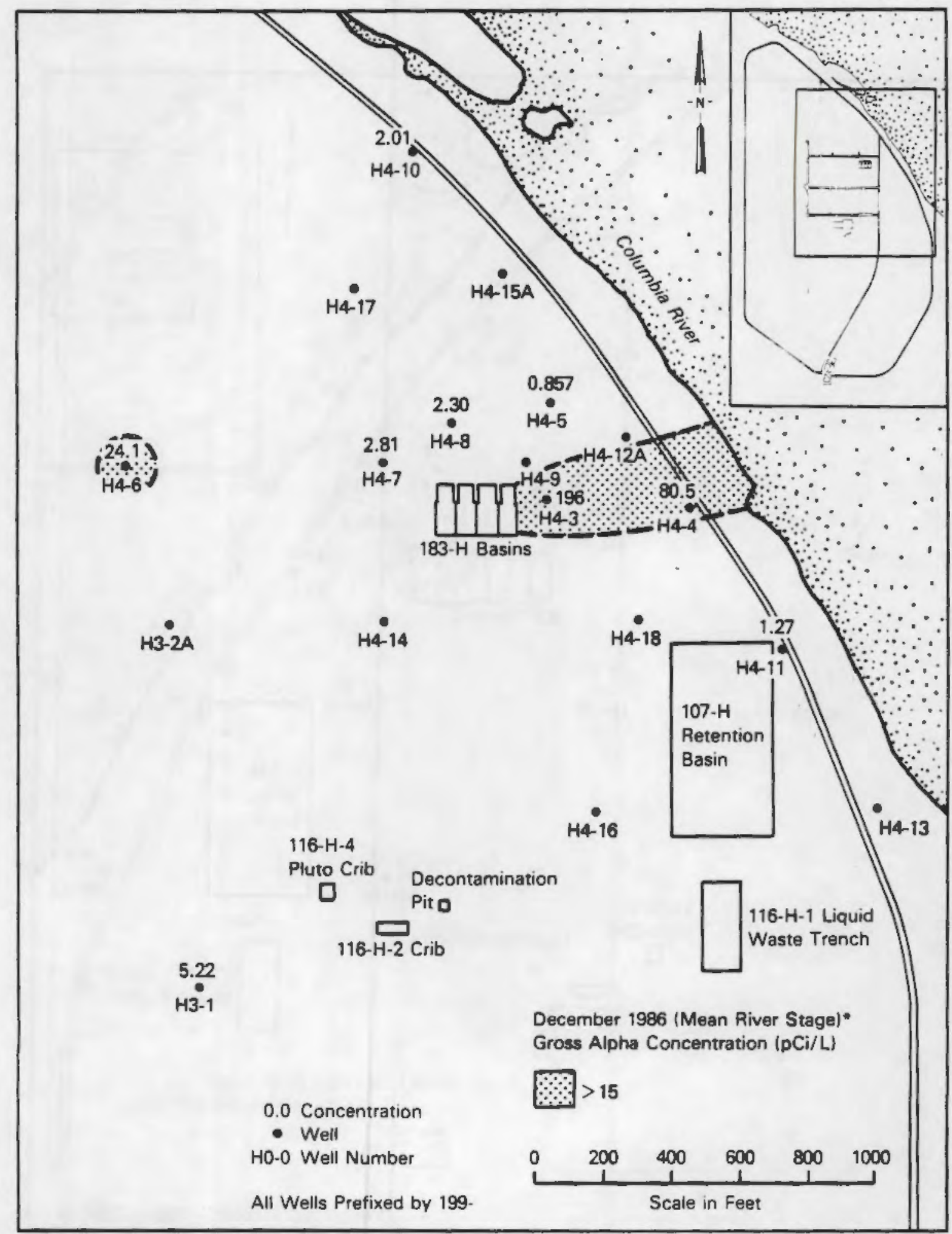

- Concentration data is limited for December because not all of the wells had been completed

FIGURE 70. Gross Alpha Concentrations (mean river stage), December 1986 


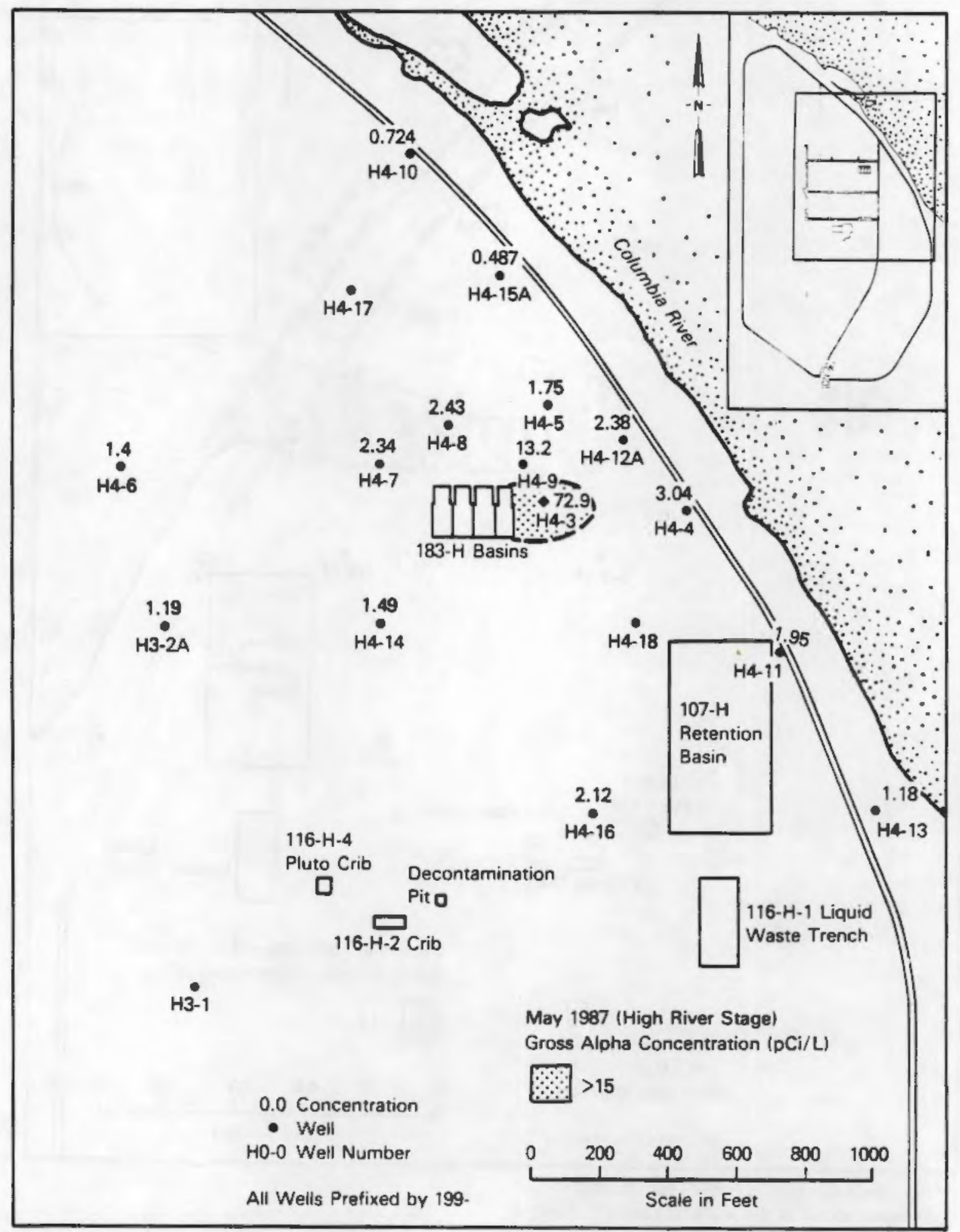

FIGURE 71. Gross Alpha Concentrations (high river stage), May 1987 


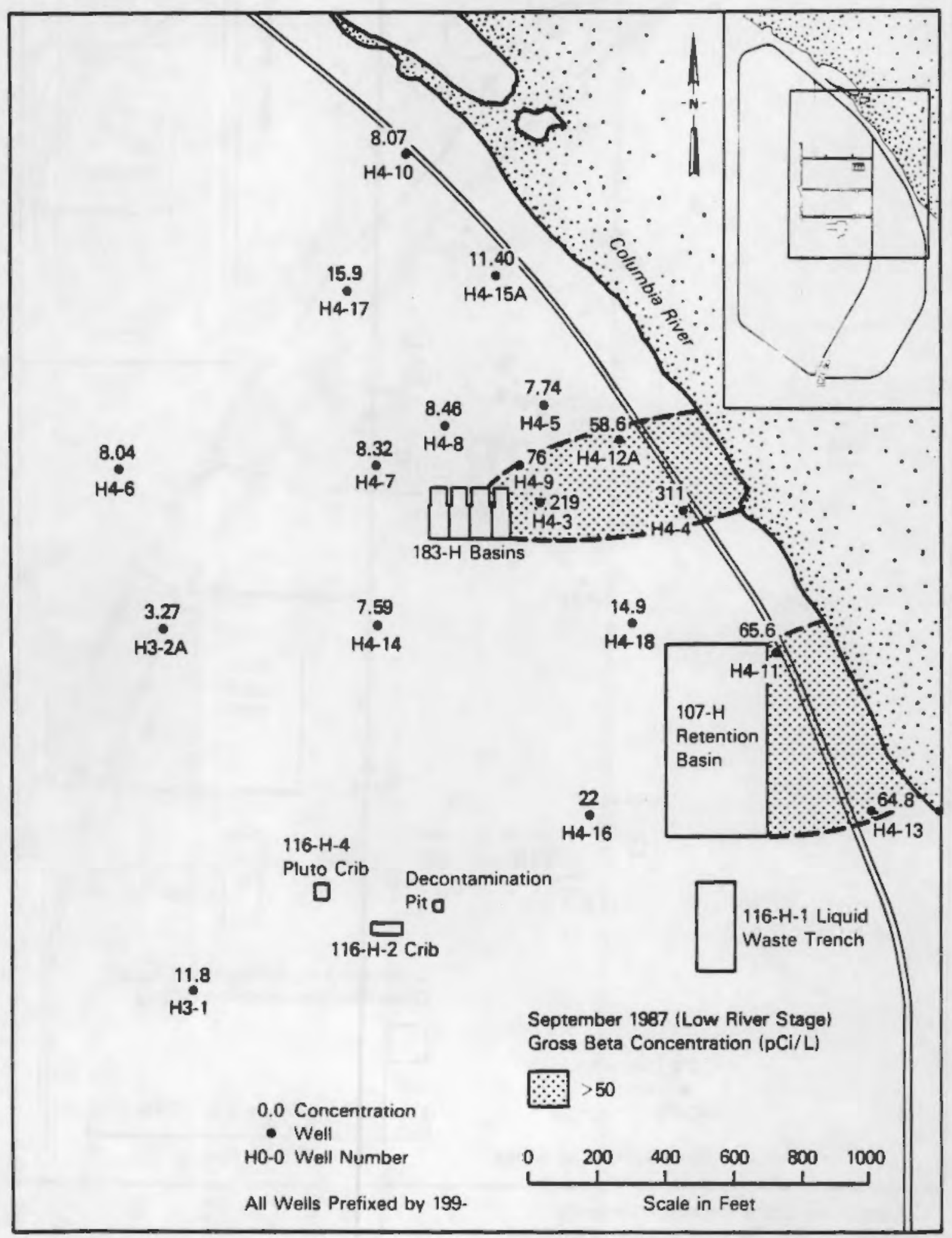

FIGURE 72. Gross Beta Concentrations (10w river stage), September 1987 


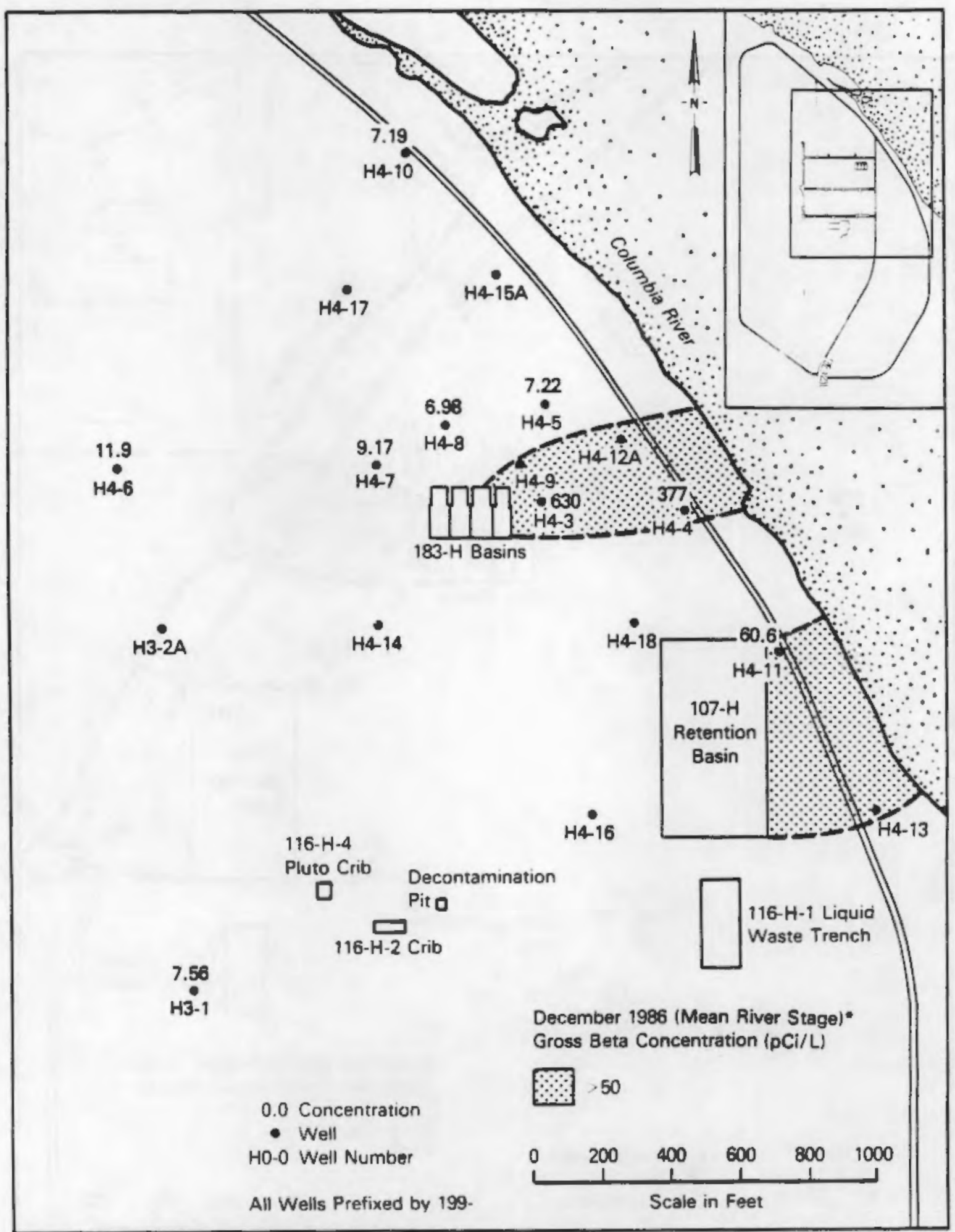

"Concentration data is limited for December because not all of the wells had been completed

FIGURE 73. Gross Beta Concentrations (mean river stage), December 1986 


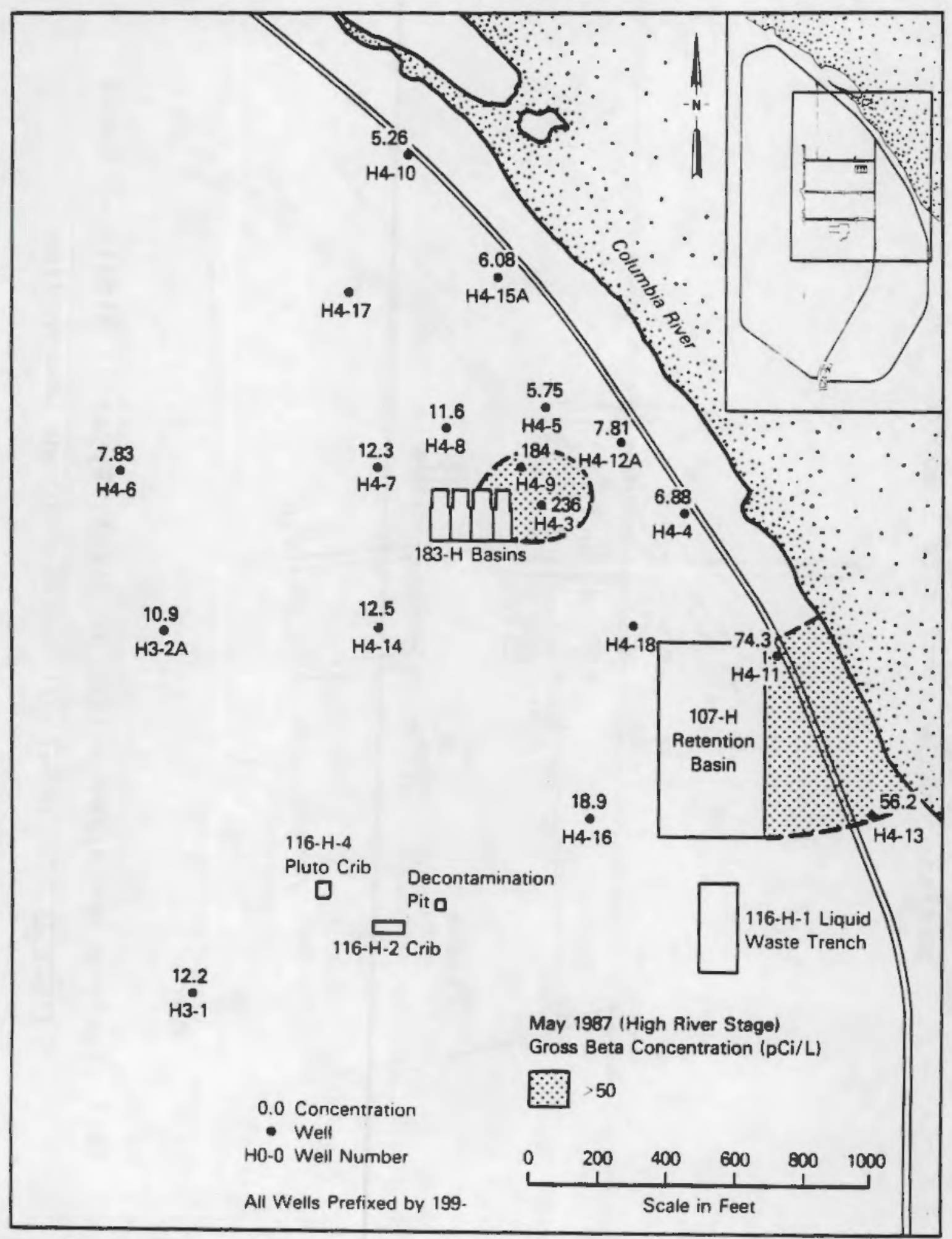

FIGURE 74. Gross Beta Concentrations (high river stage), May 1987 
RCRA Compliance Ground-water Mon1toring Project

183-H Solar Evaporation Basins Assessment Program

Maximum Value Between January and October 1887

Nitrate, maximum value is $1,020,000 \mathrm{ppb}$

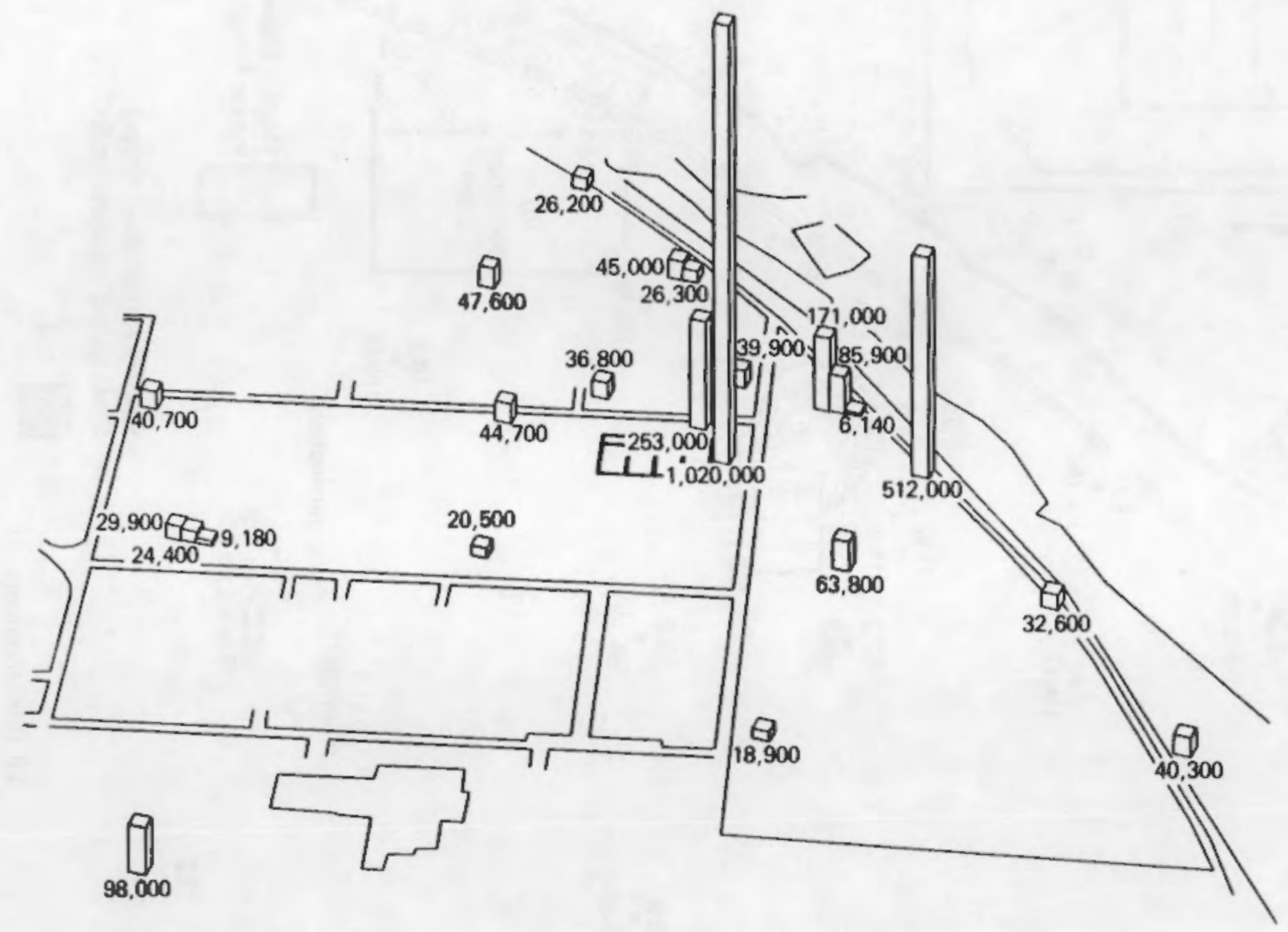

Well clusters are ordered left to right, Upper $\rightarrow$ Hiddle $\rightarrow$ Lower

FIGURE 75. Horizontal Distribution of Nitrate Concentrations 
RCRA Compliance Ground-water Monitoring Project

183-H Solar Evaporation Basins Assessment Program

Maximum Value Between January and October 1987

Sod1um, maximum value is $450,000 \mathrm{ppb}$

岕

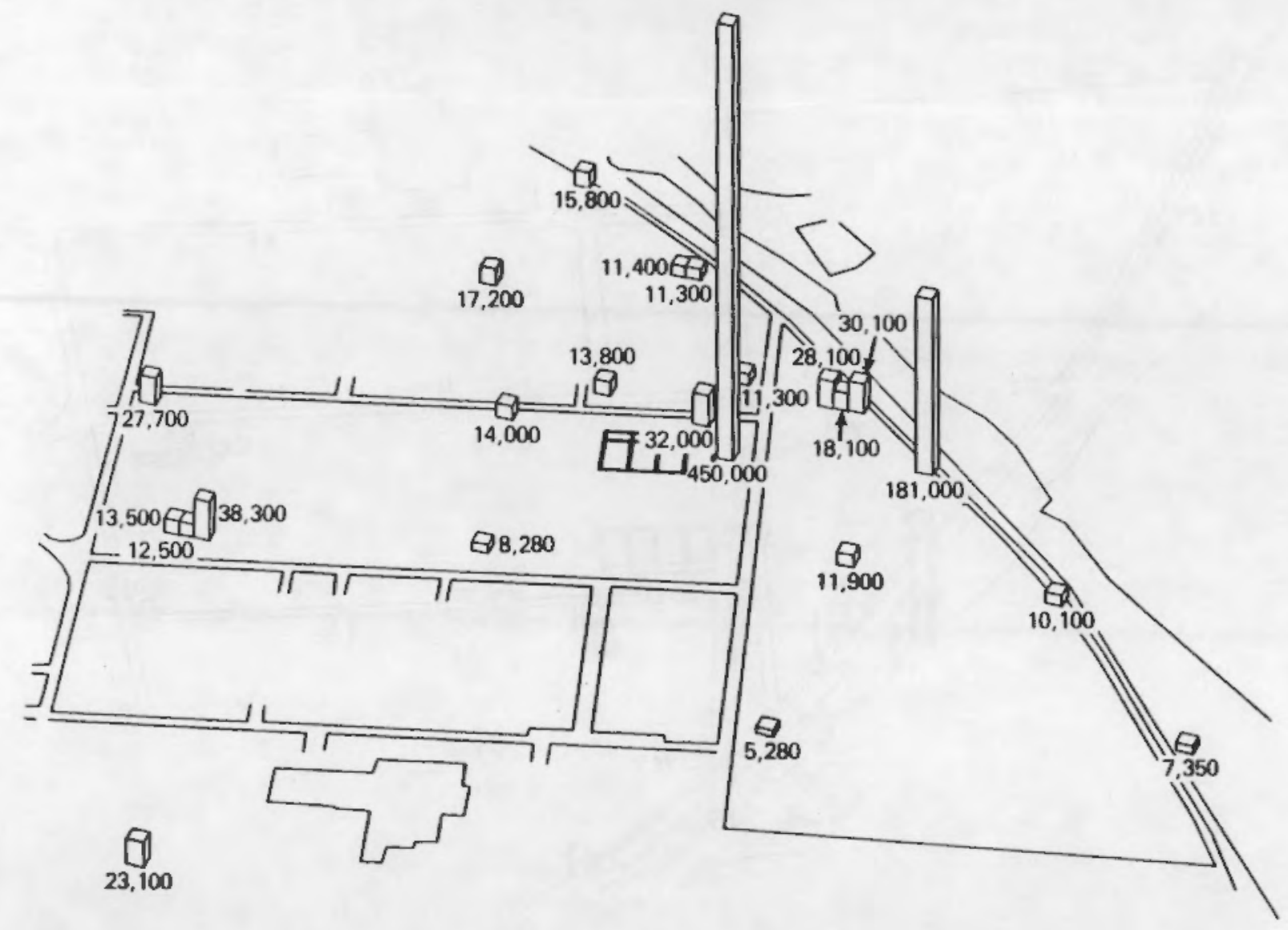

Well clusters are ordered left to right, Upper $\rightarrow$ Middle $\rightarrow$ Lower

FIGURE 76. Horizontal Distribution of Filtered Sodium Concentrations 
RCRA Compl 1 ance Ground-water Monitoring Project

183-H Solar Evaporation Basins Assessment Program

Maximum Value Between January and October 1987

Gross Alpha, maximum value is $269 \mathrm{pC} 1 / \mathrm{L}$

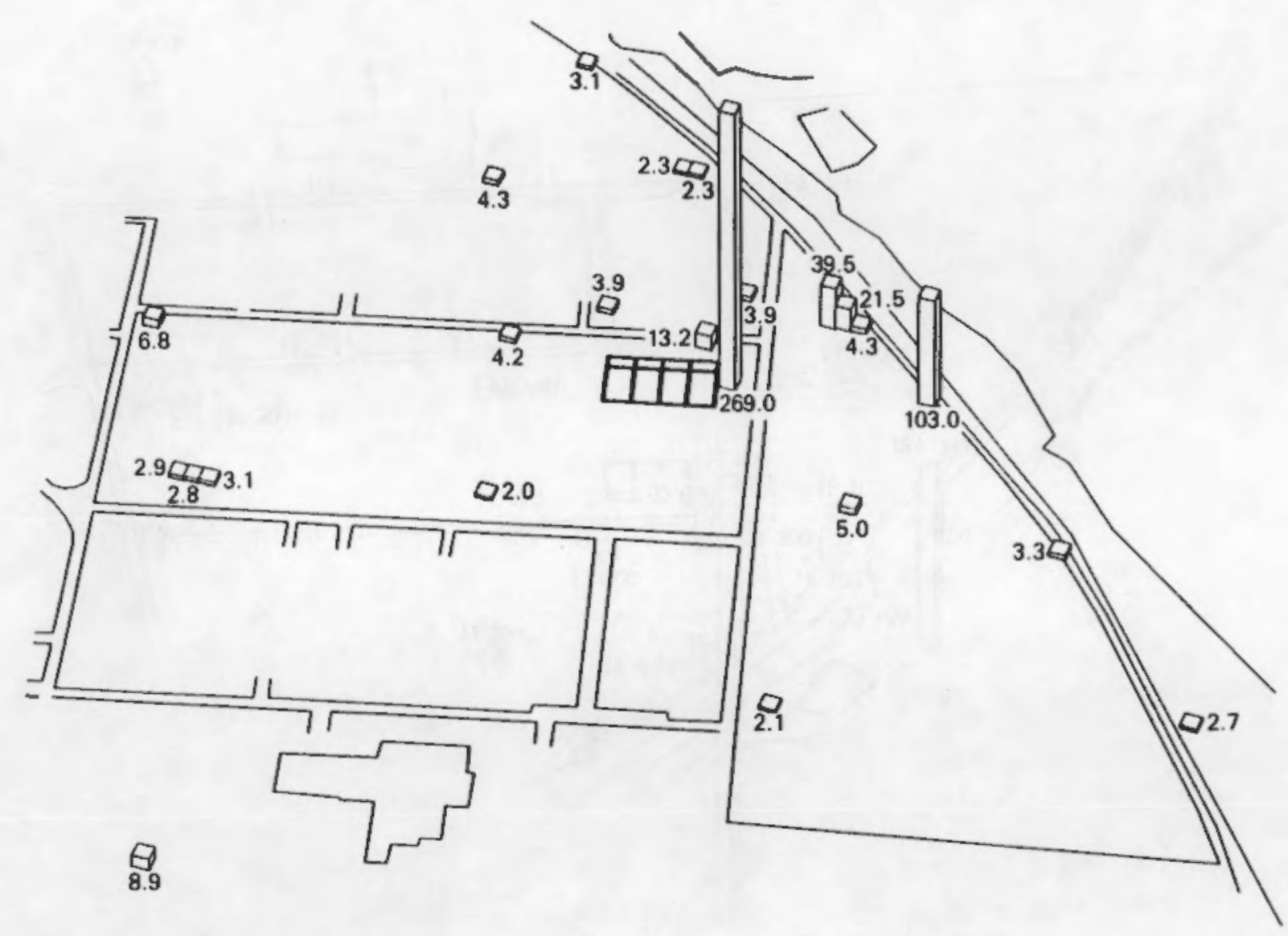

Well clusters are ordered left to right, Upper $\rightarrow$ Middle $\rightarrow$ Lower

FIGURE 77. Horizontal Distribution of Gross Alpha Concentrations 
RCRA Compliance Ground-water Monitoring Project

183-H Solar Evaporation Basins Assessment Program

Maximum Value Between January and October 1987

Grosg Beta, maximum value is $908 \mathrm{pCi} / \mathrm{L}$

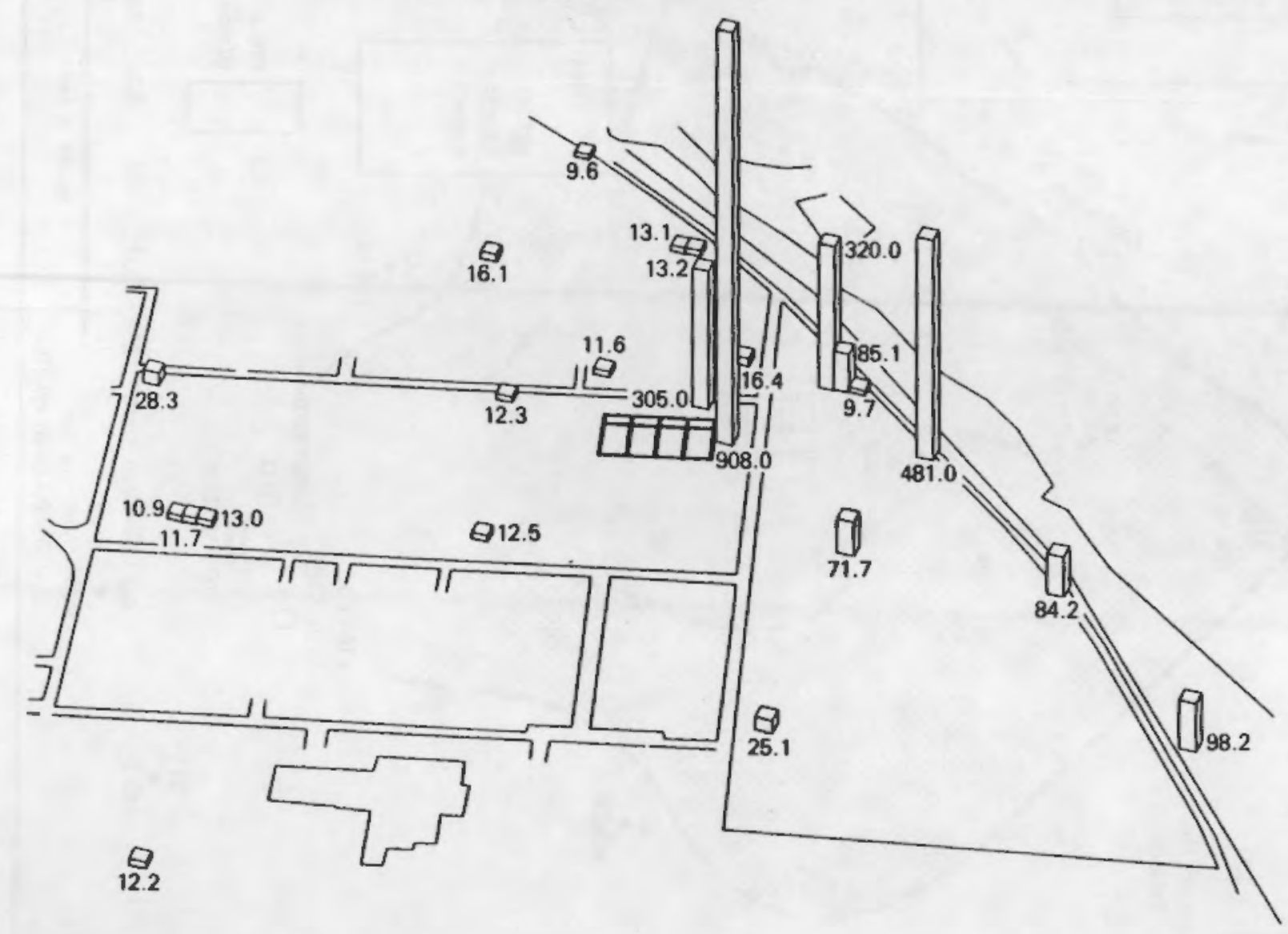

Well clusters are ordered left to right, Upper $\rightarrow$ Middle $\rightarrow$ Lower

FIGURE 78. Horizontal Distribution of Gross Beta Concentrations 


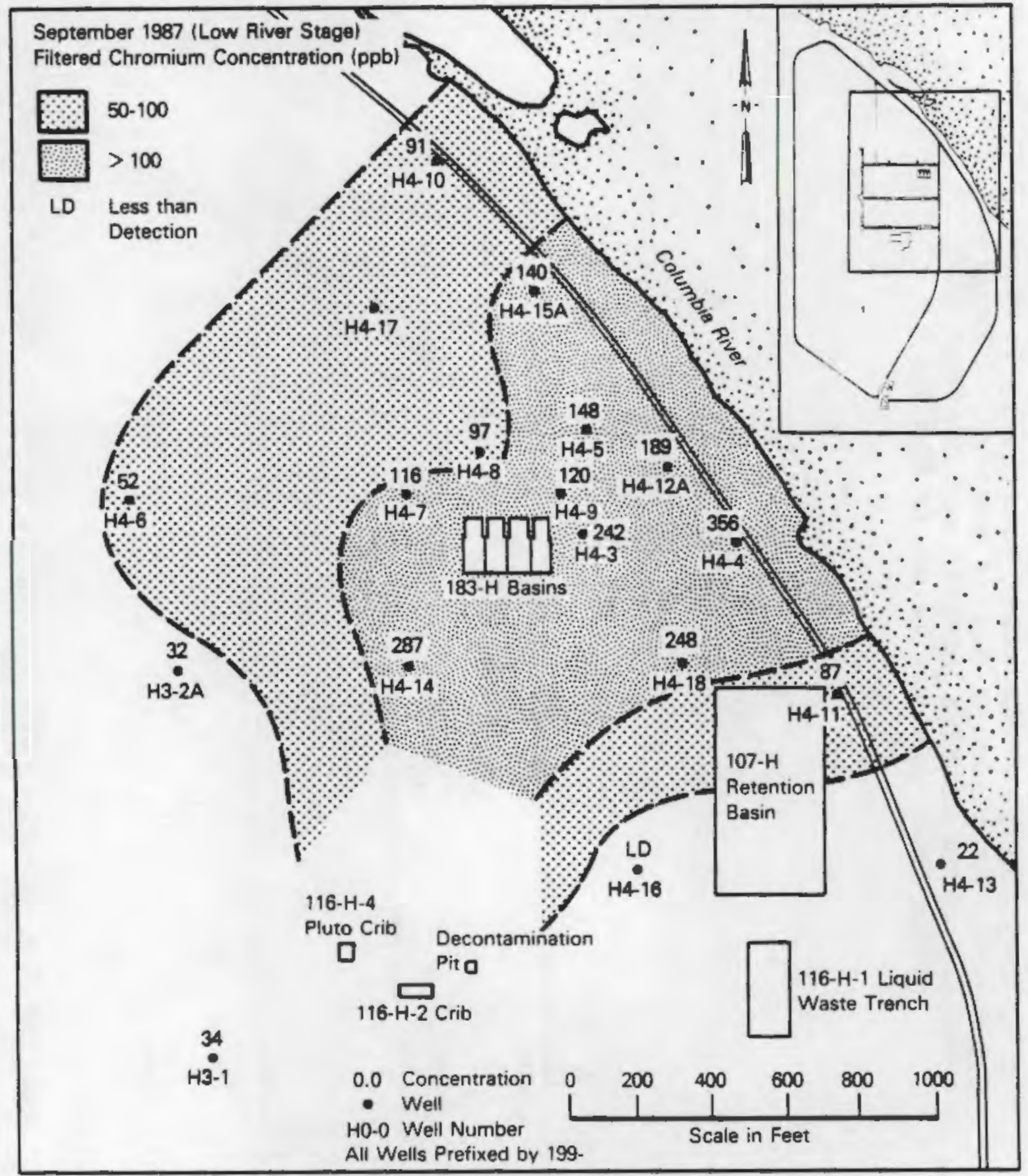

FIGURE 79. Filtered Chromium Concentrations (10w river stage), September 1987 


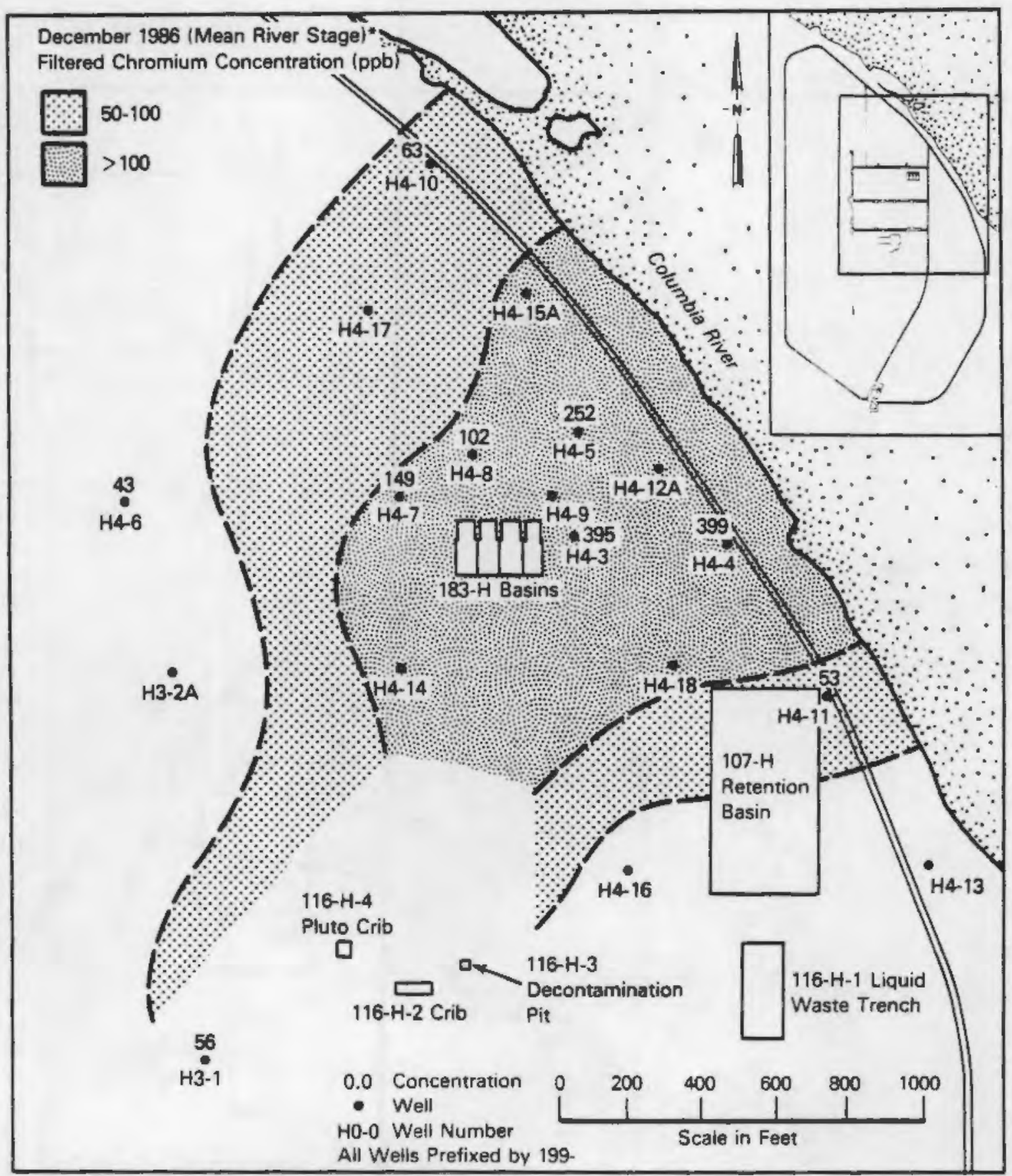

- Concentration data is limited for December because not all of the wells had been completed

\section{FIGURE 80. Filtered Chromium Concentrations (mean river} stage), December 1986 


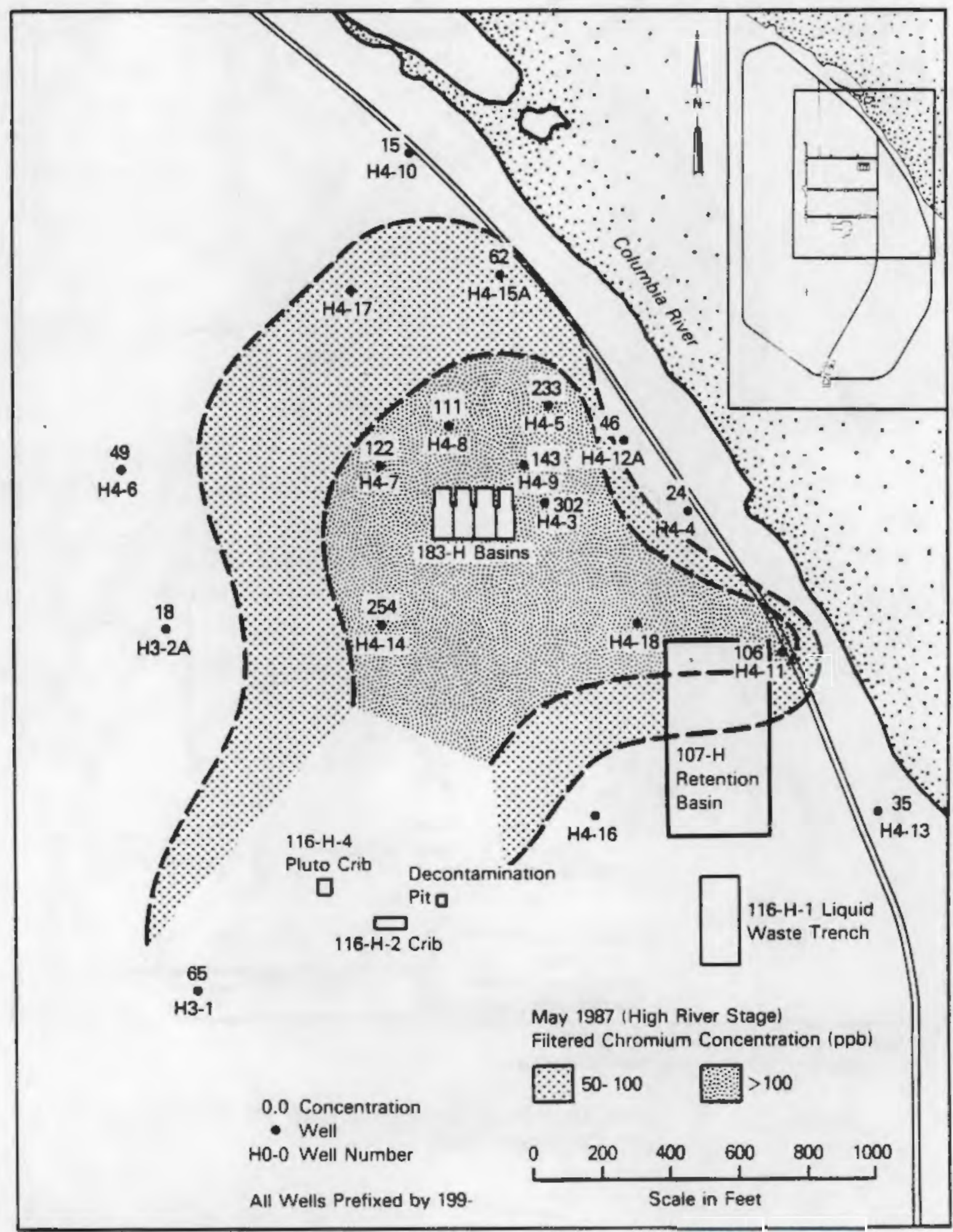

FIGURE 81. Filtered Chromium Concentrations (high river stage), May 1987 
RCRA Compliance Ground-water Monitoring Project 183-H Solar Evaporation Basing Assessment Program Maximum Value Between January and October 1987

Chromium, maximum value is $437 \mathrm{ppb}$

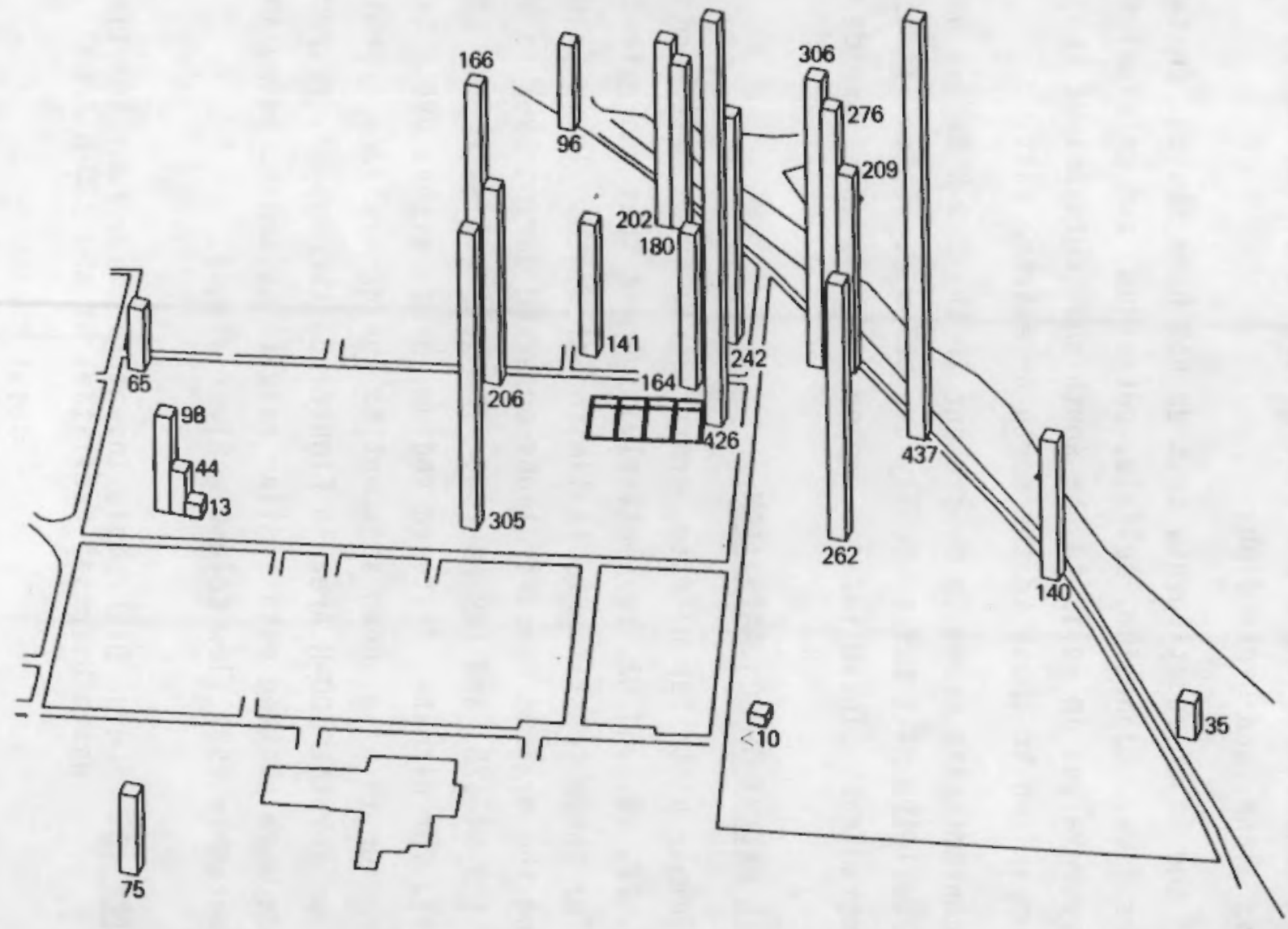

Well clusters are ordered left to right, Upper $\rightarrow$ Middle $\rightarrow$ Lower

FIGURE 82. Horizontal Distribution of Filtered Chromium Concentrations 
received high concentrations of sodium dichromate (Table 18). Further studies of chromium distribution are warranted to discriminate the contaminant contributions of each facility.

Specific conductance shows the same general distribution as nitrate, sodium, gross alpha, and gross alpha.

Most of the major constituents that do not have obvious contamination distributions (i.e., magnesium, sulfate, potassium, and calcium) show generally lower values in wells to the south and southeast of the $183-\mathrm{H}$ Basins in comparison to those to the north or extreme east.

other contaminants known to be present in the 183-H Basins have been detected in Well 199-H4-3 but typically are below detection limits in wells further downgradient. These include copper, nickel, and fluoride.

\subsection{VERTICAL EXTENT OF CONTAMINATION}

The columnar plots for nitrate, gross alpha, gross beta, and chromium (Figures 75, 77, 78, and 82 , respectively) suggest that the extent of contamination for these constituents is limited at depth. These figures were plotted using the maximum concentrations observed during 1987 in Wells 199-H4-12A, 199-H4-12B, and 199-H4-12C. The vertical extent of contamination in these wells for nitrate, filtered sodium, gross alpha, gross beta, and filtered chromium is also shown adjacent to the generalized hydrostratigraphic column for the 100-H Area in Figures 83 through 87 , respectively. These figures were plotted with similar results as above, using analytical data from September 1987 (low Columbia River stage).

TABLE 18. Sodium Dichromate Inventories for Four Inactive Waste Disposal Facilities at the 100-H Area

Facility

116- $\mathrm{H}-1$

$116-\mathrm{H}-2$

$116-\mathrm{H}-3$

$116-\mathrm{H}-4$
Total Sodium

Dichromate (kg)

90.00

600.00

2000.00

1000.00 


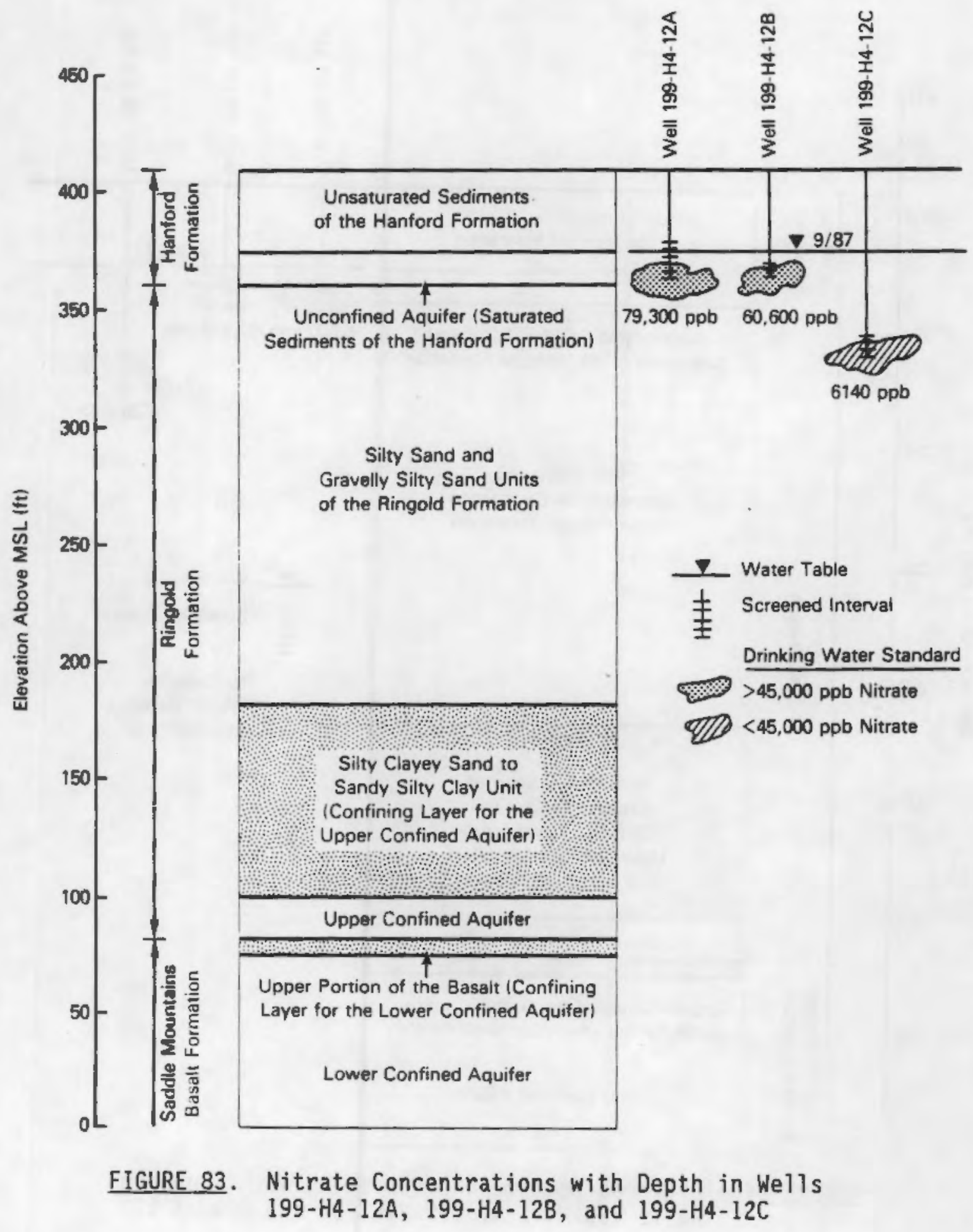




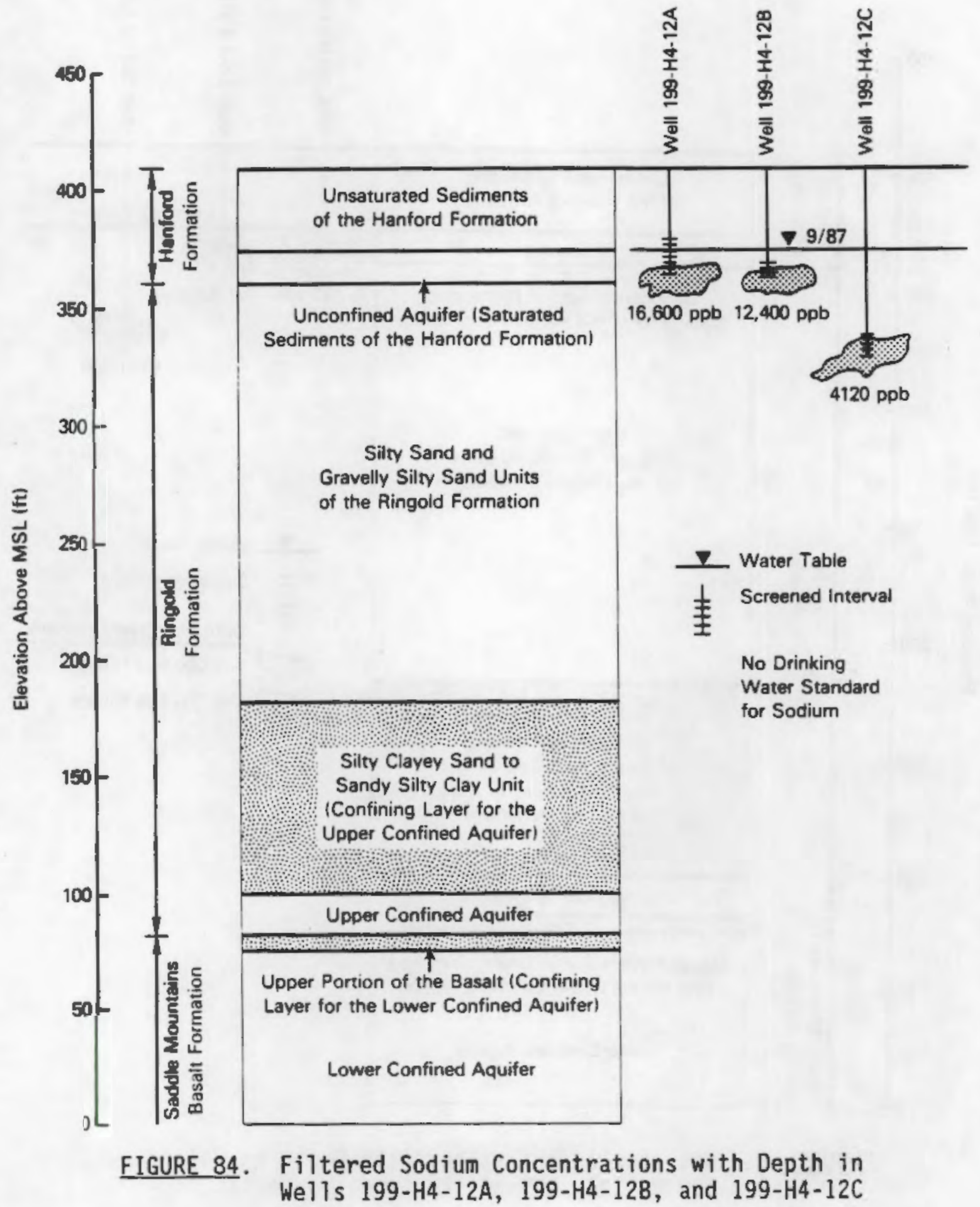




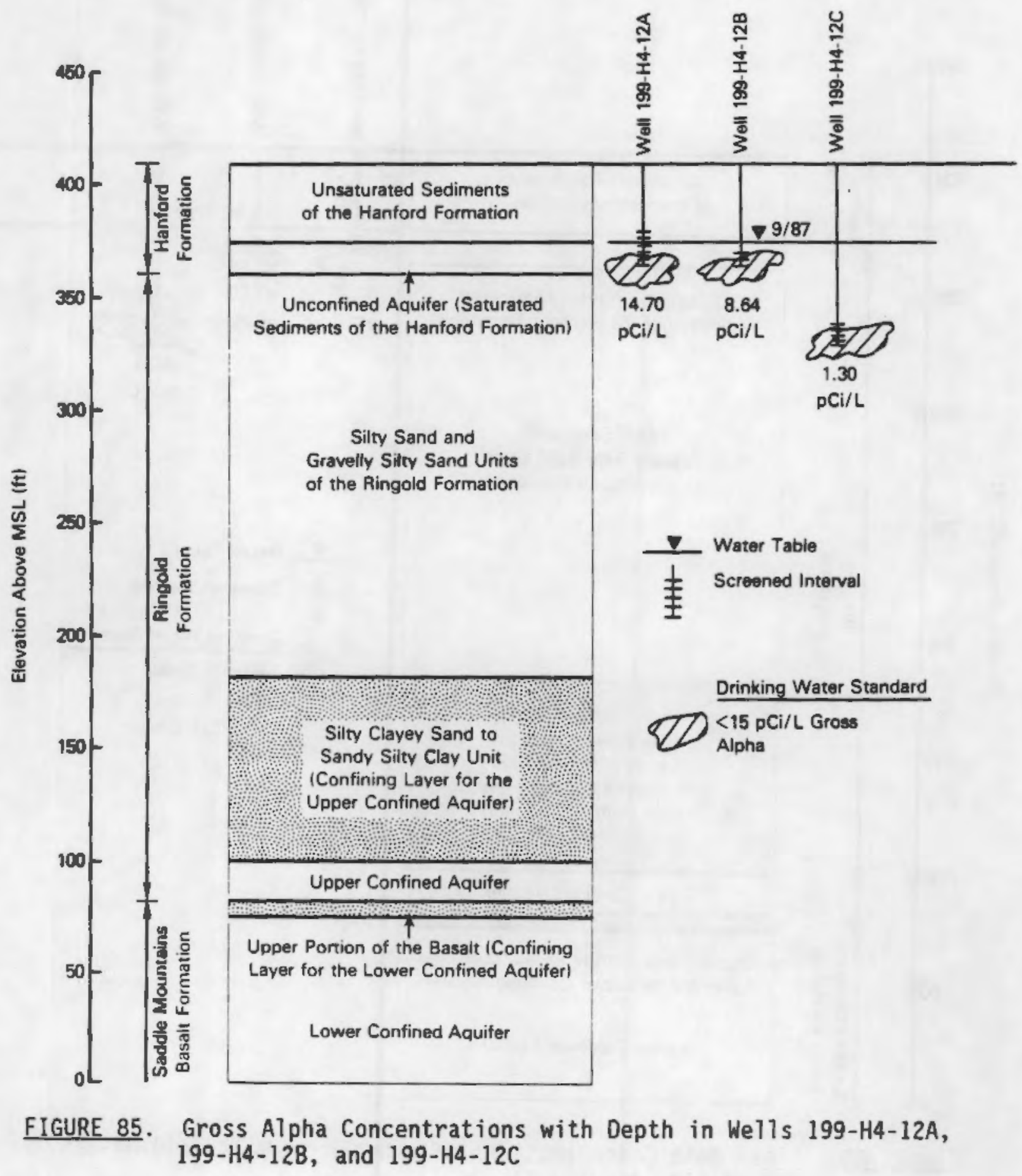




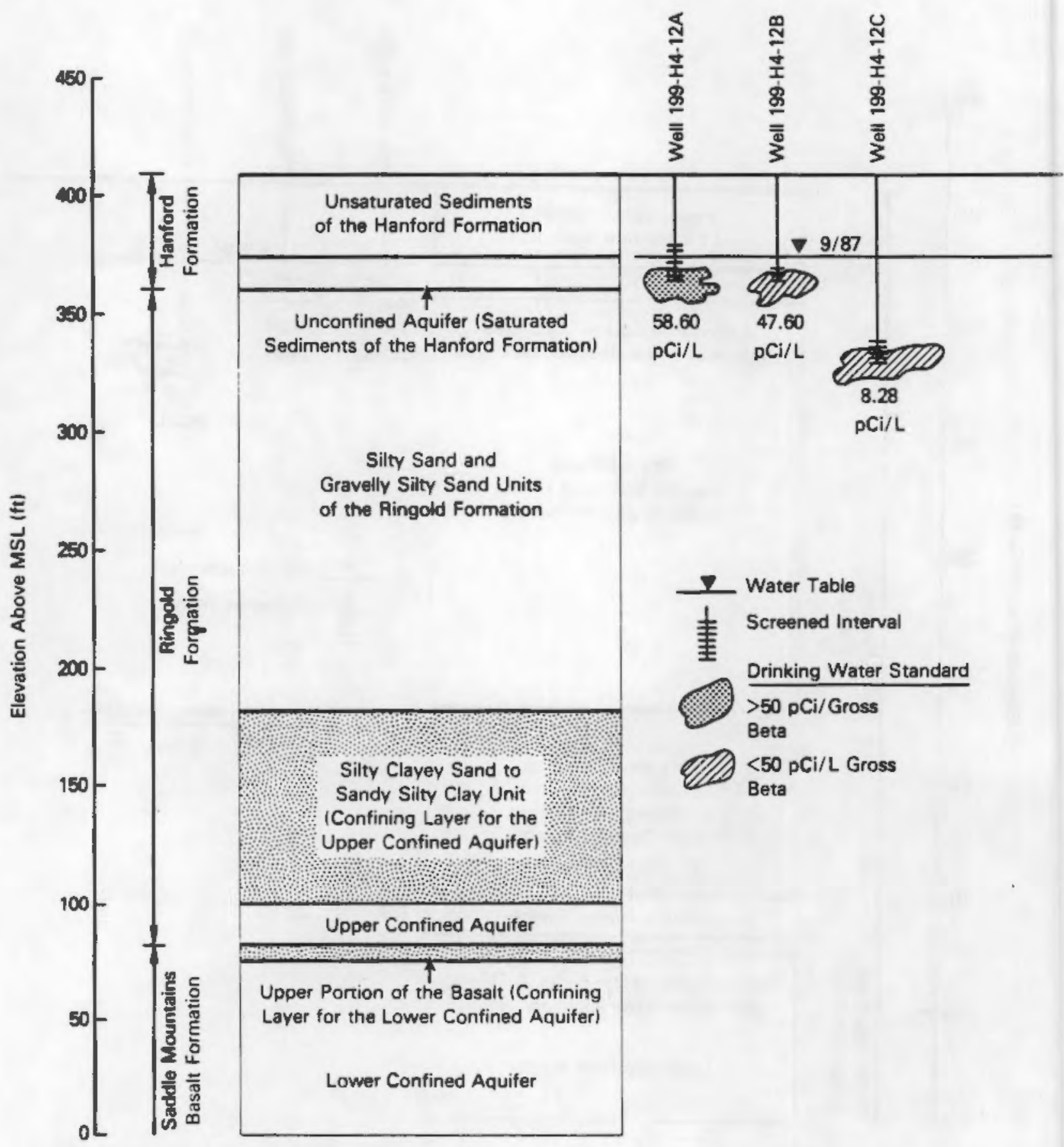

FIGURE 86. Gross Beta Concentrations with Depth in Wells 199-H4-12A, 199-H4-12B, and 199-H4-12C 


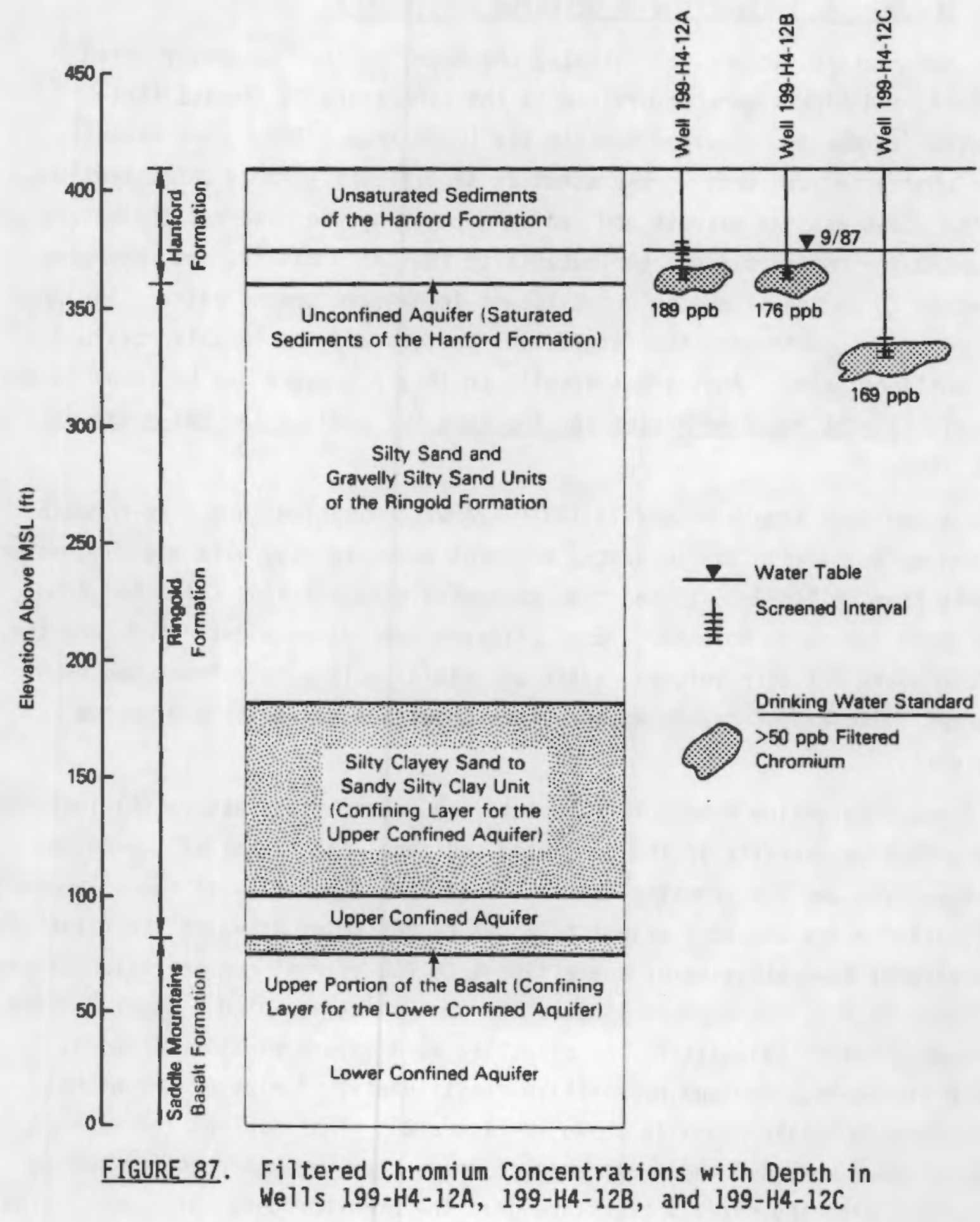




\subsection{GEOCHEMICAL INTERACTION OF SELECTED CONSTITUENTS}

Retardation factors for nitrate, chromium, sodium, copper, fluoride, sulfate, and nickel were determined in the laboratory to predict their behavior in the ground water beneath the $100-\mathrm{H}$ Area. These constituents were chosen because they were present in significantly large concentrations in the 183-H Basins; nitrate and sodium were among the clearest indicators of ground-water contamination attributable to the 183-H Basins; and they were expected to be nonattenuated constituents in Hanford ground water. The procedure used to determine the retardation factors and the results obtained are outlined below. Additional details on this procedure can be found in the Interim Characterization Report for the Area Surrounding the 183-H Basins (PNL 1987).

A sediment sample from Well 199-H3-2A was compacted in a flow-through column permeameter. The compacted sediment was saturated with a ground-water sample from Well 699-\$3-25 and then contacted with solution collected from the 183-H Basins in November 1986. Effluent samples were collected from the column every 0.1 pore volumes, after an initial 0.17 pore volumes had been leached. The effluent samples were then submitted for anion and cation analyses.

The information needed to calculate the retardation factors $(R)$ included the effective porosity of the compacted sediment, the volume of the column permeameter, and the leaching data. The effective porosity of the column was calculated where one pore volume is equal to the point at which the ratio of the element concentration of the effluent to the element concentration of the influent is 0.5 . This ratio is also the same point at which elemental breakthrough occurs. Calculating the effective pore volume by this method is valid for nonretarded and nonreactive constituents. A plot of the nitrate and chromium breakthrough is shown in figure 88 . The $R$ values for nitrate and chromium were 1.0 and 1.04 , respectively. The breakthrough for sodium coincided with the nitrate breakthrough. The breakthroughs for copper, fluoride, sulfate, and nickel coincided with the chromium breakthrough.

The low $R$ values indicate that nitrate, chromium, sodium, copper, fluoride, sulfate, and nickel are essentially nonattenuated when moving through 


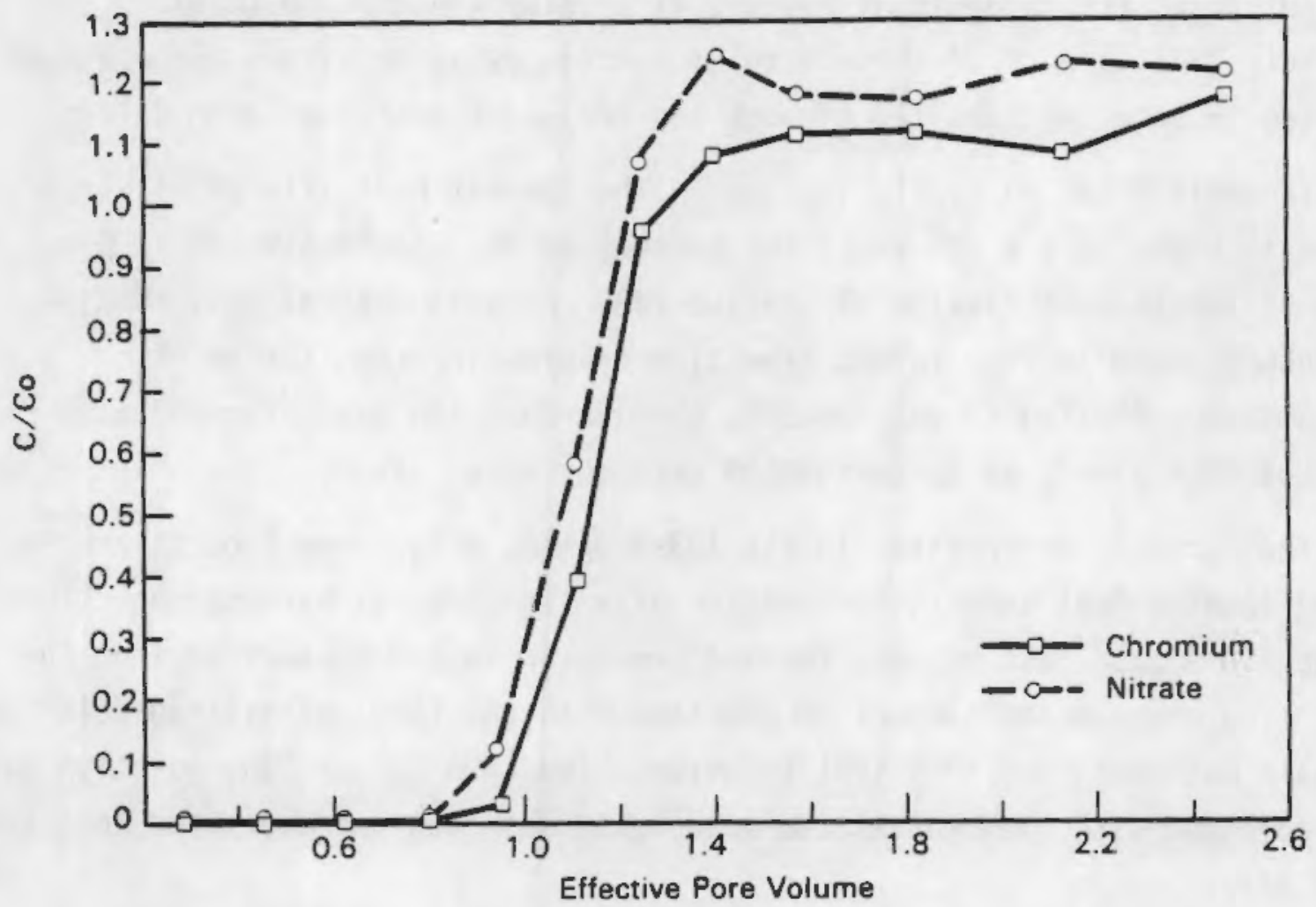

FIGURE 88. Breakthrough Curves for Nitrate and Chromium

the sediment tested. Several of these constituents are in their anionic form and would not be attracted to the typically anionic Hanford soils.

No laboratory studies were conducted to determine retardation factors for uranium or technetium in the sediments near the 183-H Basins. These constituents are thought to be the primary contributors to the gross alpha and gross beta concentrations, respectively. However, a significant amount of information exists where the behavior of uranium and technetium in the ground water can be predicted.

Uranium concentrations in the liquid phase of the waste material from basin \#1 averaged $645,000 \mathrm{ppb}$. The expected uranium species present in the solution phase of basin \#1 and \#2 at a pH range of 9.32 to 10.5 would be $\mathrm{UO}_{2}\left(\mathrm{CO}_{3}\right)_{3}{ }^{4-}$ (Langmuir 1978). As the basin solution percolates through the carbonate-rich Hanford soils, the pH would be expected to decrease and approach a range of 7 to 8 , which is normal for Hanford ground water. At 
this $\mathrm{pH}$ range, the predominant species of uranium would be $\mathrm{UO}_{2}\left(\mathrm{CO}_{3}\right)_{2}{ }^{2-}$ (Langmuir 1978). Both of these uranium species exist as anions and would be expected to move unattenuated through the sediments near the 183-H Basins.

Technetium has no stable isotopes. The longest half-life of all technetium isotopes is $2 \times 10^{6}$ years for technetium-97. Technetium-99 is produced by spontaneous fission of uranium-238. A small natural contribution of technetium-99 is also formed from slow neutron-induced fission of uranium-235. Fission of uranium-233, thorium-232, and plutonium-239 also produces high yields of technetium-99 (Kotegov et a1. 1968).

The technetium deposited in the 183-H Basins originated from the reprocessed uranium fuel used in conjunction with the chemical milling operations in the 300 Area. This process removed some uranium and technetium from the fuel. The uranium and technetium remained with the chemical milling solution and were not reclaimed from that solution. The chemical milling solution was then combined with the neutralized acid waste solution and deposited into the 183-H Basins.

The average concentration of technetium in basin \#1 was $7.5 \times 10^{5} \mathrm{pCi} / \mathrm{L}$. Because of the highly oxidative chemicals used during the fuels fabrication process, the technetium was oxidized to pertechnetate $\left(\mathrm{TcO}_{4}{ }^{-}\right)$, a highly water-soluble anion. The technetium would be expected to remain as pertechnetate after neutralization. The pertechnetate ion has a tendency to migrate with ground water, unattentuated by Hanford soil (Brown 1967). The mobility of pertechnetate in the ground water would be similar to that of tritium and nitrate.

\subsection{PATHLINE ANALYSIS}

A pathline analysis was performed to estimate the flow paths and travel times of nonattenuated contaminants in the ground water beneath the $183-\mathrm{H}$ Basins. These pathlines were estimated with a ground-water flow model of the area near the 183-H Basins. The analysis considered simulated ground-water flow in the unconfined aquifer under the effects of transient Columbia River stage. 
The modeling, which provided the basis for the pathline analysis, was completed using the Coupled Fluid, Energy, and Solute Transport (CFEST) computer code (Gupta 1982). The model of the unconfined aquifer underlying the 100-H Area consisted of a two-dimensional area with varying thickness. The finite-element grid used for the simulations is shown in figure 89 . The bottom of the aquifer was assumed to be the top of the Ringold Formation and was defined by interpolating the elevations obtained from drilling logs. The thickness of the aquifer was defined as the vertical distance from the bottom of the aquifer to the water table.

The northern and southern boundaries for the model were assumed to be no-flow boundaries because they are parallel to streamlines defined by the direction of regional ground-water flow. The western boundary was outside the region estimated to be influenced by the river level fluctuations and was implemented as a fixed head boundary. The eastern boundary was the columbia River and was implemented as a time-varying prescribed head boundary. This boundary was changed each time step to simulate the fluctuations in river stage. No areal recharge was assumed to enter the model; therefore, the water table fluctuations resulted entirely from changes in river level. Initial conditions assumed a steady-state water table surface, as calculated by CFEST, using the river level from the first week of September 1986 .

A total of eight pathlines were simulated (Figure 90) starting at locations in the unconfined aquifer directly beneath the 183-H Basins. The pathlines were continued until they reached the Columbia River. The maximum travel time, based on previous modeling results reported in the Interim Characterization Report for the Area Surrounding the 183-H Basins (PNL 1987) was estimated to be approximately 5 years. Therefore, a transient simulation of ground-water flow spanning 6 years was used to allow all the pathlines to reach the river. A 6-year digitized record of Columbia River stages was not available for the 183-H Area; therefore, because of the time frame involved for the pathlines, ground-water flow was modeled using a yearly cycle of river level fluctuations. The river level data from September 1986 to September 1987 were assumed to represent a yearly cycle in river stage. These data were repeated to simulate a 6 -year cycle. 


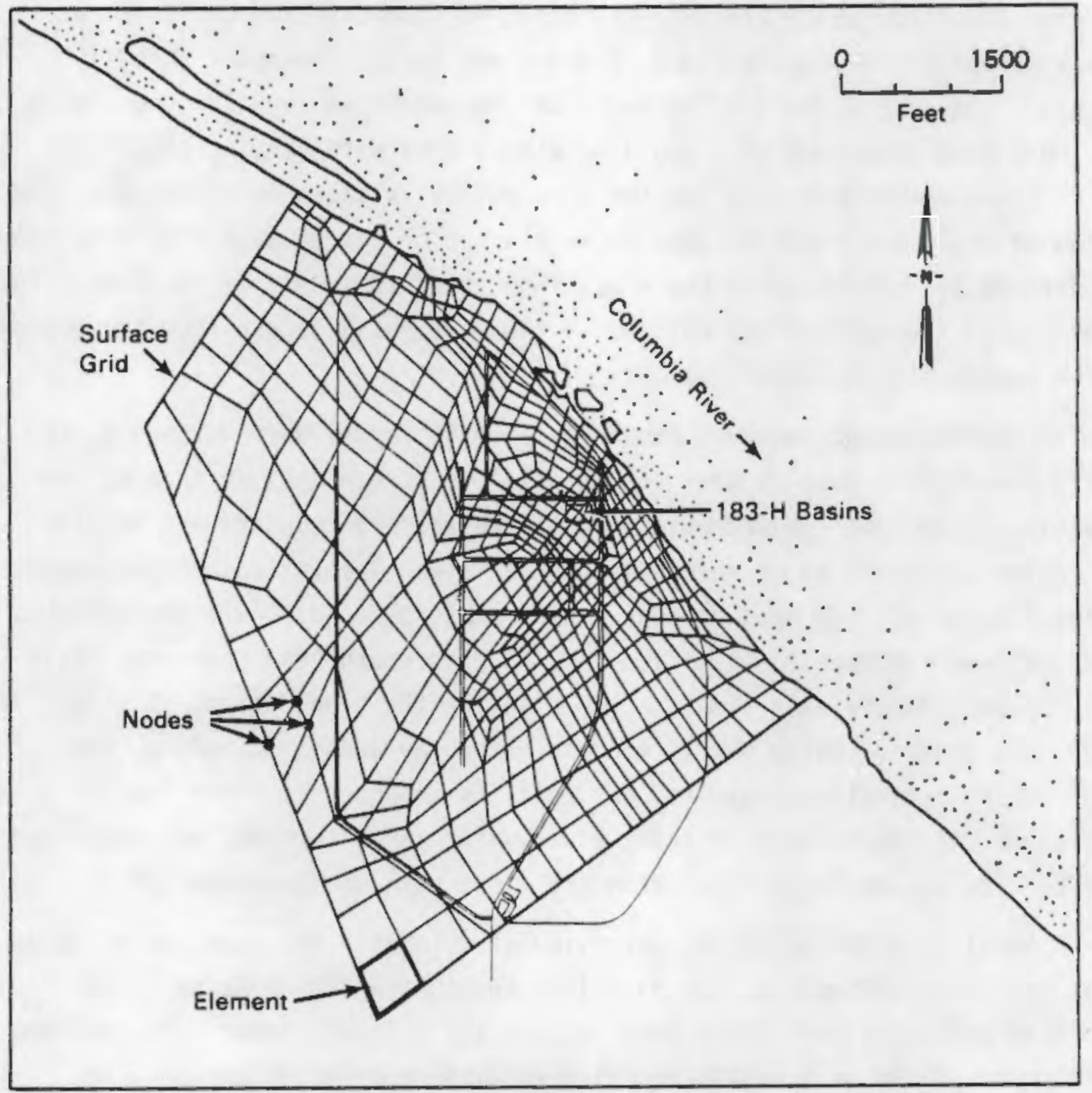

FIGURE 89. Finite-Element Grid Used for Simulations

The travel times and distances traveled by these simulated pathlines are shown in Table 19.

The travel times range from 1.2 to 4.1 years, while the distances traveled range from 607 to $1357 \mathrm{ft}$. The spread in times and distances traveled reflect the variable flow paths resuiting from changes in the water table that, in turn, are caused by the fluctuating river stage. A spread of $173 \mathrm{ft}$ was observed for the locations where the flow paths entered the river, and it 


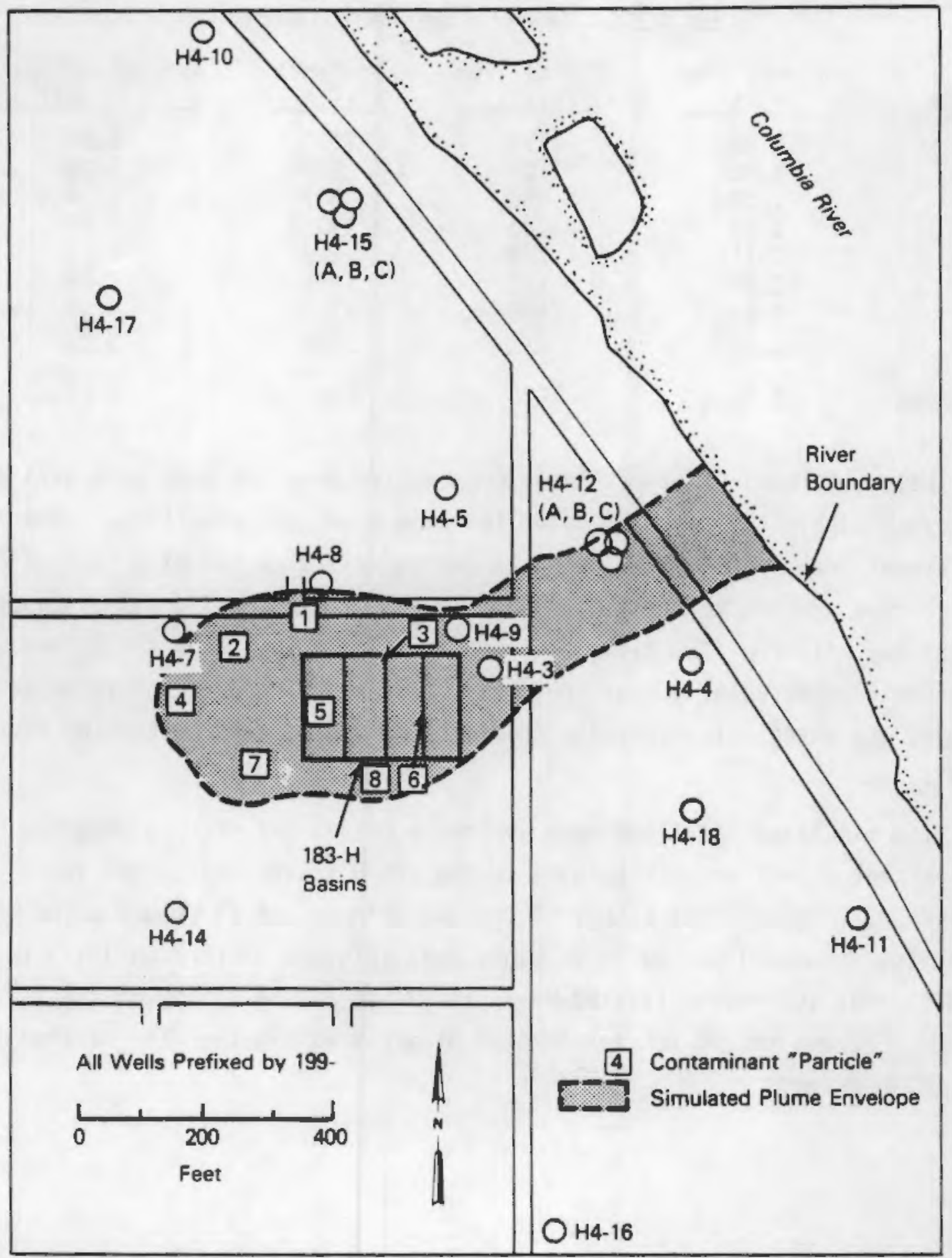

FIGURE 90. Simulated Contaminant Plume. Computer-derived flow paths for eight contaminant "particles" in the ground water near the 183-H Solar Evaporation Basins converge to form a plume that migrates toward the Columbia River and is contained within the shaded area. 
TABLE 19. Travel Time and Distances

\begin{tabular}{|c|c|c|c|c|}
\hline Path & $\begin{array}{c}\begin{array}{c}\text { Travel Time } \\
\text { (yr) }\end{array} \\
\end{array}$ & $\begin{array}{l}\text { Trave1 Time } \\
\text { (days) }\end{array}$ & $\begin{array}{l}\text { Distance } \\
\text { (ft) }\end{array}$ & $\begin{array}{l}\text { Average Velocity } \\
\text { (ft/day) }\end{array}$ \\
\hline $\begin{array}{l}1 \\
2 \\
3 \\
4 \\
5 \\
6 \\
7 \\
8\end{array}$ & $\begin{array}{l}4.09 \\
3.02 \\
1.24 \\
3.53 \\
2.11 \\
2.06 \\
4.01 \\
\underline{2.40} \\
\end{array}$ & $\begin{array}{r}1494 \\
1105 \\
452 \\
1289 \\
772 \\
752 \\
1465 \\
877 \\
\end{array}$ & $\begin{array}{r}1291 \\
974 \\
607 \\
1133 \\
827 \\
996 \\
1357 \\
842 \\
\end{array}$ & $\begin{array}{l}0.86 \\
0.88 \\
1.34 \\
0.88 \\
1.07 \\
1.33 \\
0.93 \\
\underline{0.96} \\
\end{array}$ \\
\hline Averages & 2.81 & 1026 & 1003 & 1.03 \\
\hline
\end{tabular}

is likely that most other pathlines originating from the same area will reach the river within this spread, under the same transient conditions. The average travel time is 2.8 years, and the average distance traveled is $1003 \mathrm{ft}$. The average seepage velocity based on the travel times and total distances associated with the flow paths is $1 \mathrm{ft} / \mathrm{day}$. The actual flow velocities vary considerably, especially near the river, because of changes in hydraulic properties and changes in hydraulic gradients caused by the fluctuating river level.

The simulated pathlines were generally consistent with 1) observed contaminant migration attributable to the 183-H Basins (discussed in Section 9.2, "Horizontal Extent of Contamination") and 2) ground-water flow direction indicated on the water table maps (Figures 39 through 41 ). The results indicate that Wells 199-H4-3, 199-H4-4, 199-H4-9, 199-H4-12A, 199-H4-12B, and 199-H4-12C are located directly within the flow related to the 183-H Basins. 
point-of-compliance we11, 199-H4-3, between April and August 1986 . Concentrations of this magnitude have not been repeated since that tine.

- Nitrate, sodium, gross aipha, and gross beta were identified as the clearest indicators of ground-water contamination attributable to the 183-H Basins.

- In genera 1 , We17s 199-H4-3, 199-H4-4, 199-H4-9, and 199-H4-12A show the highest constituent concentrations. These concentrations are affected by variations in Columbia River stage, increasing during periods of low river stage and decreasing during periods of high river stage.

- Gross beta concentrations near the 107-H Retention Basin do not correlate with the distribution of the other major contaminants attributable to the $183-\mathrm{H}$ Basins, and may be a result of past operational practices at this facility.

- Chromium concentrations do not correlate with the distribution of the other major contaminants attributable to the 183-H Basins. Four other potential sources of chromium from inactive waste disposal facilities at the 100-H Area have been identified.

- Concentrations of nitrate, gross alpha, gross beta, and chromium in We17s 199-H4-12A, 199-H4-12B, and 199-H4-12C suggest that the extent of contamination for these constituents is limited at depth.

- Standard deviations and coefficients of variation are relatively large for a number of constituents and wells. Concentrations of several of these constituents are changing significantly with time and water table elevation.

\section{Ground-Hater Modeling}

- Pathline analysis results estinated a range of travel times fron 1.2 to 4.1 years and an average distance of $1003 \mathrm{ft}$ from the $183-\mathrm{H}$ Basins to the Columbia River. The average seepage velocity based on the travel times and total distances associated with the flow paths was $1 \mathrm{ft} / \mathrm{day}$. 
- The simulated pathlines were generally consistent with observed contaminant migration attributable to the $183-\mathrm{H}$ Basins and groundwater flow direction. 


\subsection{RECOMMENDATIONS}

The geohydrologic investigation of the area surrounding the $183-\mathrm{H}$ Basins has resulted in the following recominendations:

- Soil samples within the unsaturated sediments of the Hanford formation should be collected adjacent to and directly beneath the 183-H Basins. These samples should be chemically analyzed to deternine the types and extent of contamination present on the soil column.

- In addition to wells 199-H4-4 and 199-H4-5, continuous head data should be collected using data loggers and transducers in the selected wells proposed for continued sampling $(199-\mathrm{H} 3-2 \mathrm{~A}$, 199-H4-3, 199-H4-6, 199-H4-9, 199-H4-12A, and 199-H4-18). These data will be correlated with 1) continuous Columbia River level data and 2) contaminant data collected from the wells to further define their relationships.

- Geochemical modeling should be conducted to assess the geochemical processes affacting transport of the waste constituents in the ground water.

- Beginning in Fy 1989, ground-water sampling should be conducted on a quarterly basis until closure activities commence and during the post-closure period for Wells 199-H3-2A, 199-H4-3, 199-H4-4, 199-H4-5, 199-H4-6, 199-H4-9, 199-H4-12A, 199-H4-12B, 199-H4-12C, and 199-14-18. Sampling of these wells should increase to a monthly frequency during closure activities. Sampling of the remaining 13 wells should be conducted on an annual basis.

- Sample analyses to be conducted on the 100-H Area ground-water samples for the perfod beyond $F Y 1988$ should include nitrate, sodium, chromium, gross alpha, gross beta, uranium, technetium, Tox, alkalinity, and $p H$. In addition, analysis for those constituents 1isted in the WAC 173-303-9905 should be analyzed on an annual basis in the point-of-compliance we11, 199-H4-3. 
- \$ampling of the Columbia River should be conducted at points upstream, adjacent to, and downstrean of the $100-\mathrm{H}$ Area to determine the impact of ground-water contamination on the river.

- Sampling of ground-water springs at the 100-H Area should be conducted to help determine the extent of contamination at the surface-water/ground-water interface.

- Additional studies are needed to discriminate the gross beta and chromium contributions from other potential sources within the 100-H Area. 


\section{REFERENCES}

APHA. 1985. Standards Methods for the Examination of Water and Wastewater. 16 th ed, American Public Health Association, Washington, D.C,

Brown, D. J, 1967. "Migration Characteristics of Radionuclides Throughout Sediments Underlying the Hanford Reservation," In Disposal of Radioactive Wastes into the Ground: A Svmposium. ISO-SA-32, CONF-670512-2, U.S. Atomic Energy Commission, Washington, D.C.

CFR (Code of Federal Regulations). 1987. "Title 40, Protection of Environment, "Current Version. U.S. Government Printing Office, Washington, D.C.

DoE (U.S. Department of Energy). 1984. Draft Environmental Assessment: Reference Repository Location, Hanford Site, Washington. D0E-RW-0017, U.S. Department of Energy, Washington, D.C.

DOE. 1986. Ground-Water Monitoring Comoliance Projects for Hanford Site Facilities: Progress Report for the Period May 1 to September 30, 1986. PNL-6466, Pacific Northwest Laboratory and Rockwe11 Hanford Operations for the U.S. Department of Energy, Richland, Washington.

DoE. 1987a. Ground-Water Monitoring Compliance Projects for Hanford Site Facilities: Progress Report for the Period october 1 to Decenber 31, 1986, Vo1. 1. PNL-6465, Pacific Northwest Laboratory and Rockwe11 Hanford Operations for the U.S. Department of Energy, Richland, Washington.

DOE. 1987b. Ground-Water Monitoring Compliance Projects for Hanford Site Facilities: Progress Reports for the Period January 1 to March $31,1987$. PNL-6467, Pacific Northwest Laboratory and Rockwell Hanford Operations for the U.S. Department of the Energy, Richiand, Washington.

DOE. 1987c. Ground-Water Monitoring Compliance Projects for Hanford Site Facilities: Progress Report for the Period April I to June 30, 1987. PNL -6468 , Pacific Northwest Laboratory and Rockwe11 Hanford Operations for the U.S. Department of Energy, Richland, Washington.

DOE. 1987d. Ground-Water Monitoring Compliance Projects for Hanford Site Facilities: Progress Report for the Period July 1 to September 30. 1987. PNL-6469, Pacific Northwest Laboratory and Rockwe1] Hanford Operations for the U.S. Department of Energy, Richland, Washington.

DOE. 1988. Ground-Water Monitoring Compliance Projects for Hanford Site Facilities: Progress Report for the Period October 1 to December $31,1987$. PNL 6536 , Pacific Northwest Laboratory and Rockwell Hanford operations for the U.S. Department of Energy, Richland, Washington. 
EPA (U.S. Environmental Protection Agency). 1980. Code of Federal Regulations. "Title 40, Protection of Environment, Part 261, Identification and Listing of Hazardous Waste." U.S. Environmental Protection Agency, Washington, D.C.

EPA. 1982. Test Methods for the Evaluation of Solid Waste: Physical/ Chemical Methods (revised Ju7y 1982). SW-846, U.S. Environmenta] Protection Agency, Washington, D.C.

EPA. 1984. Code of Federal Regulations. "Title 40, Protection of Environment, Part 265, Interim Status Standards for Owners and 0perators of Hazardous Waste Treatment, Storage, and Disposal Facilities," amended November 1984. U.S. Environmental Protection Agency, Washington, D.C.

EPA. 1986. Test Methods for the Evaluation of Solid Waste: Physical/ Chemical Methods. SW-846, 3rd ed., revised November 1986. U.S. Environmental Protection Agency, Office of Sol id Waste and Emergency Response, Washington, D.C.

ERDA (U.S. Energy Research and Development Administration). 1975. Final Environmental Statement, Waste Management Operations, Hanford Reservation. ERDA-1538, National Technica] Information Service, Springfield, Virginia.

Fecht, K. R., S. P. Reidel and A. M. Tallman. 1985. Paleodrainage of the Columbia River System on the Columbia Plateau of Washington State: A Summary. RHO-BW-SA-318 P, Rockwell Hanford Operations, Richland, Washington.

Folk, R. L. 1968. Petrology of Sedimentary Rocks. University of Texas, Austin, Texas.

Gephart, R. E., R. C. Arnett, R. G. Baea, L. S. Leonhart and F. A. Spane, Jr. 1979. Hydrologic Studies Within the Columbia Plateau, Hashington: An Integration of Current Knowledge. RHO-BWI-ST-5, Rockwell Hanford Operations, Richland, Washington.

Graham, M. J., G. V. Last and K. R. Fecht. 1984. An Assessment of Aquifer Intercommunication in the B Pond - Gable Mountain Pond Area of the Hanford Site. RHO-RE-ST-12 P, Rockwell Hanford Operations, Richland, Washington.

Greager, E. M. 1982. Environmental Effects of Leakage from the 183-H Solar Evaporation Basin. UNI-2128, UNC Nuclear Industries, Richland, Washington.

Gupta, S. K., C. T. Kincaid, P. R. Meyer, C. A. Newbill and C. R. Cole. 1982. A Multi-Dimensional Finite Element Code for the Analysis of Coupled Fluid, Energy and Solute Transport (CFEST). PNL-4260, Pacific Northwest Laboratory, Richland, Washington.

Jacquish, R. E., and P. J. Mitche11, eds. 1988. Environmental Monitoring at Hanford for 1987. PNL-6464, Pacific Northwest Laboratory, Richland, Washingotn. 
Johns, F. B. 1975. Handbook of Radiochenical Analytical Methods Ënvironmental Monitoring Series). EPA/680/4-75-001, National Environnenta? Research Center, Las Vegas, Nevada.

Klute, A., ed. 1986 . "Water Retention: Laboratory Methods." In Methods of Soil Analysis, Part 1. American Society of Agronomy, Madison, Wisconsin.

Kotegov, K. V., 0. N. Pavlov and V. P. Shvedov. 1968. "Technetium." in Advances in Inorganic Chemistry and Radiochemistry, Vol. II, pp. 1-90. Academic Press, New York.

Krieger, H. L. 1980. Prescribed Procedures for Measurement of Radioactivity in Drinking Water. EPA/600/4-80-032, U.S. Environmental Protection Agency, Washington, D.C.

Langmuir, D. 1978. "Uranium Solution-Mineral Equilibria at Low Temperatures with Applications to Sedimentary Ore Deposits." Geochin. Cosmochim. Acta $42: 547$.

Ledgerwood, R. K., C. W. Myers and R. W. Cross. 1978, pasco Basin Stratigraphic Nomenclature. PNL-5453, Pacific Northwest Laboratories, Richland, Washington.

Myers, C. W., and S. M. Price, J. A. Caggiano, M. P. Cochran, H. J. Czimer, N. J. Davidson, R. C. Edwards, K. R. Fecht, G. E. Holmes, W. G. Jones, J. R. Kunk, R. D. Landon, R. K. Ledgerwond, J. T. Lillie, P. E. Long, 1. H. Mitchell, E. H. Price, S. P. Reidel and A. M. Tallman. 1979. Geologic Studies of the Columbia Plateau: A Status Report. RHO-BWI-ST-4, Rockwell Hanford Operations, Richland, Washington.

Myers, C. W., and S. M. Price, eds. 1981. Subsurface Geology of the Cold Creek Syncline. RHO-BWI-ST-14, Rockwell Hanford Operations, Richland, Washington.

0'De1T, J. H., J. D. Pfaff, M. E. Gales and G. D. MeKee. 1984. Technical Addition to Methods for Chemical Analys is of Hater and Wastes lalso known as the Determination of Inorganic Anions in Water by Ion Chromatography -Method 300.0). EPA/600/4-84-017, U.S. Environmental Protection Agency, Washington, D.C.

PNL. 1986. Revised Ground-Hater Monitoring Compliance Plan for the 183-H Solar Evaporation Basins. Ptil-6470, Pacific Northwest Laboratory, Richland, Washington.

PNL. 1987. Interim Characterization Report for the Area Surrounding the 183-H Basins, PNL-6471, Pacific Northwest Laboratory, Richland, Washington. 
Reide1, 5. P., and K. R. Fecht. 1981. "Wanapum and Saddle Mountains Basalts of the Cold Creek Syncline Area." In Subsurface Geology of the Cold Creek Syncline, eds. C. W. Myers and S. H. Price, RHO-BWI-ST-14, Rockwell Hanford Operations, Richland, Washington.

Rokkan, R. C. 1973. UNC Nuclear Industries Reactor and Fuels Production Facilities, 1985 Effluent Release Report. UNI-3880, UNC Nuclear Industries, Richland, Washington.

Rokkan, D. J. 1986. UNC Nuclear Industries Reactor and Fuels Production Facllities, 1985 Effluent Ralease Report. UN1-3880, UNC Nuclear Industries, Richland, Washington.

Schatz, A. L., J. J. Antmerman and J. A. Serkowsk . 1987. Hanford Site Water Iable Map. June 1987, WHC-EP-0054, Westinghouse Hanford Company, Richland, Washington.

Stone, W. A., J. M. Thorp, 0. P. Gifford and 0. J. Hotionk. 1983. Clinatological Sumary for the Hanford Area. PNL-4622, Pacific Northwest Laboratory, Richland, Washington.

Swanson, D. A., T. L. Wright, P. R. Hooper and R. D. Bentley. 1979. "Revisions in Stratigraphic Nomenclature of the Columbia River Basalt Group." U.S. Geological Survey Bulletin 1457, U.S. Government Printing office, Washington, D.C.

TaTlman, A. M. J. T. Lll1ie and K. R. Fecht. 1981. "Suprabasalt Sediment of the Cold Creek Syncline Area." In Subsurface Geology of the Cold Creek Syncline, eds. C. W. Myers and S. M. Price. RHO-BWI-ST-14, Rockwell Hanford Operations, Richland, Washington.

Tallman, A. M., K. R. Fecht, M. C. Marratt and G. V, Last. 1979. Geolooy of the Separations Areas, Hanford Site, South-Central Wastington. RHO-ST-23, Rockwell Hanford Operations, Richiand, Hashington.

Vedder, B. L. 1985. Waste Characterization-183-H Basin No. 1. UNI-3514, UNC Nuclear Industries, Richland, Washington.

WDOE. 1983. Chemical Testing Methods for Complying with the State of Washinaton Dangerous Waste Regulations. WooE 83-13, Washington State Department of Ecology, 0lympla, Washington.

WDOE. 1986a. "Dangerous Waste Regulations," In Washington Adninistrative Code, WAC 173-303, Washington State Department of Ecology, OTympia, Washington.

WDOE. 1986b. Minimum Standards for Construction and Maintenance of Water Weils." In Washington Administrative Code, WAC 173-160, Washington State Department of Ecology, olympia, Washington. 


\subsection{CONCLUSIONS}

The geohydrologic investigation of the area surrounding the 183-H Basins has resulted in the following conclusions:

\section{Geology}

- The Elephant Mountain Member of the Saddle Mountains Basalt Formation is the topmost basalt flow in the 100-H Area.

- The sediments of the Ringold Formation beneath the 100-H Area were characterized as section type II, consisting of predominantiy sands, silts, and clays. This formation was subdivided into three principal lithologic units, including the silty clayey sand to sandy silty clay, silty sand, and gravelly silty sand.

- The top of the Ringold Formation is an erosional unconformity, with peak elevations located to the east and northeast of the $183-\mathrm{H}$ Basins.

- The Hanford formation at the 100-H Area has been severely modified by past operational and waste management activities. Backfill materials were often indistinguishable from the in situ gravels and sands, resulting in this formation being treated as a single silty sandy gravel unit.

Hydrology

- Five principal hydrostratigraphic units were defined beneath the 100-H Area, including the lower confined aquifer, upper confined aquifer, silty sand and gravelly silty sand units, saturated sediments of the Hanford formation, and unsaturated sediments of the Hanford formation.

- Testing of piezometer (0) and (A) in He11 199-H4-15C may have altered the integrity of the bentonite seals adjacent to their screened intervals. Observation of the piezoneter for several years may be necessary to determine if the annulus reseals. 
- The unconfined aquifer occurs within the Hanford formation and ranges in thickness from 3 to $15 \mathrm{ft}$. This variation is a result of the erosional unconformity at the contact between the Hanford and Ringold Formations and the variation in the water table.

- Ground-water flow in the 100-H Area is generally northeast and east toward the Columbia River. Changes in water table elevation in all wells correspond to changes in river stage.

- Variability in aquifer testing results for the unconfined aquifer indicates that this aquifer is heterogeneous at the 100-H Area.

\section{Geochemistry}

- Sampling of waste material from Basin \#1 indicate a wide variability in chemical composition among sampling locations, as a result of the formation of several solid and slurry-like layers.

- Sampling of waste material from Basin \#2 indicate this material is predominantly a sodium nitrate solution.

- Analytical results from the wastes contained in basins \#1 and \#2 identified chromium, technetium, sodium, uranium, fluoride, nitrate, and sulfate as potential ground-water contaminants associated with the 183-H Basins.

- Retardation factors for nitrate, chromium, sodium, copper, fluoride, sulfate, and nickel indicate that these constituents are essentially nonattenuated.

\section{Ground-Water Monitoring}

- Background values for nitrate and chromium in the upgradient wells near the 183-H Basins were higher than the background values for the Hanford Site, indicating other sources of these constituents located upgradient of the facility.

- Ground-water monitoring results revealed that concentrations of approximately 20 constituents showed very marked increases in the 
APPENDIX A

CONSTRUCTION DIAGRAMS, LITHOLOGIC DIAGRAMS, AND GEOPHYSICAL LOGS FOR THE 100-Y AREA HELLS 


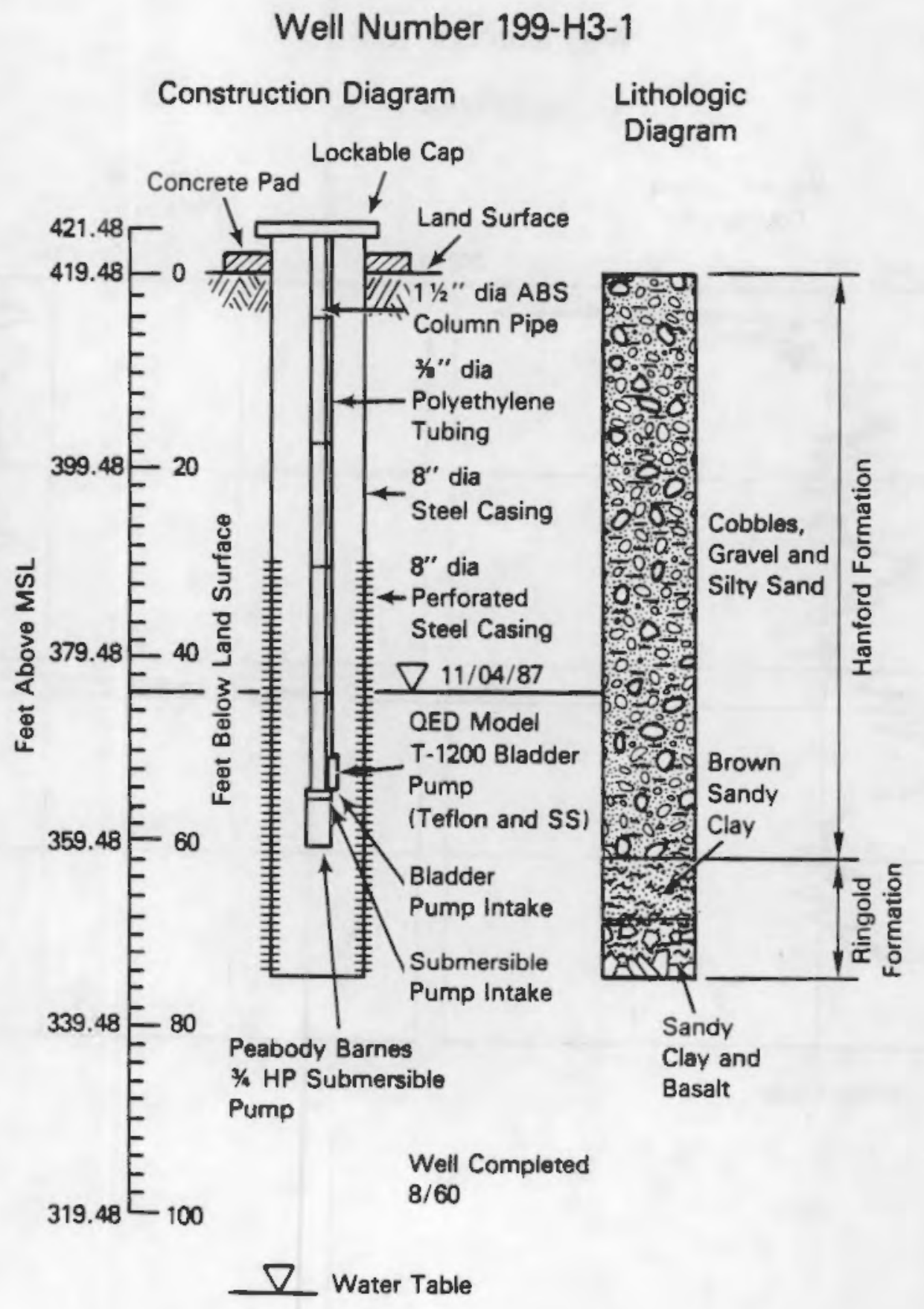


Well Number 199-H3-1

Geophysical Logs

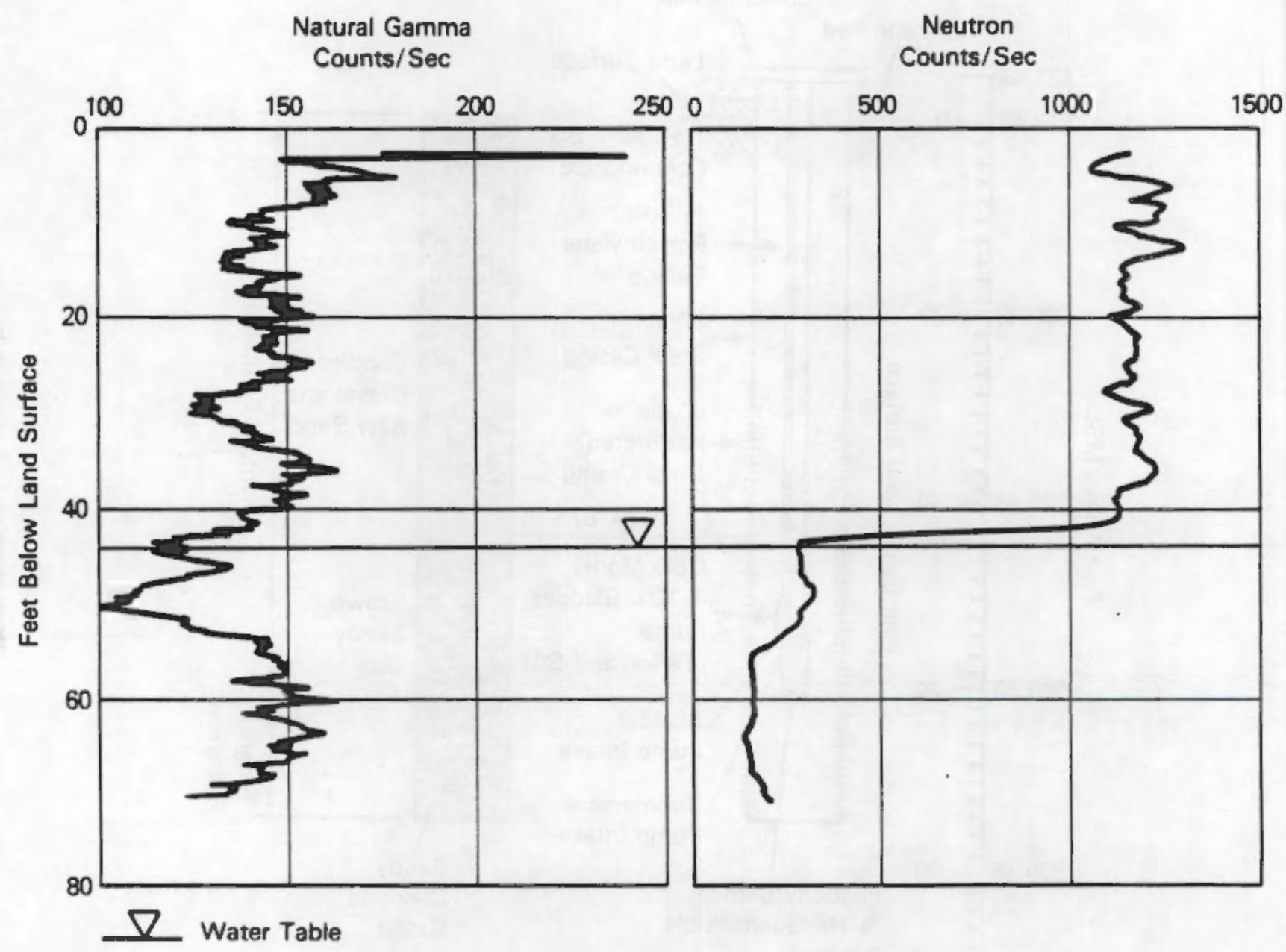

A. 2 


\section{Well Number 199-H3-2A}

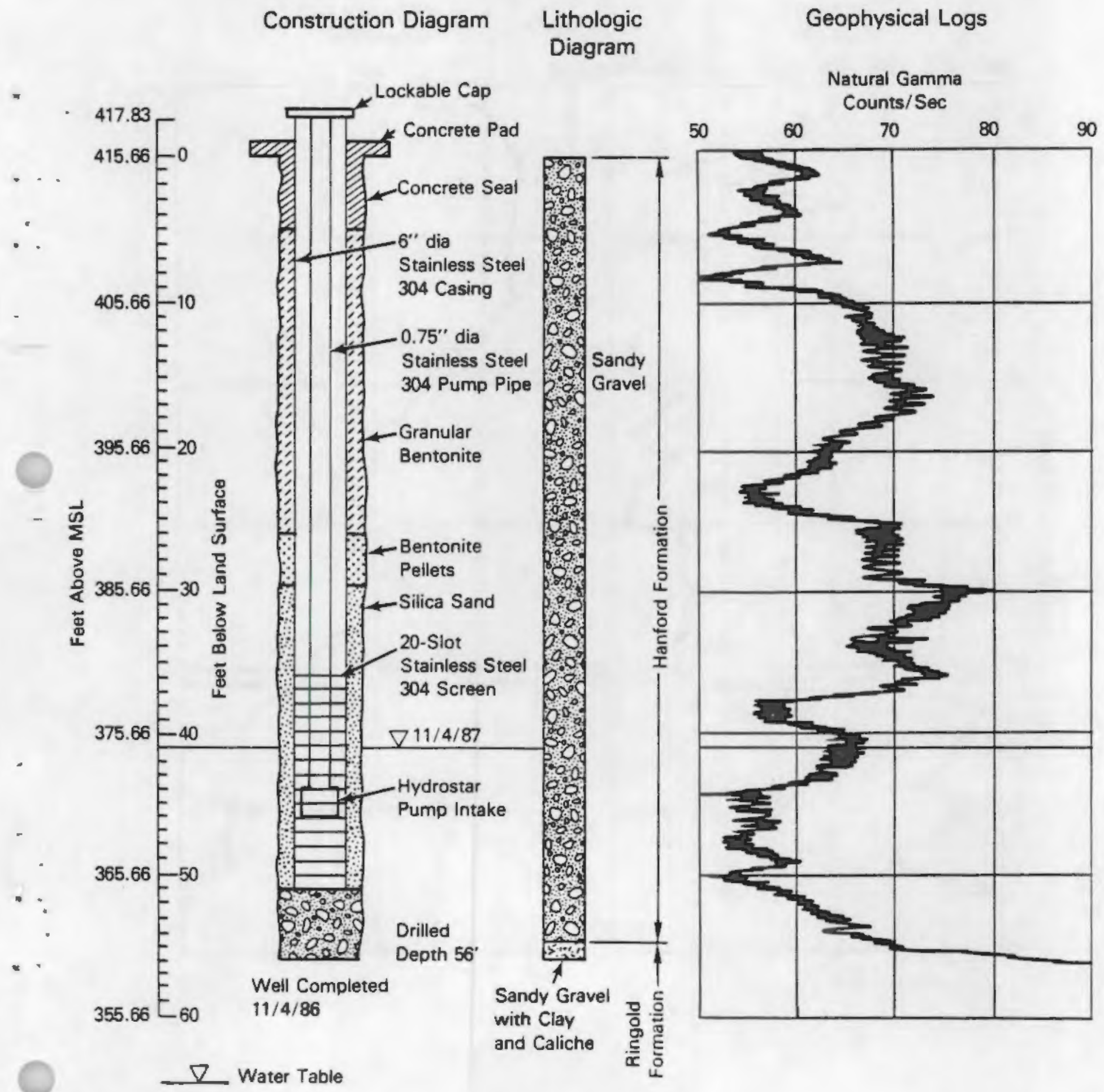




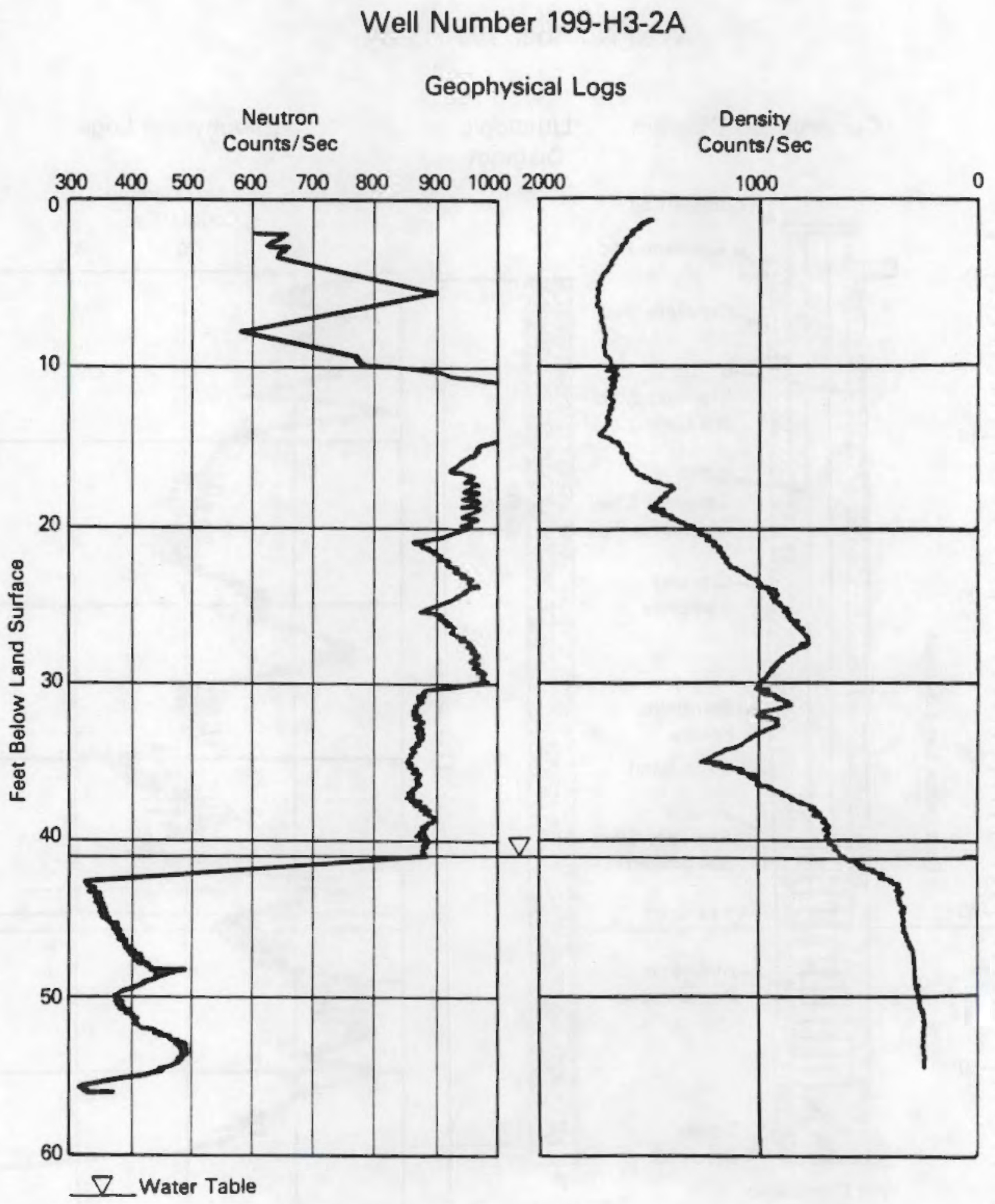


Well Number 199-H3-2C

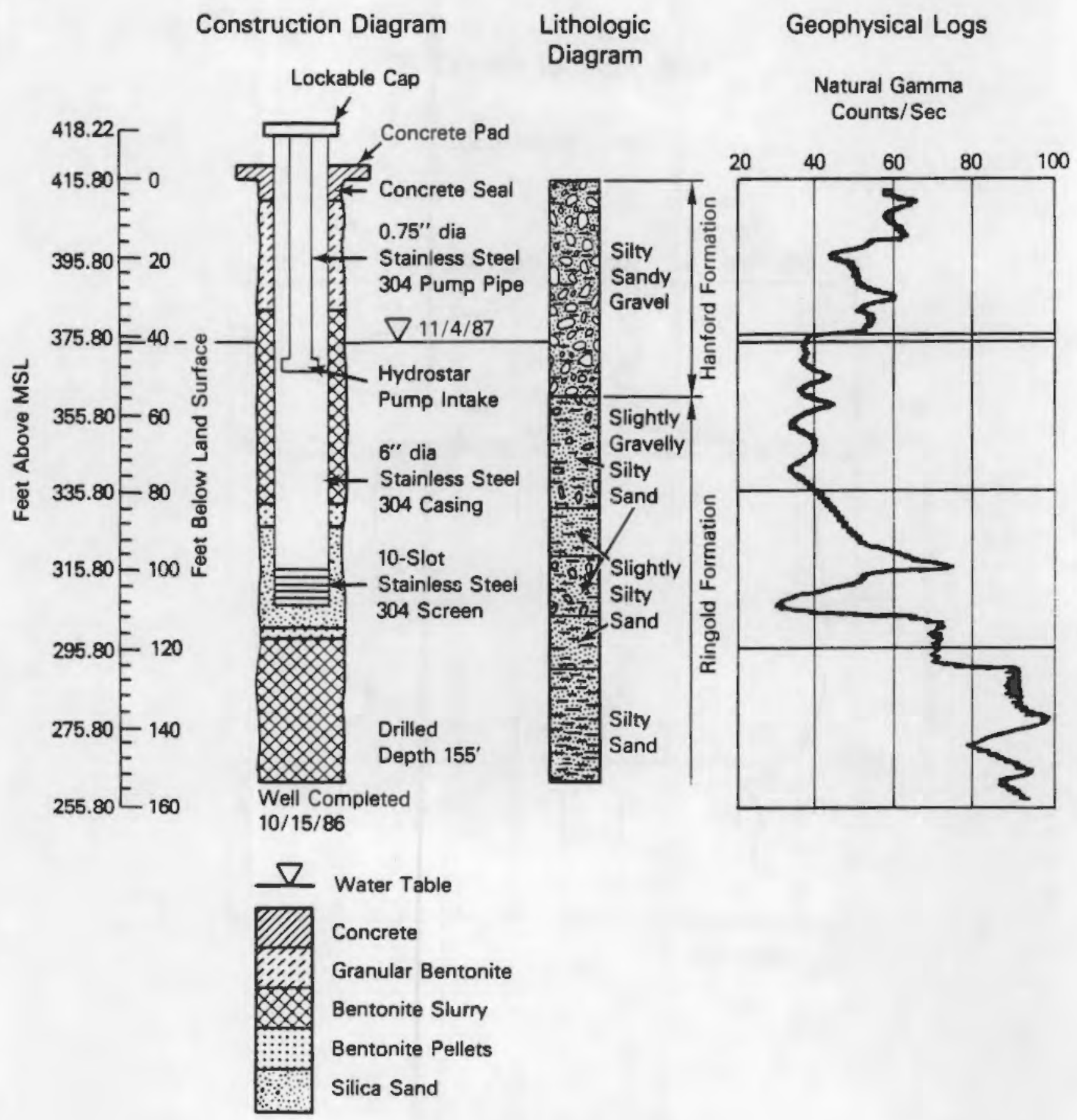




\section{Well Number 199-H3-2C}

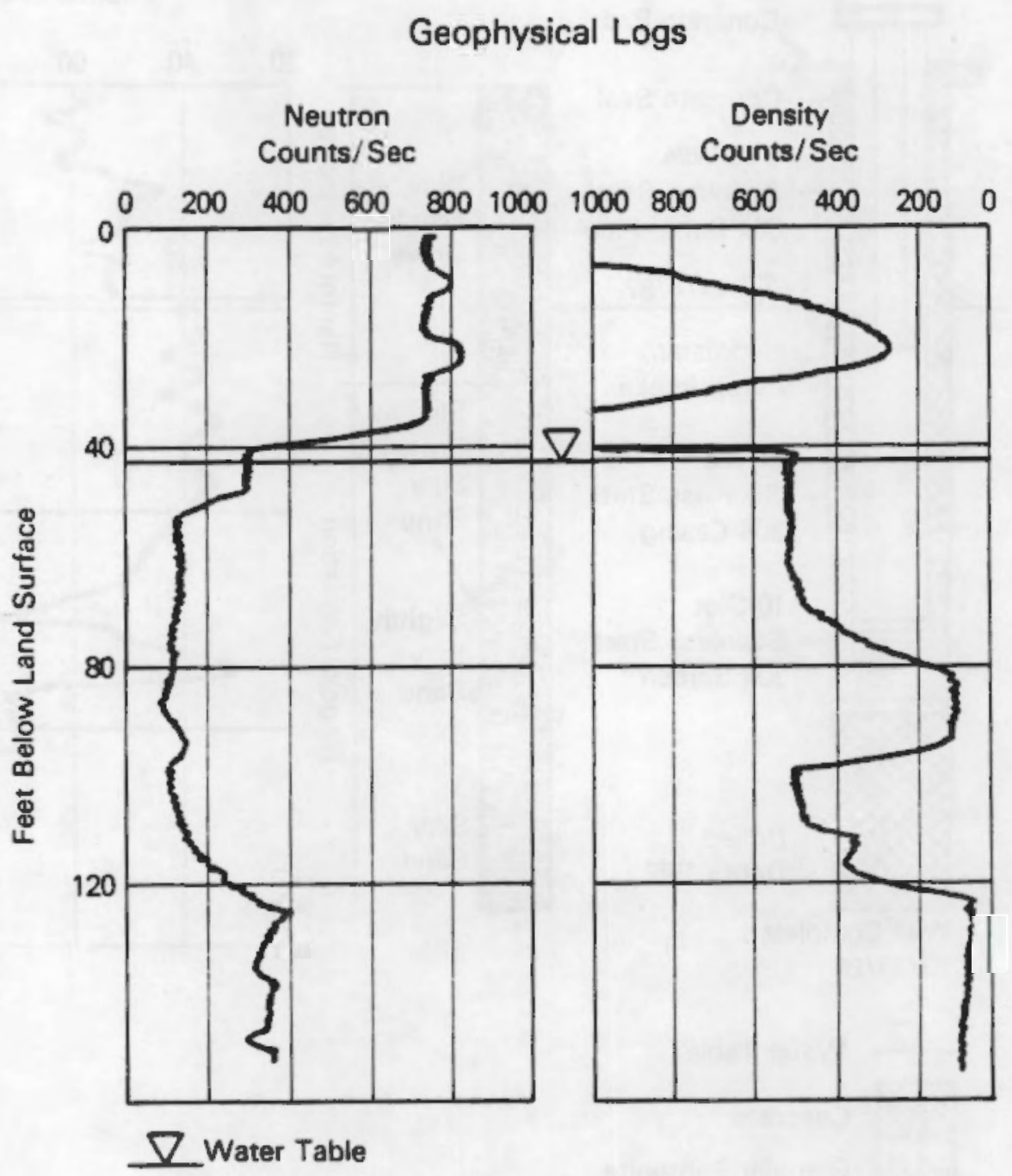


Well Number 199-H3-2B

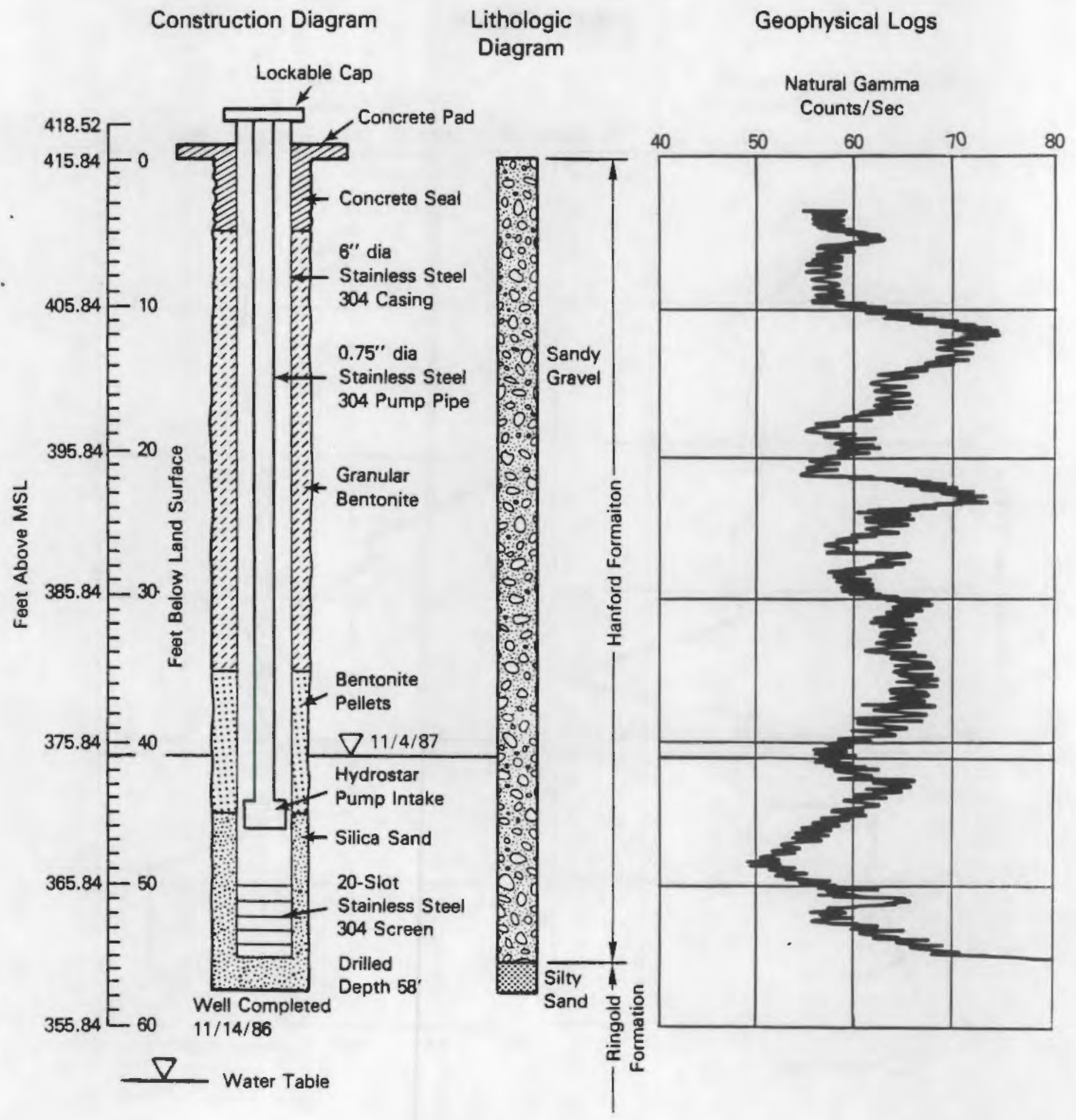




\section{Well Number 199-H3-2B \\ Geophysical Logs}

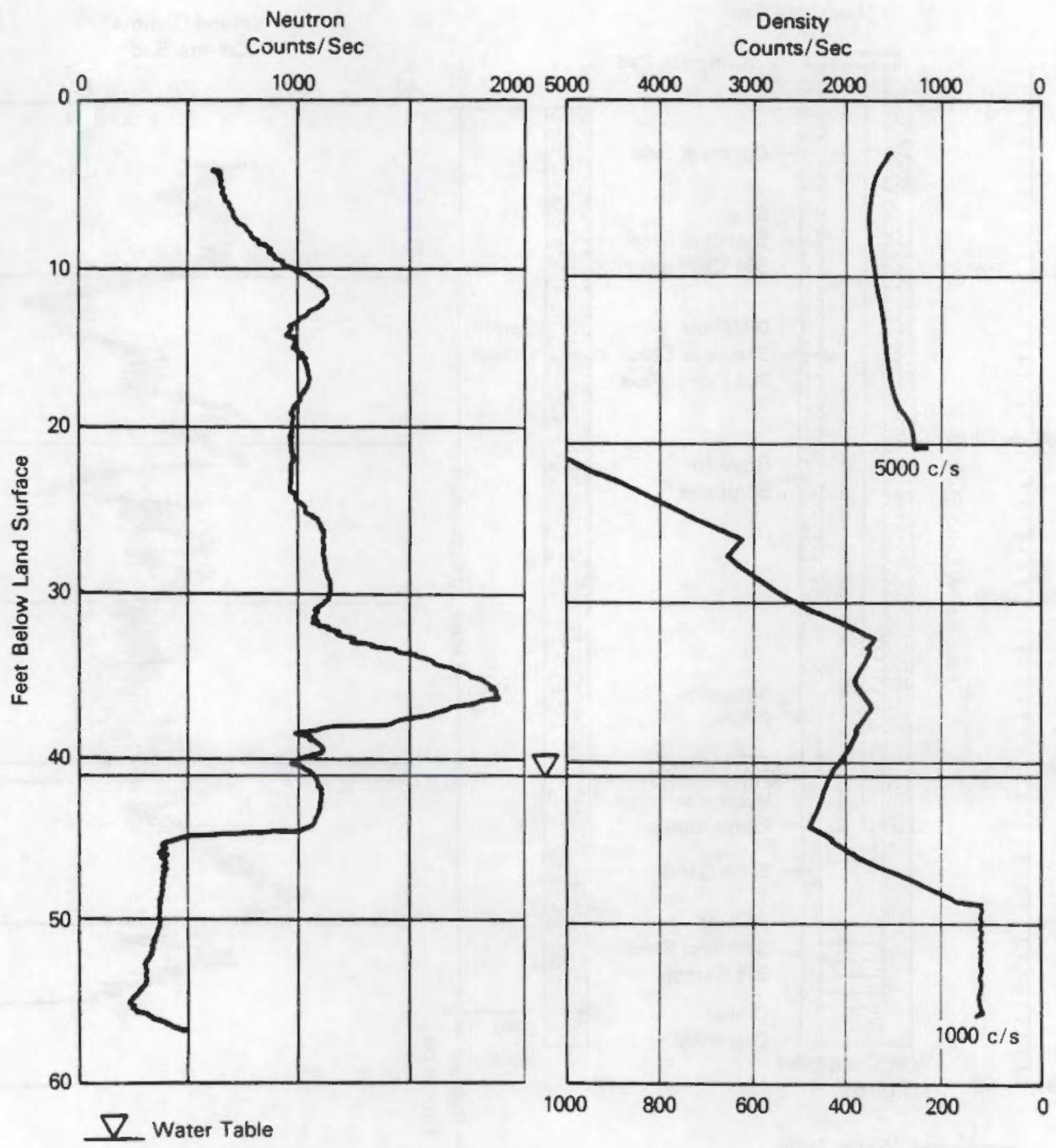




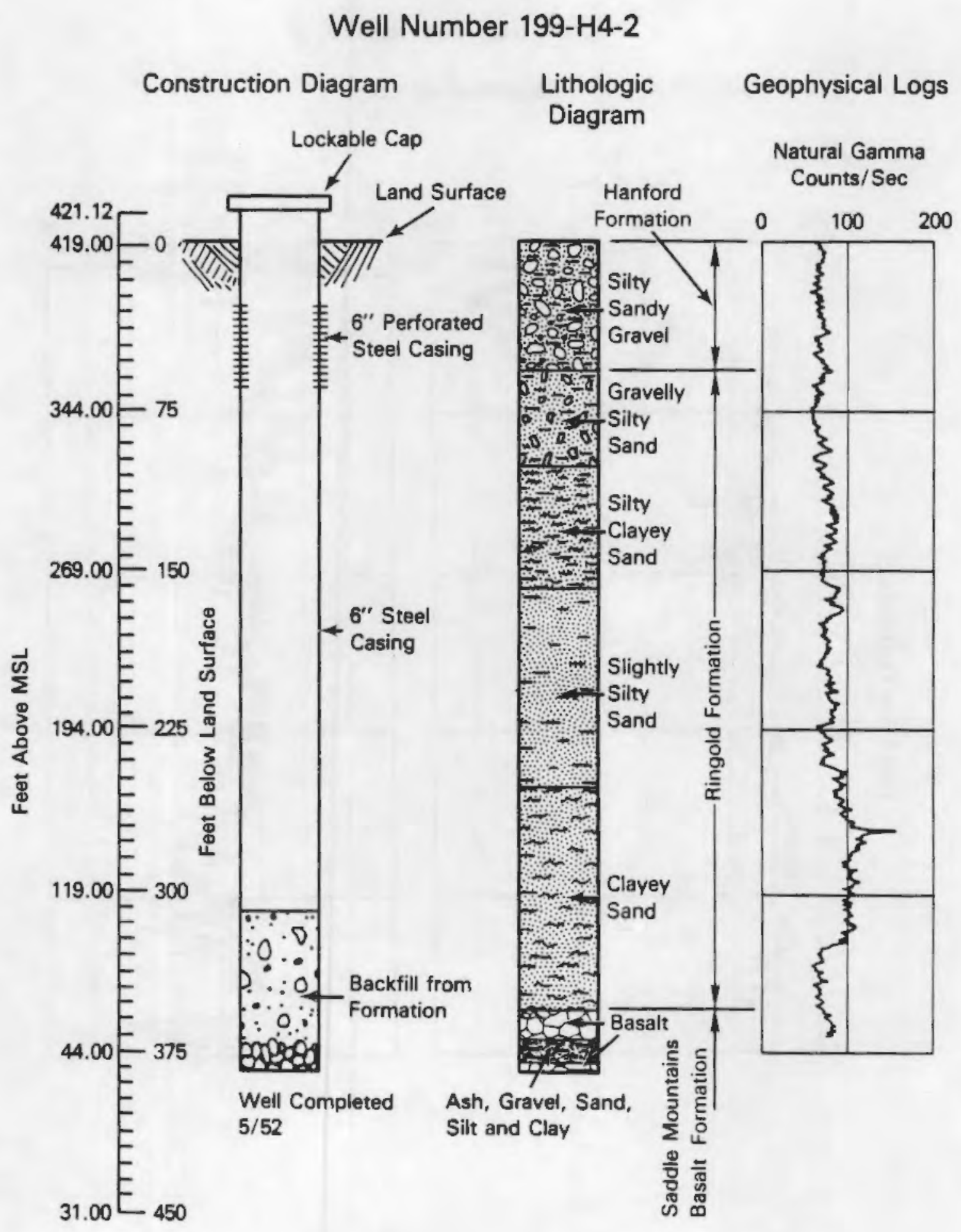




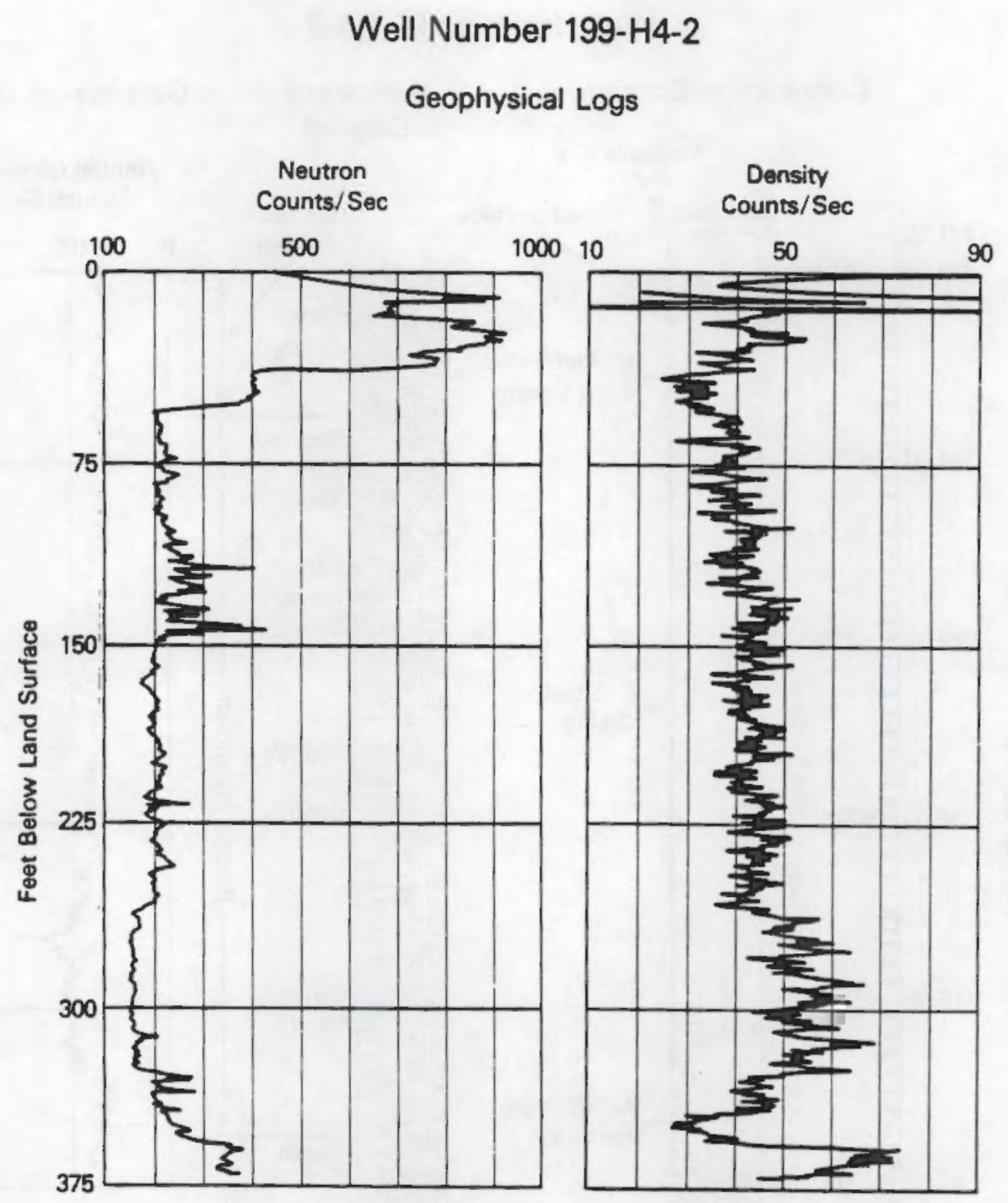




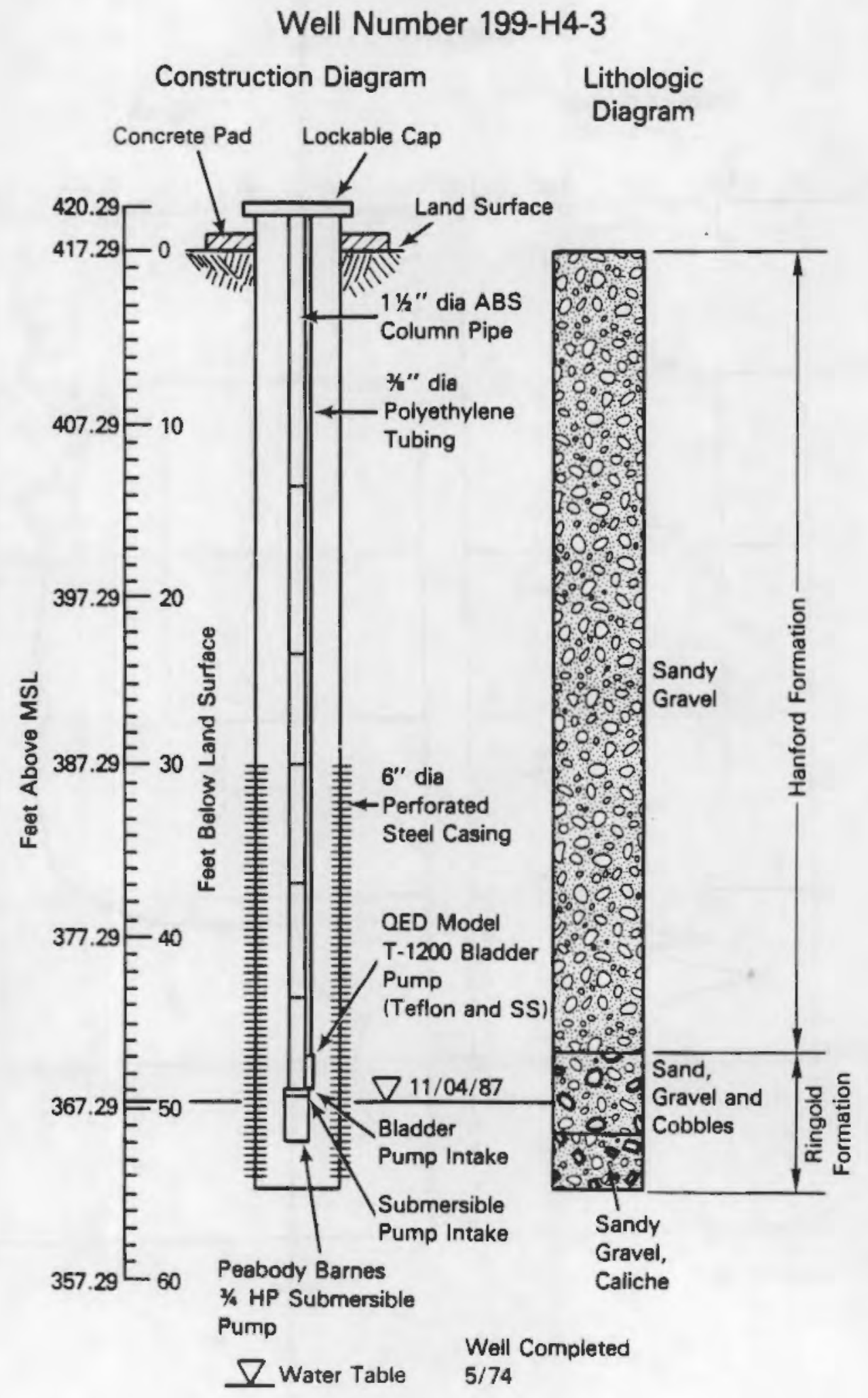

A. 11 


\section{Well Number 199-H4-3 \\ Geophysical Logs}

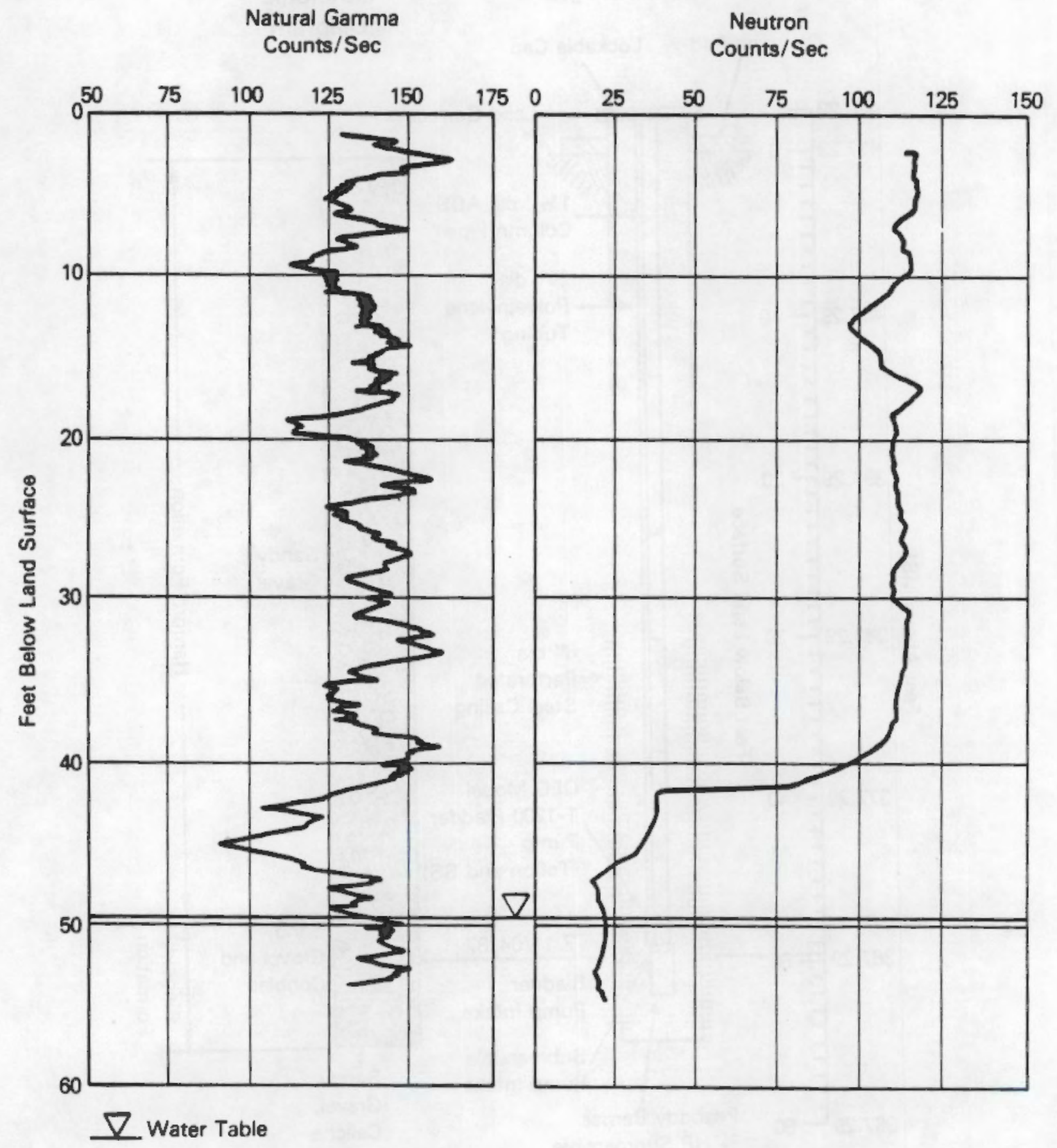




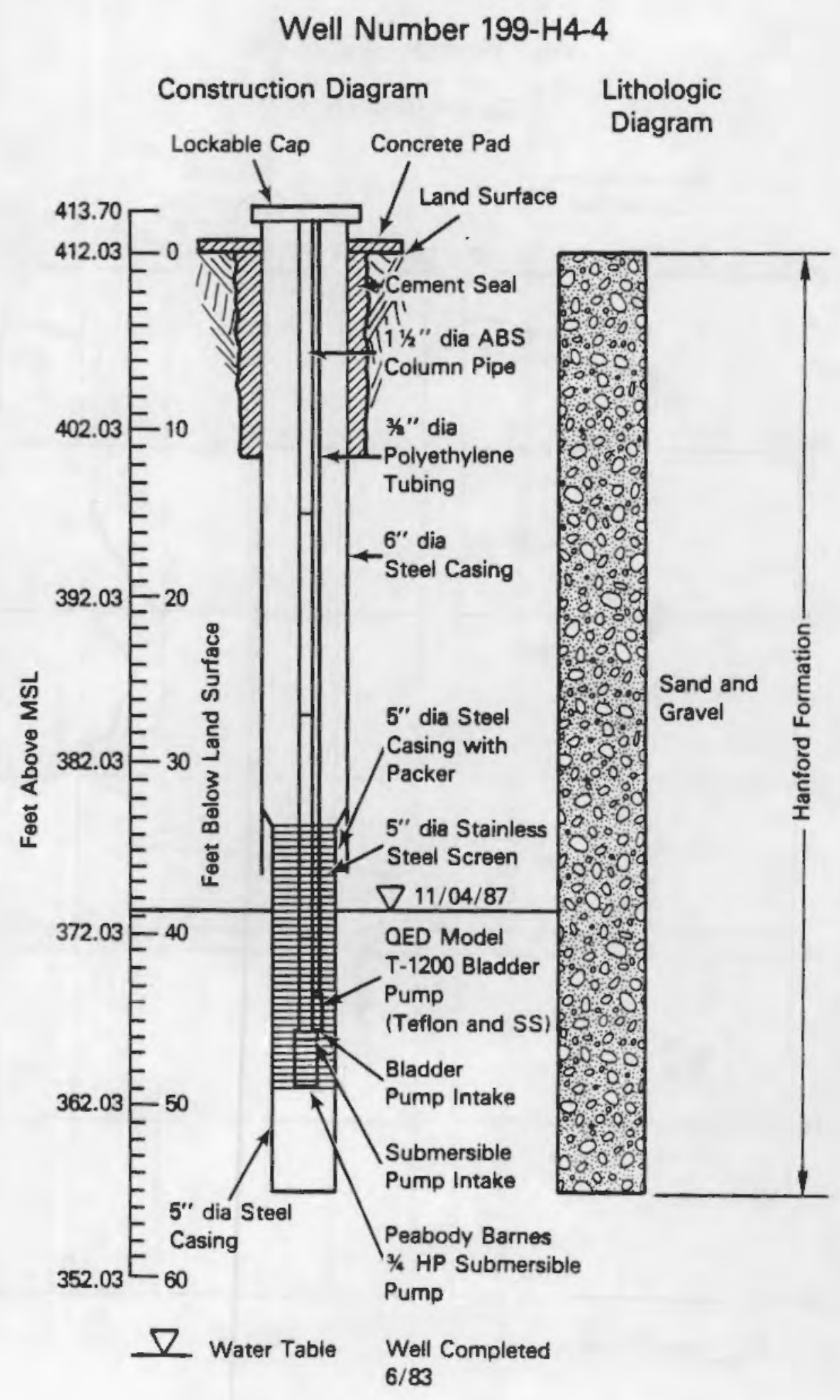




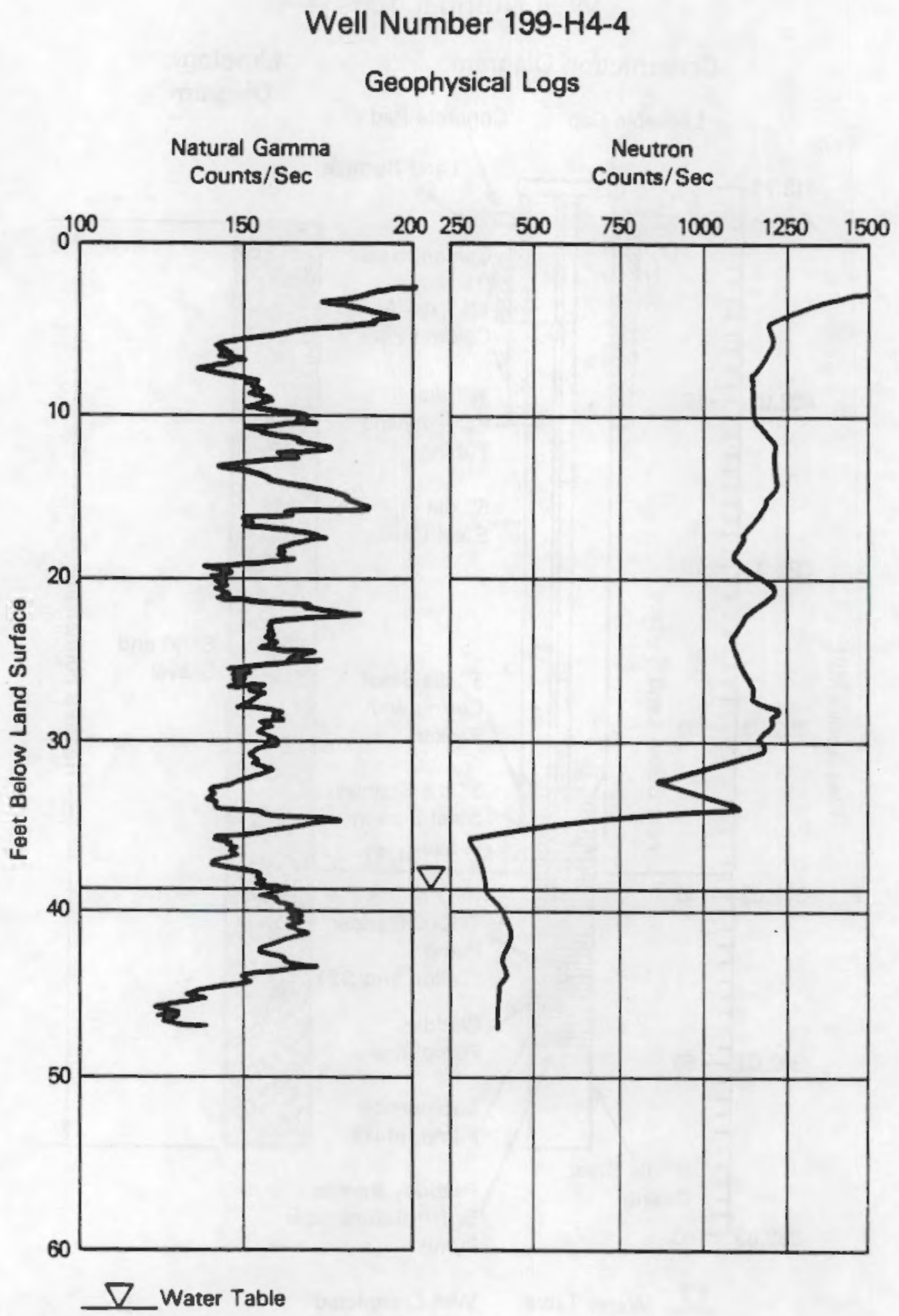




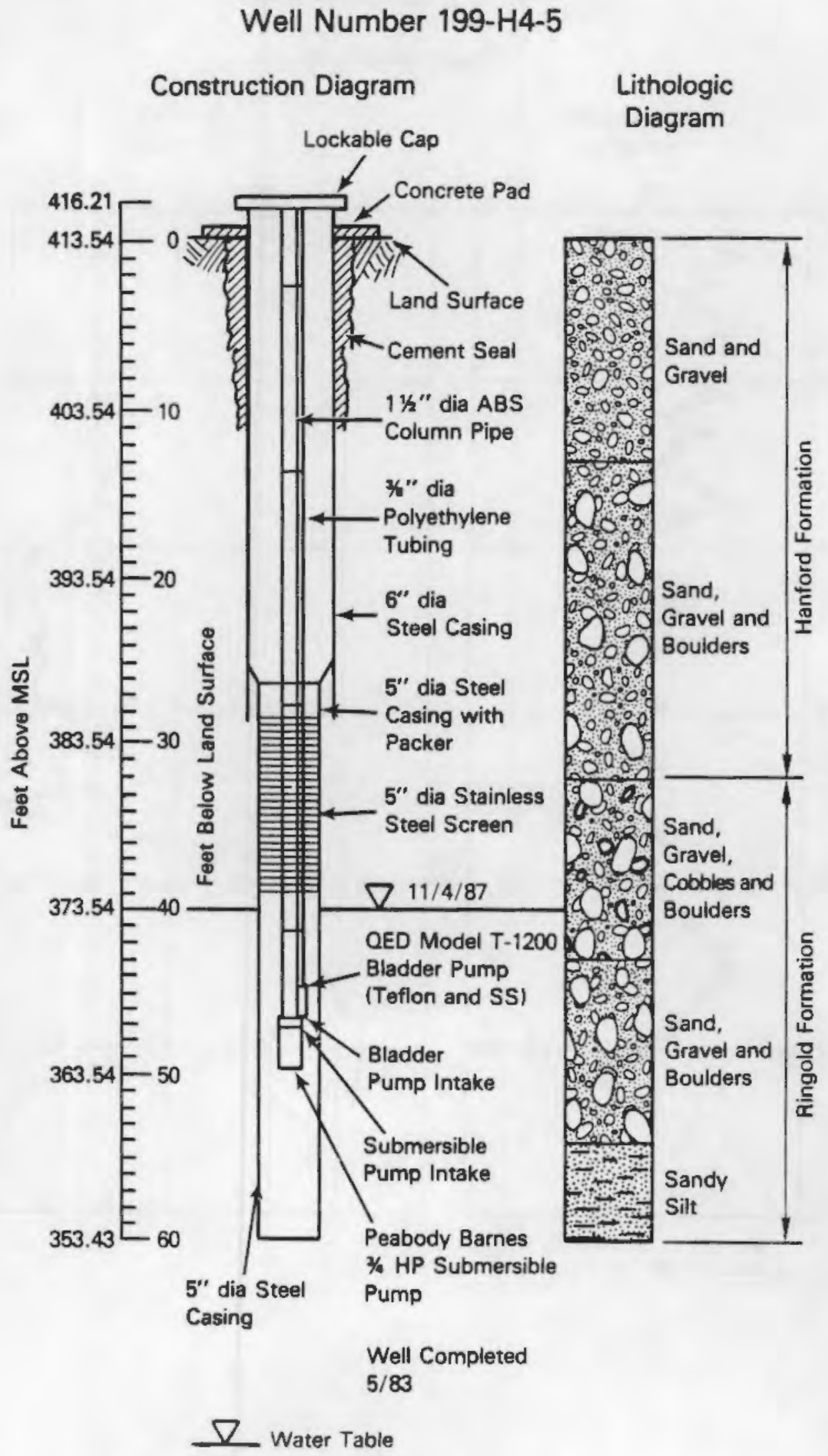

A. 15 


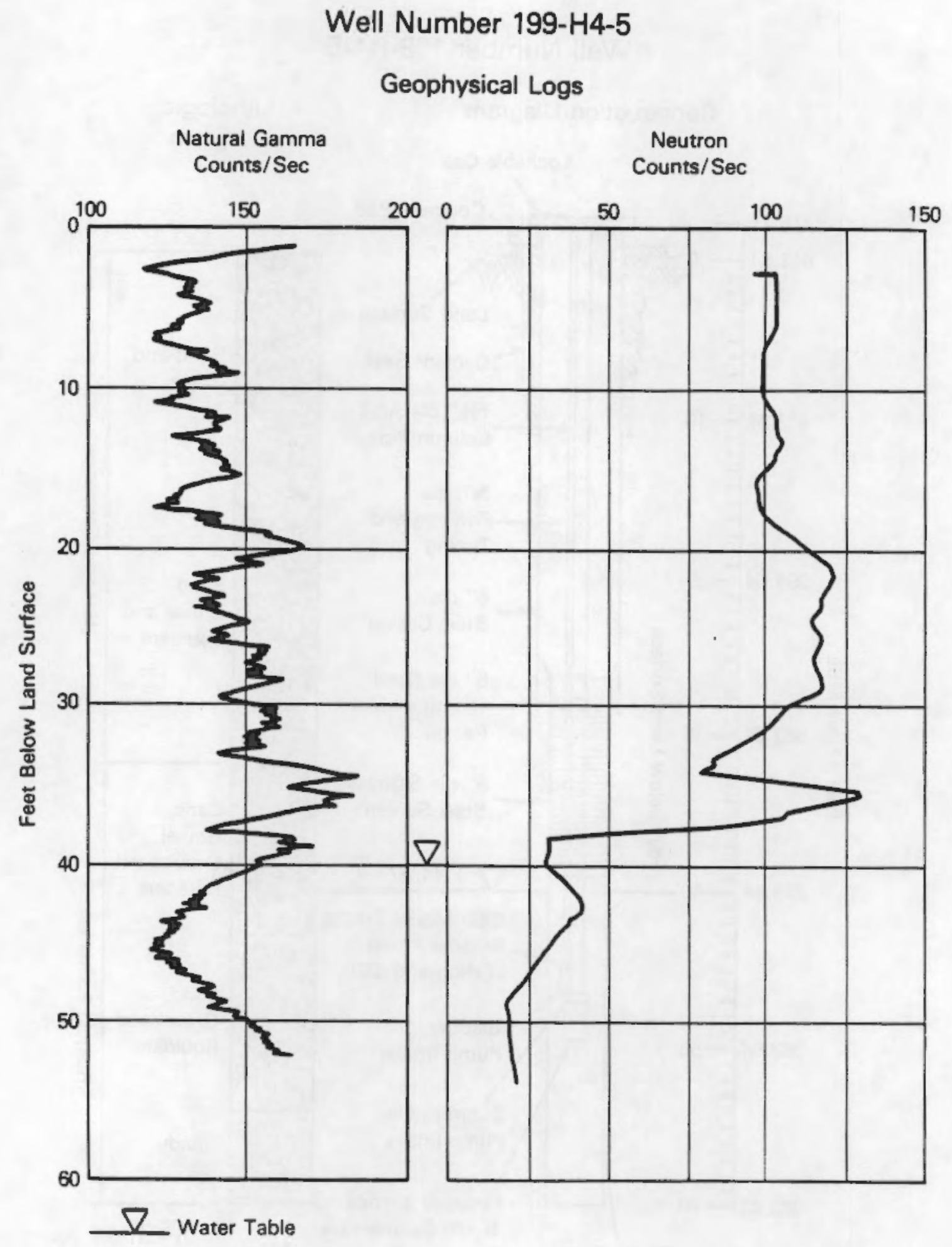




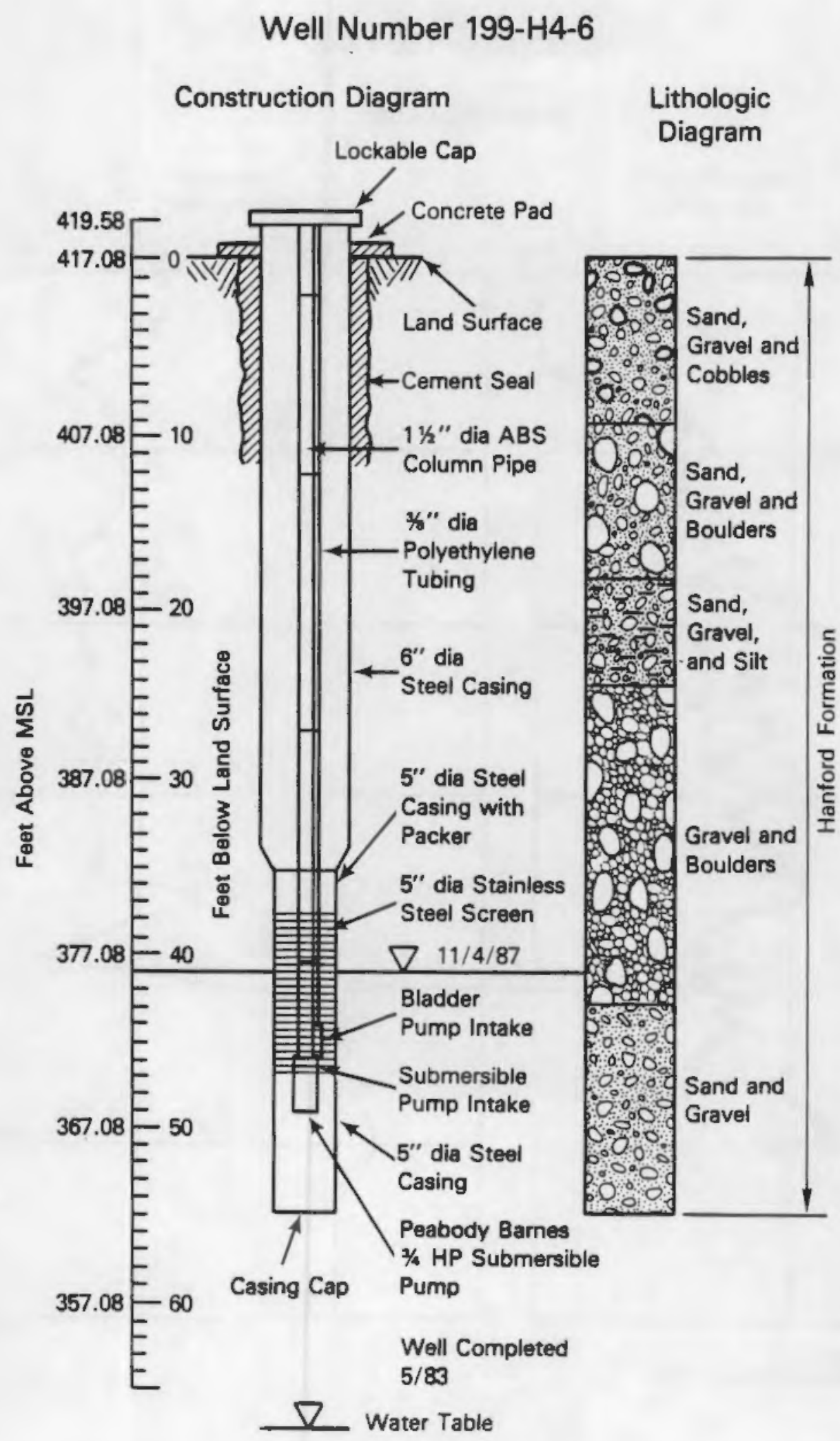




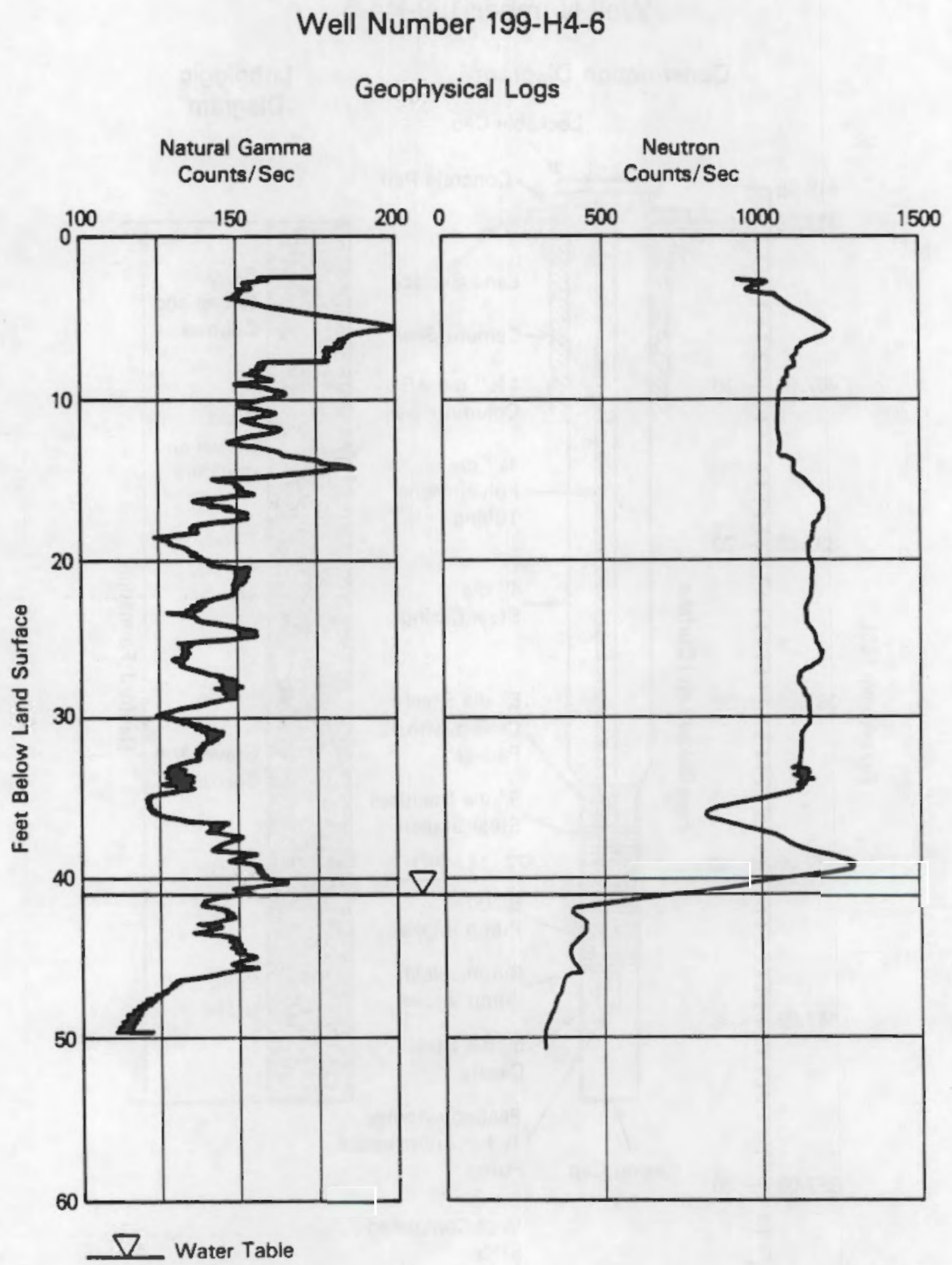




\section{Well Number 199-H4-7}

$\begin{array}{cc}\text { Lithologic } \\ \text { Construction Diagram } & \text { Diagram }\end{array}$

Geophysical Logs

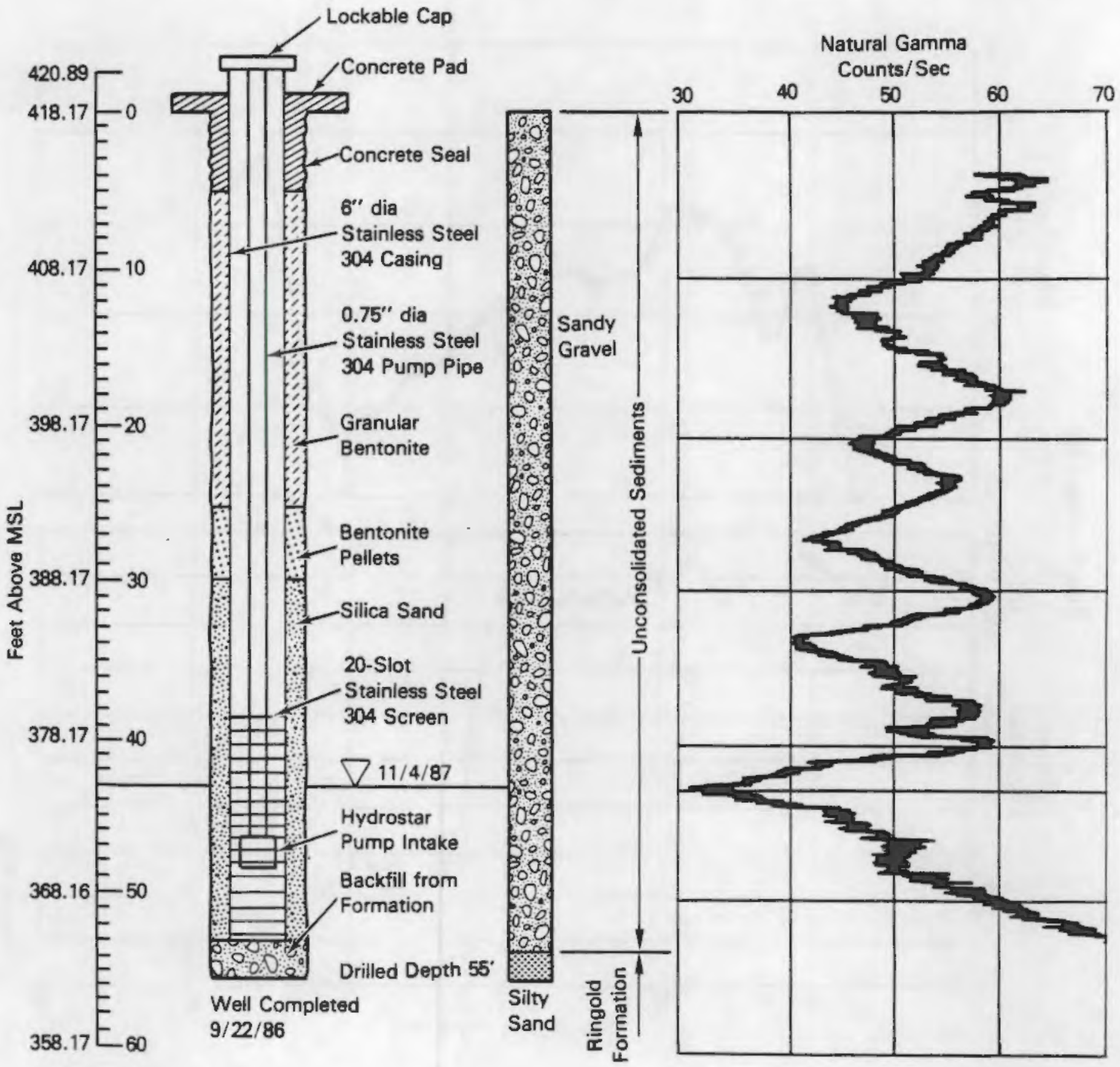

$\nabla$ Water Table 


\section{Well Number 199-H4-7}

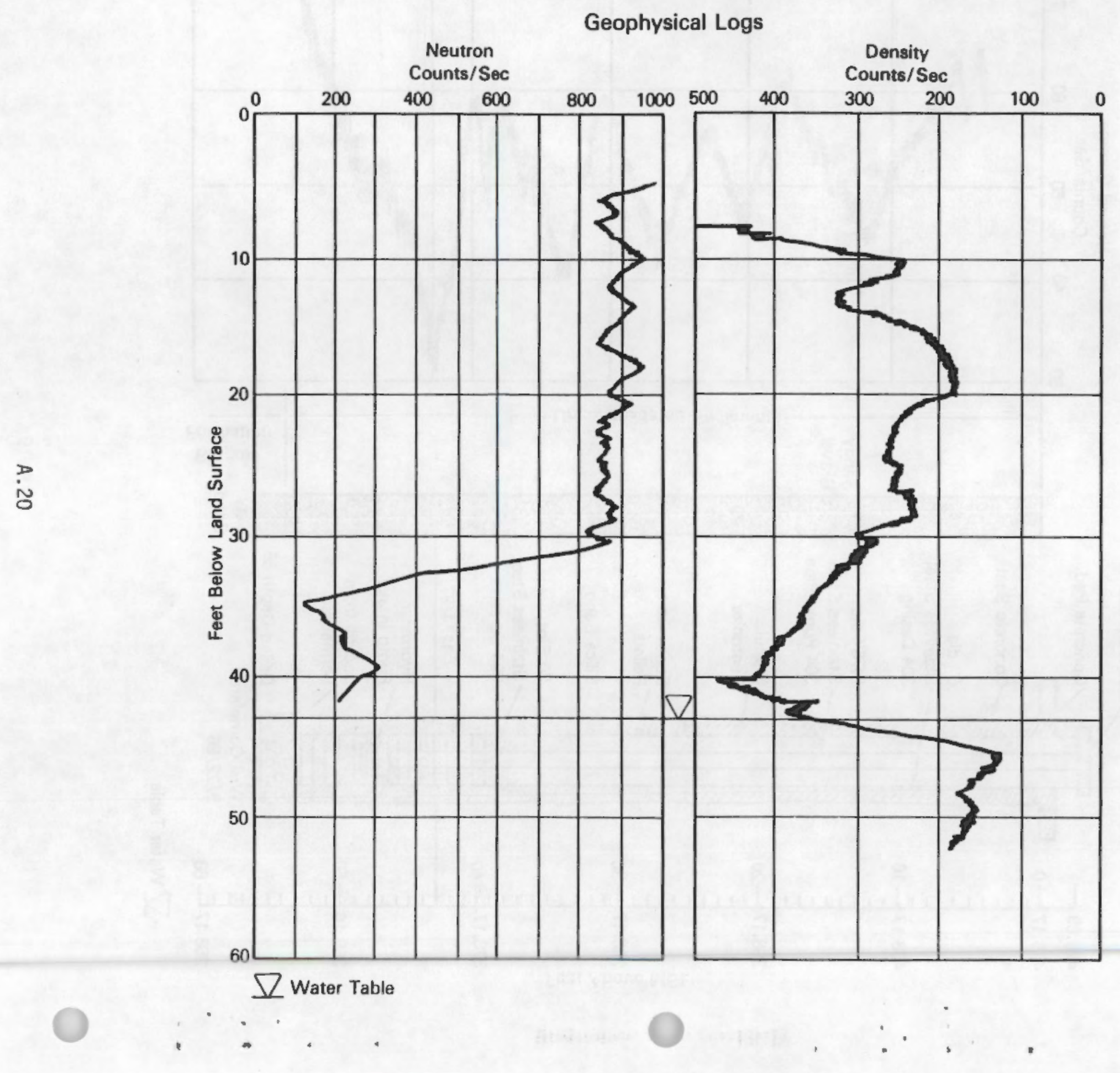




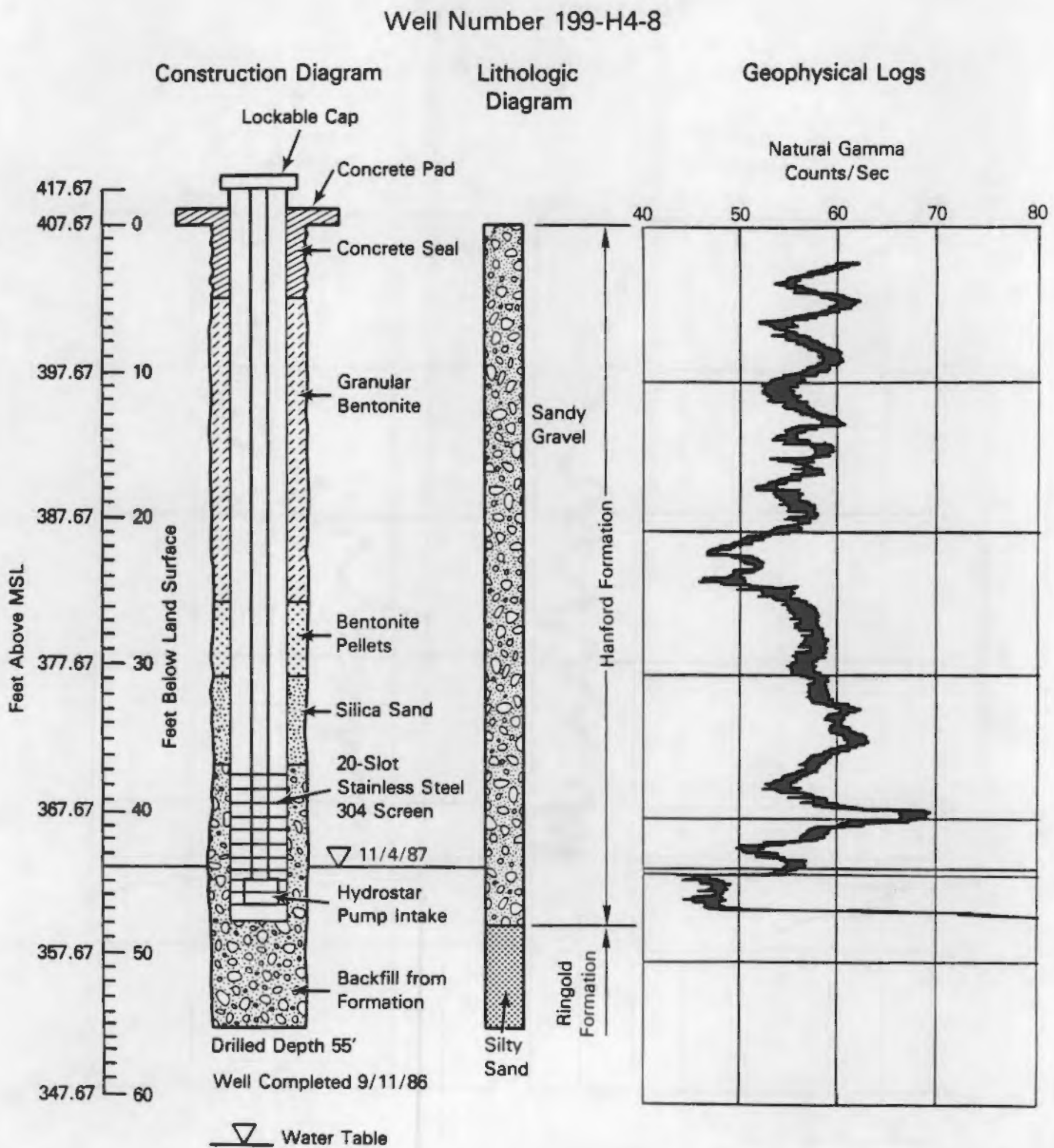




\section{Well Number 199-H4-8}

\section{Geophysical Logs}

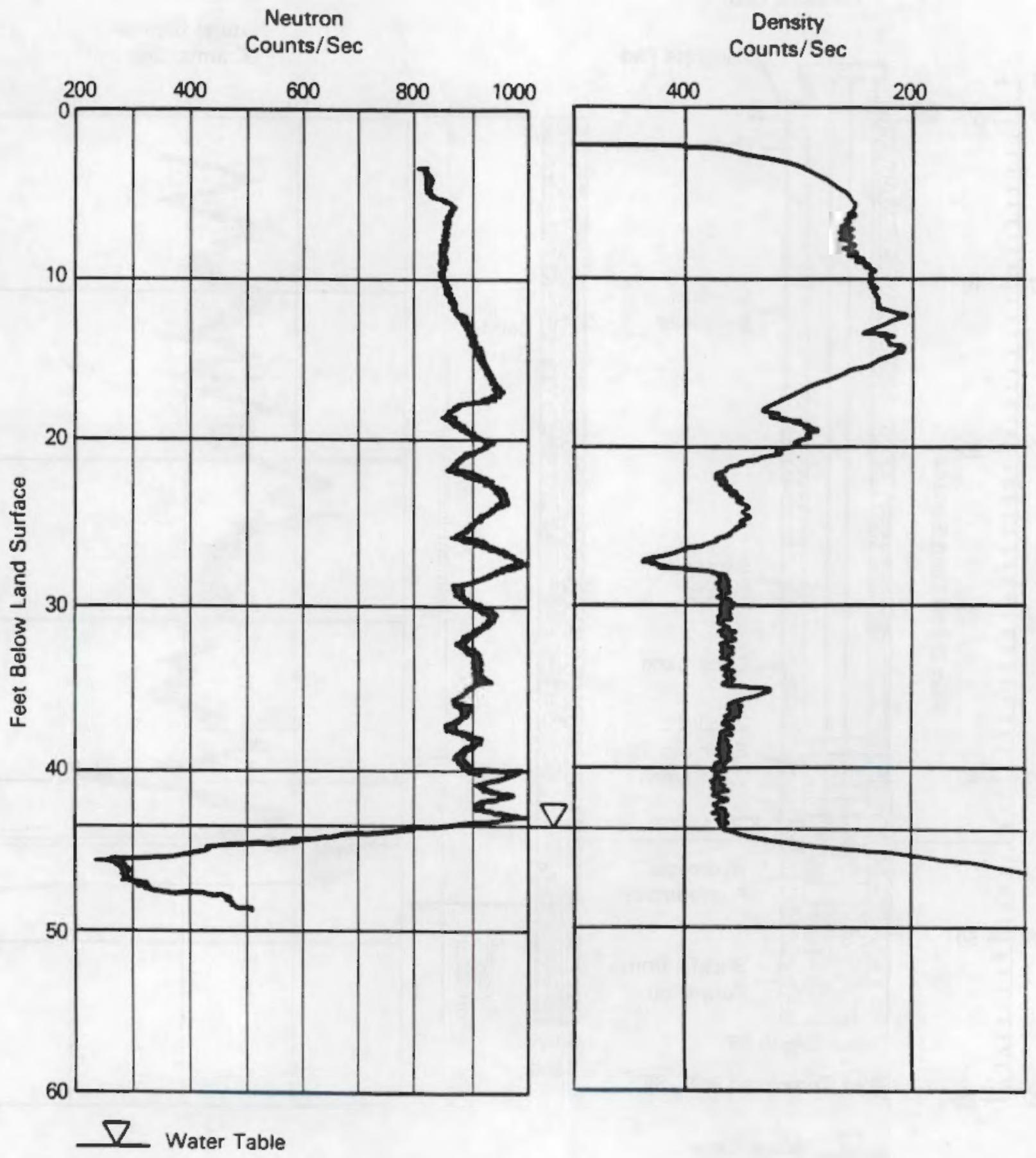


Well Number 199-H4-9

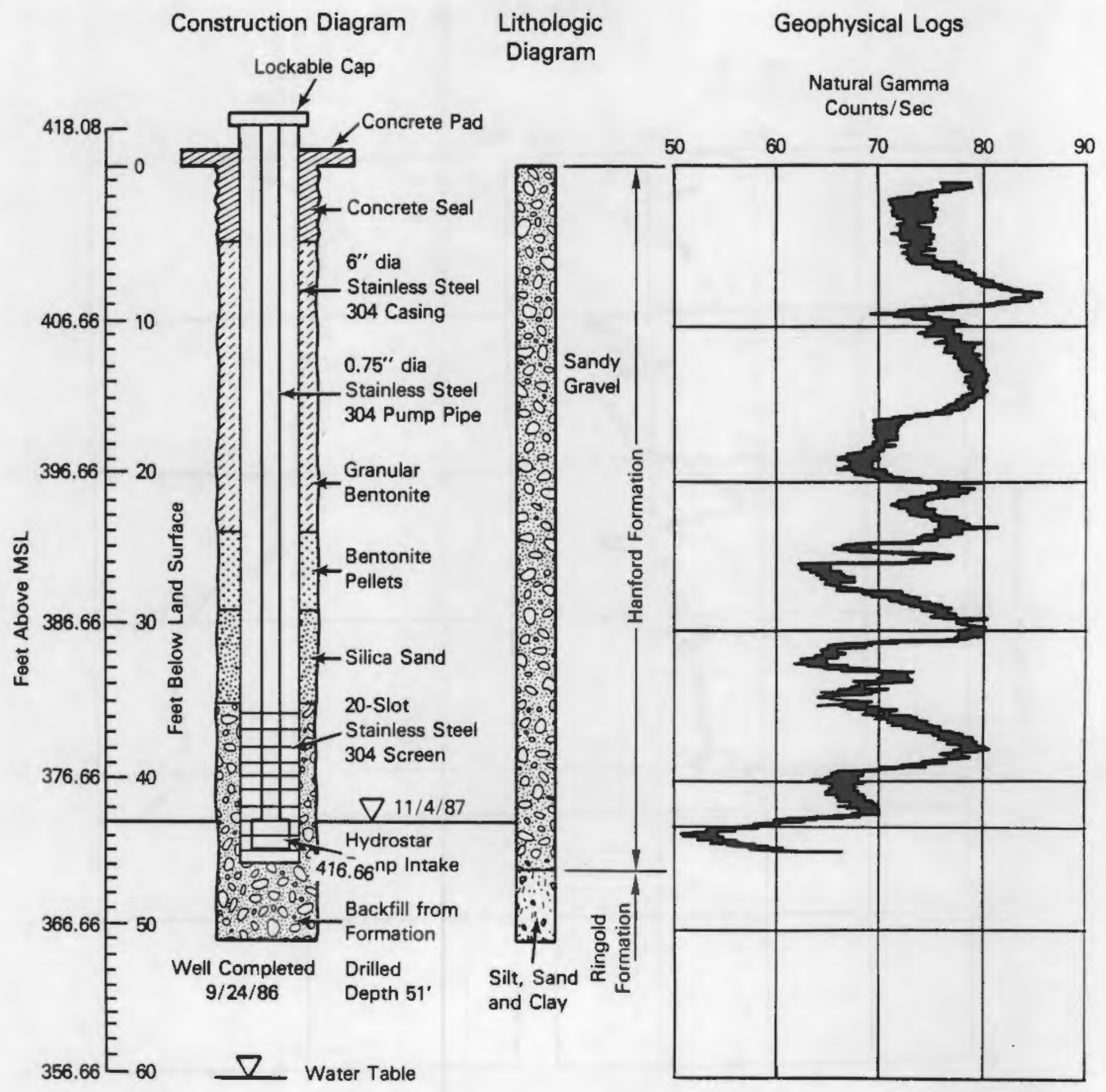




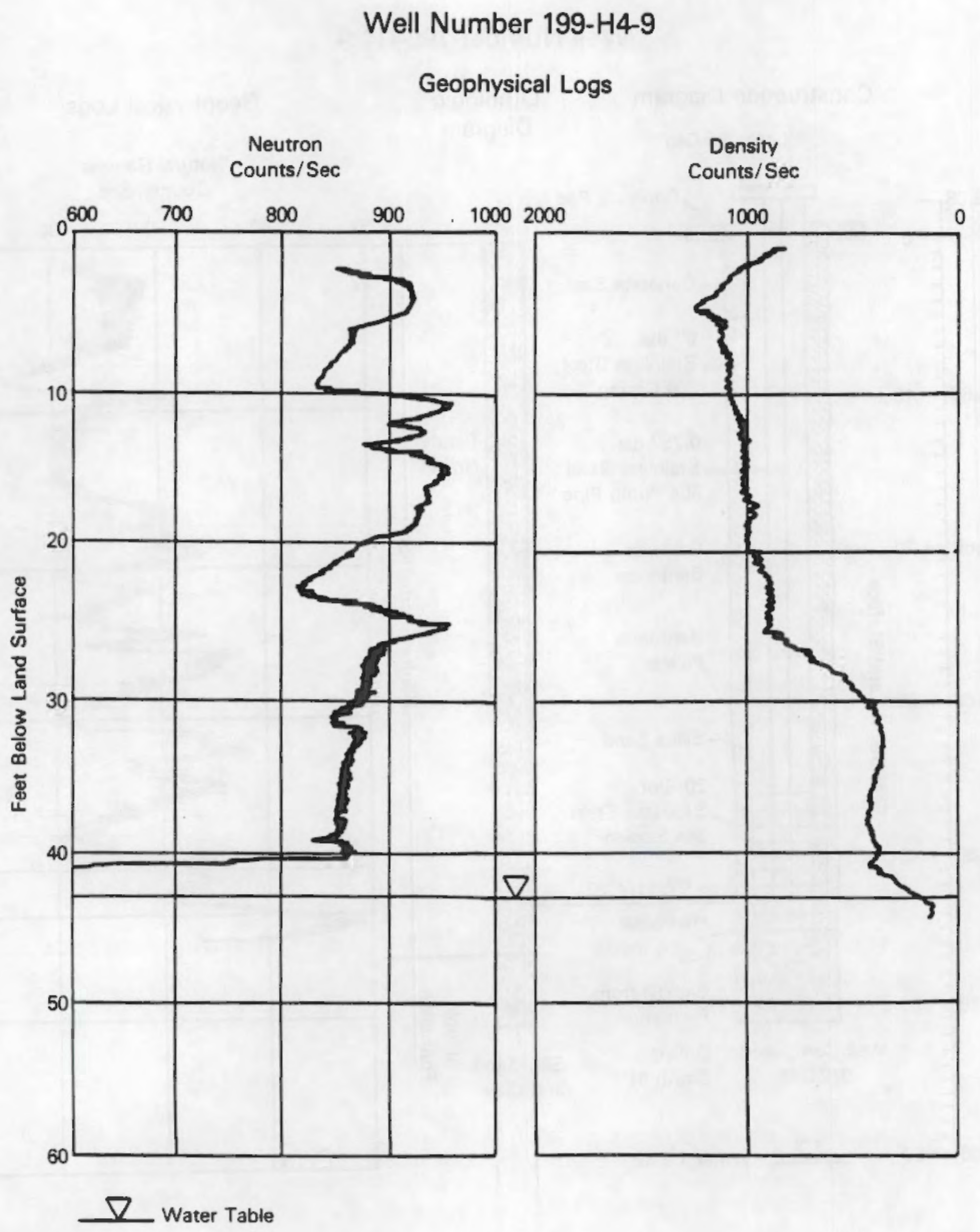




\section{Well Number 199-H4-10}

\section{Construction Diagram \\ Lithologic \\ Diagram \\ Geophysical Logs}

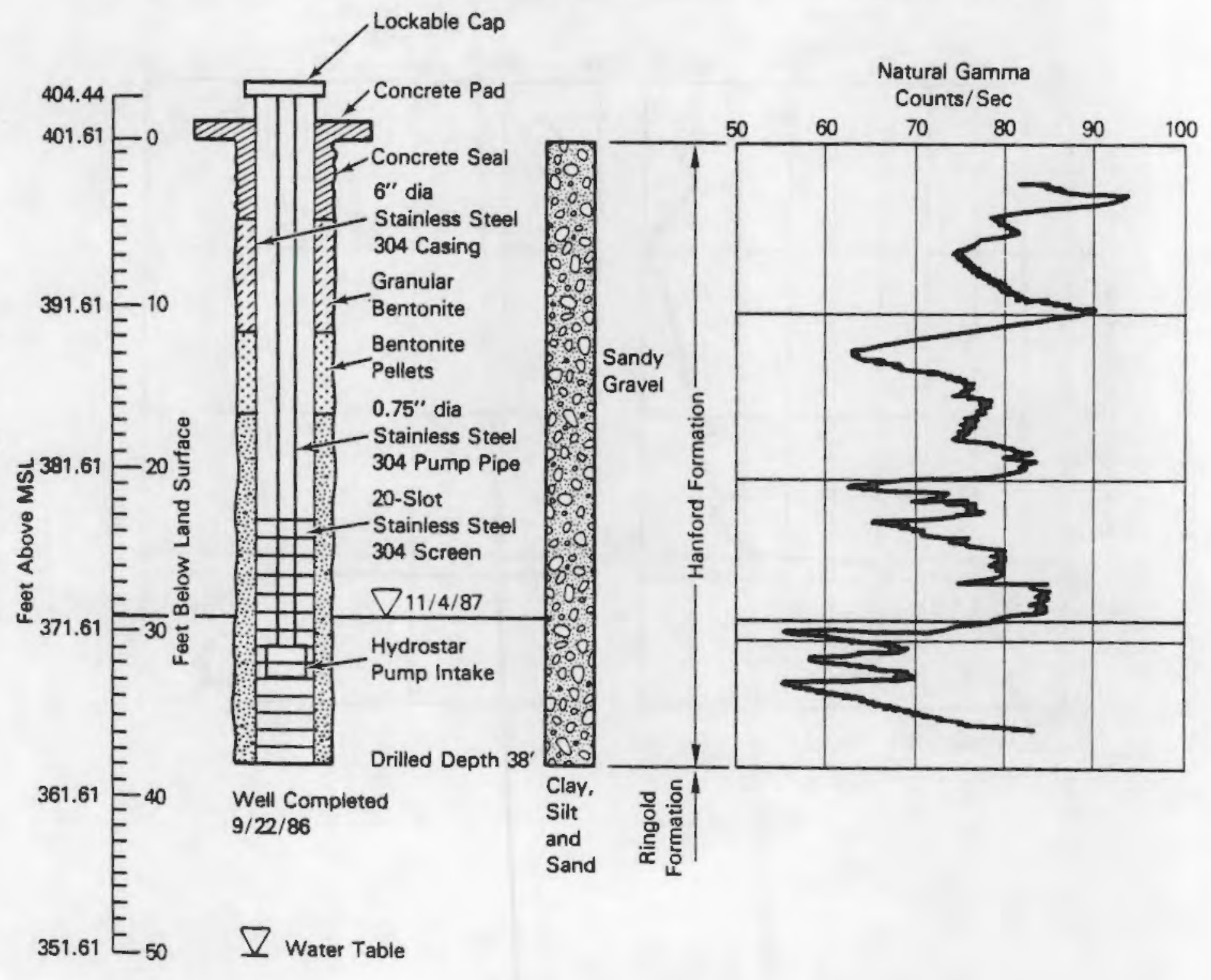


Well Number 199-H4-10

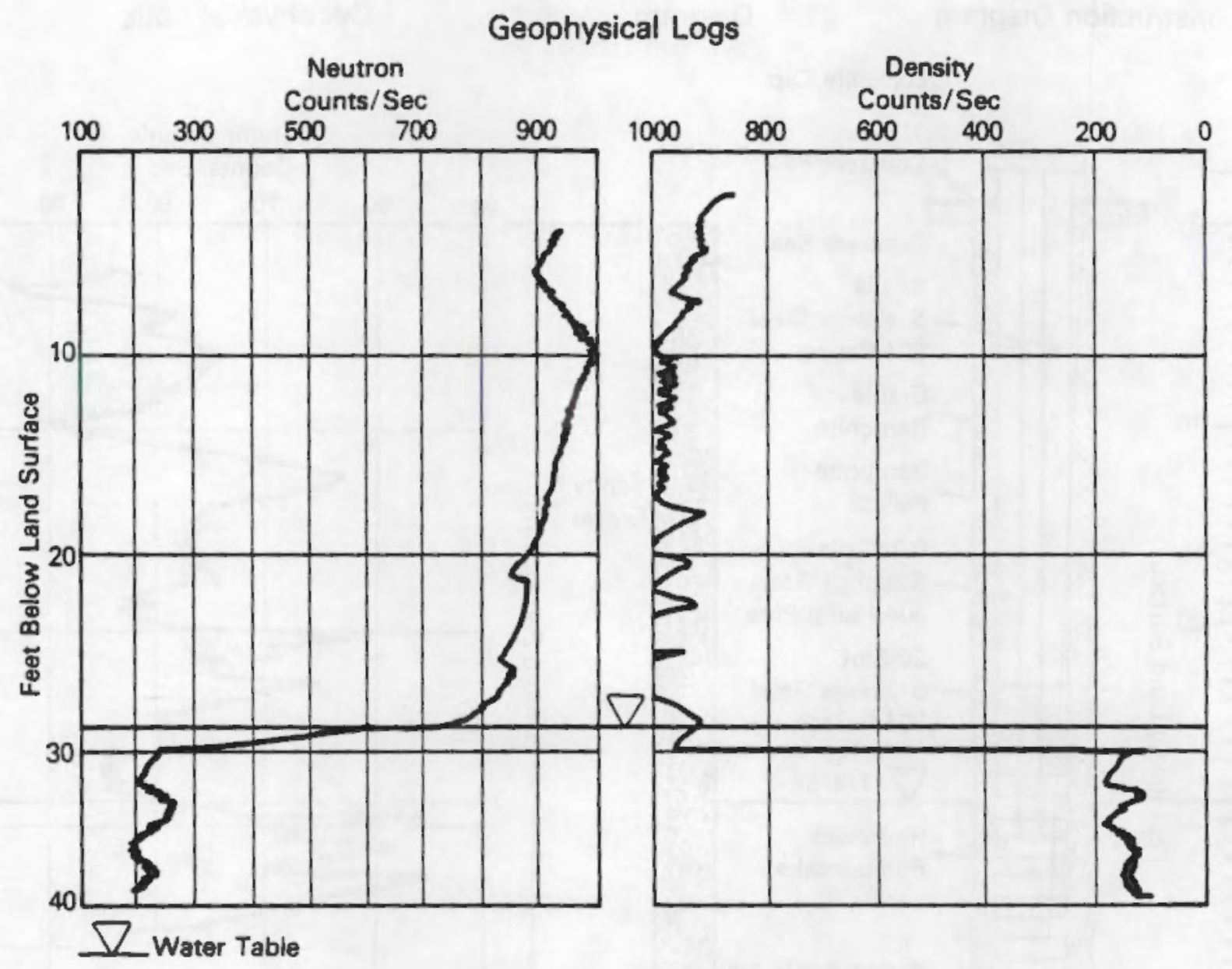




\section{Well Number 199-H4-11}

\section{Construction Diagram}

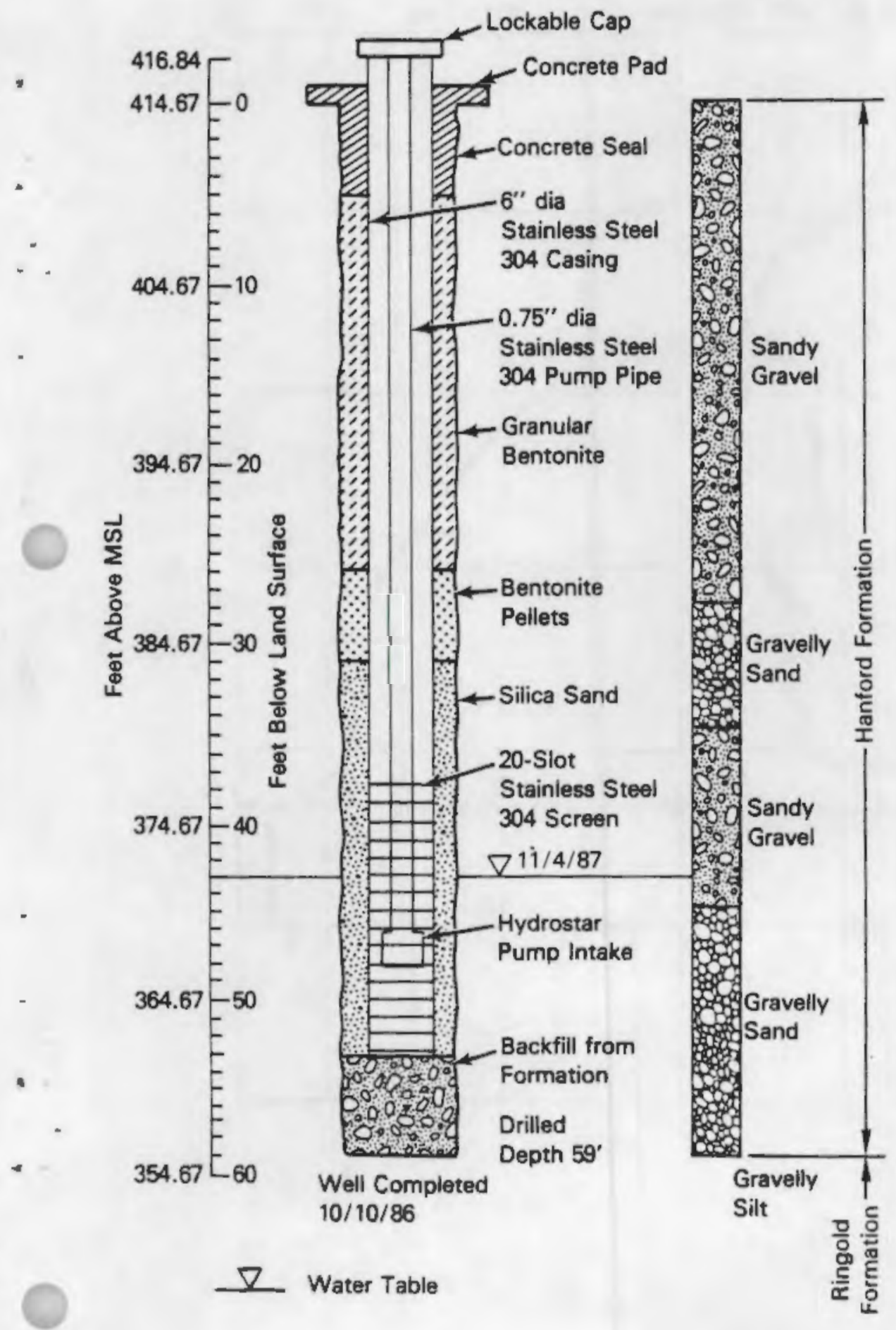

$\nabla$ Water Table

\section{Lithologic \\ Diagram}

\section{Geophysical Logs}

Naturai Gamma

Counts/Sec

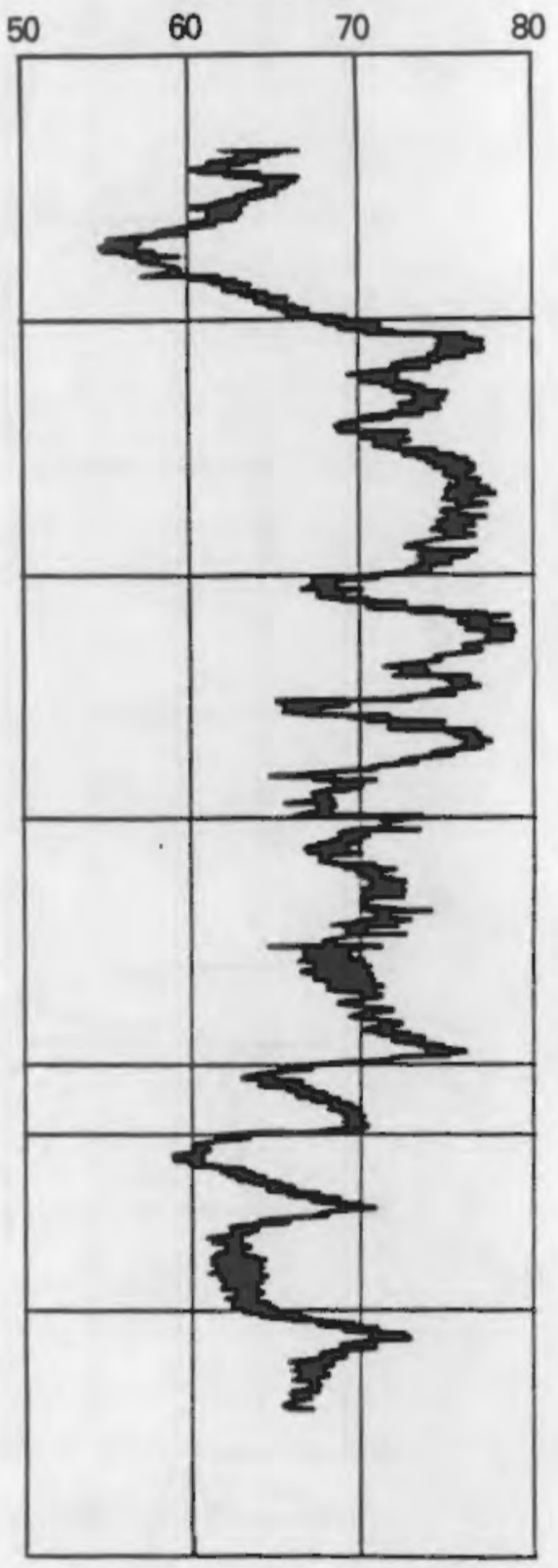




\section{Well Number 199-H4-11}

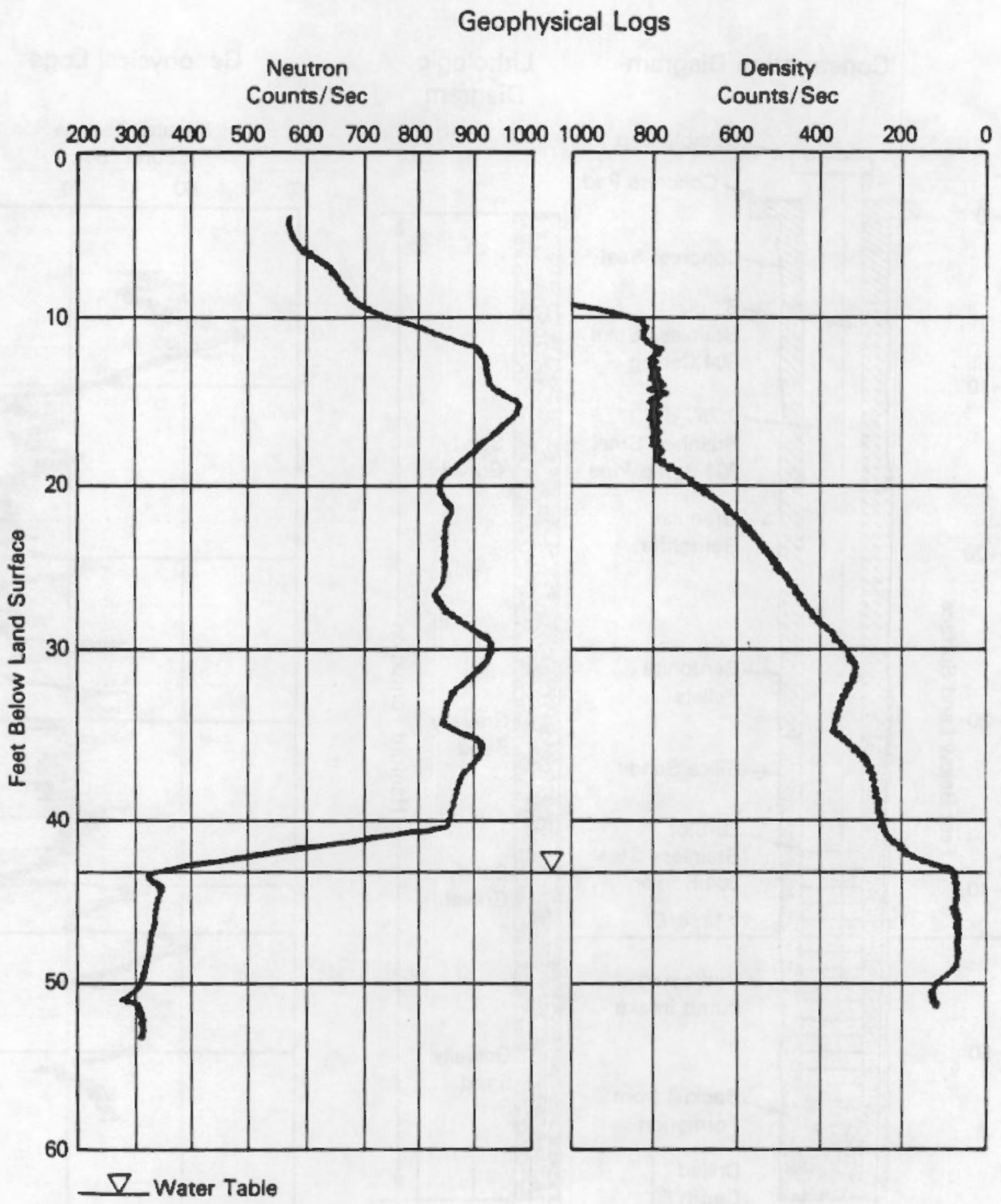


Well Number 199-H4-12A

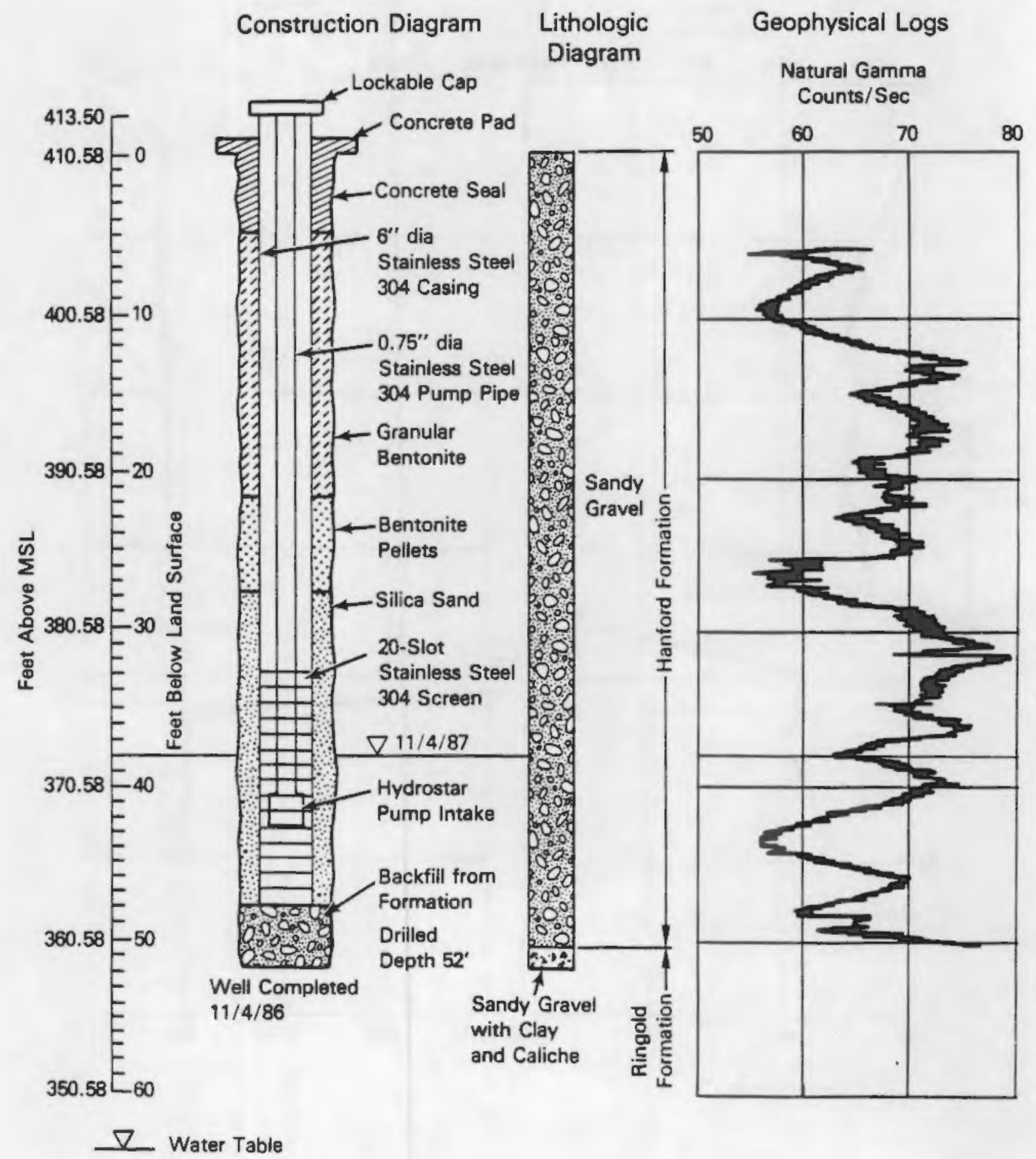




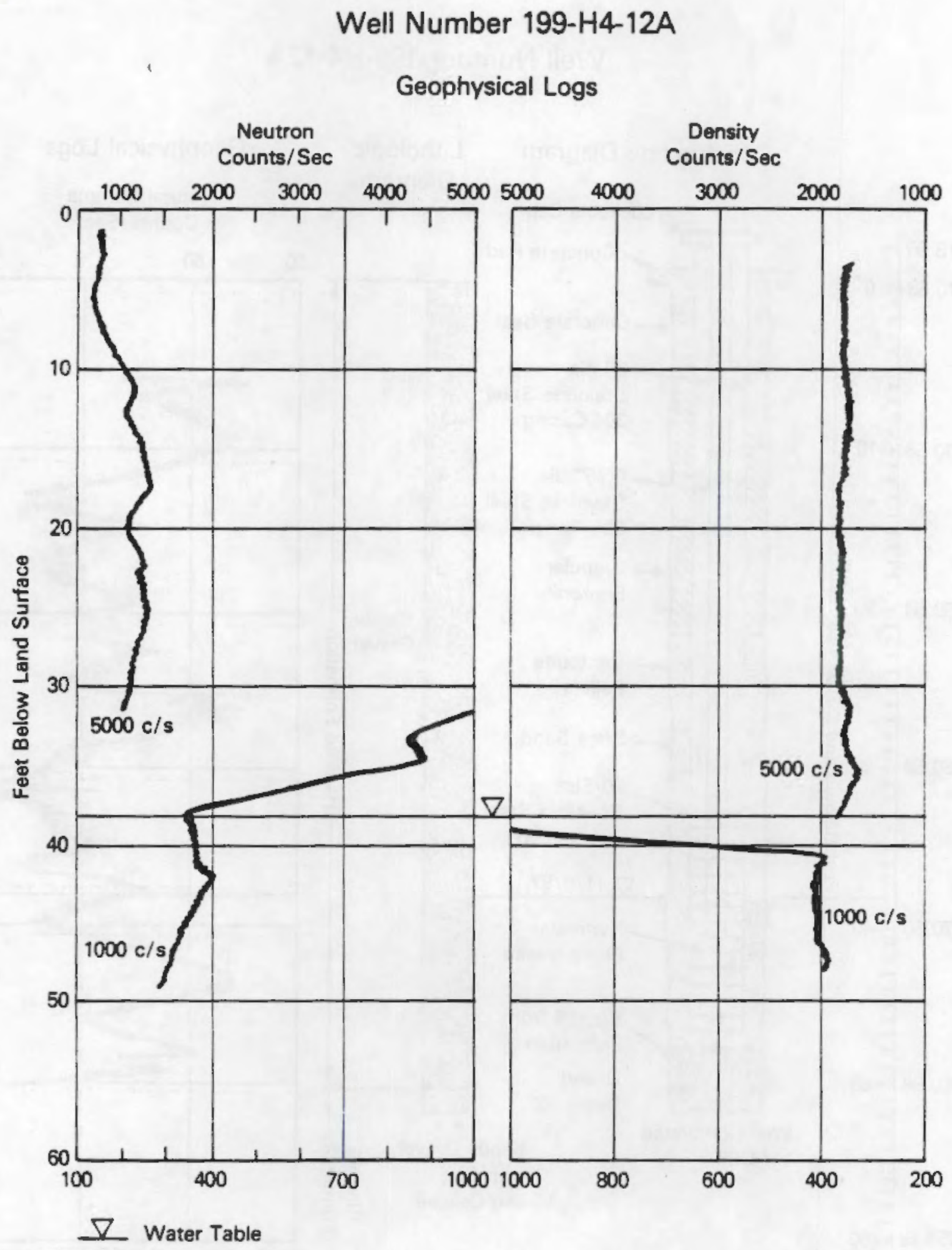


Well Number 199-H4-12B

Construction Diagram

Lithologic

Geophysical Logs

Diagram

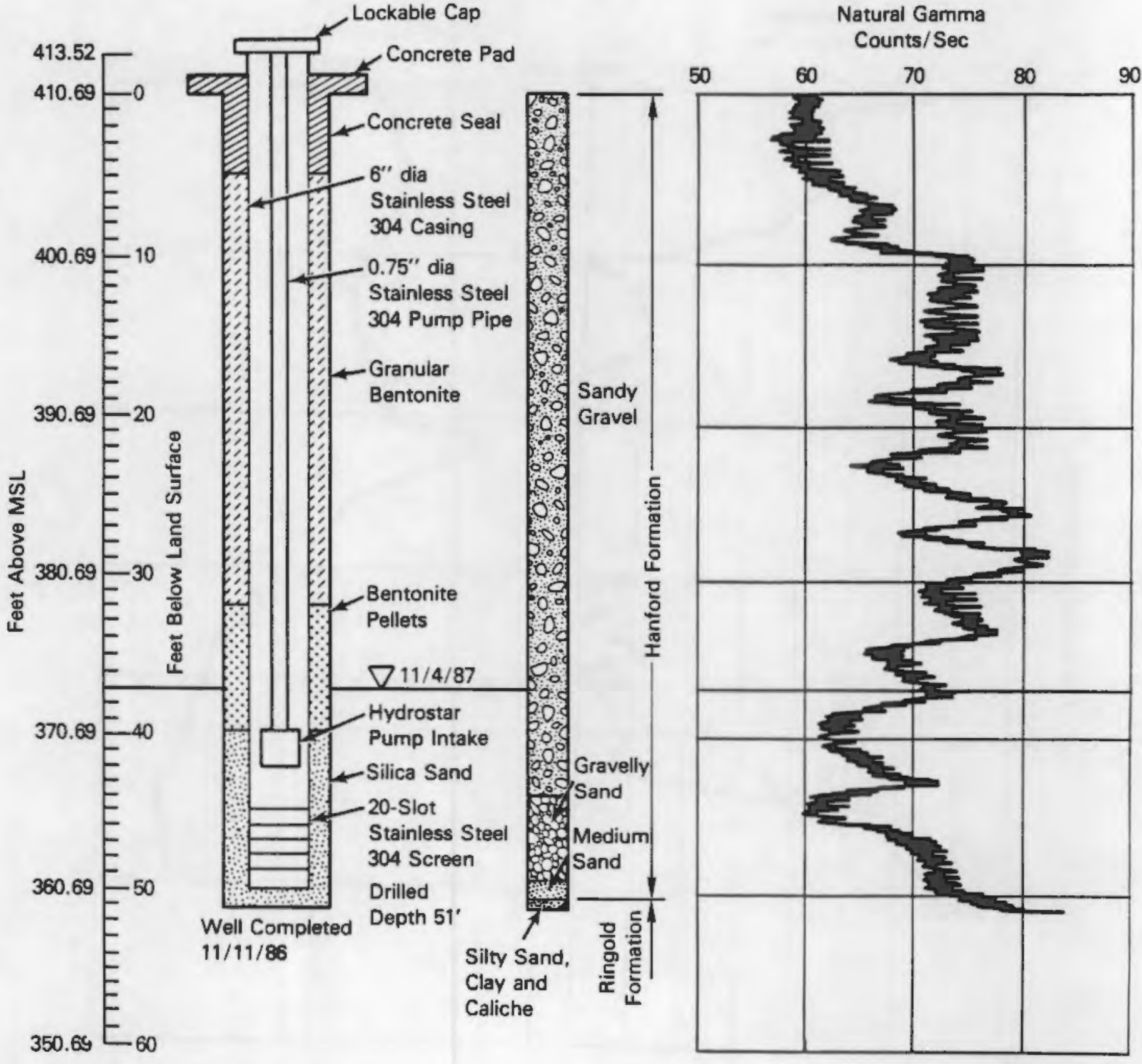

$\nabla$ Water Table 
Well Number 199-H4-12B

Geophysical Logs

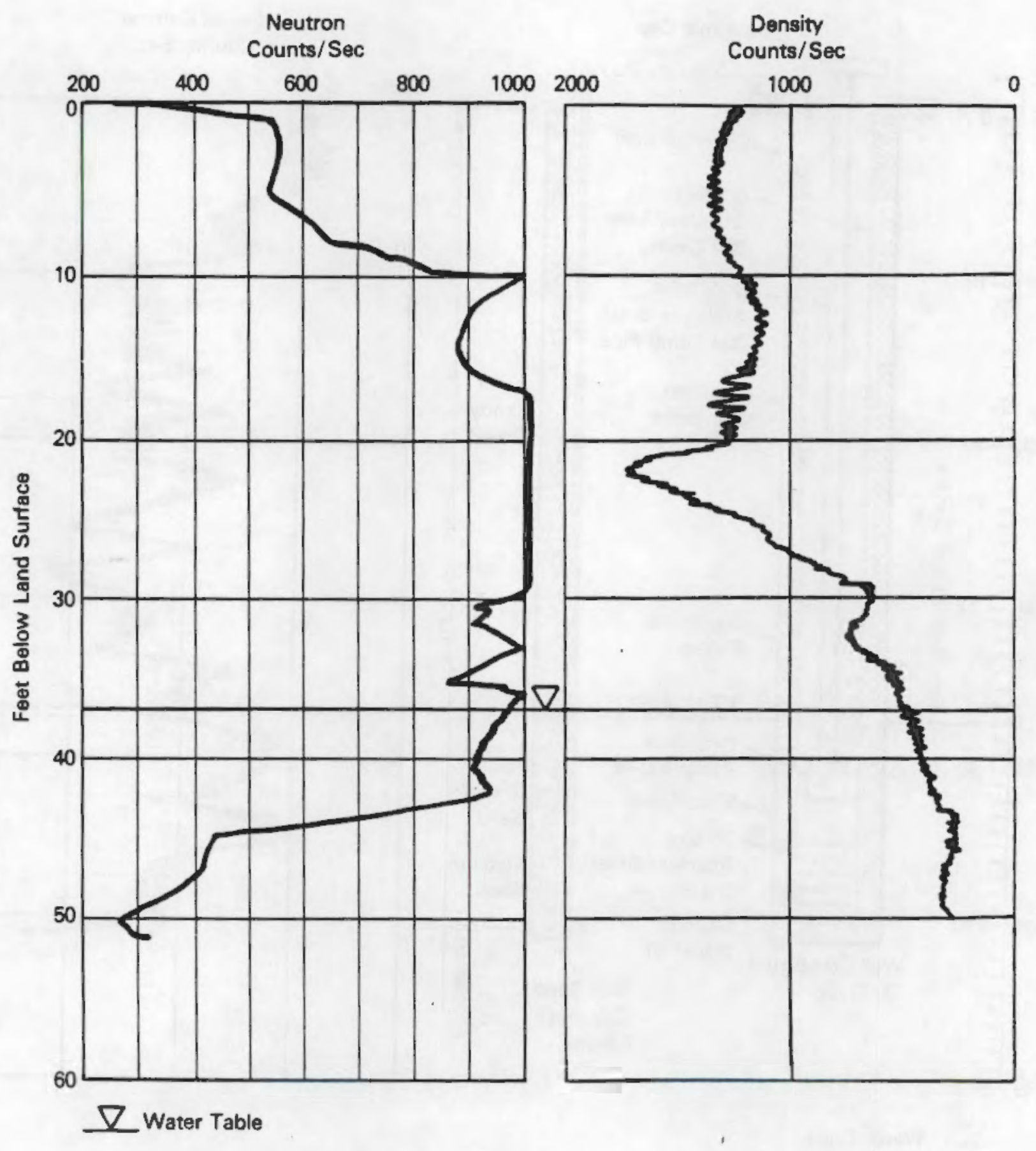




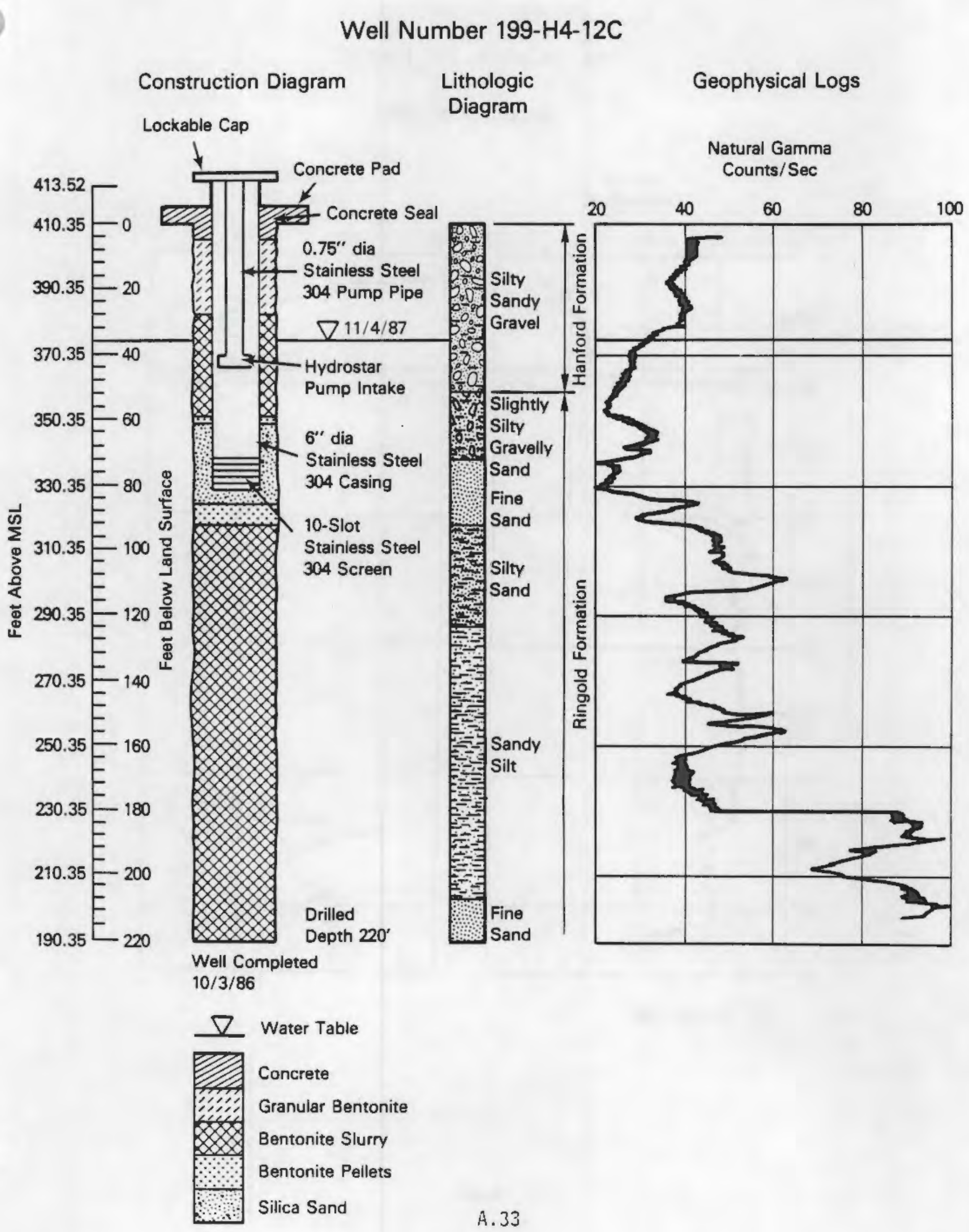




\section{Well Number 199-H4-12C}

\section{Geophysical Logs}

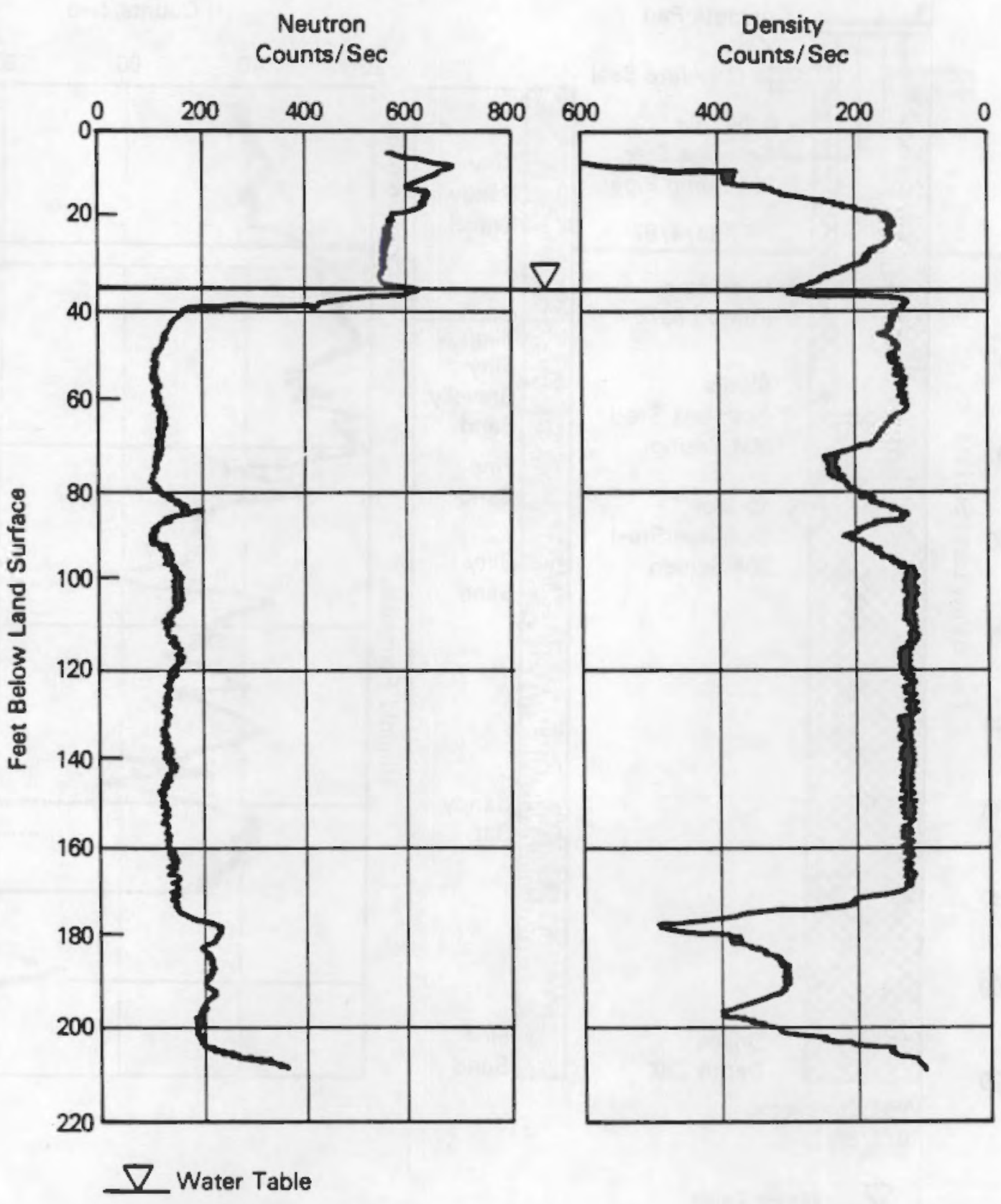


Well Number 199-H4-13

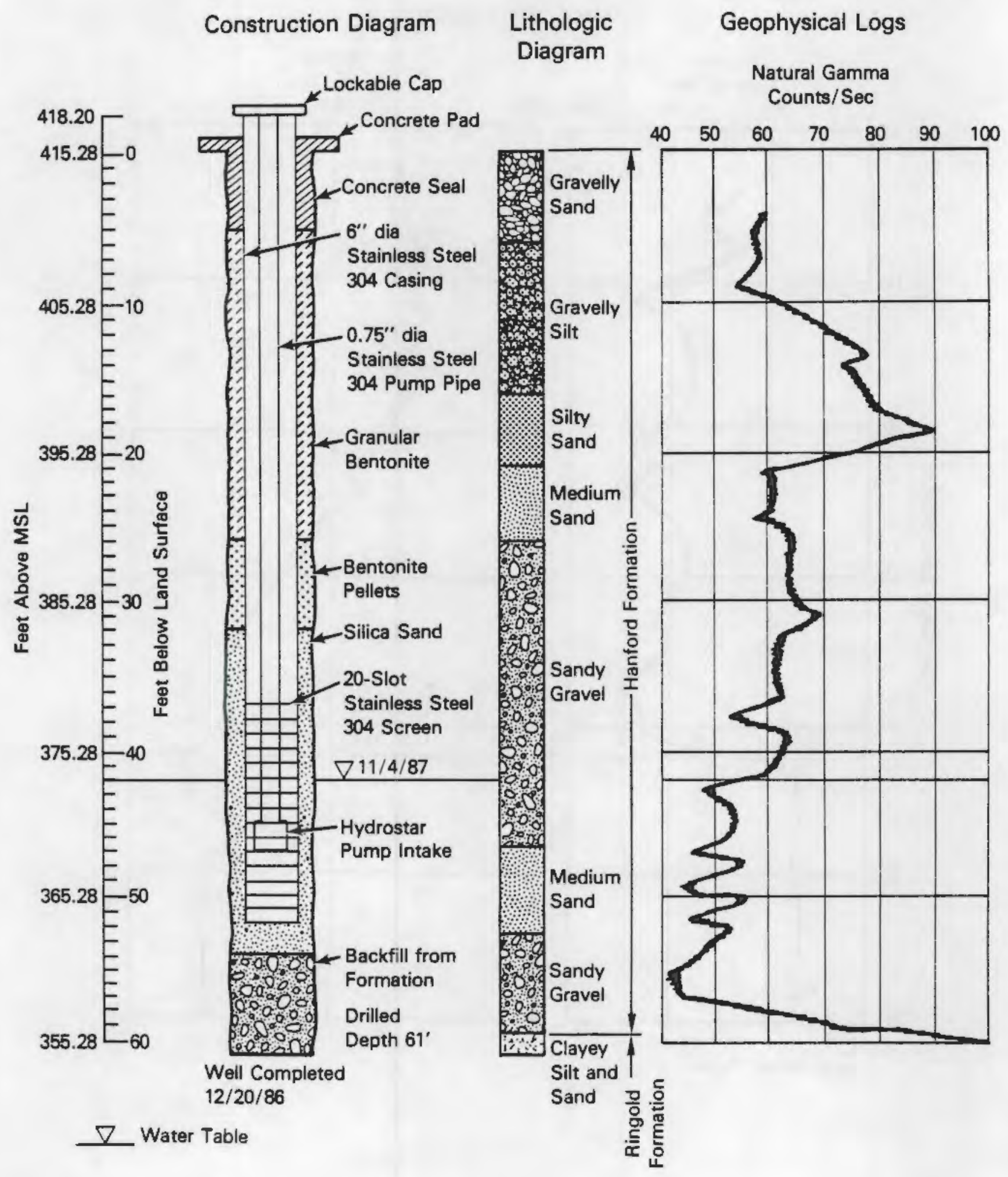




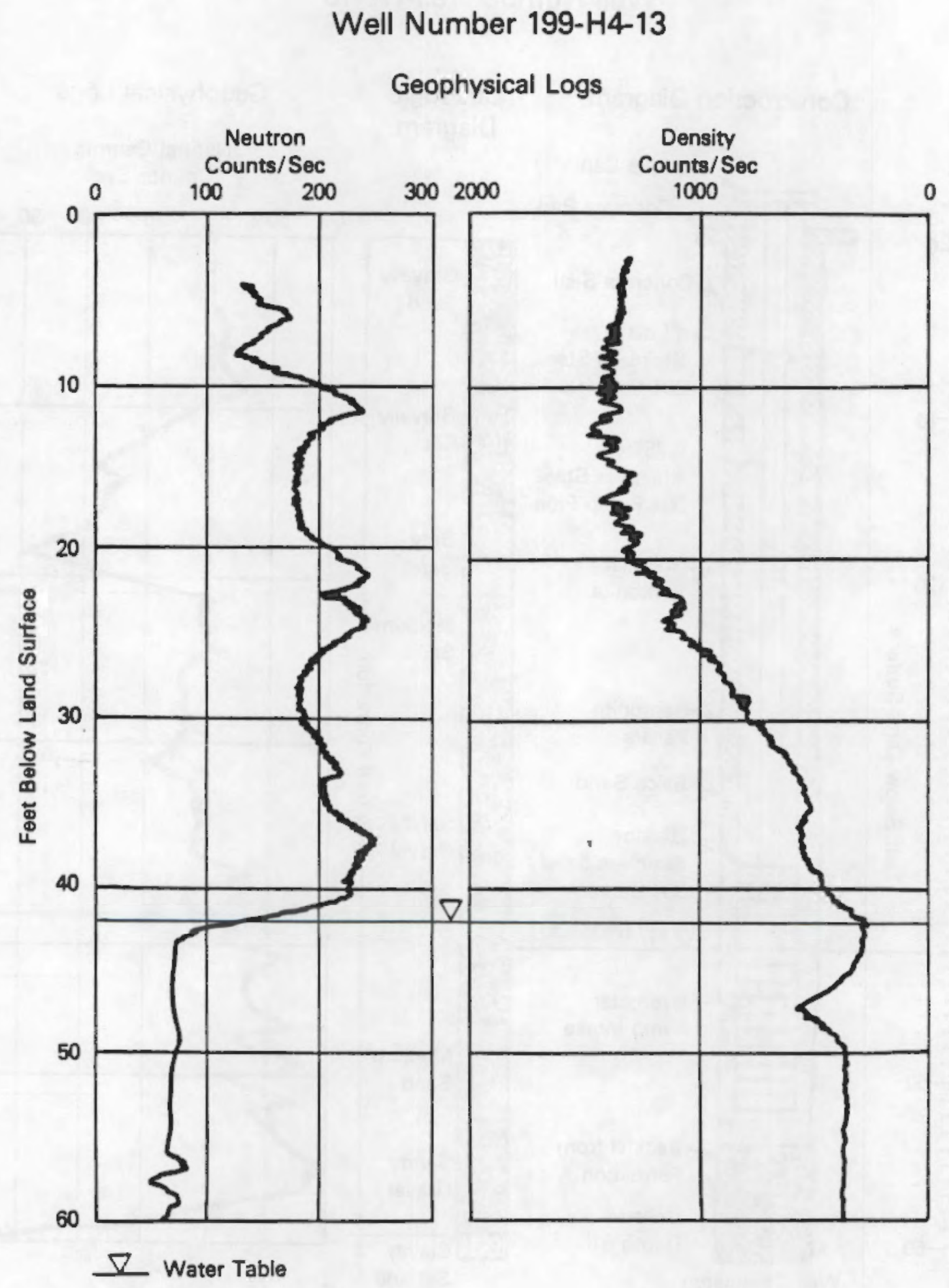


Well Number 199-H4-14

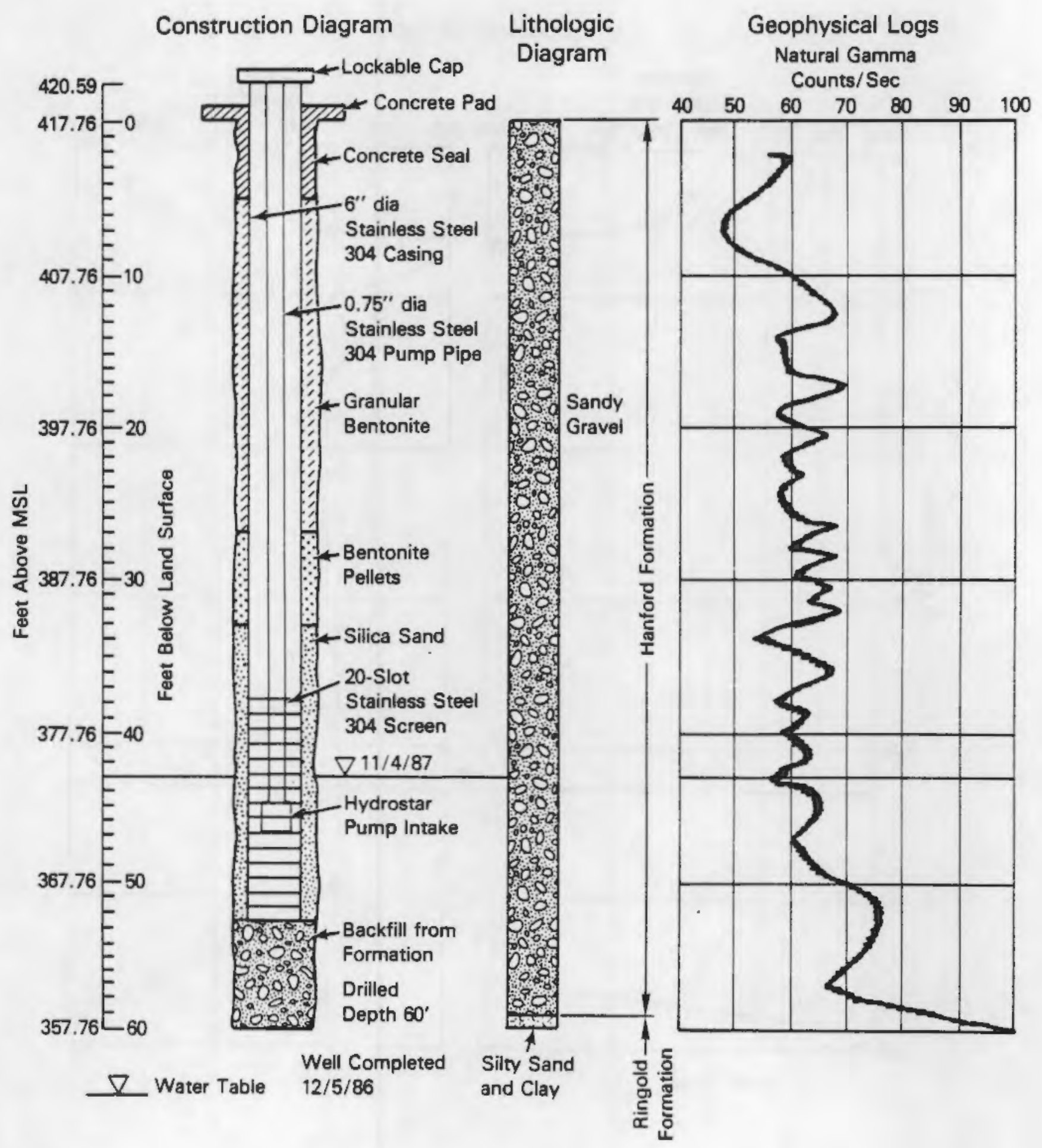




\section{Well Number 199-H4-14}

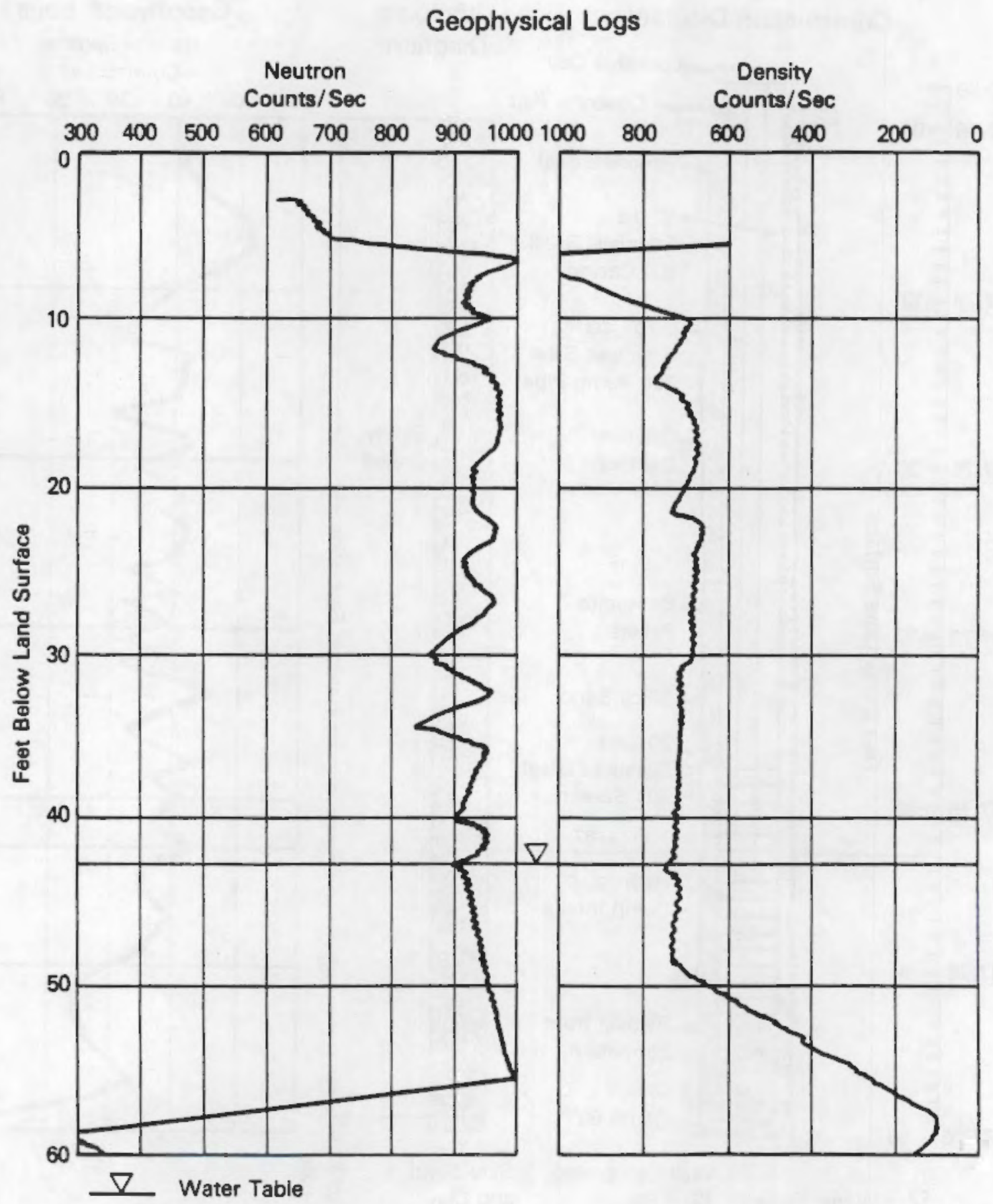


Well Number 199-H4-15A

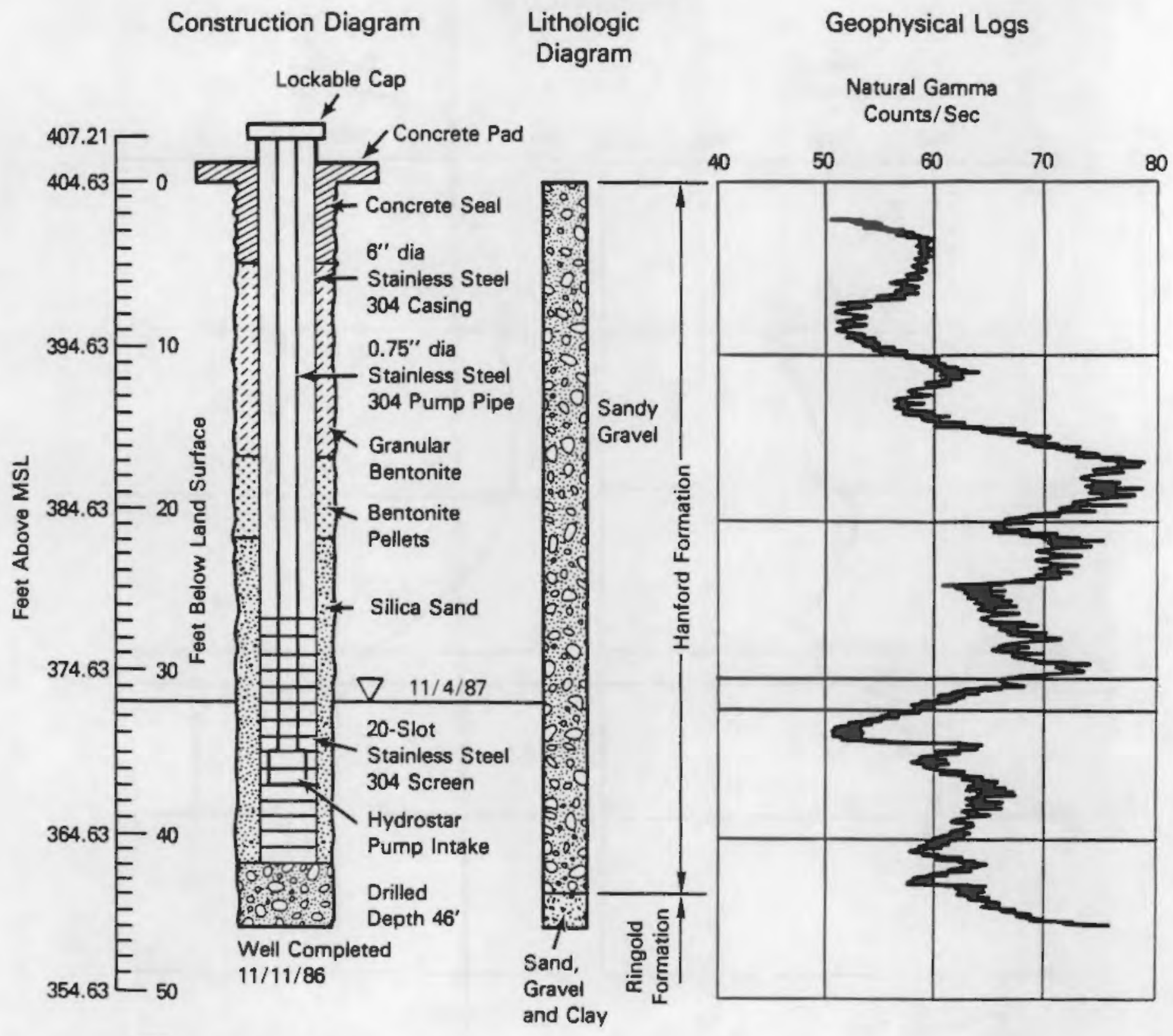

$\nabla$ Water Table 


\section{Well Number 199-H4-15A}

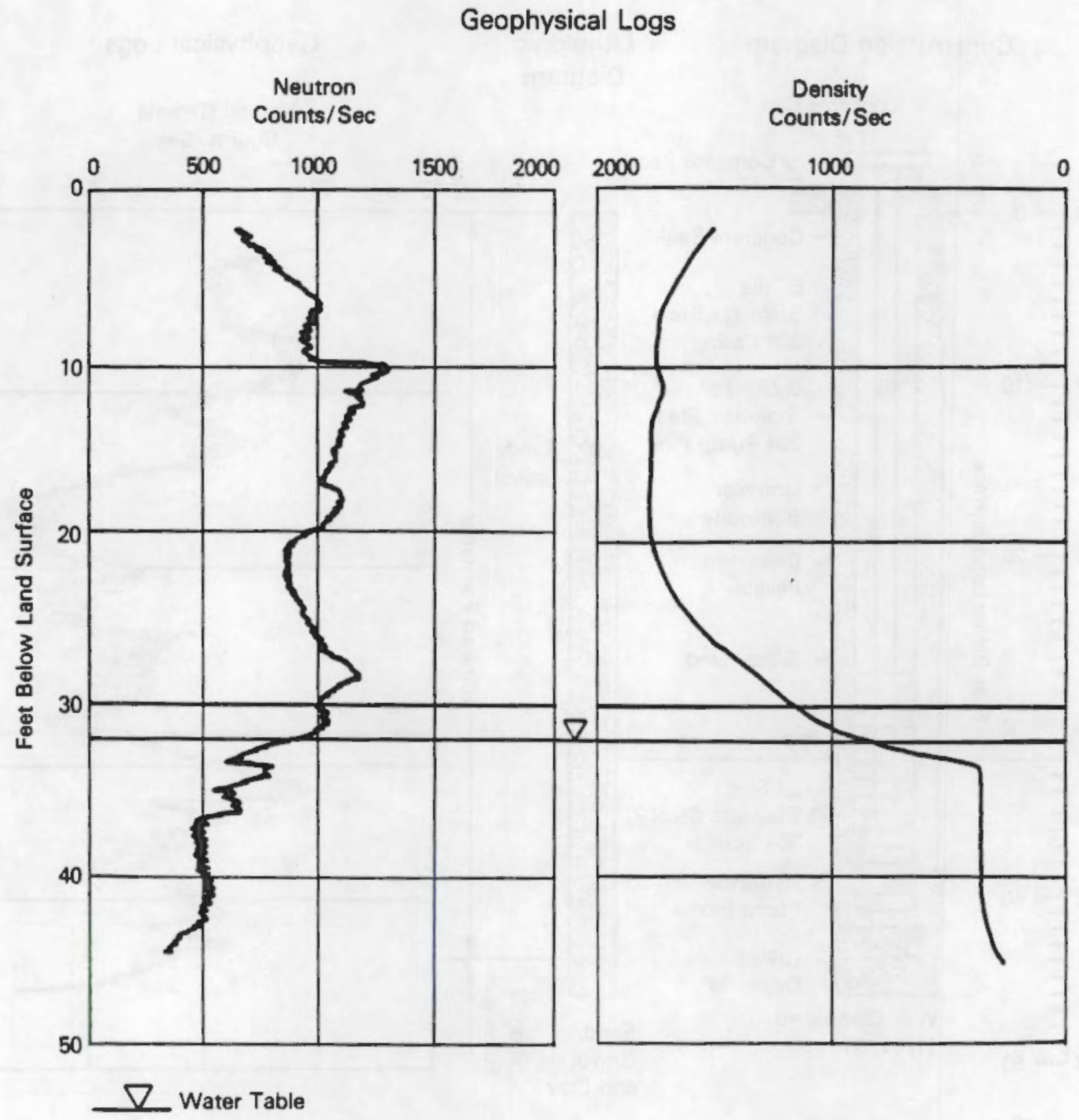




\section{Well Number 199-H4-15B}

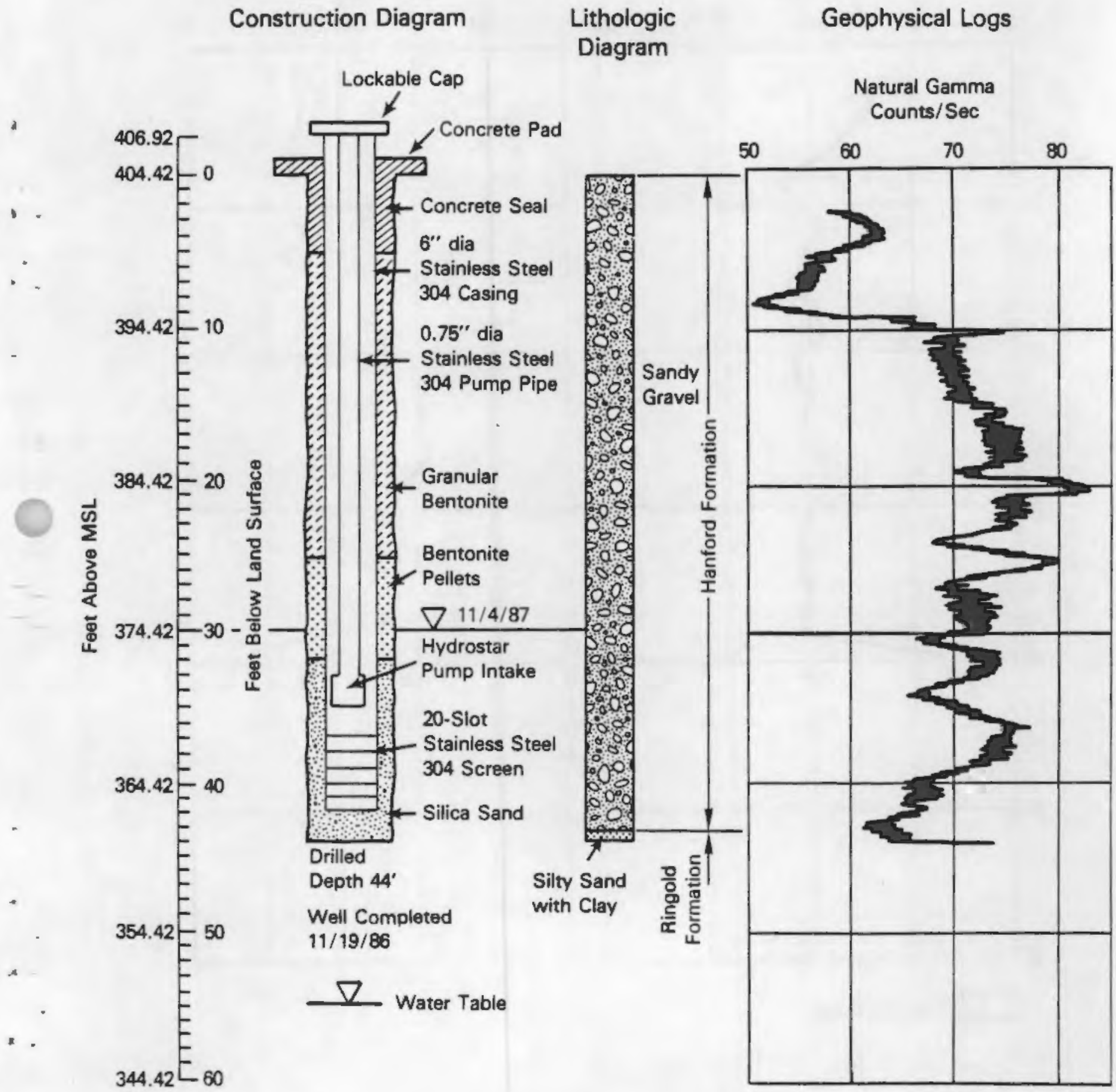


Well Number 199-H4-15B

Geophysical Logs

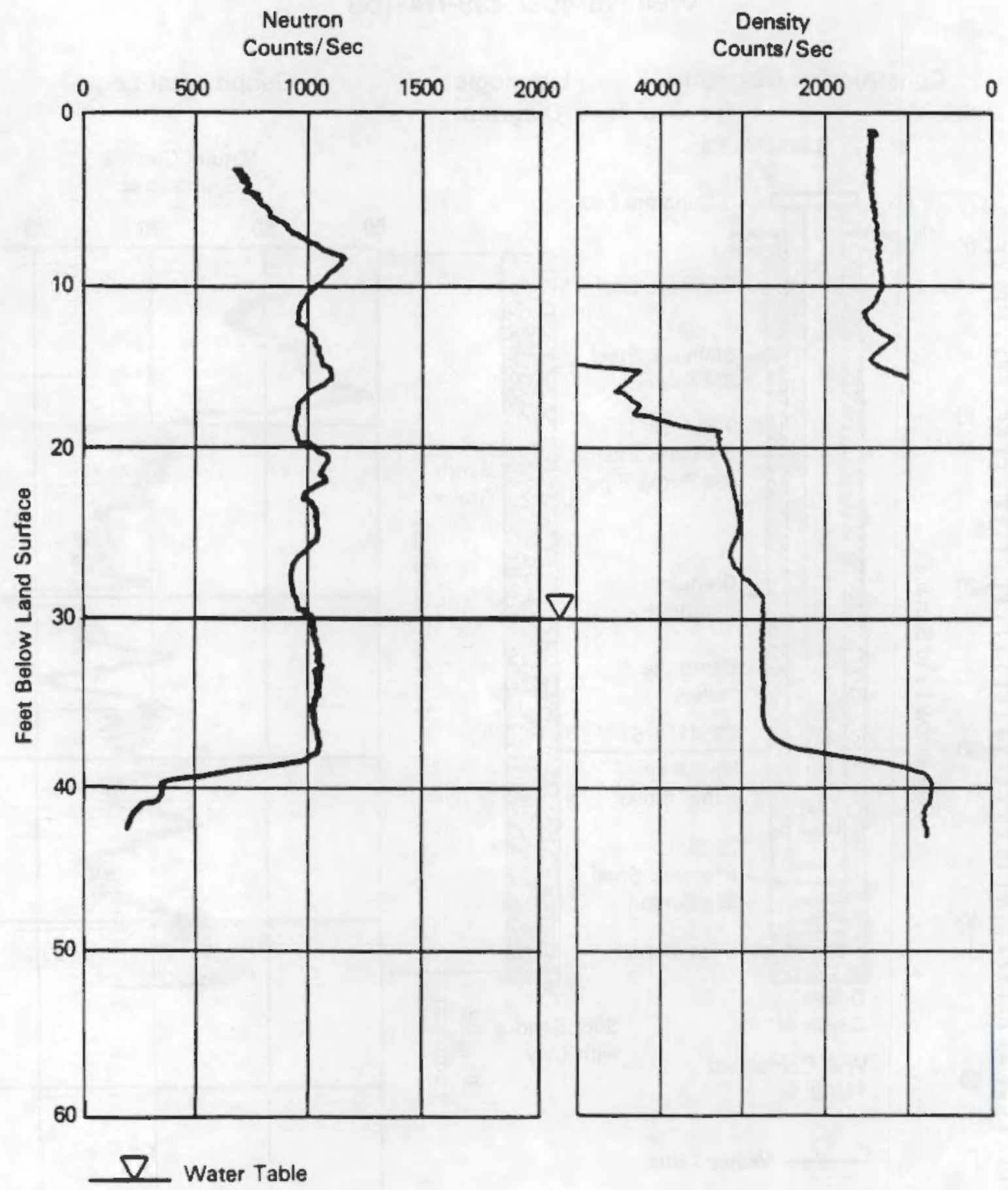


Well Number 199-H4-15C ,

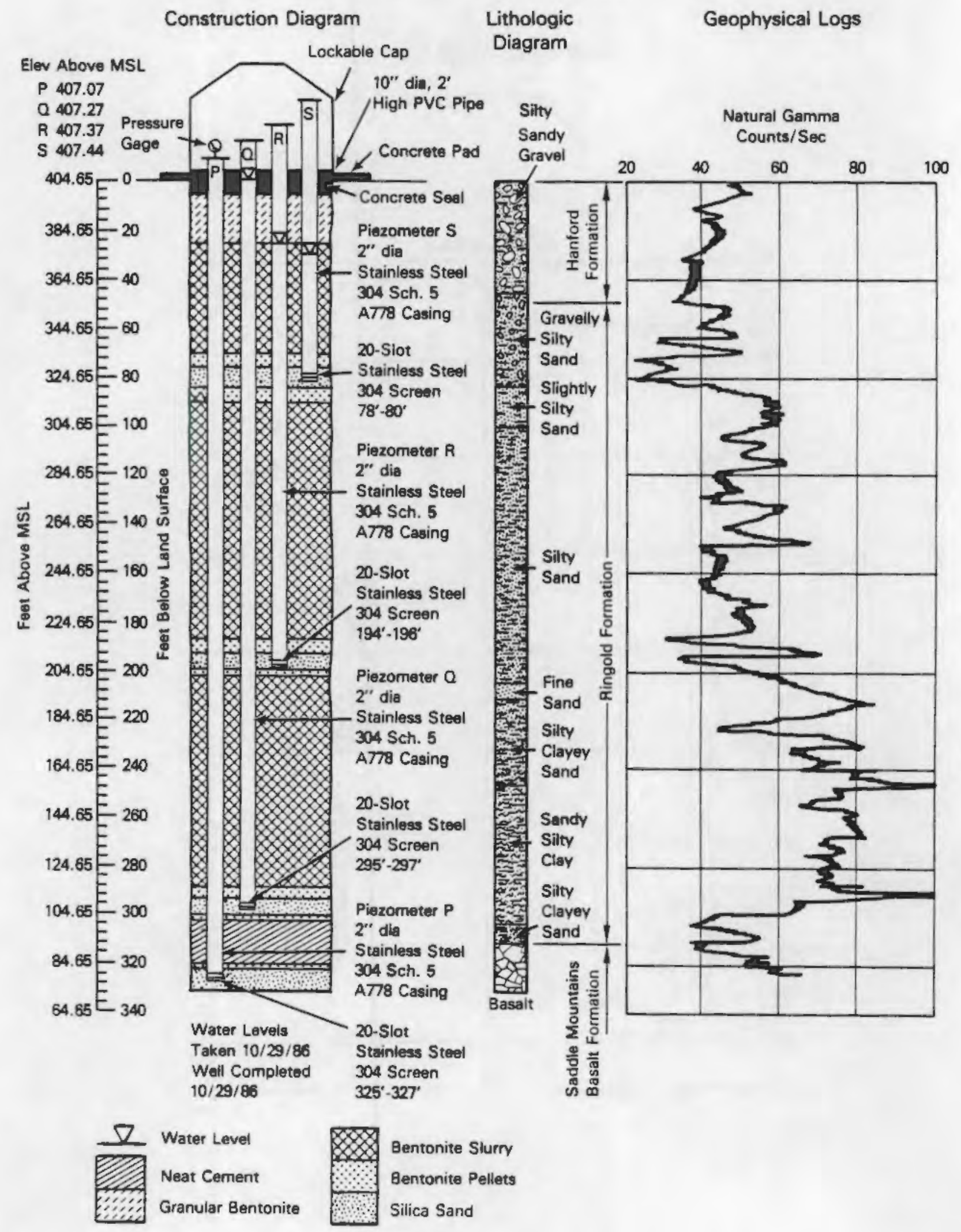


Well Number 199-H4-15C

Geophysical Logs

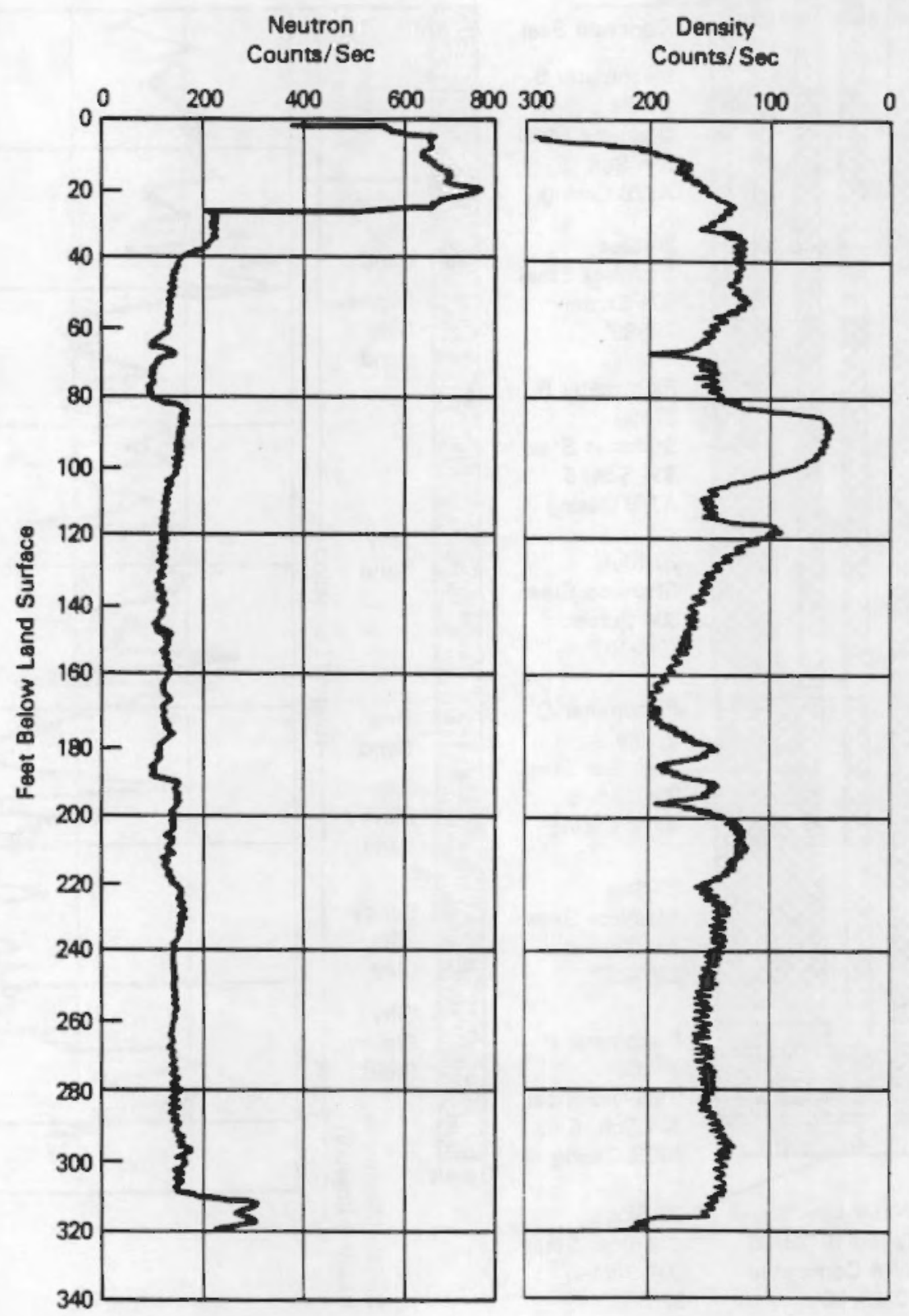




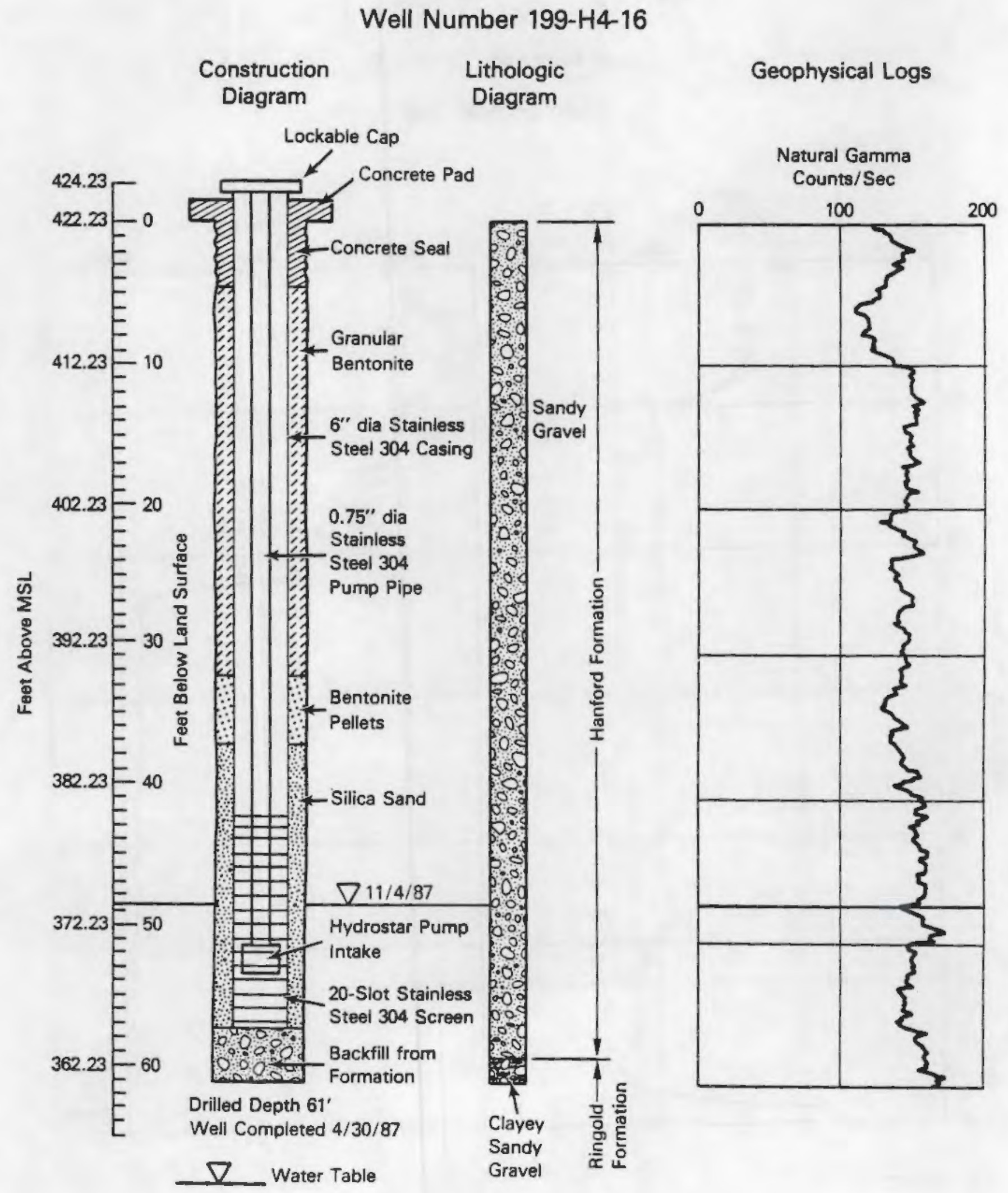




\section{Well Number 199-H4-16}

\section{Geophysical Logs}

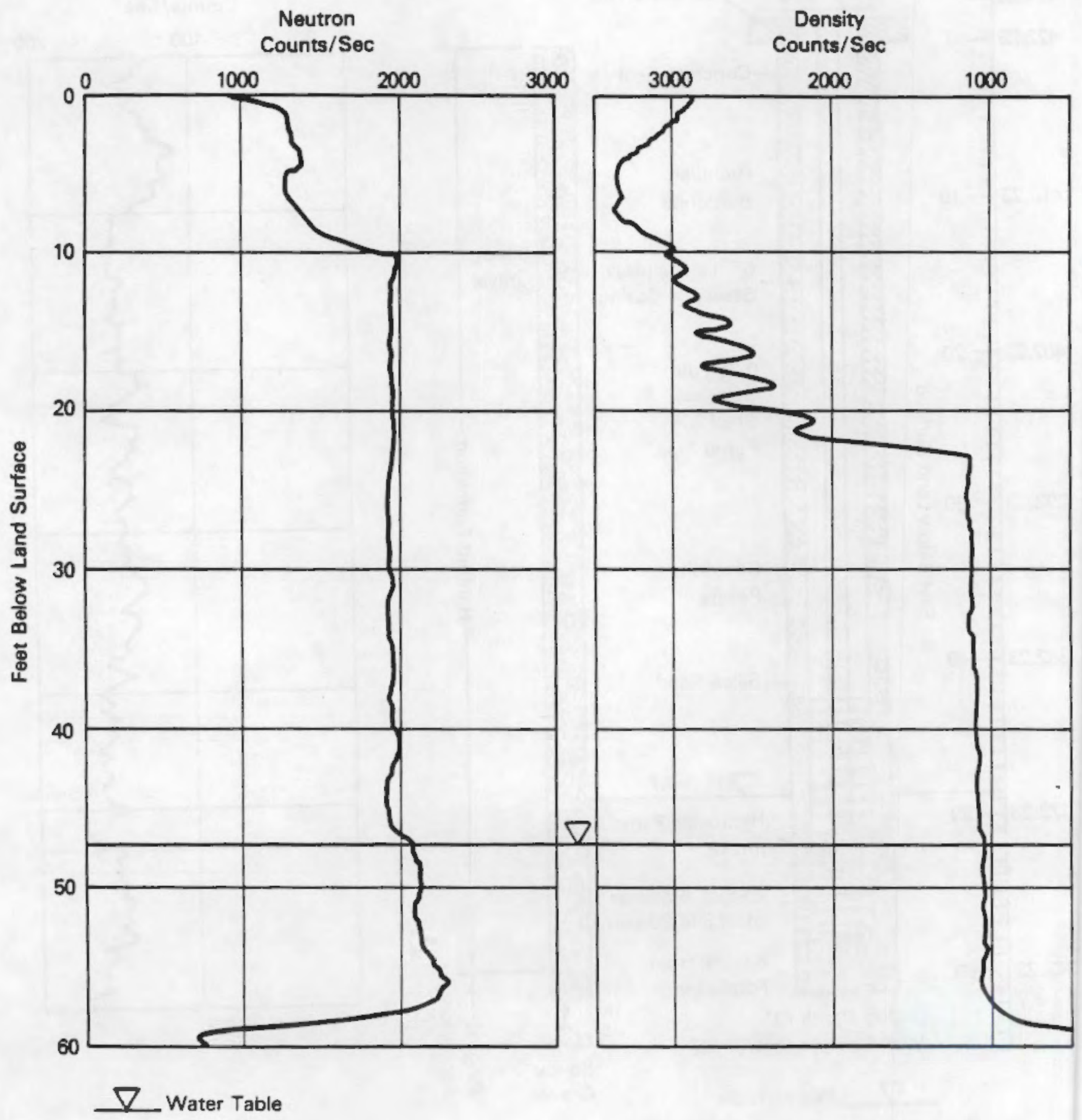


Well Number 199-H4-17

$\begin{array}{cc}\begin{array}{c}\text { Construction } \\ \text { Diagram }\end{array} & \begin{array}{c}\text { Lithologic } \\ \text { Diagram }\end{array}\end{array}$

\author{
Geophysical Logs
}

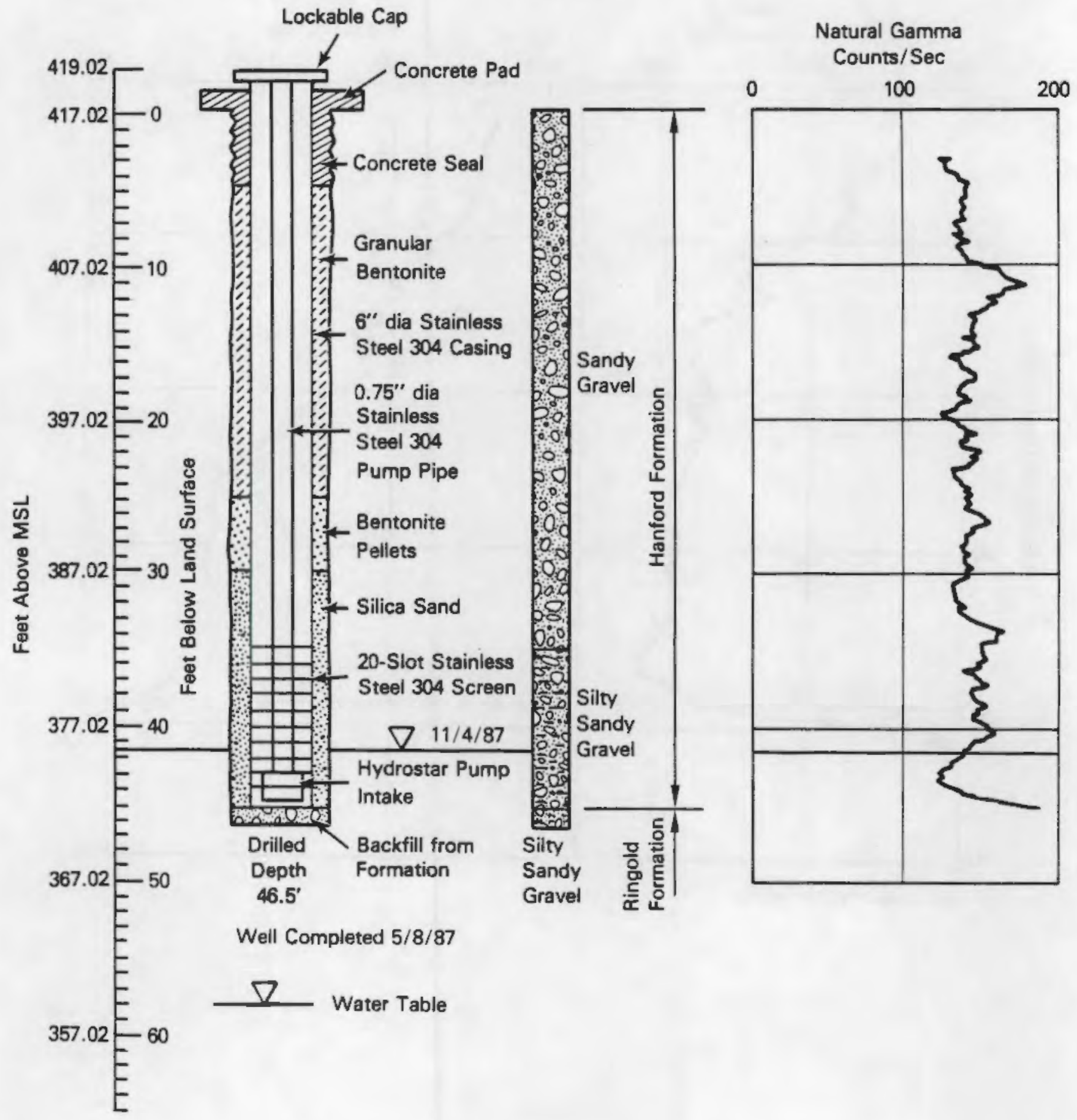


Well Number 199-H4-17

Geophysical Logs

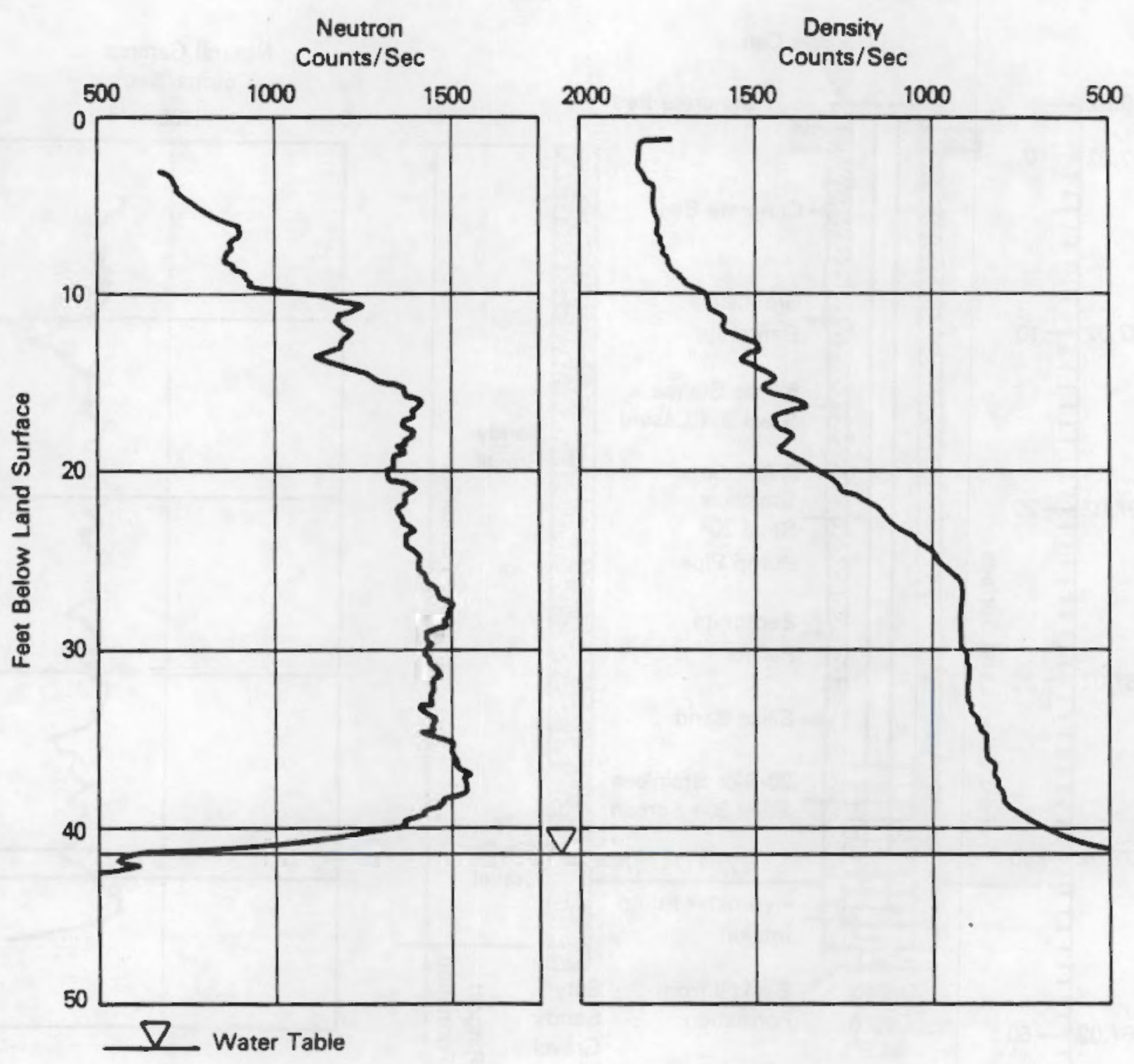


Well Number 199-H4-18

$\begin{array}{cc}\begin{array}{c}\text { Construction } \\ \text { Diagram }\end{array} & \text { Lithologic } \\ \text { Diagram }\end{array}$

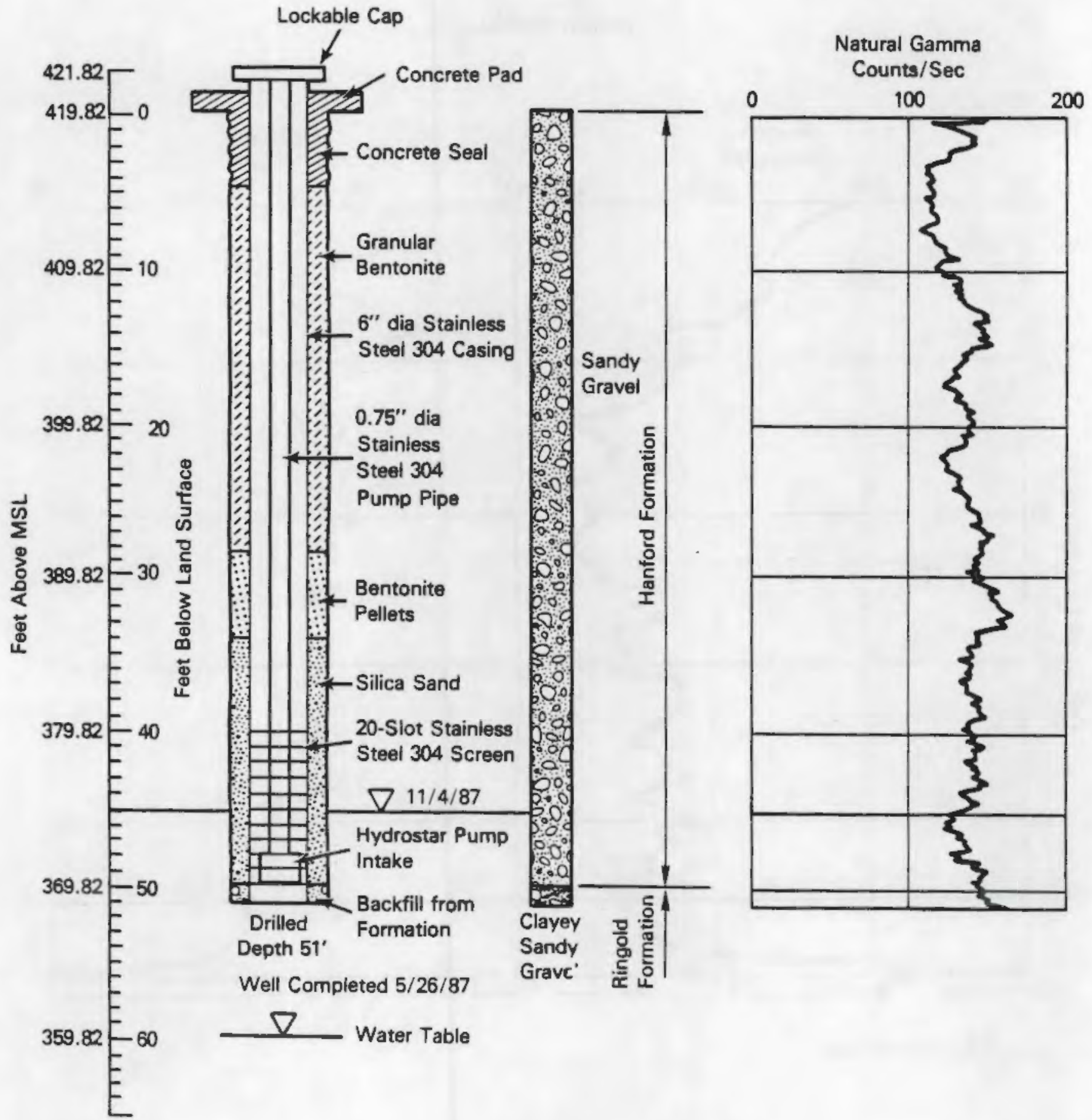




\section{Well Number 199-H4-18}

\section{Geophysical Logs}

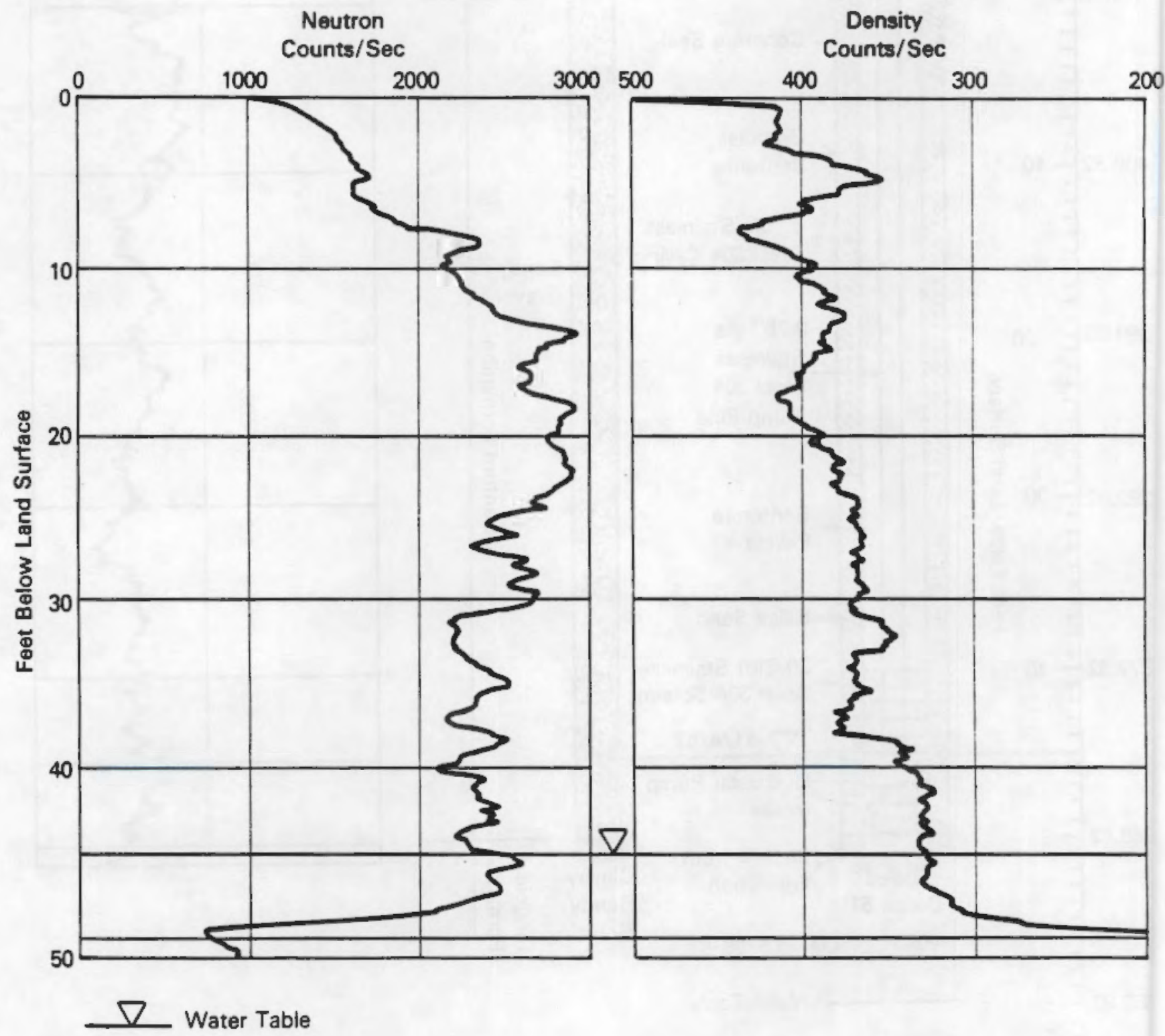




\section{APPENDIX B}

BASIC DESCRIPTIVE STATISTICS FOR THE 68 CONSTITUENTS THAT HAD AT LEAST ONE VALUE ABOVE THE DETECTION LIMIT 
- Constitumnt=1,1,1-triahlaranthane

WELEMAME SAMPES BFLOWDL OAYS

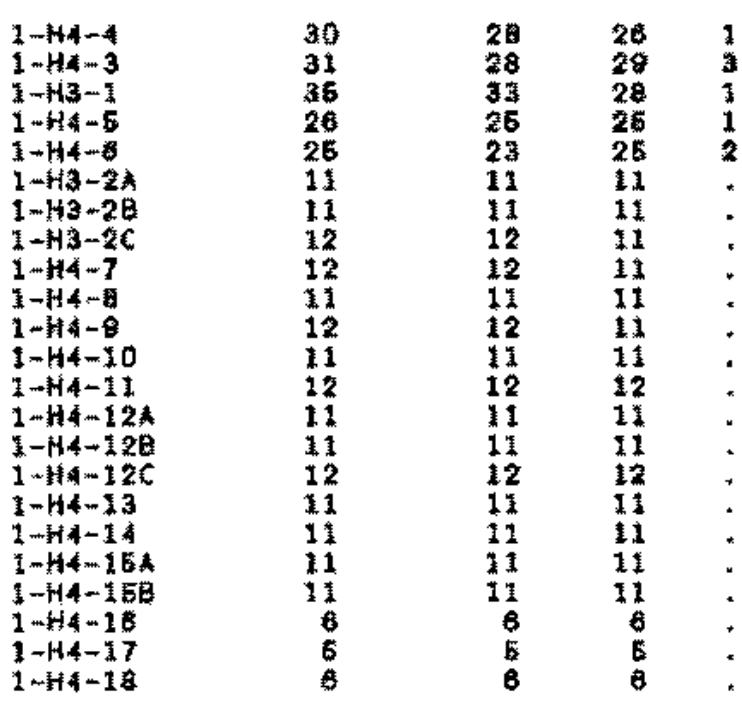

- Constituentugrass olpho

WELLWANE SKUPLES BELOWDL DAYS N

$1-14-3$

$1+1+14+4$

$1-44-12 \mathrm{~A}$

$1-\mathrm{H} 1-12 \mathrm{~B}$

$1+14-9$

$1+\mathrm{H}-\mathrm{a}$

I-

$1+k 4-5$

a-14-18

$1-14-17$

$1+3-26$

$1-44-2$

$1-44-1$

$1+14-10$

1-H3- $\mathrm{A}$

$1-\mathrm{H}^{3}-2 \mathrm{-2}$

$1-414-13$

$1+54-168$

$1-44-1 E x$

$1-1+4-18$
$1+1+4=14$

$\begin{array}{rr}30 & 0 \\ 32 & 0 \\ 11 & 0 \\ 11 & 0 \\ 12 & 0 \\ 31 & 1 \\ 28 & 2 \\ 12 & 1 \\ 37 & 4 \\ 8 & 0 \\ 1 & 0 \\ 12 & 0 \\ 11 & 4 \\ 11 & 0 \\ 12 & 0 \\ 11 & 2 \\ 11 & 1 \\ 11 & 0 \\ 11 & 3 \\ 11 & 0 \\ 11 & 1 \\ 7 & 1 \\ 11 & 3\end{array}$

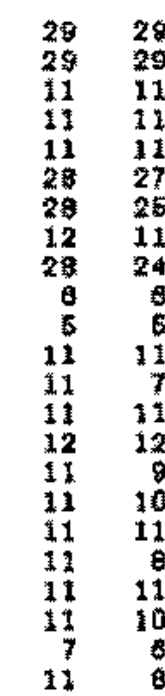

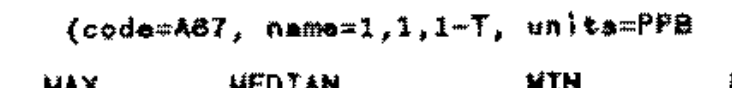

$d t=10$

, $4=200$

- $\operatorname{reg} E \mathrm{EPA})$

WAX WEDAN

MIN

0.00
52.00

0.00

0.00

93.00
22.00

115.00
2.40

1 s. 50

11.00
22.00

22.00
14.00

14.00
14.00

0.00

LEA

\$TO

c.

14.00
14.00

$1+00$

15.00

32.90

22.00

14.00
1.00

$27.0 \dot{0} \quad 0.2 \dot{2}$

.00
$:$

$:$

:

:

0.000 .00 (code=212, name=APHh, unitsmPCIfL, dl=m WAX

1230.00

148.00
39.60

21.50

13.20

11. 60

e.78

c.

8.03

4.31

4.20

3.83

3. a 5

3.34

2.91

2.91
2.70

2.70

2.32

2. 28

2,12
$1.9 ?$

vIN

71.20
3.04

199.00
$\$ 7.15$

18,00

B. 04

6. 84

2.82

1.89

2.50

2.47
2.17

2.34

1.00

2,30

2.91

1.50

1.80

1.11
1.00

1.58

1.22
RㅅNGE

11 148,80

142.96

37,12
10.31

10.31
8.75

8.75

6.63

5.71

4.91

2.5

2,04

2.78

2.07

2.17

1.79

1.79
1.82

1.82

1.26

1. 17

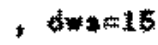

HEAN

275.22

57.37
10.98

10.21

7.43

6.12

3.10
2.38

2.38

2.86
2.92

2.89

2.46

2.64

2.36

i. 80

1. 7

$1.7 \%$

$1+34$

1.08

1.67
1.37

1.32
1.57
, $\operatorname{reg}=\mathrm{E}$ A )

sto

$245.6 \% \quad 0.80$ $32.45 \quad 0.57$ $11.7 \quad 0.82$ $\begin{array}{ll}5.22 & 0.51 \\ 2.37 & 0.39\end{array}$

1. 84 0.32

1. 020.49

1.700 .72

$1.36 \quad 0.48$

$1.27 \quad 0.43$

$\begin{array}{ll}1.31 & 0.46 \\ 0.73 & 0.30\end{array}$

1.030 .48

$0.09 \quad 0.28$

$0.59 \quad 0.29$

0.56

0.50 0.33

0.00 .45

$0.49 \quad 0.31$

$0.31 \quad 0.20$
$0.58 \quad 0.35$

0.24 
- ConntitienteAluminum

$1-144-17$

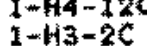

$1-\mathrm{H} 4 \mathrm{-B}$

$1+14-16$

$1-\$ 4-3$

$1+44-11$
$1-4+4$
$1-43$

$1+144-18$

1-14-15

$1-43-1$

$1-\mathrm{H} 4-5$

$1-\mathrm{H} 4-7$

$1+3+14-6$

1.-14-124

$1-1+4=9$

$1-13-2 x$

$1-113-29$

1-10 $4-10$

$1-14 \times 12$ 知

$2-114-14$

$1-H 4-16 s$

5
17
11
11
7
30
12
12
8
11
35
38
11
28
30
11
11
11
11
11
11
11
11

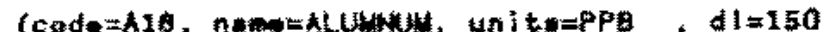

HXX

MEDTAN

IN

RANGE

10100.00

$\mathrm{s} 020,00$
3760,00

3700.00

1180.00

1160.00
1076.00

1076.00

$908 \times 00$

895.00

822,00

548.00

543.00

304.00

$\$ 47.00$

$332, \mathrm{do}$

ग0. 00

258.00

1000 . 00

1180.00

1580.00

11.60 .00

430. 00

200.00

447.00

540.00

384.00

218.00

ros.po

278.50

243.00

259.00

\subsection{0} o.? . 00 007.00

1160.00

100.00

90s, 00

224.00

822.00

$549+90$

$223 \cdot 00$

163.00

$1 \mathrm{is.00}$

226.00

25800

258.00

412.00

593.00

0.0u

asa.

\&1.00

0,00

320.00

201.00

$164.0 \mathrm{a}$

107,00

107, on

71.00

240.00
, dwa=

DEAN

2003.40

1719.80

1778.40

1132.75

529.41

000.00

$52 x .00$

822.00

540.00

383,3

246.67

205.00

278,50

248.00

250.00

201. DO

- Constituent=A I uminum, fil tored

(code=H2s, ns

WELLNAME

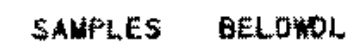

DAYS

$1+\mathrm{H} 4-12 \mathrm{C}$

$1-143-2 C$

$1+44-16$

$1+44-16$

1-44-7

$1+14+15$

1-H3-1

1. $-43-2 A$

$1+13-2 \theta$

$1-14-3$

$1+\mathrm{H} 4-4$

$1-514-6$

1-m4-6

1-54-8

$1-14-8$

$1 \rightarrow 44-10$

1.m4-120

1- $14-13$

$1-14-24$

$1-44-16$

1-k4-17?

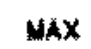

2380.00

\$70.00

602.00

454.00

438.00

31.00

202.00
WN

RANGE:

200.00

453.00

602.00

454.00

438,00

iti. 06

202,00

2180. 00

17.00
0.00

o. 00

0.00

a. 00

0.00

454.00

13. 00

3 a

, d $d x=$

WAN

$1052+40$

707.3

602.00

454.00

438.00

34 . ot

202.00

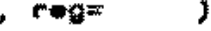

STD CY

4095.00

$1883.02 \quad 1.10$

2233.08 0.68

78․․ 38 - 25

$270.0 \dot{0} 0.51$

$343.73 \quad 0.65$

180.000 .19

$103,73 \quad 0.4$

0.74

$53.87 \quad 0.22$

$40.7 i \quad 0.20$

, $r * g=3$

5TE tV

$813.55 \quad 0.9$

$223.10 \quad 0.32$ 
- Conot i tumnteAmmon ism ion WELLNAHE SAMPLES BELOWDL

\begin{tabular}{|c|c|}
\hline 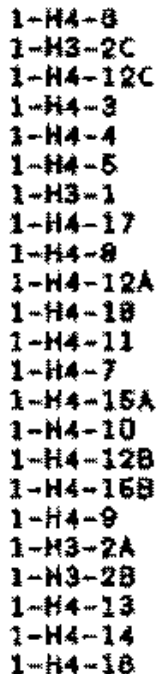 & $\begin{array}{l}27 \\
11 \\
12 \\
20 \\
32 \\
37 \\
34 \\
5 \\
11 \\
11 \\
8 \\
12 \\
12 \\
11 \\
11 \\
11 \\
11 \\
12 \\
11 \\
11 \\
11 \\
21 \\
8\end{array}$ \\
\hline
\end{tabular}

- Constituantarmonic WELINALE SAWPLES $1-44-9$ $1-\mathrm{H}+4-6$
$1-\mathrm{H}-4$ $1+H 4-3$ $1-\mathrm{H4}-12 \mathrm{C}$ 1-M-13-1 $1-43-2 C$ $1+14+150$ $1+H 3+2 \mathrm{C}$ $1+\mathrm{H}) 2$ $1-4+3-3$
$1-14-7$ $1-44-7$ i $-4+4-10$

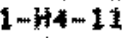
$1-4 \mid 4-12 A$ $1+\mathrm{ki} 4-1 \mathrm{t}$ $1-41-13$ 1-H4-15A $1-14-18$ $1-\mathrm{H} 4 \mathrm{-1}-1$ 1-1 4 - 19

\begin{tabular}{|c|c|c|}
\hline $\begin{array}{l}27 \\
11 \\
12 \\
20 \\
32 \\
397 \\
34 \\
5 \\
11 \\
11 \\
11 \\
12 \\
12 \\
11 \\
11 \\
11 \\
11 \\
12 \\
11 \\
11 \\
11 \\
11 \\
11 \\
8\end{array}$ & $\begin{array}{r}1 \\
2 \\
3 \\
22 \\
28 \\
18 \\
21 \\
3 \\
8 \\
8 \\
5 \\
10 \\
11 \\
9 \\
10 \\
10 \\
10 \\
11 \\
11 \\
11 \\
11 \\
11 \\
0\end{array}$ & $\begin{array}{r}27 \\
11 \\
22 \\
28 \\
28 \\
28 \\
28 \\
5 \\
11 \\
11 \\
1 \\
12 \\
11 \\
11 \\
11 \\
11 \\
11 \\
11 \\
11 \\
11 \\
11 \\
11 \\
0\end{array}$ \\
\hline
\end{tabular}

BELOWDL DAYS N

11
36
30
30
42
35
11
11
11
11
11
28
11
11
11
12
11
11
11
11
6
6
4

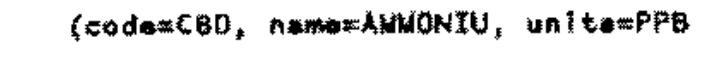

, $d=50$

WIN RANGE

783.00

528.00

503.00
189.00

168.00

172.00

100.00

91.00

42.00

37.00

146.00

104,00

74.00

60.00

86.00

67.00

84.00

54.00

$$
\begin{aligned}
54,00 \\
54,00
\end{aligned}
$$

62.00

28.60

83.00

69.50

84.60

84.00

5.5.50

64. 00

64.00

$8+00$

3.00

0.00

3.00

0.00

0.00

0.00

54.00
62.00 d dwam

MEAN

$23 \mathrm{e} .98$

208.11

261.33

180.80
133.20

123.60

187.57

89.60

8.80

74.00

64.50

56.50

54.00

54,00

54.00

$5 \% .00$
, rog 1

163.141 .10

$203.40 \quad 0.60$

$155.65 \quad 0.60$

$02.86 \quad 0.38$

60.120 .48

$67.45 \quad 0.48$

$36.03 \quad 0.26$

$64.38 \quad 0.68$

20.180 .38

$2.1 \dot{z} 0.03$

$2.12 \quad 0.04$

.

:

;

( $r \operatorname{ag}=\mathrm{EA}$ a )

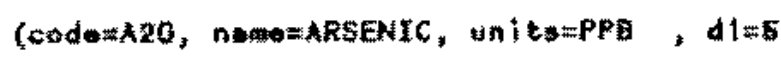

wax

MEDYAN

WIN

RANGE

ME,AN

STO $\mathrm{CV}$

13.00

0.00

5.00

11.00

8.00

8.00

3.00
8.00

8.00

6.00

5.00

5.00

$\$ .50$

8.00

8.00

5.60

$\$ .00$

8.00

B.00

4.00

3.00

2.00

0.00

1.00

0.00

7.78

8.36

6. 20

6.00

8.00

8.50

6.00

5.00

$2.19 \quad 0.32$

1. $07 \quad 0.91$

$1.79 \quad 0.29$

$0.02 \quad 0.14$

0.720 .13 
- Conatituent=aranle, flltored

WELLLAME SANPLES BELONOL

\begin{tabular}{|c|c|c|c|}
\hline 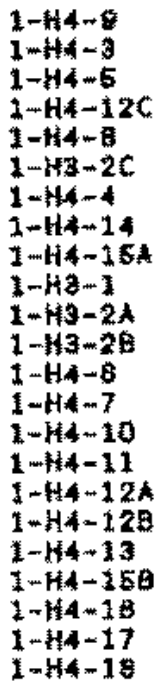 & $\begin{array}{l}10 \\
15 \\
14 \\
12 \\
11 \\
11 \\
16 \\
11 \\
11 \\
14 \\
11 \\
11 \\
14 \\
12 \\
11 \\
12 \\
11 \\
10 \\
11 \\
11 \\
8 \\
3 \\
8\end{array}$ & $\begin{array}{r}4 \\
10 \\
6 \\
0 \\
10 \\
11 \\
8 \\
10 \\
14 \\
11 \\
11 \\
11 \\
12 \\
11 \\
12 \\
11 \\
10 \\
11 \\
11 \\
8 \\
3 \\
6\end{array}$ & $\begin{array}{l}10 \\
15 \\
14 \\
18 \\
11 \\
11 \\
14 \\
11 \\
11 \\
14 \\
11 \\
11 \\
14 \\
11 \\
11 \\
12 \\
11 \\
10 \\
11 \\
11 \\
8 \\
3 \\
6\end{array}$ \\
\hline
\end{tabular}

- Const toent=Ërium

WELLWHAE SAMPLES gELDWL DAYS

$1-14-3$

$1-44-17$

$1-44-178$
$1+14-168$
$1-14-12 a$

$1-1+14-12$

$1-144-16 A$

$1-34-12 \lambda$

$1-14-8$
$1-4+10$

$1+H 4-\frac{1}{6}$

$1-\mathrm{n}+3-1$

$1+4-1$

$1-44-8$

1. $\mathrm{HA}-18$

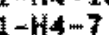

1. $+4-11$

$1+43-28$

$1+-43-13$
$1-4-13$

$1-4+18$

1

$1-114-12 C$

$1+14-14$

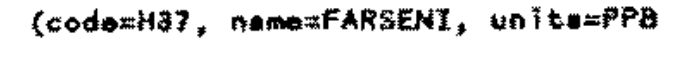

WAX MEDIAN MIN RANOE

1 $d w=60$

* reg=EPA )

15.00

0.00

7.00

7.00

5.10
5.00
6.00

5.00

7.50
5.00
5.50

5.50
6.00

5.05
5.00

5.00
5,00

5.00
5.00

7.00

6.00

1.00
4.00

4.00
2.00

2.01

2. 10

5.30

5. 00

5.00

5,00

0.00

0.00

0.00

0.00

5.00

$\vdots$

(

$\vdots$

:

(

B.B3

5.74

5.75

5.06

5,00

5.00

5.00

5.00
STO CV

.130 .85

$1.32 \quad 0.23$

0.7 o.12

$0.07 \quad 0.01$

0.0000

$0.00 \quad 0.00$

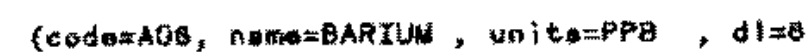

whx

437.00
153.00

$11 \%, 00$

113.00

120.60

11.00

4. 00

83.00

73.00

69.00
62.00

69.00

59.00

4)

14.00

15. 00

12.00

30.00

30.00

33.00

30.00

20. 00
MIN

16.00
60.00

92.00

73.00

22.00

33,00

$4 E .00$

37.00

39.00

37.00

16.00
41.00

41. 00

30.00

20.00

24.00

16. 00

20.00

17.00

2. 00

7.00
18.00
RANGE

42100

25.00

40.00

98,00

2. .00

56.00

38,00

36.00

30.00

25.00

4,00

16,00

13.00

16.00

18.00

18.00

20.00

18,00

21.00

11.00

23.00

10.00
- $4=100$

WEAN

98. 07

53*20

\$3. 81

A. 2.36

90.73

87.36

a. 45

4.3. 36

60, 25

50.25
41.79

$48.8 \%$

37.83

36.73

$92 * 75$

36.00

28.91

28.43

22.73

28.81

11,17
21.56
, $m$ -

sto cV

33.90

12.02

to. 81

$7.52 \quad 0.09$

$15.92 \quad 0.25$

12.01 0.18

$12.30 \quad 0.10$

7.410 .14

5.85

47

8.01 0.18

$4.82 \quad 0.13$

$5.39 \quad 0.16$

0.350 .18

4.35 0.21

0.24

0.24

$0.26 \quad 0.56$ 
- Constituentaneriva, Hiltared

\section{$1-44-158$}

$1-H 4-128$

$1-44-1$

$1-\mathrm{H}+1 \mathrm{EA}$

$1-44+\cdots$
$1+14-3$

$1-1+4+12 A$

$1+4 x-10$

$1-1+4-12$

$1-4+4-5$
$1++4-1$

$1-44=6$

$1+44-8$

1 $-W 4-7$

$1-43-20$
$1-14-18$

$1-\mathrm{H} 4-11$

$1+13-2 A$

$1-+14-18$

$1-43-2 C$

$1+44-14$

1-HA-12C

EELOHL

fed $\alpha=H 20$,

- Constituent=leryllium

WELLNAWE SAMPLES BELOMDL

DAYS N

$1-k+3-1$

$1-1 \mathrm{H3}-\mathrm{2A}$

$1-\mathrm{H3}-2 \mathrm{~B}$
$1-\mathrm{Ha}-2 \mathrm{C}$

$1-14-3$

$1-\mathrm{H} 4-4$

1-1+4- 5

$1-H 4-5$

i $-\mathrm{Hit}-\mathrm{T}$

1-

$1+1-14-9$

$1-H 4-10$

$1+44-12 k$

$1-14-12 \theta$

$1-14-12 c$

$1-H 4-13$

$1-44-14$

1 $=44-16 \mathrm{~B}$

$1-14-16$

1 $+34-17$

$1-14-18$

33
11
11
11
29
24
23
22
11
11
11
11
12
11
11
12
11
11
11
11
5
6
0

DAFS

$\begin{array}{cc}11 & 11 \\ 10 & 10 \\ 14 & 14 \\ 11 & 11 \\ 10 & 10 \\ 16 & 15 \\ 11 & 11 \\ 11 & 11 \\ 3 & 3 \\ 11 & 14 \\ 14 & 14 \\ 14 & 14 \\ 11 & 11 \\ 11 & 11 \\ 11 & 11 \\ 8 & 8 \\ 12 & 12 \\ 11 & 11 \\ 6 & 8 \\ 11 & 11 \\ 11 & 11 \\ 11 & 11 \\ 12 & 12\end{array}$

\begin{tabular}{|c|c|}
\hline$w x$ & MED IN \\
\hline $\begin{array}{r}123.00 \\
107.00 \\
06.00 \\
24.00 \\
67.00 \\
94.00 \\
92.00 \\
77.00 \\
74.00 \\
48.00 \\
80.00 \\
52.00 \\
40.00 \\
46.00 \\
41.00 \\
44.00 \\
41.00 \\
34.00 \\
33.00 \\
31.00 \\
30.00 \\
27.00 \\
16.00\end{array}$ & $\begin{array}{r}197.00 \\
89.80 \\
87.00 \\
80.00 \\
88.00 \\
20.00 \\
87.00 \\
70.00 \\
73.00 \\
65.00 \\
50.00 \\
47.00 \\
10.00 \\
38.00 \\
35.00 \\
36.00 \\
33.00 \\
24.00 \\
23.00 \\
28.00 \\
18.00 \\
23.00 \\
10.00\end{array}$ \\
\hline
\end{tabular}

wax

UIN

07.00
72.00

7.00

82.00
+4.00

44.00

33.00

42.00

48.00
47.00

47.00

4.00

30. 00

29.00

24.00

89.00

28.00

20. 00

$2 ., 00$
20,00

11.00

$1 \% .00$
7.00

$($ cod $=\lambda a 1$, mame=EERYLUM, un t tapePB,$d I=5$

\begin{abstract}
Max
WEOIAN
\end{abstract}

6. Do

5.00

JiN

DANOE

6.00

0.

RANGE

28. 010

38.00

32,00

43.00

72.00

36.00

B. 00

21.00

8.00

13.00

17.00

20.00

15.00
12.00

12.00
14.00

12. 140

1.1.

14.00

8.00

9.00

$\begin{array}{rr}28 & 1 \\ 11 & : \\ 11 & : \\ 11 & : \\ 21 & : \\ 23 & : \\ 22 & : \\ 22 & : \\ 11 & : \\ 11 & : \\ 11 & : \\ 11 & : \\ 12 & : \\ 11 & : \\ 11 & : \\ 12 & : \\ 11 & : \\ 11 & : \\ 11 & : \\ 11 & : \\ 6 & : \\ 6 & : \\ 6 & \end{array}$

, dWH=1000 ,

WEAK

107,00

95.00

3. 4.97
80. .56

a. 56

38.87

64.64

81. 71

56,43

50,00
46,79

4.79
41.36

38.95

34.65

36.33

33.87

26.45

24.50

$27+45$

19.65

23,19
10.12

STO CV

$7.05 \quad 0.07$

$12.35 \quad 0.13$

$0.06 \quad 0.11$

$14.0 \mathrm{e} 0.21$

$22.17 \quad 0.57$

18.260 .26

11.45 0.18

8.37 0.11

07
0.09

3.800 .08

6. 5 日

5.89 0.18

4.070 .14

4. 0.14

$4.32 \quad 0.18$

$3.80 \quad 0.13$

$\begin{array}{ll}5.24 & 0.27 \\ 2.04 & 0.13\end{array}$

$2.81 \quad 0.25$

,


- Conntituentmeryllium, filtered

\begin{tabular}{|c|c|c|c|}
\hline 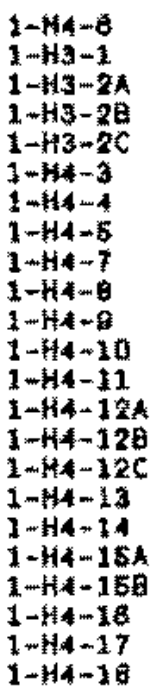 & $\begin{array}{l}11 \\
12 \\
11 \\
11 \\
11 \\
11 \\
18 \\
11 \\
12 \\
11 \\
11 \\
11 \\
12 \\
11 \\
10 \\
12 \\
11 \\
11 \\
11 \\
11 \\
8 \\
3 \\
6\end{array}$ & $\begin{array}{l}10 \\
12 \\
11 \\
11 \\
11 \\
14 \\
16 \\
11 \\
12 \\
11 \\
11 \\
11 \\
12 \\
11 \\
10 \\
12 \\
11 \\
11 \\
11 \\
11 \\
6 \\
3 \\
6\end{array}$ & $\begin{array}{l}12 \\
12 \\
11 \\
11 \\
11 \\
53 \\
12 \\
11 \\
11 \\
11 \\
11 \\
11 \\
12 \\
11 \\
10 \\
12 \\
11 \\
11 \\
11 \\
11 \\
8 \\
3 \\
0\end{array}$ \\
\hline
\end{tabular}

- Constituent=6rowa botis

WELLNANE SANFLES ELLOMOL

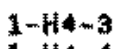
$1-34-4$
$1-44-124$ $1+44-124$
$1-H A+9$ 1.

$1-14-128$

$1+14-11$

$1 .+14+18$

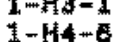

$1-144-16$

$1-14+5$

$1-44-17$
$1+44-168$

$1-44-15 A$

1. $-4 a-2 c$

$1-14-14$

1. $-4+4$

$1-13-28$ $\operatorname{lin}+1+3-2 k$

$1-\$ 1+12 C$

$1+44-10$
(Fod

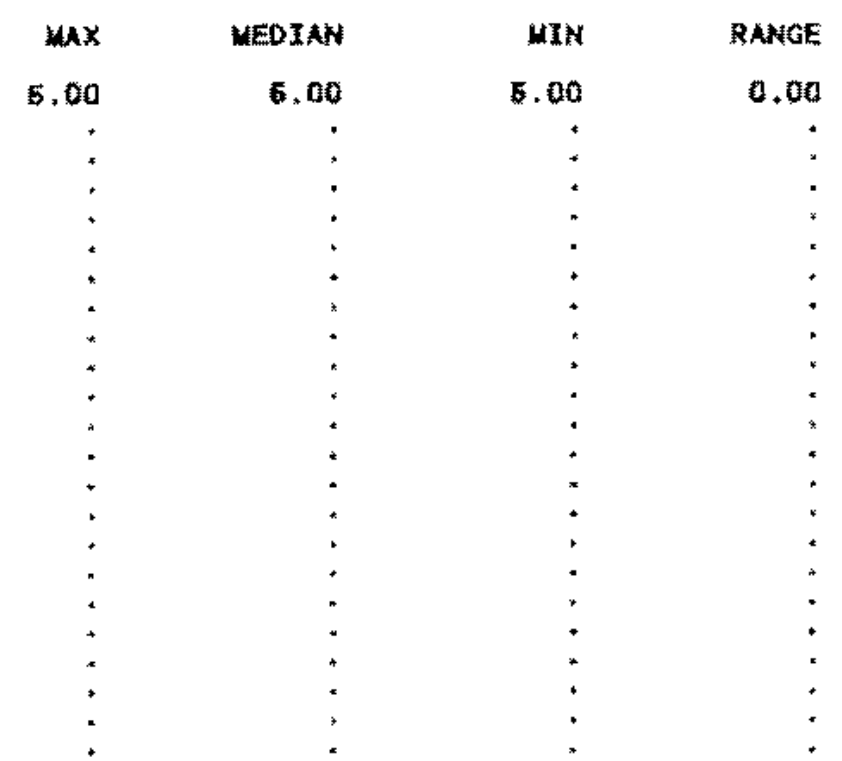

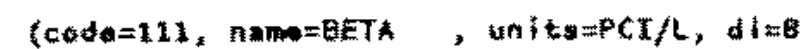

WAX

WFOTAN

NIN

RANOE

1920.00
421.00
320.00
30.00
08.20
86.10
64.20
71.70
34.10
21.30
25.10
23.40
16.10
13.20
13.10
13.00
12.50
12.90
11.70
11.60
10.90
9.72
9.82

7.85
8.17
8.89
9.06
7.71

5.49

3.39

6. 68

?. +11

b.

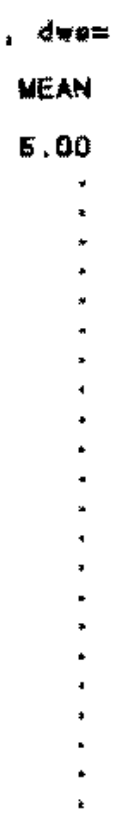

, d $d=50=50$

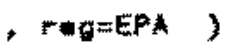

WEAN

720.57

20,14

62,13

1.41.12

71.85

46.70

87.86

27,00
13,01

13.01
10.58

18.00

8. 55

12.53

औ. 24

9. 30

0.3.

$7.8 \mathrm{a}$

7 , Ba

7.44

8. 16

$7 \times 11$

7.53
7.35
, rege )

STO $\mathrm{CY}$
sTo

cV

\begin{tabular}{|c|c|}
\hline $\begin{array}{r}416.89 \\
139.11 \\
85.60 \\
82.70 \\
11.75 \\
20.83 \\
7.87 \\
21.90 \\
5.67 \\
4.78 \\
5.03 \\
4.08 \\
4.60 \\
2.37 \\
2.24 \\
3.67 \\
2.17 \\
2.69 \\
2.14 \\
1.07 \\
2.17 \\
2.08 \\
1.34\end{array}$ & $\begin{array}{l}0.68 \\
0.62 \\
1.04 \\
0.50 \\
0.18 \\
0.43 \\
0.22 \\
0.80 \\
0.43 \\
0.48 \\
0.28 \\
0.49 \\
0.37 \\
0.28 \\
0.24 \\
0.43 \\
0.20 \\
0.33 \\
0.27 \\
0.23 \\
0.28 \\
0.27 \\
0.18\end{array}$ \\
\hline
\end{tabular}




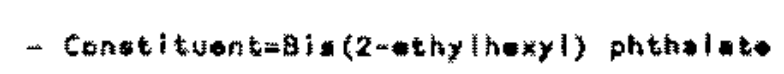
HELLNAME SAUPLES BELOWDL DAYS N

$\begin{array}{lllll}1-H 4-3 & 13 & 11 & 13 & 1 \\ 1-H 3-1 & 18 & 18 & 12 & \end{array}$

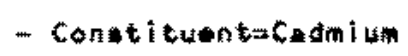

WELLNALE SAMPLES DELOWDL DAYS N

\section{$1+H 4+6$
$I-H 4-3$}

I $-\mathrm{HA}-3$

$1-1+4-5$

$1+14+11$

$1 \rightarrow+14+17$

$1+13-1$

$1 \rightarrow-14-104$

$1+\operatorname{Hin}-2 A$

$1-1+9-\frac{2 B}{10}$

$1+43-25$

$1+4<-7$
$1-64-8$

$1-64-8$

$1-+44+120$

$1-H i-12 C$

$1-H 4-13$

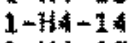

$1+\mathrm{H}+16 \mathrm{~m}$

1-144-166

$1+\mathrm{H}+4-18$
$1-H 4-18$

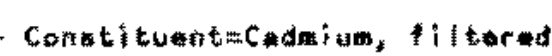

WELLNAHE SAMPIIES EELOWOL

$1+14-5$

$1-43-2 \mathrm{~A}$

$1 \mathrm{H} 4 \mathrm{M}-\mathrm{9}$

1-H4- $12 \mathrm{C}$

$1-43-1$

$1-\mathrm{H3}-\mathrm{zC}$

$1+1, x-3$

$1-144-4$

$1-N 1$
$1-14$

$1-144-7$
$1-+14-6$

1-HA -10

$1-H A-11$

$1-14-12 \lambda$

$1-44-12$

$1+144-14$

$-44-15 A$

$1-144-15 B$

1-44-18

$1-\mathrm{H}+4-17$
$1-44-18$

$\begin{array}{rrrr}28 & 28 & 28 & 2 \\ 30 & 28 & 29 & 2 \\ 30 & 28 & 28 & 2 \\ 38 & 31 & 28 & 3 \\ 12 & 31 & 12 & 1 \\ 5 & 15 & 5 & 1 \\ 35 & 34 & 19 & 1 \\ 11 & 8 & 11 & 2 \\ 11 & 10 & 11 & 1 \\ 11 & 11 & 11 & : \\ 11 & 11 & 11 & : \\ 11 & 11 & 11 & : \\ 11 & 11 & 11 & : \\ 11 & 11 & 11 & : \\ 11 & 11 & 11 & : \\ 12 & 11 & 11 & : \\ 12 & 12 & 12 & : \\ 11 & 11 & 11 & : \\ 11 & 11 & 11 & : \\ 11 & 11 & 11 & : \\ 11 & 11 & 11 & : \\ 7 & 7 & 7 & : \\ 6 & 6 & 3 & :\end{array}$

SAMPLES BELOWOL DAYS N

$\begin{array}{rrrr}14 & 13 & 14 & 1 \\ 11 & 10 & 11 & 1 \\ 11 & 10 & 11 & 1 \\ 11 & 10 & 10 & 1 \\ 12 & 11 & 12 & 1 \\ 14 & 14 & 14 & : \\ 11 & 11 & 11 & : \\ 16 & 18 & 16 & : \\ 17 & 17 & 14 & : \\ 14 & 14 & 11 & : \\ 12 & 12 & 11 & : \\ 11 & 11 & 11 & : \\ 11 & 11 & 11 & : \\ 12 & 11 & 12 & : \\ 11 & 11 & 11 & : \\ 10 & 10 & 10 & : \\ 11 & 11 & 11 & : \\ 11 & 11 & 11 & : \\ 11 & 11 & 11 & : \\ 11 & 11 & 11 & : \\ 8 & 8 & 6 & : \\ 3 & 3 & 3 & : \\ 6 & 6 & 6 & :\end{array}$

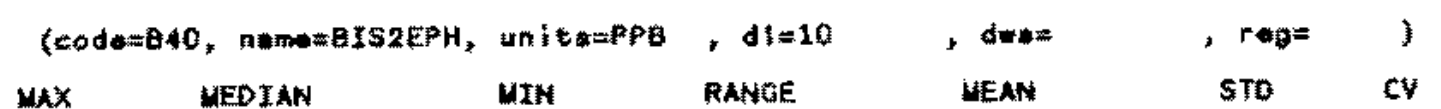

$13.0013 .00 \quad 13.00 \quad 0.00 \quad 13.00$

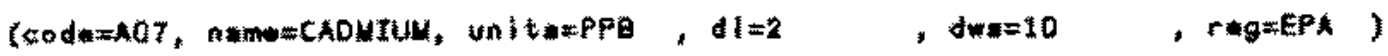

WAX WEDTANY MIN NAWGE SEAH STO CY

$13.00 \quad 7.50 \quad 2.00 \quad 11.00$

$\begin{array}{llll}5.00 & 3.50 & 2.00 & 8.00 \\ .00 & 3.60 & 3.00 & 1.00\end{array}$

4.00

3.50
3.00

3.00
3.00

3.00

2.10
2.00

3.60

3.20

3.00
3.00

3.00

2.10

3.00

3.00
3.00

3.00
3.00

5. 10

1. 00

0.50
0.00

0.00
0.00

2.00

2.00

2.00
2.00

0.00

0.00

$:$
$\vdots$
$\vdots$
$\vdots$
$\vdots$
$:$
$:$

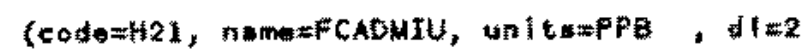

7.50

7. 181.04

3.50 $2.12 \quad 0.61$

$\begin{array}{lll}3.50 & 0.71 & 0.20 \\ 3.23 & 0.25 & 0.04\end{array}$

3.00

3.00

2.10

2.00

0.000 .00

wax

MEDTAN

UrN

RANGE

3.00
2.00

3.00
2.00

2.00
2.00

3.00

2,00

s.

2.00

0.00

0.00
0.00

0.00
0.00

2.00

2.00

2. 00

0.00

* dw: 10

\& regeEft

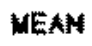

STD

3.00
2.00

2.00
2.00

2.00
2.00

2.00 
- Conet tuontzcolci lam

WELLLWUE SANPLES

$1-H A-3$

$1+f+-9$

$1-43-1$

$1-k 4=12 A$

$1+1+12 \mathrm{~B}$

$1-14 \div 4$

$1-44-8$

$1-H \rightarrow i+5$
$1-H i m-7$

1) $-N+4-8$

$1=-43 \rightarrow 2 A$
$1=14-8$

$1-44-10$

$1-44=16 x$

1. $-14-11$

$1=+44-16 B$

$1-44-13$

$1+H A+10$

$1-114-18$

$1+1+1.2 \mathrm{C}$

$1-43-2 \mathrm{C}$

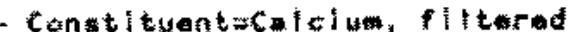

WELLNAME SANPLES BELOWOL

$1-1+4-0$

$1-1+3-1$
$1-44-12$

$\underset{1-144-17}{1-44}$

$1-44-6$

$1-K+\cdots$

$1+14-?$

$1-44-6$

$1-\mathrm{H} 4 \mathrm{4}-\mathrm{A}$

$1-193-2 A$

$1-4+1-16$

$1-44-16 \lambda$

$1 \rightarrow-44-169$

$1-\mathrm{H}-4+3$

$1-43-2 B$

$1-44-16$

$2-M 4-23$

$1-\mathrm{H} 4-1 \mathrm{O}$

$1+14-14$

$1+1+2 C$

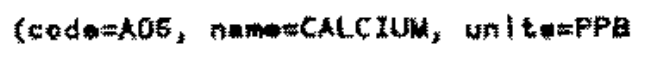

Gelawal

$\begin{array}{rr}\text { DAYS } & \\ 29 & 2 \% \\ 11 & 11 \\ 5 & 5 \\ 28 & 28 \\ 11 & 11 \\ 11 & 31 \\ 25 & 25 \\ 24 & 24 \\ 21 & 24 \\ 11 & 11 \\ 11 & 11 \\ 11 & 11 \\ 6 & 5 \\ 11 & 11 \\ 12 & 12 \\ 11 & 11 \\ 11 & 11 \\ 11 & 11 \\ 11 & 11 \\ 7 & 7 \\ 11 & 11 \\ 12 & 12 \\ 11 & 11 \\ \end{array}$

$M A x$

4EDIN

3.4000 .00

118000.00

0100,00

$\$ 0000.00$

82400.00

7900.00

78300.00

76000.00

72100.00

$\$ 2100.00$

58600.00

57700.00

5.500,00

52400.00

E2100.00

47000.00

16400.00

48300.00

4500.00
34000.00

34000.00
26200.00

35500.00

espoc. 0

71300.00

77550.00

73100.00

70200.00

41200.00

62450.00

56860.00

$\$ 4300.00$

83700.00

40400.00

48450

48200.00

$4 \$ 200.00$

18200.00

ston

$4 \$ 0 b 2.00$

torco.

43000.00

$11 \% 00=00$

42400.00

20100.00
20800.00
UIN

11300.00

85100.00

69300, 00

copos.d0

5000.00

10500.00

37800.00

.4000 . Da

47200,00

86300.00

36000.00

38200.00

2100.00
1600.00

30500.00

41600.00

31400.00

2. 400.00

34700.00

23300.00

20300.00
RANGE

322700,00

47900, 00

30800.00

20100.00

4300 .00

28100.00

$5 \% 800,00$

38100.00

0100.00

1.4000 .00

28500.00

20300.00

15800.00

16200.00

13900.00

10600.00

16800.00

19000.90

$11 \mathrm{cod}, 00$

10700.00

5odo.00
* dwe

MEAN

6E5 39.85

73181,62

$7276 a, 00$

7668.29

$685 \mathrm{B2} . \mathrm{B2}$

46883.84

42430.00

$60728 \times 17$

67200.00

63E81.82

43027.27

40000,00

19408.09

49408

44118.18

47863.64

\$9964, ह5

40454.56

$+1100.00$

41000.00

$27333 \cdot 33$
$2.746 \cdot 45$

y $d w=$

MENAN

01180.00

76371.43

6483.38

6217.57

6e172. 67

85663.84

$50522 \div 73$

0455.71

81110. 00

4114.29

$43+54.58$

47983.33

50418.15

48472.73

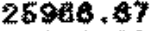

48.11 .67

43619.18

39990.81

40400.00

40972,73

27526.00

23027,27 $\because \quad r e$

$5 \mathrm{TO}$

)

71371.03

$1.7 \% 0.01 \quad 0.17$

$11088.33 \quad 0.16$

7330.720 .10

14413.81 0.22

44.14

$837.03 \quad 0.14$

GA50.85 0.20

$\begin{array}{ll}7081.12 & 0.14 \\ 4437.63 & 0.07\end{array}$

$7177.20 \quad 0.17$

$6898.64 \quad 0.14$

430 吾. 51 o. 0 .

$4071.6 \mathrm{~A} \quad 0.06$

4464.260 .10

$3048.1 \% 0.08$

$\begin{array}{ll}417.32 & 0.11\end{array}$

620.650 .16

3253.920 .06

$\begin{array}{ll}306.89 & 0.11 \\ 17.06 & 0.07\end{array}$

)

\$TO

cy

13930.000 .15

$9251.40 \quad 0.12$

$13342.90 \quad 0.21$

$11689.33 \quad 0.16$

4916.620 .07

6682. 1100

E64. 30.430 .12

E644.73 0.09

$170.97 \quad 0.12$

$\begin{array}{rr}16843.80 & 0.37 \\ 7898.82 & 0.18\end{array}$

7507.970 .18

$4191.68 \quad 0.08$

$3853.62 \quad 0.02$

13797.280 .53

$2471.48 \quad 0.05$

40.440 .00

$\begin{array}{rr}4359.65 & 0.11 \\ 250.92 & 0.11\end{array}$

elas.08 0.15

2624.710 .00

$3274.73 \quad 0.12$

$\begin{array}{ll}3274.73 & 0.12 \\ 2354.61 & 0.10\end{array}$ 
- Conctituentachloride

MELLNAME SAMPLES

\section{BELOUDL.}

1- $-13-1$

$1+14+12 \mathrm{C}$

$1+144-8$

$1-4+4-3$

$1+\mathrm{H}+4=17$

$1-44 m$

$1+1+18+2 k$

$1+1+4-9$

$1+4+4$

$3-H 4-22 A$

$1-43-2 B$

$1+14-6$

$1-44-128$

$1+44-16$ A

$1-4+18$

$1-44-168$

1 $-\mathrm{HA}-14$

1. $-14-18$

$1+1+14-13$

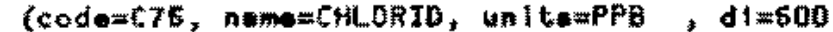

WAX

$30 \$ 00,00$ 30800.00
24500.00 24700.00 20200.00 13100.00 10800.00 10750.00 10400.00 10100.00 $10100=00$

8970.00

9660.00

8040,60

8710.00

$\$ 340,00$

ation. no

8290.60

6230.00

5820.00

$\$ 770.00$

5820.00

5460.00

MEDIAN

MIN

RANoE

2200.00 3940.00 3240.00 40 6. $* 0$ Q34. $\$ 3.0 .00$ 6 . 8710.00 870.00 8190.00 6.50 .00 6700.00 बroo.00 6700.00 6620.00 1570.00 5450,00 4 ato 5100,00 4530.00
9000.00

24600.00 2530.00 2470.00 100.0 4. and c.4., Gaso. c3so. 8890.0 1280.00 2720.0 5700.00 2750.00 1400.00 4290.00 3670.00 4720.00 $37 \% 0.00$ 4000,00 300 4750 . 2960.00 21970.00 21230.00 1830. ธ10. 2100. 0 4 ing. 4870.00 37. 3280.00 6320.00 $\$ 010.00$ s590. 05 $\$ 940.00$ 3260.01 2810.00 1510.00 2040 , 00 1770.00 1720.00 700.00 2430.00
, dwE=250000, rog=EPAS

NEAN

STD CY

$105: 7+14$

8067.60

7895.15

11170.00

8430.63

9704.00

8145,45

8867.2

-315. 16

ment

5146.21

a66, 62

$6840 * 00$

6163.79

6397.27

\$346. 33

$\$ 600.00$

6560.00

4862.50

4867.57

5080.00

4204,05

$0 \times 42$

$1+1.45 \quad 0.80$

0.00

42.80

0.26

0.12

110.70

130.200

1207.190 .15

$1148.00 \quad 0.13$

$1061.04 \quad 0.26$

82.6.65 0.14

143.75
0.28

2081.790 .38

1044.420 .16

$790.16 \quad 0.14$

E0a, 5e 0.69

631.640 .1

583.770 .1

571.500 .12

$268.59 \quad 0.05$

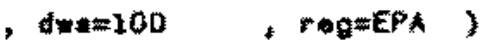

(code=ABO, nem=CHLFOKM, un th=PPE, $A 1=10$

MEAN

ANAGE

32.81

28.00

28.09

28.00

28.00

23,43

$2+\infty$

28.7

23,9

10.12

14.81

20.1

18.8

19.40

19.40

18.45

1.

13.11

$11 \times 78$

11.20

11.25
sTt

$3.14 \quad 0.10$

6.850 .19

3.50 0.12

3.220 .12

0.22

$3.80 \quad 0.17$

4.300 .10

2.940 .13

3. 050.10

4.710 .20

2.47

0.2

$2.08 \quad 0.17$

3.07

2.7. 0.21

1.34 o.1

$\begin{array}{ll}1.34 & 0.11 \\ 2.36 & 0.21\end{array}$
2. $42 \quad 0.12$

12.00

10.50

1.00
0.00

5.00

0.00

$1-\mathrm{Hi}-17$

$1-H+12 C$

3.00

. 
- Conot lumetumfoml um

WELLAMAE SANPLES

EELOWDL

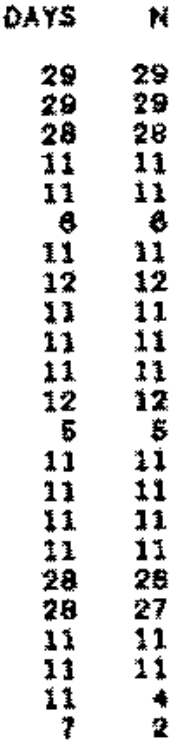

- Centituoftuchromism, filterod

WLLWNAHE SAUPLES DELOWDL

Bays N

$1-H+-3$

$1-14-1$

$1-H+-5$

$1-41+12 k$

$1+\mathrm{H}+18$

$1-144-12 C$

$1-1+14-125$

$1-4+2-15 A$

$1+\mathrm{H} \rightarrow \mathrm{s}-\mathrm{s}$

$1-\mathrm{H}+11$

$1-\mathrm{Hi} \rightarrow 7$

1-1-44-8

$1 \rightarrow+4 \rightarrow 0$

i- $-13=1$

$1+43-2=$

$1+4<-17$

$1-\mathrm{H3}-2 \mathrm{~g}$

$1-13-26$

$1-\mathrm{H}+16$

16
17
11
14
11
6
12
10
11
11
11
12
12
11
11
14
34
11
3
11
11
11
6

$\begin{array}{rr}15 & 15 \\ 11 & 14 \\ 11 & 10 \\ 14 & 14 \\ 12 & 11 \\ 6 & 6 \\ 12 & 11 \\ 10 & 10 \\ 11 & 11 \\ 11 & 11 \\ 10 & 10 \\ 12 & 12 \\ 11 & 11 \\ 11 & 11 \\ 11 & 11 \\ 14 & 14 \\ 14 & 11 \\ 11 & 11 \\ 3 & 3 \\ 11 & 10 \\ 11 & 10 \\ 11 & 2 \\ 8 & 1\end{array}$

- Corsti tuentecobo $1 t-60$

WELLNAME SALPLES

EEL.WWT.

DAYS

$1-13$
$1-14 \cdot \frac{1}{4}$

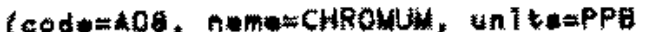

MAX WEOAH NAN RANOE

, dwats 50

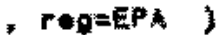

$30.00 \quad 571.00$

$571.00 \quad 241.00$

26.00
133.00

148.00

264 ion

207.00

207.00

25.50

$17+00$
17.50

177.50

120.00

1 हs, 00

154.00

90.50
82.00

187.00

113,00

37.00

77.00

59.50

49.00

26.00
27.00

27.60
2.50

57.00

237.00

152.00
62.00

112 . to

60,00

107.00

A 1.00

$10 \mathrm{~b} .00$

ge. 00

27.00

17.00

3. 00

26. 00

17.00

14.00
11.00

13.00

10,00

$0 \% 0.00$

703.00

440.50

163.00

245.00

43.00
12.00

200.00

94.00

142 . OD

73.00

160.00

113,00

58.00

71.00

7.00

ह5. the

63.00

31.00

30.00

12.00
.00

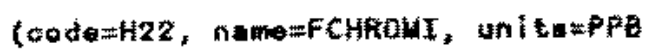

, $d=10$

$$
\text { wax }
$$

NEOIAN

WIN

$\cos 1.00$
$\sin .00$

304.00

303.00

2 a. 00

272.00

250.00

205.00

171.00

104.00

455.00

112.00

112.00
$\$ 2.00$

8. 00

70.00

80.00

67,00

40.00
4t.

1.1. 00

348.00
339.75
268.00
194.00
197.00
252.60
168.00
187.50
147.00
153.00
129.00
89.50
185.50
102.00
92.00
43.00
51.00
32.00
50.00
25.50
30.50
10.50
11.00

210.00

24.00
154.00

154.00

142.00

242. 0

*4.00

137,00

82.00

89.00

10? .00

63.

98.00

$\$ 4.00$

$15 \times 00$

36.00

31.00
18.00

18.00
43.00

33.00
13.00

14.00

$10.0 \mathrm{O}$

nANGE

351 .

498, 00

Is). 00

161.00

40.0

218.00

213,00

143.00

72.00

57.00

102.00

55. 80

18.00

77.00

落3.00

30.00

51.00
34.00

35.00

28.00

1.00
0.00

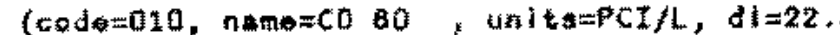

WAX WEOTAN WIPE RANCE

5.98
6.63

5.85

$5 \cdot 63$

RANGE

0.45
0.00

5.83

(1)

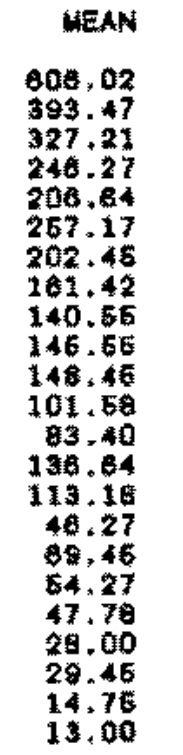

, dw: $=50$

MEAN

345.60

30.

28.20

205.79

201.01

256.33

160.6

191.50

146.55

149.91

131.00

96.17

$126 \times 6$

102.52

87.65

47.07

52.68
$\mathrm{a} 5.82$

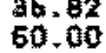

27.50

27.00

10.50

1.00

, $d w=100$

MEAN

5.86

5.83

0.32

0.320 .05

$90.36 \quad 0.29$

$134.23 \quad 0.44$

50.30 0.20

$\begin{array}{ll}60.28 & 0.24 \\ 0.34 & 0.40\end{array}$

14.730 .06

0.67

4. 14 0.31

$22.32 \quad 0.15$

\$. 1.410 .3

10.00

6.29 0.08

$28.80 \quad 0.43$

13.180 .29

$\begin{array}{ll}11.93 & 0.23 \\ 1.42 & 0.40\end{array}$

$17.00 \quad 0.34$

$10.31 \quad 0.37$

$\begin{array}{ll}0.71 & 0.07\end{array}$

, rOgFEFA )

STE $\mathrm{CV}$ 


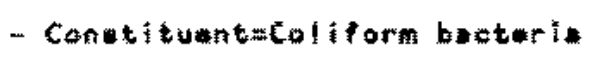

VELLHAVE SAUPLES

\begin{tabular}{|c|c|c|c|}
\hline 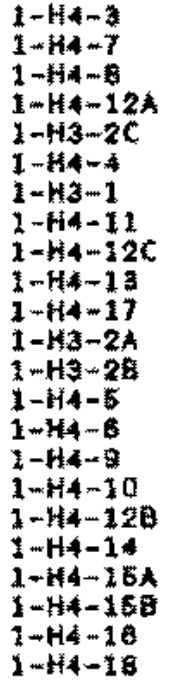 & $\begin{array}{l}20 \\
11 \\
11 \\
11 \\
11 \\
20 \\
34 \\
12 \\
12 \\
11 \\
5 \\
11 \\
11 \\
37 \\
28 \\
11 \\
11 \\
11 \\
11 \\
11 \\
11 \\
6 \\
8\end{array}$ & $\begin{array}{l}26 \\
10 \\
10 \\
10 \\
10 \\
26 \\
33 \\
11 \\
10 \\
10 \\
11 \\
11 \\
11 \\
37 \\
39 \\
11 \\
11 \\
11 \\
11 \\
11 \\
11 \\
0 \\
4\end{array}$ & $\begin{array}{l}29 \\
11 \\
11 \\
11 \\
11 \\
20 \\
29 \\
12 \\
12 \\
11 \\
5 \\
11 \\
11 \\
29 \\
28 \\
31 \\
11 \\
11 \\
11 \\
11 \\
11 \\
6 \\
8\end{array}$ \\
\hline
\end{tabular}

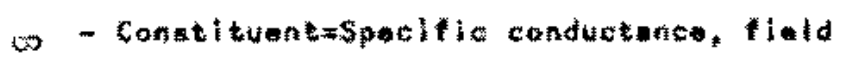

WELLNAWE SAMPLES BELOWDL DAYS N

\section{$3=4+3-3$}

$1+44-9$

$1-H 3-1$

$1-4+12 \mathrm{~A}$

$1+64+6$

$3-144-120$

$1+\mathrm{H}-\mathrm{M}-\mathrm{B}$

$1-\mathrm{H} 4+\mathrm{W}$

$3-N+5$

$1-13+2 A$
$1-34-152$

1- $-14-164$

$1-14-10$

$1+H+10$
$1-43-39$

$1-33-39$

$1-44-126$

$1=+44-11$

it $-4+13$

$1+\mathrm{H} 4-14$

28
20
11
28
11
28
5
11
11
11
21
11
11
11
8
11
11
11
12
12
11
11
6

(cos $6=100$,

WAX WEDAN

$\begin{array}{rr}23.00 & 10.05 \\ 16.00 & 10.00 \\ 16.00 & 10.00 \\ 16.00 & 10.00 \\ 6.10 & 5.10 \\ 4.00 & 2.20 \\ 2.20 & 5.20 \\ 2.20 & 1.20 \\ 2.20 & 2.20 \\ 2.20 & 2.20 \\ 2.20 & 2.20\end{array}$

20

$\div$

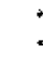$$
\text { : }
$$

$\begin{array}{cc}\text { FRM, unite=MPN } & \text {, di=2.2 } \\ \text { MIN } & \text { RANGE } \\ 2.20 & 20.80 \\ 2.20 & 13.80 \\ 18.00 & 0.00 \\ 18.00 & 0.00 \\ 6.10 & 0.00 \\ 2.20 & 1.80 \\ 2.20 & 0.00 \\ 2.20 & 0.00 \\ 2.20 & 0.00 \\ 2.20 & 0.00 \\ 2.20 & 0.00 \\ \vdots & \vdots \\ \vdots & \vdots \\ \vdots & \vdots \\ \vdots & \vdots \\ \vdots & \vdots\end{array}$

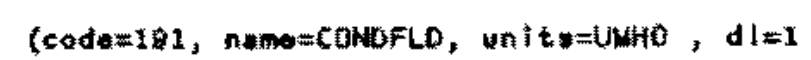

iriv

RANGE

$$
\text { , dwa }=700
$$

5790.00

$265 \times 00$

725.00

870.00

589.00

556.00

539.00

528.00

ए06.00

475.00

465.00

418.00

14.00
390.00

390.00
385.00

36: 00

376.00

371.00

364,00

352.00

318.00

295.00

910.00
715.00
378.00
458.00
272.00
293.00
171.00
331.00
356.00
320.00
302.00
252.00
208.00
310.00
239.00
201.00
268.00
167.00
321.00
246.00
168.00
208.00
130.00

เลลด 00

1142,00

389.00

398.00

278.00

84.00

20 .00

173.00

177.00

173.00

203.00

118.00

104.00

$15 \%, 00$

$1 \mathrm{EQ} .00$

128.00

115.00
209.00

209.00
180.00

180.00

110.00

$1 \mathrm{es} .00$

109,00

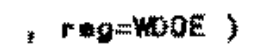

MWN

$$
\text { STE }
$$$$
\text { cV }
$$

- $r * F=E P A)$

STb EV

$0.82 \quad 0.84$

1.04 $0.9 \%$

0. 0.

2101.41

1176.25

0,60

119.37 0.12

38.54 0.12

$126.44 \quad 0.26$

$79.16 \quad 0.18$

$70.47 \quad 0.18$

19.10 0.11

$54, \mathrm{E} \quad 0.13$

$6.00 \quad 0.12$

$62.63 \quad 0.10$

$3.54 \quad 0.0 \%$

5.03

60.030

04.80

36.890 .11

$76.67 \quad 0.28$

$4.92 \quad 0.17$

$83 .+20.20$

$\begin{array}{ll}32.24 & 0.11 \\ 42.67 & 0.17\end{array}$ 


\begin{tabular}{|c|c|c|c|c|c|c|c|c|c|c|c|}
\hline \multicolumn{5}{|c|}{ - Comet tuent=Cappor } & \multicolumn{3}{|c|}{ 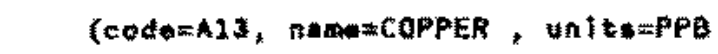 } & $d \quad d=10$ & , two=1 300 & \multicolumn{2}{|c|}{, renmEPAP ) } \\
\hline WLLWAEE & SAMPLES & BELDWEL & DAYs & $k$ & $\max$ & WEDIAN & MIN & RAHGE & MEAN & $\$ T D$ & $C \forall$ \\
\hline 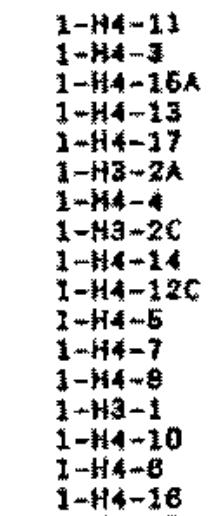 & $\begin{array}{l}12 \\
30 \\
11 \\
11 \\
5 \\
11 \\
30 \\
11 \\
11 \\
12 \\
38 \\
11 \\
11 \\
36 \\
11 \\
28 \\
7\end{array}$ & $\begin{array}{r}0 \\
0 \\
0 \\
9 \\
2 \\
5 \\
28 \\
5 \\
7 \\
40 \\
33 \\
6 \\
83 \\
33 \\
7 \\
26 \\
6\end{array}$ & $\begin{array}{l}12 \\
29 \\
11 \\
11 \\
6 \\
11 \\
29 \\
11 \\
11 \\
12 \\
20 \\
11 \\
11 \\
20 \\
11 \\
20 \\
7\end{array}$ & $\begin{array}{r}3 \\
29 \\
3 \\
2 \\
3 \\
2 \\
4 \\
0 \\
4 \\
2 \\
2 \\
2 \\
5 \\
2 \\
4 \\
3 \\
2\end{array}$ & $\begin{array}{r}274.00 \\
133.00 \\
103.00 \\
08.00 \\
30.00 \\
28.00 \\
28.00 \\
28.00 \\
28.00 \\
28.00 \\
20.00 \\
17.00 \\
18.00 \\
15.00 \\
14.00 \\
12.00 \\
12.00\end{array}$ & $\begin{array}{l}19.00 \\
16.00 \\
12.00 \\
39.00 \\
11.00 \\
23.50 \\
20.50 \\
22.50 \\
16.00 \\
18.00 \\
18.25 \\
18.50 \\
13.00 \\
12.50 \\
11.00 \\
11.50 \\
11.50\end{array}$ & $\begin{array}{l}13.00 \\
10.00 \\
11.00 \\
10.00 \\
10.00 \\
18.00 \\
11.00 \\
10.00 \\
10.00 \\
10.00 \\
18.00 \\
18.00 \\
10.00 \\
10.00 \\
10.00 \\
11.00 \\
11.00\end{array}$ & $\begin{array}{r}261.00 \\
123.00 \\
82.00 \\
58.00 \\
20.00 \\
11.00 \\
18.00 \\
18.00 \\
18.00 \\
10.00 \\
3.50 \\
1.00 \\
5.00 \\
5.00 \\
1.00 \\
1.00 \\
1.00\end{array}$ & $\begin{array}{r}102.00 \\
18.48 \\
42.00 \\
39.00 \\
17.00 \\
23.50 \\
20.26 \\
20.60 \\
17.50 \\
18.00 \\
16.25 \\
16.60 \\
12.60 \\
12.60 \\
11.50 \\
11.50 \\
11.60\end{array}$ & $\begin{array}{r}1.48 .09 \\
3.3 .80 \\
52.83 \\
11.01 \\
11.07 \\
7.76 \\
10.11 \\
7.46 \\
7.69 \\
11.31 \\
2.47 \\
0.71 \\
2.39 \\
3.54 \\
1.73 \\
0.71 \\
0.71\end{array}$ & $\begin{array}{l}1.48 \\
0.70 \\
1.28 \\
1.06 \\
0.86 \\
0.39 \\
0.08 \\
0.36 \\
0.48 \\
0.03 \\
0.14 \\
0.04 \\
0.18 \\
0.28 \\
0.16 \\
0.08 \\
0.06\end{array}$ \\
\hline $1-43-20$ & 11 & 11 & 11 & 4 & $=$ & $\cdot$ & . & . & $\cdot$ & * & ? \\
\hline $1-n=0$ & 11 & 14 & 11 & . & . & . & . & . & * & • & " \\
\hline $1-H 4-12 \lambda$ & 21 & 11 & 11 & . & + & . & . & - & $=$ & . & * \\
\hline $1-14-12 a$ & 11 & 11 & $1 \mathbf{1}$ & · & • & • & r & - & - & • & - \\
\hline $1-H 4-158$ & 11 & 11 & 11 & • & . & $=$ & - & . & $=$ & - & • \\
\hline $1-44-18$ & 6 & 6 & 8 & - & + & • & • & " & • & • & " \\
\hline \multicolumn{5}{|c|}{ - Constituent=Coppor, fittered } & \multicolumn{3}{|c|}{ 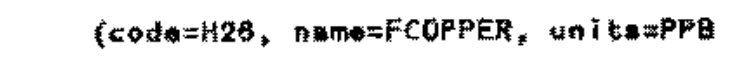 } &,$d 1=10$ &,$d y=1300$ & \multicolumn{2}{|c|}{$, \quad r \otimes p=E F A P\}$} \\
\hline WELLLNAME & SNUPLES & BELOWDL. & DAYS & n & wax & WEOTAN & Min & RANGE & WEN & \$70 & $c y$ \\
\hline $\begin{array}{l}1-H 4-3 \\
1-H 1-12 C \\
1-+3-2 C \\
1-14-150 \\
1-14-10 \\
1-H+11\end{array}$ & $\begin{array}{l}16 \\
12 \\
11 \\
11 \\
11 \\
12\end{array}$ & $\begin{array}{r}5 \\
10 \\
10 \\
10 \\
10 \\
11\end{array}$ & $\begin{array}{l}15 \\
12 \\
11 \\
11 \\
11 \\
12\end{array}$ & $\begin{array}{r}10 \\
2 \\
2 \\
1 \\
1 \\
1\end{array}$ & $\begin{array}{l}83.00 \\
33.00 \\
22.00 \\
13.00 \\
11.00 \\
11.00\end{array}$ & $\begin{array}{l}34.50 \\
24.00 \\
14.00 \\
19.00 \\
11.00 \\
13.00\end{array}$ & $\begin{array}{l}23.00 \\
15.00 \\
14.00 \\
13.00 \\
11.00 \\
11.00\end{array}$ & $\begin{array}{r}45.00 \\
18.00 \\
9.00 \\
0.00 \\
0.00 \\
0.00\end{array}$ & $\begin{array}{l}37.00 \\
24.00 \\
13.00 \\
13.00 \\
11.00 \\
11.00\end{array}$ & $\begin{array}{r}13.84 \\
12.73 \\
5.88 \\
:\end{array}$ & $\begin{array}{r}0.38 \\
0.63 \\
0.31 \\
\vdots \\
.\end{array}$ \\
\hline $1-133-1$ & 14 & 14 & 11 & , & , & . & - & 4 & . & , & - \\
\hline $\mathbf{1}-\mathrm{H} 3 \mathrm{3}-2 \mathrm{~A}$ & 11 & 12 & 11 & . & * & $\cdot$ & $\cdot$ & - & ; & + & · \\
\hline $1-13-2 \mathrm{~B}$ & 11 & 11 & 11 & . & $\cdot$ & . & ' & - & - & - & * \\
\hline $1-44-4$ & 17 & $\mathbf{3 7}$ & 14 & . & - & . & - & - & . & • & • \\
\hline $1-44-6$ & 14 & 14 & 14 & . & - & $=$ & * & - & $*$ & $*$ & $\therefore$ \\
\hline 1-H4 & 14 & 14 & 24 & • & . & $x$ & $*$ & * & " & . & $\dot{.}$ \\
\hline $\begin{array}{l}1-8+4-7 \\
1-74-8\end{array}$ & 22 & $\begin{array}{l}12 \\
12\end{array}$ & 21 & $\cdot$ & $:$ & $=$ & $=$ & " & $x^{*}$ & $\cdot$ & $\therefore$ \\
\hline $\begin{array}{l}1-+44-8 \\
1-14-8\end{array}$ & 11 & $\begin{array}{l}1: 2 \\
11\end{array}$ & $\begin{array}{l}11 \\
10\end{array}$ & $:$ & ; & $:$ & : & : & : & $\dot{*}$ & : \\
\hline $\begin{array}{l}1-74-8 \\
1-H 4-12 A\end{array}$ & i1 & 11 & 11 & . & 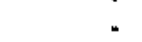 & . & . & , & . & $*$ & $*$ \\
\hline $1-144-128$ & 10 & 20 & 10 & . & * & . & . & * & . & , & - \\
\hline $1-\mathrm{H}+13$ & 21 & 11 & 12 & . & . & $*$ & . & - & . & * & . \\
\hline $1-14-14$ & 11 & 11 & 11 & $*$ & $z$ & . & - & • & $*$ & * & " \\
\hline $1-144-16 \lambda$ & 11 & 11 & 11 & $\cdot$ & • & . & - & . & • & - & - \\
\hline$y-14-16$ & 6 & $\theta$ & 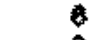 & . & - & $*$ & , & : & $\cdot$ & $\cdot$ & + \\
\hline $1-44-17$ & $\mathbf{3}$ & 3 & 3 & . & * & • & * & • & $\cdot$ & ' & $*$ \\
\hline $1-H 4-16$ & 6 & 6 & 8 & $*$ & - & , & . & - & - & , & . \\
\hline
\end{tabular}




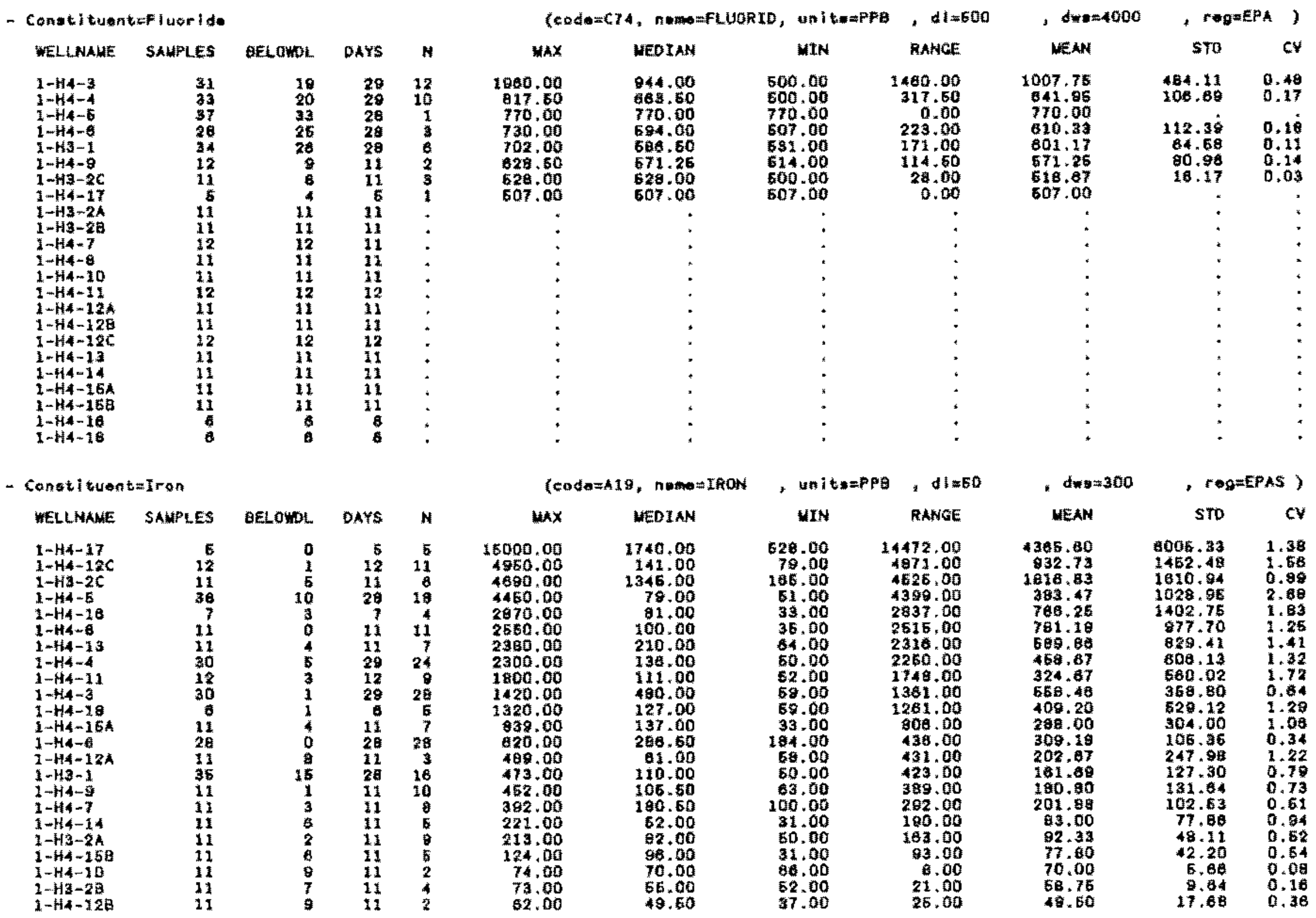




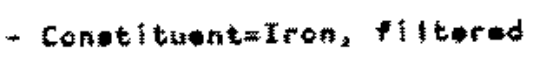

IFELINALE SANPLES DELOWOL

OAYS
11
11
12
11
11
11
11
11
3
11
14
11
11
10
14
15
14
11
14
10
11
11
6

o - Constituentwand (graphite furface)

WLLANME SAMPLES GELOML DAYS

1-W4-5 $1-114-17$
$1-144-11$

$1-14+11$

$1+44-4$
$1+14-12 C$

$1-43+1$

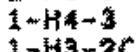

$\rightarrow-13+25$

$3-43-2 A$

1-耕-2

$1+44-6$

$1-\mathrm{H}-7$

$1=144-8$

$1-1+10$

$1+44-12 \mathrm{a}$

$1+\mathrm{H}-13$

$1=+4-14$

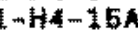

$1-44-169$

$1+44-16$
$1 \rightarrow+4 \rightarrow 10$

39
5
12
30
12
35
30
11
11
11
51
20
11
11
11
11
11
11
11
11
11
0
5

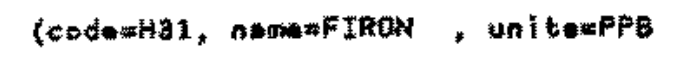

\begin{tabular}{|c|c|c|c|}
\hline$\omega k x$ & MEOIAN & Mur & RANGE \\
\hline $\begin{array}{r}3220.00 \\
2380.00 \\
1100.00 \\
918.00 \\
830.00 \\
684.00 \\
307.00 \\
243.00 \\
200.00 \\
180.00 \\
169.00 \\
90.00 \\
83.00 \\
30.00 \\
56.00 \\
40.00\end{array}$ & $\begin{array}{r}1669.00 \\
512.00 \\
1100.00 \\
392.60 \\
630.00 \\
310.50 \\
121.00 \\
162.00 \\
110.00 \\
172.00 \\
169.00 \\
86.00 \\
83.00 \\
60.00 \\
56.00 \\
10.00\end{array}$ & $\begin{array}{r}90.00 \\
48.00 \\
1100.00 \\
59.00 \\
630.00 \\
57.00 \\
78.00 \\
70.00 \\
87.00 \\
207.00 \\
169.00 \\
90.00 \\
83.00 \\
80.00 \\
34.00 \\
40.00\end{array}$ & $\begin{array}{r}722.00 \\
2332.00 \\
0.00 \\
300.00 \\
0.00 \\
507.00 \\
231.00 \\
173.00 \\
103.00 \\
73.00 \\
0.00 \\
0.00 \\
0.00 \\
0.00 \\
24.00 \\
0.00\end{array}$ \\
\hline * & 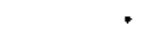 & . & • \\
\hline$=$ & . & . & $=$ \\
\hline 4 & * & . & - \\
\hline . & " & " & 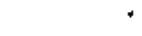 \\
\hline+ & x & • & n \\
\hline 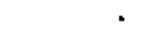 & n & $"$ & • \\
\hline
\end{tabular}

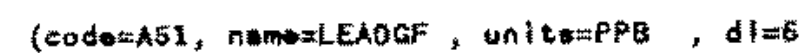

$$
\text { MAX MEOTAN }
$$

ag. 00

18.00

11.60

11. 20

8.20

C. 00

8. 00

50
6,00

$$
\begin{array}{r}
48.51 \\
14.50 \\
11.80 \\
0.20 \\
8.20 \\
6.00 \\
8.00 \\
5.10 \\
5.00
\end{array}
$$

MIN

5.01

11.80

E. 01

C.20

\&. of

5.10

5.10
6.00
- $\alpha \omega=300$

MEAN

1869.00

․․․ 95

1100.00

468,17

330.00

310.60

169.00

168.60

148.60

I5s.00

169.00

98.00

63.00

60.00

43.00

40. 00
- $r a g=\operatorname{Eas}$ )

STP CV

$2207.60 \quad 1.33$

389.100 .90

$358.50 \quad 1.1 \dot{0}$

$121.80 \quad 0.72$

$122.33 \quad 0.78$

72.030 .40

$23.0 \dot{0} \quad 0.27$
, $d w=50 \quad, \quad E=0=E P A)$

MEAN

48.51

1. 00

7.74

\%. 20

6.00

5.70

5.10
STO दV

$\begin{array}{rr}58.80 & 1.28 \\ 2 \times 22 & 0.16\end{array}$

3. 0.30

$0.6 \dot{2} 0.0 \dot{0}$ 


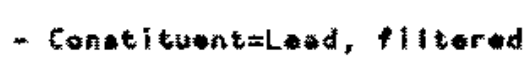

WELLANAE SAUPLES BELOWOL

DAYS N

$1-H i m-5$

1-114me

1) $1+4-4-12 x$

$1+14-150$

$1-\mathrm{H}^{3}-1$

$1-43-2 A$
$1-43-29$

1-13-2C

$1-344-3$

1-H4-?

1. $-14-8$

$1-4-9$

1-Hi-10

$1-44-11$
$-H 4-128$

1) $-\mathrm{H} 4-12 \mathrm{C}$

$1+8+13$

$1-H 4-16 \mathrm{~A}$

$1-44-16$

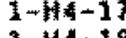

$3-44-18$

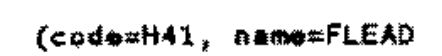

$$
\text { vax }
$$

7.70

$7 \times 30$
7.10

5.00
5.00

;

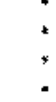

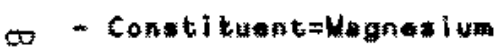

\begin{tabular}{|c|}
\hline 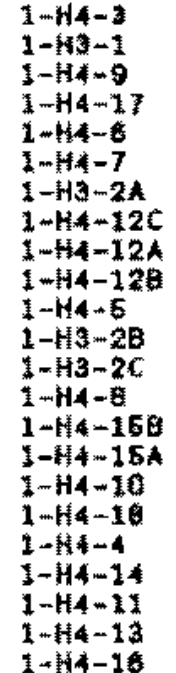 \\
\hline
\end{tabular}

EELEWDL DAYS N

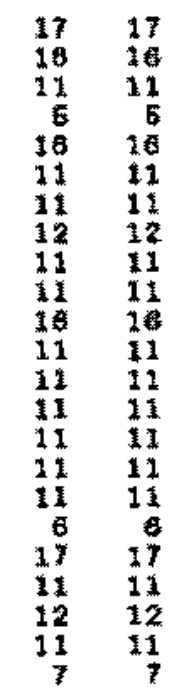

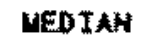

7.70

7.50

7.10

5. 00

$\begin{array}{lllr}18 & 0 & 17 & 17 \\ 18 & 0 & 18 & 16 \\ 11 & 0 & 11 & 11 \\ 5 & 0 & 5 & 6 \\ 16 & 0 & 18 & 16 \\ 11 & 0 & 11 & 11 \\ 11 & 0 & 11 & 11 \\ 12 & 0 & 12 & 12 \\ 11 & 11 & 11 \\ 11 & 0 & 11 & 11 \\ 18 & 0 & 11 & 11 \\ 11 & 0 & 18 & 16 \\ 11 & 0 & 11 & 11 \\ 11 & 0 & 11 & 12 \\ 11 & 0 & 11 & 11 \\ 11 & 0 & 11 & 11 \\ 11 & 0 & 11 & 11 \\ 6 & 0 & 11 & 11 \\ 18 & 0 & 6 & 6 \\ 11 & 0 & 17 & 17 \\ 12 & 0 & 11 & 11 \\ 11 & 0 & 12 & 12 \\ 7 & 0 & 11 & 11 \\ 12 & 0 & 7 & 7\end{array}$

wkx

$2 \operatorname{sog} .00$

22400.00

7900.00

15500.00

15500.00

14200.00

13200.00

12700.00

12500.00

12200.00

11700.00

11800.00

11000.00

11400,00

11300.00

10600.00

10400.00

9830.00

8670.00

790.00

7910.00
5590.00
+ HnitimupPa ,

MIN

7,70

7,10

6.90

5.00

$:$
- $4 w=50$

RANCE

0. 00

0.0

0.00
0.00
WEAN

$7 \cdot 70$

$7 \times 30$

7.10

5.00

b. 00
- rogePA)

sto cV

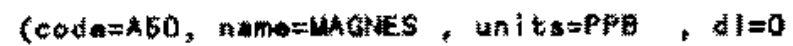

\section{MEDIAN}

Win

4230,00 17000.00

14100.00

14100.00

14260,00

10700.00

9640.00
11100.00

10700.00

11100.00

10000.00

se. 30.00

9010.00

10800.00

11000.00

10100.00

9650.00

$\$ 320.00$

8700.00

7 7. 00

6935.00

8860.00
5170.00
1950.00 18200.00 12700.00 13100.0

$136 \mathrm{E0} .00$

9910.00

B3tó. 0

10500.00

7320.00

0310.00

8130.00

$\$ 190.00$

7050.00

ब\$60.00

9790.00

9esto. 0

82.20:60

7670.0

3710.00

3710.00

7210.00

sas

4600,00

\section{RANCE}

2655000 6200.00 as. 4e.0u.

200. 00

4200.00

4900 . Do

2200.00

5180.00

3900 . 00

2070.00

2510.00

3750.00

1640.00

1810,00

2450.00

43.50 .00

2730.00

2730.00

6120.60

1380.00

1430.00

1950.00
a.0.00
MEAN

6698. 02

1968.7

1884546

15000

1 Axos. 25

11118.09

$973 x+7$

11441.8

10353.84

10608.16

101 숭.6

10020.00

\%40.010

10032.73

10800.00

10237.27

9341 .

931.82

6 ET 3

aी 04

8041.82

1020.00

8190.57

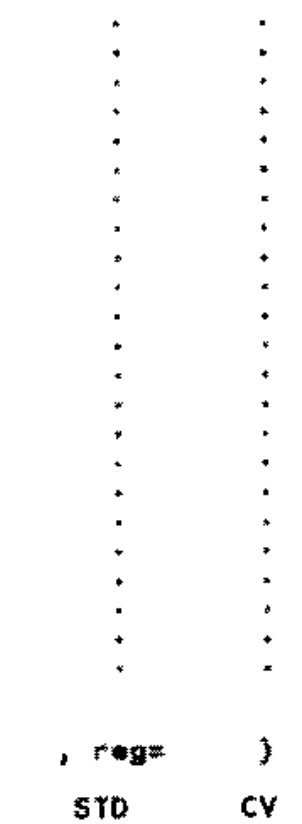

$7101.92 \quad 1.03$ $1557.86 \quad 0.08$ $1000.00 \quad 0.13$ 1898.00 a.13 00.34 1381.64 0.14 $569.62 \quad 0.06$

$1612.40 \quad 0.16$

$1376.37 \quad 0.11$

$777 \times 50.0$

621.350 .0

1204.350 .13

840.140 .08

$44.70 \quad 0.04$

118.030 .0

$1420.18 \quad 0.15$

97.16 o.11

100.04

40.03

का०.4

$204.34 \quad 0.08$ 


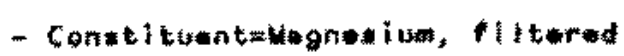

WELLNANE SANPLES EELOWDL DAYS

\begin{tabular}{|c|}
\hline 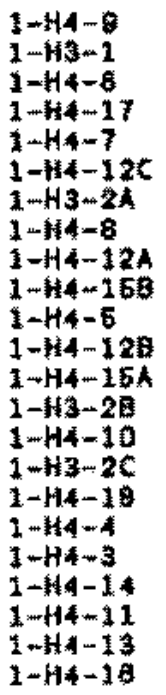 \\
\hline
\end{tabular}

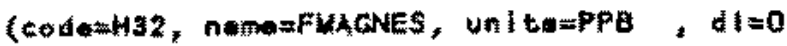

Mix

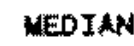

27800.00 21800.00 15700,00 13000.00

13000.00

12000.00

12400.00

12300.00

12400.00

12000.00

11800.00

11700.00

11300.00

10900.00

10400.00

10100,00

9430.00

9030.00

820.00

7800.00

5000.00
10000.00

19660.00

14800.00

16200.00

11.00 .00

9480.00

11000.00

10700.00

10800.00

19250.00

10700.00

10500.00

$8 \$ 40.00$

8900.00

8410.00

8385.00

615.00

3310.00

7005.00

$6 \$ 10.00$

5320.00
WII

RANGE

12600.00

16100.00

13200.00

10700.00

300.00

9800.00

7240.00

10600.00

9420.00

1090.00

\% 840.00

900,00
470,00

7870.03

0020.00

3830.00

110.00

7330.60

$\$ 280.00$

6640.00

1780.00
10000.00

6600. 00

1500.00

1600.00

3920.00

2300.00

1500.00

2 apo. 00

5080.00

2500.00

2580.00
$10 \% 10.00$

2960.00

2300.00

4430.00

2689.00

2080.00

5600.00

7020.00

1390.00

1720.00

2210 .00
13900.00

1040.00

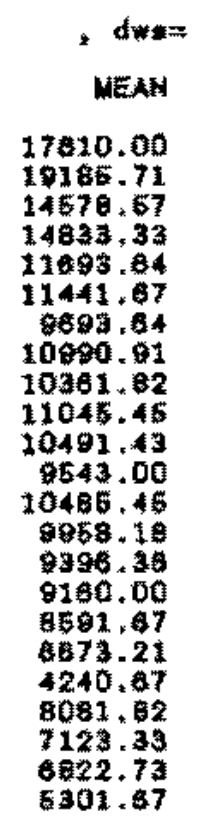

, $₫=5$

(cod*mA17, nam =WANGESE, In i to=PPB

WAX

MEOIAN

UIN

RANGE

1. $+\mathrm{H4}-17$

$1-f_{13}-2 C$
$1-1-3-2 C$

$1-H 3-26$
$1-1+4-6$

$1+14-12 \mathrm{C}$

$1+44+16$

1-Ha-8

$1-1+16$

1-H4-11

$1-14-13$

$1+\mathrm{nit}-3$

I-Hi -5

$1-1+3-1$

1.m.4 -15

1-W $+14-25 A$

I $-\mathrm{H} 4 \mathrm{~m} \mathrm{9}$

1-44-12A

1. -144

$1-4 i-14$

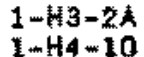

$\begin{array}{rr}6 & \text { BELOMOL } \\ 11 & 0 \\ 11 & 0 \\ 28 & 1 \\ 12 & 0 \\ 7 & 1 \\ 11 & 5 \\ 8 & 6 \\ 12 & 5 \\ 11 & 5 \\ 12 & 7 \\ 30 & 4 \\ 38 & 36 \\ 35 & 28 \\ 11 & 7 \\ 30 & 26 \\ 11 & 6 \\ 11 & 7 \\ 11 & 10 \\ 11 & 6 \\ 11 & 10 \\ 11 & 11 \\ 11 & 11 \\ 11 & \end{array}$

$\begin{array}{rr}01 Y S & N \\ 5 & 5 \\ 11 & 11 \\ 11 & 10 \\ 59 & 28 \\ 12 & 11 \\ 7 & 5 \\ 11 & 8 \\ 6 & 2 \\ 12 & 3 \\ 11 & 3 \\ 11 & 4 \\ 28 & 25 \\ 28 & 3 \\ 28 & 4 \\ 11 & 4 \\ 28 & 4 \\ 11 & 2 \\ 11 & 4 \\ 11 & 1 \\ 11 & 5 \\ 11 & 1 \\ 11 & : \\ 11 & : \\ \end{array}$

$326 \cdot 00$

186.00

142.00

115.00

2.00

70.00

Q3.00

54.00

44.00

37.00

30.00

30.0

28.00

IE, 00

14.00

12.00

$12 \times 00$

10. 00

$\$ .00$
11.00

Q. 00

32.00

32.00
6.00

12.0n

8.00
1.00

16.00
5.00

5.00
7.00

6.00

5.00

15.00

8.00

6.00

7.00

F. on

12.00

5.00

0.00

6.00
$\$ 15.00$

178.00

110 , 00

整. 00

1.7.

81.00

72.00

47.00

40.00

37.00

32.00

25.00

15. 00

20.00

23.00

9.00

7.00

7.00

0.00

5.000
0.00
, dw50

ME추사

I22. 10

$64+27$

90.40

72.75

40.18
62.00

62.00
36.17

30.50

21.87

27.00
29.00

10.60

10.80
20.33

I. 84

1., 10

10.50

8.25

12. 00

4. 80

5.00 $\sin _{\sin }$

$3583.12 \quad 0.20$

$1963,67 \quad 0.30$

$684 \times 13 \quad 0.06$

$3328.93 \quad 0.11$

000.710 .05

$1361.20 \quad 0.14$

$77 \% .80 \quad 0.07$

$1 \% 02.18$

$709.07 \quad 0.08$

1164.03 0.33

$739.14 \quad 0.07$

a. 0.08

$146.58 \quad 0.25$

782.1100 .08

1938.23 0.29

2385.510 .56

$398.37 \quad 0.05$

62.01 0.07

$\begin{array}{ll}\text { 8.5. } & 8.88 \\ 411.61 & 0.08\end{array}$

* reguefis

STD $C Y$

$138.43 \quad 1.13$

$69.24 \quad 0.92$

0.4 है

$23.04 \quad 0.32$

$31.32 \quad 0.78$

$28.67 \quad 0.72$

$33.23 \quad 0.84$

$28.01 \quad 1.29$

18.680 .68

13.290 .70

$5.32 \quad 0.50$

$\begin{array}{ll}8.39 & 0.41 \\ 9.03 & 0.67\end{array}$

10.230 .73

$4.92 \quad 0.48$

$2.90 \quad 0.36$

1. $8 \dot{2} 0.28$ 


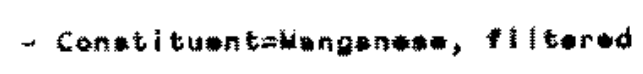
WELLNAHE SALPLES BELOML DAYS

$\begin{array}{rr}11 & 5 \\ 11 & 11 \\ 14 & 14 \\ 12 & 11 \\ 0 & 2 \\ 11 & 4 \\ 10 & 2 \\ 12 & 1 \\ 3 & 2 \\ 11 & 1 \\ 8 & 1 \\ 11 & 1 \\ 11 & 8 \\ 11 & 1 \\ 15 & 1 \\ 11 & 1 \\ 14 & : \\ 11 & : \\ 14 & : \\ 14 & : \\ 10 & : \\ 11 & : \\ 11 & \end{array}$

- Constitumbethorcury

WELLWAUE SAMPLES

\section{$1-H 4-4$
$1-44 m-3$}

1.-H4-3

$1-4{ }^{3}-2 \theta$

$1-43-2 A$

$1-H 3-26$

i.m.

$3+14-8$
$1-1+44-7$

$1+41+9$

$1-4+40$

$1+-14-12$

1-14-12A

$1-4+12 B$

$1-H 4-126$

$1-\mathrm{H} 4-1.3$

$1+14-14$

$1-H 4-15 B$

1-将- -16

1-H4 -17

29
29
36
11
11
11
38
28
11
11
11
11
12
11
11
12
11
11
11
11
6
0
6

BELOWEL DAYS

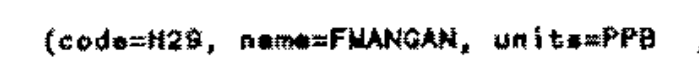

$+1=8$

, $d *=50$

, rmg=EFAs)

WX UEOIAN WRN RANQE WEN STO CV

\begin{tabular}{|c|c|c|c|}
\hline $\begin{array}{r}123.00 \\
120.00 \\
08.00 \\
76.00 \\
81.00 \\
68.00 \\
30.00 \\
10.00 \\
10.00 \\
10.00 \\
10.00 \\
8.00 \\
7.00 \\
7.00 \\
5.00 \\
5.00\end{array}$ & $\begin{array}{r}95.00 \\
38.00 \\
63.00 \\
35.00 \\
33.00 \\
17.60 \\
18.60 \\
19.00 \\
19.00 \\
10.00 \\
10.00 \\
8.00 \\
8.50 \\
7.00 \\
6.00 \\
5.00\end{array}$ & $\begin{array}{r}28.00 \\
7.00 \\
48.00 \\
8.00 \\
6.00 \\
5.00 \\
7.00 \\
19.00 \\
7.00 \\
10.00 \\
10.00 \\
6.00 \\
6.00 \\
7.00 \\
8.00 \\
5.00\end{array}$ & $\begin{array}{r}106.00 \\
121.00 \\
30.00 \\
70.00 \\
65.00 \\
53.00 \\
23.00 \\
0.00 \\
12.00 \\
0.00 \\
0.00\end{array}$ \\
\hline 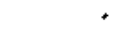 & $*$ & . & \\
\hline . & $=$ & + & \\
\hline • & . & • & \\
\hline F & - & * & \\
\hline * & • & - & \\
\hline " & . & . & \\
\hline
\end{tabular}

91.1.

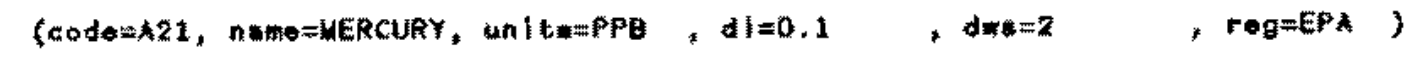

NEOIAN
5,82
6,3
60

63.00

35.82

33. 60

24.60

10.50

19.00

$13.0 \mathrm{n}$

10.00

10.00
0.00

0.00
6.60

6.50
7.00

6.00

E.00

Wn

RANGE

UEA

STO

0.00

0.00

0.00

7.40

4.80

4.75
0.16

$36.67 \quad 0.44$

11.02 0.17

2.720 .56

24.1200

10.260 .88

$6.4 \dot{8} 0.6 \dot{6}$

$0.7 i \quad 0.11$

$\begin{array}{ll}4.75 & 0.00 \\ 0.10 & 0.00\end{array}$


- Conctituent=liethylot chlorido WELLMALE SAWPLE BELOWOL

DAYS
$1-41-4$ $1=+43-26$ $1-\mathbf{h} 3=1$ 1- $-\mathrm{H} 3 \mathbf{4}+\mathbf{3}$

$2+44-3$

$1+\mathrm{HA}+8$

1-144-16 I-HA-12C $1-44-17$ $1-H_{3}-28$ $1-1+4-1+14$ $1-\mathrm{H} 3-2 \mathrm{a}$ 1-H4-3

$1+14-6$

i-H4-9

1-1+10

$1+\mathrm{H} 4-11$

1 $-4+4-12 A$ $1-M 4-13$

$1-34-15 A$ $1+1 i x-16$

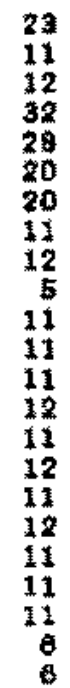

19
8
4
20
24
16
14
10
11
4
10
10
10
12
11
12
11
12
11
11
11
6
8

19
11
11
28
26
20
20
11
11
6
11
11
11
11
11
11
11
12
11
11
11
6
6

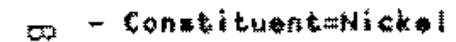

WELLNAHE 5AMPLES

GELOWDL

1-44-3 $1+14-17$ 1- $+4-11$ $1-1+4-12 c$ $1-1+4=4$

1. $+44-4$

$1-13-2 C$

$1+43-2 A$

$1-14-9$

$1-1+10$

$1-\mathrm{HA}-14$

$1+x_{31}-18$

$1-13=-2 B$

$1-43-2$

1 $-\mathrm{H}+4-6$

$1-H+12 \mathrm{~A}$

$1-14-1$ 然

1) +4 4-13

$1-44-15$

$1-4+158$
$1-14+16$

$\begin{array}{rr}30 & 0 \\ 5 & 1 \\ 12 & 9 \\ 12 & 0 \\ 11 & 9 \\ 30 & 13 \\ 11 & 9 \\ 11 & 10 \\ 11 & 9 \\ 11 & 10 \\ 11 & 10 \\ 11 & 10 \\ 6 & 5 \\ 35 & 35 \\ 11 & 11 \\ 38 & 36 \\ 28 & 29 \\ 11 & 11 \\ 11 & 11 \\ 11 & 11 \\ 11 & 11 \\ 11 & 11 \\ 7 & 1\end{array}$

fcodsmas, nwmmETHYCH, unit:mPPB , di=10

\begin{tabular}{|c|c|}
\hline wax & MEDTAN \\
\hline $\begin{array}{r}4800.00 \\
2850.00 \\
2360.00 \\
1500.00 \\
1400.00 \\
820.00 \\
470.00 \\
480.00 \\
410.00 \\
48.00 \\
12.00 \\
37.00 \\
12.00\end{array}$ & $\begin{array}{r}570.00 \\
1506.00 \\
1410.00 \\
36.00 \\
250.00 \\
504.50 \\
70.00 \\
40.00 \\
410.00 \\
19.00 \\
42.00 \\
37.00 \\
12.00\end{array}$ \\
\hline . & $=$ \\
\hline * & * \\
\hline$\cdot$ & ${ }^{*}$ \\
\hline & \\
\hline . & * \\
\hline ^ & . \\
\hline & $=$ \\
\hline . & : \\
\hline
\end{tabular}

MIN

RANTGE

- dwes:

mog $\quad)$

STD tY

$340.00 \quad 0280.00$

$\begin{array}{rr}360.00 & 2290.00 \\ 140.00 & 1840.00\end{array}$

140.00

28,00

34.00

1472.00

1366,00
873,00

873.00

22.00

480.00

110.60

49.00

148.00

0.00

0.00

0.00

32.00

12,00

0.00

0.00

2503.3

2503.33

1410.00

336.60

403.80

$.84,00$

135.00

480.00

410.00

19.00

.900
12.00

37.60

12.00

codo=A12, nama=NICKEt, uniteppe

What

WEDIAN

UIN

RAMCE

dw: $=$

MEAN

45.74

28.67

150.00

38.00

11.50
63.00

11,00

14.00

22.00

19.00

17.60

10.00

10.00

13.60

12.00

11.00

11. 00
10.00

11.00

10.60

11,00

i. 0.00

16.00

18.00
13.00

13.60
13.00

12.00

11.00
11.00

11.00
10.00

0.100
50.00

28.0

28.00

18.00

16.00

1.00
., 00

0.00

1.00

0.00

0.00

0.00

10. 7

19.8?

16.72

16.00

16.00

13.60

12.00

i1, 00

11.00
10.00

$3549.60 \quad 1.42$

$1810.27 \quad 2.00$

137.750 .97

$80.8 \mathrm{~S}$

$306.03 \quad 0.74$

$170.10 \quad 1,28$

:

r $r 9 g=$

5TO $\mathrm{CF}$

$37.45 \quad 0.71$

20.040 .50

7.480 .30

0.020 .48

$1.90 \quad 0.23$

$0.7 i \quad 0.05$ 


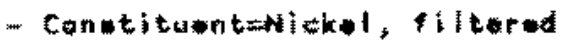

WELLNAUE SAH ES

$1-34-12 \mathrm{C}$ $1-\mathrm{fin}-3$

$1-14+\infty$

$1+44-150$

$1-1+4-17$

$1-14-8$

$1-13-1$

$1+\mathrm{Hg}-\mathrm{zA}$

$1-1+3-2 \mathrm{a}$

$1-13+2 C$

1...H4 - E

$1-1,1-8$

$1-H 4=30$

$1-44-11$

$1-H \rightarrow-128$

$1-H 4-13$

$1+14-11$

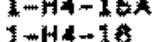

ELOMDL

OAYS
12
15
14
6
11
3
11
10
14
11
11
11
14
14
11
11
12
11
10
11
11
11
6

- Constituentwnitrato

WELLHAME SAMPLES

BEL OWDL

DAYS

1) $-44-3$

$1=0.4-6$

$1-114=12 \mathrm{i}$

$1-1+3-1$

$1+\mathrm{H4}+12 \mathrm{ta}$

$1-H 4-18$

$1-14 \div 15$ k

$1+\mathrm{H} 4-3$

$1+44-6$

$1-44-13$

$1+44-5$

$1-4+11$

$1-4+14-11$

$1-H 4+15 B$

$1-14-10$

$1+13-28$

$1-H 4-14$

$1-+14-16$

$1-43-25$
$1+-14-12 C$

31
33
12
11
34
11
6
5
11
12
28
11
37
11
12
11
11
11
11
11
7
11
12

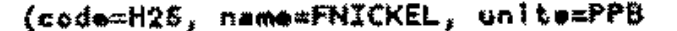

,

\& tow

- r*g*

)

MAX WEOIAN WIN RANGE

85.00

27.00

11.00

74.00

24.50

11.00

9.00

99.00
15.00

18.00
0.00

10.00
21.00

2.00
21.00

21.00
18.00

21.00

18.00

16. 00

15.00

13.00

$1 \mathrm{a} .00$

15.00

10.00

10.00

10.00

0.00

B. 00

0.00
0.00

MEAX

STO

cr

$24.10 \quad 18.38 \quad 0.56$

12.60
4.76

21.00

t. 00

18.00

13.00

10.00

,

(eode=C72, nementhTRATE, units=PPS

$A=\$ 00$

wax

MEDIAN

3160000.00

1300000.00

253000.00

171000 on

0000.00

86000.00

63000,00

45000.00

16000.00

44700.00

40700.00

10300.00

39000.00

3400

32800.00

0000

2500

.

2400.00

$24+400$

2000.00

16900.00

8120.00
है 140.00
018000.00

326000.00

145000.00

17) 80.00

58400 .00

24300.00

43500.00

28100 .00

29800.00

$3 \hat{z} 250.00$

21500.00

28550.010

2900000

(2)

12300.00

24800.00

21900.00

18700.00

19200.00

13000.00

4010.00
5195.00
UIN

240000.00

2720.00

51800.00
22800.00

2.2909 .00

1300.00

20100.00

12100.00

तb400.00

20600.00

1 isono. 00

13100.00

15000.00

27800 00

21800.00

15800.00

14700.00

17100.00

8320.00

2840.60
RANCE:

2904000.00

12002000

201200.00

48100.00

sovoto. 0

56800.00

$43700 \times 00$

400.00

19800.00

18100.00

25700.00

20200.00

$24 \$ 00.01$

8000.00

10800.00

14300.00

6300.00

15300.00

9700.00

3400.00

13820.00

5920,00
3600,00 332731.72

152163.84

4007

7164. 58

0.450.00

4840.00

20454.55

410.00

31476,00

23090.81

27440.23

\$1E90. 21

27025.00

20345.45

25051.55

21072.73

10518 .

g0is

190140

\$554. B5

4875,00 $63138.83 \quad 0.76$ 0.45

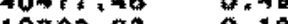
103 年3.23 O.16 1314.01 447.60 5301.62 avi.s? 902.97 3164.00

1516. A

$1057.86 \quad 0.19$

$3182.0 \mathrm{E}$

966.2500

0.49

$2480.26 \quad 0.15$

$1027.81 \quad 0.21$ 


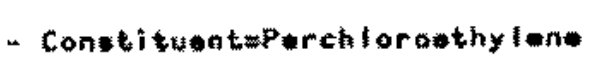

WELLKANE SAMLES GELOWOL.

DAYS $N$

$1-14-4$

1) $-44+3$

$1-\mathrm{H} 4-6$

$\frac{1}{1-3}+\mathrm{H}^{3}-1$

1 $-\mathrm{H} 3-2 k$

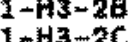

$1-\mathrm{HB}^{3}-\mathrm{CC}$

$1+64$

1 $-\mathrm{H4}-\mathrm{B}$

$1-\mathrm{H}-\mathrm{\theta}$

$1-$ 静4-10

$1+\mathrm{H} 4-11$

$1-H 4-129$

$1-\mathrm{H}+12 \mathrm{C}$

$-44-13$

$1-14=14$

$1-14-16 A$

$1+44-16$

i. $-14=17$

30
31
25
38
13
11
12
28
12
11
12
11
12
11
11
12
11
11
11
11
6
5
6

28
27
24
34
11
11
12
28
12
11
12
11
11
11
11
12
11
11
11
11
0
5
6

26
28
25
26
11
11
11
26
12
11
11
11
12
11
11
12
11
11
11
11
6
5
6

Conatituont=ph, 1 in it

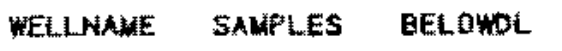

DAYS N

$1-H 4-12 A$

$1+-14-3$
$1-144-18$

$1-\mathrm{Ha}-1$.

1- $+4-7$

$1+H 4-B$

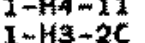

I $114-14$

$1-\mathrm{H}=-5$

i $\rightarrow+44-120$

$1-H^{4}+19$

1. $-14+12 C$

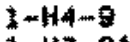

$1-A 3-2 k$

$3-13-20$

$-14-158$

$1-14-14$
$1-H 4-15$

$1-14-16$.

$\mathrm{I}-\mathrm{HA}+\mathrm{I}-\mathrm{I}$
(codeaATO, nam PERCENE, unit:=PPB

\begin{tabular}{|c|c|c|c|c|}
\hline wax & HEDTAN & WIN & RANGE & MENH \\
\hline $\begin{array}{l}52.00 \\
23.00 \\
15.00\end{array}$ & $\begin{array}{l}52.00 \\
11.20 \\
15.00\end{array}$ & $\begin{array}{l}52,00 \\
10,00 \\
16,00\end{array}$ & $\begin{array}{r}0.00 \\
13.00 \\
0.00\end{array}$ & $\begin{array}{l}52.00 \\
13.96 \\
16.00\end{array}$ \\
\hline . & $*$ & . & - & . \\
\hline • & . & . & * & 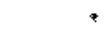 \\
\hline • & $*$ & " & • & $=$ \\
\hline . & . & . & . & 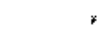 \\
\hline . & $=$ & . & - & 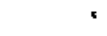 \\
\hline . & . & * & . & - \\
\hline . & * & . & * & n \\
\hline . & . & - & . & $x$ \\
\hline . & * & . & . & . \\
\hline$=$ & . & , & * & . \\
\hline * & * & . & . & . \\
\hline+ &. & . & * & * \\
\hline$=$ & . & . & . & - \\
\hline . & . & . & . & . \\
\hline * & $=$ & . & v & . \\
\hline . & . & . & . & - \\
\hline . & $*$ & . & . & . \\
\hline , & - & . & . & 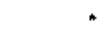 \\
\hline . & $=$ & . & . & . \\
\hline " & . & 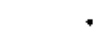 & $=$ & 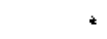 \\
\hline
\end{tabular}

(codem18\$, namePlFIELE, wnite=

. $4=0.1$

RANAE

2.40
2.60

2.60
3.20

2.00

2.60

3.10

1. 30

2.00

1.70

$1+20$

1.50
2.70
3.90

2.90

1.86

1. 10

1.70

1.70

1. 30

0.80

1.18
1.00 dw5
WEAN
7.67
7.76
7.45
7.98
7.63
7.39
7.68
7.48
7.65
7.56
7.59
7.64
7.13
7.28
7.65
7.84
7.11
7.56
7.25
7.46
7.17
7.11
7.09
* $m * g=$

STo

0.130 .44 
- Conatituont=pH, laboratory WELLNAME SAMPLES BELOWOL DAYS N $1 m+14-3$
$1-1+3 m-2 B$ $1-63-28$
$1-1+4-14$ $1+\mathrm{H}_{3}-2 \mathrm{~A}$ $1-14-4$ $1-6+1-8$ 1-H4 -126 $-44-1$ I-H4-125 $1-H 4-16 \mathrm{~B}$ $1-k 4-16$ $1+44-7$ $1-43-2 \mathrm{C}$ $1-4+16$ $1=44-6$

1. $44-18$

$1-13-1$

$1-\mathrm{HA}-17$

$1+44-1$

$1+44-10$

$\begin{array}{llll}2 & 0 & 2 & 2 \\ 2 & 0 & 2 & 2 \\ 2 & 0 & 2 & 2 \\ 2 & 0 & 2 & 2 \\ 2 & 0 & 2 & 2 \\ 1 & 0 & 1 & 1 \\ 2 & 0 & 2 & 2 \\ 2 & 0 & 2 & 2 \\ 2 & 0 & 2 & 2 \\ 2 & 0 & 2 & 2 \\ 2 & 0 & 2 & 2 \\ 2 & 0 & 2 & 2 \\ 1 & 0 & 1 & 1 \\ 1 & 0 & 1 & 1 \\ 2 & 0 & 2 & 2 \\ 1 & 0 & 1 & 1 \\ 2 & 0 & 0 \\ 2 & 0 & 2 & 2 \\ 1 & 0 & 2 & 2 \\ 2 & 0 & 1 & 1 \\ 2 & 0 & 2 & 2 \\ 1 & 0 & 2 & 2 \\ 1 & 0 & 1 & 1 \\ 2 & 0 & 1 & 1\end{array}$

- Conatitiontaplosphate

WELLNAME

BELOWDL OAYS

$1-h 1-3$

1:-144-9

$1-\mathrm{NA}-4$

$1-H 4+12$

$1-13-1$

$1-+13-2 B$

$1-113-25$

$1-14-6$

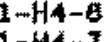

$1-4 i+9$

$1+4-10$

$1+H-11$

$1-14+32 \mathrm{~A}$

$1-\mathrm{t}_{4}-12 \mathrm{~s}$

$1-\mathrm{H}_{4}+12$

$1-4+1-14$

1- $-44-16$

$1-14+18$

$1-44-17$

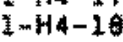

$\begin{array}{rr}31 & 30 \\ 12 & 10 \\ 33 & 31 \\ 12 & 11 \\ 34 & 33 \\ 11 & 11 \\ 11 & 11 \\ 11 & 11 \\ 37 & 37 \\ 38 & 28 \\ 12 & 12 \\ 11 & 11 \\ 11 & 11 \\ 12 & 12 \\ 21 & 11 \\ 11 & 11 \\ 11 & 11 \\ 11 & 11 \\ 11 & 21 \\ 11 & 11 \\ 6 & 8 \\ 6 & 5 \\ 6 & 6\end{array}$

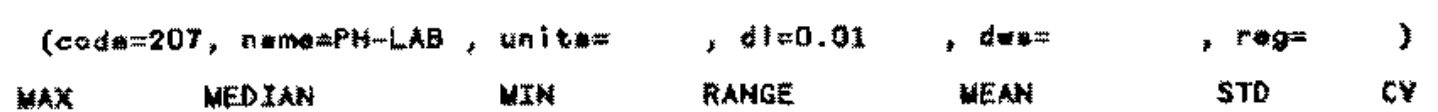

MAX MEDINA MIN RANGE WEAN

$\begin{array}{lllllll}8.30 & 0.13 & 7.97 & 0.33 & 8.13 & 0.73 & 0.03 \\ 8.18 & 7.30 & 7.77 & 0.41 & 7.98 & 0.29 & 0.04\end{array}$

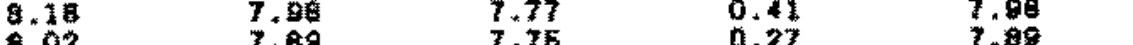

8.020 .7 .750 .2709

0.00

$\frac{7.91}{7.09}$

7.77

$7 \times 74 \quad 7.76$

7.747 .60

$7.74 \quad 7.71$

$\begin{array}{rr}7.73 & 7.87 \\ 7.70 & 7.70\end{array}$

7.89

7.60

$7.09 \quad 7.67$

$7.8 \mathrm{e}$

$7.68 \quad 7.47$

7.50

7.50

7.60

7.47
7.46
7.10

$7+49$

7.43

7.93
7.64

7.4

7.60

7.03

$7+69$

7.60

7.60

7.45

7.87

7.87

7.57

7.40

7.38

7.46
7.10

7.91

7.80

$0.12 \quad 0.0 \%$

$\begin{array}{ll}0.12 & 0.02 \\ 0.06 & 0.01\end{array}$

$0.11 \quad 0.0 j$

$0.12 \quad 0.02$

$0.00 \quad 0.01$

0.08 0.010

0.080 .01

$0.1 \% \quad 0.02$

$\begin{array}{ll}0.16 & 0.02 \\ 0.00 & 0.00\end{array}$

$0.01 \quad 0.00$

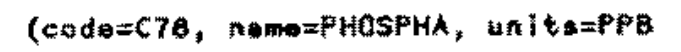

MAX MEOIAN

MIN

0.06

0.11

0.00

0.21

0.21

0.00

0.00

0.02

0.00

0.00

- $I=1000$

RANCE

NEAN

0.00

$0.00 \quad 11700.00$

6570.00

$\begin{array}{rrr}11700.00 & 11700.00 & 11700.00 \\ 8670.00 & 6570.00 & 6570.00\end{array}$

6360.00 6380.00

6300.00

1090.00

0.00

6300,00

1000.00 


\begin{tabular}{|c|c|c|c|c|c|c|c|c|c|c|c|}
\hline \multicolumn{5}{|c|}{ - Conmtituent:Fotentum } & \multicolumn{4}{|c|}{ 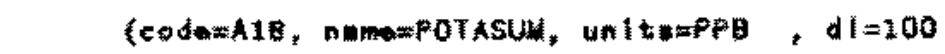 } & \multicolumn{2}{|r|}{, regat } & 3 \\
\hline WELLNALE & SAMPLES & BELENEDL & DEYS & $\mathbf{N}$ & $W \ldots x$ & HEDIN & MIN & AANGE & WEAN & sto & $\mathrm{CV}$ \\
\hline 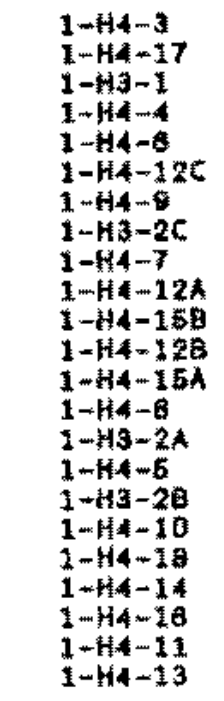 & $\begin{array}{l}30 \\
6 \\
36 \\
30 \\
20 \\
12 \\
11 \\
11 \\
11 \\
11 \\
11 \\
11 \\
11 \\
11 \\
11 \\
30 \\
11 \\
11 \\
5 \\
11 \\
7 \\
12 \\
11\end{array}$ & $\begin{array}{l}0 \\
0 \\
0 \\
0 \\
0 \\
0 \\
0 \\
0 \\
0 \\
0 \\
0 \\
0 \\
0 \\
0 \\
0 \\
0 \\
0 \\
0 \\
0 \\
0 \\
0 \\
0 \\
0\end{array}$ & $\begin{array}{l}29 \\
5 \\
29 \\
28 \\
28 \\
12 \\
11 \\
11 \\
11 \\
11 \\
11 \\
11 \\
11 \\
11 \\
11 \\
20 \\
11 \\
11 \\
6 \\
11 \\
7 \\
12 \\
11\end{array}$ & $\begin{array}{r}29 \\
5 \\
28 \\
29 \\
29 \\
12 \\
11 \\
11 \\
11 \\
11 \\
11 \\
11 \\
11 \\
11 \\
11 \\
29 \\
11 \\
11 \\
6 \\
11 \\
7 \\
12 \\
11\end{array}$ & $\begin{array}{r}18900.00 \\
6900.00 \\
7006.00 \\
7420.00 \\
7290.00 \\
7 \% 20.00 \\
8560.00 \\
6600.00 \\
6120.00 \\
6620.00 \\
5760.00 \\
5820.00 \\
5520.00 \\
5240.00 \\
5170.00 \\
5110.00 \\
5080.00 \\
4600.00 \\
4550.00 \\
1420.00 \\
3040.00 \\
2720.00 \\
2400.00\end{array}$ & $\begin{array}{l}8780.00 \\
7190.00 \\
6405.00 \\
5380.00 \\
8020.00 \\
5290.00 \\
5920.00 \\
1820.00 \\
6000.00 \\
5190.00 \\
5350.00 \\
5180.00 \\
5240.00 \\
1920.00 \\
1810.00 \\
4485.00 \\
4710.00 \\
4210.00 \\
4035.00 \\
1020.00 \\
2870.00 \\
2820.00 \\
2250.00\end{array}$ & $\begin{array}{l}3480.00 \\
8600.00 \\
5370.00 \\
3180.00 \\
4000.00 \\
1480.00 \\
5000.00 \\
4370.00 \\
6850.00 \\
4000.00 \\
4940.00 \\
1370.00 \\
4720.00 \\
440.00 \\
3990.00 \\
3170.00 \\
4570.00 \\
2880.00 \\
3620.00 \\
3800.00 \\
2550.00 \\
2210.00 \\
1900.00\end{array}$ & $\begin{array}{r}1310.00 \\
2280.00 \\
2636.00 \\
4270.00 \\
2410.00 \\
2610.00 \\
1600.00 \\
2130.00 \\
1270.00 \\
1860.00 \\
610.00 \\
1260.00 \\
800.00 \\
600.00 \\
1120.00 \\
1640.00 \\
520.00 \\
1740.00 \\
730.00 \\
540.00 \\
490.00 \\
670.00 \\
500.00\end{array}$ & 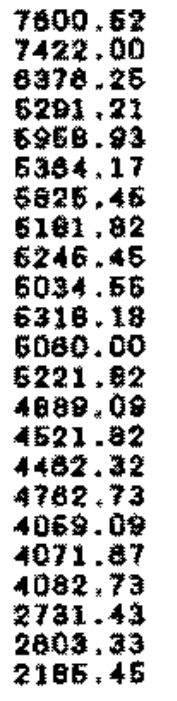 & 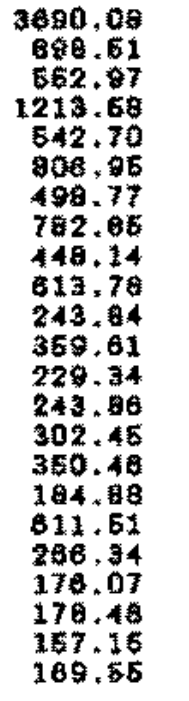 & $\begin{array}{l}0.40 \\
0.12 \\
0.00 \\
0.23 \\
0.08 \\
0.16 \\
0.09 \\
0.16 \\
0.00 \\
0.12 \\
0.05 \\
0.07 \\
0.04 \\
0.05 \\
0.07 \\
0.09 \\
0.04 \\
0.16 \\
0.07 \\
0.04 \\
0.07 \\
0.02 \\
0.04\end{array}$ \\
\hline - Conmtituent & Patmosiw & tiltere & & & & 0, nom & S, $u n$ & $. d f=100$ & , dewa: & , rog $=$ & $\xi$ \\
\hline WELLINANE & SAMPLES & BELOYOL & okts & $N$ & $u k x$ & MED HAN & MUN & RANGE & MENA & $\$ T$ & $C V$ \\
\hline 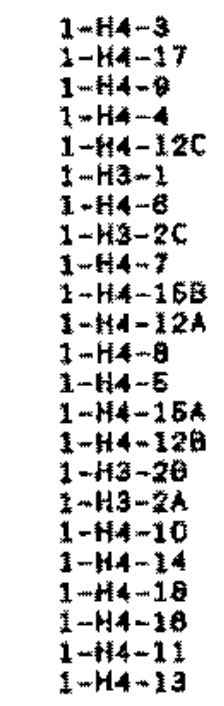 & $\begin{array}{r}18 \\
3 \\
11 \\
11 \\
12 \\
11 \\
14 \\
11 \\
12 \\
11 \\
11 \\
11 \\
14 \\
11 \\
10 \\
11 \\
11 \\
11 \\
11 \\
6 \\
6 \\
12 \\
11\end{array}$ & $\begin{array}{l}0 \\
0 \\
0 \\
0 \\
0 \\
0 \\
0 \\
0 \\
0 \\
0 \\
0 \\
0 \\
0 \\
0 \\
0 \\
0 \\
0 \\
0 \\
0 \\
0 \\
0 \\
0 \\
0\end{array}$ & $\begin{array}{l}16 \\
3 \\
10 \\
14 \\
12 \\
14 \\
14 \\
11 \\
11 \\
11 \\
11 \\
11 \\
14 \\
11 \\
10 \\
11 \\
11 \\
11 \\
11 \\
8 \\
8 \\
12 \\
11\end{array}$ & $\begin{array}{r}16 \\
3 \\
10 \\
14 \\
12 \\
14 \\
14 \\
11 \\
11 \\
11 \\
11 \\
11 \\
14 \\
11 \\
10 \\
11 \\
11 \\
11 \\
11 \\
8 \\
6 \\
12 \\
11\end{array}$ & 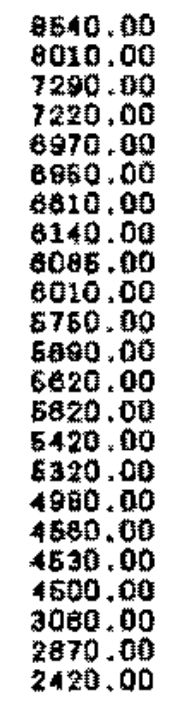 & $\begin{array}{l}4640.00 \\
7560.00 \\
6130.00 \\
5100.00 \\
6325.00 \\
6525.00 \\
6360.00 \\
5160.00 \\
6220.00 \\
5310.00 \\
5180.00 \\
5030.00 \\
1590.00 \\
5360.00 \\
5055.00 \\
4820.00 \\
4490.00 \\
4310.00 \\
4090.00 \\
4150.00 \\
2010.00 \\
2615.00 \\
2260.00\end{array}$ & $\begin{array}{l}2200.00 \\
7520.00 \\
5030.00 \\
3080.00 \\
4680.00 \\
5620.00 \\
5800.00 \\
4380.00 \\
170.00 \\
4820.00 \\
3900.00 \\
1680.00 \\
1370.00 \\
1760.00 \\
1390.00 \\
4530.00 \\
3830.00 \\
2830.00 \\
3760.00 \\
3870.00 \\
2800.00 \\
2680.00 \\
2030.00\end{array}$ & $\begin{array}{r}\$ 340.00 \\
190.00 \\
2280.00 \\
1160.00 \\
2410.00 \\
1430.00 \\
750.00 \\
1780.00 \\
1346.00 \\
1190.00 \\
1860.00 \\
1000.00 \\
1260.00 \\
810.00 \\
1030.00 \\
780.00 \\
1160.00 \\
1730.00 \\
750.00 \\
830.00 \\
480.00 \\
310.00 \\
380.00\end{array}$ & 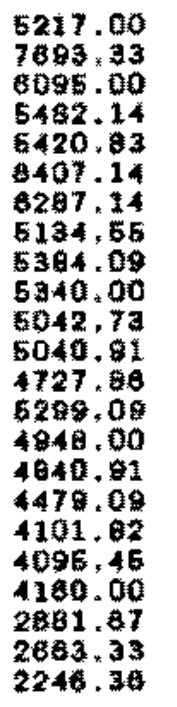 & $\begin{array}{r}1744.11 \\
274.96 \\
715.72 \\
1326.70 \\
742.86 \\
367.90 \\
271.90 \\
572.72 \\
131.05 \\
287.12 \\
654.59 \\
268.70 \\
380.09 \\
230.54 \\
335.89 \\
272.63 \\
323.74 \\
618.42 \\
198.19 \\
285.83 \\
181.70 \\
108.64 \\
130.50\end{array}$ & $\begin{array}{l}0.33 \\
0.04 \\
0.12 \\
0.24 \\
0.14 \\
0.06 \\
0.04 \\
0.11 \\
0.05 \\
0.08 \\
0.13 \\
0.06 \\
0.08 \\
0.04 \\
0.07 \\
0.00 \\
0.07 \\
0.16 \\
0.00 \\
0.00 \\
0.08 \\
0.04 \\
0.08\end{array}$ \\
\hline
\end{tabular}


- Constitumt=rote 1 rodium

WELLAAME SAMPLES DELOHDL

$1-54-12 C$
$1-44-17$

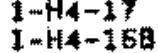
$1 .+14-168$
$1-13-2 C$ $1-64-128$

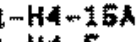
$1-14-6$

$1-39-1$

$1-1-13-28$

$1-H-12 A$

$1-14-16$

$1+14-3$

$1-1+4=8$

$1-64+13$

$1-44-13$

$1-+14-18$
$1-43-2 A$

$1-H 4-3$

$1-\mathrm{H} 4-\mathrm{A}$

$1-64-6$

12
6
11
11
11
11
37
34
11
11
11
8
28
11
21
12
11
6
11
11
29
29
11

DAYS

N

wax

5
1
0
4
4
5
33
30
5
3
5
5
15
4
5
10
5
4
7
6
19
26
8

$\begin{array}{rr}12 & 7 \\ 8 & 4 \\ 11 & 11 \\ 11 & 7 \\ 11 & 7 \\ 11 & 8 \\ 20 & 1 \\ 28 & 4 \\ 11 & 8 \\ 11 & 8 \\ 11 & 8 \\ 4 & 1 \\ 28 & 14 \\ 11 & 8 \\ 11 & 8 \\ 12 & 2 \\ 11 & 8 \\ 8 & 2 \\ 11 & 4 \\ 11 & 3 \\ 29 & 10 \\ 26 & 3 \\ 11 & 3\end{array}$

- Conetitumetzon l on tum

WELLINANE SANHES

BELONOL

DAYS N

1-Ha-6

$1-H 3-1$

I $-1-13-21$

$1-13-2 C$

1-Hitm 3

$1-H 4-1$

ini -8

$1+4+4-7$

1) $-44-3$

$1-4+\cdots$

$1-\mathrm{H} 4-11$

$1-14-112 A$

$1-1+128$

$1-64 m 126$

$1-44=13$

$1+14-16 \mathrm{~A}$

1-H4-150

$1-\mathrm{H}_{4}-1 \mathrm{H}$

1-H4-1

$\begin{array}{ll}38 & 36 \\ 36 & 36 \\ 11 & 11 \\ 11 & 11 \\ 11 & 11 \\ 30 & 30 \\ 30 & 30 \\ 28 & 28 \\ 11 & 11 \\ 11 & 11 \\ 11 & 11 \\ 11 & 11 \\ 12 & 12 \\ 11 & 11 \\ 11 & 11 \\ 12 & 12 \\ 11 & 11 \\ 11 & 11 \\ 11 & 11 \\ 11 & 11 \\ 6 & 8 \\ 5 & 5 \\ 6 & 6\end{array}$

1.30
1.30

0.83

0.00

0.72

0.39

0.61
0.68

0.68
0.55

0.81

0.43

0.42
0.40

0.40

0.37
0.34

c.as

0.33

0.31

0.31

0.31

0.21

Mex

12,50

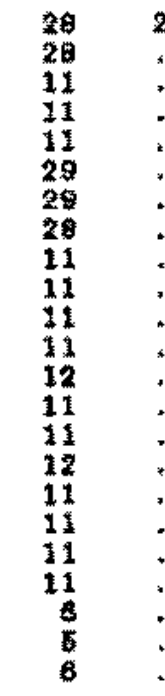

foode=191, nmm=RADIUL, unitamCI/L, dI=1

$$
\text { MEDIAN }
$$

\subsection{86}

0.26

6. 41

0.33

0.25

0.23

0.31

0.32

0.37

0.31

0.26

0.20
0.23

0.29

0.24

0.18

1.13

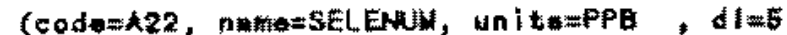

WEOIAN

0.00
RANoE

UIX

0.85

0.75

0.68

0.67

0.35
0.37

0.38

0.35

0.25

0.00
0.22

0.21

$0.1 \%$
0.18

0.18
0.17

0.17

0.07

0.21

0.18

0.12

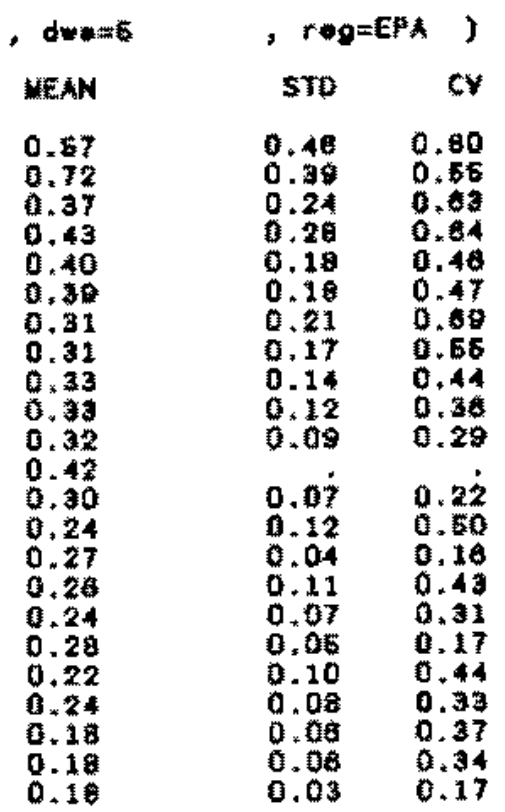

, dw: 10

RANGE

WIN

MNGE

NENN

- $\left.\operatorname{cog}=5 \mathrm{st}_{\mathrm{A}}\right)$

8.00

4.860 .56 


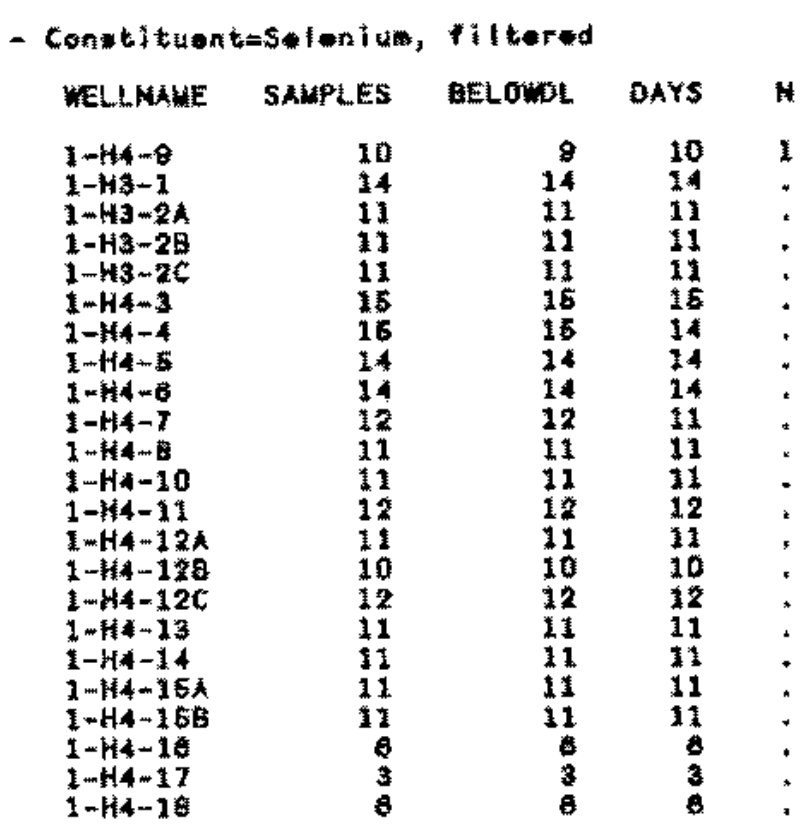

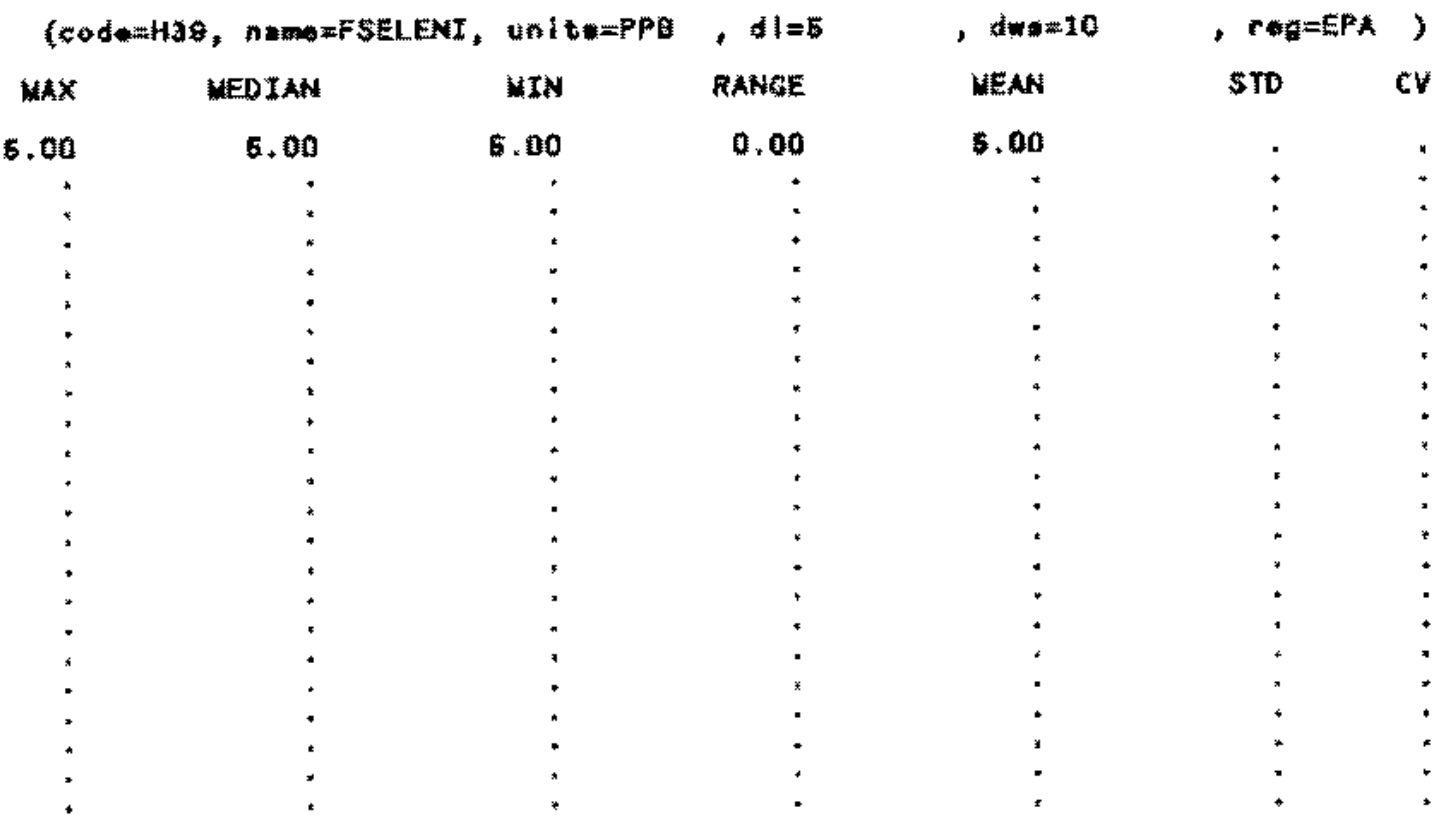

- Cenetituentesilyor

WELLNAEE SALPLES BELOWOL DAYS N

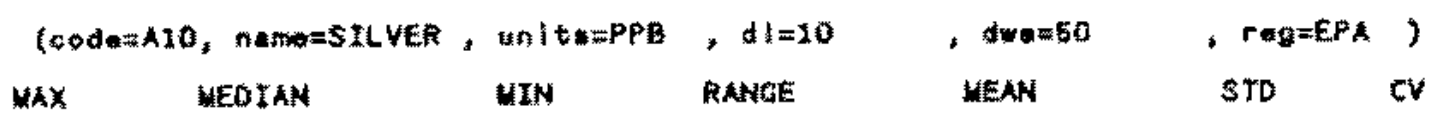

\begin{tabular}{|c|c|c|c|}
\hline 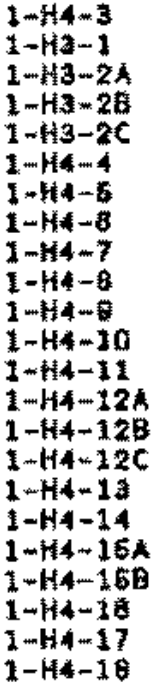 & $\begin{array}{l}30 \\
35 \\
11 \\
11 \\
11 \\
30 \\
38 \\
28 \\
11 \\
12 \\
11 \\
11 \\
12 \\
11 \\
11 \\
12 \\
11 \\
11 \\
11 \\
11 \\
7 \\
5 \\
6\end{array}$ & $\begin{array}{l}29 \\
35 \\
11 \\
11 \\
11 \\
30 \\
39 \\
28 \\
11 \\
11 \\
11 \\
11 \\
12 \\
11 \\
11 \\
12 \\
11 \\
11 \\
11 \\
11 \\
7 \\
5 \\
6\end{array}$ & $\begin{array}{l}28 \\
28 \\
11 \\
11 \\
11 \\
29 \\
28 \\
48 \\
11 \\
11 \\
11 \\
11 \\
12 \\
11 \\
11 \\
12 \\
11 \\
11 \\
11 \\
11 \\
7 \\
5 \\
6\end{array}$ \\
\hline
\end{tabular}

11 tet

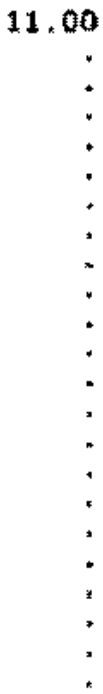

21. 09

0.00

11.00 
- Conmt tuant=\$adium

WELLWAME SAMPLES

I) $-14-3$

$1-\mathrm{H} 4-4$

$\lim _{1 \rightarrow+14-12 C}$

$1-\mathrm{A}+4)$

$1-14-124$

$1-\mathrm{H}-1$

1-Ha-1)

$1+4)^{4}-10$

$1+4<-1$

$1-1+4=8$

$1-\operatorname{Ha}^{3}-2 \mathrm{2}$

$1-H 3-25$

$1+H 4-18 k$

$1+44-6$

1-1 $1+4-16$

$1-4+41$

$1-\mathrm{H} 4+13$

$1-14-18$
EELOHDL DEYS N

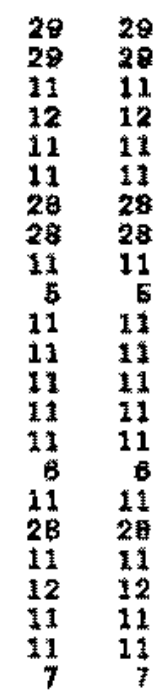

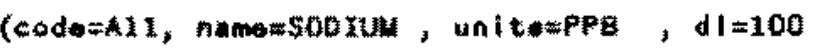

Mx

MEDTAN

What

RANGE

\$\$2000. 00

213000,60

48.

36100.00

32000.00

28100.000

23700.00

18100.00

17200.00

15800.00

14000 o0

4000.00

13000.00

13500.00

12600.00

11800.00

11100.00

11300.00

11300.00

10100.00

6250.00

7350.00

5280.00
351000 . 00

143000,00

1700.00

12100.00

28600.00

10700.00

22300.00

12300.00

15200.00

13400.00

13300.00

12000.00

11000.00

co00.00

990.00

10000.00

9810.00

10200.00

7285.00

1470.00

8.400 .00
4480.00
172000.00

12400.00

3870.00

19600.00

10700.00

16700.00

1 E700.00

14200.00

7890.00

10200.00

$\$ 0000.00$

10600.00

$\$ \$ 00.00$

2330.00

000.00

93.5. 0a

9080.00

3720.00

7000.00

$5 \$ 30.00$

4090,00
720000.00

200600.00

37200.00

12400.00

17400 .00

11000.00

8000,00

1000.00

0110.00

3900 on

$3900 * 00$

3000.00

3840.00

870.0

1900.00

2916.00

2210.00

3390.00

1200.00

1420.00
1190.00
11000.00

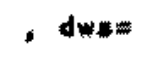

MEN

304082.07

12456

21481.92

14389.17

26716.10

1 aล5. 71

ats

13254.55

15840,00

13050 . 100

1500.1

12.72 .73

17038. 36

2038.36

9814.65

$1074 \% .5$

8sit: 0

10195,45

7897.50

7683.04

8827.27
$452.5 ?$

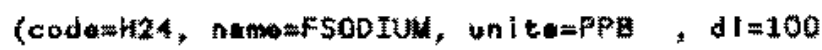

diw:

WEAI

29500000

1357.92 .96

21346.45

14436.00

18218 .

23935.71

3110208

1182.86

17000.00

137.00

12700.08

1)

11300.91

12072.73

10737.14

9639.05

$10945=45$

10310.91

10321.67

$\mathrm{7045.83}$

7861.62

$6094 \div 5$

4950.00 rea $)$

STD

191966.01

60280.83

$11077.06 \quad 0.77$

4420.370 .17

6100.600 .20

$2838.7 \mathrm{e} \quad 0.13$

$1830.73 \quad 0.08$

$2214.66 \quad 0.17$

$1209.23 \quad 0.08$

2 tos.35 0.22

1408.58

1023.080 .09

1188.40

1358.55

507.7005

$892.57 \quad 0.07$

$131.34 \quad 0.14$

333.580 .04

$\begin{array}{ll}495.74 & 0.07 \\ 108.02 & 0.09\end{array}$

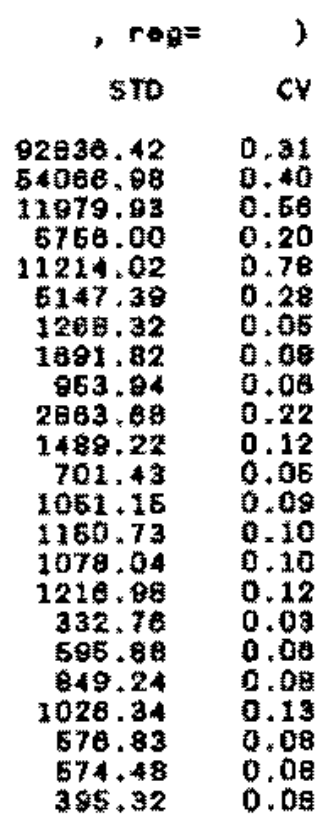




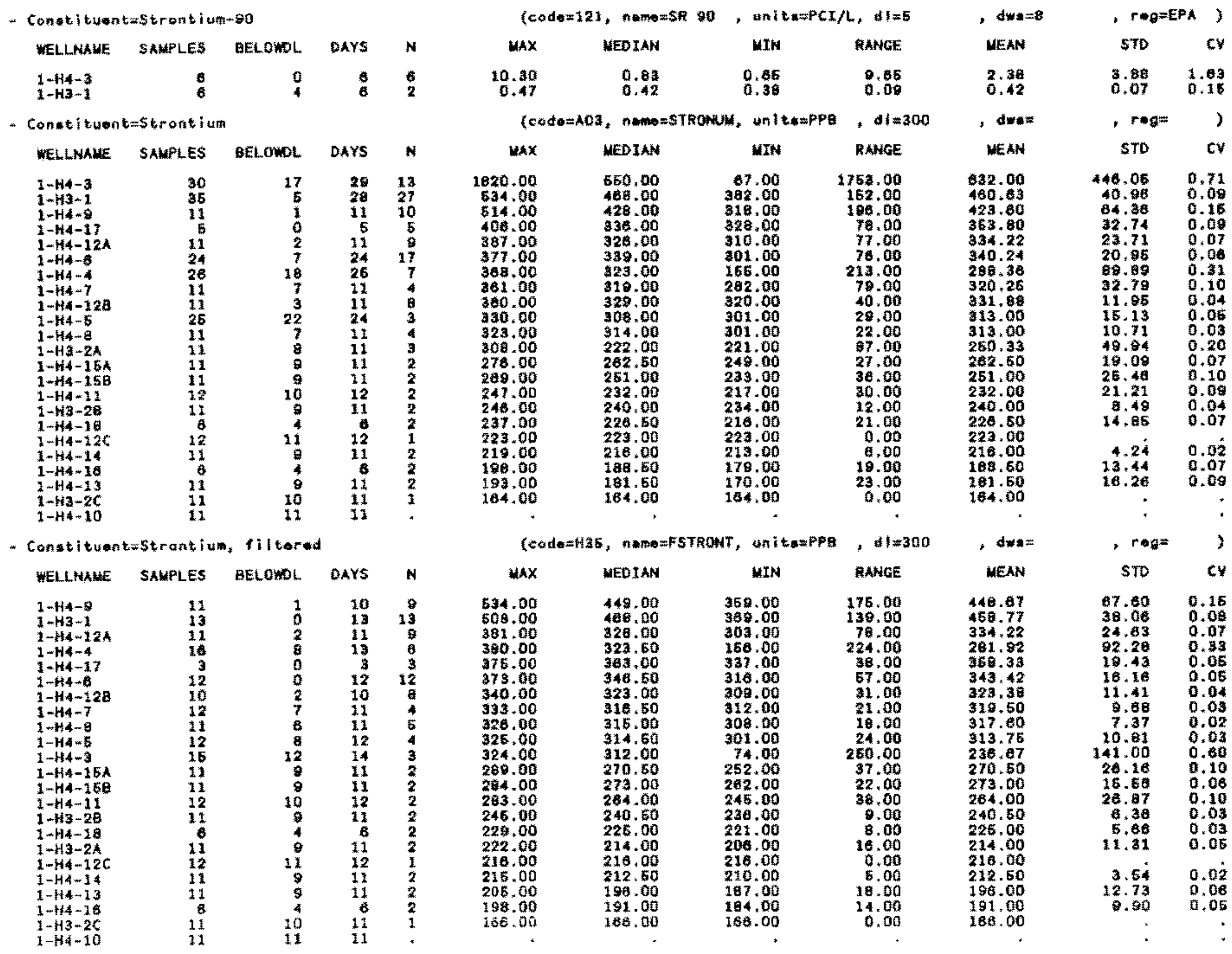


- Conotitomt=Sull ato

WELLNAME \$ANPLES

$1-\mathrm{H}-\mathrm{a}$

$1-14-7$

$1-H 4-4$

$1+\mathrm{HA}-17$

$1+13-1$

$1+44-9$

$1-13-2 \mathrm{~A}$

$-44-6$

$1-14-12 A$

$1-14 \rightarrow-15 A$

$1-\mathrm{B} 3-2 \mathrm{~B}$

$i-43-26$

$1-44-10$

$1-24-18$

$1-14+14$

$1-44-11$

$1-\mathrm{HA}_{4}-\mathrm{Iz}$

$1-14-16$

$1-14-12 \mathrm{C}$
QEFoWDL

$\begin{array}{rr}\text { DAYS } & \text { N } \\ 28 & 29 \\ 28 & 28 \\ 11 & 10 \\ 29 & 28 \\ 6 & 5 \\ 26 & 28 \\ 11 & 11 \\ 11 & 11 \\ 11 & 11 \\ 28 & 28 \\ 11 & 11 \\ 11 & 11 \\ 11 & 11 \\ 11 & 11 \\ 11 & 11 \\ 11 & 11 \\ 11 & 11 \\ 8 & 6 \\ 11 & 11 \\ 12 & 12 \\ 11 & 11 \\ 8 & 8 \\ 12 & 12\end{array}$

- Conatituentwhal carbon

WELLIMME \$AUFLES DELOWDL.

DAYS

$1+\mathrm{H3}-\mathrm{I}$

$1-\mathrm{H} 4-17$

$1-14-1$

$1-\mathrm{H}^{2}-12 \mathrm{~A}$

$1-H 4-6$

$1-44-126$

$1 \rightarrow+1)=6$

$1-\mathrm{H}+\mathrm{m}$

$1-4+25 x$

$1-4-160$

$1-14-7$

1.m+ha -10

$1-\mathrm{H} 4-11$

$1-14+19$

1-

$1+H^{3}-20$

$1+H 3-20$

$1+\cdots+13$

$1-+14+16$

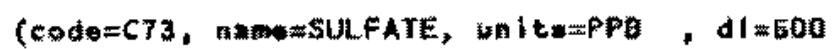

vitw

RANGE

62200.00

40000.00

46600.00

$1400,000.13300 .00$

52000.00

setono 00

68300.00

68300.00

30000.00

29600.00

29400.00

36400.00

32300.00

33600.00

19800.00

22700 , of

34300.00

37300.00

3200.00

32900.00

27700.00

24800,00

24200.00

26200.00

19000.00

13100.00

37400.00

a1600.00

3000000

23800.00

22100.00

33300.00

2000.00

14000.00

8100.00
10500.00

sat? 00

3500.00

5000.00

4700.100

28650.00

, dw:200000, r.g-EPAS)

NEAN

sit

c*

29800,00

(codewt16, nnmemic

unito=PPB, $d 1=1000$

43700.00

36000.00
36.400 .00

34000.00

33300.00

33800,00

24700.00

32300.00

32000.00

2300.00

31200.00

30900.00

30600.00

$\$ 300.00$

30200 . 00

20700.00

26500.00

73000.00

24800.00

24000,00

22300,00

13000.00

32000.00
$\times 1 \% 00.00$

1600.00

100.00
0

2100.00

700.00

0.00

9200.000
1500.00

0.00

0.00

800,00

0.00

2200.00

0.00

500.00

2200.00

1100,00

o.00

1300.00

900.00

23250.00

23700.00

125877,50

71005.00

62179.31

88180.00

72048.21

76877.27

2700.0

42708.03

48100.93

$52064 \times 55$

48343.64

12990.21

30472.73

39081.02

44227.27

39706,67

40004 .

38618.87

3 200.00

27250.00

26500.00

, dwat

NEAN

c1a61.01

$21894.87 \quad 0.28$

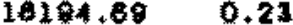

$19850.04 \quad 0.32$

$8236.75 \quad 0.07$

10186.210 .14

$0337.37 \quad 0.11$

1)

$10002.07 \quad 0.27$

$105+3.41$

$10543+140.21$

0000.300 .13

$7219.07 \quad 0.17$

$12019.08 \quad 0.39$

9645.130 .24

$2842.30 \quad 0.07$

$3172+50 \quad 0.09$

2504.840 .06

$2767.90 \quad 0.08$

$\begin{array}{ll}18.9 .42 & 0.07 \\ 1545.87 & 0.08\end{array}$

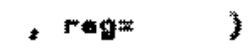

43700.00

38400.00

36000.00

35050.00

33660.00

3000.00

29300.00

33050.00

32800.00

32300,00

31800.00

$\$ 1100.00$

$30 \mathrm{ec0} .00$

28000.00

30200.00

26950.00

26700.00

26000.00

25360.00

24000.00

23100.00

23250 , 000

22450.00

1131,3

$484.87 \quad 0.01$

$6505.3 \% 0.22$

1080.80 0.03

645.600 .02

202.040 .01

848.53 $0.0 \dot{3}$

353.580 .01

202.840 .01

$1565.63 \quad 0.08$

777.82

$1131.37 \quad 0.06$

$\begin{array}{rl}836.40 & 0.03 \\ 1767.77 & 0.07\end{array}$ 


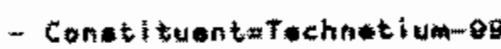

WELLNAHE SAMPLES EELOHOL DAYS N

$1 \sim \mathrm{H} \rightarrow 3-3 \quad 0 \quad 1$

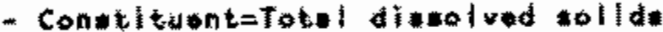

MELLNAHE SAMPLES BELOWDL DAYS $N$

$1 \rightarrow+44-3$

1 $-\mathrm{H} 4-\mathrm{H}-9$

1- $-\mathrm{H}^{3}+\mathbf{I}$

$1-14-17$

$1 \div-14-8$

$1+H 4-12 A$

$1-14+12$

$1-14-9$

$1-H 4-15$

$1+44-6$

$1+14-7$

$1-44-15 \lambda$

$1-H 4-10$

$1-14-14$

$1-H 4-11$

$1-\mathrm{Ha}^{3}+\mathrm{m}$

$1-44-16$

$1-13-2 A$

$1+\mathrm{H4}-13$

$1-14-17 \mathrm{C}$

$1 \rightarrow H 3-26$

$\begin{array}{lll}2 & 0 & 2 \\ 2 & 0 & 2 \\ 2 & 0 & 2 \\ 1 & 0 & 1 \\ 2 & 0 & 2 \\ 2 & 0 & 1 \\ 2 & 0 & 2 \\ 2 & 0 & 2 \\ 1 & 0 & 1 \\ 2 & 0 & 2 \\ 1 & 0 & 1 \\ 1 & 0 & 1 \\ 2 & 0 & 2 \\ 2 & 0 & 1 \\ 2 & 0 & 2 \\ 2 & 0 & 2 \\ 2 & 0 & 2 \\ 2 & 0 & 2 \\ 2 & 0 & 2 \\ 2 & 0 & 2 \\ 2 & 0 & 2 \\ 2 & 0 & 2 \\ 2 & 0 & 2 \\ 1 & 0 & 1\end{array}$

- Constituantzhallium

WELLNAME SMHPLES BELOWDL DAYS N

$1-H 4-3$
$1-43-1$

12
12

$\begin{array}{lll}11 & 12 & 1 \\ 18 & 12 & 1\end{array}$

$1-4 a-1$

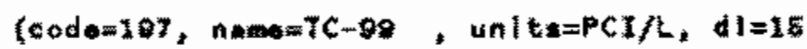

whX

WED IAN

UIN

RANGE

39.36.00

3835.00

3036.00

0.00

, Un 1 t* $=P P Q, d 1=5000$

RANOE

wax

MEDIAN

แIN

17000.00 103000.00 82000.00

711000.00

687600.00 402500.00 10. 432000.00 371000.00 377000.00 $3 \mathrm{Ate000} .00$ 3 30000 .00 807000.00 270000.00 290000.00 204000 . 00 275500.00 229000.00 219500. an $2 \% 1000.00$ 211500.00 219000.00 21 400 2176000.00 176000.00 47000 I 03000.00

084000.00 401000.00 448000.00 132000.00 35000.00 37000.00 330000.00 $31 \mathrm{k000.00}$ 307000.00 265000.00 299000.00 204000.00 267000 .00 220000.00 211000.00 215000.00 190000 15000.00 208000.00 165000 . 173000.00 168000.00 0.00 20000.00 0.00 38000.00 14000.00 4 acoo.00 0.0

$$
0.00
$$

17000.00 0.00

17000.00 12000.00 25000.00 anoo too

11000.00

212000.00

000000

15000.00 162000,00 173000.00
$1 \mathrm{ag000} .00$
- dwe $=900$

- regmem

MEN

sTt CY

3ez5.00

.

$+$

, $d w=500000, r e g=$ EpAS )

MEN STD CY

$607500.00 \quad 33234.02 \quad 0.05$

$482600.00 \quad 116268.41 \quad 0.24$

$180000.00 \quad 67892.76 \quad 0.12$

432000.00

313000

37000.00

340000.00

325000,00

37000.00

290000.00

23.000 .00

276600.00

223000.00

218500.00

211600.00

212000.00

21 15e0.00

176000.00

17500.00

160000,00

16384.780 .06

$28870.0 \dot{8} \quad 0.0 \dot{0}$

9800.480 .03

32526.010 .12

120大0.8\% 0.0\%

12020.320 .05

6485.28 D.04

$1767.67 \quad 0.06$

$1242.04 \quad 0.02$

16558.3500 .00

8363.98

coes, 00 0.06

\begin{tabular}{|c|c|c|c|}
\hline wax & NEO 美NN & WIN & RANGE \\
\hline $\begin{array}{r}1,00 \\
+, 00\end{array}$ & $\begin{array}{l}21.00 \\
11.00\end{array}$ & $\begin{array}{l}21.00 \\
14,00\end{array}$ & $\begin{array}{l}0.00 \\
0.00\end{array}$ \\
\hline
\end{tabular}

, dima=
NEN 21.00

STo SV

21.00 
- Conetitumtatotal organic camon

WELLNAWE SAMLLS BELOWEL DAYS

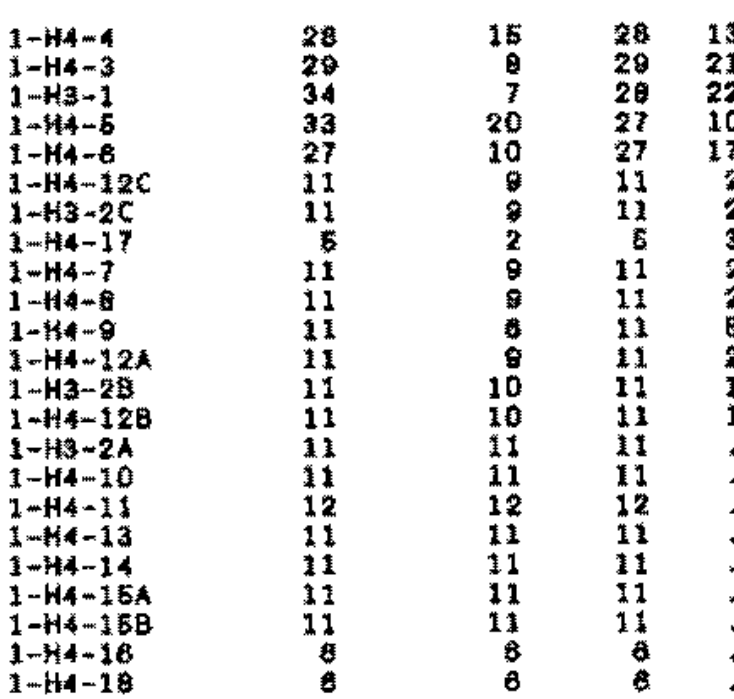

- Constituentototel organic halogen

WELLHAHE SAMPLS BELOMDL DAYS

$1-43-2 \mathrm{C}$

$1-\mathrm{HA}-1$

1-H4-128

$1 \rightarrow \mathrm{H}+-3$

$1-7 i x+6$

$1-1+4-6$

$1+H 4-136$

$1+14=2 k$

$1-113-28$

$1-\mathrm{H}_{4}-\mathrm{B}$

$1-1+4-8$

1-Hitio

1-Ni-11

$1-54-12 k$

1-H14 -1

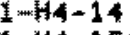

I $-44-15$.

$1+54-16$

$1-14-17$

$2-14+18$

11
28
11
34
29
33
11
27
12
11
11
11
11
11
11
12
11
11
11
11
6
5
6

\begin{tabular}{|c|c|}
\hline $\operatorname{mx} x$ & UEIIAN \\
\hline $\begin{array}{l}9219.00 \\
2990.00 \\
8410.00 \\
6720.00 \\
2460.00 \\
2020.00 \\
1890.00 \\
1300.00 \\
1220.00 \\
1120.00 \\
1070.00 \\
1040.00 \\
1020.00 \\
1010.00\end{array}$ & $\begin{array}{l}2830.00 \\
1070.00 \\
1220.00 \\
1165.00 \\
1130.00 \\
1636.00 \\
1820.00 \\
1050.00 \\
1165.00 \\
1006.00 \\
1040.00 \\
1020.00 \\
1020.00 \\
1010.00\end{array}$ \\
\hline • & • \\
\hline 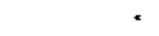 & • \\
\hline * & - \\
\hline 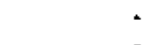 & * \\
\hline 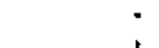 & : \\
\hline 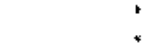 & : \\
\hline . & * \\
\hline & * \\
\hline
\end{tabular}

(codam $\{B 8$, name=Tax

MAX

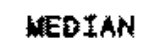

4510.00

4220.00

3200.00

2860.00

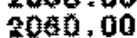

836.00

$41 ., 00$

364,00

312.00
2434.00

e2z.00

3200 " 00

3660.00

102.00

e.

114. 00

258.60
299.60
- in t tomper

UIN

RANOCE

MEAN

1010.00

1000.00

1030.00

1020.00

1010.00

1260.00

1300.00

1020.00

1090.00

1060.00

$10 \times 0.00$

1000.00

1020.00

1020.00
1010.00

8200.00

7800.00

7410.00

5700,00

1450.00

770.00

$3 \mathrm{ag} .00$

130.00

70.00

50. DO

10.00

0.00
0.00

3122.31

3000.05

1850.23

$170 \% .60$

1332.04

1635,00

1620.00

1123.35

1158 , on

10दE. 00

1044.00

jost

102xit.00

:
+ $r m g=$ )

STI Cy

$2322.66 \quad 0.74$

$5367,27 \quad 0,77$

1634.040 .83

$1750.21 \quad 0.00$

408.610 .30

54.47 0.33

163.73

0.920 .00

$9.50 \quad 0.05$

2甘. 28 0.03

312.00

, unit:*PPB $\quad d 1=100$

MIIN

RANGE

4152, 00

1007.00

0.00

1923.00

40).00

0.00

2.16 .0

$14 \%, 00$

25.00
, $d w=$

MEAN

2434.00

3200.00

2000.00

Q 313

58.37

598.87

414.00

256.50

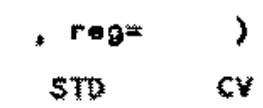

$7935.91 \quad 1+21$

$1042.2 \dot{0} \quad 1.20$

$244.20 \quad 0.44$

$162.03 \quad 0.69$ 


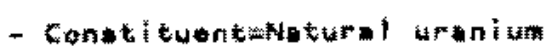

WELLNAME SAMFLES BELOWDL DAYS N

$1-+i+3$

$\begin{array}{llll}6 & 0 & 0 & 8 \\ 6 & 0 & 8 & 6\end{array}$

- Conoti tuent=inknown

MELLNAME SAMPLES BELOHDL DAYS $N$

$1-13-1$

1001

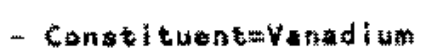

WELLLAME SALPLES BELOWDL DKYS N

1- $+14-5$

$1-13-1$

$1 \rightarrow+4-12 C$

$1-4=4$

$3-\mathrm{H}^{3}-2 \mathrm{C}$

1-44-6

$1+\mathrm{H} 4-4$

$1+H 4-12 A$

1-He-15.

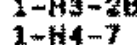

$1-14-10$

1-44-13A

$1-14-14$

1-H4-18

1-14-9

1. $+44-120$

$1-14$
$1-51-13$

1-nit-13

36
5
35
12
30
12
28
30
11
11
11
11
11
11
11
11
11
8
11
11
12
7
11

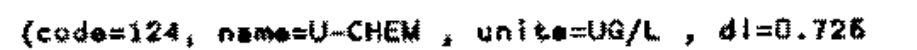

Max

MEOTAN

atw

RANCE

$, \quad d w *=1 \%, 5$

UEAN

638.60
. 69

8.77

, 4wa

RANGE

NEAH

0.00

8.00

9.00

$\$ .00$

0.00

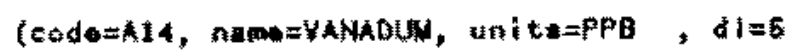

WAX

HEDAN
8.00
6.00
10.00
20.00
11.00
18.00
7.00
5.00
5.00
10.00
6.00
8.00
7.00
9.00
8.00
6.00
8.00
6.00
7.00
7.00
6.00
6.00
5.00

UIM

RANGE

32.

28.00

29.00

24.00

20.00

10.00

14.00

15.00

13.00

11.00

$11.0 \mathrm{~m}$

10.00

10.00
10.00

10.00

10.

10.00

9.00

i.00

8.00

0.00
7.00

5.60

27.00

28.00

23.00

10.00

19.00
7.00

13.00

11. 00

10.00

a.00

6.00

4.00

4.00
5.00

5. 00

5. 00

5.00
2.00

2.00
4.00

4.00
3.00

3.00
3.00

3.00
2.00

1

7
11

\begin{tabular}{|c|c|c|}
\hline$d t a=$ & $\Rightarrow \log =$ & ) \\
\hline UEAN & STD & CV \\
\hline $\begin{array}{r}10.27 \\
16.67 \\
11.08 \\
18.87 \\
10.68 \\
19.91 \\
7.33 \\
7.47 \\
8.27 \\
9.68 \\
8.09 \\
7.73 \\
7.80 \\
7.81 \\
6.10 \\
8.80 \\
8.89 \\
8.00 \\
7.25 \\
8.83 \\
8.20 \\
6.40 \\
5.87\end{array}$ & 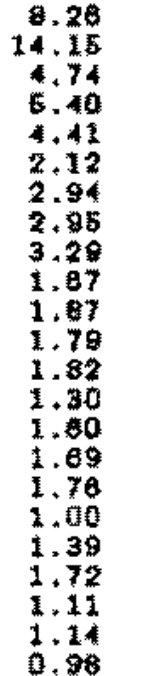 & $\begin{array}{l}0.80 \\
0.00 \\
0.43 \\
0.27 \\
0.41 \\
0.13 \\
0.10 \\
0.39 \\
0.40 \\
0.17 \\
0.23 \\
0.23 \\
0.24 \\
0.18 \\
0.20 \\
0.28 \\
0.20 \\
0.11\end{array}$ \\
\hline
\end{tabular}


- Cansti tumbayanedium, fl tarod WELLNAE SAMPLES BELOMD DAYS

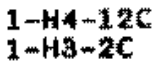
$\underset{1 \rightarrow H A-3}{1-H a}$ in $=4+160$ 1.+13-1

1. $14-7$

$1-43-2 k$

$2+43-20$

$1-4+4$

$1-1,4=1$

$1+i+4=4$

$1-\mathrm{H} 4-10$

$1-\mathrm{H4}-12 \mathrm{~B}$

$1-1+4+1$

$1-\mathrm{HA}+12 \mathrm{~A}$

$1+\mathrm{Hi}-17$

$1+N 4-9$

$1+44-18$
$1-14-13$

$1-14-13$

12
12
16
11
14
11
11
11
11
14
12
11
17
21
10
14
17
11
3
11
6
11
8

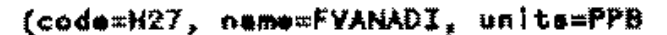

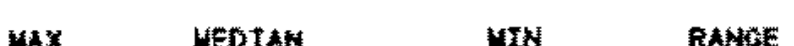

N

$\begin{array}{rr}12 & 22 \\ 11 & 11 \\ 15 & 10 \\ 11 & 10 \\ 14 & 14 \\ 11 & 8 \\ 11 & 10 \\ 11 & 11 \\ 11 & 7 \\ 14 & 11 \\ 11 & 11 \\ 11 & 8 \\ 14 & 8 \\ 11 & 9 \\ 10 & 8 \\ 14 & 8 \\ 12 & 3 \\ 11 & 5 \\ 3 & 1 \\ 10 & 5 \\ 6 & 4 \\ 11 & 4 \\ 6 & 2\end{array}$

Contituentminc

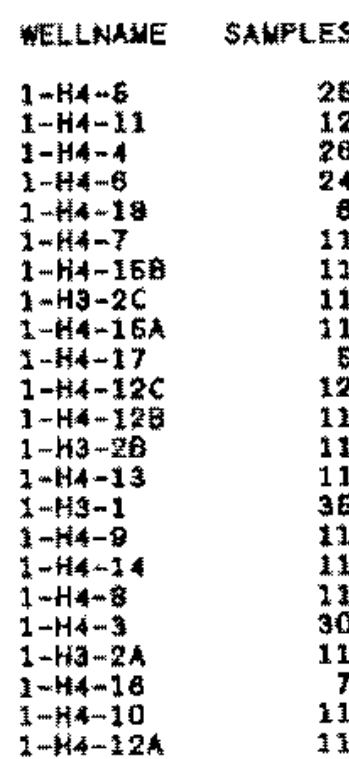

EELOWE.

$\begin{array}{rr}\text { DAYS } & \text { N } \\ 24 & 24 \\ 14 & 7 \\ 12 & 25 \\ 28 & 25 \\ 24 & 74 \\ 6 & 8 \\ 11 & 8 \\ 11 & 8 \\ 11 & 11 \\ 11 & 8 \\ 5 & 5 \\ 12 & 12 \\ 11 & 8 \\ 11 & 6 \\ 11 & 10 \\ 28 & 8 \\ 11 & 7 \\ 11 & 8 \\ 11 & 5 \\ 39 & 8 \\ 11 & 7 \\ 7 & 3 \\ 11 & 7 \\ 11 & 4\end{array}$

wax Medtat

27.06

11.00

13.00

11.00

11.00

10.00

10.00

10.00

10.00

8.00

0.00
8.00

8.00

. 60

8. 00

8.00

7.00

7.00

6.00
6.00

19.00

$1 \%, 00$
9.00

9.0.0

8.00

7.00
0.00

今.00

3.00

7.00

5.75

8.00
8.60

8.00

*.00

8.00

\%.00

\%.00

5.00

1100

11.00
10.00

10.00
5.00
6.00

6.00
8.00

8.00
5. 00

6.00
7.00

7.00
5. 00

5.00
5.00

5. 60

*.00

5.00

7.00

5.00
5.00

E.00

6.00

8.00

8.00

5.00

16.00

16.00
10.00

1).00

3.00
7.00

3.00
6.00

6. 00

3,00
$*, 00$

E.00

4.80
5.00

1.00

2.00

4.00

3.00

3.00

3.00

0,00

2,00

2.00
1.00
1.00

1. 船

(codesndia, neme=zINC

, UHittomPS

- $11=6$

MAX

Meority

UTh

RANGE

2400.00
104.00

104.00
354.00

300.00

115.00

80.00

70,00

71.00
53.00

45.00

44.00

41. 00

38.00

38.00

30.00

23.00

23.00
22.00

22.00

20.00

is., 00

12.00
12.00

58.50
1.000
69.00
17.50
9.50
14.50
28.50
1.00
9.00
1.00
13.00
10.00
7.00
11.00
7.00
8.00
11.50
13.00
7.00
7.00
9.00
9.00
7.00

38.00

5.00

21.00
104.00

10. 80

2.00

8.00

6. 00

6,00
1100

E.00

5. 00

6.00

5.00

$\% .00$

6.00

5. 00

5.00

5.00
5.00

5.00

5. an

0.00
20.00
$1+, 00$
2 dww

, reg $=$ )

Wext|

19.33

16.81

ค. $7 \mathrm{a}$

0.20

7.41

8.80

8.81
7.00

7.36

3.41

0.8

6. 1 \&

9. 00

8.00

8.33

6.00

B. 00

8.00

6.25

6.75

- $d w s=6000$

STD

$6.10 \quad 0.26$

$3.02 \quad 0.35$

$2.10 \quad 0.33$

$1.72 \quad 0.20$

$1.04 \quad 0.28$

$\begin{array}{ll}1.82 & 0.18 \\ 1.22 & 0.14\end{array}$

2.240 .32

$\begin{array}{ll}1.69 & 0.23 \\ 1.74 & 0.24\end{array}$

1.480 .21

1.51 0.24

$\begin{array}{ll}0.87 & 0.11 \\ 1.37 & 0.20\end{array}$

$1.00 \quad 0.17$

$\begin{array}{ll}1.63 & 0.24 \\ 1.28 & 0.22\end{array}$

$1.00 \quad 0.17$

$0.50 \quad 0.09$

UE체

\$. 90

67.62

168.17

28.33

35.75

21.00

21.00

190

1.42

14.75

14.80

๑. 11

$+14$

13.80

12.89

9.25

8.67
8.87
8.57

8.87
8.25

- reg=EPAS )

s7o

470.74

147.91

81.4203

4.050

43.01 1.63

$2 \mathrm{E} .110 .06$

$18.53 \quad 0.88$

$16.10 \quad 2.21$

$14.27 \quad 0.72$

11.720 .67

$12.10 \quad 0.52$

$14.00 \quad 1.09$

10.290 .70

0.020. ae

6.900 .76

$6.23 \quad 0.54$

5.01

4.470

$5.03 \quad 0.62$

$\begin{array}{ll}3.21 & 0.37 \\ 2.07 & 0.36\end{array}$

.


- Constituentming, Nitiond WELLNANE SANPLES BEIOWLL

$1+044-3$ $1+44-8$
$1+4+10$ $1-14-12 C$

$1-144-4$

$1-1+4-5$

$1+14-165$

$1-14-18$

$1-13-2 c$

$1-\mathrm{HA}-1 \mathrm{t}$

$1-13-1$

$1-14-13$

1- +4 is

$1+1+14-8$

$1+34-14$

1- $+44-11$

$1-14+17$

$1+4+14+12 A$

$1=414+16 A$

$1 \rightarrow H 3=2 B$

$\begin{array}{rr}16 & 11 \\ 11 & 0 \\ 11 & 7 \\ 12 & 1 \\ 17 & 0 \\ 14 & 0 \\ 12 & 3 \\ 11 & 8 \\ 6 & 0 \\ 11 & 2 \\ 6 & 3 \\ 14 & 8 \\ 10 & 3 \\ 11 & 4 \\ 11 & 6 \\ 11 & 6 \\ 11 & 8 \\ 12 & 10 \\ 3 & 1 \\ 11 & 9 \\ 11 & 10 \\ 11 & 0 \\ 11 & 11\end{array}$

lcodenHIS, nommafiLC

, unltm=PPB

, $d !=6$

Mit

RAHGE

5.
107.00

\%. 00

8.00

$33 \times 00$

$5 \times 00$

$8 \times 00$

10.00

6.00
5.00
5.00

5.00

5. .00

7.00

5.00

5.00

7.00

6.00

5,00

6.00

5.00

8.00

5. 00

8. 50

क.
$13 \% 5.00$

140.00

ita. bu

11E.

76.00

71. 00

63.00

52.00

47.00

40. 00

26.00

29.00

12.00
6.00

6.00
6.00

3.00

4.00

2.00

1. .00

0.00

.00

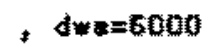

MEAN

287.40

143.38

54.25

85.99

62,80

$20+83$

37.60

15. 00

14.11

18.33

10.17

13.28

11.43

3.00
7.25

7.25
6.50

7.00

0.00

E. 50

6.00

$5 ., 00$
- ripupas

STD $\mathrm{CV}$

21.972 .16

$36.40 \quad 0.25$

$98.80 \quad 1.78$

$61.96 \quad 1.76$

28.980 .44

24.53

$18.31 \quad 0.50$

$20.63 \quad 1.38$

23.09

10.23 1.0.

$7.97 \quad 0.40$

$4.79 \quad 0.42$

$2.24 \quad 0.28$

$2.22 \quad 0.31$

$2.83 \quad 0.28$

2.830 .40

$0.72 \quad 0.13$

0.000 .00 


\section{DISTRIBUTION}

No. of

Copies

OFFSITE

10 DOE/Office of Scientific and Technical Information

\section{ONSITE}

5 DOE Richland Operations Office

R. D. Izatt

M. W. Tiernan

DOE-RL Public Reading Room (2)

4 Westinghouse Hanford Company

K. R Fecht

E. M. Greager

D. G. Kachele

A. C. Mckarns

38. Pacific Northwest Laboratory

R. L. Aaberg

N. J. Aimo
No. of

Copies

D. J. Bates

M. P. Bergeron

R. M. Ecker

J. W. Falco

M. D. Freshley

R. 0. Gilbert

T. J. Gilmore

M. J. Graham

J. M. Haies

S. H. Hall (7)

$P$. C. Hays

M. R. Kerns

S. A. Kreml

G. V. Last

P. J. Mitche11

K. B. 01 sen

K. R. Oster

J. C. Simpson

R. M. Smith

S. S. Tee]

E. J. Westergard

R. E. Wildung

Publishing Coordination

Technical Report Files 
k

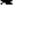

- 